\title{
Eratyki fennoskandzkie w osadach glacjalnych Polski i ich znaczenie badawcze
}


盗 
Eratyki fennoskandzkie w osadach glacjalnych

Polski i ich znaczenie

badawcze 
Piotr Czubla - Uniwersytet Łódzki, Wydział Nauk Geograficznych Instytut Nauk o Ziemi, Pracownia Geologii, 90-139 Łódź, ul. Narutowicza 88

\author{
RECENZENT \\ Jan Dzierżek \\ REDAKCJA TECHNICZNA I SKŁAD KOMPUTEROWY \\ Aleksandra Retkiewicz \\ KOREKTA \\ Paweł Czubla \\ OPRACOWANIE GRAFICZNE \\ Piotr Czubla \\ PROJEKT OKŁADKI \\ Stämpfli Polska Sp. z o.o. \\ Na okładce wykorzystano fotografie autorstwa Olafa i Piotra Czubli
}

Wydrukowane z gotowych materiałów dostarczonych do Wydawnictwa UŁ przez Wydział Nauk Geograficznych

(C) Copyright by Uniwersytet Łódzki, Łódź 2015

Wydane przez Wydawnictwo Uniwersytetu Łódzkiego

Wydanie I. W.06918.15.0.M

Ark. druk. 21,125

ISBN 978-83-7969-675-8 (wersja papierowa)

ISBN 978-83-7969-676-5 (wersja online)

Wydawnictwo Uniwersytetu Łódzkiego

90-131 Łódź, ul. Lindleya 8

www.wydawnictwo.uni.lodz.pl

e-mail: ksiegarnia@uni.lodz.pl

tel. (42) 66558 63, faks (42) 6655862 
Pamięci mojego ojca Czesława 



\section{SPIS TREŚCI}

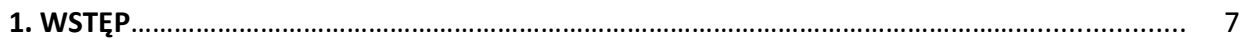

2. CELE BADAŃ

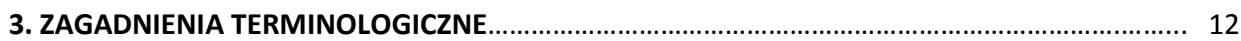

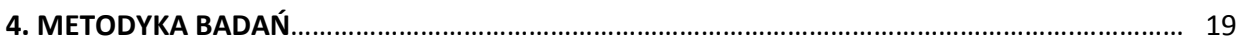

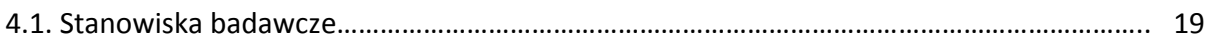

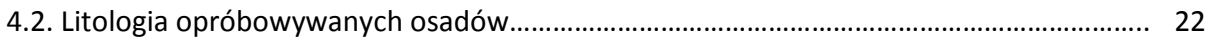

4.3. Frakcja badanego materiału i wielkość próby................................................................... 24

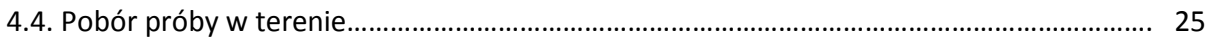

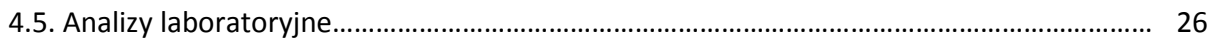

4.6. Opracowanie kameralne wyników badań...................................................................... 30

5. METODY INTERPRETACII I PREZENTACJI WYNIKÓW BADAŃ ERATYKÓW............................... 35

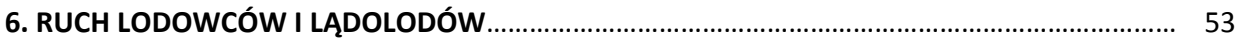

6.1. Płynięcie deformacyjne.................................................................................................. 53

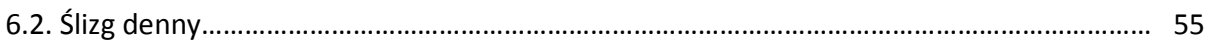

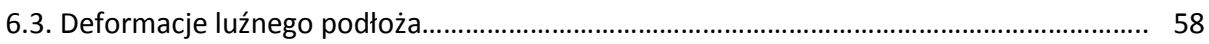

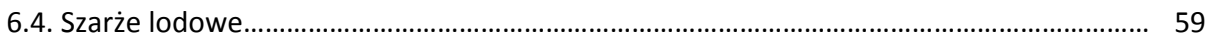

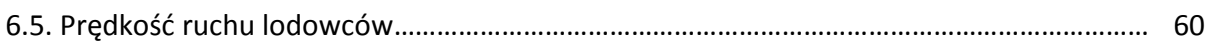

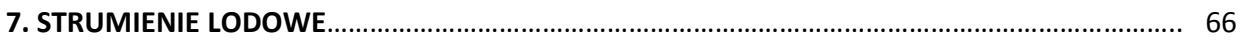

7.1. Czynniki warunkujące rozwój i dynamikę strumieni lodowych........................................... 67

7.2. Klasyfikacja i identyfikacja strumieni lodowych............................................................... 69

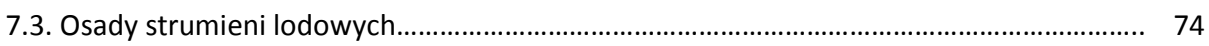

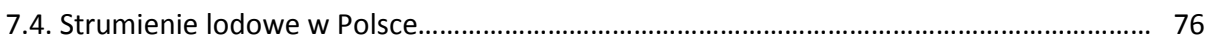

8. PROCESY EROZYJNE JAKO ŹRÓD ŁO MATERIAŁU MORENOWEGO ......................................... 82

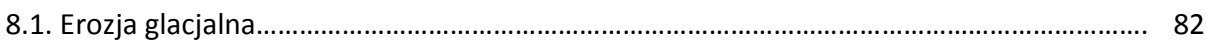

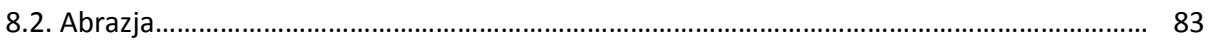

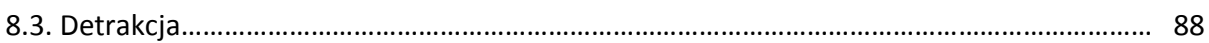

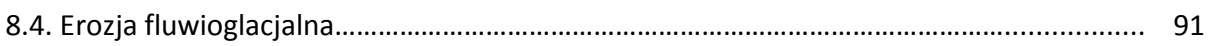

8.5. Wietrzenie i jego potencjalny wpływ na skład materiału pobieranego przez lodowce.... 93

8.6. Procesy fluwialne, brzegowe, stokowe i ich wpływ na skład materiału morenowego..... 94

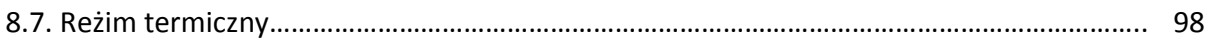

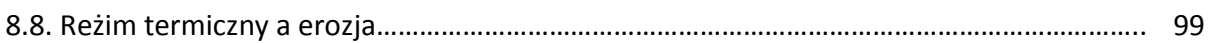

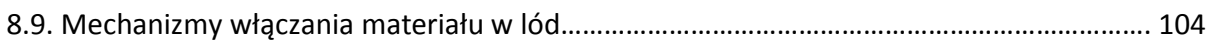

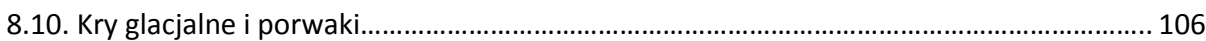

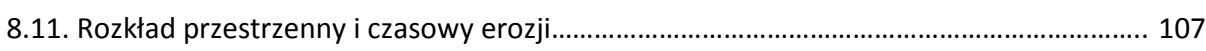




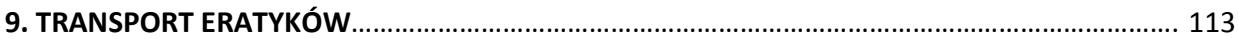

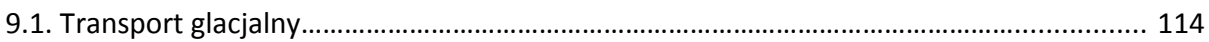

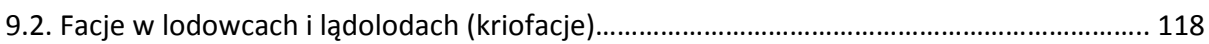

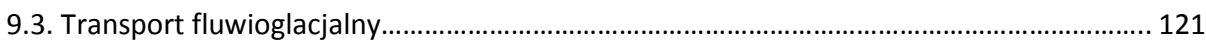

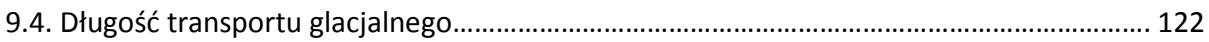

9.5. Długość transportu a frakcja i kształt ziaren......................................................................... 125

10. ERATYKI WSKAŹNIKOWE - PRZEWODNIE I POMOCNICZE............................................. 127

10.1. Eratyki z Ångermanlandu i krain przyległych - północna Szwecja................................... 134

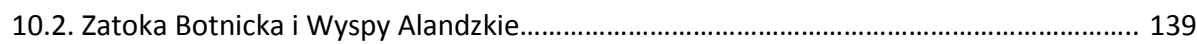

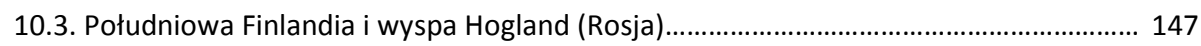

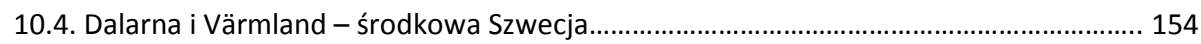

10.5. Uppland i Södermanland - środkowo-wschodnia Szwecja............................................. 168

10.6. Dno środkowego Bałtyku włącznie z wyspami Szwecji i Estonii...................................... 175

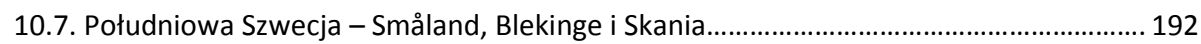

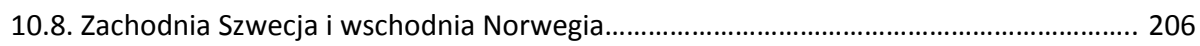

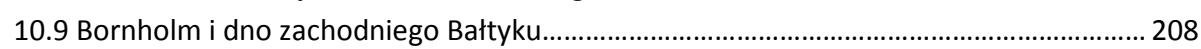

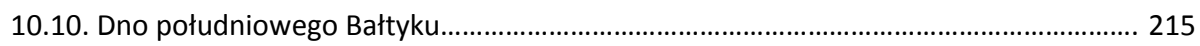

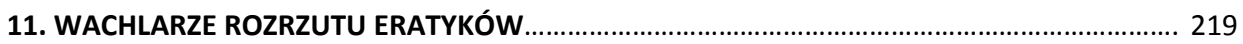

12. WIETRZENIE GLIN LODOWCOWYCH I JEGO WPŁYW NA BADANIA ERATYKÓW................... 226

13. WYKORZYSTANIE ANALIZ ERATYKÓW W GEOLOGII ZŁOŻOWEJ............................................ 233

14. ANALIZA STATYSTYCZNA SKŁADU PETROGRAFICZNEGO OSADÓW GLACJALNYCH............. 238

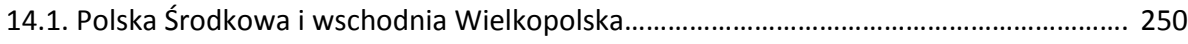

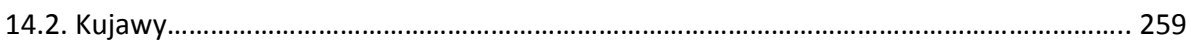

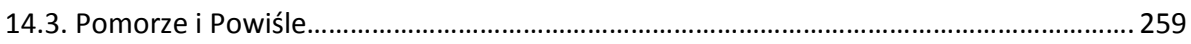

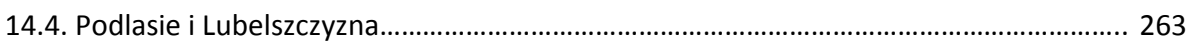

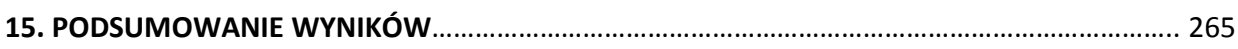

15.1. Metody badań eratyków w osadach glacjalnych........................................................... 265

15.2. Metodyka badań a korelacja i rozróżnianie różnowiekowych osadów glacjalnych...... 266

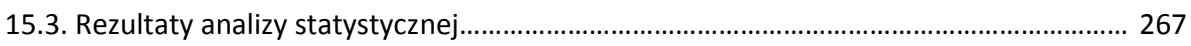

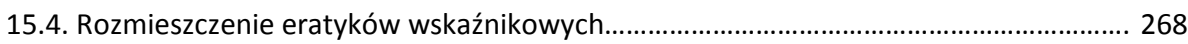

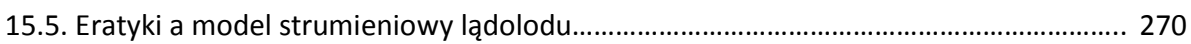

15.6. Wybrane koncepcje glacjologiczne w świetle badań eratyków...................................... 271

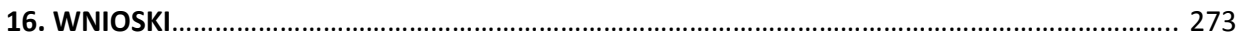

17. LITERATURA

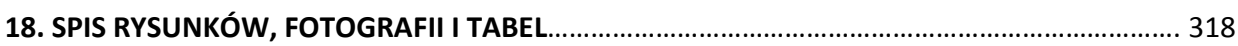

19. FENNOSCANDIAN ERRATICS IN GLACIAL SEDIMENTS OF POLAND AND THEIR RESEARCH

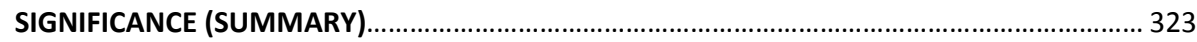

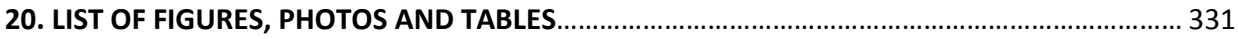




\section{WSTĘP}

Do początków XIX wieku eratyki nie przyciągały uwagi badaczy. Do wyjątków należało zainteresowanie skamieniałościami lub minerałami obecnymi w skałach narzutowych. Niektóre typy skał narzutowych wykorzystywano jako surowiec do wyrobu narzędzi (np. kamienie żarnowe), ale w tym przypadku pochodzenie skały było zupełnie bez znaczenia, liczyły się wyłącznie właściwości techniczne, które predysponowały ją do zastosowania w tej roli, bądź nie. Od najdawniejszych czasów skały narzutowe wykorzystywane były jako pociski do broni miotającej, a w średniowieczu - po odpowiedniej obróbce - jako kule armatnie. Szerokie zastosowanie skały narzutowe znalazły w budownictwie (zwłaszcza romańskim) i drogownictwie. Sprzyjało temu ich powszechne występowanie na obszarze Niżu Środkowoeuropejskiego. Pozyskiwano je na olbrzymią skalę w postaci tzw. kamieni polnych jako produkt uboczny podczas prac rolniczych. Niekiedy wyjątkowo okazałe lub z innego powodu nietypowe eratyki otaczano kultem.

Początki wykorzystania eratyków dla celów badawczych związane są z występowaniem w nich licznych skamieniałości. Przyczyniła się do tego powszechna dostępność nordyckich skał osadowych na nizinach środkowej Europy, gdzie odsłonięcia paleozoicznych skał osadowych należą do rzadkości. Ten nurt badawczy uprawiany jest do dziś i nadal przynosi znakomite efekty poznawcze - przy znacznym udziale niemieckich i holenderskich amatorów.

Znaczne rozszerzenie zakresu badań stało się możliwe, odkąd skały rozrzucone na Niżu Środkowoeuropejskim prawidłowo zinterpretowano jako eratyki pozostawione przez lądolody. Początkowo zastosowano je do wyznaczania zasięgu lądolodów. Po dowiązaniu konkretnych typów skał narzutowych do ich wychodni w obszarze alimentacji lądolodu możliwe było również wyznaczenie orientacyjnych kierunków ruchu lodu. Ten kierunek badań funkcjonuje do dzisiaj - zwłaszcza w odniesieniu do obszarów pozaeuropejskich i do zlodowaceń starszych niż plejstoceńskie. Zróżnicowanie zespołów skał narzutowych obecnych w różnowiekowych osadach glacjalnych, wynikające ze zmienności czasowej obszarów akumulacji lądolodów, pozwoliło wykorzystać je do korelacji stratygraficznej. Współczesne badania w tej dziedzinie uwzględniają ostatnie osiągnięcia w analizie termodynamiki lądolodu, wśród których na szczególne podkreślenie zasługuje strumieniowy model funkcjonowania lądolodów.

W przypadku współczesnych lądolodów analiza eratyków umożliwia rozpoznanie budowy geologicznej obszaru pokrytego lodem, np. w Antarktyce. Dawniej było to także cenne narzędzie służące analizie budowy geologicznej dna morskiego. Postęp technologiczny w badaniach geofizycznych oraz rozwój podmorskich wierceń 
geologicznych (w tym poziomych) doprowadziły do zaniechania badań eratyków mających służyć rozpoznaniu dna mórz.

Głazy narzutowe stanowią ważne źródło informacji paleogeograficznych. W oparciu o badania tzw. izotopów kosmogenicznych (na ogół ${ }^{36} \mathrm{Cl},{ }^{10} \mathrm{Be},{ }^{26} \mathrm{Al}$ ) możliwe jest określenie czasu ekspozycji powierzchni skalnej na oddziaływanie promieniowania kosmicznego. W ten sposób można ustalić, jak długo dana skała była odsłonięta na powierzchni.

Eratyki są również wykorzystywane w poszukiwaniach złóż. Regułą jest, że strefa rozproszenia ziaren poszukiwanego surowca jest $w$ osadach glacjalnych wielokrotnie większa od powierzchni jego rzeczywistej podczwartorzędowej wychodni. Znacznie większe jest zatem prawdopodobieństwo natknięcia się podczas marszrut prospekcyjnych na te rozproszone ziarna, aniżeli na samą wychodnię - tym bardziej, jeśli przykryta jest młodszymi osadami lub nadal pozostaje pod lądolodem.

Powyższe przykłady dowodzą znaczenia eratyków zarówno w badaniach podstawowych, jak i stosowanych.

Niniejsza monografia powstała w Pracowni Geologii Instytutu Nauk o Ziemi Uniwersytetu Łódzkiego. Badania terenowe, prowadzone w latach 2001-2013, sfinansowane zostały ze środków na badania własne Pracowni Geologii Uniwersytetu tódzkiego (560/844) oraz zespołowych projektów badawczych, finansowanych przez Ministerstwo Nauki i Szkolnictwa Wyższego w latach 2007-2013: N N306 766940 (kier. Piotr Paweł Woźniak - UG), N N306 284033 (kier. Joanna Petera-Zganiacz - UŁ), N N306 198739 (kier. Sławomir Terpiłowski - UMCS) i N N306 721140 (kier. Lucyna Wachecka-Kotkowska - UŁ).

Wyrazy wdzięczności kieruję do kierowników i współwykonawców grantów za wsparcie w badaniach terenowych oraz liczne, owocne dyskusje, które pozwoliły rzucić nowe światło na cały szereg zagadnień. Bardzo cenna okazała się również wymiana doświadczeń na spotkaniach terenowych Grupy Perybałtyckiej INQUA oraz cyklicznych konferencjach „Stratygrafia Plejstocenu Polski”. Pragnę serdecznie podziękować Albinowi Czubli za pomoc w przeprowadzeniu analizy statystycznej. Słowa głębokiej wdzięczności należą się recenzentowi Janowi Dzierżkowi, którego wartościowe rady i sugestie wywarły istotny wpływ na ostateczny kształt monografii. $O$ jej poprawność edytorską zadbał Paweł Czubla, któremu składam serdeczne podziękowanie. Prezentowane opracowanie nie mogłoby powstać, gdyby nie atmosfera życzliwości panująca w Pracowni Geologii Ut, kierowanej przez Macieja Ziułkiewicza.

Nie do przecenienia jest również wsparcie udzielane mi przez najbliższą rodzinę: Kasię, Olafa i Mateusza. Przez wiele lat godzili się z tym, że dużą część pracy przenosiłem do domu, kosztem czasu, który powinienem był przeznaczyć przede wszystkim dla nich. Tej straty nigdy nie będę w stanie im wynagrodzić. 


\section{CELE BADAŃ}

Ustalenie pozycji stratygraficznej osadów glacjalnych stanowi bardzo poważny problem w geologii czwartorzędu. Nie udało się dotychczas wypracować skutecznej metody datowania bezwzględnego, którą można byłoby zastosować do osadów o tej genezie. Datowania luminescencyjne (TL, OSL, IRSL) nie sprawdzają się w przypadku osadów glacjalnych ze względu na znaczne przemieszanie materiału, który w bardzo różnym stopniu wystawiony był wcześniej na działanie światła słonecznego (por. m.in. Aitken, 1985; Bluszcz, 2000; Fuchs i Owen, 2008; Munyikwa, 2014). Badania takie mogą co najwyżej być pomocne w ustaleniu ram czasowych sedymentacji, jeżeli uda się wydatować osady podścielające i przykrywające opisywaną warstwę. W podobny sposób, ale już w odniesieniu do datowania względnego, można posłużyć się analizami palinologicznymi osadów organicznych. Lichenometria i analizy izotopów kosmogenicznych mogą być wykorzystane tylko w odniesieniu do skał odsłoniętych na powierzchni ziemi i nie ma możliwości wykorzystania ich do datowania pokładów glin. Datowania radiowęglowe mają bardzo mały zasięg czasowy i wymagają obecności materii organicznej w pozycji in situ, co w osadach glacjalnych jest z założenia wykluczone. Problemy interpretacyjnie sprawia również dość częste zaangażowanie osadów glacjalnych w deformacje tektoniczne, glacitektoniczne i sedymentacyjne.

Podejmowane w północno-zachodnich Niemczech analizy różnowiekowych osadów glacjalnych i próby ich korelacji w oparciu o minerały ciężkie, minerały ilaste i skład geochemiczny nie dały przekonywujących rezultatów i ze względu na duży nakład czasu i koszty nie są podejmowane kolejne działania w tym kierunku (Ehlers, 2011). Analogiczna próba rozróżnienia glin z wykorzystaniem analizy minerałów ilastych podjęta w Polsce również zakończyła się niepowodzeniem - Stankowska, 1979. W Polsce analizy minerałów ciężkich pozwalają dość pewnie odróżnić czwartorzęd preglacjalny od glacjalnego oraz są głównym wskaźnikiem granicy pomiędzy neogenem i czwartorzędem (Marcinkowski i Mycielska-Dowgiałło, 2013), ale ich zastosowanie do badań stratygraficznych glin jest bardzo ograniczone i nie daje jednoznacznych wyników (np. Racinowski i Rzechowski, 1969; Kenig, 2009; Racinowski, 2010). Na przyszłość duże nadzieje wiąże się z automatycznym skaningiem minerałów (Qemscan), wykorzystującym technologię SEM-EDS - scanning electron microscopy with energy dispersive spektrometry i odpowiednie oprogramowanie (Haberlah i in., 2011; Meyer i in., 2013). Pierwsze próby rozróżniania w ten sposób osadów glacjalnych przeprowadzone w Niemczech są dość obiecujące (Ehlers, 2011), ale obecnie jest to jeszcze metoda trudno dostępna w Europie i wykorzystywana głównie w badaniach złóż.

Konieczne staje się zatem sięganie po metody korelacji litostratygraficznej, oparte na analizach petrograficznych frakcji żwirowej i kamienistej glin. Szeroko rozpowszechnione i zaawansowane metodycznie są badania drobnej frakcji żwirowej (rozmiary 
ziaren do $10 \mathrm{~mm}$ ). W oparciu o nie możliwe jest w wielu przypadkach ustalenie przynależności stratygraficznej osadów glacjalnych. Przegląd najważniejszych osiągnięć w tej dziedzinie zawierają liczne prace - m.in. Kenig (1998, 2009), Górska (2000), Czubla (2001), Lisicki (2003,) Gałązka (2004b). Uproszczona petrografia drobnej frakcji nie pozwala na precyzyjne ustalenie obszarów alimentacji ani na określenie drogi transportu materiału skalnego na obszar depozycji. W tym celu można wykorzystać analizy eratyków wskaźnikowych.

Eratyki, jako potencjalne narzędzie analizy i korelacji osadów glacjalnych, stanowią już od ponad dwustu lat przedmiot zainteresowania badaczy czwartorzędu. Mimo to skala ich wykorzystania jest bardzo ograniczona ogromną pracochłonnością badań, a także brakiem przekonania wśród części geologów o celowości prowadzenia takich analiz (np. Marcussen, 1978; Lamparski, 1992). Za negatywny stosunek do tych badań odpowiada w znacznym stopniu niewiarygodna metodyka, w tym zwłaszcza błędny sposób poboru prób (Marcussen, 1978; Houmark-Nielsen, 1983, 1987; Kjær i in., 2003 str. 145), stosowany nawet jeszcze w drugiej połowie XX wieku (por. Czubla, 2001; Gałązka, 2004b).

Upowszechnienie się strumieniowego modelu dynamiki lądolodów (m.in. Punkari, 1993, 1997; Kleman i in., 1997; Boulton i in., 2001a; Marks, 2002, 2004, 2005; Wysota, 2002) oraz szeregu nowych koncepcji i modeli, opisujących warunki termobaryczne w lądolodzie i jego podłożu oraz wyjaśniających mechanizm ruchu lodu (np. Boulton i Jones, 1979; Boulton i Hindmarsh, 1987; Boulton, 1996, 2006; Kleman i in., 1997, 2008; Iverson i in., 1999; Boulton i in., 2001b; Arnold i Sharp, 2002; Forström i in., 2003), nastąpiło prawie niezależnie od rozwoju badań petrograficznych osadów glacjalnych. W konsekwencji powstały uogólnione modele oparte na bardzo precyzyjnych założeniach teoretycznych, głównie fizycznych, ale w wielu przypadkach niezgodne z wynikami szczegółowych badań terenowych osadów pozostawionych przez lądolód fennoskandzki (por. m.in. Piotrowski i in., 2001, 2004; Woźniak i Czubla, w druku). Oznacza to konieczność przeprowadzenia weryfikacji proponowanych modeli m.in. w oparciu o wyniki badań eratyków w osadach glacjalnych Polski.

Na obszarze środkowej Polski badania eratyków przeprowadził autor w latach 90-tych (Czubla, 2001). W ramach ówczesnych prac została przeanalizowana i zmodyfikowana metodyka badawcza oraz określony skład zespołów eratyków, typowych dla osadów glacjalnych kompleksu środkowopolskiego. Analizy eratyków wskaźnikowych (w oparciu o zbliżone, ale nieidentyczne założenia metodyczne) na terenie Polski w ciągu ostatniego ćwierćwiecza prowadzili też Górska (m.in. 2000; Górska-Zabielska, 2008) i Gałązka (2004b). Ograniczony zakres dotychczasowych badań i brak uzgodnionej wspólnej metodyki, skłonił autora do kontynuacji i rozszerzenia analiz eratyków wskaźnikowych. Te same czynniki wpłynęły na wyznaczenie podstawowych celów badawczych prezentowanego opracowania, którymi są:

1. Analiza rozprzestrzenienia wybranych typów eratyków przewodnich w osadach glacjalnych Polski;

2. Prześledzenie zmienności zespołów eratyków w transektach poziomych (równoleżnikowym i południkowym) na obszarze Polski; 
3. Określenie wpływu procesów preglacjalnych na kształtowanie się zespołów eratyków;

4. Próba ustalenia relacji pomiędzy typem erozji i mechanizmem ruchu lodu a ilością i rodzajem materiału skalnego transportowanego z Fennoskandii na obszar Niżu Środkowoeuropejskiego;

5. Analiza składu zespołów eratyków w osadach glacjalnych w odniesieniu do współczesnych modeli termodynamicznych lądolodu;

6. Ocena zgodności wyników analiz eratyków z wybranymi koncepcjami glacjologii, m.in. strumieniowym modelem dynamiki lądolodu fennoskandzkiego;

7. Opracowanie uproszczonej metodyki badań eratyków, mającej sprzyjać upowszechnieniu tego typu analiz i wzrostowi wiarygodności wyników;

8. Weryfikacja i aktualizacja wyników badań eratyków przeprowadzonych w Polsce Środkowej w świetle nowych danych na temat stratygrafii osadów w odkrywce „Bełchatów" (np. Balwierz i in., 2006, 2008) oraz zmian w tabeli stratygraficznej plejstocenu Polski (np. Ber i in., 2007; Lindner i Marks, 2012);

9. Analiza przydatności eratyków w badaniach stratygrafii plejstocenu wybranych regionów Polski (odróżnianie różnowiekowych osadów glacjalnych i ich korelacja);

10. Wskazanie innych możliwości wykorzystania badań eratyków w geologii. 


\section{ZAGADNIENIA TERMINOLOGICZNE}

Pojęcie eratyk (w starszych opracowaniach bywa również „erratyk”) wywodzi się z łaciny (od erraticus, tj. błądzący) i oznacza ziarno skalne (mineralne) przetransportowane i następnie odłożone przez lodowiec. W definicji eratyka mieszczą się wszystkie ziarna transportowane przez lądolód, bez względu na ich rozmiary i długość przebytej wraz z lodem drogi. W zakwalifikowaniu ziarna jako eratyka nie przeszkadza również ewentualny udział procesów fluwioglacjalnych w jego przemieszczeniu.

Nie jest jasne, kto i kiedy po raz pierwszy nazwał tak głazy, wyraźnie odróżniające się składem mineralnym i budową wewnętrzną od większości skał odsłaniających się w ich otoczeniu (występujących in situ). Nazwa funkcjonuje już ponad dwieście lat. Najczęściej jej autorstwo przypisywane jest Saussure, 1779 (fide Flint, 1971; Colgan, 2009) lub 1786 (fide Ryka i Maliszewska, 1991) ${ }^{1}$. Pierwotnie pojęcie to zostało użyte do opisu skał granitowych leżących na wapiennym podłożu w Alpach Zachodnich, interpretowanych jako przetransportowane przez wodę (fide Flint, 1971). Zaledwie rok po publikacji Saussure'a pojawiła się jednak nowoczesna interpretacja genezy eratyków jako skał przenoszonych przez lodowce - Kuhn, 1787 (fide Imbrie i Imbrie, 1979). Analogiczny pogląd zaprezentował wkrótce również Hutton (1795). Ten sam termin stosuje się niekiedy w odniesieniu do skał, które zostały przetransportowane i odłożone przez inny czynnik, aniżeli odpowiedzialny za powstanie otaczających je obecnie osadów (Hawkes, 1951; Noe-Nygaard, 1975).

W języku polskim zamiennie stosuje się również określenia „głaz narzutowy” oraz „narzutniak”, ale ich zakres pojęciowy jest ograniczony do ziaren o stosunkowo grubej frakcji (Fot. 3.1 i 3.2). Nazwy te (szczególnie pierwszą z nich) należałoby właściwie zarezerwować dla eratyków o rozmiarach powyżej $200 \mathrm{~mm}$, a stosując skalę Wentwortha (1922) nawet powyżej $256 \mathrm{~mm}$.

W odniesieniu do długości przebytej w lodzie drogi można wyróżnić eratyki bliskiego i dalekiego transportu. Pojęcia te stosowane są w sposób dość dowolny i nie ma pomiędzy nimi sprecyzowanej granicy. Skały bliskiego transportu, określane również jako lokalne, są definiowane w różny sposób. W Finlandii zalicza się do tej grupy głazy przeniesione na odległość kilkuset metrów do kilku kilometrów (Bouchard i Salonen, 1990). Podobnie definiują je Krzemiński i in. (1993), jako eratyki pochodzące z wychodni podczwartorzędowych zlokalizowanych w bliskim sąsiedztwie. Autorzy unikają jednak precyzyjnego stwierdzenia, co oznacza bliskie sąsiedztwo. Ponadto przytoczona przez nich definicja wyklucza spośród skał bliskiego transportu eratyki przywleczone przez starsze nasunięcia glacjalne i złożone wśród osadów czwartorzędowych, a następnie powtórnie inkorporowane przez transgredujący lądolód. Podejście takie jest przynajmniej częściowo uzasadnione, ponieważ nie ma prawie żadnej możliwości odróżnienia

\footnotetext{
${ }^{1}$ Rozbieżność w datach wynika z faktu, że dzieło Saussure'a ukazało się w ośmiu tomach wydawanych w latach 1779-1796; pojęcie eratyk pojawiło się w tomie drugim, datowanym na rok 1786.
} 
ich od skał przywleczonych bezpośrednio (w jednym cyklu glacjalnym) z Fennoskandii. Szersza definicja skał lokalnych, przedstawiona również przez Krzemińskiego i in. (op. cit.) mówi jedynie, że skały te nie pochodzą ze Skandynawii. Jest to jednak definicja z założenia myląca, ponieważ jej dosłowna interpretacja każe zaliczać do skał lokalnych skały fińskie i bałtyckie (wywodzą się spoza obszaru Skandynawii).

Część badaczy rozróżnia aż trzy kategorie eratyków ze względu na długość transportu glacjalnego, np. Astapova (1983, 1993), Gába (2001), Schulz (2003), Hanáček i Nývlt (2009). Idea tego podziału polega na tym, że skały bliskiego transportu i skały lokalne nie są traktowane jako synonimy, lecz przypisuje się im odmienne znaczenie. Jako eratyki lokalne Schulz traktuje skały pochodzące z bezpośredniego podłoża osadów glacjalnych, np. porfiry czerwonego spągowca na obszarze Średniogórza Niemieckiego, tj. skały, których droga transportu była bardzo krótka - kilkaset metrów do kilku kilometrów. Eratykami bliskiego transportu w jego rozumieniu miałyby być klasty kredy piszącej z Rugii na obszarze Pomorza Przedniego w Niemczech, czyli przeniesione na odległość kilkudziesięciu do stu kilkudziesięciu kilometrów (Schulz, 2003). Bardzo podobna jest interpretacja Gáby (2001) oraz Hanáčka i Nývlta (2009) odnosząca się do Czech. Jako eratyki bliskiego transportu potraktowane zostały przez nich skały z polsko-czeskiego pogranicza oraz polskiej części Sudetów i Przedgórza Sudeckiego (Dolny Śląsk i częściowo Górny Śląsk). Jak we wszystkich tego rodzaju podziałach, zabrakło tu konkretnej długości drogi transportu, granicznej dla eratyków lokalnych i bliskiego transportu. Jeszcze mniej precyzyjny podział zaproponowała Astapova (1983, 1993), która wyróżniała eratyki dalekiego transportu, tranzytowe i lokalne. Analogiczne wyróżnienia zastosowała również Andreicheva (1992, 2012). Tego typu klasyfikacja mogła wynikać ze skrajnie uproszczonego podziału obszaru zajętego przez lądolód na strefę alimentacji (erozji podłoża), transportu i depozycji materiału skalnego w osadach glacjalnych. Zmienny zasięg tych trzech stref w czasie właściwie uniemożliwia praktyczne zastosowanie proponowanego podziału eratyków na obszarze Polski, a i dla wschodniej Europy wydaje się być co najmniej dyskusyjny.

Poważny problem w zaklasyfikowaniu eratyków do jednej z grup, wyróżnianych na podstawie długości transportu, stanowi rozległość obszaru badań, przeprowadzonych przez autora. Osady glacjalne analizowane były od okolic Jeleniej Góry na południu, aż po rejon Władysławowa na północy i od doliny Bugu na wschodzie po dolinę Bobru na zachodzie. Klast skały występującej in situ w dnie Zatoki Gdańskiej, znaleziony w osadach na Pomorzu lub Dolnym Powiślu bez większych wątpliwości mógł zostać zaklasyfikowany do eratyków lokalnych, ale identyczny klast zidentyfikowany w glinach Dolnego Śląska lub Lubelszczyzny nie spełniał już podstawowego warunku, jakim jest krótka droga transportu. Dla ujednolicenia procedury badawczej w niniejszym opracowaniu przyjęto jednak, że do skał lokalnych (synonimicznie - bliskiego transportu) należą wszystkie osadowe skały mezozoiczne i kenozoiczne, których obszarem alimentacyjnym była środkowa i północna Polska oraz dno południowego Bałtyku, jak również wszystkie skały bloku dolnośląskiego, orogenu karpackiego i trzonu paleozoicznego Gór Świętokrzyskich. 


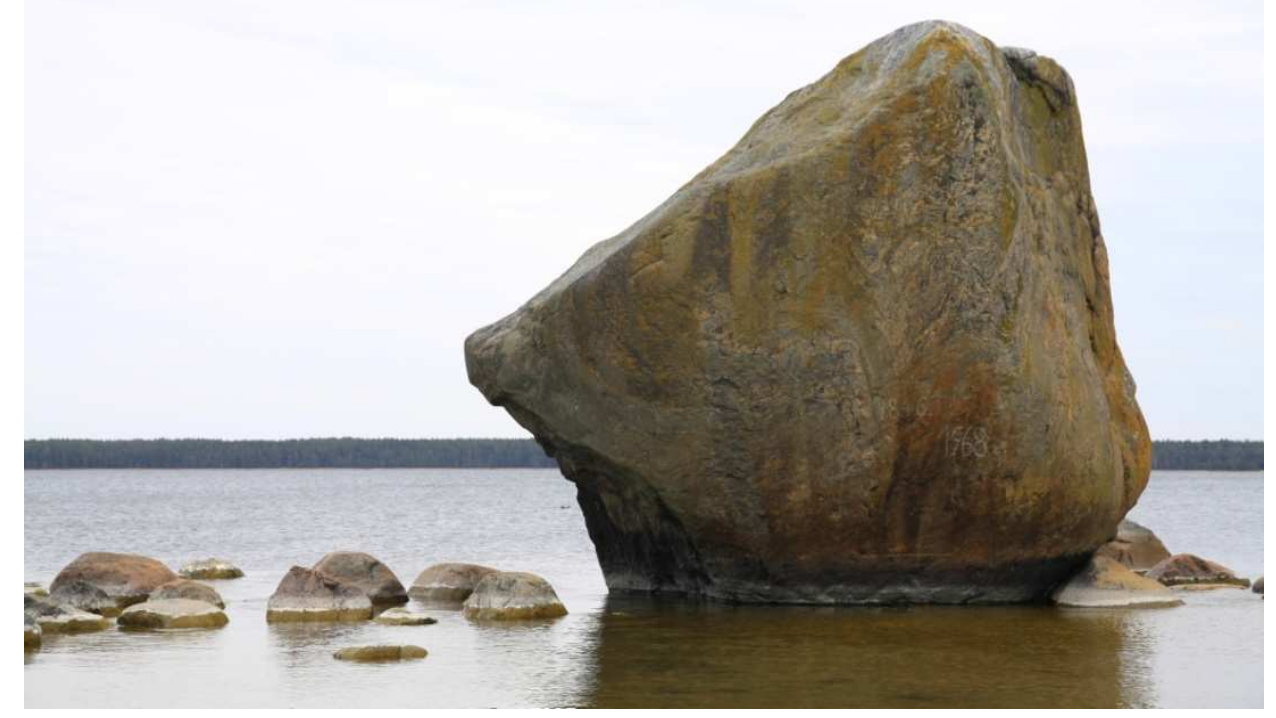

Fot. 3.1. Głazy narzutowe na wybrzeżu Estonii; fot. P. Czubla 2012

Photo 3.1. Erratic boulders on the coast of Estonia. Photo P. Czubla 2012

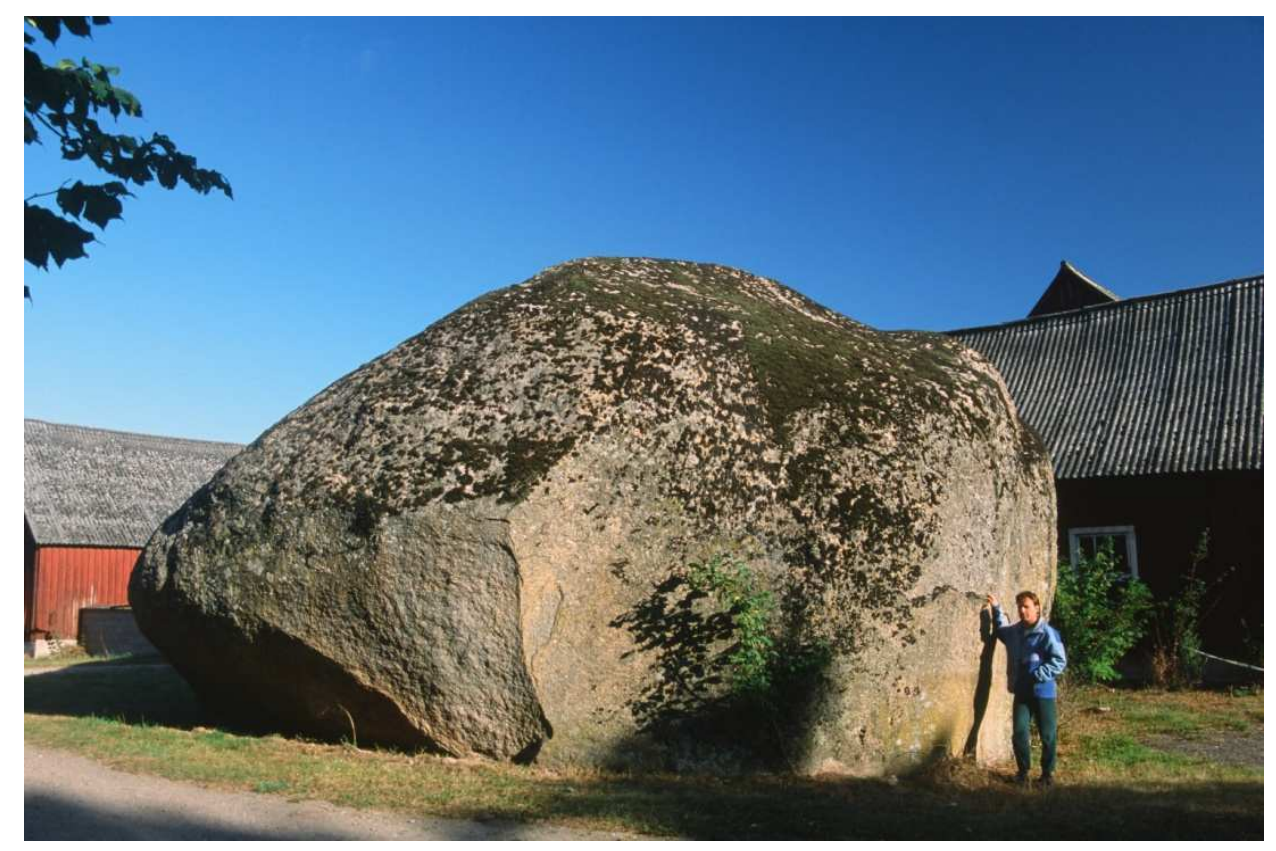


Do eratyków dalekiego transportu zostały w niniejszym opracowaniu zaklasyfikowane pochodzące z Fennoskandii i dna Bałtyku skały krystaliczne oraz paleozoiczne skały osadowe. Są one określane jako skały fennoskandzkie, nordyckie lub północne. Nordyckie skały osadowe starszego paleozoiku reprezentują płytsze facje, aniżeli ich odpowiedniki pochodzące z Gór Świętokrzyskich, co znacznie zmniejsza prawdopodobieństwo błędnej identyfikacji. Możliwość nieprawidłowego zaklasyfikowania skał krystalicznych była ograniczona właściwie tylko do stanowisk na Dolnym Śląsku, ponieważ jedynie tam w osadach glacjalnych występowały razem magmowe i metamorficzne skały sudeckie i fennoskandzkie. Na pozostałych obszarach badawczych wszystkie skały krystaliczne należy, z założenia, zaliczać do skał fennoskandzkich.

Szczególną rolę wśród skał dalekiego transportu pełnią eratyki przewodnie (niem. "Leitgeschiebe”, ang. „indicator boulders”, „indicator erratics”, „indicator pebbles”, szwedz. i duń. „ledeblokke”, niderl. „gidsgesteenten”, est. „juhträndkivid”, łot. „vadošie laukakmeni", lit. "vedamieji rieduliai”, ros. „руководящие валуны”, fiń. "siirtolohkareet”, czesk. „vưdčí nordické souvky”, franc. "roches guide”), czyli skały o znanej i ściśle określonej wychodni w strefie zasilania lądolodu. Po raz pierwszy powyższy termin został użyty przez Milthersa (1909) w mylnym przekonaniu, że eratyki północne w osadach czwartorzędowych mogą pełnić rolę podobną do skamieniałości przewodnich. Nazwa niemal od początku budziła kontrowersje, ponieważ poprzez analogię ze skamieniałościami przewodnimi sugerowała możliwość bezpośredniego wyznaczania poziomów stratygraficznych, podczas gdy w rzeczywistości eratyki przewodnie służyły głównie do określania kierunków napływu mas lodowych (por. Hucke, 1926).

Eratyki przewodnie powinny być jednoznacznie oznaczalne makroskopowo (m.in. Meyer i Lüttig, 2007). Istotne jest również, aby często występowały w osadach glacjalnych. Skały nawet wyjątkowo charakterystyczne i łatwo rozpoznawalne, ale występujące bardzo rzadko, np. kullait lub mienit (impaktyt) opisany przez Hesemanna (1975), a znaleziony tylko kilkukrotnie poza swoją wychodnią w południowej Szwecji

$\leftarrow$ Fot. 3.2. Głaz narzutowy Trollastenen, znany też jako Maglestenen koło Bäckashog w Skanii; granit ze wschodniego Smålandu uważany za dropstone ${ }^{2}$ o objętości wg różnych źródeł albo $140 \mathrm{~m}^{3}$, albo $325 \mathrm{~m}^{3}$. W otoczeniu brak glin, a obecne są jedynie piaski i muły, co potwierdza sugerowaną genezę; fot. P. Czubla, 2003

Photo 3.2. Trollastenen erratic boulder, also known as Maglestenen near Bäckashog in Skåne; East Småland granite, considered to be a dropstone with a volume of $140 \mathrm{~m}^{3}$ or $325 \mathrm{~m}^{3}$ (according to various sources). In the surroundings there are no glacial tills; sands and silts are present only, what confirms the suggested origin. Photo P. Czubla, 2003

\footnotetext{
${ }^{2}$ Dropstone jest to klast o odmiennych od otoczenia rozmiarach i/albo litologii, umiejscowiony w osadzie dzięki transportowi w kierunku pionowym lub ukośnym (Bennett i in., 1996). Jego transport wymagał odmiennych warunków, aniżeli te, które zadecydowały o powstaniu otaczających go osadów. Najbardziej typowy przykład stanowią dropstone'y glacjalne (eratyki), które zostały uwolnione z kier lub gór lodowych (topniejących na powierzchni morza lub jeziora) i następnie opadły na dno zbiornika w drobnoziarniste osady. Liczne dropstone'y autor obserwował w iłach warwowych w odkrywce KWB „Bełchatów”. Dropstone’y o innej genezie (gastrolity, bomby wulkaniczne, kamienie wypłukane spomiędzy korzeni dryfujących drzew) występują znacznie rzadziej.
} 
(Meyer, 1987; Verhaard, 2005; Förster, 2006), nie nadają się do wykorzystania w charakterze eratyków przewodnich (por. Schuddebeurs, 1980/1981). Uznanie konkretnych typów skał za eratyki przewodnie może być dyskusyjne. Dotyczy to przede wszystkim skał o rozległych wychodniach - często złożonych z kilku izolowanych części, jak np. norweskie porfiry rombowe (Oftedahl, 1981; Smed, 2002). Wątpliwości występują również w przypadku skał o znacznie mniejszych wychodniach, ale często wykształconych nietypowo bądź występujących w odmianach przejściowych do innych skał. Te ostatnie winny być wykluczone spośród eratyków przewodnich, ponieważ ich identyfikacja może mieć charakter subiektywny.

Równolegle do eratyków przewodnich usiłowano upowszechnić inne pojęcie: eratyki homochroniczne (niem. homochrone Geschiebe) - Sauramo, 1909 (fide Hesemann, 1960). Definiowano je jako eratyki, które „w tej samej fazie zostały przetransportowane z wychodni na obecne miejsce i mogą być wykorzystane do pionowego podziału plejstocenu" (Hucke, 1926). Taką funkcję miały pełnić na ograniczonym obszarze narzutniaki rud miedzi (Sauramo, 1924). Milthers (1936, 1939) usiłował tę rolę przypisać brunatnemu porfirowi bałtyckiemu w osadach lądolodu warty, ale w nowszych badaniach nie znalazło to potwierdzenia. Do dziś nie udało się wytypować ani jednego rodzaju skały, która mogłaby zostać potraktowana jako eratyk homochroniczny. Woldstedt (1935) nie wykluczał istnienia eratyków homochronicznych, ale zakładał możliwość pełnienia takiej funkcji raczej przez pewien zespół eratyków, aniżeli przez pojedynczy typ skały. W świetle współczesnych poglądów na dynamikę lądolodu fennoskandzkiego istnienie narzutniaków homochronicznych wydaje się jednak być wykluczone.

W badaniach frakcji żwirowej i głazowej osadów glacjalnych wykorzystywane są również skały o bardzo dużych wychodniach, niekiedy rozdzielonych na kilka znacznie od siebie oddalonych części. Ich pochodzenie (obszar źródłowy) można wprawdzie oznaczyć, lecz ze znacznie mniejszą dokładnością, aniżeli jest to możliwe w przypadku skał przewodnich. Smed (1993, 1994, 2002) określał je jako eratyki statystyczne, ale zamiast zdefiniować (i doprecyzować) to pojęcie, przytoczył tylko przykładowe skały należące do tej grupy, tj. amfibolity i paleozoiczne wapienie. Ich obecność może wspierać wnioski wysnute w oparciu o analizę eratyków przewodnich, ale samodzielnie nie mogą one stanowić podstawy do wyciągania wniosków paleogeograficznych lub stratygraficznych. Eratyki statystyczne były również wyróżniane przez polskich autorów, m.in. Górska, 2000; Czubla, 2001; Górska-Zabielska, 2008; Górska-Zabielska i Zabielski, 2011; Górska-Zabielska i Wachecka-Kotkowska, 2014 (Górska proponowała także nazywać je wskaźnikowymi). Należy jednak zgodzić się z opinią Meyera i Lüttiga (2007), że stosowanie tego pojęcia jest błędne metodycznie, ponieważ wszystkie eratyki podlegają w ramach badań procedurom statystycznym, a prezentowana grupa jest nawet mniej istotna statystycznie od typowych eratyków przewodnich. W związku z tym zamiast o eratykach statystycznych należy, zdaniem autora, mówić o eratykach pomocniczych. Pełnią one analogiczną rolę do wyróżnianych przez Gaigalasa i Gudelisa (1965) drugorzędnych skał przewodnich i skał towarzyszących. 
Eratyki przewodnie i pomocnicze określane są w niniejszym opracowaniu jako skały (eratyki) wskaźnikowe. Zachowano dla nich tradycyjne, lokalne nazwy skandynawskie, które w znaczącej części są niezgodne z regułami nazewnictwa przyjętymi i upowszechnianymi przez Międzynarodową Unię Nauk Geologicznych (IUGS). Współczesna klasyfikacja i nazewnictwo skał magmowych opierają się głównie na składzie mineralnym, a kryteria teksturalne i genetyczne mają znaczenie drugorzędne (Le Maitre i in., 1989; Le Maitre, 2004). Nowy schemat klasyfikacyjny został opracowany również dla skał metamorficznych (Fettes i Desmons, 2007), ale nie uzyskał on jeszcze powszechnej akceptacji i nie znalazł zastosowania w analizach eratyków. Pochodzenie skały z konkretnego stanowiska nie ma w nowoczesnej klasyfikacji skał żadnego znaczenia, podczas gdy w badaniach eratyków wskaźnikowych jest to informacja podstawowa o wiele istotniejsza od tego, czy analizowana skała jest na przykład fonolitem lub bazanitem. Zaklasyfikowanie eratyka do odpowiedniej grupy i nadanie mu prawidłowej nazwy petrologicznej w oparciu wyłącznie o cechy rozpoznawalne makroskopowo jest najczęściej niemożliwe. Niektóre skały przewodnie, opisywane jako granity, w rzeczywistości nimi nie są, lecz reprezentują inne rodzaje granitoidów, np. granodioryty lub granity alkaliczne, a zdarzają się wśród nich nawet skały uboższe w krzemionkę (pośrednie), jak np. syenitoidy lub monzonity. Na dodatek, w opracowaniach poświęconych eratykom przewodnim, skandynawskie nazwy lokalne są od wielu lat powszechnie stosowane i jednoznacznie rozumiane (np. Cohen i Deecke, 1892, 1896; Eskola, 1927; Korn, 1927; Hesemann, 1936, 1975; Lüttig, 1958; Gudelis, 1971; Smed, 1994, 2002; Zandstra, 1999; Górska, 2000; Czubla, 2001; Schulz, 2003; Gałązka, 2004b; Czubla i in., 2006; Górska-Zabielska, 2008; Rudolph, 2008a, 2008b). W związku z tym nie należy - zdaniem autora - wprowadzać do badań eratyków nowej nomenklatury, która nie usprawniłaby procedury badawczej, a wręcz przeciwnie - utrudniłaby prawidłową interpretację danych źródłowych. Zbliżoną opinię reprezentują również inni badacze eratyków w Polsce (Górska, 2000; Gałązka, 2004b). Wyjątek stanowiło odstąpienie w niniejszej pracy od stosowania nazwy porfiryt, odnoszącej się do skał o teksturze porfirowej, zawierających wśród fenokryształów skaleni same lub prawie same plagioklazy. Ryka i Maliszewska (1991) definiują porfiryt jako skałę wulkaniczną o składzie diorytu i od razu zastrzegają, że jest to nazwa zasadniczo już nieużywana. Zamiast niej w opracowaniu stosowana jest najogólniejsza możliwa nazwa teksturalna, tj. porfir, np. porfir Grönklitt zamiast „porfirytu Grönklitt”. Przedstawiona interpretacja nazewnictwa pozwoliła zachować tradycyjne nazwy związane z lokalizacją obszarów źródłowych eratyków przewodnich bez podtrzymywania błędnej nazwy petrograficznej.

Od czasu upowszechnienia się koncepcji strumieni lodowych brakuje jednoznacznego określenia dla indywidualnych mas lodu, przemieszczających się ku strefom marginalnym lądolodu, ale z prędkością nieodbiegającą od sąsiednich mas lodowych. Nie ma też jednoznacznych przesłanek, które pozwoliłyby interpretować lądolody fennoskandzkie starsze od vistuliańskich w świetle modelu strumieniowego. W związku z tym pojęcie strumień lodowy będzie w niniejszej pracy używane tylko zgodnie z definicją zaproponowaną przez Swithinbanka (1954) z późniejszymi modyfikacjami 
(np. Bennett, 2003; Kleman i Glasser, 2007) i w odniesieniu wyłącznie do ostatniego lądolodu fennoskandzkiego. Prąd lub potok lodowy będzie natomiast rozumiany jako masa lodu, poruszająca się w obrębie lądolodu zgodnie z prędkością otoczenia, a różniąca się od sąsiednich potoków co najwyżej składem transportowanego materiału morenowego. Jest to definicja zgodna z praktyką Mojskiego, który używa określenia potok lodowy do opisu wyników badań petrograficznych (2005). Autor ma świadomość, że proponowany sposób stosowania tych pojęć jest nie do końca właściwy, ponieważ prąd lodowy został po raz pierwszy użyty w języku polskim (Nechay, 1927a) w znaczeniu, które dzisiaj przypisujemy strumieniom lodowym. Pierwszeństwo w nazewnictwie musi jednak tym razem ustąpić utrwalonej już i powszechnej praktyce językowej. 


\section{METODYKA BADAŃ}

\subsection{Stanowiska badawcze}

Realizacja założonych celów badawczych wymagała przeprowadzenia badań terenowych zarówno wzdłuż linii równoległej do strefy marginalnej lądolodów fennoskandzkich, jak i w przybliżeniu prostopadłej do niej. Do badań wytypowane zostały cztery główne obszary, w których zlokalizowane były duże odsłonięcia naturalne lub sztuczne, niezbędne do poboru odpowiednio licznych prób materiału szkieletowego z glin morenowych. Przeanalizowano skład osadów glacjalnych na Dolnym Śląsku, Podlasiu oraz w pasie ciągnącym się od Pomorza Gdańskiego po Kujawy, Polskę Środkową i wschodnią Wielkopolskę. Wykorzystano również stanowiska opracowane w trakcie wcześniejszych badań, ograniczonych przestrzennie do Polski Środkowej (m.in. Czubla, 1998, 2001, 2006; Czubla i Forysiak, 2004), ale wszystkie pozyskane wówczas dane zostały zweryfikowane i dostosowane do procedury badawczej przyjętej w niniejszym opracowaniu. Ze względu na zbyt skromne ujęcie we wcześniejszych badaniach osadów vistulianu konieczne było szersze uwzględnienie osadów glacjalnych tego wieku w prezentowanej pracy. W tym celu wybrano szereg odsłonięć zlokalizowanych na Kujawach, Powiślu, Kaszubach i Pomorzu Gdańskim. Dla prześledzenia zmienności składu frakcji szkieletowej osadów glacjalnych w przekroju równoległym do czoła lodowca przeprowadzono badania na Dolnym Śląsku, w Polsce Środkowej oraz na Podlasiu i Lubelszczyźnie (rys. 4.1). Dzięki takiemu doborowi stanowisk badawczych przeanalizowano obszary powierzchniowego występowania wszystkich trzech kompleksów (sensu Ber i in., 2007) wyróżnianych w glacjalnym plejstocenie Polski. W sumie badania przeprowadzono w 60 stanowiskach, w których pobrano ogółem 138 prób (tab. 4.1).

Tabela 4.1. Stanowiska badawcze

Table 4.1. Research sites

\begin{tabular}{|c|l|c|c|}
\hline Obszar badawczy & \multicolumn{1}{|c|}{ Stanowisko } & Symbol & Liczba próbek \\
\hline 1 & \multicolumn{1}{|c|}{2} & 3 & 4 \\
\hline \multirow{5}{*}{$\begin{array}{l}\text { Pomorze, Kaszuby, } \\
\text { Powiśle i Kujawy }\end{array}$} & Barcin & Bar & 1 \\
\cline { 2 - 4 } & Babie Doły & BD & 3 \\
\cline { 2 - 4 } & Brody Pomorskie & Dęb & 1 \\
\cline { 2 - 4 } & Dębina & DębN & 1 \\
\cline { 2 - 4 } & Dębówko Nowe & Du & 1 \\
\cline { 2 - 4 } & Dulsk & Gn & 2 \\
\cline { 2 - 4 } & Gnieżdżewo & Gni & 1 \\
\cline { 2 - 4 } & Gniszewo & GnMł & 2 \\
\cline { 2 - 4 } & Gniewskie Młyny & GnP & 1 \\
\cline { 2 - 4 } & Gniew - Prom i Piaskownia & \multicolumn{2}{|c|}{3} \\
\hline
\end{tabular}


Tabela 4.1 (cd.)

\begin{tabular}{|c|c|c|c|}
\hline 1 & 2 & 3 & 4 \\
\hline \multirow{18}{*}{$\begin{array}{l}\text { Pomorze, Kaszuby, } \\
\text { Powiśle i Kujawy }\end{array}$} & Grubno & Gru & 1 \\
\hline & Kartoszyno & Kart & 5 \\
\hline & Kozłowo & Koz & 3 \\
\hline & Kuczek & $\mathrm{Ku}$ & 1 \\
\hline & Młodocin & Mło & 1 \\
\hline & Nieszawa & Nies & 3 \\
\hline & Nowe nad Wisłą & Nowe & 2 \\
\hline & Obórki & $\mathrm{Ob}$ & 1 \\
\hline & Orłowo & Ort & 6 \\
\hline & Osłonino & Osl & 3 \\
\hline & Ostrowo Zachód & Ostr-W & 1 \\
\hline & Otmianowo & Otm & 1 \\
\hline & Puck & $\mathrm{Pu}$ & 3 \\
\hline & Sampława & Samp & 1 \\
\hline & Wapienno & Wap & 6 \\
\hline & Wiąg & $\mathrm{Wi}$ & 1 \\
\hline & Wyrzysk & Wyrz & 1 \\
\hline & Żelazo & Żel I & 1 \\
\hline \multirow{5}{*}{ Dolny Śląsk } & Brodowice & Brod & 1 \\
\hline & Janowice Wielkie & JanWlk & 1 \\
\hline & Mokrzeszów & Mok & 1 \\
\hline & Rusko & $\mathrm{Ru}$ & 3 \\
\hline & Zachowice & Zach & 1 \\
\hline \multirow{20}{*}{$\begin{array}{l}\text { Polska Środkowa } \\
\text { ze wschodnią } \\
\text { Wielkopolską }\end{array}$} & Bełchatów & Bełch & 20 \\
\hline & Besiekierz & Bes & 1 \\
\hline & Brzeziny-Paprotnia & $\mathrm{Br}$ & 1 \\
\hline & Chociw & Cho & 1 \\
\hline & Daniszewice & Dan & 1 \\
\hline & Gostynin-Lisica & G & 2 \\
\hline & Kleczew & $\mathrm{KI}$ & 4 \\
\hline & Koźmin i Koźmin-Północ & Ko & 12 \\
\hline & Kruszów & $\mathrm{Kr}$ & 1 \\
\hline & Lewkówka & Lewk & 1 \\
\hline & Łazy Duże & Łazy & 1 \\
\hline & Łódź & Łódź & 2 \\
\hline & Łaznowska Wola & $Ł W$ & 2 \\
\hline & Masłowice & Masł & 1 \\
\hline & Mąkolice & Mąk & 1 \\
\hline & Moszczenica & Mosz & 1 \\
\hline & Siedlątków & $\mathrm{Si}$ & 3 \\
\hline & Smulsko & Sm & 6 \\
\hline & Tum & Tum & 1 \\
\hline & Warka & War & 1 \\
\hline
\end{tabular}


Tabela 4.1 (cd.)

\begin{tabular}{|l|l|c|c|}
\hline \multicolumn{1}{|c|}{1} & \multicolumn{1}{|c|}{2} & 3 & 4 \\
\hline \multirow{4}{*}{$\begin{array}{l}\text { Podlasie } \\
\text { i Lubelszczyzna }\end{array}$} & Huta Radoryska & HR & 2 \\
\cline { 2 - 4 } & Kaczory & Kacz & 1 \\
\cline { 2 - 4 } & Kolonia Domaszewska & KD & 2 \\
\cline { 2 - 4 } & Kocianów & Koc & 1 \\
\cline { 2 - 4 } & Mielnik & Mi & 2 \\
\cline { 2 - 4 } & Neple & Ne & 2 \\
\cline { 2 - 4 } & Wólka Zagórna (Kózki) & WZag & 1 \\
\hline
\end{tabular}

* wszystkie tabele w opracowaniu własnym autora.

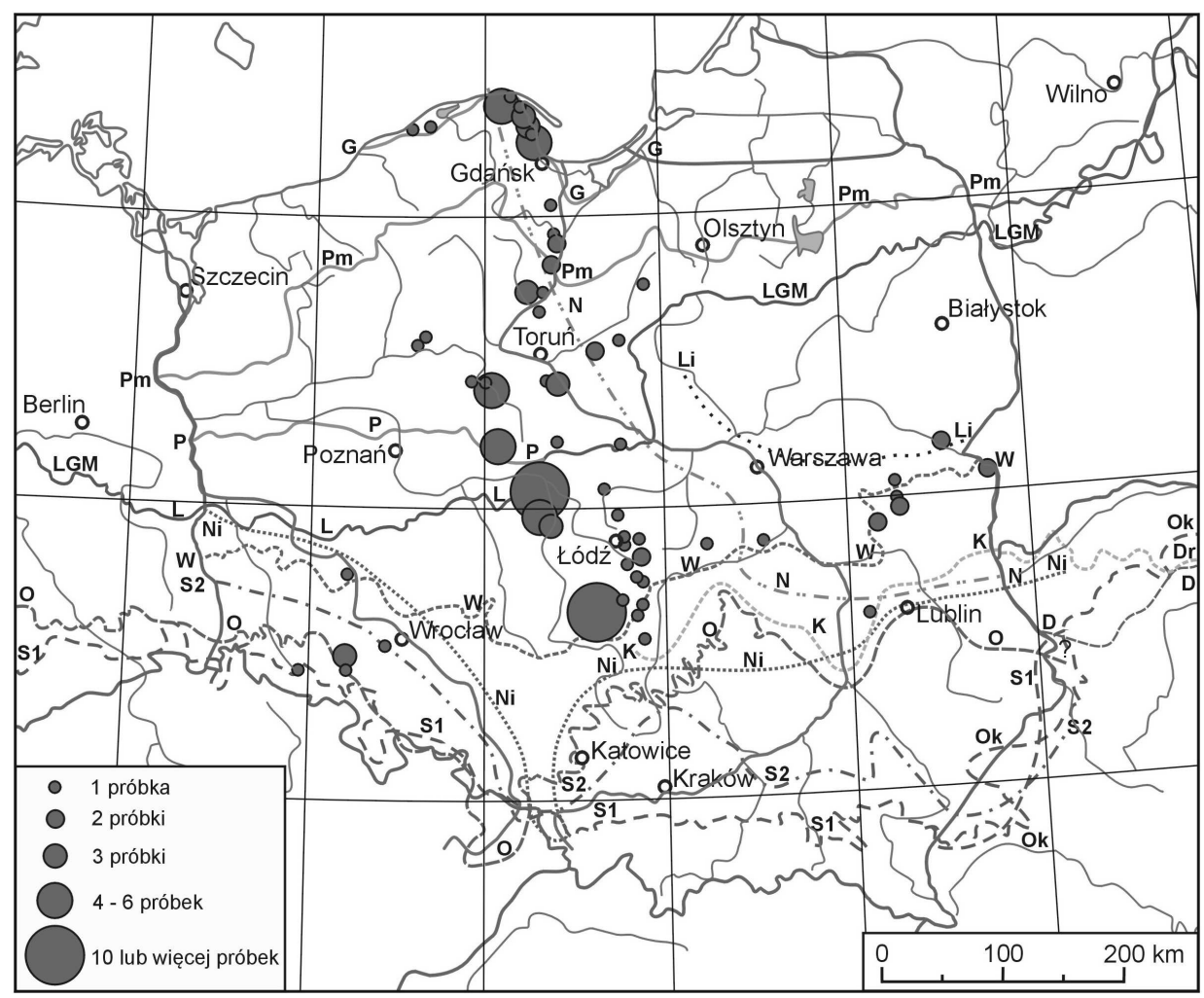

Rys. 4.1. Rozmieszczenie stanowisk badawczych na tle zasięgów zlodowaceń (zasięgi zlodowaceń wg Lindner i in., 2013; Ehlers i in., 2011; Karabanov i in., 2004; Marks, 2011; Matoshko, 2011 (Ukraina) - uproszczone i uzupełnione): $\mathrm{N}$ - narew, $\mathrm{Ni}$ - nida, S1 - san 1, Ok - oka, S2 - san 2, Li - liwiec, K - krzna, O - odra, D - dniepr, Dr - recesja dniepru, W - warta, LGM - maksymalny zasięg lądolodu wisły, L - faza leszczyńska, P - faza poznańska, Pm - faza pomorska, G - faza gardnieńska

Figure 4.1. Location of the research sites against the glacial limits (ice-sheets extents according to Lindner et al., 2013; Ehlers et al., 2011; Karabanov et al., 2004; Marks, 2011; Matoshko, 2011 (Ukraine) - simplified and supplemented): N - Narevian, Ni - Nidanian, S1 - Sanian 1, Ok - Okian, S2 - Sanian 2, Li - Liwiecian, K - Krznanian, O - Odranian, D - Dnieperian, Dr - Dnieperian recession, W - Wartanian, LGM - Last Glacial Maximum (Weichselian), L - Leszno (Brandenburg) Phase, P - Poznań (Frankfurt) Phase, Pm - Pomeranian Phase, G - Gardno Phase 
Przy doborze stanowisk kierowano się przede wszystkim możliwością poboru w jednym profilu prób z osadów glacjalnych różnego wieku. Ten warunek spełniały przede wszystkim kopalnie kruszyw naturalnych, surowców ceramicznych i węgla brunatnego oraz nadmorskie klify. W znacznej części przebadanych stanowisk warunki były jednak zdecydowanie mniej sprzyjające i możliwe było opróbowanie tylko jednego poziomu gliny morenowej. Ze względu na olbrzymi nakład pracy i konieczność użycia ciężkiego sprzętu tylko w wyjątkowych wypadkach wykonywano wkopy specjalnie na potrzeby prowadzonych badań. Pobór odpowiednio licznej próby eratyków wymagał dokładnego przebrania kilku metrów sześciennych gliny. Z tego względu wykluczone było wykorzystanie materiału wiertniczego.

\subsection{Litologia opróbowywanych osadów}

Typ genetyczny osadów badanych metodami litostratygraficznymi stanowi nadal przedmiot gorących dyskusji. Badania eratyków frakcji żwirowej i głazowej prowadzone były przez różnych autorów w oparciu o materiał bardzo zróżnicowanego pochodzenia. Przegląd argumentów przeciwko pobieraniu prób eratyków ze żwirów plażowych, bruków erozyjnych lub pryzm kamieni zebranych z pól, co w przeszłości było powszechnie stosowaną praktyką (np. Milthers, 1909; Hesemann, 1930; Konieczny, 1956; Groetzner, 1972; Astapova, 1987), został zaprezentowany w innych pracach autora (Czubla, 1999a, 2001). Ten sposób pozyskiwania materiału do badań przeszedł już na szczęście do historii. Analizy frakcji żwirowej prowadzono zarówno w osadach typowo glacjalnych, jak i fluwioglacjalnych (Richter, 1933; Vijding, 1957; Groetzner, 1972; Ehlers, 1979; Gałązka, 2004b). Również i współcześnie są zwolennicy traktowania prób pobranych z osadów fluwioglacjalnych jako równie miarodajnych, jak pozyskane z glin morenowych, np. Hoffmann i Meyer (1997, 1999), Górska (2000, 2003a, 2006), Lüttig (2005), Górska i Zabielski (2006), Górska-Zabielska (2007a, 2008, 2010), Ratajczak (2007), Rutkowski (2007), Lipka (2011). Dyskusja poglądów na temat wyboru typu litogenetycznego osadów do badań petrograficznych była już wielokrotnie prezentowana w literaturze (m.in. Nunberg, 1971; Puranen, 1990; Górska, 2000; Czubla, 2001; Górska-Zabielska, 2008). W ostatniej przywoływanej pracy podkreślana jest duża zbieżność wyników analiz petrograficznych przeprowadzonych w osadach glacjalnych i fluwioglacjalnych, ale z zastrzeżeniem, że „może wyniki te mają charakter przypadkowy z uwagi na niewielką liczbę przeprowadzonych analiz" (str. 44). Do tego należałoby dołączyć zbyt małą liczebność analizowanych zespołów eratyków. W żadnej spośród 6 prób pobranych z diamiktonów nie udało się autorce zidentyfikować minimalnej liczby 50 eratyków przewodnich, mimo że uwzględniała również skały osadowe (piaskowce). Trochę liczniejsze były próby pobrane z osadów fluwioglacjalnych, wśród których 7 (na 54) osiągnęło tę minimalną liczbę. Z pewnością należy również zgodzić się z argumentem Górskiej-Zabielskiej (2008), że na korzyść poboru prób z osadów fluwioglacjalnych przemawia dostępność odsłonięć i znacznie ułatwiony (w stosunku do glin) pobór prób. 
Z badań Cummingsa i in. (2011) wynika jednak, że pierwotnym źródłem materiału w osadach fluwioglacjalnych (ozach) jest zazwyczaj nie twarde podłoże, lecz glina (często starsza od deponowanej przez transgredujący lądolód), a strefa rozrzutu ma charakter wtórny. W związku z tym śledzenie wskaźników glacjalnych (patrz rozdz. 13) w ozach jest czynnością dwuetapową - najpierw należy prześledzić szlak ziaren w ozie, by dotrzeć do strefy rozrzutu w glinie i dopiero na jej podstawie można dotrzeć do wychodni poszukiwanego minerału w podłożu (rys. 4.2). Oznacza to, że w osadach fluwioglacjalnych bardzo duży udział ma materiał inkorporowany w stosunkowo niewielkiej odległości od miejsca depozycji, a zatem pochodzący z odłożonych wcześniej osadów glacjalnych lub wychodni innych skał lokalnych. Potwierdzają to analizy Rdzanego (2009), który podkreśla, że zawartość skał lokalnych w osadach fluwioglacjalnych jest znacznie wyższa niż w osadach glacjalnych i niekiedy może sięgać nawet $80-90 \%$, podczas gdy w osadach glacjalnych Polski Środkowej osiąga maksymalnie około 30\% (Czubla, 2001). Negatywny wpływ na wiarygodność badań eratyków w żwirach fluwioglacjalnych wywiera bardzo głębokie (nawet ponad $100 \mathrm{~m}$ ) erodowanie podłoża przez subglacjalne wody ablacyjne (Smed, 2010). Testy kontrolne przeprowadzone przez autora w osadach fluwioglacjalnych w odkrywkach centralnej Polski (Czubla, 2001) oraz w Rusku na Dolnym Śląsku i w Hucie Radoryskiej na Podlasiu wykazały odmienny skład zespołów eratyków od stwierdzonych w tych samych stanowiskach w osadach glacjalnych. Można stąd wysnuć wniosek (zgodny zresztą z opinią Cummingsa i in., 2011), że osady fluwioglacjalne stanowią zapis co najmniej dwóch etapów transportu, których stosunek przestrzenny i czasowy jest zmienny i bardzo trudny do sprecyzowania. Dodatkowym mankamentem analiz osadów fluwioglacjalnych jest istotny wpływ sortowania gęstościowego na skład transportowanego przez wodę materiału żwirowego (m.in. Rudnicka, 1969; Nunberg, 1971, 1979).

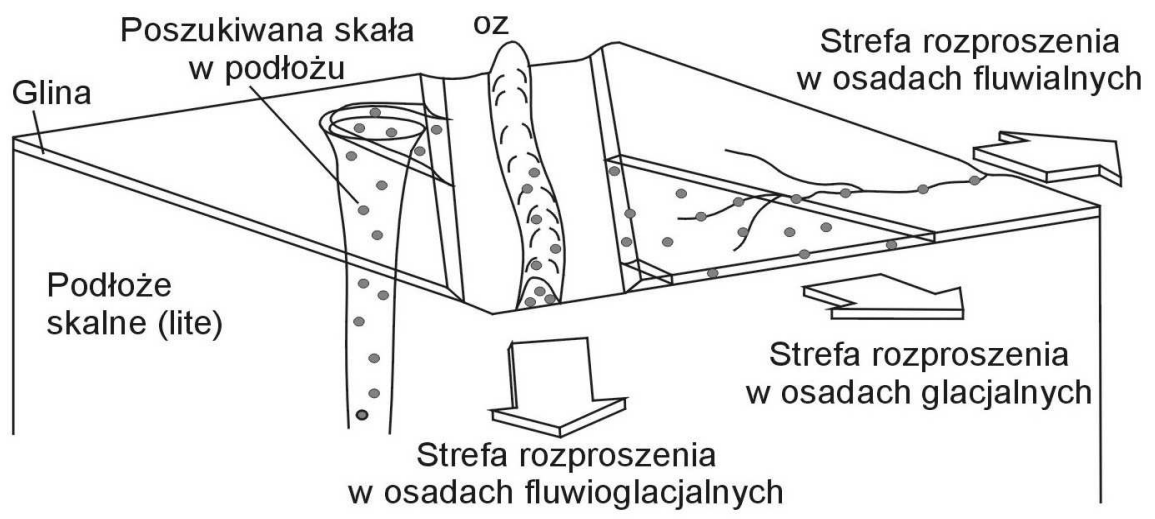

Rys. 4.2. Strefy rozproszenia skały z litego podłoża (w tym przypadku z pnia kimberlitowego) w osadach glacjalnych, fluwioglacjalnych i fluwialnych (wg Cummingsa i in., 2011; zmodyfikowany)

Figure 4.2. Dispersal trains of the bedrock fragments (in this case from diamond-bearing kimberlite pipe) in glacial, glaciofluvial (esker) and fluvial deposits (after Cummings et al., 2011; modified) 
Powyższe rozważania, wyznaczone cele badań oraz wnioski wynikające z przeglądu literatury (por. Czubla, 2001) skłoniły autora do skoncentrowania się na osadach glacjalnych. Spośród 138 przeanalizowanych prób tylko 11 pochodziło ze żwirów, 2 ze spływowych diamiktonów, pozostałe 125 zaś - z glin lodowcowych. Zgodnie z sugestią Puranena (1990) preferowane były gliny bazalne, w których dodatkowo unikano najniższej części pokładu, gdzie udział materiału lokalnego i inkorporowanego ze starszych osadów glacjalnych i fluwioglacjalnych mógł być najwyższy (por. Saarnisto, 1990).

\subsection{Frakcja badanego materiału i wielkość próby}

Obszerna analiza i dyskusja frakcji przydatnych w analizach eratyków wskaźnikowych została przedstawiona w starszych pracach autora (Czubla, 1999a, 2001). Zgodnie z ówczesnymi ustaleniami utrzymany został pobór ziaren o rozmiarach powyżej $20 \mathrm{~mm}$ bez ustalania górnej granicy. Duże głaziki o rozmiarach pięści i większe były już w terenie rozbijane, aby uzyskać świeży przełam oraz zmniejszyć ciężar próbki zabieranej do laboratorium. Z zebranych doświadczeń terenowych wynika, że odsetek głazików o rozmiarach ponad 60 lub $64 \mathrm{~mm}$, które pomija większość badaczy eratyków (z wyjątkiem Schuddebeursa, 1980/1981; Vinxa i in., 1997 i Gałązki, 2004b) jest stosunkowo nieduży. Autor podtrzymuje jednak opinię, że ustalenie górnej granicy rozmiarów pobieranych do badań eratyków, co stosują m.in. Meyer (1983), Górska (2000), Víšek i Nývlt (2006), Górska-Zabielska (2008), Lipka (2011), wyklucza z badań skały grubokrystaliczne (wyborgity, granity Revsund, Arnö, Björna), które w mniejszych ziarnach są zwykle nierozpoznawalne i w ten sposób wpływa negatywnie na końcowy wynik. Podobną opinię o negatywnym wpływie odrzucania „nadwymiarowych” klastów na wynik analiz eratyków przewodnich wyraził ostatnio również Smed (2010).

Przyjmuje się, że reprezentatywna próba powinna zawierać minimum 50 zidentyfikowanych eratyków (m.in. Meyer, 1983; Smed, 1993, 1994; Czubla, 2001). W próbach analizowanych przez autora średnia liczba rozpoznanych krystalicznych eratyków przewodnich wynosiła 57,4, a po doliczeniu piaskowców wzrosła do ponad 66. Osiągnięcie tak licznych zespołów zidentyfikowanych eratyków wymagało poboru nie mniej niż 1000 głazików z jednego analizowanego pokładu (całkowita liczebność próbki wynosiła średnio 1080 głazików). Znacznie mniejsze próbki interpretowała Górska, np. liczącą zaledwie 15 eratyków przewodnich z jednej z glin w Ujściu (2000), czy jeszcze mniejszą - 11 głazików ze żwirów w Pławnie (Górska-Zabielska, 2008). Uzyskanie odpowiednio dużej liczby eratyków przewodnich w wyjątkowo ubogich w skały nordyckie osadach zachodnich Czech wymagało poboru skrajnie dużych prób, liczących od 5000 do nawet 20000 głazików (Víšek i Nývlt, 2006). W liczącej ponad 1300 głazików próbie z diamiktonu w Janowicach Wielkich w Kotlinie Jeleniogórskiej skały nordyckie stanowiły niecałe 5\% ogólnej liczby klastów, a wśród nich udało się zidentyfikować tylko 2 eratyki przewodnie (granit Vänge i piaskowiec Hardeberga). Oznacza to, że istotna statystycznie próbka z tego stanowiska musiałaby liczyć ponad 30 tys. głazików. Szerszą dyskusję na temat wielkości próby i sposobu poboru materiału na tle poglądów prezentowanych przez licznych badaczy zawierają wcześniejsze prace autora (Czubla, 1999a, 2001). 


\subsection{Pobór próby w terenie}

Próbki pobierane były bezpośrednio ze ściany odkrywki lub klifu, tylko wyjątkowo z odspojonych bloków gliny leżących pod ścianą, pod warunkiem, że w stanowisku występowała tylko jedna warstwa gliny. Luźno leżące eratyki, bez względu na profil geologiczny stanowiska, uznawane były za nieprzydatne do badań. Zawartość frakcji żwirowej w glinach lodowcowych w Polsce jest bardzo niska. W odkrywce KWB „Bełchatów" udział wagowy ziaren o rozmiarach ponad $5 \mathrm{~mm}$ wahał się w granicach 0,6-4,3\% (Baraniecka i in., 1995). W okolicach Workuty na północy Rosji zawartość frakcji >1cm w glinach wynosi 5-6\% (Andreicheva, 2012), ale jest to już stosunkowo niedaleko obszarów źródłowych na Nowej Ziemi i Uralu. W literaturze nie ma szczegółowych danych odnoszących się do frakcji ponad $20 \mathrm{~mm}$, ale należy mieć świadomość, że jej udział jest kilkukrotnie mniejszy od przytoczonych powyżej. Analizy uziarnienia glin w Holandii wykazały obecność zaledwie około 25 głazików o średnicy ponad $5 \mathrm{~cm}$ w $1 \mathrm{~m}^{3}$ gliny (De Waard, 1949). Niewiele wyższą zawartość (33 do 36 sztuk w $1 \mathrm{~m}^{3}$ ) odnotował Veenstra (1963 - fide Schuddebeurs, 1980/1981). Schuddebeurs przytacza też przykład ze Zweloo, gdzie w profilu długiego na $35 \mathrm{~m}$ rowu nie znaleziono w szarej glinie ani jednego głazika o rozmiarach ponad $2 \mathrm{~cm}$. W związku z podobnie niskim udziałem frakcji grubożwirowej w osadach glacjalnych Polski, wyselekcjonowanie z gliny głazików o odpowiednich rozmiarach musiało zostać przeprowadzone bezpośrednio w terenie. Wożenie wielu ton gliny do laboratorium i jej szlamowanie było niemożliwe logistycznie.

Przed rozpoczęciem poboru eratyków konieczne było dokładne oczyszczenie powierzchni gliny z produktów wietrzenia oraz materiału deluwialnego. Dopiero wtedy można było zebrać wszystkie głaziki wystające z wybranego fragmentu ściany, po czym zdejmowane były cienkie warstewki gliny $(1-2 \mathrm{~cm})$, co pozwalało pozyskać wszystkie ziarna o rozmiarach ponad $20 \mathrm{~mm}$. Była to procedura bardzo praco- i czasochłonna. W zależności od wielkości dostępnej ściany, zawartości odpowiedniej frakcji w glinie oraz od wilgotności i spoistości osadu, pobór jednej odpowiednio licznej próby zajmował wprawionej osobie od jednego do ponad trzech dni roboczych. Podobnie uciążliwy pobór materiału relacjonują Hoffmann i Meyer (1997) z okolic Lipska, gdzie pobór jednej próby i to o liczbie eratyków przewodnich zredukowanej do zaledwie 30, zajmował również około trzech dni. Skrajnie długi czas poboru próbki (trzy dni pracy dwóch osób) podaje Lipka (2011 - str. 78) dla ubogiej w głaziki gliny w stanowisku Nowy Świat w zachodniej Polsce.

W wielu stanowiskach nie było dostępu do wody, a ziarna - zwłaszcza wybrane z glin o dużym udziale frakcji pelitowej - były oblepione drobniejszym osadem. W związku z tym końcową selekcję wielkościową ziaren przeprowadzano dopiero po dokładnym ich oczyszczeniu, już na etapie prac laboratoryjnych. 


\subsection{Analizy laboratoryjne}

Najbardziej czasochłonną część opracowania kameralnego stanowiła identyfikacja wszystkich eratyków zawartych w próbach. Wymagała ona wcześniejszego dokładnego oczyszczenia głazików z przylepionego drobniejszego osadu. Po oczyszczeniu odrzucane były klasty o rozmiarach mniejszych od wymaganego minimum $20 \mathrm{~mm}$. Selekcja wielkościowa prowadzona była przy użyciu specjalnie w tym celu wykonanego sita o okrągłych oczkach średnicy $20 \mathrm{~mm}$. Z wysortowanego materiału były wyodrębniane skały przewodnie i pomocnicze, pozostałe zaś dzielono na około 40 grup petrograficznych. W późniejszych obliczeniach, np. udziału procentowego poszczególnych grup skał, uwzględnione zostały również skały przewodnie, np. w kategorii skały krystaliczne znalazły się wszystkie eratyki przewodnich granitoidów i skał wulkanicznych. Starano się wyróżnić możliwie jak najwięcej różnych grup petrograficznych (tab. 4.2). Przyświecały temu dwa cele, tzn. poszukiwanie cech najlepiej różnicujących zespoły eratyków pochodzące z różnowiekowych osadów glacjalnych (patrz rozdz. 14) oraz umożliwienie późniejszych porównań z wydzieleniami petrograficznymi i współczynnikami stosowanymi przez innych autorów, m.in. Trembaczowski (1961, 1967), Rzechowski (1971), Böse (1979), Gałązka (2004b), Górska-Zabielska (2008).

Tabela 4.2. Grupy petrograficzne wyróżniane w trakcie analizy prób. W miarę możliwości starano się stosować ogólnie przyjęte symbole i nie wprowadzać bez potrzeby nowych (pominięto eratyki przewodnie przedstawione $w$ tab. 4.4)

Table 4.2. Groups of rocks separated in petrographical analysis. In most cases generally accepted symbols and abbreviations are used and no new ones were introduced (indicator erratics presented in Tab. 4.4 have been omitted)

\begin{tabular}{|c|c|c|}
\hline Skład wyodrębnionej grupy & Symbol & Uwagi; wybrane cechy diagnostyczne \\
\hline 1 & 2 & 3 \\
\hline Skały lokalne & Lk & $\begin{array}{l}\text { W obliczeniach skały lokalne liczono } \\
\text { w dwóch wariantach, tzn. albo włączając } \\
\text { do nich krzemienie i czerty, albo traktując } \\
\text { je jako samodzielną grupę }\end{array}$ \\
\hline $\begin{array}{l}\text { Wapienie mezozoiczne i kenozoiczne, } \\
\text { margle, opoki wapniste }\end{array}$ & $\mathbf{W}_{\mathrm{m}-\mathrm{k}}$ & $\begin{array}{l}\text { Zwykle bardziej miękkie (słabiej zdiagene- } \\
\text { zowane) od paleozoicznych skał węglano- } \\
\text { wych }\end{array}$ \\
\hline Piaskowce mezozoiczne i kenozoiczne & $\mathbf{P}_{\mathrm{m}-\mathrm{k}}$ & Ujęto także wapniste piaskowce i zlepieńce \\
\hline $\begin{array}{l}\text { Mułowce i drobnoziarniste piaskowce } \\
\text { wapniste, gezy, opoki }\end{array}$ & & $\begin{array}{l}\text { Kredowe i kenozoiczne, często zawierają } \\
\text { ziarna glaukonitu, niektóre przesycone } \\
\text { krzemionką }\end{array}$ \\
\hline Konkrecje żelaziste & $\mathrm{K}_{\mathrm{Fe}}$ & $\begin{array}{l}\text { Włącznie z syderytami ilastymi, czesść może } \\
\text { mieć charakter wtórny (powstała w osa- } \\
\text { dzonej już glinie) }\end{array}$ \\
\hline Konkrecje pirytowe i markasytowe & $\mathrm{K}_{\mathrm{FeS2}}$ & Większość ma zapewne charakter wtórny \\
\hline Węgiel brunatny & $\mathbf{L}$ & $\begin{array}{l}\text { W północnej Polsce bardzo rzadki, wszę- } \\
\text { dzie zawartość uzależniona głównie od } \\
\text { stosunku poziomu morenowego do podło- } \\
\text { ża, a nie od pozycji stratygraficznej gliny }\end{array}$ \\
\hline
\end{tabular}


Tabela 4.2 (cd.)

\begin{tabular}{|c|c|c|}
\hline 1 & 2 & 3 \\
\hline Bursztyn & & $\begin{array}{l}\text { Występuje sporadycznie w osadach glacjal- } \\
\text { nych; łatwo rozpoznawalny w oparciu } \\
\text { o małą twardość i niewielki ciężar właści- } \\
\text { wy }\end{array}$ \\
\hline Kwarc żyłowy z Dolnego Śląska & & $\begin{array}{l}\text { Nie zawsze możliwy do odróżnienia od } \\
\text { kwarcu powstałego z rozpadu skał północ- } \\
\text { nych }\end{array}$ \\
\hline Skały metamorficzne z Dolnego Śląska & & $\begin{array}{l}\text { Jako niewątpliwie sudeckie były traktowa- } \\
\text { ne fyllity, łupki metamorficzne, zieleńce } \\
\text { i serpentynity }\end{array}$ \\
\hline Skały magmowe z Dolnego Śląska & & $\begin{array}{l}\text { Głównie różnego rodzaju porfiry i granito- } \\
\text { idy }\end{array}$ \\
\hline Lidyt & & $\begin{array}{l}\text { Obecny niemal wyłącznie w próbach z Dol- } \\
\text { nego Śląska; na ogół pocięty cienkimi żył- } \\
\text { kami kwarcu }\end{array}$ \\
\hline Krzemienie i czerty & $\mathbf{F}$ & $\begin{array}{l}\text { Nie rozróżniano krzemieni lokalnych i bał- } \\
\text { tyckich; w części prób oddzielnie liczono } \\
\text { krzemienie i czerty, ale ten podział jest } \\
\text { raczej subiektywny }\end{array}$ \\
\hline Pozostałe skały lokalne & & - \\
\hline Skały bałtycko-fennoskandzkie & BF & $\begin{array}{l}\text { Skały krystaliczne oprócz dolnośląskich oraz } \\
\text { paleozoiczne i starsze skały osadowe }\end{array}$ \\
\hline $\begin{array}{l}\text { Fennoskandzkie skały krystaliczne i kwarc } \\
\text { z ich rozpadu }\end{array}$ & $\mathrm{Kr}$ & $\begin{array}{l}\text { Włącznie ze skałami przewodnimi, bez } \\
\text { kwarcytów }\end{array}$ \\
\hline Kwarc z rozpadu skał krystalicznych & $\mathbf{Q}_{\mathrm{kr}}$ & $\begin{array}{l}\text { Zawartość zwykle proporcjonalna do } \\
\text { udziału skał krystalicznych, wyraźnie } \\
\text { podwyższona w osadach zwietrzałych }\end{array}$ \\
\hline Skały magmowe bałtycko-fennoskandzkie & & $\begin{array}{l}\text { Wliczone wszystkie magmowe skały wskaź- } \\
\text { nikowe }\end{array}$ \\
\hline $\begin{array}{l}\text { Skały plutoniczne i kwarc z rozpadu skał } \\
\text { krystalicznych }\end{array}$ & & Wliczone plutoniczne skały wskaźnikowe \\
\hline Skały wulkaniczne i subwulkaniczne & & Włącznie ze skałami wskaźnikowymi \\
\hline $\begin{array}{l}\text { Skały metamorficzne bałtycko-fenno- } \\
\text { skandzkie }\end{array}$ & & $\begin{array}{l}\text { Wliczone metamorficzne skały wskaźniko- } \\
\text { we }\end{array}$ \\
\hline $\begin{array}{l}\text { Łupki metamorficzne bałtycko-fenno- } \\
\text { skandzkie }\end{array}$ & Łm & $\begin{array}{l}\text { Czytelna makroskopowo oddzielność } \\
\text { łupkowa wynikająca z foliacji lub laminacji }\end{array}$ \\
\hline Fennoskandzkie skały osadowe & $\mathbf{0}$ & $\begin{array}{l}\text { Włącznie z kwarcytami, bez względu na ich } \\
\text { genezę }\end{array}$ \\
\hline Paleozoiczne skały węglanowe & $W\left(=W_{p}+D_{p}\right)$ & $\begin{array}{l}\text { Wapienie, margle i dolomity bałtycko-fen- } \\
\text { noskandzkie }\end{array}$ \\
\hline $\begin{array}{l}\text { Wapienie paleozoiczne (bałtycko-fenno- } \\
\text { skandzkie) }\end{array}$ & $\mathbf{W}_{\mathrm{p}}$ & Włącznie z rzadko występującymi marglami \\
\hline Wapienie bitumiczne & & $\begin{array}{l}\text { Pod wpływem kwasu lub uderzenia wydzie- } \\
\text { lają zapach bituminów }\end{array}$ \\
\hline Wapienie krynoidowe & & $\begin{array}{l}\text { Zawierają rozpoznawalne makroskopowo } \\
\text { szczątki liliowców jako główny składnik } \\
\text { ziarnisty }\end{array}$ \\
\hline Wapienie paleoporellowe & & $\begin{array}{l}\text { Najczęściej kremowe, różowawe lub beżo- } \\
\text { we z licznymi rurkowatymi skamieniałoś- } \\
\text { ciami glonów }\end{array}$ \\
\hline
\end{tabular}


Tabela 4.2 (cd.)

\begin{tabular}{|c|c|c|}
\hline 1 & 2 & 3 \\
\hline Wapienie beyrichiowe & & $\begin{array}{l}\text { Zawierają liczne skamieniałości małżoracz- } \\
\text { ków }\end{array}$ \\
\hline Wapienie czerwone (ordowickie) & & $\begin{array}{l}\text { Często zawierają szczątki łodzików } \\
\text { (np. Orthoceras, Endoceras) }\end{array}$ \\
\hline $\begin{array}{l}\text { Wapienie wschodniobałtyckie „tłuste” } \\
\text { (cieliste) }\end{array}$ & & $\begin{array}{l}\text { Wapienie pelitowe - brak widocznych } \\
\text { makroskopowo składników ziarnistych }\end{array}$ \\
\hline Wapienie plamiste Wesenberga & & $\begin{array}{l}\text { Podobne do „tłustych” wapieni pelitowych } \\
\text { (o kremowym zabarwieniu), ale z wyraź- } \\
\text { nymi różowawymi lub jasnofioletowymi } \\
\text { plamami }\end{array}$ \\
\hline Wapienie paleozoiczne z interesującą fauną & & $\begin{array}{l}\text { Oddzielane tylko ze względu na możliwość } \\
\text { późniejszego wykorzystania do badań } \\
\text { paleontologicznych lub dydaktyki }\end{array}$ \\
\hline $\begin{array}{l}\text { Dolomity paleozoiczne i margle } \\
\text { dolomityczne }\end{array}$ & $\mathbf{D}_{\mathrm{p}}$ & $\begin{array}{l}\text { Występują razem z wapieniami paleozo- } \\
\text { icznymi - zwłaszcza „tłustymi” }\end{array}$ \\
\hline $\begin{array}{l}\text { Piaskowce, mułowce, zlepieńce, brekcje, } \\
\text { arkozy i kwarcyty proterozoiczne i } \\
\text { paleozoiczne (bałtycko-fennoskandzkie) }\end{array}$ & $\mathbf{P}_{\mathrm{p}}$ & $\begin{array}{l}\text { Oddzielanie kwarcytów od piaskowców } \\
\text { i włączanie ich do skał metamorficznych } \\
\text { byłoby wątpliwe z uwagi na częste wystę- } \\
\text { powanie form przejściowych oraz osado- } \\
\text { wą genezę niektórych kwarcytów }\end{array}$ \\
\hline Piaskowce jotnickie & & $\begin{array}{l}\text { Zwykle o charakterze piaskowca kwarcy- } \\
\text { tycznego }\end{array}$ \\
\hline Czerwone bałtyckie piaskowce kambru & & $\begin{array}{l}\text { Odróżniane od jotnickich na podstawie } \\
\text { stopnia selekcji, stopnia rekrystalizacji } \\
\text { spoiwa oraz obtoczenia ziaren (subiek- } \\
\text { tywne i bardzo niepewne kryterium) }\end{array}$ \\
\hline Łupki paleozoiczne & $\lfloor p$ & $\begin{array}{l}\text { Wyjątkowo rzadkie we frakcji }>20 \mathrm{~mm} \\
\text { nawet w północnej Polsce }\end{array}$ \\
\hline Krzemienie „Wallstein” & Fw & $\begin{array}{l}\text { Mało liczne, we wschodniej Polsce prawie } \\
\text { nieobecne }\end{array}$ \\
\hline Konkrecje fosforytowe & $K_{f}$ & $\begin{array}{l}\text { Ciemnobrunatne do czarnych, ciężkie, } \\
\text { bryłowate skupienia, często zawierają } \\
\text { dobrze obtoczone ziarna kwarcu - niekie- } \\
\text { dy wyraźnie niebieskiego }\end{array}$ \\
\hline
\end{tabular}

Oznaczeń dokonywano metodami makroskopowymi, tzn. bez sporządzania szlifów cienkich lub polerów, które należałoby analizować przy użyciu mikroskopu polaryzacyjnego. Badania mikroskopowe eratyków uznane zostały za zbyt kosztowne i czasochłonne w odniesieniu do problematyki geologii czwartorzędu. Zapewne w niektórych wypadkach pozwoliłyby określić precyzyjnie miejsce pochodzenia konkretnego eratyka. Należy jednak liczyć się z dużą zmiennością petrograficzną w obrębie samej wychodni oraz brakiem jednoznacznych i precyzyjnych opisów skał fennoskandzkich, które pozwoliłyby wyróżnić uniwersalne cechy, posiadane tylko przez konkretną skałę. Wykonanie szlifów z jednej tylko próbki (ponad 1000 klastów) i następnie ich przegnalizowanie wymagałoby wielomiesięcznej pracy. Możliwa do uzyskania informacja byłaby zatem nieproporcjonalnie mała w stosunku do poniesionych nakładów.

Badania makroskopowe przebiegają zdecydowanie sprawniej. Analiza jednej próbki zajmowała autorowi od jednego do trzech dni. Większość klastów była rozbijana w celu uzyskania świeżej powierzchni, na której łatwiej było zidentyfikować składniki skały oraz 
określić jej budowę wewnętrzną. Klasty były oglądane w stanie suchym i po zwilżeniu wodą pod lupą zwykłą, powiększającą 3 lub 8 razy, bądź - w przypadku skał drobnokrystalicznych - pod binokularem, umożliwiającym powiększenie do 64x. Na sucho dobrze widoczne są granice ziaren, powierzchnie łupliwości, rodzaj połysku - zwłaszcza na powierzchniach niezwietrzałych. Wietrzenie i abrazja powierzchni ziaren prowadziły do rozjaśnienia skały (większość minerałów skałotwórczych ma białą rysę), słabnięcia i zaniku połysku, spadku twardości minerałów, zatarcia granic pomiędzy składnikami. Zwilżenie nadwietrzałych powierzchni ujawniało te granice, zwiększało nasycenie kolorystyczne porysowanych (pościeranych) powierzchni minerałów i w ten sposób znacznie ułatwiało identyfikację eratyków. Odwrotne skutki pociągało za sobą zmoczenie świeżo odłupanych powierzchni skały, ponieważ cienka warstewka wody maskowała powierzchnie łupliwości oraz uniemożliwiała określenie jednej z najważniejszych cech diagnostycznych minerałów, tj. połysku. W rozpoznawaniu skał węglanowych oraz skał krzemionkowych i okruchowych, zawierających węglanowe składniki lub spoiwo, bardzo użyteczny był $10 \%$ roztwór wodny kwasu chlorowodorowego (solnego).

Oznaczenia eratyków wskaźnikowych prowadzone były w oparciu o kolekcję wzorcową skał przewodnich i pomocniczych, zebraną przez autora w trakcie kilkukrotnych wyjazdów do Skandynawii (w tym dwóch zorganizowanych w 2002 i 2003 roku przez dr. P.P. Woźniaka z Katedry Geomorfologii i Geologii Czwartorzędu Uniwersytetu Gdańskiego), przechowywaną obecnie w Pracowni Geologii Uniwersytetu Łódzkiego. Próby skał pobrane w odsłonięciach w Fennoskandii zostały uzupełnione o liczne eratyki pozyskane w odkrywkowych kopalniach węgla brunatnego Polski Środkowej, na południowym wybrzeżu Bałtyku od Wismaru aż po Narwę oraz w wielu naturalnych i sztucznych odsłonięciach rozrzuconych po prawie całej Polsce. Stanowią one ważny zbiór porównawczy, ponieważ w Fennoskandii nie zawsze udało się pobrać okazy typowo wykształconych skał wskaźnikowych, co wynikało przede wszystkim ze stosunkowo dużej zmienności przestrzennej w obrębie poszczególnych wychodni. Nie sposób wykluczyć, że w przeszłości ta zmienność była w obrębie niektórych wychodni jeszcze większa, a odmiany skał najbardziej podatne na erozję zostały całkowicie zdenudowane.

Bardzo pomocne w oznaczeniach były również atlasy skał i inne opracowania poświęcone eratykom wskaźnikowym. Wśród nich należy wymienić przede wszystkim: Cohen i Deecke (1892, 1896), Hucke (1917), Korn (1927), Gudelis (1971), Hesemann (1975), Smed (1994, 2002), Zandstra (1999), Schulz (2003), Rohde (2007, 2008), Rudolph (2008a, 2008b). Są to opracowania głównie niemieckich autorów, ale przed kilku laty ukazał się również polskojęzyczny, bogato ilustrowany artykuł poświęcony identyfikacji najważniejszych eratyków wskaźnikowych (Czubla i in., 2006). W przypadku niektórych typów eratyków dobry materiał ilustracyjny i opisowy zawierają serwisy internetowe, przede wszystkim: www.kristallin.de, www.strand-und-steine.de, www.skan-kristallin.de. Bardzo dobre wprowadzenie do makroskopowego rozpoznawania skał, szczególnie polecane osobom bez przygotowania mineralogicznego i petrograficznego, stanowi wyczerpująca praca Vinxa, która doczekała się już czterech wydań (2005, 2008, 2011, 2015). 
Należy jednak mieć świadomość, że wymienione publikacje i serwisy sieciowe prezentują skały tylko w najbardziej charakterystycznym wykształceniu. Wspomniana zmienność petrograficzna w obrębie wychodni w Fennoskandii (niebędąca zresztą niczym wyjątkowym) sprawia, że tylko niektóre typy występujących tam skał mogą zostać jednoznacznie rozpoznane w postaci eratyków w osadach glacjalnych Niżu Środkowoeuropejskiego. Oznacza to, że w dużej wychodni tylko kilkadziesiąt, a w skrajnych przypadkach zaledwie kilka procent jej powierzchni zajmuje skała identyfikowalna. Potwierdzają to bezpośrednie obserwacje terenowe dokonane przez autora podczas czterech wyjazdów na obszar Fennoskandii w latach 2002, 2003, 2009 i 2011.

\subsection{Opracowanie kameralne wyników badań}

Wyniki analiz zostały wprowadzone do specjalnie przygotowanych arkuszy kalkulacyjnych w programie Microsoft Excel. Przy ich pomocy zostało wyliczonych ponad 100 różnych wskaźników i współczynników, mających w założeniu posłużyć rozróżnianiu różnowiekowych osadów glacjalnych (tab. 4.3). Wyznaczone zostały formuły głazowe wg metody Hesemanna (1930). Przetestowano również przydatność wyznaczania udziału poszczególnych obszarów alimentacyjnych w dostawie materiału skalnego zgodnie z propozycją Gałązki (2004b).

Tabela 4.3. Wybrane wskaźniki i współczynniki przeanalizowanych zespołów eratyków poddane analizie statystycznej (pominięto grupy petrograficzne wymienione w tab. 4.2 oraz poszczególne eratyki wskaźnikowe uwzględnione $w$ tab. 4.4)

Table 4.3. Selected petrographical coefficients and ratios in analyzed erratics samples used in statistical analysis (petrographical groups listed in Tab. 4.1 and the individual indicator erratics included in Tab. 4.4 have been omitted)

\begin{tabular}{|c|c|}
\hline Lp. & Opis wskaźnika (współczynnika) \\
\hline 1. & Odsetek skał lokalnych (bez konkrecji, krzemieni i czertów) w próbce \\
\hline 2. & Odsetek skał lokalnych (bez krzemieni i czertów) w próbce \\
\hline 3. & Odsetek skał lokalnych (z krzemieniami i czertami) w próbce \\
\hline 4. & Udział skał dolnośląskich wśród lokalnych (bez krzemieni i czertów) - tylko próby z Dolnego Śląska \\
\hline 5. & $\begin{array}{l}\text { Udział skał dolnośląskich wśród lokalnych (z krzemieniami i czertami) - tylko próby z Dolnego } \\
\text { Śląska }\end{array}$ \\
\hline 6. & Udział skał węglanowych wśród lokalnych (bez krzemieni i czertów) \\
\hline 7. & Udział skał węglanowych wśród lokalnych (z krzemieniami i czertami) \\
\hline 8. & Stosunek skał lokalnych (z krzemieniami i czertami) do bałtycko-fennoskandzkich \\
\hline 9. & Stosunek skał lokalnych (bez krzemieni i czertów) do bałtycko-fennoskandzkich \\
\hline 10. & Udział skał alandzkich wśród przewodnich krystalicznych \\
\hline 11. & Udział skał alandzkich, botnickich i porfirów bałtyckich wśród przewodnich krystalicznych \\
\hline 12. & Udział skał północnoszwedzkich wśród przewodnich krystalicznych \\
\hline 13. & Udział skał z Dalarna wśród przewodnich krystalicznych \\
\hline 14. & Udział skał z Upplandu i okolic Sztokholmu wśród przewodnich krystalicznych \\
\hline 15. & Udział skał ze Smålandu i Blekinge wśród przewodnich krystalicznych \\
\hline
\end{tabular}


Tabela 4.3 (cd.)

\begin{tabular}{|c|c|}
\hline Lp. & Opis wskaźnika (współczynnika \\
\hline 16. & Udział skał zachodnioszwedzkich i norweskich wśród przewodnich krystalicznych \\
\hline 17. & Udział skał bornholmskich wśród przewodnich krystalicznych \\
\hline 18. & Odsetek skał fennoskandzkich w próbce (z konkrecjami, krzemieniami i czertami) \\
\hline 19. & Odsetek skał fennoskandzkich w próbce (bez konkrecji, krzemieni i czertów) \\
\hline 20. & Odsetek skał krystalicznych wśród bałtycko-fennoskandzkich \\
\hline 21. & Odsetek skał magmowych wśród bałtycko-fennoskandzkich \\
\hline 22. & Odsetek skał plutonicznych wśród bałtycko-fennoskandzkich \\
\hline 23. & Odsetek skał wulkanicznych wśród bałtycko-fennoskandzkich \\
\hline 24. & Odsetek skał metamorficznych wśród bałtycko-fennoskandzkich \\
\hline 25. & Odsetek przewodnich skał krystalicznych wśród bałtycko-fennoskandzkich \\
\hline 26. & Odsetek przewodnich skał krystalicznych wśród krystalicznych \\
\hline 27. & $\begin{array}{l}\mathrm{O} / \mathrm{K}=\text { bałtycko-fennoskandzkie skały osadowe włącznie z kwarcytami }(\mathrm{Wp}+\mathrm{Dp}+\mathrm{tp}+\mathrm{Pp}) / \\
\text { bałtycko-fennoskandzkie skały krystaliczne i kwarc z rozpadu skał krystalicznych }\left(\mathrm{Kr}+\mathrm{Q}_{\mathrm{Kr}}\right)\end{array}$ \\
\hline 28. & $\begin{array}{l}\mathrm{K} / \mathrm{W}=\text { bałtycko-fennoskandzkie skały krystaliczne i kwarc z rozpadu skał krystalicznych }(\mathrm{Kr}+\mathrm{Qp}) / \\
\text { bałtycko-fennoskandzkie skały węglanowe }(\mathrm{Wp}+\mathrm{Dp})\end{array}$ \\
\hline 29. & $\begin{array}{l}A / B=\text { bałtycko-fennoskandzkie skały podatne na wietrzenie }(W p+D p+t p) / \text { bałtycko-fennoskandz- } \\
\text { kie skały odporne na wietrzenie }\left(K r+Q_{k r}+P p\right)\end{array}$ \\
\hline 30. & Udział krzemieni i czertów w całej próbce \\
\hline 31. & Udział krzemieni i czertów wśród skał bałtycko-fennoskandzkich \\
\hline 32. & Stosunek krzemieni i czertów do skał krystalicznych włącznie z kwarcem F/K \\
\hline 33. & Udział fosforytów wśród skał bałtycko-fennoskandzkich \\
\hline 34. & Udział fosforytów w całej próbce \\
\hline 35. & Udział piaskowców oraz innych skał okruchowych i kwarcytów wśród bałtycko-fennoskandzkich \\
\hline 36. & Stosunek skał okruchowych (włącznie z kwarcytami) do węglanowych Pp/W \\
\hline 37. & Udział wapieni paleozoicznych wśród skał bałtycko-fennoskandzkich \\
\hline 38. & Udział dolomitów wśród skał bałtycko-fennoskandzkich \\
\hline 39. & Stosunek dolomitów do wapieni paleozoicznych Dp/Wp \\
\hline 40. & Udział dolomitów wśród paleozoicznych skał węglanowych Dp/W = Dp/Wp + Dp \\
\hline 41. & Udział wapieni paleoporellowych wśród paleozoicznych skał węglanowych \\
\hline 42. & Udział wapieni paleoporellowych wśród paleozoicznych wapieni \\
\hline 43. & Udział wapieni beyrichiowych wśród paleozoicznych skał węglanowych \\
\hline 44. & Udział wapieni beyrichiowych wśród paleozoicznych wapieni \\
\hline 45. & Udział wapieni krynoidowych wśród paleozoicznych skał węglanowych \\
\hline 46. & Udział wapieni krynoidowych wśród paleozoicznych wapieni \\
\hline 47. & Udział „tłustych” wapieni bałtyckich i Wesenberga wśród paleozoicznych skał węglanowych \\
\hline 48. & Udział „tłustych” wapieni bałtyckich i Wesenberga wśród paleozoicznych wapieni \\
\hline 49. & Udział czerwonych wapieni ordowickich wśród paleozoicznych skał węglanowych \\
\hline 50. & Udział czerwonych wapieni ordowickich wśród paleozoicznych wapieni \\
\hline
\end{tabular}

Surowe dane oraz wyliczone wskaźniki zostały poddane analizie statystycznej (rozdz. 14), której podstawowym celem było wskazanie tych, które najlepiej różnicują różnowiekowe osady glacjalne. W tym celu przeprowadzono test istotności różnicy dwóch średnich (T-Test). Test ten pozwala określić różnicę pomiędzy dwoma zbiorami 
danych, przy czym każdy z tych zbiorów charakteryzuje wartość średnia i odchylenie standardowe. W oparciu o powyższe dane i z wykorzystaniem odpowiedniego wzoru (Davis, 2002 - wzór 2.48, str. 73) obliczono wartość parametru $t$, a następnie wyznaczono liczbę stopni swobody. Ze względu na poszukiwanie cech wskazujących na rozbieżność analizowanych grup przyjęto, że poziom ufności (w odniesieniu do zgodności prób) powinien wynosić <0,05. Przeprowadzono również analizę statystyczną przy użyciu nieparametrycznego testu Manna-Whitneya (U-test). Ocenę zgodności/odrębności prób przeprowadzono poprzez porównanie parametru $U$ z wartościami krytycznymi podanymi przez Walpole'a i in. (2012). Dla wybranych parametrów przeprowadzono również test korelacji liniowej. Obliczono w tym celu współczynnik Pearsona. Jeżeli korelacja występuje, to oznacza, że stosunek analizowanych parametrów w obrębie grupy jest stały i może charakteryzować grupę. Założono, że warunkiem granicznym jest poziom ufności 0,05. Te same dane zostały również przeanalizowane przy pomocy nieparametrycznego współczynnika Spearmana. Uzyskana wartość była porównywana z wartością krytyczną podawaną przez Davisa (2002 - str. 613).

W oparciu o typy i liczbę zidentyfikowanych w każdej próbce eratyków wskaźnikowych wyliczono teoretyczne centrum (ośrodek) głazowe (TCG). Przetestowano zarówno tradycyjną metodę Lüttiga (1958), jak też różne jej modyfikacje zaproponowane przez Groetznera (1972), Vinxa i in. (1997) oraz autora (Czubla, 2001). Ze względu na znaczne zaawansowanie procesów wietrzeniowych osadów glacjalnych w niektórych stanowiskach, autor podjął próbę wykorzystania dla potrzeb korelacyjnych wskaźnika bazującego wyłącznie na skałach krystalicznych (magmowych i metamorficznych). Jeśli z obliczeń wykluczone zostaną również skały krystaliczne bogate w biotyt (np. niektóre typy z Upplandu), to wyznaczone centrum głazowe powinno mieć prawie identyczne współrzędne zarówno w świeżej glinie, jak i w mocno zwietrzałym diamiktonie (zakładając, że zostały odłożone przez ten sam lądolód). W poszukiwaniu prostszej niż dotychczasowa metody badawczej, pozwalającej upowszechnić analizy eratyków w osadach glacjalnych (włącznie ze zwietrzałymi), przeanalizowano dodatkowe osiem zestawów skał przewodnich, w których uwzględniono tylko wybrane typy eratyków niemal wyłącznie krystalicznych (patrz rozdz. 5).

Współrzędne geograficzne eratyków przewodnich i pomocniczych, wykorzystywane w obliczeniach teoretycznych ośrodków głazowych (tab. 4.4) zostały zaczerpnięte z publikacji Lüttiga (1958), a w pojedynczych przypadkach uzupełniono je w oparciu o mapy Smeda (1993, 1994, 2002). Ostatnio, w oparciu o „Sveriges Nationalatlas, bind 6, Geologi" (Fredén, 1994), zaproponowano współrzędne dla wybranych skał pomocniczych (Smed, 2000, 2010). Różnią się one nieznacznie od wartości wykorzystywanych we wcześniejszych pracach autora (np. Czubla, 2001), ale do obliczania teoretycznych ośrodków głazowych i tak nie mogły zostać wykorzystane (skały pomocnicze nie były uwzględnione przez autora przy wyznaczaniu większości wskaźników TCG), a w prezentacji na mapach kołowych ich dokładna lokalizacja ma znaczenie drugorzędne. O wiele istotniejsze jest, aby konsekwentnie stosować tę samą wartość. W związku z tym autor uznał za celowe pozostanie przy współrzędnych stosowanych w starszych pracach. 
Tabela 4.4. Współrzędne geograficzne centralnych punktów wychodni eratyków wskaźnikowych - przewodnich i pomocniczych; wg Lüttiga (1958) i map Smeda (1993, 1994, 2002) - częściowo zmodyfikowane; ze względu na sposób wyliczania teoretycznych ośrodków głazowych współrzędne zostały przedstawione w stopniach i ich dziesiętnych częściach, a nie w stopniach i minutach kątowych

Table 4.4. Geographical coordinates of midpoints of indicator erratics (selected auxiliary ones including) source areas; after Lüttig (1958) and Smed's maps (1993, 1994, 2002), partly modified; due to the method of calculation of theoretical boulder centers, coordinates are shown in degrees and decimal parts, rather than in degrees and minutes of arc

\begin{tabular}{|c|c|c|c|}
\hline $\begin{array}{c}\mathrm{Nr} \\
\text { punktu }\end{array}$ & Eratyki przewodnie i pomocnicze & Długość geogr. & Szer. geogr \\
\hline 1 & 2 & 3 & 4 \\
\hline 1 & Granit i granitognejs Ångermanland & 18,5 & 63,0 \\
\hline 2 & Porfiry, granity, granitoporfiry i sjenity Ragunda & 17,0 & 63,0 \\
\hline 3 & Granit rapakiwi Rödö & 18,0 & 62,5 \\
\hline 4 & Granit i granitoporfir Rödö, porfir kwarcowy Rödö & 17,2 & 62,6 \\
\hline 5 & Granit Revsund, Björna & 15,0 & 63,0 \\
\hline 6 & Granit Rätan & 14,5 & 62,5 \\
\hline 7 & Porfiry botnickie & 19,5 & 61,8 \\
\hline 8 & Granit rapakiwi Nystad, szary granodioryt Nystad & 21,2 & 60,8 \\
\hline 9 & Pyterlit alandzki lub Nystad & 20,6 & 60,4 \\
\hline 10 & $\begin{array}{l}\text { Granit alandzki, Haga, Kökar, rapakiwi, granitoporfir alandzki } \\
\text { i porfir kwarcowy alandzki }\end{array}$ & 20,0 & 60,0 \\
\hline 11 & Granit Ytö & 21,7 & 60,9 \\
\hline 12 & Granit Perniö & 23,3 & 60,2 \\
\hline 13 & Porfir Hogland & 26,9 & 60,1 \\
\hline 14 & Porfir bałtycki czerwony & 21,1 & 59,1 \\
\hline 15 & Diabaz melafirowy (melafir) bałtycki, sjenitoporfir bałtycki & 19,0 & 59,0 \\
\hline 16 & Porfir bałtycki brunatny & 18,9 & 58,7 \\
\hline 17 & Granit Uppsala, Vänge, Arnö & 17,0 & 59,7 \\
\hline 18 & Granit Sala & 16,5 & 59,7 \\
\hline 19 & Granit sztokholmski & 18,0 & 59,3 \\
\hline 20 & Porfir Mälar & 17,4 & 59,4 \\
\hline 21 & Porfir Glöte & 13,8 & 62,2 \\
\hline 22 & Porfir i tinguait Särna & 13,1 & 61,7 \\
\hline 23 & Porfir Tadsjöborg & 14,7 & 61,7 \\
\hline 24 & Porfir szary z Dalarna i czerwony Grönklitt, diabaz Åsby & 14,5 & 61,5 \\
\hline 25 & Porfir Åsen, Bredvad, Kåtilla, granit Garberg & 13,9 & 61,4 \\
\hline 26 & $\begin{array}{l}\text { Porfir Blyberg, porfir i ignimbryt Klittberg, ignimbryty Rännås, } \\
\text { Blyberg, Orrlok, inne porfiry i ignimbryty z Dalarna }\end{array}$ & 14,3 & 61,3 \\
\hline 27 & $\begin{array}{l}\text { Diabaz i melafir Öje, piaskowiec Dala, piaskowiec i zlepieniec } \\
\text { Digeberga }\end{array}$ & 13,3 & 61,1 \\
\hline 28 & Porfir Heden & 13,4 & 60,9 \\
\hline 29 & Porfir Venjan & 14,1 & 60,7 \\
\hline 30 & Granit Järna & 14,7 & 60,9 \\
\hline 31 & Granit Siljan, rapakiwi Siljan, porfir Månsta & 14,8 & 60,5 \\
\hline 32 & Granit Graversfors brunatny i czerwony, Östgöta & 16,2 & 58,7 \\
\hline
\end{tabular}


Tabela 4.4 (cd.)

\begin{tabular}{|c|c|c|c|}
\hline 1 & 2 & 3 & 4 \\
\hline 33 & Granit Kinda & 15,8 & 58,1 \\
\hline 34 & Kwarcyt Västervik & 16,6 & 57,7 \\
\hline 35 & Granit Uthammar & 16,5 & 57,5 \\
\hline 36 & Granit Flivik, Virbo, porfir Påskallavik i Sjögelö & 16,4 & 57,3 \\
\hline 37 & Granit Marianelund, porfir Emarp, Nymala, Fagerhult, Lönneberga & 15,6 & 57,5 \\
\hline 38 & Granit Växjö różowy i szary & 15,0 & 57,0 \\
\hline 39 & Granity Småland czerwone i Vislanda, porfiry i ignimbryty Småland & 15,5 & 57,0 \\
\hline 40 & Granit Vånevik & 16,1 & 57,0 \\
\hline 41 & Piaskowce Kalmarsund i Tessini & 16,2 & 56,4 \\
\hline 42 & Granit Filipstad & 13,7 & 60,5 \\
\hline 43 & Granit Kristinehamn i Filipstad (południowa odmiana) & 14,4 & 59,6 \\
\hline 44 & Diabaz Kinne & 13,5 & 58,5 \\
\hline 45 & Sjenit Vaggeryd, granit Barnarp (trójkolorowy) & 14,2 & 57,6 \\
\hline 46 & Amfibolity z granatami & 13,4 & 57,0 \\
\hline 47 & Granit Karlshamn i Spinkamåla (Halen) & 14,8 & 56,2 \\
\hline 48 & Kullait, piaskowiec skolitusowy i Hardeberga & 13,6 & 55,6 \\
\hline 49 & Piaskowiec Köpinge & 14,3 & 55,7 \\
\hline 50 & Bazalt ze Skanii & 13,5 & 55,9 \\
\hline 51 & Granit Bohuslän & 11,5 & 59,0 \\
\hline 52 & Granity Hammer i Vang, gnejsy bornholmskie & 15,0 & 55,2 \\
\hline 53 & Dolomity & 21,9 & 58,4 \\
\hline 54 & Czerwone piaskowce bałtyckie kambru & 17,9 & 58,3 \\
\hline 55 & Czerwone wapienie ordowickie (m.in. ortocerasowe) & 17,2 & 57,2 \\
\hline 56 & Piaskowce Old-Redu & 19,4 & 56,6 \\
\hline 57 & Wapienie beyrichiowe & 18,0 & 56,4 \\
\hline 58 & Wapienie paleoporellowe & 17,6 & 57,7 \\
\hline
\end{tabular}

Wyniki analiz eratyków wskaźnikowych (przewodnich i pomocniczych) do celów interpretacyjnych zostały przedstawione na mapach kołowych (kartodiagramach) zgodnie z propozycją Smeda (1993). Wszystkie mapy kołowe oraz wyliczone różnymi metodami teoretyczne ośrodki głazowe zostały zinterpretowane w oparciu o dostępne mapy geologiczne $\mathrm{i}$ istniejące publikacje na temat budowy geologicznej odpowiednich regionów. Pozwoliło to wyciągnąć szereg szczegółowych wniosków paleogeograficznych, geomorfologicznych i stratygraficznych, stanowiących przedmiot opracowań już opublikowanych (m.in. Czubla, 1998, 1999a, 1999b, 2001, 2006, 2011, 2013a, 2013b; Czubla i Forysiak, 2003, 2004, 2006, 2013; Czubla i Krzyszkowski, 2013, Czubla i in., 2007a, 2007b, 2008, 2010a, 2010b, 2013a, 2013b, 2013c; Woźniak i in., 2008, 2009, 2012a, 2012b, 2013a, 2013b, 2013c; Czubla i Wachecka-Kotkowska, 2009; Terpiłowski i in., 2012, 2013, 2014; Wachecka-Kotkowska i in., 2012a, 2012b, 2012c, 2013 a, 2013b, 2013c; Pidek i in., 2013, 2014; Woźniak i Czubla, 2011, 2014a, 2014b, w druku; Czubla i Sokołowski, 2014), bądź będących obecnie na etapie przygotowywania do publikacji. W związku z tym nie będą one powtarzane w niniejszej pracy. 


\section{METODY INTERPRETACJI I PREZENTACJI WYNIKÓW BADAŃ ERATYKÓW}

Identyfikację eratyków wskaźnikowych występujących w badanej próbie wieńczy sporządzenie listy, która jest trudna do bezpośredniej interpretacji, a tym bardziej do porównania z analogicznymi listami uzyskanymi w innych stanowiskach. Stąd już na początkowym etapie badań eratyków pojawiły się pomysły wykorzystania tylko wybranych typów eratyków (np. Milthers, 1909, 1936) i poszukiwania tzw. „eratyków homochronicznych" (Sauramo, 1909 - fide Hucke, 1926). Jedynym konsekwentnym zwolennikiem prowadzenia badań w oparciu o bardzo małą liczbę eratyków pozostał jednak tylko Vitus Milthers. Uzyskiwane przez niego wyniki miały charakter fragmentaryczny, chociażby ze względu na wykorzystanie tylko kilku (maksymalnie jedenastu) rodzajów eratyków przewodnich. Były to: porfir rombowy i zlepieniec porfiru rombowego, porfiry Bredvad i Grönklitt, czerwony i brunatny porfir bałtycki, porfir Påskallavik, diabaz Kinne, bazalt ze Skanii, inne porfiry dalarneńskie i skały alandzkie. Sześć pierwszych skał uważał za najważniejsze i wydzielił wśród nich trzy grupy regionalne: $\mathrm{n}$ - porfir rombowy i zlepieniec porfiru rombowego, $s$ - porfiry Bredvad i Grönklitt, $\varnothing$ - czerwony i brunatny porfir bałtycki, których proporcje można było przedstawić na wykresie trójkątnym (Milthers, 1942). Ta metoda prezentacji miała sens w Danii, gdzie reprezentowane były wszystkie trzy grupy włącznie z porfirami z Norwegii. Dla stanowisk z Polski, gdzie skały norweskie są na ogół nieobecne, pozostawało tylko porównywanie spisów zidentyfikowanych eratyków. Ewentualnie możliwe było wykorzystanie współczynnika s/ø i porównywanie jego wartości dla poszczególnych stanowisk. Nawet jeśli pominiemy problematyczną interpretację wyników (patrz tab. 5.1), to i tak metodykę Milthersa dyskwalifikował pobór eratyków z powierzchni terenu.

Analiza przedstawionych w tabeli danych pozwala stwierdzić, że w glinach zlodowacenia san 2 we wschodniej Polsce występują równoważne ilości porfirów bałtyckich i dalarneńskich, w starszej glinie kompleksu środkowopolskiego (MIS-8) przeważają porfiry dalarneńskie, a w młodszej glinie środkowopolskiej (MIS-6) dominują porfiry bałtyckie. Uzyskane wyniki są w ogólnych zarysach zgodne z wnioskami opartymi na bardziej zaawansowanych metodycznie badaniach (mapy kołowe, teoretyczne ośrodki głazowe). Zastrzec jednak należy, że przedstawione w tabeli dane liczbowe zostały pozyskane dzięki analizie prób eratyków pochodzących z konkretnych pokładów osadów, a nie z powierzchni terenu, jak to robił Milthers. 
Tabela 5.1. Główne skały przewodnie wykorzystywane przez Milthersa pogrupowane regionalnie oraz współczynnik s/ø dla stanowisk z Polski Wschodniej

Table 5.1. Main indicator erratics used by Milthers grouped regionally and $s / \varnothing$ coefficient for the research sites in Eastern Poland

\begin{tabular}{|c|c|c|c|c|c|c|c|c|}
\hline \multirow[b]{2}{*}{ Stanowisko } & \multirow{2}{*}{$\begin{array}{c}\mathrm{n} \\
\text { Porf. } \\
\text { norw. }\end{array}$} & \multicolumn{3}{|c|}{$\mathrm{s}$} & \multicolumn{3}{|c|}{$\varnothing$} & \multirow[b]{2}{*}{$s / \varnothing$} \\
\hline & & $\begin{array}{c}\text { Porf. } \\
\text { Bredv. }\end{array}$ & $\begin{array}{c}\text { Porf. } \\
\text { Grönk. }\end{array}$ & Łącznie & $\begin{array}{l}\text { Porf. } \\
\text { bałt. } \\
\text { brun. }\end{array}$ & $\begin{array}{c}\text { Porf. } \\
\text { bałt. } \\
\text { czerw. }\end{array}$ & Łącznie & \\
\hline Kaczory-odra/warta & 0 & 1 & 0 & 1 & 0 & 4 & 4 & 0,25 \\
\hline Mielnik grn glina - odra/warta & 0 & 0 & 0 & 0 & 0 & 1 & 1 & 0 \\
\hline Neple grn glina - odra/warta & 0 & 1 & 2 & 3 & 1 & 3 & 4 & 0,75 \\
\hline Wólka Zagórna - odra/krzna & 0 & 2 & 4 & 6 & 1 & 2 & 3 & 2 \\
\hline Mielnik dln glina - san 2 & 0 & 0 & 0 & 0 & 0 & 0 & 0 & 0 \\
\hline Neple dln glina - san 2 & 0 & 0 & 1 & 1 & 0 & 1 & 1 & 1 \\
\hline Huta Radoryska glina - san 2 & 0 & 0 & 0 & 0 & 0 & 1 & 1 & 0 \\
\hline Kocianów - san 2 & 0 & 0 & 1 & 1 & 0 & 0 & 0 & - \\
\hline Kolonia Domaszewska glina - san 2 & 0 & 5 & 0 & 5 & 0 & 5 & 5 & 1 \\
\hline $\begin{array}{l}\text { Huta Radoryska diamikton/żwir - } \\
\text { san } 2 \text { (?) }\end{array}$ & 0 & 1 & 0 & 1 & 0 & 0 & 0 & - \\
\hline $\begin{array}{l}\text { Kolonia Domaszewska diamikton - } \\
\text { san } 2 \text { (?) }\end{array}$ & 0 & 13 & 6 & 19 & 3 & 11 & 14 & 1,36 \\
\hline
\end{tabular}

W opozycji do metodyki Milthersa rozwijała się idea wykorzystania w badaniach możliwie największej liczby rodzajów eratyków przewodnich i ich opracowania statystycznego. Ten pogląd pozostaje aktualny do dziś. Problematyczne jest tylko porównywanie długich spisów rozpoznanych w poszczególnych próbach skał. Skłoniło to do poszukiwania sposobu pogrupowania regionalnego eratyków i następnie wyliczania różnego rodzaju współczynników, które byłyby bardziej dogodnym narzędziem do korelacji osadów. Prekursorem tego kierunku był Hesemann, który dzielił skały na 4 grupy: 1 - wschodniofennoskandzkie (północna Szwecja, Wyspy Alandzkie, Zatoka Botnicka i Finlandia), 2 - północno- i środkowoszwedzkie włącznie ze środkowym Bałtykiem, 3 - zachodnio- i południowoszwedzkie włącznie z Bornholmem i południowym Bałtykiem oraz 4 - norweskie (Hesemann, 1930, 1931 i nowsze). Następnie procentowy udział poszczególnych grup zaokrąglał do pełnych dziesiątek i uzyskane w ten sposób liczby zestawiał w czterocyfrową formułę, stanowiącą efekt kolejnych przybliżeń (tab. 5.2). Hesemann nie ustrzegł się jednak podstawowego błędu, jakim był pobór eratyków spośród leżących na powierzchni ziemi. Próba wykorzystania metody Hesemanna do badań w Polsce Środkowej (eratyków nie pobierano jednak z powierzchni terenu) zakończyła się niepowodzeniem (Czubla, 2001). W osadach reprezentowane były tylko 3 pierwsze grupy eratyków, a proporcje pomiędzy nimi zmieniały się $w$ zakresie trudnym do wychwycenia $w$ formule (efekt zaokrąglania do dziesięcioprocentowych przedziałów udziału). Najbardziej czytelna okazała się różnica pomiędzy osadami zlodowacenia T4 (san 2) i T6-T7 (odra/warta) - interpretowanymi wówczas jako odra i warta (Czubla, 2001) - tab. 5.3. Wadą metody Hesemanna była przede wszystkim zbyt duża powierzchnia wydzielanych regionów. Same formuły są też dość trudne do porównywania. 
Tabela 5.2. Udział regionów wyróżnianych przez Hesemanna oraz formuły Hesemanna obliczone dla prób ze stanowisk wschodniej Polski

Table 5.2. Shares of regions distinguished by Hesemann and values of Hesemann formula calculated for glacial deposits in Eastern Poland

\begin{tabular}{|l|c|c|c|c|c|}
\hline \multicolumn{1}{|c|}{ Stanowisko } & $\begin{array}{c}\text { Region 1 } \\
\text { (w \%) }\end{array}$ & $\begin{array}{c}\text { Region 2 } \\
\text { (w \%) }\end{array}$ & $\begin{array}{c}\text { Region 3 } \\
\text { (w \%) }\end{array}$ & $\begin{array}{c}\text { Region 4 } \\
\text { (w \%) }\end{array}$ & Formuła \\
\hline Kaczory - odra/warta & 58,54 & 20,73 & 20,73 & 0,00 & 6220 \\
\hline Mielnik grn glina - odra/warta & 61,90 & 19,05 & 19,05 & 0,00 & 6220 \\
\hline Neple grn glina - odra/warta & 72,06 & 13,24 & 14,71 & 0,00 & 7110 \\
\hline Wólka Zagórna - odra/krzna & 56,44 & 26,73 & 16,83 & 0,00 & 6320 \\
\hline Mielnik dln glina - san 2 & 46,43 & 21,43 & 32,14 & 0,00 & 5230 \\
\hline Neple dln glina - san 2 & 51,85 & 20,37 & 27,78 & 0,00 & 5230 \\
\hline Huta Radoryska glina - san 2 & 42,42 & 33,33 & 24,24 & 0,00 & 4320 \\
\hline Kocianów - san 2 & 56,36 & 23,64 & 20,00 & 0,00 & 6220 \\
\hline Kolonia Domaszewska glina - san 2 & 50,00 & 18,09 & 31,91 & 0,00 & 5230 \\
\hline Huta Radoryska diamikton/ziwir - san 2 (?) & 39,39 & 24,24 & 36,36 & 0,00 & 4240 \\
\hline Kolonia Domaszewska diamikton - san 2 (?) & 45,10 & 36,60 & 18,30 & 0,00 & 5420 \\
\hline
\end{tabular}

Tabela 5.3. Wartości formuł Hesemanna wyliczone dla osadów glacjalnych Polski Wschodniej i Polski Środkowej (T1-T7 gliny wyróżniane w odkrywce KWB Bełchatów, np. Krzyszkowski, 1992, 1995) - Czubla, 2001 (stratygrafia w KWB Bełchatów zmodyfikowana w oparciu o Balwierz i in., 2006, 2008; Ber i in., 2007; Lindner i Marks, 2012; Lindner i in., 2013; Pawłowska i in., 2014) i porównywalne uśrednione wskaźniki z północnych Niemiec (Hesemann, 1932); tłustym drukiem zaznaczono najczęściej występujące wartości

Table 5.3. The values of Hesemann formula calculated for glacial deposits in Eastern and Central Poland (T1-T7 - till beds described in Bełchatów outcrop, e.g. Krzyszkowski, 1992, 1995) - Czubla 2001; stratigraphy in Bełchatów modified based on Balwierz et al., 2006 , 2008; Ber et al., 2007; Lindner \& Marks, 2012; Lindner et al., 2013; Pawłowska et al., 2014, and comparable average formulas for Northern Germany (Hesemann, 1932); the most frequently occurring values in bold

\begin{tabular}{|l|c|c|c|}
\hline \multirow{2}{*}{\multicolumn{2}{|c|}{ Zlodowacenie }} & \multicolumn{3}{|c|}{ Formuła Hesemanna } \\
\cline { 2 - 4 } & Wschodnia Polska & Środkowa Polska & Północne Niemcy \\
\hline wisła & - & $4420,3340,2440$ & $\mathbf{4 4 2 0}$ \\
\hline odra/warta (T6, T7) & $\mathbf{6 2 2 0 , 7 1 1 0}$ & $\mathbf{5 3 2 0 , 4 3 3 0}$ & $\mathbf{4 3 3 0}$ \\
\hline krzna (T5) & 6320 & $\mathbf{4 4 2 0}$ & $\mathbf{2 3 4 1}$ \\
\hline san 2 (T4) & $4320, \mathbf{5 2 3 0 , 6 2 2 0}$ & $\mathbf{2 4 4 0 , 2 5 3 0}$ & \multirow{2}{*}{$\mathbf{6 3 1 0}$} \\
\hline san 1 (T2) & - & 5230 & \\
\hline nida (T1) & - & $3430,3520,2530$ & \\
\hline
\end{tabular}

Autor podjął próbę doprecyzowania metody Hesemanna poprzez rezygnację $z$ drugiego stopnia upraszczania danych i uwzględnienie dokładnego udziału procentowego poszczególnych regionów (bez zaokrąglania do dziesiątków procent). Dzięki nieobecności w przebadanych próbach skał norweskich, w obliczeniach reprezentowane były tylko trzy pierwsze regiony, których sumaryczny udział był równy $100 \%$. Pozwoliło to na przedstawienie wyników z Polski Środkowej na wykresie trójkątnym (Czubla, 1999a), który daje dużo większe możliwości porównywania i interpretacji danych aniżeli kilkadziesiąt czterocyfrowych formuł. Wykres okazał się jednak również mało przejrzysty - łatwe do odróżnienia były tylko te zespoły głazowe, których 
odrębność czytelna była również w klasycznej formule Hesemanna, tj. osady zlodowaceń san 2 i odra/warta (Czubla, 1999a, 2001). Zestawienie wykresów dla różnych regionów Polski pozwala dostrzec regionalną zmianę proporcji pomiędzy eratykami z różnych części Fennoskandii - rys. 5.1. Wraz z przesuwaniem się na wschód wyraźnie zaznacza się wzrost udziału skał wschodniofennoskandzkich.
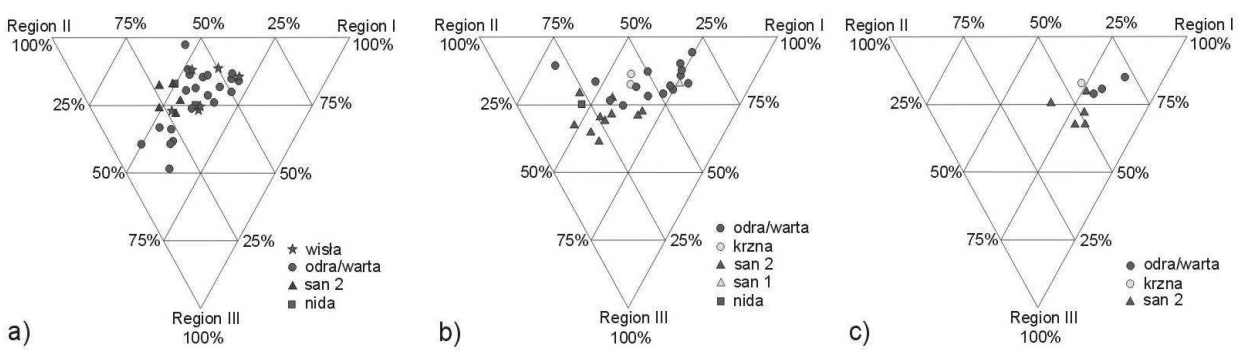

Rys. 5.1. Graficzny obraz zmodyfikowanych formuł Hesemanna; a) wschodnia Wielkopolska,

b) Polska Środkowa, c) Podlasie i Lubelszczyzna

Figure 5.1. Graphic presentation of modified Hesemann's formulas; a) Eastern Wielkopolska,

b) Middle Poland, c) Eastern Poland

W podobnym kierunku formułę Hesemanna próbował modyfikować także Eskola (1933). Doszedł on do wniosku, że fińska grupa eratyków wyróżniona przez Hesemanna ma dla badaczy pracujących w Danii, Niemczech, Polsce, Litwie i Łotwie jedynie złudną wartość, ponieważ skały z tego obszaru występują tam bardzo nielicznie lub są zupełnie nieobecne. Dlatego zaproponował wyróżnianie trzech grup skał: 1 - dno Bałtyku i przyległe wybrzeża (skały bałtyckie, alandzkie, botnickie, włącznie z fińskimi i szwedzkimi wybrzeżami Zatoki Botnickiej oraz masywami rapakiwi Laitila i Vehmaa w kontynentalnej Finlandii); 2 - Småland wraz ze środkową i południową Szwecją; 3 - Norwegia. Sam jednak zastrzegł się, że udział skał bałtyckich w tym systemie obliczeń może być tak wysoki, że bardzo ograniczy to wartość analityczną wyników. Podział regionalny Eskoli w Polsce jest w rzeczywistości nieprzydatny, ponieważ skał norweskich nie ma w ogóle, a oznaczenia musiałyby się ograniczyć do dwóch pierwszych grup. Na dodatek Eskola nie rozwiązał podstawowego problemu, jakim jest szybkie porównanie zespołów głazowych i ewentualna korelacja na ich podstawie prób z różnych stanowisk oraz nie zaproponował żadnej metody prezentacji graficznej wyników badań. Analogiczne podziały regionalne eratyków próbowano również przeprowadzić w Holandii i na Litwie (De Waard, 1955 - fide Lüttig, 1958; Tarvydas, 1957, 1960; Tarvydas i Gudelis, 1958), gdzie wyróżniano po 5 obszarów, z których pochodziły skały narzutowe. Na przeszkodzie szerszemu wykorzystaniu ówczesnych pomysłów stanęła przede wszystkim mała czytelność uzyskanych wyników i brak łatwej do interpretacji prezentacji graficznej.

Kolejną próbę modyfikacji formuły Hesemanna podjęto po około trzydziestu latach znowu w Holandii, ale tym razem wyróżniono aż 10 regionów źródłowych eratyków (Zandstra, 1983a, 1983b, 1986). Zaproponowane regiony dostosowane zostały do zespołów głazowych występujących na zachodnich peryferiach zlodowaceń fennoskandzkich. 
1. Obszar wschodniobałtycki - skały północnoszwedzkie, botnickie, alandzkie, fińskie i porfir Hogland,

2. Obszar bałtycki na południe od Wysp Alandzkich - czerwony porfir bałtycki,

3. Obszar bałtycki w pobliżu Sztokholmu (na południowy zachód od Wysp Alandzkich) - brunatny porfir bałtycki,

4. Uppland,

5. Sztokholm i okolice, Örebro,

6. Dalarna,

7. Småland i okolice,

8. Południowo-zachodnia i południowa Szwecja: Bohuslän, Blekinge, Skania,

9. Bornholm,

10. Południowa Norwegia.

Dla ułatwienia interpretacji postulowano wprowadzenie graficznej metody prezentacji w postaci kartodiagramu. Poszczególne próby zaznaczono przy pomocy wykresów kołowych, ale uwzględniających tylko część wyróżnionych grup eratyków przewodnich. Ponadto w prezentacji graficznej uwzględniano tylko cztery przedziały wielkości udziału, a zatem wprowadzono kolejne uproszczenie (Zandstra, 1983a - str. 464, 466). Interpretacja kartodiagramu była dość subiektywna, a sam obraz - mało przejrzysty (patrz np. Zandstra, 1986). W konsekwencji metoda ta również się nie przyjęła.

Podział regionalny eratyków przewodnich został przeprowadzony także w Polsce (Gałązka, 2004b). Położenie geograficzne obszaru badań Gałązki sprawiło, że znacznie dokładniej ujęta została wschodnia część Fennoskandii. Przyjęcie podziału na 10 prowincji przewodnich (na wzór metody holenderskiej) spowodowało zupełne pominięcie Norwegii, jako obszaru reprezentowanego na terenie Polski tylko przez efemeryczne znaleziska (dokonywane zresztą poza terenem badań Gałązki - patrz rozdz. 10).

1. Bornholm,

2. Bohuslän,

3. Småland,

4. Dalarna,

5. Uppland,

6. Ångermanland,

7. Środkowy Bałtyk,

8. Wyspy Alandzkie wraz z Botnikiem Południowym,

9. Południowo-zachodnia Finlandia,

10. Południowo-wschodnia Finlandia.

Wyniki analiz Gałązka przedstawiał na wykresach liniowych. Pojedynczy wykres jest bardzo łatwy do interpretacji, ale już porównanie kilku staje się kłopotliwe, a kilkudziesięciu zupełnie niemożliwe. Przyjęta metoda prezentacji graficznej nie pozwala na korelację osadów z różnych stanowisk. Gałązka (2004b) liczył się z ograniczeniami 
możliwości interpretacyjnych wykresów liniowych, bo dodatkowo przedstawił wyczerpujące opracowanie statystyczne występowania eratyków dla każdej z wyróżnionych prowincji oddzielnie oraz zaprezentował na bardzo czytelnych wykresach punktowych teoretyczne ośrodki głazowe oraz wskaźniki regionalne. Zupełnie niezrozumiała jest jednak próba wprowadzenia przez Gałązkę wspomnianych wskaźników regionalnych $\mathrm{E} / \mathrm{W}$ i N/S, gdzie $\mathrm{S}=1+2+3, \mathrm{~W}=\mathrm{N}=4+5+6, E=7+8+9+10$ (cyfry odnoszą się do numerów prowincji). Wyróżnianie trzech zaledwie „superprowincji” (W i N pokrywają się, obejmując te same prowincje przewodnie, tj. Dalarna, Uppland i Ångermanland) jest z założenia sprzeczne z koncepcją bardzo precyzyjnego podziału na aż 10 prowincji przewodnich i sprowadza ten podział do wersji jeszcze bardziej ogólnej niż zakwestionowana przez Gałązkę (2004b) koncepcja Hesemanna. Tym bardziej zaskakujące jest stwierdzenie, jakoby analiza wskaźników była dokładniejsza od analiz TCG (Gałązka, 2004b - str. 67).

Autor podjął próbę wykorzystania w swoich badaniach sugerowanego przez Gałązkę sposobu prezentacji, ale wynik okazał się bardzo trudny do interpretacji, a porównywanie składu zespołów eratyków w różnowiekowych osadach glacjalnych miało raczej subiektywny charakter (rys. 5.2.a). Opisywane wykresy liniowe należy zatem traktować jako formę dokumentacji i prezentacji wyników analiz, która daje dobre wyniki jedynie w przypadku opisu pojedynczych próbek osadów (rys. 5.2.b i 5.2.c). Badania autora potwierdziły natomiast przydatność wyróżnianych przez Gałązkę prowincji przewodnich (zwłaszcza 1, 3, 4, 5, 7 i 8) do rozróżniania różnowiekowych glin, pod warunkiem wykorzystania w tym celu analizy statystycznej, a nie wykresów.

Wszystkie metody oparte na wyróżnianiu regionalnych grup eratyków zawierają wewnętrznie sprzeczny mechanizm, jakim jest precyzyjne identyfikowanie co najmniej kilkudziesięciu typów eratyków, by następnie uprościć wyniki do dziesięciu, a w skrajnych przypadkach - zaledwie trzech lub dwu grup regionalnych. Granice poszczególnych regionów są ustalane w sposób subiektywny.

Wspomnianych wad pozbawiona jest metoda obliczania teoretycznych ośrodków głazowych (TCG) wprowadzona przez Lüttiga (1958), a następnie przyjęta przez wielu badaczy - w tym polskich. Końcowy wynik analizy tą metodą stanowi punkt o ściśle określonych współrzędnych geograficznych, obliczony w oparciu o wszystkie skały przewodnie zidentyfikowane w próbce. Wyniki badań z wielu stanowisk mogą zatem być zaprezentowane jako punkty w dwuosiowym układzie współrzędnych i dzięki temu dość łatwo analizowane i interpretowane. Pozwala to na szybką i skuteczną korelację stratygraficzną analizowanych stanowisk (rys. 5.3). Powyższe zalety przyczyniły się do rozpowszechnienia tego sposobu prezentacji wyników badań eratyków w Europie Środkowej. Z tej metody prezentacji korzysta również autor niniejszej pracy, ale z zastrzeżeniem, że obliczenia teoretycznych ośrodków głazowych zostały przeprowadzone nie tylko w oparciu o tradycyjną metodę Lüttiga (1958), lecz także w wersjach zmodyfikowanych - w niektórych przypadkach znacznie odbiegających od pierwotnej (m.in. wg Groetznera - 1972 i starszej koncepcji autora - Czubla, 2001). 


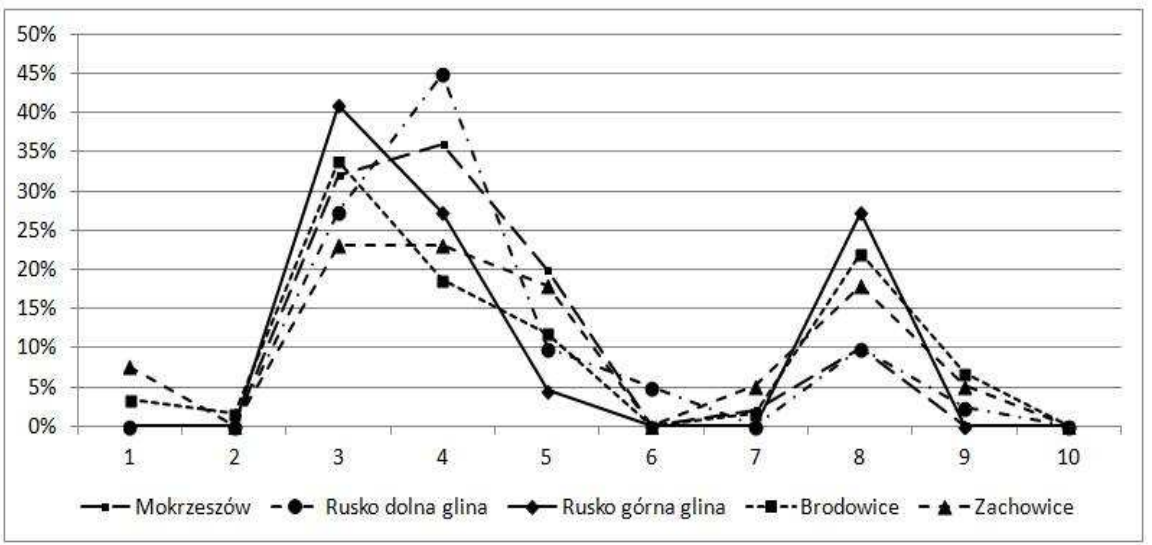

a)

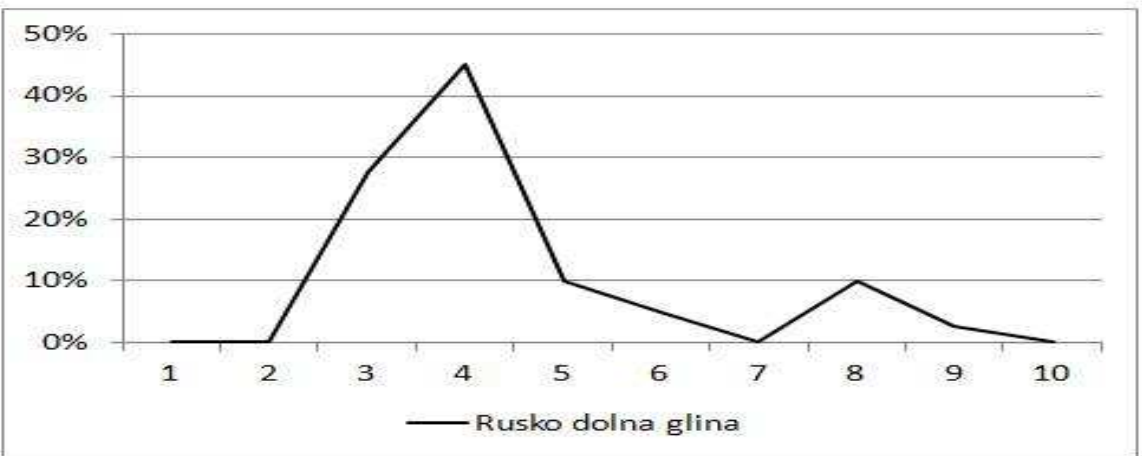

b)

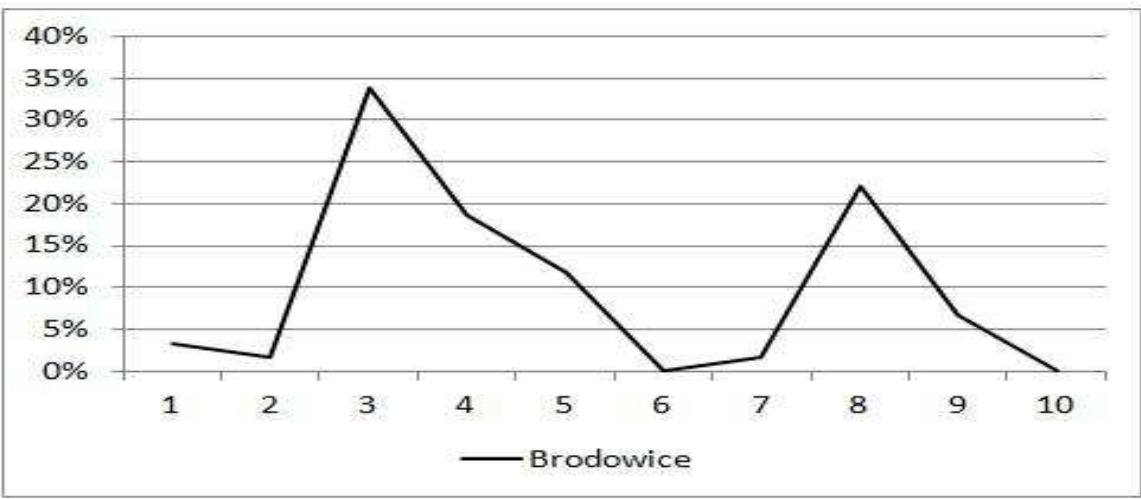

c)

Rys. 5.2. Eratyki przewodnie w glinach Dolnego Śląska (grupy regionalne wg Gałązki - 2004b):

a) zestawienie zbiorcze 5 prób, b) glina kompleksu południowopolskiego (san 1?) - Rusko koło Jaroszowa, c) glina kompleksu południowopolskiego (san 2) - Brodowice

Figure 5.2. Indicator erratics in the glacial deposits of Lower Silesia (regional groups and graphic presentation, according to Gałązka - 2004b): a) summary graph of 5 samples, b) the South-Polish Complex (Sanian 1?) till Rusko by Jaroszów, c) the South-Polish Complex (Sanian 2) till - Brodowice 


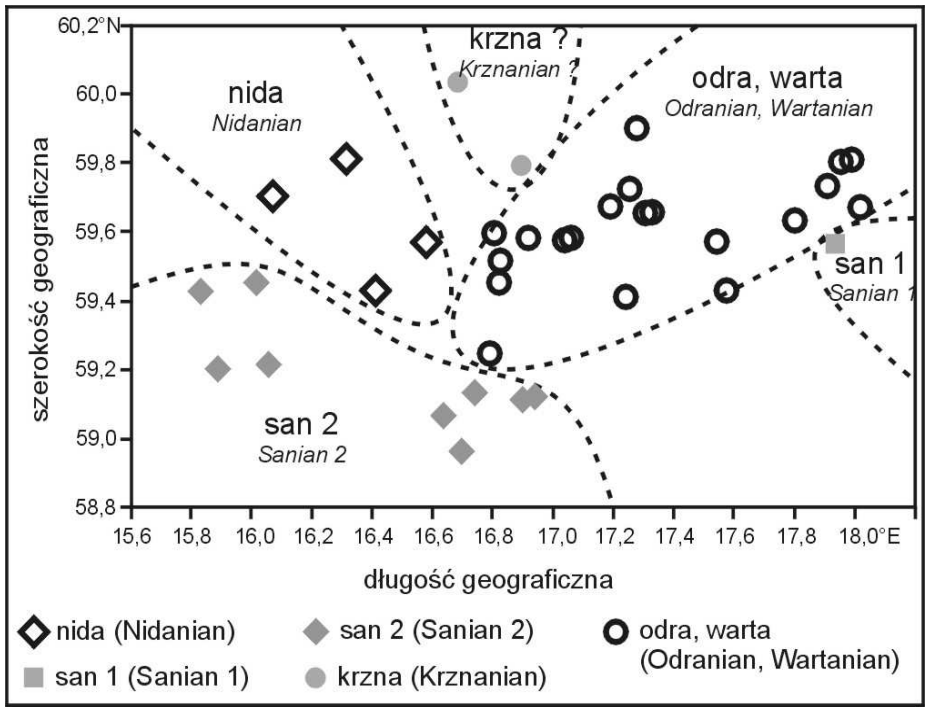

Rys. 5.3. Teoretyczne ośrodki głazowe w Polsce Środkowej z zasięgami pól przypisanych do poszczególnych nasunięć lądolodu (Czubla, 2001; Czubla i in., 2012); stratygrafia zmodyfikowana w oparciu o nowe badania

(Balwierz i in., 2006, 2008; Ber i in., 2007; Lindner i Marks, 2012)

Figure 5.3. Theoretical boulder centers (TBC) calculated for glacial tills of central Poland - Czubla, 2001;

Czubla et al., 2013a; stratigraphy modified on the basis of new research (Balwierz et al., 2006, 2008; Ber et al., 2007; Lindner \& Marks, 2012)

Po negatywnych wynikach analizy teoretycznych ośrodków głazowych z uwzględnieniem rozszerzonego zestawu skał osadowych włącznie z węglanowymi (Czubla, 2001), autor ograniczył wykorzystywanie tych najmniej wiarygodnych skał w obliczeniach TCG. Jedynie dla celów porównawczych wyliczone zostały wskaźniki bazujące na zespołach eratyków rozszerzonych o wybrane skały osadowe. Procedura stosowana przez Vinxa i in. (1997) i zaadaptowana pierwotnie przez autora (Czubla, 1999a, 2001), polegała na zaokrągleniu liczby wybranych skał pomocniczych w próbce do pełnych dziesiątek, ale tylko w górę i następnie uwzględnieniu w obliczeniach TCG otrzymanej liczby dziesiątek zamiast rzeczywistej liczby eratyków. W ten sposób malał wpływ pospolitych skał osadowych o rozległych wychodniach (wapienie paleoporellowe, beyrichiowe, czerwone wapienie ordowiku, dolomity, piaskowce Old-Redu, piaskowce skolitusowe i czerwone piaskowce kambryjskie) na położenie TCG. Jest to jednak procedura metodycznie błędna (pomijając nawet kwestię wątpliwej wartości przewodniej wymienionych skał - patrz rozdz. 10), bo przypisuje taką samą wagę jednemu idziesięciu ziarnom skały pomocniczej, ale już jedenaście ziaren miałoby wagę dwukrotnie większą. Podjęta przez autora próba korekty tej metody, polegająca na przypisywaniu pomocniczym skałom osadowym dziesięciokrotnie mniejszej wagi niż typowym skałom przewodnim (akceptująca wartości ułamkowe, np. 27 klastów dolomitów było równoważne 2,7 ziarna typowej skały przewodniej, np. brunatnego porfiru bałtyckiego) nie przyniosła zadowalających rezultatów. W odniesieniu do terytorium Polski pomysł szerszego uwzględnienia w badaniach eratyków osadowych skał 
pomocniczych z basenu Bałtyku (Smed, 1997, 2000, 2002, 2010) wydaje się zatem niecelowy. W zasadzie każdy lądolód nasuwający się z północy na terytorium naszego kraju musiał przekroczyć wychodnie paleozoicznych skał osadowych, wyściełających nieckę Bałtyku. W związku z tym obecność określonego typu skały, np. czerwonego piaskowca bałtyckiego informuje wyłącznie o przekroczeniu jego wychodni, ale czy miało to miejsce w pobliżu Wysp Alandzkich, czy na południowy zachód od Olandii i tak pozostaje pytaniem otwartym. Na dodatek centralne punkty wychodni skał pomocniczych (niesłusznie nazywanych przez Smeda statystycznymi - 2002) zostały zaproponowane dość dowolnie, np. centrum wychodni czerwonych piaskowców bałtyckich miałoby się znaleźć tuż na południe od Wysp Alandzkich (Smed, 2002), a według Lipki (2011) nawet na obszarze Botniku Południowego. Nowe metody badawcze powinny z założenia prowadzić do obiektywizacji wyników i wniosków; tymczasem Smed (2002) proponuje dwa punkty centralne wychodni wapieni beyrichiowych, a czerwonym granitom ze Smålandu przypisał aż trzy punkty do wyboru (subiektywnego?) przez badacza.

Obliczenia teoretycznych ośrodków głazowych (TCG) przy użyciu metody Lüttiga (1958) wymagają umiejętności rozpoznawania stu kilkudziesięciu skał przewodnich. Jednak tylko około 40 spośród nich występuje dość często w osadach glacjalnych Polski. W związku z tym autor podjął próbę uproszczenia procedury badawczej poprzez eliminację rzadkich typów eratyków przewodnich i oparcie się tylko na tych, które mają największy wpływ na położenie TCG. W tym celu zostało przetestowanych osiem autorskich zestawów eratyków, które stanowiły podstawę do obliczenia testowych teoretycznych ośrodków głazowych, opisywanych jako TCG-W1 do TCG-W8 (tab. 5.4). Ostatni z proponowanych testowych TCG (TCG-W8) jest bardzo zbliżony do wykorzystywanego w dawniejszych opracowaniach autora standardowego TCG, bazującego na skałach krystalicznych i wybranych skałach okruchowych (m.in. Czubla, 2001). Różnica polega na pominięciu w obliczeniach TCG-W8 piaskowców Dala i kwarcytów Västervik. Włącznie ze wspomnianymi wcześniej „tradycyjnymi” metodami, obliczenia teoretycznych ośrodków głazowych wykonano w szesnastu wariantach.

Analiza rozmieszczenia teoretycznych ośrodków głazowych obliczonych w oparciu o różne założenia metodyczne pozwala wskazać warianty najbardziej skuteczne w rozróżnianiu różnowiekowych osadów. Na obszarze Polski Wschodniej gliny zlodowaceń san 2 i odra/warta różnią się głównie zawartością skał alandzkich, dalarneńskich i południowoszwedzkich (patrz rozdz. 14). Pozostałe eratyki przewodnie odgrywają mniejszą rolę. W związku z tym różnice w rozmieszczeniu teoretycznych ośrodków głazowych okazały się najwyraźniejsze w wariantach TCG-W1, TCG-W3, TCG-W4 i TCG-W5 (rys. 5.4). Wykresy bazujące na wszystkich krystalicznych eratykach przewodnich, rozbudowywane stopniowo - najpierw o przewodnie piaskowce, a następnie o pomocnicze skały osadowe okruchowe i węglanowe okazały się mniej czytelne. Zauważalny jest również wzrost rozproszenia wyników wraz z rosnącą liczbą typów uwzględnianych w obliczeniach skał pomocniczych. Przetestowano również wybiórcze TCG (Auswahl TGZ - Groetzner, 1972). Wyniki dla prób z Polski Wschodniej okazały się nieco czytelniejsze niż przeanalizowane w trakcie badań w Polsce Środkowej (Czubla, 1999a, 2001), ale nadal mniej przejrzyste od autorskich wariantów TCG-W1 i TCG-W3 - TCG-W5. 
Tabela 5.4. Rodzaje skał przewodnich wykorzystane do obliczeń testowych teoretycznych ośrodków głazowych

Table 5.4. Indicator rocks types used to calculate experimental theoretical boulder centers (TBC)

\begin{tabular}{|c|c|}
\hline $\begin{array}{c}\text { Testowe } \\
\text { TCG }\end{array}$ & Uwzględnione w obliczeniach testowych TCG eratyki przewodnie \\
\hline TCG-W1 & $\begin{array}{l}\text { Granity alandzki, Haga, Kökar, rapakiwi alandzki, granit aplitowyalandzki granitoporfir alandzki, } \\
\text { alandzki porfir kwarcowy, granity Filipstad, Filipstad (S-odmiana), Hammer, Vang, Uthammar, } \\
\text { Vånevik, czerwone granity Småland, Vislanda, pyterlit alandzki lub Nystad, ignimbryty Rännås, } \\
\text { Blyberg, Orrlok, kullait, porfiry Åsen, bałtycki brunatny i czerwony, Blyberg, Bredvad, czerwony } \\
\text { Grönklitt, szary z Dalarna, Emarp, Fagerhult, Lönneberga, Glöte, Heden, Hogland, porfir i ignim- } \\
\text { bryt Klittberg, porfiry Kåtilla, Mälar, Månsta, Nymala, Påskallavik, Sjögelö, Tadsjöborg, Venjan, } \\
\text { botnickie, porfiry i ignimbryty z Dalarna, porfiry i ignimbryty Småland }\end{array}$ \\
\hline TCG-W2 & $\begin{array}{l}\text { Granity alandzki, Haga, Kökar, rapakiwi, granit aplitowy alandzki i granitoporfir alandzki, alandz- } \\
\text { ki porfir kwarcowy, granity Sala, Uppsala, Vänge, Arnö, Uthammar, Vånevik, czerwone granity } \\
\text { Småland, Vislanda, pyterlit alandzki lub Nystad, ignimbryty Rännås, Blyberg, Orrlok, porfiry } \\
\text { bałtycki brunatny i czerwony, Bredvad, czerwony Grönklitt, szary z Dalarna, Venjan }\end{array}$ \\
\hline TCG-W3 & $\begin{array}{l}\text { Granity alandzki, Haga, Kökar, rapakiwi, granit aplitowy alandzki i granitoporfir alandzki, alandz- } \\
\text { ki porfir kwarcowy, granity Vånevik, czerwone granity Småland, Vislanda, pyterlit alandzki lub } \\
\text { Nystad, porfiry bałtycki brunatny i czerwony, Bredvad, czerwony Grönklitt, szary z Dalarna, } \\
\text { Kåtilla, Venjan }\end{array}$ \\
\hline TCG-W4 & $\begin{array}{l}\text { Granity alandzki, Haga, Kökar, rapakiwi, granit aplitowy alandzki i granitoporfir alandzki, alandz- } \\
\text { ki porfir kwarcowy, granity sztockholmski, Uppsala, Vänge, Arnö, Vånevik, czerwone granity } \\
\text { Småland, Vislanda, pyterlit alandzki lub Nystad, porfiry bałtycki brunatny i czerwony, Bredvad, } \\
\text { czerwony Grönklitt, szary z Dalarna }\end{array}$ \\
\hline TCG-W5 & $\begin{array}{l}\text { Granity alandzki, Haga, Kökar, rapakiwi, granit aplitowy alandzki i granitoporfir alandzki, alandz- } \\
\text { ki porfir kwarcowy, granity Sala, Uppsala, Vänge, Arnö, Vånevik, czerwone granity Småland, } \\
\text { Vislanda, porfiry bałtycki brunatny i czerwony, Bredvad, czerwony Grönklitt, szary z Dalarna }\end{array}$ \\
\hline TCG-W6 & $\begin{array}{l}\text { Granity alandzki, Haga, Kökar, rapakiwi, granit aplitowy alandzki i granitoporfir alandzki, alandz- } \\
\text { ki porfir kwarcowy, granity Sala, Uppsala, Vänge, Arnö, Vånevik, czerwone granity Småland, } \\
\text { Vislanda, porfiry bałtycki brunatny i czerwony, Bredvad, czerwony Grönklitt, szary z Dalarna, } \\
\text { piaskowiec Tessini }\end{array}$ \\
\hline TCG-W7 & $\begin{array}{l}\text { Granity alandzki, Haga, Kökar, rapakiwi, granit aplitowy alandzki i granitoporfir alandzki, alandz- } \\
\text { ki porfir kwarcowy, granity czerwone Småland, Vislanda, porfiry bałtycki brunatny i czerwony, } \\
\text { Bredvad, czerwony Grönklitt, szary z Dalarna }\end{array}$ \\
\hline TCG-W8 & $\begin{array}{l}\text { Amfibolity z granatami, bazalt ze Skanii, diabazy Åsby, Kinne, diabaz i melafir Öje, diabaz mela- } \\
\text { firowy (melafir) bałtycki, sjenitoporfir bałtycki, gnejsy bornholmskie, granity alandzki, Haga, } \\
\text { Kökar, rapakiwi, granit aplitowy alandzki i granitoporfir alandzki, alandzki porfir kwarcowy, } \\
\text { granity Ytö, Bohuslän, Filipstad, Filipstad (S-odmiana), Flivik, Garberg, Graversfors brunatny } \\
\text { i czerwony, Östgöta, Hammer, Vang, granit i granitoporfir Rödö, porfir kwarcowy Rödö, granity } \\
\text { Järna, Karlshamn, Kinda, Kristinehamn, Marianelund, Perniö, rapakivi Nystad, pyterlit Nystad, } \\
\text { szary granodioryt Nystad, rapakiwi Rödö, granity Rätan, Revsund, Björna, Sala, Siljan, rapakivi } \\
\text { Siljan, granity Spinkamåla (Halen), sztokholmski, Uppsala, Vänge, Arnö, Uthammar, Vånevik, } \\
\text { Växjö różowy i szary, Virbo, granit i granitognejs Ångermanland, granity Småland czerwone, } \\
\text { Vislanda, Barnarp (trójkolorowy), pyterlit alandzki lub Nystad, sjenit Vaggeryd, ignimbryty } \\
\text { Rännås, Blyberg, Orrlok, kullait, porfiry Åsen, bałtycki brunatny i czerwony, Blyberg, Bredvad, } \\
\text { czerwony Grönklitt, szary z Dalarna, Emarp, Fagerhult, Lönneberga, Glöte, Heden, Hogland, } \\
\text { porfir i ignimbryt Klittberg, porfiry Kåtilla, Mälar, Månsta, Nymala, Påskallavik, Sjögelö, skały } \\
\text { (porfir, granit, granitoporfir i sjenit) Ragunda, porfiry Särna, Tadsjöborg, Venjan, botnickie, } \\
\text { porfiry i ignimbryty z Dalarna, porfiry i ignimbryty Småland, tinguait Särna, piaskowiec i zlepie- } \\
\text { niec Digeberga, piaskowiec Hardeberga, piaskowiec Kalmarsund, piaskowiec Tessini }\end{array}$ \\
\hline
\end{tabular}



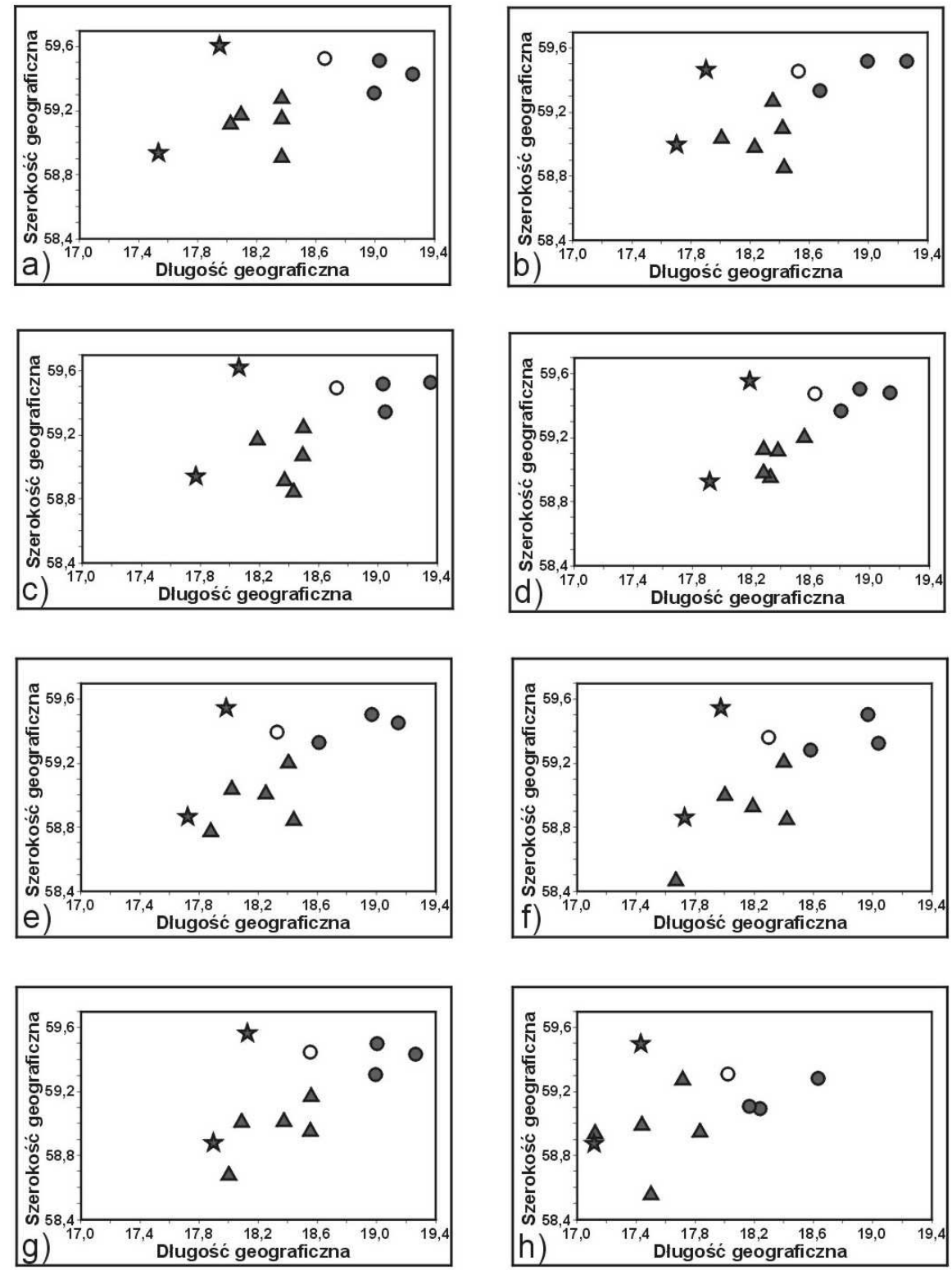

\section{$\Delta \operatorname{san} 2 \quad \circ \quad \mathrm{krzna} \quad \circ \quad$ odra/warta $\star$ żwiry i diamiktony}

Rys. 5.4. Położenie testowych teoretycznych ośrodków głazowych wyznaczonych dla osadów ze stanowisk w Polsce Wschodniej: a) TCG-W1, b) TCG-W2, c) TCG-W3, d) TCG-W4, e) TCG-W5, f) TCG-W6,

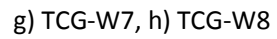

Figure 5.4. Experimental theoretical boulder centers calculated for glacial deposits in Eastern Poland: a) TCG-W1, b) TCG-W2, c) TCG-W3, d) TCG-W4, e) TCG-W5, f) TCG-W6, g) TCG-W7, h) TCG-W8 
Nieco inaczej różnice pomiędzy różnowiekowymi osadami glacjalnymi rozkładają się na obszarze Polski Środkowej. Na wykresie zbiorczym (rys. 5.3) odmienność położenia TCG dla osadów glacjalnych zlodowaceń san 2 i odra/warta zaznacza się bardzo wyraźnie. Teoretyczne ośrodki głazowe przedstawione na wspomnianym wykresie zostały obliczone w oparciu o pełny zestaw skał przewodnich. Ograniczenie liczby eratyków przewodnich wykorzystywanych do obliczania TCG (TCG-W1 - TCG-W7) spowodowało częściowe nałożenie na siebie na wykresie pól odpowiadających poszczególnym zlodowaceniom. Jedynie TCG-W8, czyli wersja najbliższa zaprezentowanej pierwotnie przez Lüttiga (1958) pozwala jednoznacznie odróżniać omawiane osady. Wskaźniki Groetznera (op. cit.) również dały słaby wynik, a co ciekawe wszystkie 4 sprawdzone wersje (piąta różniła się od jednej z nich tylko doliczaniem skał norweskich, które w Polsce są prawie nieobecne i dlatego została pominięta) mają prawie identyczny obraz graficzny. Oznacza to, że w przypadku Polski Środkowej różne metody wyznaczania TCG przynoszą pozytywny efekt, ale najlepsze są te, w których uwzględniana jest możliwie największa liczba typów skał przewodnich. Dalsze poszerzanie listy eratyków uwzględnianych w obliczeniach TCG o skały pomocnicze (wybrane skały węglanowe i okruchowe) nie przynosi już korzystnych efektów. Dowiodły tego testy kontrolne przeprowadzone w oparciu o próby pobrane w odkrywce KWB Bełchatów i w innych odsłonięciach Polski Środkowej (Czubla, 2001).

Powyższe wyniki wskazują, że do odróżniania osadów zlodowaceń san 2 i odra/ warta można skorzystać ze zredukowanej liczby skał przewodnich, tj. skał alandzkich, botnickich, bałtyckich, dalarneńskich, smalandzkich i bornholmskich (TCG-W1). Co prawda dla Polski Środkowej wynik będzie trochę słabszy, aniżeli pozyskany z wykorzystaniem wszystkich skał przewodnich, ale ta uproszczona wersja obliczeń pozwoli zrezygnować z rozpoznawania części eratyków wskaźnikowych, mających niewielki wpływ na rezultat badań. Warto jednak zauważyć, że najlepszy wynik testowego TCG dotyczył wskaźnika wyznaczonego w oparciu o nadal dość wysoką liczbę typów eratyków (TCG-W1). Dalsza redukcja liczby wykorzystywanych typów skał (TCG-W2 - TCG-W7) wpłynęła negatywnie na przejrzystość wyników. Oznacza to, że znaczące skrócenie i uproszczenie procedury badawczej obniża wiarygodność analiz osadów glacjalnych tą metodą. Być może przynajmniej częściowo odpowiada za to spadek liczebności zespołów eratyków po odrzuceniu części typów skał. Można byłoby temu zaradzić poprzez zwiększony pobór eratyków (np. 1500 zamiast 1000 eratyków w próbce), ale wymagatoby to dodatkowych prac terenowych.

Różnica pomiędzy osadami glacjalnymi zlodowaceń kompleksu południowopolskiego (san 1 i san 2) na Dolnym Śląsku zaznaczyła się najlepiej na wykresie TCG-W1, nieco słabsze wyniki dało wykorzystanie zestawów skał TCG-W2, TCG-W3, TCG-W5, TCG-W6 i TCG-W7 (rys. 5.5). Zdecydowanie najsłabiej prezentują się wyniki analizy wykorzystujące wszystkie przewodnie eratyki krystaliczne, włącznie z wersjami uzupełnionymi o skały osadowe. Mało czytelny jest również wariant TCG-W4, TCG-W8, zaś wszystkie wskaźniki Groetznera dają wynik niewiele lepszy od uzyskanego tradycyjną metodą Lüttiga z wcześniejszymi usprawnieniami. 

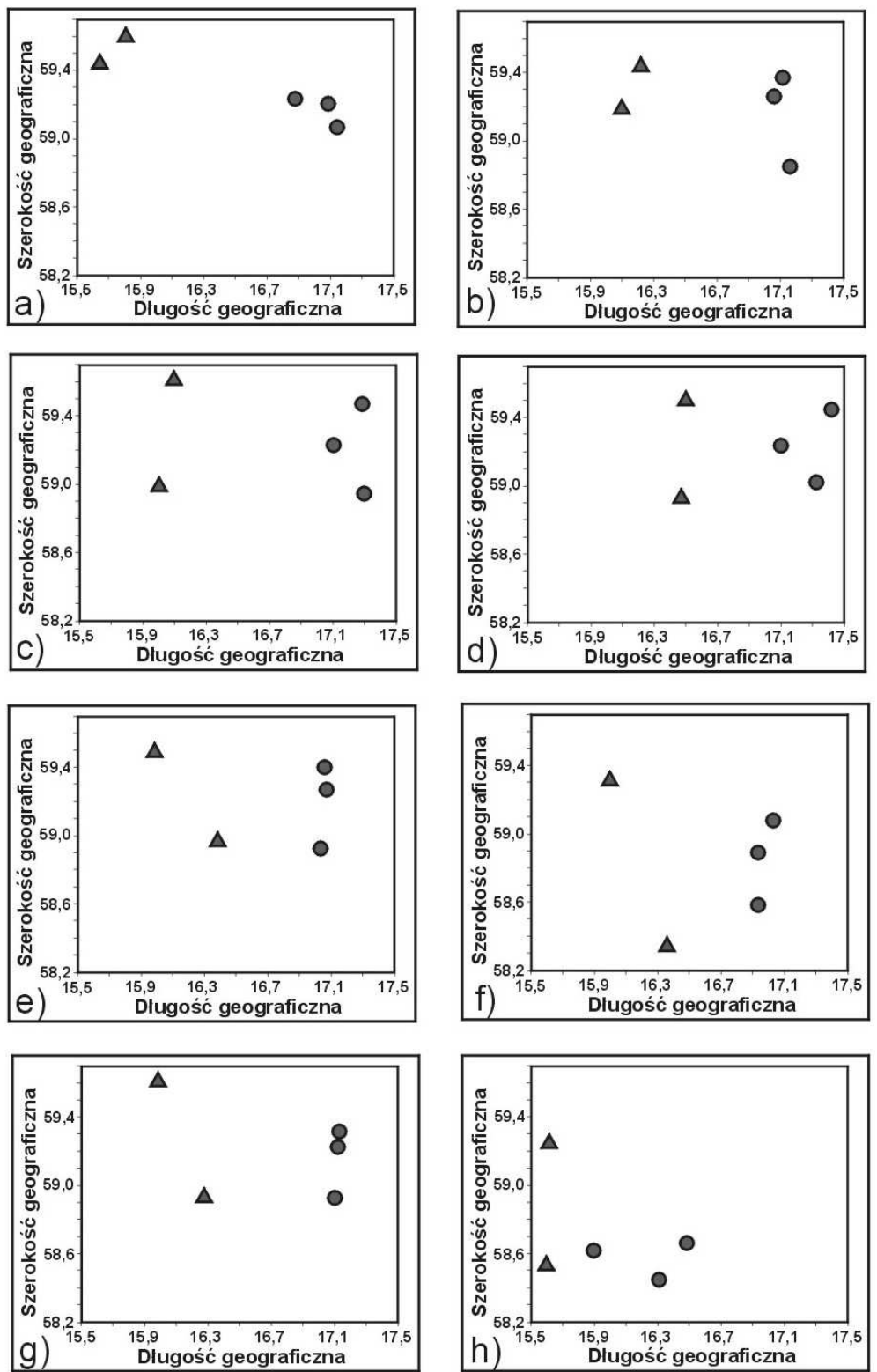

$\Delta \operatorname{san} 1$

- $\operatorname{san} 2$

Rys. 5.5. Położenie testowych teoretycznych ośrodków głazowych wyznaczonych dla osadów glacjalnych sanu 1 i sanu 2 na Dolnym Śląsku: a) TCG-W1, b) TCG-W2, c) TCG-W3, d) TCG-W4, e) TCG-W5, f) TCG-W6, g) TCG-W7, h) TCG-W8

Figure 5.5. Experimental theoretical boulder centers calculated for glacial deposits of the South-Polish Complex (Sanian 1 and Sanian 2) in Lower Silesia: a) TCG-W1, b) TCG-W2, c) TCG-W3, d) TCG-W4, e) TCG-W5, f) TCG-W6, g) TCG-W7, h) TCG-W8 
Analiza teoretycznych ośrodków głazowych jest znacznie mniej skuteczna w przypadku rozróżniania osadów glacjalnych zlodowaceń odra/warta i wisła. Jedynie na Kujawach ośrodki głazowe tych dwóch zlodowaceń różnią się położeniem na wykresie. TCG starszych glin zlokalizowane są bardziej na południowy zachód niż TCG osadów vistulianu (por. Czubla i Sokołowski, 2014). Różne metody obliczania TCG prowadzą do podobnego rezultatu i różnią się jedynie stopniem rozproszenia wyników. Różnica lokalizacji TCG różnowiekowych glin jest w tym przypadku najlepiej widoczna dla TCG-W8 (rys. 5.6.a).

Na Pomorzu i Powiślu analiza wskaźników TCG jest mniej wiarygodna ze względu na niewielką liczbę przebadanych glin środkowopolskich (zaledwie $5 \mathrm{w}$ stosunku do 42 prób z glin północnopolskich). TCG glin vistulianu cechują się bardzo dużym rozproszeniem, co związane jest ze zmiennością czasową i przestrzenną dynamiki lądolodu (por. m.in. Woźniak i Czubla, 2014a, 2014b, w druku). Rozmieszczenie TCG-W8 dla glin zlodowacenia odra/warta wykazuje podobną tendencję do zaobserwowanej na Kujawach. Przejawia się ona koncentracją wskaźników w południowo-zachodnim sektorze wykresu, podczas gdy TCG osadów zlodowacenia wisła rozproszone są po całym polu wykresu (rys. 5.6.b).
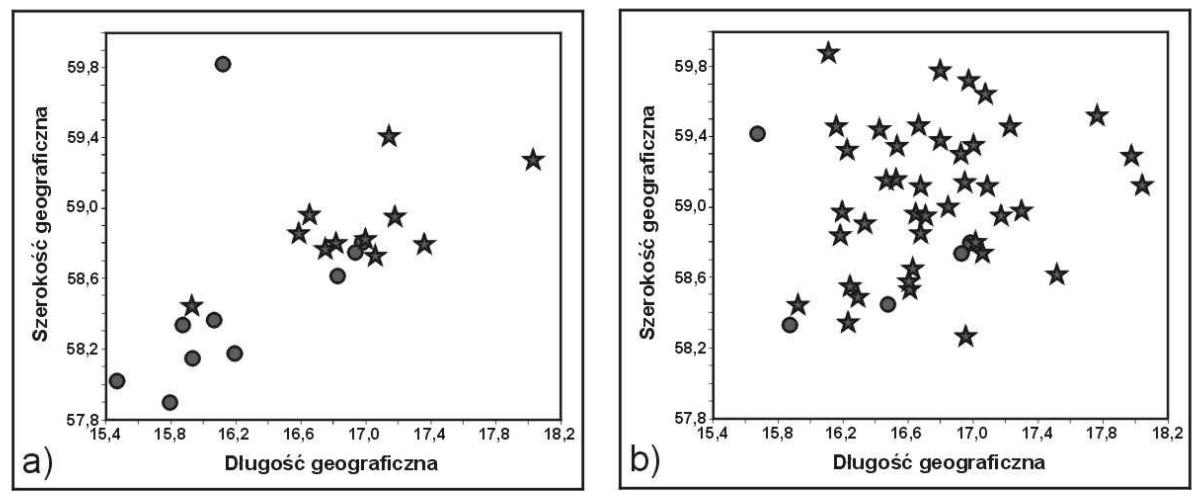

\section{o odra/warta $\star$ wisła}

Rys. 5.6. Położenie teoretycznych ośrodków głazowych wyznaczonych dla osadów glacjalnych zlodowaceń odra/warta i wisła (testowe TCG-W8): a) Kujawy, b) Pomorze i Powiśle

Figure 5.6. Theoretical boulder centers calculated for glacial deposits of Odranian/Wartanian and Weichselian Glaciations (experimental TCG-W8): a) Kuyavia, b) Pomerania and Lower Vistula Valley

Teoretyczne ośrodki głazowe stanowią dobry wskaźnik pozwalający na rozróżnienie różnowiekowych glin, ale nie we wszystkich przypadkach. Stosunkowo najlepiej różnica w lokalizacji TCG zaznacza się w przypadku osadów zlodowaceń san 2 i odra/warta. Podstawowa tendencja zmienności TCG powtarza się od wschodniej Wielkopolski aż po Lubelszczyznę i Podlasie. Najłatwiej rozróżnić wspomniane gliny przy użyciu TCG-W1, ale kilka innych wariantów również prowadzi do zadowalającego rezultatu. Obiecujące wydaje się również odróżnianie glin zlodowaceń krzna i odra/warta z wykorzystaniem TCG. Zaobserwowana w Polsce Środkowej tendencja, polegająca na bardziej wschodnim położeniu tego wskaźnika dla osadów starszego nasunięcia, powtórzyła się 
w jedynym, jednoznacznie datowanym na MIS-8 (Terpiłowski i in., w przygotowaniu) stanowisku na Podlasiu. Bardziej wiarygodne potwierdzenie powyższej obserwacji wymaga jednak znalezienia kolejnych stanowisk z glinami tego wieku dostępnymi do badań. Próba rozróżniania glin odłożonych przez kolejne lądolody kompleksu południowo-polskiego na Dolnym Śląsku również wydaje się perspektywiczna (rys. 5.5), ale wymaga weryfikacji w oparciu o większą liczbę stanowisk. Gliny zlodowacenia wisła zawierają bardzo zróżnicowane przestrzennie zespoły eratyków, co uniemożliwia ich jednoznaczną korelację na podstawie cech petrograficznych frakcji $>20 \mathrm{~mm}$. Badania w północnej Polsce dowiodły też bardzo ograniczonych możliwości rozróżniania osadów poszczególnych faz stadiału głównego zlodowacenia wisła w oparciu o badania frakcji $>20$ mm. Zaobserwowano w nich znaczną lokalną zmienność składu zespołów eratyków (pochodzących z równowiekowych osadów glacjalnych), co daje podstawy do analiz o charakterze bardziej paleogeograficznym niż stratygraficznym (m.in. Czubla $i$ in. 2007a, 2007b; Woźniak i in., 2008, 2009, 2012a, 2012b, 2013a, 2013b, 2013c; Woźniak i Czubla, 2014a, 2014b, w druku).

Teoretyczne ośrodki głazowe są łatwe do interpretacji, ale zdaniem Smeda (1993) część informacji jest $\mathrm{w}$ tej metodzie tracona. W związku z tym przywoływany autor zaproponował nowy sposób graficznej prezentacji wyników analiz, który miał być łatwiejszy do interpretacji i jednocześnie pozwalał zachować wszystkie dane dotyczące przebadanego materiału. Jest to metoda tzw. map kołowych (kartodiagramy), znajdująca ostatnio zastosowanie również w Polsce (np. Górska, 2000; Czubla, 2001, 2006; Czubla i in., 2007, 2010, 2013; Górska-Zabielska, 2008).

Do prezentacji wyników na mapach kołowych przygotowano specjalny podkład kartograficzny w odwzorowaniu możliwie bliskim wiernopowierzchniowemu, na którym naniesiono centralne punkty wychodni eratyków wskaźnikowych (tab. 4.4). Punkty te traktowane były przy kreśleniu map jako środki kół, których powierzchnia odpowiadała procentowemu udziałowi eratyków z danego obszaru źródłowego w zespole eratyków wskaźnikowych z danego stanowiska. W celu uniknięcia zdominowania kartodiagramu przez pospolite osadowe skały pomocnicze, zredukowano ich liczbę dziesięciokrotnie. Numery skał (tab. 4.4) odpowiadają numerom wychodni i jednocześnie kół przedstawiających udział odpowiednich skał na mapach. Dla uniknięcia pokrywania się na mapie kół symbolizujących eratyki z bardzo bliskich wychodni, wyznaczano wspólne centrum wychodni i w nim lokowano diagram odpowiadający sumarycznemu udziałowi tych eratyków. Nie udało się jednak całkowicie uniknąć nakładania się na siebie diagramów, prezentujących udział eratyków z niezbyt od siebie odległych obszarów, np. różnych skał dalarneńskich. Na mapach nie zaznaczano teoretycznych ośrodków głazowych, ponieważ stanowią one jedynie wskaźniki obliczone w oparciu o liczbę zidentyfikowanych eratyków przewodnich oraz o współrzędne geograficzne ich wychodni. Nie są one równoznaczne z centrum egzarowanego przez lądolód obszaru i stwierdzenie, że któryś położony jest, np. w północnym Smålandzie i tak nie wniosłoby żadnej istotnej geologicznie informacji. 
W przypadku analizy pojedynczych prób kartodiagramy (mapy kołowe) Smeda są rzeczywiście łatwe do interpretacji i bardzo sugestywne (rys. 5.7). Pozwalają nie tylko precyzyjnie zaprezentować skład zespołu eratyków, ale i prześledzić hipotetyczną drogę materiału skalnego do analizowanego stanowiska, a w niektórych wypadkach nawet wykluczyć pojedyncze eratyki inkorporowane ze starszych osadów (pod warunkiem, że osady te reprezentują wyraźnie odmienny kierunek transgresji lądolodu). Problemy pojawiają się w przypadku konieczności przeanalizowania większej liczby próbek. Już zestawienie i porównanie kilku kartodiagramów sprawia spory kłopot techniczny i jest obarczone wadą subiektywizmu (rys. 5.7 i 5.8). W przypadku kilkunastu i więcej map kołowych taka analiza porównawcza jest niewykonalna. Wydaje się zatem, że mapy kołowe mogą służyć głównie do rekonstrukcji paleodynamiki lądolodu (por. Czubla, 2001; Czubla i in. 2007a; Woźniak i in., 2008, 2009; Woźniak i Czubla, 2014a, 2014b, $w$ druku) i chyba właśnie w tym kierunku zmierza twórca tej metody, wprowadzając do
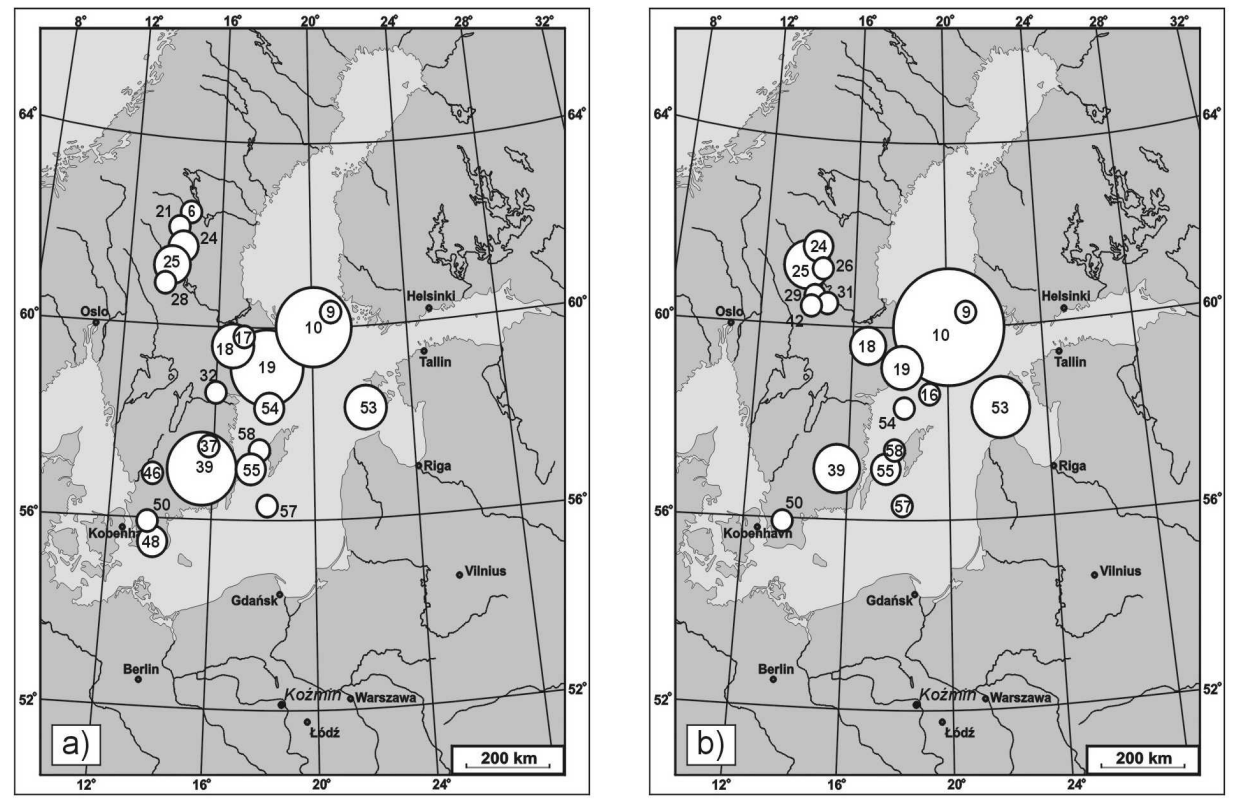

Rys. 5.7. Eratyki wskaźnikowe (przewodnie i pomocnicze) w osadach glacjalnych odkrywki Koźmin Północ (wg Czubli i in. 2010): a) glina kompleksu południowopolskiego (san 2); 66 eratyków, b) glina kompleksu środkowopolskiego (odra/warta); 68 eratyków - eratyki pomocnicze w liczbie zredukowanej zgodnie z ideą Vinxa (Vinx i in. 1997); oznaczenia diagramów zgodne z numeracją eratyków w tab. 4.4; powierzchnia diagramu kołowego odpowiada udziałowi procentowemu danego eratyka w zespole; prezentacja graficzna wg Smeda (1993), zmodyfikowana

Figure 5.7. Indicator erratics (including auxiliary rocks) in glacial deposits of the Koźmin North outcrop: a) the South-Polish Complex till (Sanian 2) - 66 erratics, b) the Middle-Polish Complex till (Odranian/Wartanian) - 68 erratics; number of auxiliary erratics reduced according to Vinx et al. (1997); circles signs are in accordance with the numbering of indicator rocks in the Tab. 4.4; the circle's area corresponds to the percentage of erratics in an analysed stone sample; graphic presentation method (circle map) after Smed (1993), modified 

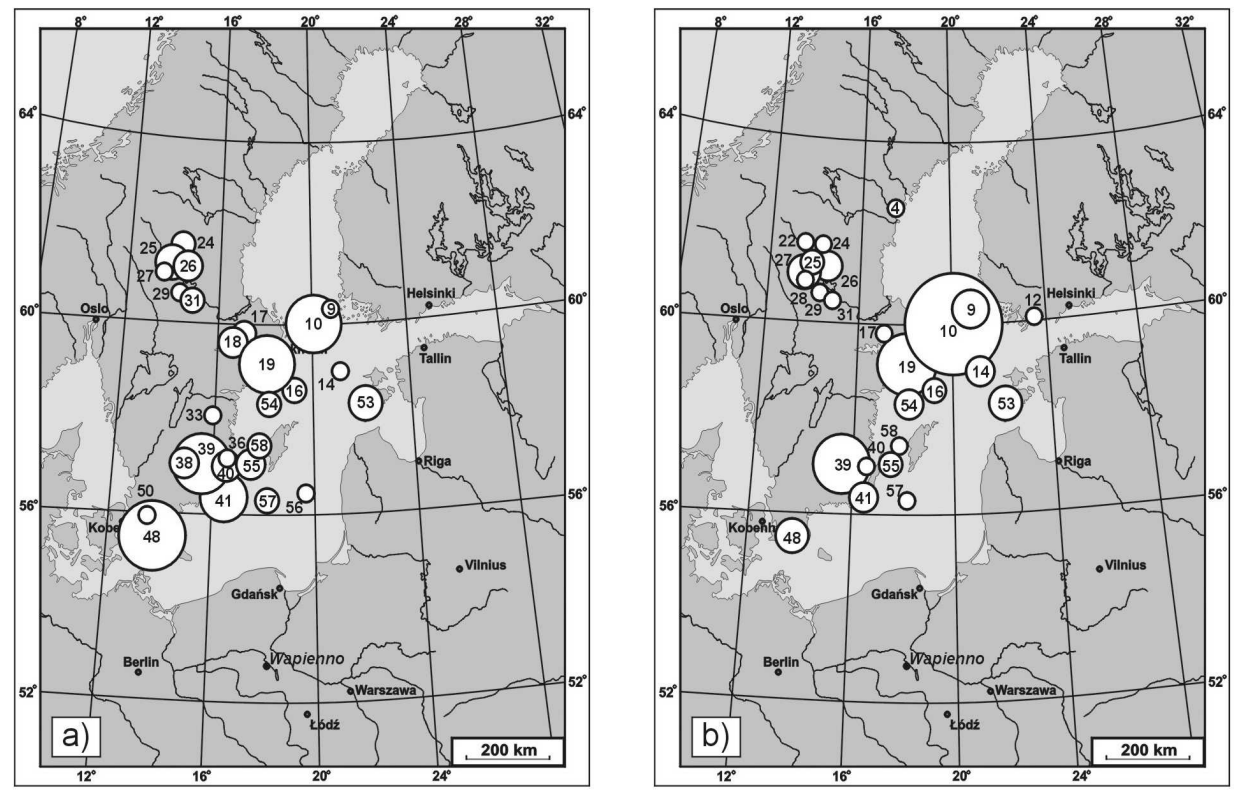

Rys. 5.8. Eratyki wskaźnikowe (przewodnie i pomocnicze) w osadach glacjalnych odkrywki Wapienno na Kujawach (zachodnia część odsłonięcia): a) glina kompleksu środkowopolskiego (odra/warta); 103 eratyki, b) glina kompleksu północnopolskiego (stadiał główny vistulianu - faza poznańska?); 106 eratyków - liczba eratyków pomocniczych zredukowana zgodnie z ideą Vinxa (Vinx i in., 1997); pozostałe objaśnienia jak na rys. 5.7

Figure 5.8. Indicator erratics (including auxiliary rocks) in glacial deposits of the Wapienno open-cast mine in Kujawy (western part of the outcrop): a) the Middle-Polish Complex till (Odranian/Wartanian) - 103 erratics,

b) the North-Polish Complex till (Weichselian Main Stadial - Poznań/Frankfurt Phase?) - 106 erratics; for further explanations see Figure 5.7

swych prezentacji coraz to liczniejsze rodzaje skał osadowych, pozbawione roli przewodniej (Smed, 1997, 2000, 2002, 2010). Ze względu jednak na olbrzymią rozciągłość geograficzną wychodni pomocniczych skał osadowych, rysowanie drogi lądolodu przez proponowany przez Smeda centralny punkt może być bardzo mylące. Obecność konkretnego typu skały nie mówi nam, przez którą część jej wychodni przesunął się lądolód, a odległość od południowo-zachodnich do północno-wschodnich peryferii wychodni piaskowców i wapieni starszego paleozoiku może przekraczać nawet 500 km (np. Smed, 2002; Tuuling i in., 2011).

Kilka powyższych metod próbowała połączyć Górska (np. 2000; Górska-Zabielska, 2008), która zidentyfikowane skały wskaźnikowe przedstawiała na wykresie słupkowym (poziomym), a dodatkowo prezentowała mapę kołową sporządzoną w oparciu o program CirMap 3.0 (Geisler, 1999). Istotną wadą powyższego programu jest zastosowanie podkładu kartograficznego w odwzorowaniu wiernokątnym, ułatwiającego - co prawda - wprowadzanie stanowisk eratyków przewodnich na bazie ich współrzędnych geograficznych oraz automatyczny import danych, ale zafałszowującego stosunki powierzchni 
obszaru alimentacji lądolodu i depozycji osadów glacjalnych. Na mapie zaznaczany był również teoretyczny ośrodek głazowy, co wywoływało złudne wrażenie jego istotności geograficznej. Przyjęty przez Górską-Zabielską sposób prezentacji jest za to bardzo korzystny ze względu na przedstawianie na wykresach surowych danych, które mogą następnie zostać przeliczone przy użyciu innych metod badawczych.

Z przedstawionego przeglądu metod i doświadczeń autora wynika, że dla potrzeb korelacji litostratygraficznej najbardziej przydatne jest obliczanie teoretycznych ośrodków głazowych, a następnie ich zestawianie w dwuosiowym układzie współrzędnych. Można w tym celu wykorzystać uproszczone testowe ośrodki głazowe, które w większości przypadków dadzą zadowalające wyniki. Należy mieć świadomość, że wraz ze zwiększaniem liczby typów skał wykorzystanych w obliczeniach testowych TCG (tab. 5.4) dokładność metody wzrasta. Analiza map kołowych dobrze sprawdza się $w$ analizach paleogeograficznych, podczas gdy korelacja osadów glacjalnych jest w oparciu o interpretację tych map bardzo trudna, o ile w ogóle możliwa. 


\section{RUCH LODOWCÓW I LĄDOLODÓW}

Ruch lodowców i lądolodów zależy m.in. od: reżimu termicznego, miąższości lodu, tempa akumulacji śniegu i przekształcania go w lód w polu firnowym, warunków klimatycznych, rzeźby podłoża, obecności wody w podłożu i wielu innych. Część z nich ma również wpływ pośredni, ponieważ decyduje o warunkach termicznych w stopie lodowca. Należy do nich miąższość lodu, gdyż wraz z jej wzrostem zwiększa się ciśnienie w dolnej części lodowca, a to ułatwia osiągnięcie punktu topnienia. W stopie lodowca o miąższości $2000 \mathrm{~m}$ temperatura topnienia lodu obniża się do $-1,6^{\circ} \mathrm{C}$. Na reżim termiczny może też oddziaływać wielkość i rodzaj opadów śniegu. Na ogół w centrum lądolodu gromadzi się śnieg chłodny i suchy, co wpływa na zimny reżim termiczny podłoża; w miarę przesuwania się ku strefom marginalnym rosną opady śniegu, ale jest on stosunkowo ciepły, co przyczynia się do utrzymywania się ciepłego reżimu termicznego podłoża. To oddziaływanie związane jest z temperaturą na powierzchni lodu spadek temperatury $\circ 1^{\circ} \mathrm{C} \mathrm{w}$ warstwie przypowierzchniowej generuje analogiczny spadek temperatury $\mathrm{w}$ stopie lądolodu i odwrotnie. Przesiąkanie wody ablacyjnej z powierzchni w głębsze warstwy lodu i jej zamarzanie powoduje wzrost temperatury otoczenia. Przejście $1 \mathrm{~g}$ wody w stan stały uwalnia ilość ciepła pozwalającą na wzrost temperatury $160 \mathrm{~g}$ lodu o $1^{\circ} \mathrm{C}$ (Bennett i Glasser, 2009). Dynamika lądolodów jest w dużym stopniu zależna od strumienia cieplnego podłoża. Im wyższa jest jego wartość, tym łatwiej w stopie lodowca osiągany jest punkt topnienia. Dodatkowe ilości ciepła uwalniane są na skutek tarcia wewnętrznego lodu. Bennett i Glasser (op. cit.) szacują, że lód poruszający się w tempie zaledwie $20 \mathrm{~m} /$ rok generuje $\mathrm{w}$ ten sposób ilość energii zbliżoną do średniej wartości strumienia cieplnego podłoża.

Obecnie wyróżniane są trzy mechanizmy ruchu lodu:

1. Deformacje wewnętrzne (ruch deformacyjny lodowca, ślizg wewnętrzny, płynięcie nasuwcze, płynięcie deformacyjne),

2. Ślizg denny (poślizg lodowca po podłożu, ślizg bazalny),

3. Deformacje (przekształcenia) luźnego (miękkiego, podatnego, nieskonsolidowanego) podłoża.

\subsection{Płynięcie deformacyjne}

Deformacyjne płynięcie lodu zachodzi po osiągnięciu minimalnej miąższości 60 metrów (Ehlers, 2011). Ruch ten odbywa się na drodze pełzania oraz wielkoskalowego fałdowania i nasunięć (Bennett i Glasser, 2009). Pełzanie polega na deformacjach kryształów oraz ich wzajemnych przemieszczeniach, zachodzących pod wpływem naprężeń ścinających $w$ lodzie. Skala pełzania jest pochodną wielkości naprężenia 
ścinającego - prawo przepływu Glena (Bennett i Glasser, op. cit.). W lodowcach o zimnym podłożu wewnętrzne przekształcenia są jedynym mechanizmem ruchu i dlatego tempo przemieszczania się u podstawy wynosi zero (rys. 6.1.a). Stopa lądolodu jest wówczas przymarznięta do podłoża. W takim wypadku inkorporacja materiału skalnego z podłoża nie jest możliwa. Wraz z odległością od stopy lądolodu (wysokością ponad podłożem) prędkość ruchu wewnętrznego wzrasta. Oznacza to, że wyższe

a)

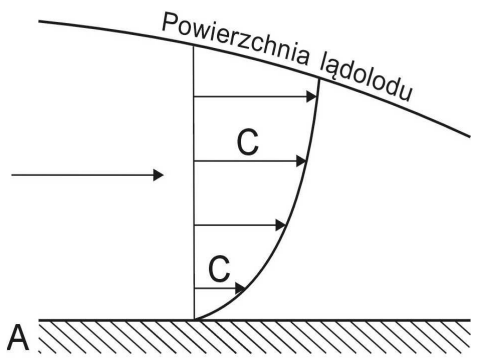

b)

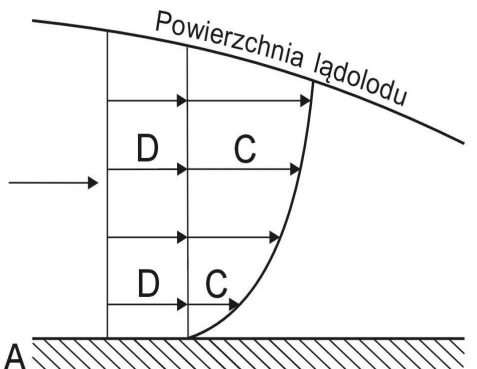

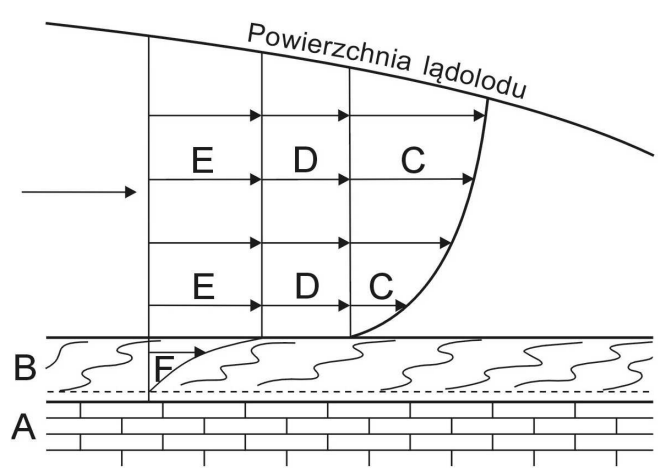

c)

Rys. 6.1. Rozkład prędkości i mechanizmy ruchu lodu w lodowcu w zależności od reżimu termicznego oraz rodzaju podłoża: a) lodowiec o zimnym reżimie podłoża zalegający na litych skałach, b) lodowiec o ciepłym reżimie podłoża zalegający na litych skałach, c) lodowiec o ciepłym reżimie podłoża zalegający na miękkich (podatnych = deformowalnych) osadach; A - skały lite, B - skały podatne (deformowalne), C - składowa ruchu lądolodu uwarunkowana płynięciem deformacyjnym (różna w zależności od wysokości ponad stopą lądolodu), D - składowa ruchu lądolodu uwarunkowana ślizgiem dennym (niezależna od wysokości ponad

stopą lądolodu), E - składowa ruchu lądolodu uwarunkowana deformowaniem podatnego podłoża (niezależna od wysokości ponad stopą lądolodu), F - ruch podatnego podłoża (malejący wraz z głębokością); wg Bennetta i Glassera (2009 - str. 56, zmodyfikowany)

Figure 6.1. The velocity distribution within three glaciers of different basal thermal regimes resting on different substrate: a) cold-based glacier resting on bedrock, b) warm-based glacier resting on bedrock,

c) warm-based glacier resting on deformable (soft) sediment; A - stable bed, B - deforming horizon,

$\mathrm{C}$ - movement determined by internal deformation (increasing with height above the glacier bed), D - movement by basal sliding (independent of the height above the glacier bed), E-movement by subglacial sediment deformation (independent of the height above the glacier bed), $\mathrm{F}$ - subglacial sediment movement (diminishing with the depth below the glacier); after Bennett \& Glasser (2009 - p. 56), modified 
warstwy lądolodu poruszają się szybciej od dolnych. W nieco inny sposób deformacyjne płynięcie lodu interpretują Hambrey i Glasser (2012). Ich zdaniem odbywa się ono głównie w najniższej kilkumetrowej warstwie lodu oraz w podłożu (pogląd ten łączy dwa mechanizmy ruchu, tj. płynięcie deformacyjne $z$ deformacjami podatnego podłoża). Różnice prędkości ruchu deformacyjnego w wyższych warstwach lodu będą w takim przypadku już nieznaczne. Strumień cieplny podłoża jest niewielki, co pozwala na odprowadzanie ciepła przez lód bez jego topnienia. Fałdowania i nasunięcia zachodzące w trakcie ruchu deformacyjnego mogą przemieścić warstwy lodu bogate w materiał skalny ze strefy bazalnej do wyższych części lodowca. Może wówczas dojść do przeniesienia na dużą odległość materiału o nienaruszonym składzie, a nawet o zachowanej strukturze (por. Dreimanis, 1976; Ehlers, 2011). W trakcie wzajemnego przemieszczania się pakietów lodu może dochodzić do rotacji większych klastów, a w minimalnym stopniu również do rozcierania i kruszenia ziaren skalnych - pod warunkiem, że znalazły się na powierzchni nieciągłości w lodzie. Większość materiału skalnego nie podlega jednak obróbce $w$ trakcie płynięcia deformacyjnego. Przynajmniej częściowo związane jest to z bardzo dużą (w porównaniu z lodem) twardością i odpornością na ścinanie większości skał.

\section{2. Ślizg denny}

Ślizg denny występuje niemal wyłącznie w lodowcach o ciepłym reżimie termicznym. W przypadku, kiedy miąższość lodu jest bardzo duża (odpowiednio wysokie ciśnienie) i/lub strumień cieplny podłoża jest zbyt wysoki, żeby uwolnione ciepło mogło być odprowadzane na drodze przewodnictwa cieplnego lodu, stopa lodowca znajduje się w punkcie topnienia pod ciśnieniem. Tworzy się wówczas cienka warstewka wody, po której lód przemieszcza się generalnie zgodnie z grawitacją (por. Weertman, 1964). Na nierównościach (po ich dystalnej stronie) może dojść do odspojeń lodu od podłoża. Wzrost ciśnienia w wypełnionych wodą przestrzeniach w przydennej części lodu i na granicy z podłożem wpływa stymulująco na ruch lodu. Mechanizm ten polega na poszerzaniu się $\mathrm{w}$ warunkach podwyższonego ciśnienia wolnych przestrzeni i w ten sposób zmniejszaniu tarcia o podłoże (Lliboutry, 1968, 1987). W ten sposób łatwo wyjaśnić szybszy ruch lodowców obserwowany w lecie (Sugden i John, 1976). Przy znacznych nachyleniach (ponad $15^{\circ}$, czyli możliwych tylko w lodowcach górskich) odspojenia mogą powstawać również bez obecności wody (Kamb, 1970 - fide Jania, 1993).

Składowa ruchu lodu uwarunkowana ślizgiem dennym jest teoretycznie jednakowa i w stopie lądolodu, i na jego powierzchni (rys. 6.1.b). W rzeczywistości jednak tylko w bardzo cienkich pokrywach lodowych nie występują przekształcenia wewnętrzne. W przypadku lądolodu o znacznej miąższości to one decydują o zróżnicowaniu prędkości płynięcia w dolnej i w wyższych warstwach lodu.

Nowoczesną analizę ruchu lodowca na skutek poślizgu po podłożu zapoczątkował Weertman (1957, potem m.in. Weertman, 1979; Hutter, 1982). Wyróżniane są dwa rozwiązania teoretyczne mechanizmu ślizgu dennego: po litej skale oraz po osadach nieskonsolidowanych, w tym częściowo w wyniku ich deformowania. W przypadku 
poślizgu po litej skale istotną rolę odgrywa regelacja oraz wzmożone pełzanie przydennej warstwy lodu (Bennett i Glasser, 2009), jak również wspomniane wyżej odspojenie spagowej części lodu na nierównościach podłoża. Weertman (1957) przywiązywał dużą wagę do regelacji. Opisał model, w którym lód oddziela od podłoża warstewka wody o miąższości zaledwie rzędu 0,001 mm. Po proksymalnej stronie nierówności podłoża ciśnienie wzrasta i prowadzi do miejscowego topnienia lodu, a po stronie dystalnej przeszkód ciśnienie maleje i tam dochodzi do zamarzania. Z tym wiąże się oddawanie utajonego ciepła zamarzania, które na drodze przewodnictwa cieplnego migruje na proksymalną stronę przeszkody. Według Weertmana (op. cit.) przeszkody w podłożu prowadzą do wzmożonego pełzania dolnej części lodu, co przyspiesza jego ruch. Gdy nierówności podłoża mają ponad 1 metr długości regelacja przestaje być efektywna. Kamb wyliczył, że jeżeli przeszkody są wyższe niż 0,5 m, to dominującym mechanizmem ruchu jest pełzanie, przy mniejszych przeszkodach - regelacja (1970 fide Jania, 1993). Jest to jednak schemat wyidealizowany, pomijający dużą zawartość materiału skalnego w dolnej części lodowca, znacząco zwiększającego tarcie. Właściwości i „zachowanie” lodu zanieczyszczonego nie zostało jeszcze dogłębnie przeanalizowane (por. Jania, 1993). Poślizg z udziałem regelacji ma znaczący wpływ na wielkość erozji glacjalnej.

Ślizg denny odbywa się w wielu przypadkach w sposób nieregularny. Dłuższe okresy stabilnego i powolnego ruchu przerywane są gwałtownymi i krótkotrwałymi etapami przyspieszenia - jest to ruch przywierająco-ślizgowy (stick-slip behaviour). Model fizyczny opisujący ruch o takiej charakterystyce został opracowany w trakcie badań mechanizmu przemieszczeń wzdłuż powierzchni uskokowych oraz interpretacji wstrząsów podczas trzęsień ziemi (m.in. Rundle i Jackson, 1977; Cao i Aki, 1986), a dopiero później zaadaptowany dla wyjaśnienia specyfiki ruchu lodowców (Beeman i in., 1988; Bahr i Rundle, 1996; Fischer i Clarke, 1997). Ruch przywierająco-ślizgowy możliwy jest dzięki występowaniu w podłożu lodowców i lądolodów obszarów o podwyższonym współczynniku tarcia, np. niepodatne osady lub lite skały o nierównej powierzchni, które zatrzymują ślizg denny - są to punkty przywierania (sticky spots). Przyczyną blokowania ślizgu dennego może być również zamarzanie wód subglacjalnych i przymarzanie lodu do podłoża (por. Stokes i in., 2007). Kumulowanie się naprężeń prowadzi w końcu do przekroczenia oporu tarcia i nagłego oderwania się lodu, co skutkuje gwałtownym przyspieszeniem ruchu. Czynnik wyzwalający może pochodzić także spoza środowiska glacjalnego, np. sejsmika lub pływy morskie (por. Bindschadler i in., 2003).

Interesujące wyniki udało się uzyskać w badaniach lodowca Trapridge w Kanadzie. W otworze wiertniczym sięgającym podłoża umieszczono przyrządy pomiarowe, które pozwoliły monitorować aktualną prędkość ślizgu dennego. Okazało się, że występują bardzo duże i niezbyt regularne wahania prędkości ruchu (od 0 do $2 \mathrm{~m} / \mathrm{dobę)}$ ), ale daje się też zauważyć cykl dobowy, związany z ilością i ciśnieniem wód ablacyjnych (Fischer i Clarke, 1997). Pulsacyjny charakter ruchu lodu zaobserwowano i pomierzono również w strumieniach lodowych Antarktydy (m.in. Alley, 1993; Anandakrishnan i Alley, 1994; Bindschalter i in., 2003; Stokes i in., 2007). Badania plejstoceńskich osadów glacjalnych w Irlandii potwierdzają prawidłowość koncepcji ruchu przywierająco-ślizgowego także w odniesieniu do kopalnych środowisk glacjalnych (Knight, 2002). 
Ślizg denny przyczynia się w dominującym stopniu do inkorporacji materiału z podłoża (Drewry, 1986). Zależy od niego intensywność i aktywność detrakcji i abrazji. Wysokie ciśnienie wód podlodowcowych zwiększa separację stopy lodowca od podłoża i redukuje tarcie. Oznacza to, że prawdopodobieństwo znaczącej erozji i inkorporacji materiału subglacjalnego, mimo ciepłego reżimu podłoża, malałoby wraz ze wzrostem ciśnienia wód subglacjalnych.

Analizę ślizgu dennego w odniesieniu do plejstocenu Europy komplikuje dodatkowo fakt, że przeważającą część podłoża lądolodów fennoskandzkich budowały kenozoiczne skały osadowe luźne lub słabo zlityfikowane. Ocenia się, że przypadało na nie aż 70-80\% powierzchni podłoża (Jania, 1993; Menzies, 2002). Można się z tym zgodzić w odniesieniu do wstępnych faz zlodowaceń. Jednak zwietrzelina i luźne osady dość szybko były usuwane przez lód i w późniejszych etapach rozwoju lądolodu udział skał litych (w przypadku lądolodu fennoskandzkiego głównie proterozoicznych skał krystalicznych i paleozoicznych skał osadowych) w budowie podłoża znacząco wzrastał. W efekcie zmieniał się charakter ślizgu dennego. Dotyczy to oczywiście centralnej części czaszy lądolodu. W strefach peryferyjnych lądolodu fennoskandzkiego, w których znajdował się obszar Polski, udział litego podłoża był jeszcze mniejszy, aniżeli wynikający ze wspomnianych powyżej szacunków (rys. 6.2).

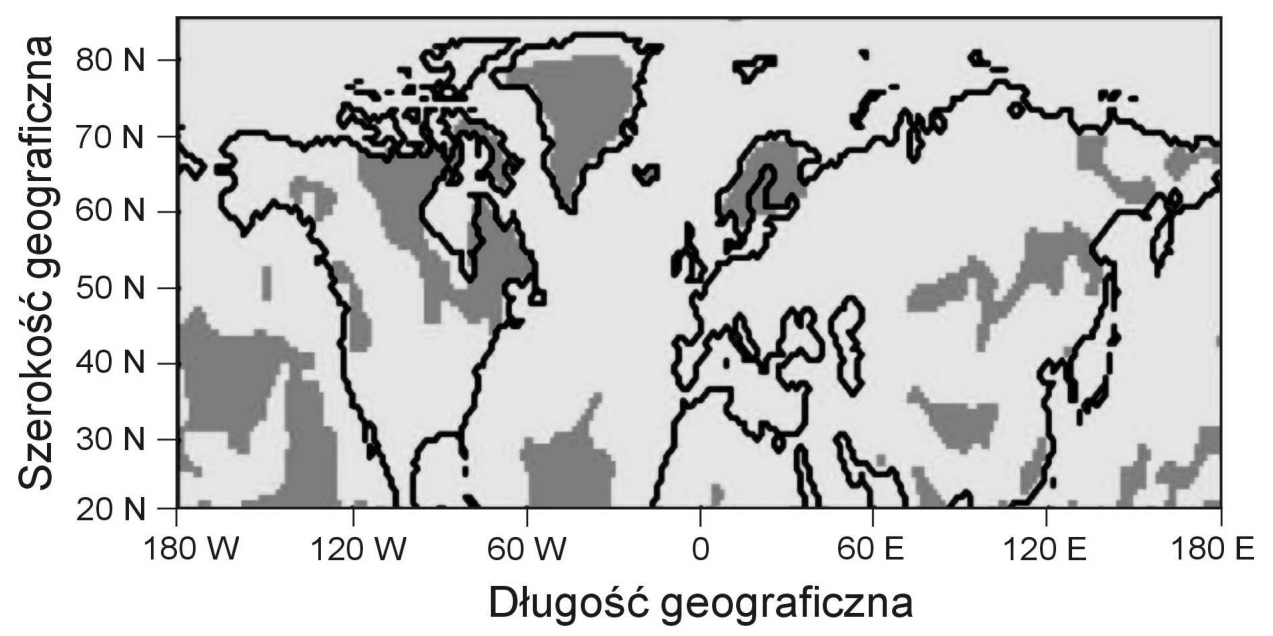

Rys. 6.2. Rozmieszczenie skał budujących powierzchnię Ziemi na półkuli północnej; pola jasnoszare - obszary pokryte luźnymi skałami osadowymi (luźnymi osadami), pola ciemne - obszary pokryte skałami krystalicznymi (magmowymi i metamorficznymi) oraz zwięzłymi skałami osadowymi; wg Calova (2006 - str. 15)

Figure 6.2. Types of bedrock on the Northern Hemisphere; light grey indicates regions with soft (unconsolidated) sediments and dark grey shows regions with hard rocks (crystalline - igneous and metamorphic rocks and lithified sedimentary rocks; after Calov (2006 - p. 15) 


\subsection{Deformacje luźnego podłoża}

Ruch lodowców w oparciu o deformacje podatnego podłoża możliwy jest wyłącznie w ciepłym reżimie termicznym stopy lądolodu. $W$ proces ten zaangażowany jest nie tylko lód, ale i przyległa warstwa luźnego podłoża (zwietrzelina i nieskonsolidowane skały - rys. 6.1.c - F). Powyższy mechanizm został udowodniony w oparciu o badania w tunelu wydrążonym w bazalnej części jednego z lodowców na Islandii (Boulton i Jones, 1979). Miąższość lodu wynosiła w tym miejscu około 20 metrów, co wyklucza udział płynięcia deformacyjnego. Eksperyment przeprowadzony w luźnym (niezlityfikowanym) podłożu ciepłego lodowca wykazał, że aż $88 \%$ bazalnego ruchu lodu zamyka się w deformacjach podłoża, a tylko $12 \%$ stanowi poślizg stopy lodu po powierzchni gliny (Boulton i in., 1974; Boulton, 1979). Według Boultona i Jonesa (op. cit.) to właśnie deformowanie podłoża miało odpowiadać za szybki ruch lądolodów plejstoceńskich w północnej Europie. Miąższość warstwy deformacyjnej najczęściej miała zawierać się w przedziale od 0,3 do 0,65 m (Boulton, 2006), a tylko wyjątkowo mogła przekraczać $2 \mathrm{~m}$ (Truffer i in., 2000). Dodatkowych argumentów wspierających tę teorię dostarczyły badania w północnych Niemczech. Nierzadko w spągu glin subglacjalnych natrafiano tam na warstwę materiału redeponowanego, który uziarnieniem odpowiadał podłożu, ale strukturą przypominał przykrywającą go glinę subglacjalną. Pierwotne warstwowanie jest w takich osadach zaburzone, występują ścięcia, nasunięcia. Ten typ osadów został określony jako morena spągowa (Sohlmoräne) (Grube, 1979), ale swoją budową odpowiada raczej glinie deformacyjnej (Elson, 1989; Benn i Evans, 1997) lub przekształconemu podłożu (sensu Alley i in., 1986, 1987). Stephan i Ehlers (1983) zalecają stosowanie dla takich osadów określenia „osady przekształcone subglacjalnie”. Warstwę deformacyjną w spągu gliny zidentyfikowali i opisali m.in. Boulton i Hindmarsh (1987), Van der Meer i in. (2003), a na obszarze Polski Kozarski i Kasprzak (1992) określili ją jako strefę glacimylonityzacji. Miąższość zdeformowanej, spągowej części glin bazalnych w Niemczech waha się od kilku decymetrów do maksymalnie 2 metrów (Stephan i Ehlers, 1983). Jeśli powyższy mechanizm jest powszechny, to w przypadku dwóch leżących na sobie horyzontów morenowych, górna część starszego z nich powinna charakteryzować się odmiennymi cechami kierunkowymi głazików niż niższa, zgodnymi zaś z występującymi w młodszym poziomie morenowym (Ehlers, 2011). Przekształcone podłoże, w przypadku braku typowej gliny deformacyjnej, może być ograniczone do materiału skalnego wchłoniętego przez lądolód (por. Alley i in., 1987).

Właściwości nieskonsolidowanych osadów pod lodowcami i zachodzące w nich deformacje stanowiły przedmiot zainteresowań wielu badaczy (m.in. Clarke, 1987b; Shreve, 1984; Brown i in., 1987; Echelmeyer i Wang, 1987; Boulton, 1987; Hart i Rose, 2001). Zdaniem niektórych obecność lub brak warstwy podatnych osadów subglacjalnych jest czynnikiem determinującym dynamikę lodowców i lądolodów i może znacząco wpłynąć na przebieg zlodowacenia (np. Boulton, 1986; Alley, 1991; Clark, 1994; Murray, 1997). 
Procesy deformowania podłoża są zwykle stowarzyszone zarówno ze ślizgiem dennym, jak i z przekształceniami wewnętrznymi lodu. Ich wzajemny udział w generowaniu ruchu lodu stanowi nadal przedmiot dyskusji. Zdaniem części autorów ranga przekształceń subglacjalnego podłoża jest wyraźnie przeceniana (np. Piotrowski i in., 2001, 2004). W przypadku, kiedy deformowanie podłoża zachodziłoby jednak na większą skalę niż sugerowane przez Piotrowskiego i in. (op. cit.) kilka centymetrów, łatwo prowadziłoby do dużej i wielokrotnej inkorporacji luźnych skał podścielających lądolód. W ten sposób materiał skalny na drodze z Fennoskandii mógłby podlegać wielokrotnej redepozycji nawet w podłożu tego samego lądolodu.

\subsection{Szarże lodowe}

Szarże lodowe (surge-type glaciers) polegają na lokalnym wzroście prędkości ruchu lodu dziesięcio- do nawet stukrotnie w stosunku do normalnych kilku - kilkudziesięciu metrów na rok. Szarżujące (pulsujące) lodowce są definiowane jako lodowce doznające nagłego przyspieszenia ruchu i awansu bez związku ze zmianami klimatycznymi (Meier i Post, 1969) lub krócej jako lodowce wykazujące okresowo znacznie większą prędkość płynięcia (Benn i Evans, 2010). Przyczyny szarży nie są znane, wykazano natomiast, że są aktywne stosunkowo krótko - 1 do 5 lat, po czym przechodzą na 15-100 lat (Meier i Post, op. cit.) w stan spoczynku, by później znowu się odnowić. Bennett i Glasser (2009) sugerują szerszy zakres zmienności okresów stagnacji, wynoszący od 10 do 200 lat. Niewątpliwie aktywności szarży lodowych towarzyszą ponadprzeciętne ilości wód ablacyjnych (Sugden i John, 1976). Prędkość lodu w trakcie szarży lodowca Variegated na Alasce w 1983 roku przekraczała okresowo 50 m/dobę (Jania, 1993), a lodowca Brúarjökull na Islandii na przełomie 1963 i 1964 osiągała nawet do 5 m/h (Thorarinsson, 1969).

Próbę przebadania dynamiki szarżującego lodowca przy użyciu wiercenia z umieszczonymi w lodzie i podłożu czujnikami podjęto na Alasce (Truffer i in., 2000). Tempo ruchu lodu wynosiło w tym miejscu około $60 \mathrm{~m} /$ rok. $Z$ tego $20-30 \mathrm{~m} /$ rok realizowane było na zasadzie ruchu wewnętrznego (deformacyjne płynięcie), a pozostałe 30-40 winno przypadać na ślizg bazalny. W podłożu lodu zalegała warstwa nasyconej wodą gliny o miąższości do 7 metrów. Klinometry zainstalowane na głębokości 1 i 2 metrów w osadzie przez 410 dni prowadzenia obserwacji nie wykazały żadnych istotnych deformacji w osadzie, ani też istnienia ślizgu bazalnego. Oznacza to, że ślizg bazalny odbywał się na większej głębokości w osadzie na zasadzie ścinania wewnętrznego, bądź jeszcze głębiej na granicy luźnego osadu (w tym wypadku gliny) z litym podłożem.

Rozmieszczenie szarżujących lodowców w odniesieniu do budowy geologicznej podłoża przeanalizowano na Svalbardzie (Jiskoot i in., 2000). Okazało się, że najczęściej ten typ reprezentują długie lodowce politermalne o urwistych stokach, podścielone młodymi drobnoziarnistymi osadami, podatnymi na deformacje. Nie udało się jednak stwierdzić istnienia istotnej statystycznie relacji pomiędzy geologią podłoża i szarżami lodowców. 
Nie ma jednoznacznie ustalonej granicy pomiędzy szarżami i strumieniami lodowymi. Zwykle przyjmuje się, że szarże są krótkotrwałe, a czas ich trwania ograniczony jest ilością lodu w strefie zasilania. Strumienie lodowe tworzą się w obrębie dużych czasz lodowych i ich obszar zasilania jest bardzo duży, co pozwala utrzymać się aktywnemu strumieniowi lodowemu przez bardzo długi okres (Bennett i Glasser, 2009). Niektórzy badacze nie widzą jednak istotnej różnicy pomiędzy nimi (np. Ehlers, 2011). Wątpliwości budzi zaklasyfikowanie lodowca Jacobshavn na Grenlandii. Zdaniem Jani (1993) reprezentuje on strumień lodowy, podczas gdy Ehlers (2011) podaje go jako przykład szarży lodowej. Wydaje się, że obydwa poglądy mogą być niezbyt zasadne, ponieważ przyspieszony ruch tego lodowca wypustowego jest wymuszony przez rzeźbę terenu.

Szarże lodowe występują przede wszystkim w lodowcach górskich bądź w lodowcach wypustowych (outlet glaciers). Lodowce szarżujące stanowią około 35\% lodowców Svalbardu (Bennett i Glasser, 2009). Brak jednoznacznych informacji na temat występowania szarż lodowych w lądolodach. Jeśli nawet przyjmiemy, że szarże lodowe w nich występują, to mogą być związane tylko z ich obszarami marginalnymi. W związku z tym wzmożona erozja podłoża, uwarunkowana przyspieszonym ruchem lodu, dotknęłaby głównie skały lokalne, np. starsze osady glacjalne. Należy też mieć świadomość, że szarże lodowe mogą pozostawiać dokładnie takie same świadectwa geomorfologiczne i sedymentologiczne jak strumienie lodowe. Nie jest zatem niczym zaskakującym, że w materiale morenowym przebadanym przez autora nie udało się zidentyfikować żadnej cechy, która mogłaby wskazywać na odłożenie osadu podczas szarży lodowej.

\subsection{Prędkość ruchu lodowców}

Wszystkie lodowce i lądolody cechują się zmiennością przestrzenną i czasową prędkości ruchu. Zmiany tempa związane są m.in. z czynnikami o zasięgu kontynentalnym lub globalnym, jak np. długoterminowe zmiany klimatyczne, które dotykają w różnym stopniu wszystkie lodowce na Ziemi. Inne przyczyny wahań tempa płynięcia lodu mają charakter lokalny i dotyczą konkretnego lodowca, np. klimat, zmiany bilansu masy lodowca, rzeźba terenu, warunki odpływu wód ablacyjnych, wahania ciśnienia (Menzies, 2002). Na prędkość przemieszczania się lodu wpływają także pokrycie powierzchni podlodowej osadami o niewielkim współczynniku tarcia, np. iłami warwowymi oraz znaczna miąższość pokrywy lodowej, zmniejszająca tarcie wewnętrzne i ułatwiająca deformacje wewnętrzne (efekt wzrostu ciśnienia). Wzrost prędkości bazalnej lodu mogą spowodować dowolne osady - niwelując nierówności i wygładzając podłoże, przyspieszając ruch deformacjami osadów oraz zwiększając ciśnienie wód w podłożu, co z kolei przyspiesza ślizg denny i deformacje podłoża (Alley i in., 2003a). W związku z tym marginalne obszary lodowców cechują się często podwyższoną prędkością ruchu w stosunku do stref centralnych oraz małym nachyleniem powierzchni, a to sprawia, że są bardzo wrażliwe na wahania klimatyczne. O przemieszczaniu się lodu - zwłaszcza w obniżeniach - decydują w dużym stopniu wody subglacjalne i inglacjalne ułatwiające ślizg denny. Istotne jest ciśnienie wody w stopie lodowca, ale w niektórych przypadkach 
podstawowe znaczenie ma objętość wody w przestrzeniach podlodowych (por. Vieli i in., 2004). Wzrost prędkości lodu po zmianie warunków hydrologicznych w podłożu przeanalizowali m.in. Arnold i Sharp (2002).

Duże zmiany prędkości lodowców wypustowych na Grenlandii, świadczące o zmianach bilansu masy lądolodu, zostały zanotowane pod koniec ubiegłego i w pierwszej dekadzie bieżącego wieku (Joughin i in., 2004; Moon i in., 2012). Dynamika lodowców w bardzo dużym stopniu uzależniona jest również od sezonowych zmian warunków pogodowych (np. Howat i in., 2010). W lecie prędkość ruchu może być nawet o 20 do 100\% większa niż w zimie (Menzies, 2002). W przypadku lądolodów wahania dynamiki były mniejsze i dotykały głównie ich zewnętrznych stref o ciepłym reżimie.

Prędkość ruchu lodowców usytuowanych w dolinach górskich najczęściej zawiera się w przedziale od 10 do $200 \mathrm{~m} /$ rok, a w strumieniach lodowych w obrębie lądolodu antarktycznego może osiągać nawet do 1400 m/rok (Paterson, 1994; Van der Veen, 1999; Menzies, 2002). Za najszybciej poruszający się lodowiec powszechnie uznawany jest Jakobshavn na zachodzie Grenlandii, przemieszczający się w tempie $8,4 \mathrm{~km} / \mathrm{rok}$ (Menzies, 2002). Podczas krótkookresowych szarży mogą jednak wystąpić znacznie większe prędkości. 9 czerwca 1983 roku lodowiec Variegated na Alasce przez dwie godziny płynął w tempie około $65 \mathrm{~m} /$ dobę, czyli ponad $23 \mathrm{~km} /$ rok - Kamb i in. (1985). Ostatnie pomiary wykazały wzrost prędkości Jakobshavn do około $11 \mathrm{~km} / \mathrm{rok}$ w 2010 roku, ale jeszcze szybciej płynął wtedy lodowiec Ikeq Fjord na wschodnim wybrzeżu Grenlandii - 12 km/rok (Moon i in., 2012). Zaprezentowane dane odnoszą się do prędkości powierzchniowej lodowców. W stopie, ze względu na opory tarcia, ruch lodu jest zdecydowanie wolniejszy. Menzies (2002) podaje, że prędkość bazalna może stanowić 10-20\% prędkości powierzchniowej, co wydaje się wartością raczej niedoszacowaną. Duża różnica prędkości zaznacza się niekiedy nawet pomiędzy przydenną warstwą lodu i tkwiącymi w niej dużymi głazami. Hagen i in. (1983) przedstawiają wyniki pomiarów z południowej Norwegii, gdzie głaz o średnicy $0,7 \mathrm{~m}$ poruszał się około dwukrotnie wolniej od otaczającego go lodu - ok. $40 \mathrm{~mm} /$ dobę wobec ok. $80 \mathrm{~mm} /$ dobę dla lodu.

Plejstoceńskie lądolody narastały bardzo szybko. Jeszcze przed 24 ka południowa Szwecja w rejonie Göteborga była wolna od lodu (Lundqvist, 2004), a już około 4000 lat później lądolód vistulianu osiągnął swój maksymalny zasięg. Oznacza to, że na obszar północnych Niemiec lądolód nasuwał się ze średnią prędkością około $75 \mathrm{~m}$ rocznie, a na obszary na południe od Bałtyku (przy uwzględnieniu ruchu z centrum czaszy lodowej) nawet 100 do $150 \mathrm{~m} /$ rok (Ehlers, 2011). Junge (1998) wykazał, że lądolód Elsterianu w Saksonii transgredował ze średnią prędkością około $400 \mathrm{~m} /$ rok. Należy uwzględnić też fakt, że rzeczywista prędkość płynięcia lodu musiałaby być większa, ponieważ duża część masy była tracona na skutek ablacji. Zdaniem Ehlersa (2011) tak szybki rozwój plejstoceńskich pokryw lodowych w Europie i Ameryce Północnej jest trudny do wyjaśnienia w tradycyjny sposób. Należy zatem odwoływać się do innych możliwości proponowanych w literaturze, tj. do „momentalnego zlodowacenia” (instantaneous glacierisation - m.in. Ives, 1962; Ives i in., 1975; Andrews i Mahaffy, 1976; Williams, 1978) lub do napływu w efekcie deformowania podłoża (deformable bed wg Boultona i Jonesa - 
1979). Istotę zlodowacenia „momentalnego” ujęto chyba najlepiej w literaturze niemieckojęzycznej, gdzie określane jest jako zlodowacenie uderzeniowe lub spontaniczne (schlagartige, spontane Vereisung) (np. Ehlers, 2011). Polega ono na wielkopowierzchniowej i nieomal jednoczesnej akumulacji śniegu na dużej powierzchni i jego szybkim przekształceniu w pokrywę lodową w ciągu zaledwie kilku stuleci (Ives i in., 1975). Dla lądolodu laurentyjskiego ta hipoteza wydaje się prawdopodobna (m.in. Clark i Lea, 1992; Bromwich i in., 2002). Przyjęcie analogicznego mechanizmu dla lądolodu fennoskandzkiego wykluczałoby znaczący transport materiału skalnego ze Skandynawii przynajmniej w początkowej fazie rozwoju zlodowacenia i musiałoby doprowadzić do dominacji moren lokalnych w północnych Niemczech i Polsce. Nowopowstałe moreny (z wyjątkiem osadów pierwszego na danym obszarze zlodowacenia) powinny odpowiadać składem najbliższym starszym osadom plejstoceńskim (w przywoływanym artykule Ehlersa: glacjalnym), z których „przerobienia” powstały (Ehlers, 1990b). Wyraźne zróżnicowanie zespołów eratyków w różnowiekowych osadach glacjalnych Polski zaprzecza jednak powyższej hipotezie.

Maksymalne prędkości ruchu lodu w lądolodach (rzędu kilkuset, a nawet kilku tysięcy metrów rocznie) osiągane są w obrębie strumieni lodowych kończących się w morzach (patrz rozdz. 7). W pozostałych częściach lądolodu występuje wyraźna prawidłowość, przejawiająca się wzrostem tempa ruchu od zera na linii podziału lodu ${ }^{3}$ aż do maksimum na linii równowagi dostawy i ablacji i spadkiem ku marginalnej strefie czaszy lodowej (Bennett i Glasser, 2009) - rys. 6.3 i 6.4. Bezpośrednie pomiary zostały uzupełnione i potwierdzone badaniami satelitarnymi (interferometria radarowa) grenlandzkiej i antarktycznej pokrywy lodowej (Rignot i Kanagaratnam, 2006; Rignot i in., 2011). Możliwa jest również zmiana kierunku i prędkości ruchu w związku z modyfikacjami termodynamicznymi antarktycznej czaszy lodowej (np. Siegert i in., 2004). Dowodów na analogiczną zmienność przestrzenną i czasową dynamiki plejstoceńskich lądolodów dostarczają m.in. badania migracji linii podziału lodu oraz kierunków nasunięć mas lodowych, np. w Danii wyróżnia się lód norweski, szwedzki i bałtycki (Houmark-Nielsen, 2004).

Rekonstrukcję dynamiki lądolodu fennoskandzkiego w odniesieniu do warunków hydrologicznych w podłożu podczas stadiału głównego vistulianu zaprezentowali Arnold i Sharp (2002). Dla obrzeży lądolodu postulują oni prędkość transgresji rzędu 200600 metrów/rok (zbliżone wartości podawane są dla strumienia lodowego Wisły w Polsce - Wysota i in., 2009; Narloch i in., 2012), centrum zaś traktują jako przymarznięte do podłoża. Ich zdaniem 18 ka BP w centralnej Szwecji, północnej Finlandii i na prawie całym obszarze dzisiejszego Bałtyku panował zimny reżim termiczny. Tak duży zasięg zimnego reżimu powinien wyraźnie zredukować udział eratyków ze wspomnianych obszarów (np. wapieni paleozoicznych) w osadach glacjalnych młodszego vistulianu, co pozostaje w sprzeczności z obserwacjami w glinach zarówno pomorskich,

\footnotetext{
${ }^{3}$ Linia podziału lodu (lododział) rozdziela obszar alimentacji lądolodu na części, z których lód rozpływa się w różnych kierunkach, $\mathrm{np}$. w lądolodzie fennoskandzkim lód spływał z północno-zachodnich stoków Gór Skandynawskich ku Morzu Norweskiemu, a z południowo-wschodnich w kierunku depresji bałtyckiej i Niżu Środkowoeuropejskiego.
} 
jak i gardnieńskich. Model Arnolda i Sharpa jest natomiast zgodny z wnioskami Klemana i in. (1997), którzy twierdzili, że przetrwanie w centralnej Skandynawii form rzeźby starszych od LGM było możliwe tylko w warunkach zimnego reżimu termicznego w stopie lądolodu. Na obrzeżach lądolodu miały panować warunki ciepłe z dużymi ilościami wody w podłożu, w obszarach przejściowych zaś występować nieregularne płaty lodu ciepłego i zimnego (fractal patchwork - Kleman i in., op. cit. - str. 296). W proponowanym modelu zaznacza się zmienność przestrzenna i czasowa rozwoju szybko płynących lobów na obrzeżach lądolodu.

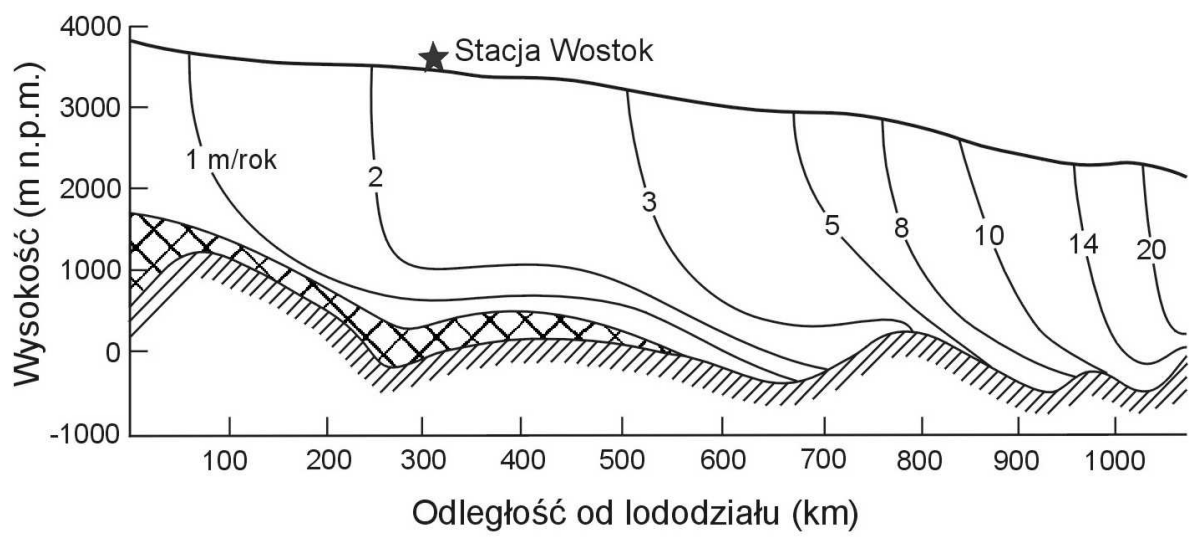

Rys. 6.3. Rozkład prędkości lodu (efekt modelowania matematycznego) w lądolodzie na wschodzie Antarktydy w przekroju wzdłuż linii płynięcia przez stację „Wostok” w kierunku Lodowca Byrda; kratkowaną szrafurą oznaczono strefę lodu nieruchomego, ukośną - lite podłoże lądolodu (wg Zotikova, 1982 - fide Jania, 1993 - str. 156)

Figure 6.3. The velocity distribution (result of mathematical modeling) within the eastern part of Antarctic Ice-Sheet along transect through the "Vostok Station" to the Byrd Glacier; crossed lines - stationary ice zone, diagonal lines - glacier bed; the vertical axis - elevation, the horizontal axis - distance from the ice-divide line (after Zotikov, 1982 - fide Jania, 1993 - p. 156)

Zróżnicowanie prędkości ruchu lodu wraz z reżimem termicznym lądolodu wpłynęły na możliwości rozprzestrzenienia eratyków w strefach marginalnych lądolodów. Skały o wychodniach położonych w pobliżu linii podziału lodu miały niewielkie szanse na dotarcie do strefy marginalnej ze względu na bardzo niską prędkość lodu, ale i dominujący często $w$ tym rejonie zimny reżim termiczny. Zapewne dlatego w Finlandii obserwowane są zwykle krótkie szlaki transportu eratyków i dość wyraźny związek między litologią glin i geologią bezpośredniego podłoża. W południowej Finlandii, około 9-10 tys. lat BP leżącej niespełna $600 \mathrm{~km}$ od linii podziału lodu, skały transportowane na dystansie dłuższym niż 10 km stanowią mniej niż $10 \%$ ogólnej liczby eratyków. W Estonii - w marginalnej strefie vistulianu - występuje znacznie więcej materiału dalekiego (100-500 km) transportu (Donner, 1989). Czas aktywności lądolodu fennoskandzkiego w vistulianie był na tyle krótki, że na większą odległość mogły być przenoszone tylko te skały, których wychodnie były dość odległe od linii podziału lodu (patrz rys. 6.4). Długiemu transportowi mogły także podlegać skały pozostawione przez starsze nasunięcia glacjalne. 

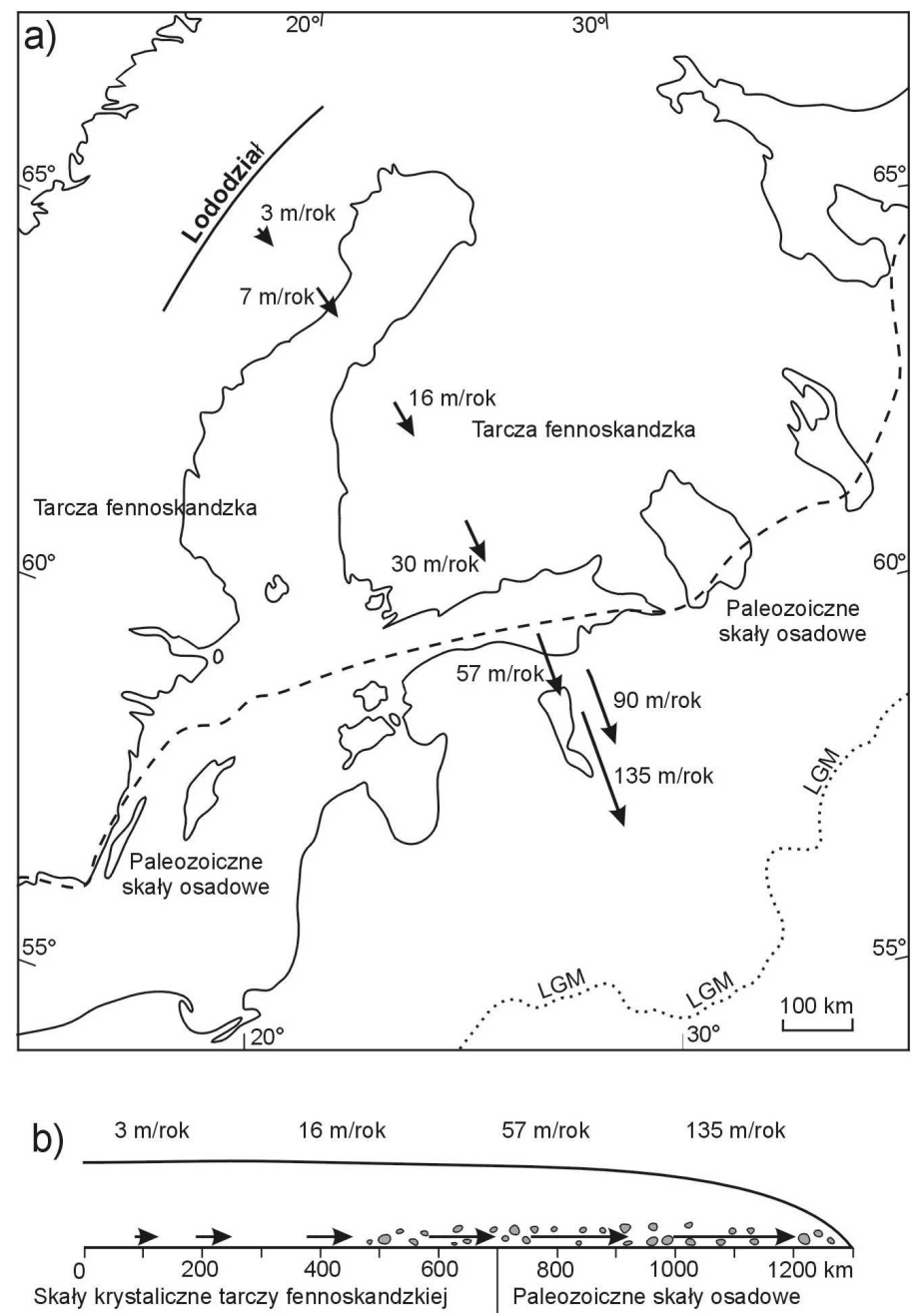

Rys. 6.4. Zmiany prędkości ruchu lodu wraz z oddalaniem się od lododziału (linii podziału lodu):

a) mapa z naniesionym maksymalnym zasięgiem ostatniego zlodowacenia (LGM) oraz granicą występowania skał krystalicznych tarczy fennoskandzkiej; z rozkładu prędkości wynika, że szybki ruch lodu po krystalicznym podłożu był możliwy głównie na etapie rozwoju lądolodu oraz podczas deglacjacji, kiedy strefa marginalna znajdowała się na obszarze tarczy krystalicznej; b) schematyczny przekrój przez lądolód fennoskandzki podczas maksimum ostatniego zlodowacenia (wg Donnera, 1989; uproszczony)

Figure 6.4. The flow rates in the Fennoscandian Ice Sheet increasing with the distance from the ice divide: a) the map of Fennoscandia: dashed line - the border between crystalline and Paleozoic sedimentary rocks in the bedrock, dotted line - an extent of ice-sheet during LGM; the velocity distribution indicates that fast movement of the ice over crystalline bedrock was possible mainly on the stage of development of the glacier and during deglaciation, when the ice marginal zone was located in the area of crystalline Baltic Shield; b) schematic cross section through the Fennoscandian Ice Sheet during the LGM (according to Donner, 1989; simplified) 
Prędkość nasuwania się ostatniego lądolodu na terytorium Polski Stankowski (1983) szacuje na około 0,5 m/dobę, czyli około $180 \mathrm{~m} /$ rok. Zdaniem Mojskiego (2005) powyższa wartość jest przesadzona. Uważa on, że lądolód rozwijał się z kilku ośrodków, z których część mogła znajdować się stosunkowo niedaleko, tj. na dnie obecnego Bałtyku. Na swojej drodze na południe lądolód napotykał przeszkody, jak glint bałtycki i zrąb Bornholmu, a jeszcze dalej strefy marginalne wcześniejszych zlodowaceń, które miały spowalniać rozprzestrzenianie się lądolodu. Model sugerowany przez Mojskiego nie znajduje potwierdzenia w składzie zespołów eratyków w osadach glacjalnych Polski. Gdyby rzeczywiście w strefie dzisiejszego dna Bałtyku (położonej co najmniej kilkaset metrów wyżej niż obecnie - efekt ruchów izostatycznych) rozwinął się jakiś niezależny ośrodek zlodowacenia, to zablokowałby, a przynajmniej ograniczył dostawę krystalicznych eratyków ze Szwecji na obszar Polski, co pozostaje w sprzeczności z wysokim udziałem skał z tego obszaru w glinach, m.in. Pomorza. Wydaje się również dość ryzykowne zestawienie razem zrębu Bornholmu (zbudowanego z twardych, proterozoicznych i paleozoicznych skał magmowych i osadowych) i luźnych osadów czołowomorenowych, jako przeszkód hamujących napływ lodu na południe. Należy raczej zakładać, że znaczna część starszych wałów moren czołowych została rozwleczona i przynajmniej częściowo inkorporowana przez lód. 


\section{STRUMIENIE LODOWE}

Strumienie lodowe (ice streams) definiowane są jako arterie w obrębie lądolodu (dosłownie części lądolodu) poruszające się znacznie szybciej i niekoniecznie w dokładnie tym samym kierunku, co otaczający lód (Swithinbank, 1954 - str. 185). Sama idea, mówiąca o przyspieszonym ruchu pewnych partii w lądolodzie (tzw. prądów lodowych) jest jednak znacznie starsza i oparta m.in. na badaniach geomorfologicznych w widłach Wisły i Drwęcy (Nechay, 1927a, 1927b). Strumienie lodowe określa się często jako wąskie korytarze szybko płynącego lodu w lądolodzie, przemieszczającego się w tempie około 0,5-1 km/rok, czyli nawet do dwóch rzędów wielkości szybciej, aniżeli otaczające masy lodowe (Kleman i Glasser, 2007). Bywają one niekiedy porównywane do lodowców dolinnych w górach, od których różnią się obecnością po jednej lub obydwu stronach powoli płynącego lodu, podczas gdy lodowce górskie i wypustowe ograniczone są ścianami skalnymi (Bentley, 1987). Duża prędkość pozwala im na nieproporcjonalnie wysoki udział w odprowadzaniu lodu i osadów z lodowca, a przez to mogą wywierać istotny wpływ na morfologię, bilans masy oraz stabilność kontynentalnych pokryw lodowych (m.in. Bamber i in., 2000; Stokes i Clark, 2001).

Lód w strumieniu jest zwykle silnie pocięty szczelinami i ma wyraźne boczne krawędzie (powierzchnie ścinania) na granicy z wolno płynącym, otaczającym strumień, lodem. Granice strumieni podkreślone są obecnością głębokich szczelin. Współczesne strumienie lodowe mają kilkaset do ponad tysiąca kilometrów długości i kilkadziesiąt kilometrów szerokości, kończą się w morzu (lub zasilają lodowce szelfowe). Znacznie mniej wiadomo na temat lokalizacji i funkcjonowania dawnych strumieni lodowych (paleo-ice streams) w lądolodach plejstoceńskich. Przedstawiono argumenty przemawiające za udziałem strumieni lodowych w kształtowaniu plejstoceńskich lądolodów Europy, Ameryki i Antarktydy (np. Dyke i Morris, 1988; Punkari, 1993; Patterson, 1997; Jørgensen i Piotrowski, 2003; Winsborrow i in., 2004; Stoker i Bradwell, 2005; Jennings, 2006; Shaw i in., 2006; Bradwell i in., 2007; De Angelis i Kleman, 2007; Graham i in., 2007; Roberts i in., 2007; Dyke, 2008; Evans i in., 2008; Ross i in., 2009; Stokes i in., 2009; Kleman i in., 2010; Stokes, 2011; Kalm, 2012; Livingstone i in., 2012) oraz opracowano modele rozwoju i zaniku lądolodów w vistulianie, uwzględniające funkcjonowanie strumieni (np. Punkari, 1993; Boulton i in., 2001b; Arnold i Sharp, 2002; Marks, 2002, 2005; Wysota, 2002; Boulton i Hagdorn, 2006; Ottesen i in., 2008; Wysota i in., 2009; Clark i in., 2012). Do dziś nie jest jednak jasne, jak miałyby funkcjonować strumienie lodowe kończące się na lądzie, a taki charakter winna mieć duża ich część w lądolodzie laurentyjskim i fennoskandzkim. Największe wątpliwości budzi odprowadzanie olbrzymich ilości osadów - zwłaszcza grubszych frakcji, bo drobne ziarna - do frakcji psamitowej włącznie - łatwo mogą być wynoszone na przedpole przez wody ablacyjne. 


\subsection{Czynniki warunkujące rozwój i dynamikę strumieni lodowych}

Na rozwój strumieni lodowych mają wpływ m.in.: wahania temperatury wód oceanicznych i powietrza (Zwally i in., 2002; Payne i in., 2004; Howat i in., 2007; Holli i in., 2008; Joughin i in., 2008; Jenkins i in., 2010), zmiany poziomu morza i pływy (Bindschadler i in., 2003; Gudmundsson, 2007), ukształtowanie podłoża (Echelmeyer i in., 1991; Clark i Stokes, 2001; Ross i in., 2009), sedymentacja podlodowa (Alley i in., 2007), warunki hydrologiczne w podłożu (Anandakrishnan i Alley, 1997; Fricker i in., 2007; Stearns i in., 2008; Bougamont i Christoffersen, 2012), warunki termodynamiczne w strumieniu lodowym (Christoffersen i Tulaczyk, 2003a, 2003b) oraz wielkość drenowanego obszaru (Ó Cofaigh i in., 2008).

W niektórych przypadkach o powstaniu strumienia lodowego może zadecydować obecność podatnych osadów w podłożu lodowca. Deformacje nieskonsolidowanego podłoża ułatwiają szybki ruch lodu (Alley i in., 1986; Boulton i Hindmarsh, 1987; Bell i in., 1998). Z czasem erozja podatnych osadów w podłożu strumienia lodowego doprowadzi jednak do powstania punktów przywierania w miejscach odsłonięcia twardego podłoża i do wyhamowania ruchu lodu (Clark i Stokes, 2001). W oparciu o badania strumienia M'Clintoc Channel w Arktyce Kanadyjskiej obliczono, że warstwa osadów o miąższości $50 \mathrm{~m}$ wystarczy do utrzymania działalności strumienia lodowego przez zaledwie 200 lat. Dostawa materiału wyerodowanego w „górnym biegu” strumienia lodowego nie rekompensuje ubytków spowodowanych erozją. Dowodzi tego znikomy udział eratyków dalekiego transportu zidentyfikowanych przez Clarka i Stokesa (op. cit.), wynoszący zaledwie 4\%. Resztę stanowił materiał lokalny. Na przeanalizowane $140 \mathrm{~km}$ długości łożyska strumienia lodowego w dolnych $70 \mathrm{~km}$ duża część luźnych osadów została już usunięta i w znaczącej części odsłonięte zostało twarde podłoże, podczas gdy w otoczeniu (poza łożyskiem) miąższość osadów glacjalnych wynosiła około $50 \mathrm{~m}$. Jeśli powyższy mechanizm odpowiadałby rzeczywistości, to w lobach Wisły i Odry osadów vistulianu być chyba nie powinno, a i osady warciańskie musiałyby mieć przynajmniej znacznie zredukowaną miąższość - chyba że strumienie kończące się na lądzie cechują się mniejszą siłą erozyjną. Ostatnie badania wskazują jednak na szybki ruch lodu w obrębie lobu wiślanego - podczas transgresji czoło lodu miało zmieniać swoje położenie w tempie 250-400 m/rok (Wysota i Molewski, 2011), a to oznacza, że rzeczywista prędkość lodu musiała być jeszcze większa. Przytoczone dane zdają się świadczyć o konieczności wystąpienia dość intensywnej erozji. Sugerowany przez Clarka i Stokesa (2001) mechanizm wygasania strumieni lodowych, uwarunkowany usuwaniem luźnych osadów i wzrostem tarcia na kontakcie z odsłoniętym w ten sposób litym skalnym podłożem, nie znajduje zastosowania w przypadku potencjalnych strumieni lodowych przyjmowanych dla obszaru Polski. Gruba pokrywa luźnych skał neogeńskich i plejstoceńskich dosyć skutecznie izolowała strumień lodowy od zlityfikowanego podłoża.

Jeżeli strumienie lodowe są rzeczywiście zależne w dużym stopniu od ilości podatnych (luźnych) osadów w podłożu, to strumienie antarktyczne są zjawiskiem krótkotrwałym, bo szybko zostaną usunięte podścielające je muły glacimorskie (Clark 
i Stokes, 2001). Najnowsze badania prowadzone w Antarktyce wskazują jednak, że opieranie się na deformowaniu podłoża jako podstawowym warunku ruchu strumienia lodowego i sugerowanie wygasania strumienia, gdy zabraknie warstwy deformacyjnej w podłożu, jest raczej błędnym kierunkiem (Reinardy i in., 2011). Badania śladów paleostrumienia lodowego na szelfie Morza Weddella na wschód od Półwyspu Antarktycznego wykazały, że w jego spągu występowały zarówno deformowalne osady, jak i twarde, niepodatne podłoże zbudowane ze zwięzłych skał osadowych i skał krystalicznych. W strefie formowania się strumienia (onset) dominującym mechanizmem ruchu był ślizg denny, ale w dół strumienia coraz większy był udział deformowania podłoża, z czym wiązało się również przyspieszenie ruchu lodu (Reinardy i in., op. cit.). Obserwacje na obszarze tarczy kanadyjskiej już wcześniej pozwoliły wysnuć wniosek, że deformowanie podatnego podłoża nie jest warunkiem niezbędnym do funkcjonowania strumienia lodowego (Stokes i Clark, 2003b). Udział ślizgu bazalnego w ruchu strumieni lodowych dostrzegają także Smith i Murray (2009). Zwrócili oni uwagę na niewielką aktywność erozji pod strumieniem lodowym Rutford w lądolodzie antarktycznym. Ma o tym świadczyć brak odsłonięć twardego podłoża w łożysku strumienia, podczas gdy na szlakach paleostrumieni doszło w wielu miejscach do erozyjnego usunięcia miękkich osadów i odsłonięcia litych skał. Smith i Murray (op. cit.) sugerują, że intensywna erozja w strefie formowania się strumienia lodowego zachodzi dopiero na końcowym etapie deglacjacji, a współczesne strumienie lodowe jeszcze tego etapu nie osiągnęły. To wyjaśnienie wydaje się mało przekonywujące, ponieważ na sugerowanym późnym etapie mały już jest przyrost lodu i możliwości inkorporacji materiału skalnego przez lód raczej maleją niż rosną. Pozostaje co najwyżej wyprowadzanie osadów przez wody subglacjalne.

Strumienie lodowe cechują się dużą zmiennością przestrzenną i czasową w skali niekiedy zaledwie kilkuletniej - zwłaszcza na etapie deglacjacji. Mogą one okresowo zamierać, po czym odnawiać się, przyspieszać i zmniejszać miąższość, zwalniać, zmieniać kierunek i tor ruchu (por. Stephenson i Bindschadler, 1988; Retzlaff i Bentley, 1993; Anandakrishnan i Alley, 1997; Convay i in., 2002; Joughin i in., 2004, 2005; Catania i in., 2006; Dowdeswell i in., 2006; Truffer i Fahnestock, 2007; Rignot, 2008; Stokes i in., 2009; Ó Cofaigh i in., 2010). Jako przykład można przytoczyć strumień lodowy Kamb na Antarktydzie (znany również jako Ice Stream C), który zamarł około 150 lat temu i do dziś pozostaje nieczynny (Anandakrishnan i Alley, 1997; Bennett i Glasser, 2009).

We współczesnym lądolodzie antarktycznym strumienie odprowadzają ponad $90 \%$ lodu i osadów - Bentley (1987), Bentley i Giovinetto (1991 - fide Bennett, 2003), Bamber i in. (2000), Payne i in. (2004), Bennett i Glasser (2009). Hughes (1992) rozszerza ten wysoki udział również na lądolód grenlandzki. Sam Jakobshavn Isbrae odprowadza 6\% lodu traconego przez lądolód grenlandzki (Clarke, 1987a - fide Jania, 1993). Lodowce Jakobshavn, Helheim i Kangerdlugssuaq odprowadzają w sumie $12 \%$ lodu traconego rocznie przez lądolód grenlandzki (Bennett i Glasser, 2009). Strumienie lodowe wpływają zatem $\mathrm{w}$ decydującym stopniu na dynamikę i stabilność lądolodów oraz warunkują sedymentację na ich przedpolu. Prawdopodobnie podobna dynamika lądolodów z dużym transportem lodu i osadów w strumieniach lodowych była 
charakterystyczna również dla zlodowaceń plejstoceńskich (Ehlers, 2011). Pozostaje tylko zagadką, dokąd miałyby być odprowadzane olbrzymie ilości osadów, jeśli strumień nie kończył się w morzu lub jeziorze. Podobne wątpliwości mieli chyba badacze deglacjacji lądolodu Morza Barentsa (Winsborrow i in., 2010a). Dowodzą oni, że lądolód ów podlegał deglacjacji przy udziale licznych strumieni lodowych kończących się w morzu. Funkcjonowanie strumieni sprzyjało szybkiemu odladzaniu szelfu Morza Barentsa. Największy z nich Bjørnøyrenna, uchodzący do Morza Norweskiego pomiędzy Skandynawią i Svalbardem, odprowadzał lód z powierzchni około 350 tys. $\mathrm{km}^{2}$ (Winsborrow i in., op. cit.). Autorzy doszli do wniosku, że w momencie, kiedy czoło lądolodu było już na lądzie, tempo recesji wyraźnie zmalało, ponieważ lód nie mógł już być odprowadzany na drodze cielenia się lodowca. Zdaniem Winsborrow i in. (2010b) cielenie się lodowców było i jest jednym z głównych czynników warunkujących funkcjonowanie strumieni lodowych. Potwierdzają tę opinię badania Jakobshavn Isbrae na Grenlandii. Ubytek lodu powodowany przez powyższy lodowiec wypustowy odbywał się w 1985 roku w tempie około $26,5 \mathrm{~km}^{3} /$ rok, po zwiększeniu prędkości przepływu zaś i - tym samym wzmożeniu cielenia się lodowca, odprowadzanie lodu wzrosło nieomal dwukrotnie, tj. do $50 \mathrm{~km}^{3} /$ rok (m.in. Joughin i in., 2004).

W przypadku lądowych strumieni lodowych szybki ruch może być ułatwiony dzięki zatrzymaniu wód ablacyjnych i utworzeniu jeziora zastoiskowego. Zachodzi wówczas intensywne cielenie się lodu do wód jeziora. Taki charakter miał strumień lodowy Dubawnt Lake w Kanadzie (m.in. Stokes i Clark, 2003a). Ci sami badacze (2004) wysunęli nawet hipotezę, że jezioro stało się czynnikiem prowokującym (wyzwalającym) ruch strumienia lodowego z uwagi nie tylko na intensywne odprowadzanie materiału, ale i wzrost ciśnienia wód w stopie lądolodu. Wyższe ciśnienie zmniejszyło opory tarcia i doprowadziło do lokalnego przyspieszenia ruchu lodu. Drugorzędność procesu cielenia się Stokes i Clark uzasadniają faktem, że po zaniku jeziora strumień lodowy wkroczył na jego dno, znacznie przy tym cieniejąc. Ten argument nie wydaje się zbyt przekonywujący, ponieważ na etapie deglacjacji, gdy zabrakło możliwości szybkiego odprowadzania lodu w postaci gór i kier lodowych, strumień lodowy rozpłynął się grawitacyjnie i przyjął formę lobową. W takim przypadku strefa marginalna strumienia lodowego nie musiałaby pozostawić ani miąższych osadów, ani wyraźnych form czołowomorenowych, ponieważ czas funkcjonowania wygasającego już strumienia lodowego byłby bardzo krótki.

\subsection{Klasyfikacja i identyfikacja strumieni lodowych}

Najczęściej wyróżnia się cztery warianty strumieni lodowych - po dwa lądowe i morskie (Stokes i Clark, 2001). Morskie miałyby kończyć się albo w lodowcu szelfowym i rozładowywać się przez cielenie się lodu wzdłuż jego krawędzi, albo bezpośrednio w morzu, gdzie następowałaby szybka degradacja lodu na drodze cielenia (rys. 7.1). Bardziej prawdopodobny z lądowych modeli miałby kończyć się w jeziorze proglacjalnym, gdzie zachodziłby taki sam proces cielenia się, jak na wybrzeżu morskim. Przykład mógłby stanowić Simcoe Lobe (Boyce i Eyles, 1991). Drugi typ miałby cienieć i rozpływać się na 
większej przestrzeni w strefie terminalnej (dystalnej), co zwiększyłoby powierzchnię ablacji i umożliwiło dość szybki zanik lodu. Przykładem miałby być Des Moines Lobe (Patterson, 1997). To jedyny z modeli, w którym w dystalnej partii strumienia lodowego rozwinąłby się wyraźny lob (rys. 7.2).

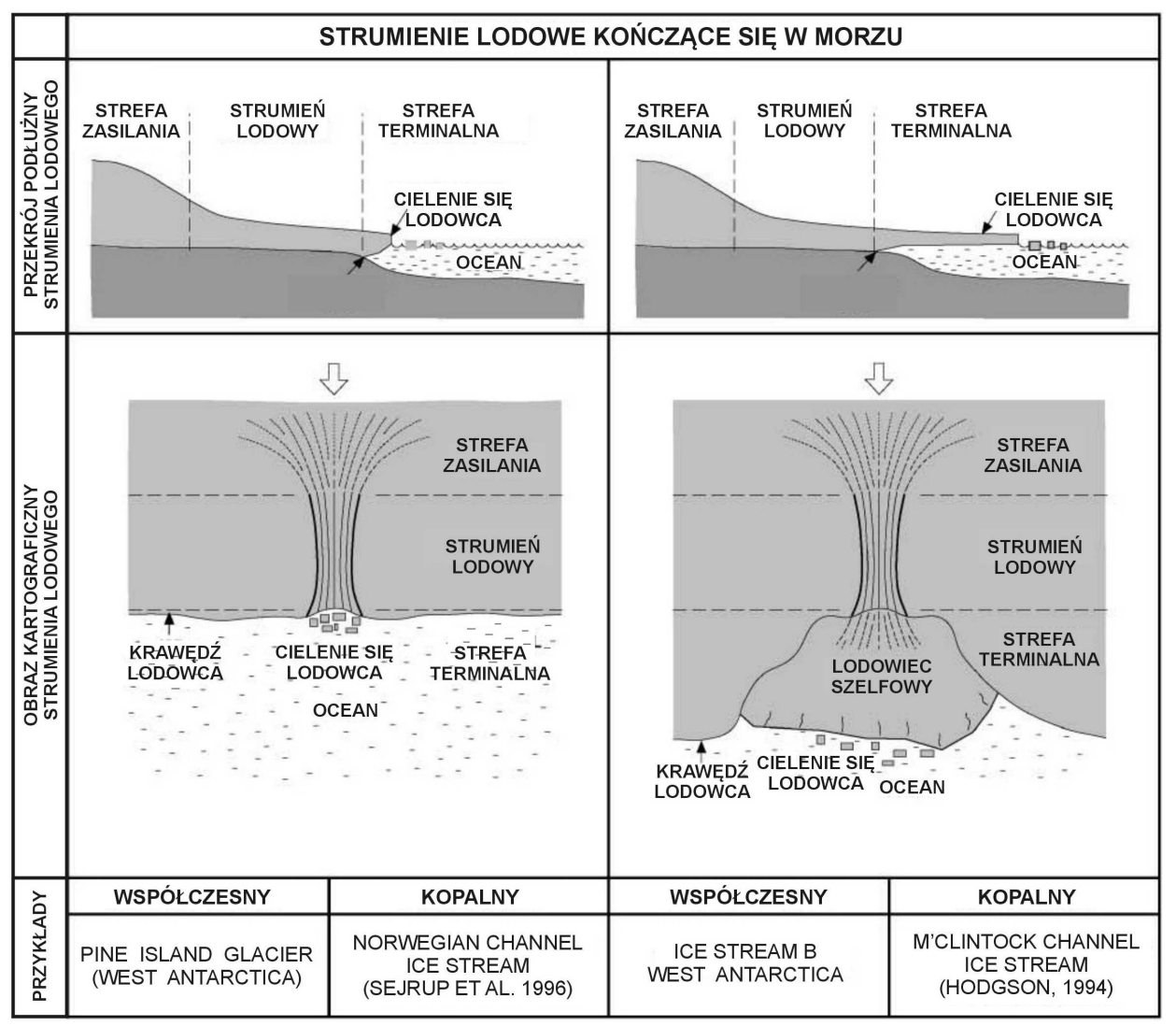

Rys. 7.1. Typy strumieni lodowych kończących się w morzu; Stokes i Clark, 2001

Figure 7.1. Marine-based ice streams; after Stokes \& Clark, 2001

Kopalne strumienie lodowe można zidentyfikować w oparciu o podstawowe kryteria geomorfologiczne i sedymentologiczne (Dyke i Morris, 1988; Stokes i Clark, 1999, 2001; Clark i Stokes, 2003; Stokes i in., 2005). Wśród nich znalazła się metoda wykorzystująca analizę szlaków rozrzutu eratyków typu Boothia (Boothia-type erratics dispersal trains) (Dyke i Morris, 1988). Szlak rozrzutu typu Boothia uwarunkowany byłby zróżnicowaniem prędkości w strumieniu lodowym i w sąsiednich strefach lądolodu. W strefie funkcjonowania strumienia transport powinien być dłuższy i zapewne intensywniejszy. Jako efekt czytelny w osadach pojawiają się wówczas linijne nagromadzenia eratyków konkretnego typu (rys. 7.3.a). Jeśli nawet te same rodzaje skał występują także po 


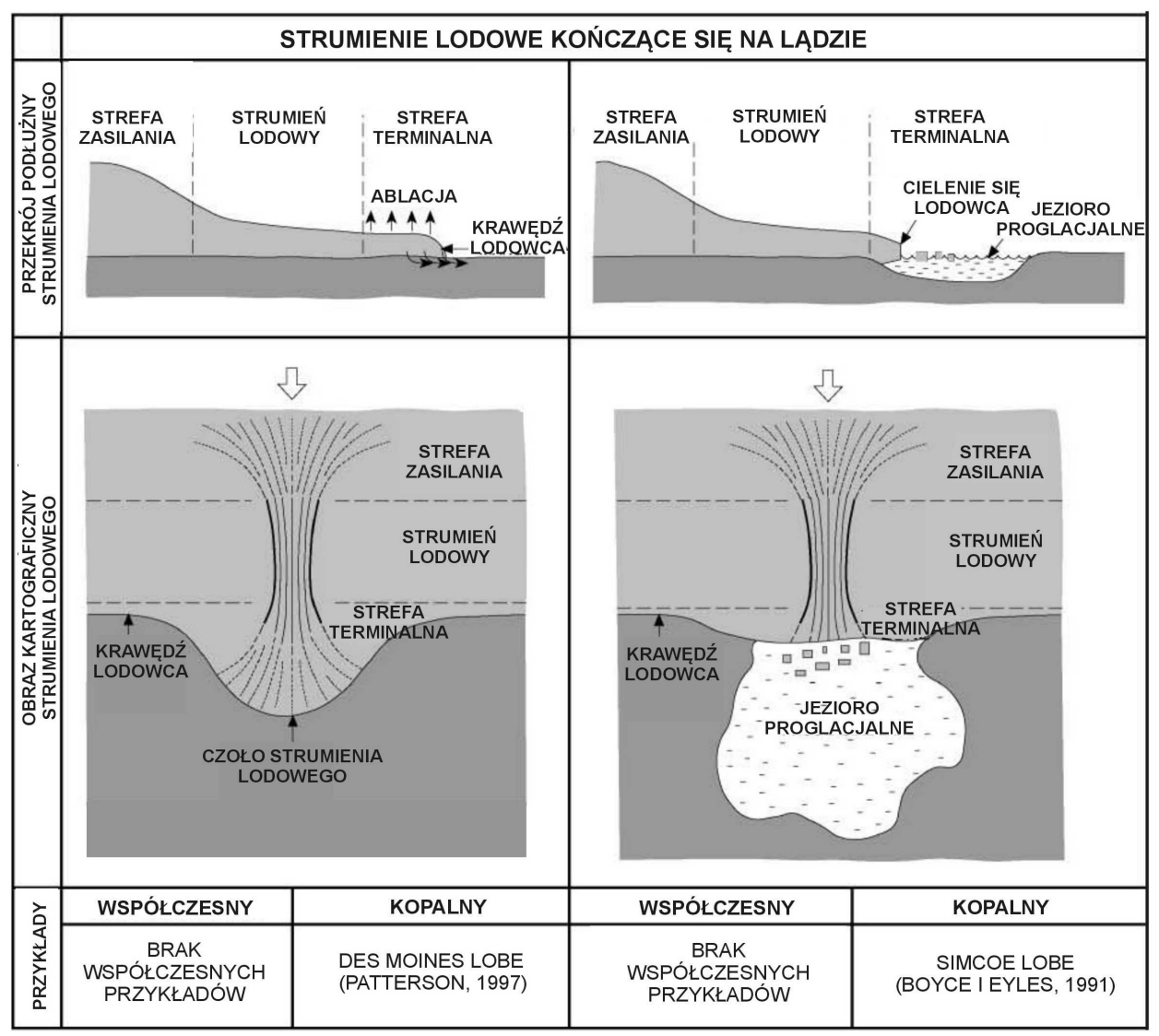

Rys. 7.2. Typy strumieni lodowych kończących się na lądzie; Stokes i Clark, 2001

Figure 7.2. Terrestrial ice streams; after Stokes \& Clark, 2001

obydwu stronach strumienia lodowego, to w znacznie mniejszej koncentracji, wynikającej z mniejszej prędkości ruchu lodu, a tym samym mniejszej dostawy materiału skalnego z obszaru alimentacyjnego. Odmienny charakter ma szlak rozrzutu typu Dubawnt Lake (rys. 7.3.b). Co prawda charakteryzuje go również linijna koncentracja eratyków jednego typu, ale przyczyną jej powstania był ograniczony zasięg przestrzenny wychodni danej skały. To spowodowało, że w sąsiednich strefach lądolodu danej skały nie było - bez względu na to, jakie były relacje prędkości lodu, który przekroczył wychodnię i tego, który ją ominął.

Analiza szlaków rozrzutu eratyków w celu identyfikacji paleostrumieni lodowych może być skuteczna na obszarach o zróżnicowanej budowie geologicznej i pozbawionych grubej pokrywy luźnych skał osadowych, np. w Kanadzie, na północy USA i w Skandynawii (Kjær i in., 2003; De Angelis i Kleman, 2007; Ross i in., 2009). Występowanie w podłożu lądolodu wychodni litych skał pozwala rozpoznać drogę transportu 

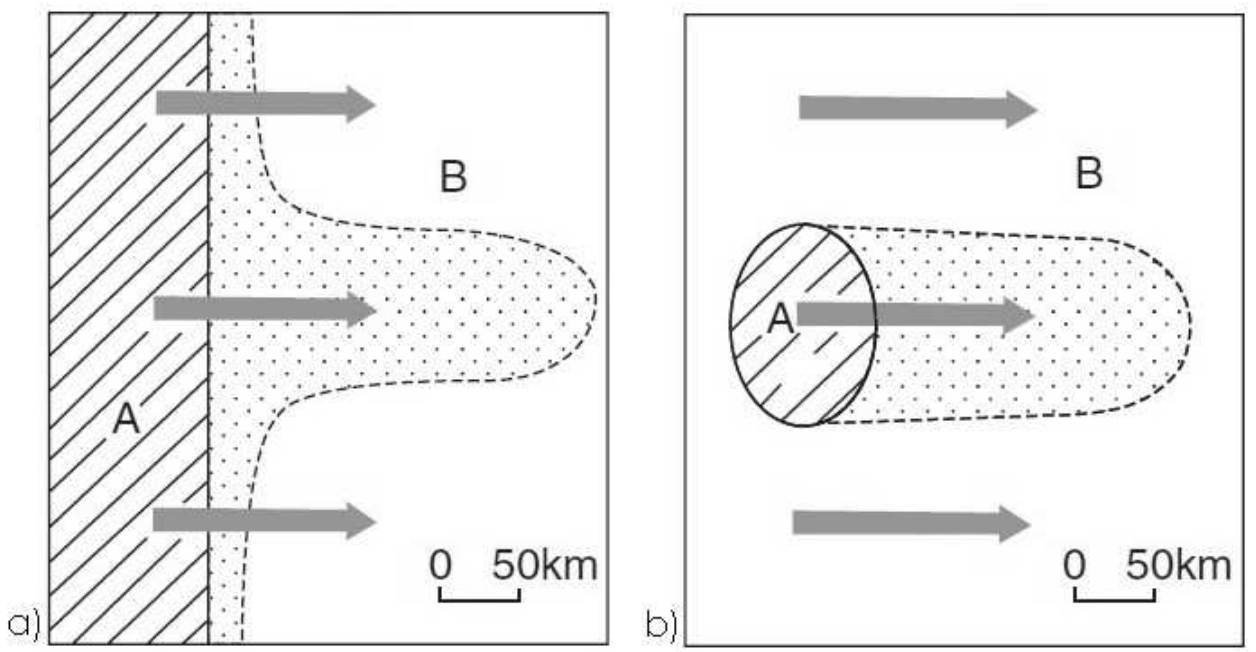

Rys. 7.3. Szlaki rozrzutu eratyków: a) typu Boothia, b) typu Dubawnt Lake; A i B - różne typy skał podłoża lądolodu; wg Dyke i Morris, 1988

Figure 7.3. Erratics dispersal trains: a) Boothia type, b) Dubawnt type; A and B - two distinctly different rock types in the glacier bed; after Dyke \& Morris, 1988

lokalnego. W oparciu o analizy drobnej frakcji żwirowej w glinach vistulianu w środkowej Danii ustalono, że w najstarszej z nich (odpowiadającej maksymalnemu zasięgowi zlodowacenia) skład i rozrzut eratyków związane były z budową podłoża na drodze lodu, co pozwoliło na zaklasyfikowanie strefy rozrzutu do typu Dubawnt Lake. Na tej podstawie możliwe było powiązanie jej genezy z powoli płynącym lodem w strefie międzystrumieniowej. W glinach dwóch młodszych nasunięć stwierdzono głównie skały dalekiego transportu, co pozwoliło zakwalifikować je do typu Boothia i przypisać ich genezę bałtyckiemu strumieniowi lodowemu (Kjær i in., 2003). Wydaje się jednak, że doszło tu do pewnej nadinterpretacji strefy rozrzutu Boothia. Na dodatek badania drobnej frakcji nie pozwalają precyzyjnie określić pochodzenia choćby nawet minimalnej części eratyków krystalicznych. W związku z tym wyniki i wnioski Kjæra i in. (op. cit.) wydają się mało przekonywujące. Próba zidentyfikowania wszystkich cech paleostrumieni lodowych we wschodniej Szkocji, a więc w obszarze o budowie sprzyjającej rozpoznaniu stref rozrzutu, zakończyła się tylko połowicznym sukcesem. Udało się znaleźć większość cech linearnych sugerowanych przez Stokesa i Clarka (1999, 2001), ale strefy rozrzutu typu Boothia wśród nich zabrakło (Golledge i Stoker, 2006). Typowej strefy rozrzutu Boothia nie udało się również stwierdzić w lobie Odry (Górska-Zabielska, 2008). Przedstawione przez autorkę przestrzenne zróżnicowanie zespołów eratyków w osadach glacjalnych i glacifluwialnych pozwala raczej doszukać się strefy rozrzutu typu Dubawnt Lake.

W oparciu o badania na zachodzie Wyspy Baffina Dyke (2008) przedstawił rozprzestrzenienie eratyków węglanowych. Otrzymany obraz kartograficzny w ogólnych zarysach odpowiada strefie rozrzutu typu Boothia, ale oparty jest wyłącznie na badaniach 
jakościowych, tzn. stwierdzeniu obecności danego typu eratyka w stanowisku lub jego braku. Brak informacji, czy sieć punktów obserwacyjnych była regularna; podano tylko, że była gęsta. W basenie Athabasca również znaleziono strefę rozrzutu, ciągnącą się na odcinku około $200 \mathrm{~km}$ (Ross i in., 2009), ale sami autorzy stwierdzili, że nie jest to typowa strefa typu Boothia, ponieważ jej granice są wyraźnie powiązane z budową podłoża. Bardziej typowy przykład strefy Boothia został zaprezentowany w oparciu o badania na Southampton Island u wylotu Zatoki Hudsona (Kosar i in., 2011). Okazało się jednak, że wyznaczony kierunek lokalnie może nie być zgodny z innym wskaźnikiem strumieniowego ruchu lodu, tj. wydłużeniem form rzeźby, co autorzy tłumaczą czasową zmianą toru ruchu strumienia lodowego, np. na skutek dopływu bocznego.

Próby identyfikacji stref rozrzutu typu Boothia na obszarach pokrytych starszymi osadami plejstoceńskimi i odległych od większych wychodni skał litych (rys. 6.2), np. w Europie Środkowej, raczej nie wydają się rokować powodzenia. Nasilona erozja w podłożu strumienia lodowego prowadzi do inkorporacji materiału skalnego o składzie podobnym do występującego również w otoczeniu strumienia. Bardzo trudno byłoby zatem wyodrębnić cechy petrograficzne pozwalające odróżnić osady strumienia lodowego od osadów utworzonych przez wolniej płynące strefy międzystrumieniowe.

Radykalna różnica składu eratyków w kolejnych fazach stadiału głównego, jaką zaobserwowano w Danii (Kjær i in., 2003) była możliwa w bezpośrednim sąsiedztwie wychodni paleozoicznego i proterozoicznego podłoża (południowa Szwecja). Analogiczna zmiana kierunku napływu - nawet jeżeli wystąpiłaby, np. w Polsce Północnej - nie pociągnęłaby za sobą tak dużej zmiany składu petrograficznego, ponieważ lód i tak przemieszczałby się nadal po tych samych luźnych osadach starszych zlodowaceń. Nic zatem dziwnego, że gliny leszczyńska i poznańska czy pomorska w Polsce są trudne do rozróżnienia w oparciu o skład petrograficzny frakcji żwirowej. Poważne wątpliwości budzi koncepcja potraktowania paleozoicznych skał osadowych, zarówno okruchowych, jak węglanowych jako lokalnych, inkorporowanych ze starszych osadów glacjalnych (Houmark-Nielsen, 1999; Kjær i in., op. cit.). Przyczyną takiego ujęcia miałby być niejasny obraz przestrzenny ich rozmieszczenia w przypadku, kiedy uwzględnione zostały wśród skał dalekiego transportu (Kjær i in., op. cit.). Nasuwa się w takim razie pytanie, dlaczego nie były inkorporowane równie aktywnie skały krystaliczne, które jako odporniejsze na wietrzenie - powinny były zachować się w większych ilościach w starszych osadach i stanowić istotny składnik materiału wchłoniętego przez strumień lodowy.

Wśród cech charakterystycznych strumieni lodowych wymieniono podwodne gliniaste delty i nagromadzenia osadów glacjalnych (Stokes i Clark, 1999, 2001), mające dokumentować strumień lodowy kończący się w morzu (Alley i in., 1989; Vorren i Laberg, 1997). Powstawały one, mimo że duża część lodu i zawartego w nim materiału skalnego odprowadzana była przez góry lodowe na znaczną odległość. Zidentyfikowano liczne podmorskie stożki osadów glacjalnych o powierzchni w niektórych przypadkach znacznie większej od Islandii (Vorren i Laberg, op. cit.); nigdzie natomiast nie udało się rozpoznać analogicznych form rozwiniętych na lądzie. Jest to jednoznaczny dowód na odmienny sposób funkcjonowania strumieni lądowych. 
Ilość osadów odprowadzonych przez strumień lodowy M'Clintock jest szacowana na $2000 \mathrm{~km}^{3}$ w ciągu około 200 lat, czyli $10 \mathrm{~km}^{3} /$ rok (Clark i Stokes, 2001). Nawet jeśli w przypadku bałtyckiego strumienia lodowego i jego hipotetycznych odgałęzień (Punkari, 1993, 1997) ilość osadów byłaby kilkadziesiąt razy mniejsza, to i tak ich nagromadzenia powinny być łatwo identyfikowalne w rzeźbie stref terminalnych lobów Odry i Wisły.

Skład glin stanowi ważny wskaźnik, pozwalający określić lokalizację i rozwój kopalnych strumieni lodowych oraz źródeł zasilania lobów lodowcowych pod oczywistym warunkiem, że podłoże obszaru zasilania będzie zróżnicowane geologicznie (Jennings, 2006). Dobry przykład stanowią loby Des Moines i Red Rivers, z których tylko pierwszy zawiera liczne kredowe łupki Pierre. Jennings uważa, że łatwe do zaakceptowania jest funkcjonowanie strumieni lodowych kończących się w morzu, gdzie lód mógł być łatwo i szybko odprowadzany (np. Sharpe, 1988; Laymon, 1992; Holmlund i Fastook, 1993; Alley i MacAyeal, 1994; Hodgson, 1994; Parent i in., 1995; Siegert i Dowdeswell, 2004). Trudne do wyjaśnienia, skomplikowane zespoły form rzeźby związane z gwałtownym zatrzymaniem i stagnacją czoła lodu w lobach kończących strumienie lodowe są zdaniem Jennings (op. cit.) jedną z przyczyn niechętnego stosunku geologów do strumieni kończących się na lądzie.

\subsection{Osady strumieni lodowych}

Szybkie strumienie lodowe aktywnie erodują podłoże (Sharp, 1988). Miejscami pod strumieniem lodowym Rutford na Antarktydzie stwierdzono tempo erozji, wynoszące nawet do $1 \mathrm{~m} /$ rok (Smith i in., 2007). Wartość ta przewyższa wielokrotnie wszelkie dane wyliczone nie tylko dla lądolodów, ale i dla znacznie szybciej erodujących dna dolin lodowców górskich (Hallet i in., 1996; Alley i in., 2003b). Brak dowodów proporcjonalnie intensywnej sedymentacji z antarktycznych strumieni lodowych (Livingstone i in., 2012), wskazuje na raczej krótkotrwały charakter zanotowanego przyspieszenia erozji.

Norweski strumień lodowy odprowadził do morza w ciągu ostatnich 500 ka aż 32 tys. $\mathrm{km}^{3}$ osadów (Nygård i in., 2007). Pomiędzy 20 i 19 ka BP dostarczał przeciętnie 1,1 Gt osadów rocznie, co stanowi ekwiwalent 8 tys. $\mathrm{m}^{3} /$ rok na metr szerokości frontu strumienia lodowego. Obliczona wartość jest większa o rząd wielkości od przyjmowanej dla większości strumieni lodowych, np. dla Isfjorden na Spitsbergenie wyznaczono ją na 560-980 m³ rok na 1 metr frontu lodu (Hooke i Elverhøi, 1996). Modelowanie dla lobu Jeziora Michigan wykazało zaledwie 100 do $400 \mathrm{~m}^{3} /$ rok (Jenson i in., 1995).

Strumienie lodowe kończące się na lądzie i w morzu mają wiele cech wspólnych, z zastrzeżeniem jednak, że akumulacja osadów w warunkach lądowych jest wynikiem zupełnie odmiennych procesów (Evans i in., 2012). Strumienie lodowe dochodzące do wybrzeży tworzyły na szelfie i u jego podnóża wielkie podmorskie stożki osadów (por. Vorren i Laberg, 1997; Ó Cofaigh i in., 2003), określane przez Clarka i Stokesa (2001) jako gliniaste delty (till delta), np. w zatoce Viscount Melville Sound w Arktyce Kanadyjskiej, gdzie kończył się strumień lodowy M’Clintock Channel. W tym przypadku 
strefa zasilania strumienia wynosiła 162 tys. $\mathrm{km}^{2}$. Podczas swojej działalności wyprowadził on około 80 tys. $\mathrm{km}^{3}$ lodu, a w nim około 2 tys. $\mathrm{km}^{3}$ osadów. Żaden współczesny strumień lodowy Antarktyki nie dorównuje mu rozmiarami i aktywnością transportowo-depozycyjną (Clark i Stokes, op. cit.).

Strumienie lodowe kończące się na lądzie pozostawiają po sobie szerokie łuki morenowe włącznie z nasunięciami i spiętrzonymi grzbietami, złożone pryzmy osadów zdeformowanych glacitektonicznie oraz submarginalne gliny (Clark i Stokes, 2003; Evans i in., 2008). Brak możliwości skutecznego odprowadzania osadów dostarczanych przez lądowe strumienie lodowe uzasadnia oczekiwanie znacznie zwiększonej miąższości glin oraz glacitektonicznego spiętrzenia osadów proglacjalnych otaczających lobowe zakończenie strumienia (Evans i in., 2012). Z ilością osadów jest ściśle związana potencjalna stabilność czoła strumienia lub jej brak. W przypadku długotrwałej równowagi dopływu lodu i ablacji powinny utworzyć się olbrzymie formy morenowe (por. Jennings, 2006) i skomplikowane sekwencje osadów glacigenicznych, zaklasyfikowane przez Evansa i in. (2008) jako przekroczone zespoły form glacimarginalnych. W prowincji Alberta (Kanada) występują również licznie małe, recesyjne moreny spiętrzone, związane z lobami o aktywności zmiennej sezonowo (Evans i in., 1999, 2006, 2008). W przeciwieństwie do bogatej literatury na temat osadów związanych ze strumieniami lodowymi kończącymi się w morzu, publikacje na temat glin i innych osadów tworzących się przy udziale strumieni lodowych kończących się na lądzie są bardzo nieliczne (Patterson, 1998; Jennings, 2006; Evans i in., 2008, 2012; Ó Cofaigh i in., 2010; Narloch i in., 2012). Ostatnio nawet najwięksi zwolennicy strumieni lodowych zdają się powątpiewać w możliwości ich funkcjonowania na lądzie. Pojawił się pogląd, że strumienie lądowe miały raczej charakter efemerycznych szarży lodowych, możliwych w przypadku, kiedy czoło lądolodu wkraczało na obszar pokryty osadami nieskonsolidowanymi (Stokes i in., 2012 - str. 101-102). Znacznie wcześniej w podobny sposób interpretowano wykształconą w postaci lobów strefę marginalną lądolodu laurentyjskiego w Albercie (Evans i Rea, 1999, 2003; Evans i in., 1999). Wydaje się, że strumienie lodowe kończące się w morzu, na etapie recesji również mogły przyjmować charakter krótkotrwałych szarży lodowych (Bindschadler, 1997; Ireassen i Winsborrow, 2009; Engelhardt i Kamb, 2013; Ireassen $\mathrm{i}$ in., 2014)

Skąpa dokumentacja aktywności depozycyjnej lądowych strumieni lodowych może być tylko częściowo wytłumaczona selekcją wytopionego materiału skalnego i odprowadzaniem drobnych frakcji do psamitowej włącznie przez wody ablacyjne. W takim przypadku w strefie dystalnej strumienia powinny nagromadzić się mniej podatne na redepozycję osady grubofrakcyjne (bruki rezydualne). W strefach czołowomorenowych ich udział jest z oczywistych względów większy, ale trudno wyjaśnić, dlaczego przed czołami postulowanych paleostrumieni lodowych miąższe serie żwirowe i głazowiska na ogół nie występują. Możliwe, że mała ilość osadów wynika z mniejszej aktywności lądowych strumieni, ograniczonej wielkością ablacji, rzeźbą podłoża, tarciem i innymi czynnikami oraz - przede wszystkim - krótkim czasem ich funkcjonowania. Na lądzie nie ma możliwości szybkiego odprowadzania olbrzymich mas lodu na wzór cielenia się lodowców. W tej sytuacji należałoby jednak zweryfikować poglądy o dominującej roli strumieni w odprowadzaniu lodu i zawartego w nim materiału skalnego z lądolodów. 
Oceny mówiące o $90 \%$ udziale strumieni w ubytku lodu z lądolodu antarktycznego (np. Bentley, 1987) nie muszą być przesadzone, ale na pewno nie można ich bezkrytycznie przenosić na plejstoceńskie lądolody, cechujące się długimi strefami czołowymi zlokalizowanymi na lądach.

\subsection{Strumienie lodowe w Polsce}

Zdaniem wielu badaczy ostatni lądolód fennoskandzki charakteryzował się występowaniem licznych strumieni lodowych, które przekraczały zbudowane z litych skał podłoże (Punkari, 1993, 1997; Kleman i in., 1997; Boulton i in., 2001b) i na południowym obrzeżu lądolodu wchodziły na obszar zbudowany ze skał luźnych (rys. 7.4 i 7.5). Zbliżoną koncepcję dynamiki lądolodu wysunął już w okresie międzywojennym Nechay (1927a, 1927b), ale jego idea pozostała właściwie niezauważona, a sam autor zaginął podczas wojny. W podobnym okresie schemat ruchu mas lodowych, nieomal identyczny z ogłoszonym ponad pół wieku później przez Punkariego (op. cit.), przedstawił Kummerow (1930, 1950, 1954). Jego zdaniem taki sam układ prądów lodowych miał powtarzać się w kolejnych zlodowaceniach. W efekcie większość eratyków dostarczanych na obszar Niżu Środkowoeuropejskiego musiałaby wywodzić się z dna Bałtyku. Być może forsowanie przez Kummerowa nieomal kompletnie zarzuconej teorii dryftowej wpłynęło na prawie zupełne przemilczenie przytaczanych przez niego argumentów na rzecz napływu mas lodowych wzdłuż depresji bałtyckiej. Jego wizja pomijała jednak bardzo ważny aspekt, jaki stanowił bardzo krótki okres funkcjonowania Morza Bałtyckiego (bądź jego wcześniejszych odpowiedników), uzależniony od izostatycznego pogrążenia Fennoskandii.

Pojawiła się też koncepcja hipotetycznego układu strumieni lodowych w Europie Środkowej w Saalianie (Van der Wateren, 2005). Ich przebieg został wyznaczony w oparciu o założenie, że lobowy układ moren czołowych jest dowodem funkcjonowania lądowych strumieni lodowych. Przedstawione kierunki (rys. 7.5) odwołują się jednak tylko do układu lobów i jeśli nawet odzwierciedlają rzeczywiste strumienie lodowe, to opisują tylko ich dystalne odcinki, które nie muszą być zgodne z głównymi kierunkami dalekiego transportu, wyznaczonymi w oparciu o zespoły eratyków przewodnich.

Strumienie lodowe w lądolodzie fennoskandzkim wykazywały niewielki związek z wychodniami deformowalnych osadów (Kleman i in., 1997; Boulton i in., 2001b). O ich ruchu decydowały raczej warunki termodynamiczne w podłożu, uzależnione głównie od jego ukształtowania (Payne i Baldwin, 1999). W podobny sposób, tj. zróżnicowaniem rzeźby podłoża i zmiennością warunków klimatycznych na obszarze źródłowym lądolodu, Nechay tłumaczył występowanie prądów lodowych na Ziemi Dobrzyńskiej (1927a, 1927b).

Niektóre spośród podrzędnych strumieni lodowych w lądolodzie fennoskandzkim mogły mieć charakter szarży lodowych (Boulton i in., 2001b). Jako granicę przyjęto aktywność utrzymującą się w okresie do 10 lat. Strumienie lodowe funkcjonują dłużej. Większość prezentowanych stref odpływu lodu miałyby stanowić właśnie strumienie, 
ale nie jest jasne, czy chodziło tylko o te kończące się w morzu. Strumienie miały prowadzić do zmniejszenia miąższości lodu - zwłaszcza podczas regresji. Zdaniem Boultona i in. (2001b) nieuwzględnianie ruchu strumieniowego w rekonstrukcjach i modelach lądolodów prowadziło do wnioskowania o bardzo dużej miąższości lodu - nawet do 3 200-3 400 m (np. Denton i Hughes, 1981; Boulton i Payne, 1994). W oparciu o analizę zmian poziomu mórz oraz rekonstrukcję przebiegu procesów glacjoizostatycznych wyznaczono znacznie mniejsze wartości - rzędu 1600 m (Lambeck i in., 1998). Ostatnie wyniki są zgodne z koncepcją strumieniowej natury lądolodu fennoskandzkiego.

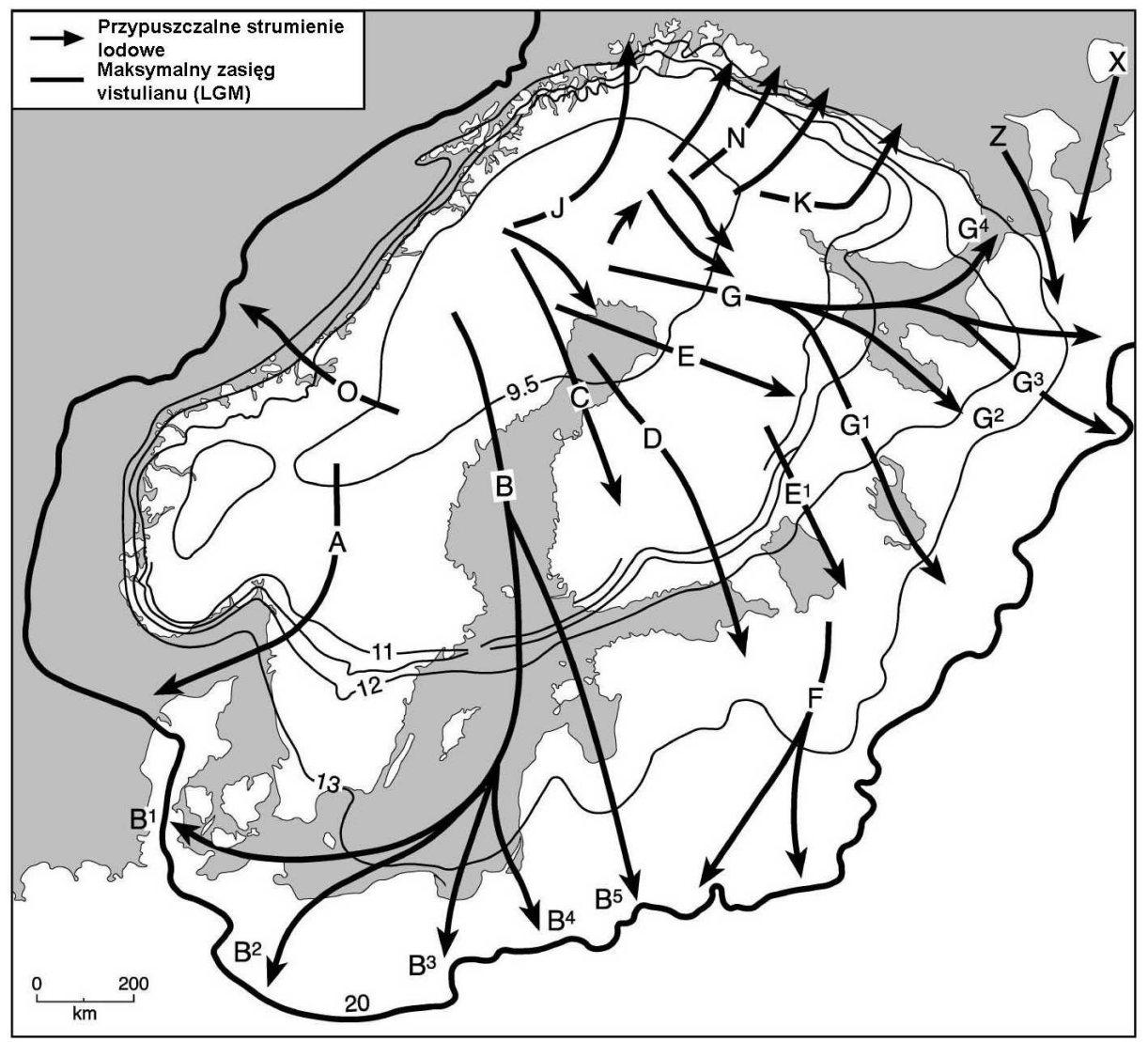

Rys. 7.4. Strumieniowy model lądolodu fennoskandzkiego $w$ vistulianie opracowany przez Punkariego (1993, 1997); izolinie oznaczają granice zasięgu lądolodu datowane w ka BP (Punkari, 1993); mapa według Stokes i Clark, 2001

Figure 7.4. Ice streams model of the Scandinavian and Novaya Zemlya Ice Sheets during Weichselian (according to Punkari, 1993, 1997); isolines indicate positions of ice-sheet limits dated in ka BP (Punkari, 1993); map after Stokes and Clark, 2001 


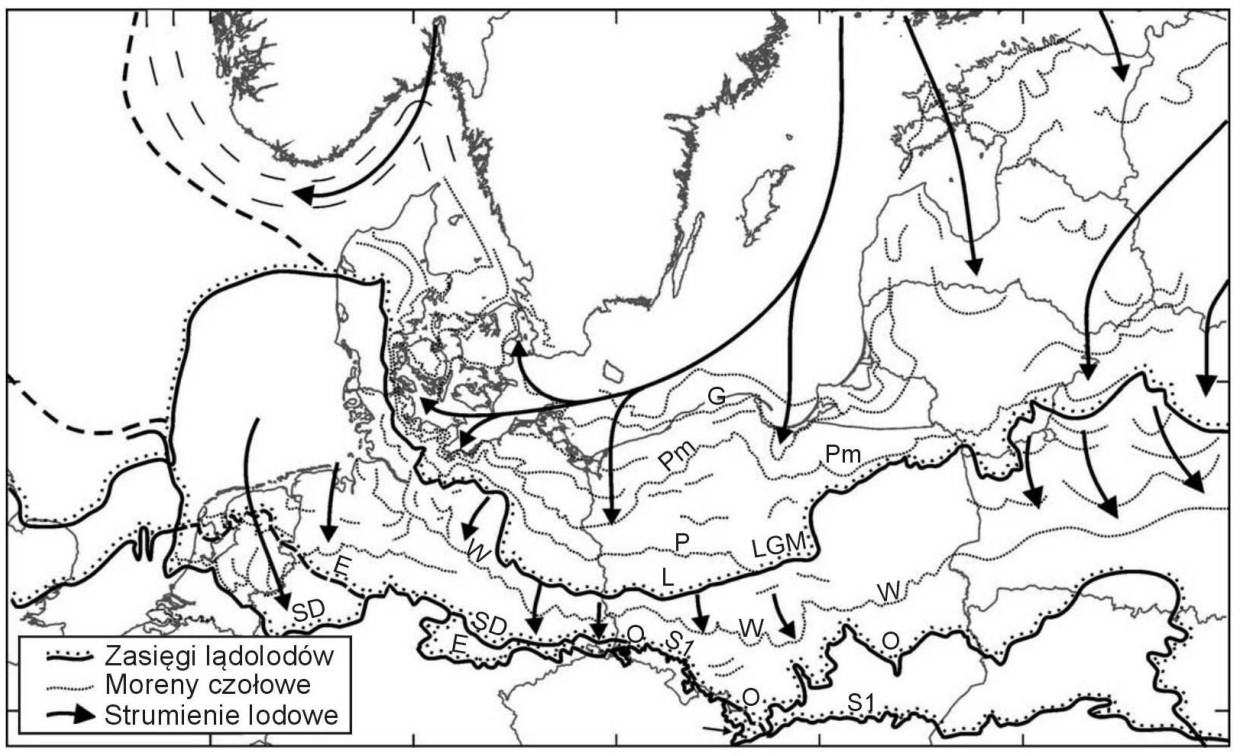

Rys. 7.5. Układ strumieni lodowych w Saalianie i Weichselianie na Niżu Środkowoeuropejskim według Van der Waterena 2005: E - Elsterian, S1 - san 1, S2 - san 2, SD - Saalian-Drenthe, O - odra, W - warta, LGM - maksymalny zasięg lądolodu wisły, L - faza leszczyńska, P - faza poznańska, Pm - faza pomorska,

$$
\mathrm{G} \text { - faza gardnieńska }
$$

Figure 7.5. Location of major ice streams in Central Europe during the Saalian and Weichselian glaciations: E - Elsterian, S1 - Sanian 1, S2 - Sanian 2, SD - Saalian-Drenthe glaciation, O - Odranian, W - Wartanian, LGM - Weichselian maximum extent, L - Leszno/Brandenburg Phase, P - Poznań/Frankfurt Phase, Pm - Pomeranian Phase, G - Gardno Phase; after Van der Wateren, 2005

Obszar północnej Polski w vistulianie znalazł się pod wpływem bałtyckiego strumienia lodowego, oznaczonego przez Punkariego (1997) jako B. Od niego odchodziły liczne odgałęzienia, tj. B1 w rejonie wysp duńskich i Jutlandii, B2 (O wg Marksa, 2005) odrzańskie, B3 (V) wiślane, B4 (M) kuroński i B5 (L) ryskie (Punkari, 1997; Boulton i in., 2001b; Marks, 2002, 2004, 2005) - rys. 7.4. Dwa z nich, tj. B2 i B3, kończące się w brzeżnej części lądolodu lobami Odry i Wisły, mogły wywrzeć znaczny wpływ na dynamikę i sedymentację ostatniego lądolodu na obszarze północnej Polski. Osady strumienia lodowego lobu Odry stanowią przedmiot zainteresowania Górskiej-Zabielskiej (m.in. 2008), badaniami zaś osadów i dynamiki w lobie Wisły, włącznie z jego rzetelnym udokumentowaniem w południowej części dolnego Powiśla, zajął się Wysota (2002; Wysota i Molewski, 2007, 2011; Narloch i in., 2012, 2013). Wysota i Molewski (op. cit.) określili tempo migracji czoła lobu Wisły podczas stadiału głównego na $250 \mathrm{~m} /$ rok w czasie transgresji i 300 w czasie regresji w fazie leszczyńskiej, a w poznańskiej - odpowiednio 400 i $450 \mathrm{~m} /$ rok w strefie o szerokości 50-70 km. Należy jednak mieć świadomość, że powyższe dane odnoszą się do przesuwania czoła lobu Wisły, a nie do rzeczywistej prędkości lodu, która z pewnością była większa na etapach transgresji, a w trakcie regresji miała zwrot przeciwny do zmian położenia czoła lądolodu. Pomimo 
tak dużej prędkości lodu, z definicji kilkakrotnie większej aniżeli w strefach międzystrumieniowych, lob wiślany właściwie nie jest wysunięty na południe w stosunku do czoła lądolodu w Wielkopolsce. Nakreślony przez Marksa (2005) układ strumieni lodowych vistulianu pozwala sądzić, że maksymalny zasięg lądolodu był porównywalny, a może nawet większy w strefie międzylobowej w Wielkopolsce, aniżeli w samych lobach Odry i Wisły, mających stanowić dystalne odcinki strumieni lodowych. Ten wniosek pozostaje w sprzeczności z podstawową ideą strumieni lodowych, jako stref przyspieszonego ruchu lodu i ich lobowych zakończeń („wypustek”). Powyższe fakty da się jednak zinterpretować przyjmując, że czas funkcjonowania strumieni lodowych na południe od Bałtyku był bardzo krótki, co uniemożliwiło znaczące wysunięcie się na południe lobowych zakończeń strumieni oraz nagromadzenie $u$ ich czoła wytopionego materiału morenowego. Oznaczałoby to, że okres aktywności strumienia lodowego nie przekraczał jednorazowo kilku lat, a czoło lądolodu podczas tych efemerycznych szarży tylko w niewielkim stopniu zmieniało swoje położenie. Całkowicie przeciwny wniosek wysuwa Jasiewicz (2007), który na podstawie licznej obecności skał alandzkich w morenie gardnieńskiej w Dębinie oraz rekonstrukcji czasu i warunków ich transportu z rejonu Wysp Alandzkich sugeruje, że bałtycki strumień lodowy był aktywny od momentu zajęcia przez lądolód obszaru wschodniego Bałtyku aż do ustąpienia lądolodu z tego obszaru.

Poważny problem interpretacyjny stanowi niemal zupełne odcięcie wschodniej części Niżu Środkowoeuropejskiego od obszaru Półwyspu Skandynawskiego podczas aktywności bałtyckiego strumienia lodowego - zwłaszcza tak długotrwałej, jak oczekiwałby Jasiewicz (op. cit.). Stabilny strumień stanowiłby barierę dla napływu skał z Dalarny, Upplandu i Smålandu na obszar Polski i krajów perybałtyckich, podczas gdy badania dowodzą powszechnej obecności skał z wymienionych regionów w osadach vistulianu. Mało prawdopodobne (a z prawami fizyki wręcz sprzeczne) wydaje się „przeplatanie" prądów lodowych w obrębie strumienia, dzięki któremu skały transportowane w północno-zachodniej strefie brzeżnej strumienia lodowego mogłyby zostać przerzucone na jego południowo-wschodnie peryferia. W takim ujęciu powszechna obecność skał szwedzkich w osadach lobów Wisły i Odry musiałaby raczej być wyrazem inkorporacji starszych osadów w stopie lądolodu. Istnieje też możliwość, że budowa lądolodu fennoskandzkiego przyjęła strumieniowy charakter dopiero w schyłkowej fazie jego rozwoju i dokumentuje bardzo krótki okres tuż przed jego zanikiem. W takim przypadku strumienie lodowe mogłyby doprowadzić do ukształtowania linearnych form rzeźby w podłożu, ale ich możliwości depozycyjne byłyby już bardzo ograniczone. Tym samym ich wpływ na skład osadów glacjalnych ostatniego zlodowacenia (w tym zespołów eratyków) byłby niewielki, a o składzie petrograficznym glin decydowałaby dynamika lądolodu sprzed ukształtowania się strumieni. W takim przypadku osady pozostawione przez strumień lodowy stanowiłyby tylko cienką warstewkę na powierzchni osadów pochodzących ze starszych etapów rozwoju lądolodu i jako pierwsze podlegałyby wietrzeniu i erozji. Uchwycenie odmienności ich składu (zespołu eratyków) w stosunku do osadów zalegających poniżej wykracza poza możliwości zastosowanej przez autora metody badawczej eratyków przewodnich. 
Zastanawiające są spostrzeżenia Górskiej-Zabielskiej (2008) na temat rozprzestrzenienia skał ze Skanii i Blekinge w lobie Odry i na obszarach sąsiednich. Eratyki ze Skanii występowały głównie w niemieckiej części obszaru badań na Pojezierzu Meklemburskim, podczas gdy skały z Blekinge w lobie Odry i dalej na wschód. Takie rozmieszczenie południowoszwedzkich eratyków (zbliżone do strefy rozrzutu typu Dubawnt Lake sensu Dyke i Morris, 1988) może stanowić cenną przesłankę, skłaniającą do zakwestionowania modelu zaproponowanego przez Punkariego (1997) - przynajmniej w odniesieniu do zachodniej części depresji bałtyckiej. Na napływ lodu bezpośrednio z północy i północnego wschodu, a nie wzdłuż depresji bałtyckiej, wskazują również: dominacja skał ze Smålandu i niewielki udział eratyków wschodniobałtyckich, zaobserwowane w osadach lobu Odry przez Górską-Zabielską (op. cit.). Do tych samych wniosków prowadzą badania eratyków przeprowadzone przez autora na Pomorzu Gdańskim i Powiślu (Czubla i in., 2007a, 2007b; Woźniak i in., 2008, 2009, 2012a; Woźniak i Czubla, 2014a, 2014b, w druku). Logicznym wyjaśnieniem niezgodności składu osadów glacjalnych i modelu bałtyckiego strumienia lodowego wydaje się przyjęcie asynchroniczności głównego etapu depozycji osadów morenowych i ukształtowania się oraz aktywności bałtyckiego strumienia lodowego. Większość osadów glacjalnych Polski musiałaby zostać odłożona jeszcze przed zainicjowaniem ruchu strumieniowego. Możliwe, że u schyłku fazy poznańskiej (do tego wniosku skłania zasięg tej fazy w lobie Wisły) wykształciły się niewielkie strumienie lodowe Odry i Wisły, ale nie były one żadnymi odgałęzieniami bałtyckiego strumienia lodowego, który zapewne wtedy jeszcze nie istniał. W maksimum fazy pomorskiej strumienie lodowe Odry i Wisły mogły ponownie się uaktywnić, na co zdaje się wskazywać lobowy przebieg zasięgu tej fazy. Właściwy (główny) bałtycki strumień lodowy rozwinął się później, być może u schyłku fazy pomorskiej i - odprowadzając szybko lód w kierunku zachodnim - odciął napływ lodu wraz z zawartym w nim materiałem morenowym na obszar Polski. W ten sposób uniemożliwił dalsze funkcjonowanie wiślanego i odrzańskiego strumienia lodowego. W podobnych ramach czasowych zamyka się koncepcja, którą Kjær i in. (2003) wykorzystali dla wyjaśnienia odmiennego składu glin głównego stadiału ostatniego zlodowacenia w Danii. Tylko najstarsza glina została tam odłożona w wyniku frontalnej, równomiernej transgresji lądolodu i dopiero w późniejszych dwóch fazach (East Jylland i Bælthav - 17-15 ka BP) decydujący wpływ na skład frakcji żwirowej w morenach miał wschodniobałtycki strumień lodowy.

Model Punkariego $(1993,1997)$ zakładał rozdzielanie się bałtyckiego strumienia lodowego na pięć ramion. Oznaczałoby to, że główny, najintensywniej erodujący strumień rozdzielał się i rozpływał ramionami na południe wbrew oddziaływaniu grawitacji. Zarówno badania dynamiki współczesnych strumieni lodowych w Antarktyce (np. Rignot i in. 2011), jak i rekonstrukcje kopalnych strumieni w lądolodzie laurentyjskim (m.in. Stokes i Clark, 2001; Kleman i Glasser, 2007) wskazują jednak na zupełnie inny sposób ich funkcjonowania. Aktywne strumienie intensywnie erodowały podłoże i odprowadzały olbrzymie ilości lodu ze swojego otoczenia („drenowały” je, a nie zasilały, jak należałoby wnioskować z modelu Punkariego - op. cit.). Utworzyły one systemy strumieniowe podobne do systemów rzecznych, tzn. złożone ze strumienia głównego 
wraz z zasilającymi go „dopływami”. Warto nadmienić, że niektórzy badacze odstąpili już od rysowania rozgałęziającego się bałtyckiego strumienia lodowego na rzecz znacznie bardziej uproszczonego schematu (Kleman i Glasser, 2007 - str. 594, Fig. 13.b).

Brak jednoznacznych dowodów na strumieniową budowę lądolodu fennoskandzkiego podczas starszych zlodowaceń. Sposób interpretacji wyników analizy eratyków przewodnich zaproponowany przez Smeda (1993) pozwala, co prawda, określić kierunek napływu lodu, ale nie mówi nic o jego prędkości, będącej podstawowym wyznacznikiem strumieniowego płynięcia lodu. Próby interpretacji składu petrograficznego różnowiekowych glin w celu określenia dróg napływu mas lodowych nie dały jednoznacznych wyników (np. Czubla, 2001; Lisicki, 2003).

W odniesieniu do dynamiki lądolodu warciańskiego Rdzany (2009) używa pojęcia prądów lodowych, które występowały w obniżeniach podłoża w środkowej Polsce. W tych strefach nasilona była aktywność erozyjna, co pozwala założyć zwiększoną prędkość przesuwania się lodu. Wprowadzenie odrębnego pojęcia dla strumieni lodowych w obrębie lądolodów starszych od vistulianu nie byłoby chyba jednak uzasadnione. Przywoływany autor też nie był przekonany co do słuszności tego rozwiązania i w dalszej części pracy stosuje pojęcia strumień i prąd lodowy zamiennie (ibid. str. 142). Mojski (2005), opisując badania petrograficzne, używa pojęcia potoków lodowych i chyba tę nazwę (lub prąd lodowy) należałoby wprowadzić jako opisującą ruch mas lodowych, nieodbiegający znacząco prędkością od pozostałej części lądolodu w przeciwieństwie do strumieni lodowych, które powinny być jednakowo nazywane bez względu na ich wiek. 


\section{PROCESY EROZYJNE JAKO ŹRÓD ŁO MATERIAŁU MORENOWEGO}

\subsection{Erozja glacjalna}

Erozja glacjalna jest jednym z podstawowych procesów umożliwiających włączanie materiału skalnego różnych frakcji w masę lodu lodowcowego. Intensywność erozji zależy od bardzo wielu czynników. Do najważniejszych należą warunki termodynamiczne w stopie lodowca, które najczęściej charakteryzowane są w sposób syntetyczny poprzez określenie reżimu termicznego. Duży wpływ na wielkość erozji wywierają również: rodzaj skał podłoża, układ i gęstość szczelin ciosowych, obecność i miąższość zwietrzeliny, tektonika podłoża lodowca, rzeźba powierzchni podlodowej, miąższość lodu, prędkość ślizgu dennego, zawartość okruchów skalnych w bazalnej warstwie lodu, obecność wód subglacjalnych i zmienność ich ciśnienia, drenaż subglacjalny i inne (por. m.in. Embleton i King, 1975; Sugden i John, 1976; Laitakari i Aro, 1985; Drewry, 1986; Laitakari, 1989; Jania, 1993; Hildes i in., 2004; Fu i Harbor, 2011; Herman i in., 2011). Powyższe czynniki pozostają w wielu przypadkach w stanie pozytywnych i negatywnych sprzężeń zwrotnych (Jania, 1993). Erozja glacjalna przejawia się najczęściej abrazją i detrakcją podłoża oraz subglacjalnymi procesami fluwioglacjalnymi (m.in. Boulton, 1974, 1979; Hallet, 1996; Iverson, 2002). Jednoznaczne rozdzielenie procesów erozji glacjalnej od fluwioglacjalnej jest najczęściej niemożliwe. Ruch lodu względem podłoża odbywa się w temperaturze punktu topnienia pod ciśnieniem lub wyższej. W takich warunkach zawsze będzie występować przynajmniej niewielka ilość wody w postaci ciekłej. W przypadku niższych temperatur dochodzi do przymarznięcia stopy lądolodu do podłoża i ruch zachodzi nieomal wyłącznie na drodze deformacji wewnętrznych, a te nie wywierają bezpośredniego wpływu na erozję podłoża. Wyjątek od tej reguły stanowią odpowiednio duże głazy. Zróżnicowana prędkość poszczególnych lamin lodu w warstwie przydennej, uwarunkowana pełzaniem deformacyjnym lodu, może spowodować ich obracanie się i niszczenie podłoża (Jania, 1993). Glina lub inne luźne skały osadowe przykrywające podłoże stanowią warstwę ochronną, dzięki której nie zachodzi erozja twardego podłoża (Dreimanis i Vagners, 1969).

Do dziś funkcjonują rozbieżne poglądy na temat aktywności erozji glacjalnej i rzecznej. Wielu autorów uważa erozję glacjalną za znacznie intensywniejszą (np. White, 1972, 1988; Bell i Laine, 1985; Braun, 1989; Harbor i Warburton, 1992; Hallet i in., 1996; James, 2003; Shuster i in., 2005, 2011). Odmienny pogląd o umiarkowanej roli glacjalnych przekształceń krajobrazu peryglacjalnego i małym udziale erozji glacjalnej (porównywalne tempo i skala z erozją rzeczną) prezentują m.in. Gravenor (1975) oraz Sugden $(1976,1978)$. Ich zdaniem lodowce głównie wygładzały tarcze kontynentalne, a skala erozji, chociaż zróżnicowana, była generalnie mała. 
Część badaczy unika jednoznacznych wypowiedzi na temat porównania skali erozji rzecznej i glacjalnej, zakładając, że są to zupełnie odmienne procesy (Elverhøi i in., 1998). W przypadku jednak, kiedy erozja dotykałaby takich samych skał a wielkość energii potencjalnej opadów (obojętne, czy w postaci ciekłej, czy stałej) byłaby jednakowa, to ich zdaniem erozja glacjalna byłaby intensywniejsza.

\subsection{Abrazja}

Abrazja polega na mechanicznym ścieraniu przez lód, a ściślej - przez zawarte w nim ziarna skalne, podłoża. Proces ten możliwy jest wyłącznie w przypadku zachodzenia ślizgu dennego. Ślizg denny o niewielkiej skali zdarza się nawet w przypadku występowania w podłożu temperatur niższych od punktu topnienia pod ciśnieniem (Shreve, 1984; Echelmayer i Wang, 1987; Cuffey i in., 1999), ale jego prędkość jest o kilka rzędów wielkości mniejsza niż w przypadku ciepłego reżimu (Iverson, 2002). Stwierdzono także abrazję podłoża w takich warunkach (Atkins i in., 2002). Zasadnicze znaczenie dla wielkości abrazji ma obecność materiału skalnego w bazalnej części lądolodu, gdyż czysty lód nie może rysować i ścierać skał (por. Embleton i King, 1975). Porównanie twardości lodu i skał jednoznacznie wskazuje, że abrazji bezpośrednio przez czysty lód mogłyby podlegać tylko niektóre skały ilaste i talkowe. Wyniki badań laboratoryjnych prowadzą jednak niekiedy do odmiennych wniosków (Budd i in., 1979). Być może przyczyną jest występowanie drobnych cząsteczek skalnych na powierzchni wykorzystywanej do eksperymentu, zanieczyszczenie lodu lub ewentualnie uwolnienie drobnych fragmentów skał podłoża w wyniku zamarzania wody w mikrospękaniach. Nie ulega jednak wątpliwości, że im wyższa zawartość materiału skalnego w lodzie, tym silniejsze oddziaływanie abrazyjne na podłoże.

Skala niszczącego oddziaływania ziaren na podłoże zależy od bardzo wielu czynników. Część z nich wiąże się bezpośrednio z lodowcem. Obok wspomnianej wcześniej koncentracji ziaren skalnych w lodzie, na intensywność abrazji wpływają także: miąższość lodu (decyduje o wielkości nacisku wywieranego przez wleczone ziarna na podłoże), prędkość ruchu lodu i zawartych w nim ziaren względem podłoża, obecność wód podlodowcowych i ich ciśnienie, stosunek twardości materiału skalnego niesionego przez lód do twardości skał w podłożu czy wielkość i kształt transportowanych okruchów skalnych. Inne czynniki odnoszą się do charakteru podłoża: ukształtowanie powierzchni podlodowej, szorstkość skał podłoża, ich cechy tekstualne i strukturalne, stan zaawansowania preglacjalnych procesów wietrzeniowych, miąższość zwietrzeliny, ilość i frakcja materiału powstającego w efekcie abrazji, wreszcie efektywność usuwania produktów ścierania, będąca pochodną ilości i aktywności wód subglacjalnych.

Należy zaznaczyć, że prędkość wleczenia okruchów skalnych w stopie lodowca będzie zwykle mniejsza od prędkości ślizgu dennego (Jania, 1993), ponieważ na styku lodu z okruchem skalnym zachodzi regelacja - lód topi się pod wpływem zwiększonego ciśnienia na proksymalnej stronie ziarna, zamiast je przesuwać. Dotyczy to w największym stopniu dużych ziaren, które zostały „zakotwiczone” na nierównościach podłoża. Intensywność erozji lodowcowej z uwzględnieniem regelacji analizowali w swoich 
obliczeniach m.in. Boulton (1974) oraz Hallet $(1975,1981)$. Eksperymenty w podłożu lodowca potwierdziły ścisły związek wielkości subglacjalnej abrazji z twardością skał (Boulton, 1979).

Boulton (1974) zakładał, że prędkość wleczenia zależy od frakcji, a intensywność abrazji głównie od siły dociskającej okruch do podłoża. Abrazja wg modelu Boultona rośnie wraz z naciskiem lodu na podłoże, ale tylko do osiągnięcia pewnej wartości, od której zaczyna maleć. Jest to związane ze wzrostem tarcia o podłoże, które wpływa hamująco na ruch lodu. Jania (1993) wyciąga stąd generalnie słuszny wniosek, że ten model wskazywałby na niewielką erozję pod bardzo grubymi lodowcami. W tym rozumowaniu pojawia się jednak konkluzja, jakoby istnienie fiordów zaprzeczało temu modelowi. Trudno doszukać się sugerowanej sprzeczności, ponieważ powstawanie fiordów nie wymagało bardzo grubej pokrywy lodowej. Na ich genezę wpłynęły w znacznym stopniu lodowce górskie, będące wczesnym etapem rozwoju czasz lodowych oraz strumienie lodowe (m.in. Aarseth, 1997; Bennett, 2003; Ottesen i in., 2005; Glasser i Ghiglione, 2009; Fu i Harbor, 2011).

Wzrost abrazji wraz z miąższością lodu sprawia, że w przegłębieniach podłoża lodowca erozja jest wzmożona bez względu na to, czy obecne są tam luźne skały osadowe, czy też skały krystaliczne (Alley i in., 2003b). Powyższe badania odnoszą się co prawda - do lodowców dolinnych i wypustowych, ale w jakiejś części można je uogólnić i na podłoże lądolodów.

Zdaniem Halleta $(1979,1981)$ siła dociskająca abradujące ziarno nie zależy od ciśnienia kriostatycznego, lecz wynika głównie z ruchu okruchów skalnych względem podłoża. Ważnym czynnikiem wpływającym na wartość tej siły jest wielkoskalowa tensja zgodna z kierunkiem nasuwania się lodu. Powoduje ona pionowe odkształcenia w lodzie i przybliża okruchy skalne do podłoża (Rötlisberger, 1968). W ten sposób coraz to nowe ziarna stykają się z podłożem (przy istotnym udziale ablacji w stopie lodowca) i podlegają szlifowaniu (rys. 8.1). Zaprzecza to poglądom, jakoby materiał morenowy był transportowany w stanie „zamrożonym”, w którym zachować się mogą ziarna o dowolnym kształcie bez względu na twardość budującej je skały. W tym kontekście staje się zrozumiałe, dlaczego niemal wszystkie głaziki w osadach glacjalnych Polski są stosunkowo dobrze obtoczone. Produkty wietrzenia mrozowego, a takie powinny stanowić znaczący składnik materiału inkorporowanego przez lód, winny być kanciaste. Zgodnie z tą koncepcją należy spodziewać się koncentracji materiału skalnego w stopie lodowca - przynajmniej w tej części, w której ciepłe podłoże umożliwia poślizg denny, ale tarcie wpływa na spadek prędkości przydennych warstw lodu w stosunku do warstw wyższych. Jest to sprzeczne z danymi m.in. DiLabio (1990), wg którego strefa rozrzutu eratyków w lodzie wznosi się wraz z odległością od wychodni pod kątem 1-3 $3^{\circ}$ na skutek ścinania wewnętrznego. Różnica wynika zapewne z odmiennego reżimu termicznego podłoża. Analiza DiLabio odnosi się raczej do lodowca zimnego - przymarzniętego do podłoża, w którym dolne warstwy lodu „ciągnięte” są na jakimś odcinku przez szybciej poruszający się lód w górnej części czaszy. Badania Rötlisbergera (1968) odnosiły się do lodowca górskiego, ale mechanizm w przypadku lądolodu o ciepłym podłożu będzie niewątpliwie ten sam. 

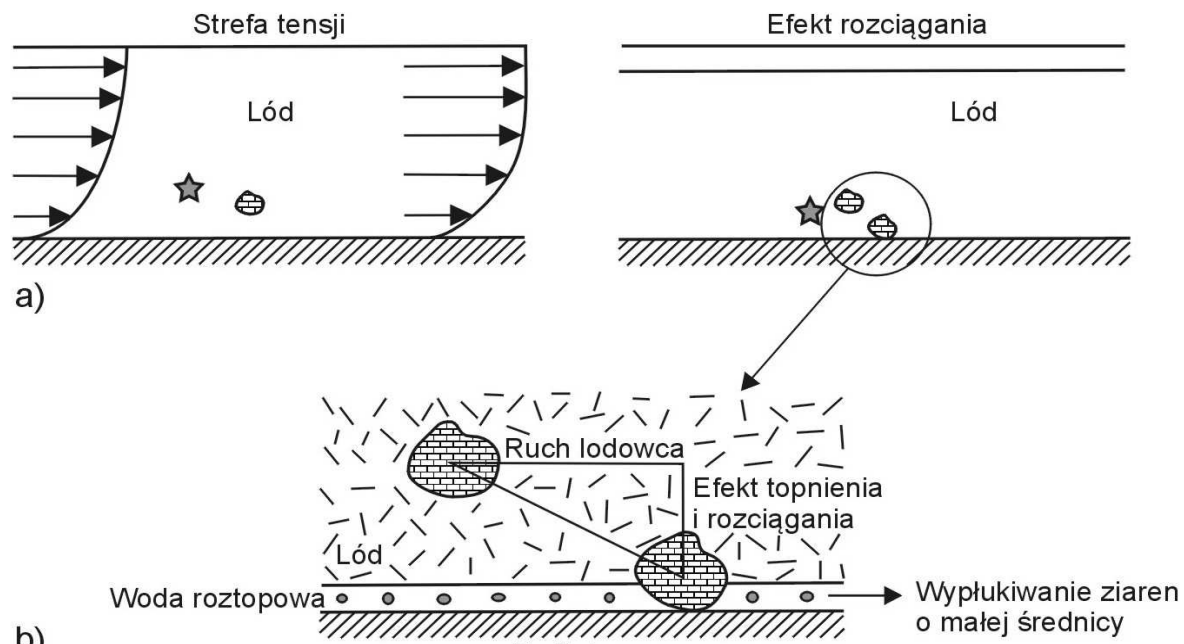

b)

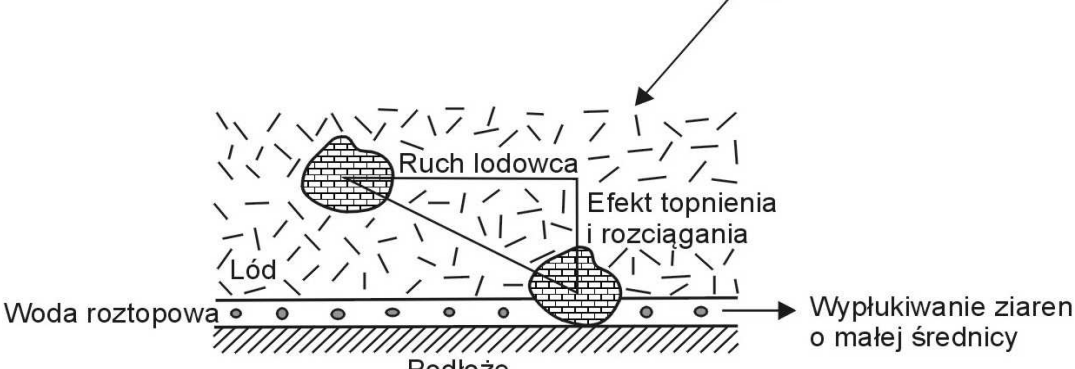

Podłoże

Rys. 8.1. Dociskanie fragmentów skalnych do podłoża w wyniku płynięcia deformacyjnego lodu (a) oraz topnienia lodu na kontakcie z podłożem (b); według Janii (1993) (zmodyfikowany)

Figure 8.1. Pressing the clasts to the ground due to deformation flow of ice (a) and due to melting of ice on contact with the bedrock (b); according to Jania (1993) (modified)

Intensywność abrazji glacjalnej (W) można określić przy pomocy wzoru: $\mathrm{W}=\mathrm{c}_{\mathrm{o}} \cdot \mathrm{u}_{\mathrm{p}}$ - $u_{n} \cdot H_{d}$ gdzie $c_{o}$ oznacza koncentrację materiału gruzowego, $u_{p}$ - prędkość wleczenia okruchów, $u_{n}$ - pionową składową ruchu w lodzie odpowiedzialną za docisk ziaren do podłoża, $H_{d}$ - współczynnik określający twardość skały (Hallet, 1981). Oznacza to, że na wielkość abrazji wpływają głównie: prędkość ślizgu dennego, twardość skał podłoża, koncentracja okruchów w lodzie oraz nierówności podłoża. Najwyższą efektywność abrazji osiąga lodowiec zawierający w stopie 10-30\% materiału skalnego. Wyższa zawartość okruchów spowalnia prędkość ślizgu i - tym samym - erozję (Hallet, 1981).

Dwa zaawansowane modele fizyczno-matematyczne abrazji subglacjalnej zaproponował Shoemaker (1988) dla interpretacji ciepłych lodowców spoczywających na litym podłożu. Uwzględniono w nich ponad 20 różnych parametrów, z których wiele obarczonych jest błędem i to raczej oceny niż pomiaru. W związku z tym wiarygodność wyników jest dyskusyjna. Bardzo zaawansowany model erozji subglacjalnej, uwzględniający wpływ subglacjalnych wód ablacyjnych i osadów, przedstawili ostatnio Egholm i in. (2012).

W oparciu o model zarysowywania podłoża przez blok tkwiący w lodzie (Drewry, 1986) Jania (1993) wnioskuje, że intensywność abrazji jest proporcjonalna do drogi przebytej przez szlifujący blok, do obciążenia bloku i odwrotnie proporcjonalna do twardości skały mniej odpornej.

Kształt rys glacjalnych wskazuje na rotację ziaren w trakcie rysowania (Iverson, 1991a). Jest to zgodne z wcześniejszymi eksperymentami (Iverson, 1990), w których w warunkach laboratoryjnych na sztucznym podłożu, w trakcie ruchu na odcinku 95-130 mm, ponad 50\% abradujących ziaren obróciło się o co najmniej $10^{\circ}$. Potwierdza to wcześniejsze szczegółowe badania Johnsona (1975 - fide Iverson, 1991a), w których 
wykazano, że niektóre formy abradowanej powierzchni mogą powstać wyłącznie przy udziale rotujących ziaren. Głębokość abrazji przez konkretne ziarno i czas jego pozostawania w kontakcie z podłożem zależą przynajmniej częściowo od jego zdolności do rotacji. Ziarna rotujące szybko abradują płycej i krócej niż rotujące powoli lub nierotujące. Klasty o nieregularnych, kanciastych kształtach abradują zdecydowanie efektywniej, ponieważ bardzo trudno ulegają rotacji i jest ona powolna. Zróżnicowanie morfologiczne rys glacjalnych jest głównie wyrazem różnej geometrii kontaktu klastów z podłożem (Iverson, 1991a).

Szczególnie intensywnej abrazji podlegają proksymalne stoki niewielkich elewacji podłoża, na których koncentrują się naprężenia (fot. 8.1 i 8.2). Dystalne stoki są zdecydowanie mniej narażone na ścieranie i rysowanie. Podatność na detrakcję rozkłada się odwrotnie.

Eksperymenty przeprowadzone w podłożu lodowca Breidhamerkur na Islandii (Boulton, 1974) i d'Argentiére w Alpach (Vivian, 1975) wykazały olbrzymią zmienność tempa abrazji od poniżej $1 \mathrm{~mm} /$ rok w przypadku płyty bazaltowej umieszczonej pod powoli płynącym lodowcem na Islandii aż po około $36 \mathrm{~mm} /$ rok w przypadku bardziej miękkiej płyty marmurowej ulokowanej pod szybko płynącym lodowcem alpejskim. Jania (1993) podaje, że w oparciu o badania sejsmiczne wyliczono prędkość abrazji pod lądolodem antarktycznym na około $0,4 \mathrm{~mm} /$ rok. Nowsze analizy wykazały jednak, że całkowita wielkość erozji glacjalnej we wnętrzu kontynentu jest o co najmniej jeden rząd wielkości niższa (Jamieson i in., 2010). Jania (op. cit.) zauważa, że „szlifowanie podłoża przez uzbrojony w okruchy skalne spód lodowca” większość badaczy uważa za proces erozyjny znacznie mniej intensywny od wyorywania (detrakcji). Powyższy pogląd potwierdzają badania w Ameryce Północnej (Briner i Swanson, 1998; Dühnforth i in., 2010). Krabbendam i Glasser (2011) dowodzą jednak, że obydwa procesy mogą być równoważne, a w przypadku skał o bardzo rzadkiej sieci spękań abrazja może nawet przeważać. Skrajne stanowisko reprezentuje Hindmarsh (1996). Jego zdaniem głównym procesem erozyjnym jest ścieranie i polerowanie podłoża przez drobny materiał okruchowy - aleurytowy, a może nawet pelitowy. Rysowanie przez grubsze ziarna odgrywa drugorzędną rolę. Z opracowanego modelu wynika, że klast rozpadający się stopniowo na coraz więcej mniejszych ziaren eroduje w sumie skały podłoża o objętości wielokrotnie większej od pierwotnej własnej. Deformowany materiał morenowy w stopie lodowca również oddziałuje abrazyjnie na lite podłoże skalne (Hindmarsh, op. cit.). Ten typ abrazji określany jest jako plastyczne żłobienie - plastic scouring (Gjessing, 1965).

Produktem abrazji jest materiał o frakcji aleurytowej do psamitowej, podrzędnie również pelitowej - zależnie od rodzaju niszczonych skał, a pod względem rzeźbotwórczym - rysy glacjalne oraz wygłady lodowcowe. Nagromadzenie się drobnoziarnistego luźnego materiału pod lodowcem izoluje go od podłoża i zmniejsza tarcie, co prowadzi do wzrostu prędkości ślizgu dennego. Redukcja wielkości tarcia i tym samym przyspieszenie ślizgu dennego następuje także dzięki obecności cienkiej błonki wody w stopie lodowca (np. Vivian, 1975). 


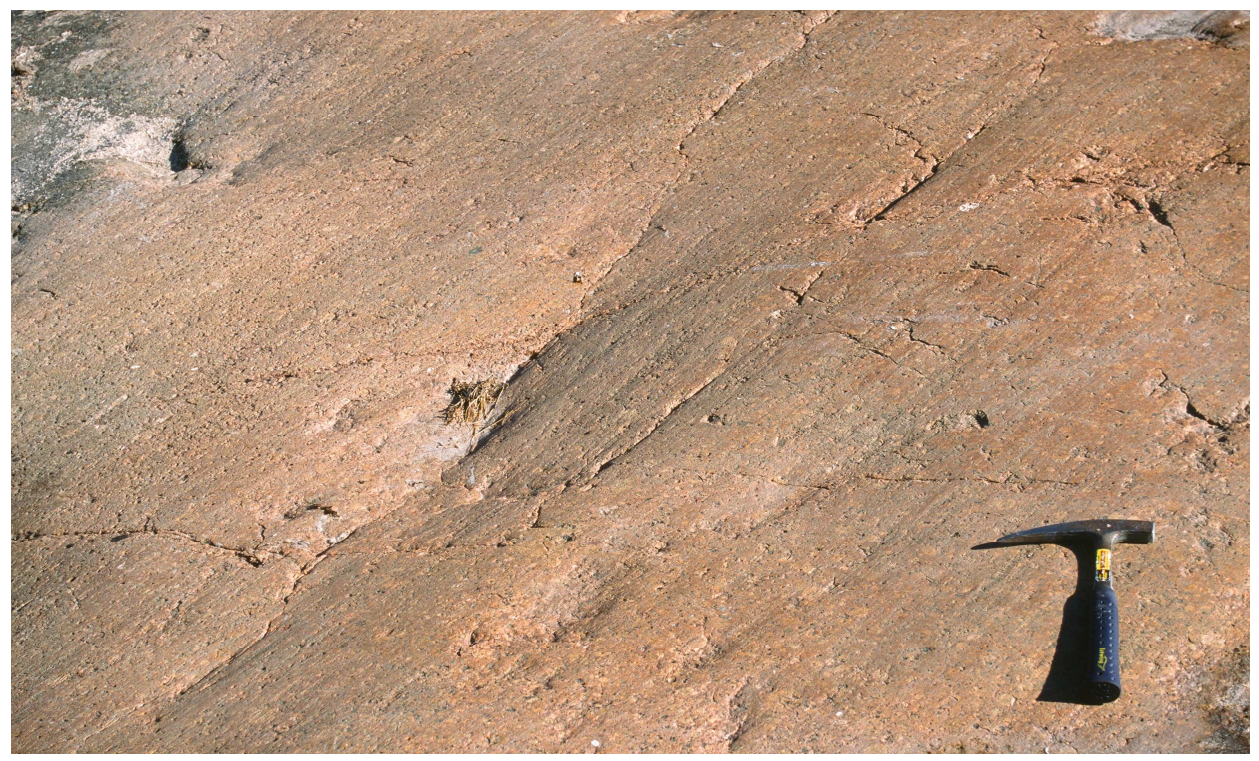

Fot. 8.1. Rysy lodowcowe na proksymalnym stoku mutona na wybrzeżu Bałtyku koło Saltvik na Wyspach Ålandzkich; fot. P. Czubla 2002

Photo 8.1. Glacial striations on the proximal slope of roche moutonnée - Baltic Sea coast near Saltvik (Åland Islands). Photo P. Czubla 2002

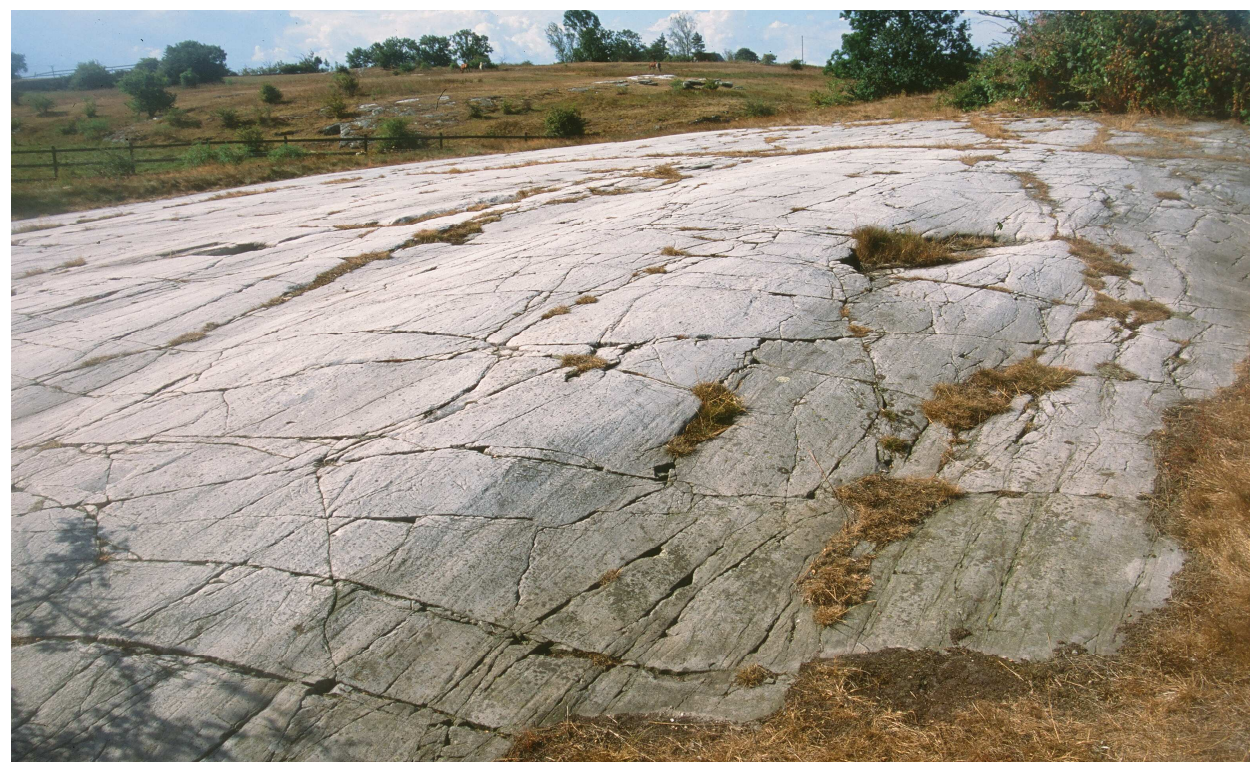

Fot. 8.2. Ukształtowany przez abrazję wygład glacjalny z rysami w Järrestad koło Simrishamn w Szwecji; fot. P. Czubla 2003

Photo 8.2. Shaped by glacial abrasion (polished and striated) surface of bedrock in Järrestad near Simrishamn in Sweden. Photo P. Czubla 2003 
Abrazja lodowcowa bezpośrednio nie ma wpływu na włączanie gruboziarnistego materiału skalnego w masę lodowca. Na dodatek prowadzi do redukcji rozmiarów ziaren tkwiących już w bazalnej części lodu i trących o podłoże. W ten sposób zmienia się skład gruboziarnistego materiału morenowego. Składniki mniej odporne podlegają dość szybko redukcji rozmiarów, a w przypadku dłuższego funkcjonowania tego procesu - zupełnemu roztarciu i przejściu do frakcji pelitowej i aleurytowej lub - co najwyżej psamitowej. W takiej postaci ich makroskopowa identyfikacja i przypisanie do konkretnego obszaru macierzystego są na ogół niemożliwe. Efektem abrazji, obserwowanym w Polsce, jest nieproporcjonalnie mały udział skał mało odpornych, np. paleozoicznych łupków we frakcji żwirowej osadów glacjalnych oraz wspomniane już obtoczenie i wygładzenie większości głazików.

Warto sobie uświadomić, że rozróżnianie abrazji i detrakcji, jak zresztą także wiele innych prób klasyfikacji procesów naturalnych ma sztuczny charakter. Rysy glacjalne są w rzeczywistości również produktem detrakcji, lecz przebiegającej w mikroskali. Pod mikroskopem rysy glacjalne widoczne są jako liczne sierpowate nierówności, o morfologii typowej dla detrakcji (por. m.in. Liu i in., 2009).

\subsection{Detrakcja}

Detrakcja polega na mechanicznym wyrywaniu (wyorywaniu) okruchów skalnych o rozmiarach od kilku milimetrów do wielu metrów z podłoża lodowca i włączaniu ich w masę lodu. Proces ten wykorzystuje istniejące wcześniej spękania (np. rozszerzone w wyniku wietrzenia mrozowego) i powierzchnie nieciągłości w skałach. Pod obciążeniem lodem i w obecności wody, będącej produktem topnienia pod ciśnieniem i następnie zamarzającej w szczelinach, tworzą się nowe pęknięcia. Odspojone od podłoża okruchy skalne są inkorporowane przez lód lodowcowy i wynoszone z miejsca erozji. Po włączeniu w masę lodu aktywnie uczestniczą w abrazji (zarówno jako materiał abradujący, jak i abradowany) i stopniowo ulegają obróbce i rozdrobnieniu. W przeciwieństwie do abrazji, detrakcja nie wymaga obecności okruchów skalnych w spągowych partiach lodu, lecz sama je wytwarza. Nawet zmiany układu naprężeń, wynikające chociażby z sezonowych zmian miąższości lodu i jego aktywności, mogą doprowadzić do utraty spójności skały i w konsekwencji do odspajania fragmentów podłoża. Istotną rolę odgrywa również zmęczenie materiału (skał) poddawanego przez setki i tysiące lat zmiennym naprężeniom, co w końcu prowadzi do ich skruszenia (por. Drewry, 1986).

Detrakcja dotyka najpierw preglacjalną zwietrzelinę i spękaną przypowierzchniową warstwę podłoża, a dopiero w dalszej kolejności - lite skały. W nich również wykorzystuje powierzchnie anizotropii, np. foliację, wynikającą z obfitego występowania minerałów o blaszkowym pokroju - głównie łyszczyków. Na przebieg detrakcji wpływają również uskoki, spękania ciosowe, granice warstw, przestrzenna zmienność porowatości całkowitej i efektywnej, rezydualne naprężenia w skałach i inne.

Nacisk lodu oraz okruchów skalnych tkwiących w jego bazalnej części, połączony z naprężeniami generowanymi przez postępowy ruch lodowca, prowadzą do powstawania spękań i szczelin subglacjalnych w podłożu. Wzdłuż nich może dochodzić do 
odrywania fragmentów skał o bardzo zróżnicowanych rozmiarach. Duży, a tym bardziej kanciasty blok skalny wleczony przez lód przyczynia się do koncentracji naprężeń na bardzo małej powierzchni, ponieważ styka się z nią tylko małym fragmentem. Rysuje on podłoże, a maksimum naprężeń występuje w kulminacji przeszkody podlodowej, gdzie dodatkowo brakuje podparcia od strony dystalnej. Tworzą się wówczas powierzchnie ścinania, dochodzi do odspajania i usuwania przez lód fragmentów przeszkody.

Systematyczne usuwanie skał przez erozję glacjalną implikuje zmiany układu naprężeń w podłożu lądolodu i prowadzi do powstania wielkoskalowego układu spękań w odniesieniu do lodowców górskich opisuje taką sytuację Augustinus (1995). Wpływ cech fizycznych podłoża lądolodu i panującego w nim układu naprężeń na detrakcję był przedmiotem analiz wielu badaczy (m.in. Boulton, 1974; Sugden i John, 1976; Drewry, 1986; Jania, 1993).

Istotny wpływ na erozję glacjalną ma ciśnienie efektywne $\left(P_{\mathrm{e}}\right)$ w podłożu lądolodu, stanowiące różnicę pomiędzy ciśnieniem wywieranym przez lód $\left(P_{i}\right)$, a ciśnieniem wody w podłożu $\left(P_{w}\right)\left[P_{e}=P_{i}-P_{w}\right]$. Oznacza to, że szczeliny łatwiej powstają, kiedy nacisk lodu jest duży, a ciśnienie wody w podłożu małe (Fu i Harbor, 2011). Wpływ wahań ciśnienia wód subglacjalnych na zmiany pola naprężeń w skałach podłoża, a w konsekwencji na oddzielanie okruchów skalnych, opisują Iverson (1991b) oraz Cohen i in. (2006). Gwałtowne zmiany ciśnienia wód w podłożu lodowca mogą następować w związku z przyspieszeniem ruchu postępowego lodu. Efekt ten określany jest mianem lewarka hydraulicznego (hydraulic jack effect - Rötlisberger i lken, 1981).

Ruch lodu po nierównym podłożu może skutkować powstawaniem pustych przestrzeni ponad zagłębieniami podłoża (o ile ruch lodu jest wystarczająco szybki, by nie doszło do ich plastycznego wypełnienia). Występowanie podlodowych pustek skutkuje koncentracją nacisku w miejscach kontaktu lodu z podłożem, gdzie rośnie w ten sposób ciśnienie efektywne. Warunki sprzyjają tam powstawaniu i propagacji spękań (Hallet, 1996). Obserwacje i pomiary przeprowadzone w tunelu podlodowym w Norwegii wykazały jednak, że nawet pod dość cienkim lodowcem tempo zamykania wolnych przestrzeni jest bardzo szybkie - 12-15 cm na dobę w stopie lodowca o miąższości zaledwie około 160 m (lodowiec Bondhusbreen - Hagen i in., 1983). W związku z tym wydaje się, że pustki podlodowe są zjawiskiem o bardzo ograniczonym czasie istnienia. Do wystąpienia zmiany układu naprężeń w skałach nie jest jednak niezbędna obecność wolnych przestrzeni. Nawet na nierównościach podłoża obleczonych przez lód notowane są znaczące różnice w wielkości naprężeń w zależności od kierunku. Przy przekraczaniu nierówności maksymalne naprężenia ścinające występują po dystalnej stronie przeszkody (fot. 8.3). W efekcie tworzą się spękania i następuje odspajanie fragmentów skał (por. Morland i Boulton, 1975). Opinię tę potwierdzają badania eksperymentalne i pomiary przeprowadzone w tunelu pod lodowcem Bondhusbreen na płaskowyżu Hardangervidda (Hagen i in., 1983).

Znaczący wpływ na przebieg detrakcji ma obecność wód ablacyjnych, zamarzających w szczelinach i rozpychających je. Tą drogą dochodzi do kruszenia podłoża. W obecności wody ułatwione jest też rozcieranie oderwanych fragmentów skał. Włączanie okruchów 


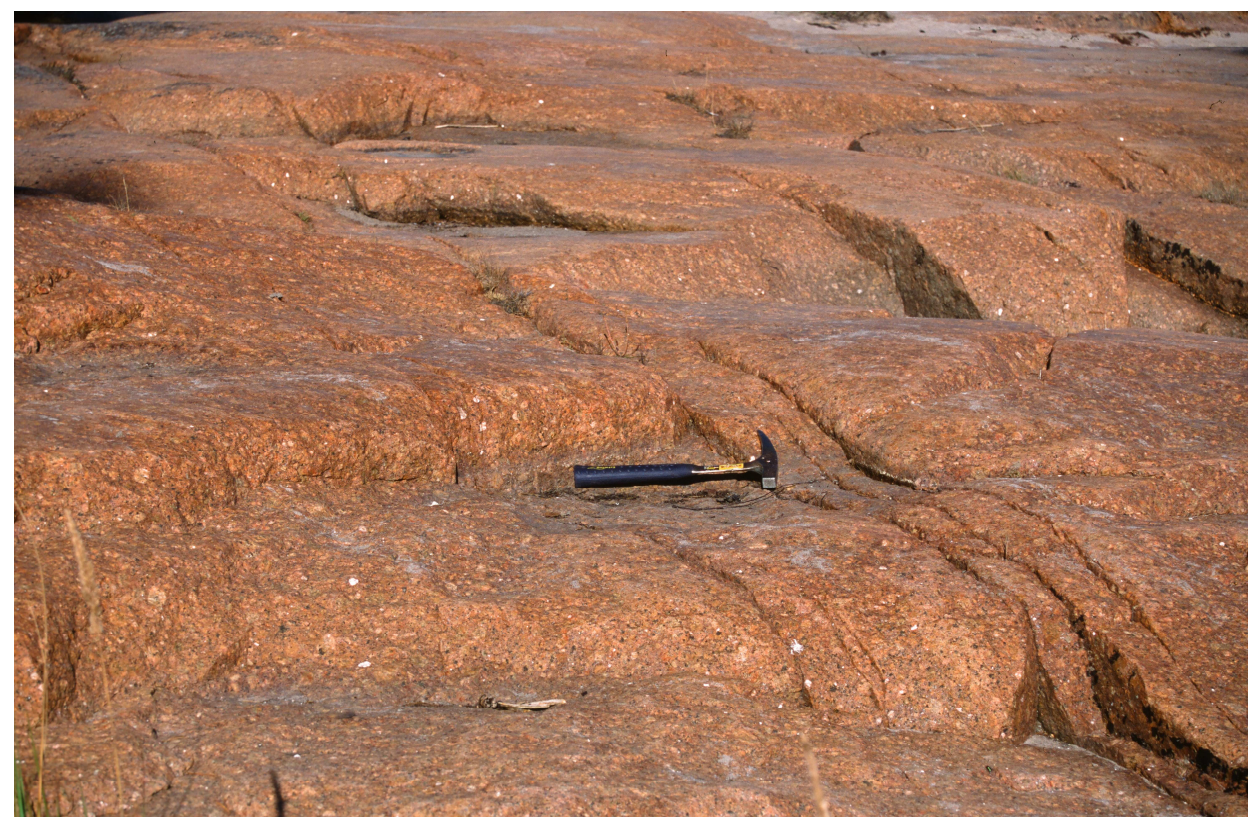

Fot. 8.3. Stopnie utworzone przez detrakcję na dystalnym stoku mutona na wybrzeżu Bałtyku koło Saltvik na Wyspach Ålandzkich; fot. P. Czubla 2002

Photo 8.3. Structures formed by detraction on the distal slope of roche moutonnée - Baltic Sea coast near Saltvik (Åland Islands). Photo P. Czubla 2002

skalnych w stopę lodowca jest wspomagane przez tzw. efekt pompy cieplnej (heat pump - Robin, 1976), wynikający z regelacji. Dochodzi do niego na skutek wzrostu ciśnienia na nierównościach podłoża na stoku proksymalnym (od strony napływającego lądolodu). Lód w tej strefie topnieje, a uwolniona woda przepływa na stok dystalny, gdzie przy niższym ciśnieniu zamarza na powierzchni podłoża i w szczelinach skalnych. Tworzą się w ten sposób płaty zimnego lodu ściśle przylegające (przymarznięte) do skał, a to skutkuje wyrywaniem luźnych bloków. W ten sposób okruchy i bloki skalne włączane są w masę lądolodu. Ciepło uwolnione podczas zamarzania może przepłynąć na drugą stronę nierówności i tam ułatwiać dalsze topnienie. Należy jednak mieć świadomość, że przewodność cieplna większości skał i lodu jest bardzo mała (tab. 8.1), co znacząco ogranicza przepływ ciepła, a tym samym wydajność przedstawionego mechanizmu. Boulton (1979) uważał za bardzo mało prawdopodobny zasięg efektywnej regelacji przekraczający kilka centymetrów. Pomiary przeprowadzone w tunelu pod aktywnym lodowcem w Norwegii wykazały, że przed głazem o średnicy 0,7 m, wleczonym w stopie lodowca z prędkością ok. $40 \mathrm{~mm} /$ dobę (prędkość lodu wynosiła około $80 \mathrm{~mm} /$ dobę), wytworzyła się strefa obniżonego ciśnienia o zasięgu około 0,5 m (Hagen i in., 1983). W tym samym stanowisku zmierzono również ciśnienie i temperaturę po proksymalnej i dystalnej stronie sztucznej przeszkody umieszczonej w podłożu lodowca. Różnica ciśnienia pomiędzy stroną proksymalną i dystalną wynosiła 21 do 29 barów, podczas gdy różnica temperatury osiągała zaledwie około $0,05^{\circ} \mathrm{C}$. 
Tab. 8.1. Przewodność cieplna właściwa skał $\lambda$ (na podstawie: Kjaran i Elliasson, 1983; Hänel i Staroste, 1988; Ostaficzuk, 2001; Egholm i in. 2012; http://wis.pol.lublin.pl/przegroda/index.php?show=spis_mat)

Table 8.1. The specific thermal conductivity of rocks $\lambda$ (according to: Kjaran \& Elliasson, 1983; Hänel \& Staroste, 1988; Ostaficzuk, 2001; Egholm et al. 2012; http://wis.pol.lublin.pl/przegroda/index.php?show= spis_mat)

\begin{tabular}{|l|c|l|c|c|c|}
\hline Rodzaj skały & $\lambda[\mathrm{W} / \mathrm{m} \cdot \mathrm{K}]$ & Rodzaj skały & $\lambda[\mathrm{W} / \mathrm{m} \cdot \mathrm{K}]$ & $\begin{array}{c}\text { Rodzaj } \\
\text { materiału }\end{array}$ & $\lambda[\mathrm{W} / \mathrm{m} \cdot \mathrm{K}]$ \\
\hline bazalt & 1,7 & dolomit & $3,8-5,9$ & diament & $900-2320$ \\
\hline doleryt & 1,6 & łupek ilasty & $1,4-1,98$ & miedź & 370 \\
\hline gabro & 2,0 & wapień & $0,92-1,4$ & stal & 58 \\
\hline granit & $2,9-4,09$ & piaskowiec & $1,7-4,6$ & lód & 2,4 \\
\hline kwarcyt & $2,9-8,0$ & glina & $0,75-1,25$ & drewno & 0,2 \\
\hline
\end{tabular}

Wszystkie lodowce i lądolody cechują się zmiennością przestrzenną i czasową warunków termodynamicznych w podłożu i w dolnej części lodu. Sprawia to, że zwietrzelina i luźne fragmenty skalne mogą przymarzać do stopy lodowca i wraz z nim przemieszczać się. Znaczącą rolę $w$ tym procesie odgrywa przechłodzona woda ablacyjna (Cook i in., 2006). W skałach osadowych (na ogół) w podłożu lodowca - najczęściej na granicy obszarów o ciepłym i zimnym reżimie - powstają powierzchnie odkłuć. Wzdłuż nich może dojść do odspojenia dużych fragmentów skał, które jako wielkie eratyki, a nawet kry glacjalne włączane są w masę lodu (Fu i Harbor, 2011).

Wyorywanie jest najefektywniejszym procesem erozji glacjalnej. Ustępują mu szlifowanie (abrazja) podłoża oraz mechaniczne i chemiczne oddziaływanie wód płynących (Jania, 1993). Wyjątek stanowią miękkie skały, w których abrazja może być intensywniejsza od wyorywania (Drewry, 1986). Powyższą opinię potwierdzają badania eratyków w Polsce, z których wynika, że udział skał mało odpornych, np. paleozoicznych łupków, w osadach glacjalnych jest znikomy. Miękkie skały podlegały głównie abrazji, a te, które przy udziale detrakcji zostały jednak włączone w masę lodu, w większości uległy roztarciu na mączkę skalną, tworzącą obecnie frakcję aleurytową i pelitową w glinie. Tempa detrakcji nie udało się zmierzyć bezpośrednio i raczej małe jest prawdopodobieństwo dokonania tego w najbliższej przyszłości. Dokonuje się tylko obliczeń pośrednich opartych na ocenie koncentracji materiału morenowego w stopie lodu i prędkości ślizgu (Jania, 1993).

\subsection{Erozja fluwioglacjalna}

Relacje pomiędzy udziałem erozji glacjalnej i fluwioglacjalnej w niszczeniu podłoża lodowców i lądolodów nie są jak dotychczas jednoznacznie wyjaśnione. Co prawda Drewry (1986) twierdzi, że abrazja i detrakcja przeważają nad erozją zachodzącą pod wpływem subglacjalnych wód, ale brak jednoznacznych danych wspierających tę hipotezę (Iverson, 2002). Często przyjmowany jest pogląd, że względnie mobilny lodowiec eroduje podłoże głównie na drodze glacjalnej abrazji i detrakcji, podczas gdy w podłożu pasywnego lodowca dominuje erozja fluwioglacjalna, np. Gustavson i Boothroyd (1982), Menzies i Shilts (2002). Wynika to z faktu, że intensywność erozji glacjalnej jest wprost proporcjonalna do prędkości ruchu lodu (Rötlisberger, 1968; 
Hallet, 1981). Podczas stagnacji lub rozpadu dużych lodowców o ciepłym podłożu dominującym procesem jest subglacjalna erozja fluwioglacjalna (Gustavson i Boothroyd pisali co prawda o rzecznej, ale z kontekstu jasno wynika, że chodziło im o fluwioglacjalną - 1982). Do podobnych wniosków prowadzą badania w Siedlątkowie nad Wartą (Polska Środkowa). Erozja w czasie subglacjalnych przepływów mogła dostarczyć znacznie więcej materiału niż bardziej powierzchniowa i płytka erozja glacjalna. Mimo niezbyt długiej drogi transportu przenoszony materiał ulegał dość szybko obtoczeniu (Rdzany, 2009).

Interesujące wyniki przyniosła analiza erozji podłoża skalnego lądolodu w Quebeku przez subglacjalne wody roztopowe (Sharpe i Shaw, 1989). Zespół form wytworzonych przez wody ablacyjne oraz powstałych przy udziale abrazji glacjalnej na kulminacjach lokalnej rzeźby świadczy o synchronicznym nasileniu erozji glacjalnej i fluwioglacjalnej. Takie warunki mogą zaistnieć podczas katastrofalnych powodzi subglacjalnych (Sharpe i Shaw, op. cit.).

Analiza stref rozrzutu wykonana dla potrzeb geologii złożowej w Kanadzie wykazała, że pierwotnym źródłem materiału w ozach jest najczęściej glina (Cummings i in., 2011). Należy zauważyć, że będzie to w wielu przypadkach glina starsza od deponowanej przez transgredujący lądolód. To spostrzeżenie zmniejsza wiarygodność badań opartych na analizie materiału fluwioglacjalnego i skłania do skoncentrowania się na typowych osadach glacjalnych.

Erozja przez wody lodowcowe jest bardzo intensywna i okresowo może ulegać znacznemu przyspieszeniu. Przepływ wód bogatych w zawiesinę oraz ziarna wleczone po dnie powoduje rysowanie, ścieranie i szlifowanie podłoża. O skali tych zjawisk decydują: prędkość przepływu wody, kąt natarcia, wielkość klastów, twardość ziaren w stosunku do twardości podłoża, koncentracja ziaren w wodzie. Tempo przepływu podczas gwałtownych wezbrań w kanałach subglacjalnych może dochodzić nawet do $50 \mathrm{~m} / \mathrm{s}$ (Vivian, 1975). W przypadku szybkiego przepływu intensywnie działa kawitacja (Drewry, 1986), która umożliwia wzmożenie erozji aż do 20 mm/godz. (Jania, 1993). Intensywność erozji fluwioglacjalnej rośnie również wraz z zawartością klastów, ale tylko do osiągnięcia udziału około $20 \%$ wagowych (Embleton i Thornes, 1985). Przy większej zawartości ma następować utrata energii na zderzenia transportowanych ziaren i osłabienie siły erozyjnej. Tak wysoka zawartość zawiesiny zdarza się jednak tylko w wyjątkowych sytuacjach. Hagen i in. (1983) zmierzyli udział materiału skalnego w wodach wypływających z lodowca - zawartość materiału stałego (zawiesiny) waha się w granicach $0,015-0,07 \mathrm{~kg} / \mathrm{m}^{3}$, czyli jest o kilka rzędów wielkości mniejsza niż w lodzie. Wydaje się jednak, że większy wpływ na wielkość abrazji mają okruchy skalne transportowane $w$ trakcji dennej aniżeli w zawiesinie. Materiał cięższy, wleczony po dnie koryta rzeki subglacjalnej lub podlegający saltacji, ma często styczność z podłożem i intensywność jego oddziaływania jest znaczna. W przypadku natomiast zawiesiny znaczną jej część stanowią cząsteczki o rozmiarach poniżej 0,3 mm, które chronione są przed zderzeniami z dnem przez otaczającą je cienką warstewkę wody i wysoką lepkość ośrodka. Eworsję należy traktować jako odmianę abrazji, w której występuje poziomy wir stacjonarny, ale natura procesu jest taka sama (Jania, 1993). 


\subsection{Wietrzenie i jego potencjalny wpływ na skład materiału pobieranego przez lodowce}

O rozmiarach i charakterze erozji glacjalnej decyduje w znacznym stopniu wcześniejsze rozluźnienie skał i zmiana ich składu mineralnego w wyniku wietrzenia. Zwietrzelina łatwiej ulega abrazji i detrakcji. Dość łatwo jest też włączana w masę lodu. Szczególnie istotny jest pod tym względem wpływ wietrzenia fizycznego, ponieważ prowadzi do otwierania szczelin w skałach i odspajania luźnych bloków. Wietrzenie przebiega szybciej wzdłuż spękań i powierzchni nieciągłości. Na dodatek stanowią one drogi migracji wód subglacjalnych oraz ułatwiają odspajanie fragmentów skał (detrakcja). Związek preglacjalnych procesów wietrzeniowych z subglacjalnymi procesami erozyjnymi stanowił przedmiot zainteresowania wielu badaczy (m.in. Lindström, 1988; Olvmo i in., 1999; Johansson i in., 2001a, 2001b; Olvmo i Johansson, 2002). Wyróżniane przez Klemana i in. (2008) strefy szorowania (scouring), w których brak osadów glacjalnych, ale i erozja nie wydaje się znacząca, obejmują najprawdopodobniej obszary, gdzie następowało jedynie usuwanie luźnego materiału przykrywającego krystaliczne podłoże. Badania w masywie Bohus (południowo-zachodnia Szwecja) wykazały, że nawet dość daleko od linii podziału lodu erozja glacjalna doprowadziła głównie do ekshumacji pierwotnej powierzchni erozyjnej (Johansson i in., 2001a). Zdarzały się jednak i takie przypadki, jak opisywany z Antarktydy, kiedy - pomimo rozwoju i przejścia wielkiej czaszy lodowej - zachowała się niezaburzona zwietrzelina (regolit) - Saltzman, 2002. Jego zdaniem lądolód przemieścił się ponad nią głównie dzięki ślizgowi dennemu.

Występowanie zwietrzeliny, a nawet wietrzeniowych form skalnych nie musi oznaczać, że dany obszar pozostawał poza zasięgiem ostatniego zlodowacenia. Badania przeprowadzone na Ziemi Baffina wykazały, że ostatni lądolód wkroczył na silnie zwietrzałą powierzchnię i w zasadzie jej nie erodował (Briner i in., 2003). Dowodzą tego datowania przy pomocy izotopów kosmogenicznych oraz obecność słabo zwietrzałych eratyków leżących na silnie zwietrzałych skałkach (tors). Obce pochodzenie eratyków było czytelne nie tylko dzięki odmiennym cechom petrograficznym, ale i w oparciu o znacznie niższy od podłoża stan zaawansowania procesów wietrzeniowych. Powyższe wyniki wskazują, że wcześniejszy pogląd (np. Ives, 1978; Nesje i Dahl, 1990), wg którego można oceniać zasięg zlodowacenia na podstawie stopnia zwietrzenia podłoża nie znajduje potwierdzenia w badaniach terenowych.

Przeanalizowany został również wpływ powierzchni nieciągłości w skałach (spękań ciosowych, uskoków, powierzchni międzyławicowych itp.) na przebieg erozji (Rastas i Seppälä, 1981; Rea, 1994; Glasser i in., 1998; Dühnforth i in., 2010; Krabbendam i Glasser, 2011). Z przeprowadzonych ostatnio w Szwajcarii i Kanadzie badań wynika, że powierzchnia poddana erozji glacjalnej (detrakcji) kształtuje się zgodnie z głównym systemem spękań bez względu na litologię, morfologię czy kierunek ruchu lodu (Hooyer i in., 2012). W okresie preglacjalnym powierzchnie nieciągłości warunkują przebieg i rozkład przestrzenny procesów wietrzeniowych, a już po wkroczeniu lądolodu mają bezpośredni wpływ na wielkość erozji. Rudberg (1973) przedstawił sekwencję zdarzeń prowadzących do powstania dolin wzdłuż stref nieciągłości w Szwecji. W pierwszym, 
preglacjalnym etapie doszło do głębokiego zwietrzenia skał - najintensywniejszego wzdłuż stref osłabień. Następnie część zwietrzeliny została odprowadzona przez rzeki i na koniec cały luźny materiał skalny został usunięty przez lądolody.

Wietrzenie chemiczne zachodzące w podłożu istniejącego lądolodu ma niewielki wpływ na inkorporację materiału grubofrakcyjnego. Prowadzi głównie do rozpuszczania i zmian składu skał, które co najwyżej ułatwiają rozdrabnianie i inkorporację fragmentów podłoża (Fu i Harbor, 2011). W podłożu lodowców ciepłych Lliboutry podkreśla m.in. rolę subglacjalnego wietrzenia chemicznego wapieni (1994). Może ono przyczynić się do zintensyfikowania detrakcji dzięki pogłębieniu i rozszerzeniu szczelin w skałach węglanowych.

Wietrzenie wywiera znaczny wpływ na skład materiału inkorporowanego przez lodowiec. Proces ten warunkuje selekcję materiału już na etapie preglacjalnym i następnie w okresach interglacjalnych. Skały zawierające znaczną ilość minerałów mało odpornych, np. łyszczyków, chlorytów, węglanów, plagioklazów zasadowych (bogatych w wapń) ulegają wcześniejszej dezintegracji, w zwietrzelinie natomiast zachowują się głównie skały bogate $\mathrm{w}$ kwarc $\mathrm{i}$ inne minerały odporne na wietrzenie. Można stąd wysnuć wniosek, że nawet niezwietrzałe osady glacjalne mogą zawierać mocno zwietrzały i wstępnie wyselekcjonowany zespół nordyckich eratyków.

\subsection{Procesy fluwialne, brzegowe, stokowe i ich wpływ na skład materiału morenowego}

Przemieszczanie ziaren przez preglacjalne bądź interglacjalne rzeki, prądy morskie, a w mniejszym stopniu także przez procesy stokowe, może doprowadzić do przeniesienia charakterystycznych skał wskaźnikowych daleko poza obszar wychodni. $\mathrm{Na}$ największą skalę może się to odbywać na drodze transportu rzecznego, w mniejszym stopniu również morskiego. Przetransportowane w ten sposób ziarna mogą być następnie inkorporowane przez transgredujący lądolód i na koniec złożone razem z materiałem skalnym wchłoniętym w obszarze alimentacji lądolodu. Skutkiem tych procesów jest pojawienie się w osadach glacjalnych zespołów skał o nietypowym składzie, np. dużej liczbie skał pochodzenia zachodniofennoskandzkiego towarzyszą pojedyncze ziarna ze wschodniej Fennoskandii. Transport fluwialny mógł dostarczać na obszar późniejszej akumulacji lodu bądź przed czoło transgredującego lądolodu ziarna skał pochodzące również z obszarów pozostających poza zasięgiem zlodowaceń.

W okresie preglacjalnym od pliocenu aż po waal ${ }^{4}$ teren dzisiejszej Fennoskandii, włącznie z obszarem współczesnego Bałtyku i częścią Niżu Środkowoeuropejskiego, był odwadniany na zachód, w kierunku Atlantyku, przez Bałtycki System Rzeczny (Bijlsma, 1981; Gibbard, 1988; Gibbard i in., 1991; Meyer, 1991; Overeem i in., 2001) - rys. 8.2. Rzeka główna systemu usypała wielką deltę u ujścia do Morza Północnego - na obszarze dzisiejszych północnych Niemiec i Holandii. Rozmiary dorzecza oraz miąższość osadów deltowych odpowiadają Orinoko i jej delcie (Overeem i in., op. cit.). Co prawda

\footnotetext{
${ }^{4}$ Nazwy jednostek stratygraficznych wg Ber i in. 2007.
} 
do środkowego i dolnego biegu rzeki docierał w przeważającej mierze materiał drobnoziarnisty, ale w zimie, uwięzione w krach lodowych, mogły tam być dostarczane również i duże głazy pochodzące $z$ dowolnego miejsca w dorzeczu. Klimat w środkowej i północnej Europie był w późnym neogenie nieco cieplejszy niż współczesny (Utescher i in., 2000; Zachos i in., 2001; Stanley, 2002; Rasmussen i in., 2008), ale nie wykluczało to zimowego zlodzenia rzek - zwłaszcza w północnej części systemu rzecznego. Transport materiału skalnego w krach lodowych funkcjonował prawdopodobnie już nawet od miocenu (Ehlers i in., 1984). Rzeźba terenu, przez który przepływała wspomniana rzeka była zupełnie odmienna od dzisiejszej. Przede wszystkim nie istniało duże obniżenie w miejscu Bałtyku. Ówczesna powierzchnia tarczy bałtyckiej lub jej platformowej pokrywy znajdowała się co najmniej 500 m wyżej od obecnej (nie licząc skutków erozji glacjalnej w środkowym i młodszym plejstocenie) - m.in. Embleton i King, 1975; Ehlers,

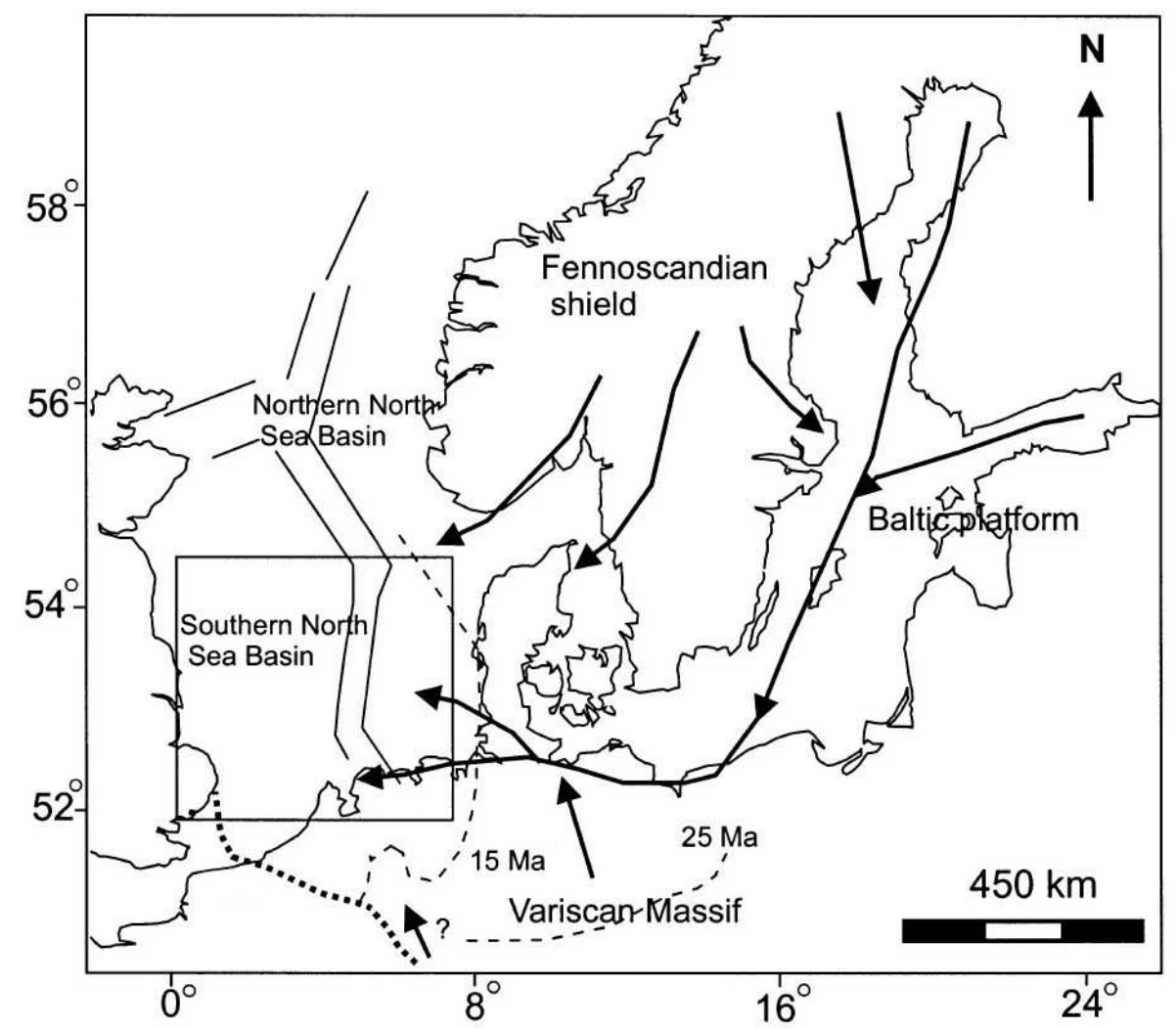

Rys. 8.2. Schemat bałtyckiego systemu rzecznego (Eridanos) z zaznaczoną linią brzegową sprzed 25 i 15 milionów lat (według Overeem i in., 2001 - Fig. 1)

Figure 8.2. A schematic sketch of the Baltic river system (Eridanos fluvio-deltaic system) and coastlines at $25 \mathrm{Ma}$ and $15 \mathrm{Ma}$ (after Overeem et al., 2001 - Fig. 1) 
2011. W rzecznych osadach najniższego menapu (warstwy Hattem) w Holandii znaleziono krystaliczne skały fennoskandzkie (porfiry dalarneńskie, granity sztokholmskie), potwierdzające daleki transport na zachód (Lüttig i Maarleveld, 1961, 1962; Zandstra, 1971, 1983b; Lee i in., 2012).

Dzieje obszaru bałtyckiego od menapu aż po elsterę (kompleks południowopolski) nie są znane. Nie jest jasne, czy istniało już w tym czasie duże obniżenie na południowo-wschodniej krawędzi tarczy fennoskandzkiej oraz jak się rozwijało. Można tylko przypuszczać, że obciążenie litosfery lądolodem podczas zlodowaceń kompleksu południowopolskiego spowodowało izostatyczne ugięcie obszaru. Niewielki udział krzemieni i kredy piszącej w glinach zlodowacenia elstery wskazuje na to, że neogeńska pokrywa osadów kredowych w zachodniej części dzisiejszego Bałtyku mogła być do tego czasu usunięta tylko w niewielkiej części (Meyer, 1991). Nie wyklucza to jednak obecności wyraźnego obniżenia morfologicznego. Najstarsze jednoznaczne dowody istnienia Bałtyku pochodzą z holsztynu. Morskie osady tego interglacjału opisano w Obwodzie Kaliningradzkim i na Łotwie (Marks i Pavlovskaya, 2003; Zels i Markots, 2004). Od holsztynu należy zatem liczyć się z możliwością również morskiego transportu materiału skalnego, niezależnego od biegu rzek i kierunku nasuwania się lądolodu. Transport okruchów skalnych w krach pędzonych dominującymi w tej strefie wiatrami zachodnimi jest jedynym logicznym wyjaśnieniem sporadycznego występowania skał zachodnioszwedzkich i norweskich w Europie Środkowej.

Przekroczenie wczesnej depresji bałtyckiej przez lądolód starszego zlodowacenia saale bez zmiany kierunku ruchu (Meyer, 1991) nie musi przemawiać przeciwko istnieniu holsztyńskiego poprzednika Bałtyku. Podobnie zachował się również lądolód $w$ vistulianie, a więc w okresie, kiedy niecka bałtycka już niewątpliwie istniała. Wskazuje na to skład frakcji żwirowej i głazowej w osadach glacjalnych na Niżu Środkowoeuropejskim. Obecność chociażby na terenie Polski licznych eratyków pochodzących ze Szwecji stawia pod znakiem zapytania długotrwałą aktywność bałtyckiego strumienia lodowego, postulowanego przez Punkariego (1993). Dla rozprzestrzeniania się lądolodu wydają się ważniejsze i bardziej miarodajne procesy dynamiki lodu, aniżeli zastana rzeźba podłoża (Ehlers, 1990a). Należy pamiętać, że zarówno kształtowanie się czaszy lądolodu, jak i istnienie potencjalnych mórz w rejonie dzisiejszego Bałtyku było w znacznym stopniu uwarunkowane ruchami izostatycznymi. Na początkowych etapach rozwoju kolejnych lądolodów Fennoskandia położona była znacznie wyżej niż obecnie, natomiast we wczesnych fazach interglacjałów morfologia tego obszaru mogła być zbliżona do współczesnej (pomijając erozyjne oddziaływanie na rzeźbę kolejnych lądolodów). W świetle tej interpretacji zbiorniki morskie w południowym sektorze tarczy fennoskandzkiej i na przyległej od południowego wschodu pokrywie platformowej mogły rozwijać się na początku interglacjałów i zanikać wraz z ich rozwojem w miarę izostatycznego wznoszenia podłoża. O wiele większe możliwości przetrwania zbiorników prabałtyckich istniały podczas ociepleń o niższej randze, tj. w interstadiałach lub interfazach, kiedy nie dochodziło do całkowitej degradacji lądolodu i izostatyczne wypiętrzanie było zdecydowanie mniej aktywne. 
Podczas zlodowaceń olbrzymie ilości wód ablacyjnych (unoszących kry i duże bloki lodu - śródlądowe odpowiedniki gór lodowych) odprowadzane były wzdłuż czoła lądolodu głównie w kierunku zachodnim (m.in. Toucanne i in., 2009, 2010; Westaway i Bridgland, 2010), a tylko okresowo występował odpływ na wschód (por. Mojski, 2005). Sprzyjało to przemieszczaniu skał wywodzących się ze wschodniej Fennoskandii na zachód. W kolejnych nasunięciach lądolodu skały złożone w osadach rzecznych lub morskich mogły być powtórnie inkorporowane przez lód. Potwierdzają to analizy eratyków, z których wynika, że skały pochodzące z zachodniej Fennoskandii (przede wszystkim norweskie) nie występują w Europie Wschodniej, a na terenie Polski stanowią znaleziska wyjątkowe, ograniczone niemal wyłącznie do zachodniej części kraju (Korn, 1920; Bennhold, 1928; Konieczny i Wdowiak, 1971; Schulz, 1973; Czubla, 2001; Górska, 2003b). Zupełnie inaczej wygląda rozmieszczenie skał wschodniofennoskandzkich zachodniofińskich i bałtyckich. Są one znajdowane aż po zachodnie granice zasięgu lądolodu fennoskandzkiego włącznie z Holandią (Zandstra, 1976, 1983a; Schuddebeurs, 1980/1981, 1981; Schuddebeurs i Zandstra, 1983; Rappol, 1987), a być może nawet z Wyspami Brytyjskimi (Phemister, 1926; Milthers, 1950; Barry, 1992; Hoare, 2012).

Procesy stokowe tylko nieznacznie przyczyniają się do rozproszenia skał pełniących rolę eratyków wskaźnikowych poza ich obszary macierzyste, ponieważ transport odbywający się przy ich udziale jest na ogół krótki. Dostarczają one jednak luźnego materiału okruchowego, który następnie może zostać rozmyty przez rzeki lub falowanie i transportowany w innym środowisku.

Przemieszczanie skał następowało również w efekcie działania lodowców górskich, które w pliocenie i plejstocenie wielokrotnie rozwijały się w Górach Skandynawskich (Fredin, 2002). W ciągu ostatnich 1,88 Ma sumaryczny okres zlodzenia obszarów górskich miał wynieść 1,3 Ma, czyli 65\% tego okresu, w ciągu zaś ostatnich 350 ka góry Skandynawii były pokryte lodem przez 115 ka, tj. 33\% czasu (ibidem). Tak długi czas funkcjonowania lodowców górskich świadczy o dużych możliwościach glacjalnej erozji i redepozycji materiału z gór na obszary przedgórskie. Świeżo złożone i słabo zdiagenezowane osady glacjalne łatwo mogły być inkorporowane i wynoszone przez rozwijające się lądolody.

Wiatr jako czynnik transportowy odgrywa dość ważną rolę w środowisku glacjalnym i peryglacjalnym, ale jego siła transportowa ogranicza rozmiary przenoszonego materiału do frakcji pelitowej i aleurytowej, rzadziej psamitowej. Teoretycznie na powierzchnię lodu mógł trafiać materiał przenoszony tą drogą, ale w przypadku lądolodów wydaje się to mało prawdopodobne, ponieważ często tworzyły się nad nimi ośrodki wysokiego ciśnienia, które generowały przeciwny układ wiatrów, tj. na zewnątrz. Stanowiące przedmiot niniejszego opracowania eratyki wskaźnikowe analizowane są we frakcji, która tylko w absolutnie wyjątkowych przypadkach może podlegać transportowi eolicznemu. Tym niemniej ślady oddziaływania procesów eolicznych bardzo często widoczne są na powierzchni eratyków. Dotyczy to przede wszystkim eologliptolitów, które w warunkach dość suchego klimatu peryglacjalnego spoczywały na powierzchni terenu. Obecność śladów obróbki eolicznej na eratykach występujących w osadach 
glacjalnych może być pośrednim dowodem świadczącym o pobieraniu materiału przyniesionego przez poprzednie nasunięcie lodowca lub dostarczonego przez inne procesy.

\subsection{Reżim termiczny}

Termika lodowców jest jednym z ważniejszych czynników warunkujących inkorporację materiału z podłoża. Z punktu widzenia badań eratyków wystarczający jest najprostszy podział obejmujący lodowce ciepłe, zimne i politermalne. Tę klasyfikację (lodowce politermalne określano pierwotnie jako przejściowe) zaproponował prawie sto lat temu Lagally (1932). Przeanalizowali ją później i rozwinęli m.in. Paterson (1981), Blatter (1985, 1990), Hutter i in. (1988), Jania (1988), Blatter i Hutter (1991), Glasser (1995), Huybrechts i T'siobbel (1995), Payne (1995), Payne i Baldwin (1999), Kleman i Glasser (2007) i inni.

Lodowce umiarkowane (ciepłe) złożone są z mieszaniny lodu, wody, powietrza, soli i ditlenku węgla, a w strefie dennej także materiału morenowego o różnej frakcji. W całym profilu lód znajduje się $w$ temperaturze topnienia (pomijając warstwę powierzchniową, w której zachodzą sezonowe zmiany termiczne). Wszystkie te składniki wpływają na temperaturę topnienia pod ciśnieniem. Ciepło uwalniane na styku lodu z podłożem (strumień cieplny Ziemi oraz ciepło tarcia) jest zużywane na topnienie lodu w spągu lodowca i nie jest przewodzone ku wyższym warstwom lodu. Mechanizm ten ułatwia ślizg denny lodowca. Lodowce ciepłe powstają w umiarkowanych warunkach klimatycznych, w których występuje duża akumulacja śniegu w zimie i intensywna ablacja w lecie (Jania, 1993).

Za zimny uważany jest lód w temperaturze niższej od punktu topnienia pod ciśnieniem. Lodowiec zimny ma w całej masie zimny lód. Tego typu lodowce powstają w polarnym klimacie, gdzie letnie topnienie jest znikome. Gradient termiczny w lodowcach zimnych jest $w$ związku z tym dodatni, tzn. temperatura w nich rośnie wraz $z$ głębokością. Za podwyższenie temperatury w dolnych warstwach lodowca odpowiada strumień cieplny Ziemi oraz energia wyzwalana w efekcie płynięcia deformacyjnego. Zimny reżim termiczny występuje głównie w cienkich pokrywach lodowych, cechujących się małą ablacją powierzchniową lub jej brakiem w lecie. W przypadku lądolodów o dużej miąższości może dojść do osiągnięcia punktu topnienia pod ciśnieniem w dolnych warstwach, pomimo zimnej górnej części czaszy lodowej. W związku z tym lądolody z najzimniejszych obszarów Ziemi nie są zimne, lecz politermalne (Jania, 1993; Bennett i Glasser, 2009; Pattyn, 2010).

Dla lodowców politermalnych wyróżniono cztery odmienne układy przestrzenne lodu ciepłego i zimnego (Blatter, 1990). Z punktu widzenia dynamiki lądolodu oraz badań materiału morenowego najistotniejszy jest ten, w którym lód ciepły leży pod grubą warstwą zimnego (Hutter i in., 1988; Blatter, 1990; Jania, 1993). Ten typ termiki reprezentowany jest przez lądolody Antarktydy i Grenlandii oraz liczne lodowce i czapy lodowe, np. w Kanadzie (Blatter, 1985; Clarke i in., 1984). 
Zrozumienie procesów glacjalnych zachodzących w plejstocenie na terenie środkowej Europy utrudnia brak modelu termiki lądolodu w strefie umiarkowanej oraz znajomości warunków termicznych na przedpolu lądolodu. Nasuwa się pytanie, czy głębokie przemarzanie gruntu nie było typowe raczej dla przedpola, a po odseparowaniu podłoża od wpływu czynników atmosferycznych przez nasuwający się lądolód zmarzlina nie zanikała, w efekcie czego zmieniał się reżim termiczny podłoża. Wydaje się prawdopodobne, że podczas transgresji lądolód wkraczał na wieloletnią zmarzlinę zajmującą jego przedpole. Następnie strumień cieplny, ciśnienie wywierane przez lądolód oraz ruch deformacyjny mogły doprowadzić do przynajmniej miejscowego topnienia wieloletniej zmarzliny i uzyskania ciepłego reżimu termicznego w strefie marginalnej. Podczas recesji lądolodu wieloletnia zmarzlina mogłaby się odnawiać. Przetrwanie reliktowej zmarzliny odkrytej w wierceniu na Suwalszczyźnie było możliwe dzięki najmniejszemu w Polsce strumieniowi cieplnemu (poniżej $40 \mathrm{~mW} / \mathrm{m}^{2}$ ) ponad dużą intruzją anortozytową (Szewczyk i Nawrocki, 2011). Znacznie wyższa wartość strumienia cieplnego w Polsce Zachodniej (około dwukrotnie większa niż na Suwalszczyźnie - Szewczyk i Nawrocki, op. cit.) mogła przyczynić się do szybszego awansu lodu w tej części kraju i tym samym - osiągnięcia większego zasięgu lądolodu wisły.

\subsection{Reżim termiczny a erozja}

Rozmieszczenie przestrzenne i czas utrzymywania się ciepłego reżimu w stopie lądolodu, umożliwiającego lokalne topnienie, wywierają decydujący wpływ na erozję i depozycję glacjalną (Clarhäll i Jansson, 2003; Harbor i in., 2006). Dla zimnego reżimu przyjmowano zazwyczaj brak ruchu lodu względem podłoża i zarazem brak procesów erozyjnych, co chroniłoby podłoże przed przekształceniami (Fu i Harbor, 2011). Szczegółowe badania erozji w podłożu zimnych lodowców wykazały jednak, że występuje tam ślizg denny, abrazja i deformacje podłoża (Echelmeyer i Wang, 1987; Cuffey i in., 1999, 2000a; Lloyd Davies i in., 2009; Waller i in., 2012), a możliwa jest też inkorporacja okruchów skalnych (Cuffey i in., 2000a; Davies i in., 2009), ale skala i tempo tych procesów są o kilka rzędów wielkości mniejsze niż w lodowcach o ciepłym reżimie podłoża (Kleman i in., 2006). Prawdopodobnie są one wtedy ograniczone do rejonów o niewielkiej grubości pokrywy lodowej, związanych ze strefą marginalną lodowca (Kleman i in., op. cit.). W związku z tym zimny reżim podłoża sprzyja zachowaniu starszych osadów i rzeźby terenu, ciepły zaś skutkuje intensywną erozją, depozycją i przekształceniami rzeźby (Kleman i Glasser, 2007).

Już w latach 70. ubiegłego wieku zaprezentowano model rozmieszczenia różnych warunków termicznych dla lądolodu laurentyjskiego. W oparciu o nie powstał schemat zależności erozji od reżimu termicznego podłoża oraz stref ablacji i zamarzania (Sugden 1977, 1978). Boulton i in. (2001b) przedstawili schemat rozkładu czasowego warunków termodynamicznych w podłożu lądolodu fennoskandzkiego dla ostatnich 120 ka. Z opublikowanego wykresu (rys. 8.3) wynika, że dno Bałtyku i obszar Polski nawet w LGM znajdowały się w strefie, w której w podłożu lądolodu zachodziło topnienie. Wzrost zasięgu lądolodu wiązał się głównie ze wzrostem zasięgu strefy o ciepłym reżimie podłoża. Obszar dominacji zimnego reżimu podlegał mniejszym zmianom. 


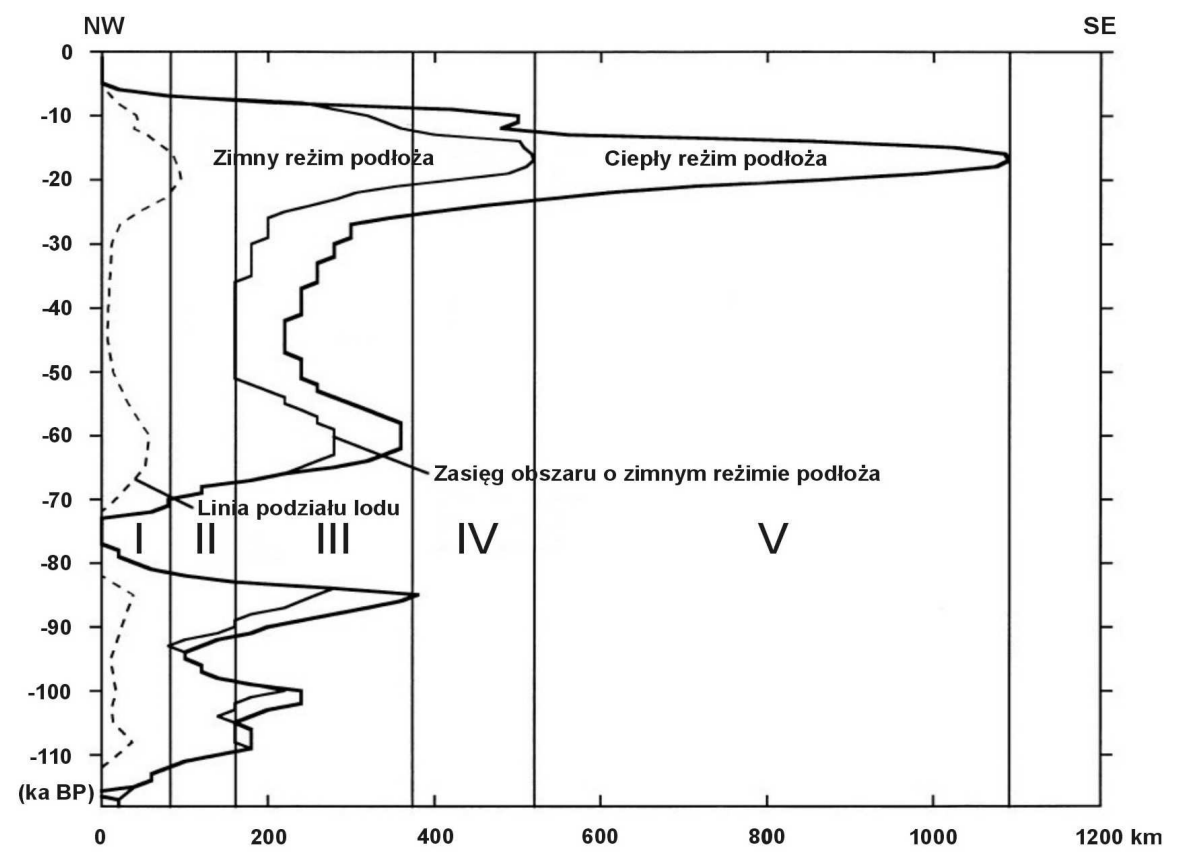

Rys. 8.3. Model warunków termodynamicznych w podłożu lądolodu fennoskandzkiego wzdłuż linii od okolic

Lillehammer w Norwegii po maksimum zasięgu vistulianu w Polsce Środkowej w ciągu ostatnich 120 ka (wg Boultona i in., 2001b - Fig. 18). Wyróżniono pięć stref geograficznych o odmiennych warunkach termodynamicznych: I - wewnętrzna, w której w ciągu ostatniego zlodowacenia nie zaznaczył się ciepły reżim podłoża, II - ciepły reżim podłoża występował tylko na wczesnym etapie zlodowacenia, a później zimny reżim chronił podłoże przed erozją, III - przeważał ciepły reżim podłoża i tylko podczas wielokrotnych awansów zlodowacenia rozwijał się zimny reżim podłoża, IV - podobna do III, ale zimny reżim rozwinął się tylko $w$ LGM, V - strefa, w której nie wykształcił się $w$ analizowanym okresie zimny reżim podłoża

Figure 8.3. Modeled thermodynamic evolution of the European ice sheet through the last glacial cycle along the transect from Lillehammer in Norway to LGM line in Middle Poland. Four geographic zones are distinguished: I - inner zone (no significant basal melting occurs through the cycle); II - a zone in which melting occurs early in the glaciation, but which is subsequently protected from erosion by frozen bed conditions; III - a zone in which melting and sediment/bedform generation prior to the glacial maximum ceases during the maximum because of frozen bed conditions but recur during deglaciation to produce crossing lineation sets, but influenced by multiple Weichselian advances; IV - similar to the zone III, but with only the LGM advance; $V$ - a zone in which there is continuous basal melting and continuous re-moulding of bedforms (after Boulton et al., 2001b - Fig. 18)

Dwa lata później zaprezentowany został odmienny model dynamiki lądolodu fennoskandzkiego w stadiale głównym ostatniego zlodowacenia (Forsström i in., 2003). Według niego ciepły reżim podłoża ograniczony był wyłącznie do stref marginalnych lądolodu, a np. region Wysp Alandzkich od 21 ka BP do 14,5 ka BP cechował się zimnymi warunkami termicznymi (rys. 8.4). Model ten jest sprzeczny z wynikami analiz osadów ostatniego zlodowacenia. Liczne występowanie eratyków z Wysp Alandzkich i środkowej Szwecji w osadach glacjalnych na Niżu Środkowoeuropejskim byłoby niemożliwe 

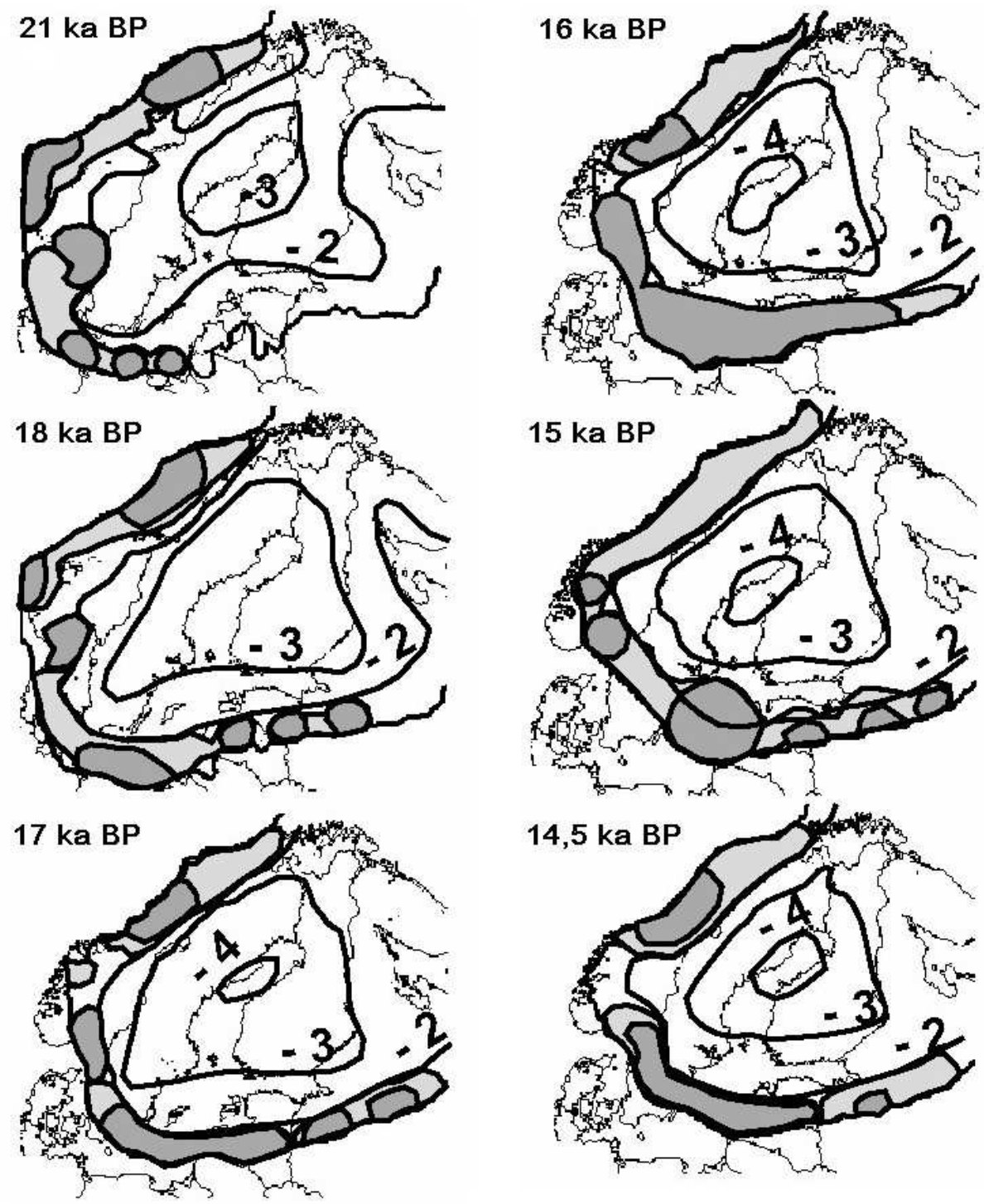

Rys. 8.4. Rezultaty symulacji temperatury podłoża lądolodu fennoskandzkiego $\left(w^{\circ} \mathrm{C}\right)$ wykonanej dla modelowania aktywności norweskiego i bałtyckiego strumienia lodowego: ciemnoszarym kolorem oznaczono obszary marginalne lądolodu o ciepłym reżimie termicznym, jasnoszarym o zimnym reżimie (wg Forströma i in., 2003 - Fig. 4)

Figure 8.4. Simulation results of the basal temperature (in ${ }^{\circ} \mathrm{C}$ ) for the Fennoscandian Ice Sheet made for modeling the Norwegian Channel and Baltic Basin ice-stream activity at 21, 18, 17, 16, 15 and 14.5 kyr BP. Dark (light) shading indicates a temperate base with temperate (cold) ice above. The outermost contour shows the ice margin (after Forsström et al., 2003 - Fig. 4) 
w przypadku utrzymującego się dłużej zimnego reżimu termicznego w obszarach źródłowych (podlodowych wychodniach) odpowiednich skał. Przytoczony przykład wskazuje na konieczność holistycznego podejścia do modelowania warunków termodynamicznych w plejstoceńskich lądolodach. Uwzględnienie tylko wybranych danych prowadzi do sformułowania modelu co najmniej kontrowersyjnego, jeśli nie zupełnie błędnego. Krańcowo odmienny model termiki lądolodu dla końcówki ostatniego zlodowacenia (od 19 ka BP) sformułowała Winsborrow i in. (2010a - str. 437) - przyjęła nieomal wyłącznie ciepłe podłoże lądolodu w Fennoskandii i na szelfie Morza Barentsa. Zimne podłoże byłoby ograniczone do małych obszarów w centrum Półwyspu Kolskiego oraz okresowo pomiędzy Półwyspem Skandynawskim i Svalbardem.

Powszechną akceptację uzyskał model jakościowy, opisujący główne czynniki warunkujące rozmieszczenie erozji i sedymentacji w zasięgu lądolodu fennoskandzkiego FIS (Kleman i in., 2008). W opracowanym modelu (rys. 8.5) uwzględniono duży postęp w interpretacji warunków termicznych w stopie plejstoceńskich lądolodów (np. Huybrechts i T'siobbel, 1995; Kleman i Stroeven, 1997; Kleman i Hättestrand, 1999; Kleman i in., 1999; Hättestrand i Kleman, 1999; Payne i Baldwin, 1999; Clark i in., 2000; Pattyn, 2003). Wzięto pod uwagę również analizy klimatu i zasięgów zlodowaceń (np. Adams i in., 1999; Clark i in., 1999; Bintanja i in., 2005) oraz obserwacje i datowania paleopowierzchni i form rzeźby (np. Sugden i John, 1976; Sugden, 1978, 1989; Hall i Sudgen, 1987; Kleman i Stroeven, 1997; Clarhäll i Kleman, 1999; Fredin i Hättestrand, 2002; Hättestrand i Stroeven, 2002; Stroeven i in., 2002a, 2002b; Li i in., 2005; Fabel i in., 2006). Model ten zakłada, że w warunkach zimnego reżimu termicznego w stopie lądolodu (frozen bed) dochodziło do zatrzymania erozji, a w warunkach subaeralnych erozja osadów glacjalnych odgrywała niewielką rolę (Kleman i in., 2008). Już dość dawno dowiedziono, że lodowiec o w pełni zimnym reżimie termicznym może transgredować i zanikać przy minimalnym zaangażowaniu materiału skalnego (Drewry, 1986), pozostawiając ledwie zauważalne ślady erozji lub depozycji (Jonsson, 1983; Dyke, 1993; Kleman, 1994). Nie wydaje się jednak prawdopodobne istnienie lądolodu, który w całości reprezentowałby zimny reżim termiczny. Nawet zlokalizowany w strefie okołobiegunowej lądolód antarktyczny cechuje się ciepłym reżimem pod znaczną częścią swojej powierzchni (Takeda i in., 2002; Pollard i in., 2005; Jamieson i in., 2010; Pattyn, 2010). Najbardziej zgodny z realiami terenowymi oraz analizami osadów jest lądolód politermalny, tzn. o zróżnicowanej przestrzennie i czasowo termice podłoża.

Centralną część czaszy lądolodu („jądro”) zajmuje w tym modelu lód zimny, przymarznięty do podłoża (rys. 8.5). Skutkuje to niemal zupełnym brakiem erozji i akumulacji w odległości do około 0,5 promienia czaszy lodowej. Jeśli przedstawiony model potwierdzi się, to należy przyjąć, że inkorporacja skał fennoskandzkich mogła zachodzić tylko na wstępnym etapie rozwoju lądolodu. Przy maksymalnym zasięgu lodu wychodnie większości skał wskaźnikowych znalazłyby się w strefie właściwie nieerodowanej. Skrajnie zewnętrzną, wąską strefę marginalną lądolodu stanowi lód o ciepłym reżimie, pod którym winny dominować procesy depozycyjne. Strefa przejściowa zajmuje największy obszar i cechuje się zmiennymi warunkami termicznymi. Stanowi ona mozaikę 
obszarów o zimnym i ciepłym reżimie - rola ciepłego reżimu narasta ku strefie marginalnej. Procesy erozyjne przeważają nad depozycyjnymi, co sprawia, że przedstawiana strefa dostarcza większości materiału skalnego odkładanego następnie w peryferyjnych obszarach lądolodu (Kleman i in., 1999, 2008). Kształt i zasięg strefy, w której przeważają procesy erozyjne, bywa bardzo nieregularny. Wynika to ze zmienności drugorzędnych czynników warunkujących rozmieszczenie obszarów o różnej termice stopy lądolodu - głównie topograficznych (por. Drewry, 1986; Kleman, 1994; Kleman i in., 1994; Heine i McTigue, 1996; Kleman i Stroeven, 1997; Stroeven i in., 2002a; André, 2004; Davis i in., 2006). Jej zasięg zawiera się najczęściej w przedziale od 0,5 do 0,95 promienia czaszy lodowej (Kleman i in. 2008). Duże znaczenie inkorporacji materiału skalnego przez lód o zmiennym reżimie termicznym (lodowiec subpolarny) dostrzega również Eyles (2006).

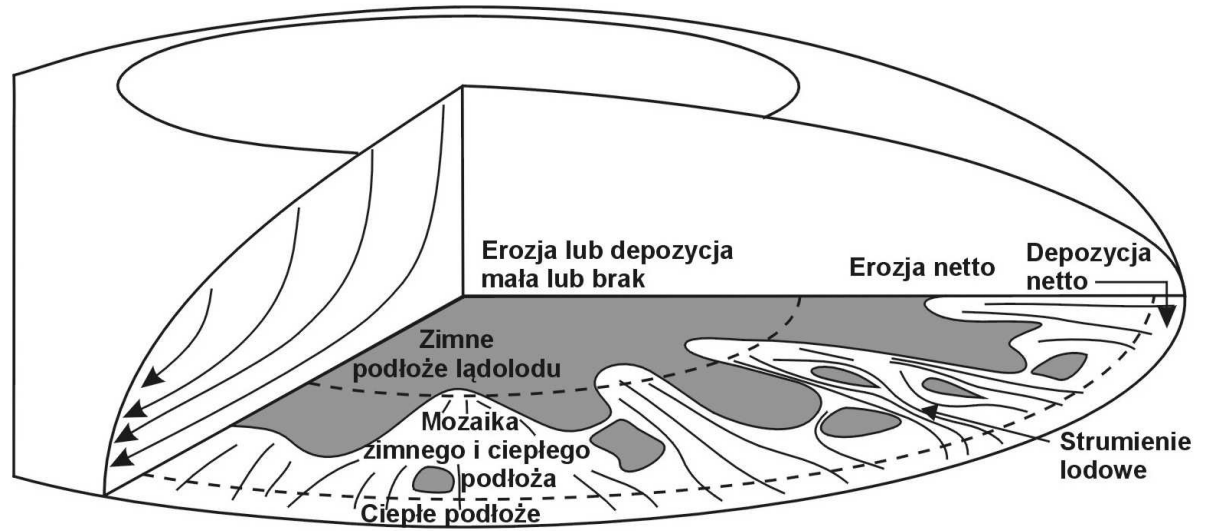

Rys. 8.5. Lodowiec politermalny (wg Klemana i in., 2008 - Fig. 4); zaznaczono obszary o różnych stosunkach pomiędzy erozją i depozycją w zależności od reżimu termicznego w stopie lądolodu. Ogólny model mogą modyfikować czynniki lokalne, wśród których najważniejsza jest topografia wpływająca na wzajemne przenikanie się stref o podłożu zimnym (na rysunku szarych) i ciepłym (białe pola)

Figure 8.5. The first-order organization of erosion and deposition zones under a steady-state polythermal mid-latitude ice sheet. In a central zone little erosion or deposition occurs and in a peripheral zone net deposition occurs. In between these two, erosion is dominating locally. This basic pattern is significantly modified by a topographically induced second-order radial pattern with frozen-bed zones (dark grey fields) fingering out and thawed-bed zones (white fields) extending inwards (after Kleman et al., 2008 - Fig. 4)

W konstrukcji powyższego modelu uwzględniono wielkość erozji i sedymentacji w Fennoskandii oszacowaną w dyskusyjny sposób, bo w oparciu o ocenę stopnia odsłonięcia litego podłoża na mapach geologicznych. Skrajne pozycje w tym podziale zajmują obszary niemal pozbawione osadów glacjalnych, np. w rejonie Narviku (gliny występują tylko miejscami - głównie w obniżeniach krystalicznego podłoża) oraz obszary z miąższą pokrywą glin, np. Botnik Północny, pomiędzy nimi zaś rozciąga się strefa pośredniej miąższości glin - Kleman i in. (2008 - str. 80). Z prezentowanej mapy wynika, że erozja w późnym vistulianie następowała głównie w rejonie Wysp Alandzkich 
oraz na przyległym dnie Bałtyku i Botniku Południowego, na południowym wybrzeżu Finlandii, włącznie z przybrzeżną strefą dna Zatoki Fińskiej, wzdłuż wybrzeża Szwecji od Upplandu po północny Småland, we wschodniej części Blekinge i na południu Olandii oraz w zachodniej Szwecji. W tym samym czasie południowo-wschodnie przedpole Gór Skandynawskich - w tym Dalarna - stanowiło obszar depozycji osadów glacjalnych. Wcześniejsze badania zdawały się wskazywać na dominację na tym obszarze zimnego reżimu termicznego (Kleman i in., 1997; Kleman i Hättestrand, 1999), w którym depozycja osadów nie zachodzi (erozja w zasadzie też nie). Obydwie hipotezy pozostają jednak w sprzeczności z licznym występowaniem skał dalarneńskich w osadach ostatniego zlodowacenia w Polsce (m.in. Czubla i in., 2007a; Górska-Zabielska, 2008; Woźniak i in., 2008; Woźniak i Czubla, $w$ druku). Możliwe są dwa rozwiązania - albo eratyki z Dalarny stanowią efekt redepozycji (inkorporacji przez lód starszych osadów), albo przedstawiony model wymaga jeszcze dopracowania. Ku wyborowi drugiej opcji skłania również obfite występowanie wapieni z dna Bałtyku, które wg Klemana i in. (2008) stanowiło raczej obszar depozycji osadów, a nie erozji. W jeszcze większym stopniu dotyczy to kredy i krzemieni z zachodniej części niecki bałtyckiej, gdyż tamten obszar jakoby nie podlegał erozji podczas ostatniego zlodowacenia, tymczasem na terenie Danii i Niemiec krzemienie występują powszechnie w osadach glacjalnych i fluwioglacjalnych tego wieku (m.in. Hesemann, 1931a; Richter, 1933; Münnich, 1936; Gauger, 1980; Stephan, 1987; Górska-Zabielska, 2008; Lüthgens i in., 2010).

Powyższych wątpliwości da się uniknąć pod warunkiem uwzględnienia dużej zmienności czasowej i przestrzennej procesów glacjalnych w Fennoskandii. Wraz z rozwojem badań czwartorzędu rośnie liczba cykli glacjalnych wyróżnianych w plejstocenie tego regionu. Obecnie przypuszcza się, że było ich co najmniej 40 (m.in. Mangerund i in., 1996; Kleman i Stroeven, 1997). Lodowce rozbudowujące się w poszczególnych cyklach cechowały się bardzo zróżnicowanym zasięgiem. Część z nich zajęła tylko obszary górskie i spłynęła jęzorami na przedpole - MIS, czyli mountain ice sheet(s), inne zajęły dużo większy obszar - niekiedy aż po Niż Środkowoeuropejski - FIS Fennoscandian ice sheet (Kleman i Stroeven, 1997). Na zmiany zasięgu nałożyła się zmienność reżimu termicznego stopy lądolodu (por. m.in. Punkari, 1984; Kleman i in., 1999; Payne i Baldwin, 1999; Boulton i in., 2001b; Forsström i in., 2003; Ottesen i in., 2005). Zmiany warunków subglacjalnych w dominującym stopniu wpłynęły na wahania zasięgu stref erozji i depozycji osadów oraz na intensywność tych procesów (Kleman i in., 2008). W konsekwencji poddajemy analizie sumaryczny wynik szeregu procesów, który nie daje się wpasować w prosty schemat.

\subsection{Mechanizmy włączania materiału w lód}

Istnieje kilka koncepcji dotyczących sposobu włączania materiału skalnego z podłoża w lodowiec, ale samo zjawisko nadal jest dość słabo rozumiane (Hoffmann i Piotrowski, 2001). Przegląd dotychczasowych poglądów był już kilkakrotnie prezentowany w literaturze (m.in. Knight, 1997; Alley i in., 1997; Kirkbride, 2002). Większość tych mechanizmów związana jest z powstawaniem lodu w środowisku subglacjalnym i przymarza- 
niem skał do lodu. Należy do nich regelacja, zachodząca na niewielkich przeszkodach podłoża o długości poniżej 1 metra (Weertman, 1964). W podobnych warunkach występuje efekt pompy cieplnej (Robin, 1976; Goodman i in., 1979). Za inkorporację większych ilości osadów może odpowiadać regelacja zachodząca w profilu pionowym i wnikanie lodu w głąb podłoża (Iverson, 1993).

Niedawno powiązano włączanie skał w masę lodu z glacjohydraulicznym przechłodzeniem (glaciohydraulic supercooling) (Strasser i in., 1996; Lawson i in., 1998; Alley i in., 1998, 1999, 2003a). Zgodnie z tą teorią woda wnikająca szczelinami i płynąca po stoku przegłębienia podlodowego przechodzi w lód przyrastający do stopy lodowca, zwiększając miąższość i zasięg strefy bazalnej. Dodatkowo gromadzący się lód przechwytuje materiał skalny z podłoża i w ten sposób buduje warstwy bogate w okruchy skalne. Przyczyną zamarzania wody jest szybszy wzrost wartości punktu topnienia pod ciśnieniem, aniżeli rzeczywistej temperatury. Tworzący się w ten sposób warstwowany lód bazalny jest generalnie młodszy od wyżej leżących warstw w lodowcu. Wstępnie udowodniono znaczenie tego mechanizmu dla lodowca Matanuska na Alasce (Lawson i in., 1998), ale pojawiły się sugestie, że ten sam mechanizm mógł funkcjonować również w stopie lądolodu fennoskandzkiego i laurentyjskiego (Larson i in., 2006). Funkcjonowanie hydraulicznego przechłodzenia udało się ostatnio wykazać w lodowcach Islandii (Roberts i in., 2002; Cook i in., 2010; Larson i in., 2010).

Na możliwość subglacjalnego wyrywania (plucking) i inkorporacji osadów scementowanych lodem zwrócił uwagę już Boulton (1979). To spostrzeżenie jest szczególnie ważne, ponieważ wyjaśnia możliwość transportu i zachowania się w glinach fragmentów utworów nieskonsolidowanych o zachowanej pierwotnej budowie wewnętrznej. Skały subglacjalne mogą znaleźć się w masie lodu także na drodze ścinania podłoża i włączania całych pakietów wzdłuż powierzchni ścinania w lód (Goldthwait, 1951; Boulton, 1970). Udowodniono również związek fałdowania podłoża lodowca z inkorporacją osadów (Sharp i in., 1994).

Infiltracja i zamarzanie wód ablacyjnych w miękkim deformowanym podłożu może doprowadzić do scalenia lodu z osadami (Iverson, 2000). Skutkuje to transportem olbrzymich ilości źle wysortowanego materiału podłoża w ciągu zaledwie paru tysięcy lat (Hooke i Elverhøi, 1996; Boulton i in., 2001b). Strefa wnikania wody pod ciśnieniem w podłoże jest na ogół bardzo płytka (od kilku do ponad $100 \mathrm{~mm}$ ) i wzrasta w sąsiedztwie kanałów subglacjalnych w efekcie podwyższonego ciśnienia. To z kolei sprzyja skoncentrowanemu odspajaniu grubszych pakietów osadów z podłoża i pogłębianiu obniżeń w obrębie subglacjalnych kanałów (Iverson, op. cit.).

Część badaczy obstaje przy przekonaniu, że jeżeli podłoże lądolodu o ciepłym reżimie zbudowane jest z nieskonsolidowanych skał osadowych, to większość materiału transportowana jest nie w lodzie, a w podłożu lądolodu jako miękka warstwa deformacyjna (np. Boulton i Hindmarsh, 1987; Boulton, 1996; Iverson i in., 1999). Łatwo dochodzi zatem do niszczenia i powtórnej inkorporacji świeżo złożonych osadów. W świetle tej hipotezy większość osadów glacjalnych Niżu Środkowoeuropejskiego stanowiłby wielokrotnie „przerobiony” materiał, pozostawiony przez starsze zlodowacenia. 
Należałoby zatem spodziewać się raczej niewielkiego udziału materiału dalekiego transportu w glinach lodowcowych. Wbrew temu przypuszczeniu udział skał bałtycko-fennoskandzkich (przynajmniej w analizowanej przez autora grubej frakcji) jest bardzo wysoki. Do wyjątków należą stanowiska (np. Gniszewo, Gniew-Piaskownia), w których skały lokalne (bliskiego transportu) występują w podobnej liczbie lub nawet liczniej od skał nordyckich (Woźniak i Czubla, w druku). Świadczy to o raczej niewielkim znaczeniu ruchu bazującego na deformowaniu podłoża w peryferyjnych, południowych częściach lądolodu fennoskandzkiego.

\subsection{Kry glacjalne i porwaki}

Występujące w obrębie glin lodowcowych fragmenty osadów o składzie i/lub budowie wewnętrznej odmiennej od otoczenia są identyfikowane stosunkowo często (np. Wawryk, 1961; Ruszczyńska-Szenajch, 1976, 1987; Stalker, 1976; Sauer, 1978; Ringberg i in., 1984; Menzies, 1990; Hoffmann i Piotrowski, 2001; Lisicki, 2003). W zależności od rozmiarów określane są jako porwaki (mające rozmiary do kilku metrów) lub kry glacjalne (megabloki - Stalker, 1976). Kry glacjalne są stosunkowo płaskie, słabo zdeformowane i często pogrzebane w grubych seriach osadów glacjalnych. Niekiedy bywają widoczne na powierzchni terenu, ale ich prawidłowe zaklasyfikowanie jest możliwe tylko dzięki wierceniom lub głębokim odsłonięciom. Zdarzają się kry glacjalne złożone z nieskonsolidowanych osadów czwartorzędowych. Występowanie śladów deformacji (strefy ścięć, fałdy, uskoki, zbrekcjonowanie), stanowiących wyraz pchnięcia przez lód, ma umożliwiać odróżnianie kier glacjalnych od wielkich eratyków (Aber, 1985). Trudno jednak zaakceptować potrzebę takiego rozróżniania, ponieważ wszystkie porwaki i kry glacjalne zgodnie z definicją (patrz rozdz. 3) są eratykami. Różne mogą być tylko długość transportu, rozmiary i litologia.

Inkorporowanie materiału z podłoża lądolodu mogło być ułatwione dzięki występowaniu przywierająco-ślizgowego ruchu lodu (patrz rozdz. 6). Podczas nagłego odrywania się lodu w takim miejscu generowane są duże naprężenia ścinające (por. m.in. Alley, 1993; Anandakrishnan i Alley, 1994; Stokes i in., 2007). Brak zaburzeń i reorientacji porwaków podkreślają dominację ścinania jako głównego procesu inkorporacji w stopie lodowca.

W przypadku wielu kier glacjalnych miejsce ich pochodzenia nie jest znane, ale najprawdopodobniej były transportowane na odcinku niewielu kilometrów (Aber i Ber, 2007). Jako wyjątkowy przypadek należy traktować kry iłów jurajskich w okolicach Łukowa (Jahn, 1950), których obszaru źródłowego doszukiwano się m.in. na Litwie (Ruszczyńska-Szenajch, 1976; Mizerski, 1980, 2009; Aber i Ber, op. cit.; Gałązka i in., 2009). Badania w Niemczech wykazały, że liczne kry glacjalne tworzą strefy rozrzutu po dystalnej stronie przekraczanych przez lądolód wysadów solnych (Gehl, 1965). Dzięki pierwotnej eksponowanej pozycji w rzeźbie, skały kredowe i paleogeńskie budujące kopuły ponad strukturami solnymi łatwo podlegały erozji glacjalnej i - następnie tworzyły dość wyraźne skupienia rozciągnięte za przeszkodą, zgodnie z kierunkiem migracji lodu. Przytoczona hipoteza nie tłumaczy jednak genezy kier łukowskich, 
ponieważ na drodze lodu z Fennoskandii w kierunku południowego Podlasia żadnych struktur solnych nie ma. Największa znana obecnie kra glacjalna środkowej Europy występuje w okolicach Kaliningradu (Steinitten, dziś Novoje) w Rosji i zbudowana jest z osadów kredy i kenozoiku. Ma ona długość 4 km, szerokość $2 \mathrm{~km}$ i miąższość od 7 do 20 metrów, a jej objętość ocenia się na 50-80 mln $\mathrm{m}^{3}$ (Petersen, 1924; Schallreuter, 1998).

Porwaki cechują się mniej regularnymi kształtami i znacznie mniejszymi od kier rozmiarami, ale żadnej precyzyjnej granicy nie ustalono. Występowanie porwaków w osadach glacjalnych zlodowacenia elstery w środkowych Niemczech opisują Hoffmann i Piotrowski (2001). Na ogół mają one niezaburzoną lub słabo zaburzoną strukturę wewnętrzną, co wskazuje na inkorporację i transport w stanie zamarzniętym. Prawdopodobnie dochodziło do penetracji podłoża przez wody ablacyjne, które tam zamarzały i w ten sposób „przytwierdzały” bloki osadu do stopy nasuwającego się lądolodu. Następnie porwane pakiety skał przemieszczały się wzdłuż powierzchni ślizgu wewnętrznego w lądolodzie na odcinku zaledwie 1-3 km (Hoffmann i Piotrowski, op. cit.).

Większość inkorporowanych przez lód fragmentów starszych skał osadowych zwłaszcza niezlityfikowanych - uległa rozproszeniu i nie zaznacza się już w glinie lodowcowej. Zachowanie pakietów luźnych osadów lub dużych płyt miękkich skał osadowych wymagało albo krótkiego i jednostajnego transportu, albo przemieszczania w stanie zamarzniętym. W analizach eratyków przewodnich mają one raczej ograniczone znaczenie. Zdarzają się jednak przypadki, kiedy nietypowo wysoki udział ziaren konkretnej skały może być odniesiony do rozwleczonego porwaka (eratyka). Odpowiada to koncepcji eratyka szrapnelowego zaproponowanej przez Eskolę (1933). W takim przypadku należałoby jednak spodziewać się nagromadzenia kanciastych ziaren tej samej skały, a w żadnym z przeanalizowanych przez autora osadów morenowych takich koncentracji nie udało się zaobserwować. Co więcej, niemal wszystkie eratyki miały obłe kształty, świadczące o stosunkowo długiej obróbce.

\subsection{Rozkład przestrzenny i czasowy erozji}

W centralnych częściach lądolodu fennoskandzkiego (w pobliżu linii podziału lodu) erozja odgrywała znikomą rolę ze względu na zimny reżim podłoża. Zbliżone warunki termiczne miały w LGM objąć także znaczną część depresji bałtyckiej (Arnold i Sharp, 2002). Pozwalało to na zachowanie w wielu miejscach preglacjalnych form rzeźby (Lagerbäck, 1988; Kleman i Stroeven, 1997; Davis i in., 2006; Darmody i in., 2007), a nawet zwietrzelin kaolinowych powstałych w znacznie cieplejszym klimacie (Nenonen, 1995; Saarnisto i Salonen, 1995). Kleman i Stroeven (1997) podkreślali dużą zmienność przestrzenną erozji. Ich zdaniem erozja miała koncentrować się w obniżeniach, podczas gdy na sąsiednich płaskowyżach i w obszarach wododziałowych mogły zachować się niezmienione relikty rzeźby. Zbliżony rozkład przestrzenny erozji i sedymentacji przytaczany jest dla kontynentu północnoamerykańskiego (m.in. Kleman i in., 1994; Briner i in., 2003; Davis i in., 2006). Powyższy wniosek potwierdzają obserwacje w Górach Torngat na Labradorze, gdzie w oparciu o analizy izotopów kosmogenicznych wyliczono 
tempo erozji w dolinach i na płaskowyżu. $W$ dolinach wyniosło ono ponad 2,5 $\mathrm{m}$ na jeden cykl glacjalno-interglacjalny, podczas gdy na sąsiednim płaskowyżu erozja nie przekroczyła 1,4 m/Ma. Oznacza to, że podczas plejstoceńskich cykli glacjalnych wysokości względne mogły zwiększyć się nawet o około 50 metrów (Staiger i in., 2005).

Rozmieszczenie obszarów o zimnym i ciepłym reżimie podłoża najlepiej rozpoznane jest dla ostatniego zlodowacenia (np. Kleman i Hättestrand, 1999) - rys. 8.6. W oparciu o badania izotopów kosmogenicznych wysuwane są przypuszczenia, że i dawniejsze czasze lodowe o zasięgu zbliżonym do późnovistuliańskiego, w ciągu ostatniego miliona lat (czyli w prawie całym okresie glacjalnym z punktu widzenia badań czwartorzędu Polski) powinny cechować się analogicznym reżimem termicznym podłoża, a w konsekwencji także zbliżonymi relacjami erozja - sedymentacja (Fabel i in., 2002; Hättestrand i Stroeven, 2002; Stroeven i in., 2002a). Dyskusyjne jest, czy w takim razie lądolody o większym zasięgu nie powinny posiadać szerszej strefy o zimnym reżimie podłoża, a więc zasadniczo mało podatnej na erozję. Jeśli rzeczywiście tak było, to należałoby zrewidować poglądy o aktywności procesów erozyjnych w Fennoskandii podczas maksymalnego rozwoju zlodowaceń. Wynikałoby z tego, że maksimum erozji przypadać powinno na okres transgresji lądolodu oraz na fazę deglacjacji, a na etapie maksymalnego zasięgu strefa erozji przesunęłaby się bardziej na południe - na obszar zbudowany ze skał osadowych, w znacznej części luźnych. Ta hipoteza zgodna jest z opinią Cornisha (1983), który na podstawie analiz eratyków, rys i osadów glacjalnych w Szkocji stwierdził, że wbrew wcześniejszym opiniom o najintensywniejszej erozji przy maksymalnym zasięgu czaszy lodowej (np. Gravenor, 1975; Sugden, 1978; Nobles i Weertman, 1971), erozja jest najszybsza na wczesnym etapie rozwoju czaszy lodowej, czyli przed osiągnięciem maksymalnego zasięgu, kiedy lód nasuwa się szybko, a w podłożu panują ciepłe warunki. Duże obszary tarczy kanadyjskiej, zachodniej Fennoskandii i Wyżyny Szkockiej wykazują cechy intensywnej erozji glacjalnej, mimo że obszary te znajdowały się w strefie podziału lodu (np. Vorren, 1977; Shilts, 1980), gdzie tempo ruchu było zerowe lub bardzo małe. Cornish (op. cit.) wyciąga stąd wniosek, że erozja w tej strefie była możliwa tylko podczas rozwoju czaszy lodowej bądź w okresach, kiedy czasza lodowa miała bardzo ograniczony zasięg przestrzenny.

Rdzany (2009) podkreśla dominację ciepłego reżimu lądolodów w ich zewnętrznych strefach, co pozwala na intensywną i głęboką erozję glacjalną, m.in. w środkowej Polsce. Jej dobitnym efektem było wykształcenie się już w elsterze niecki południowego Bałtyku (Meyer, 1991; Marks, 1998). W tej strefie wystąpiła intensywna erozja podłoża, która spowodowała przemieszanie i rozniesienie dalej na południe znacznych ilości starszych osadów glacjalnych i interglacjalnych. Niecka została później wypełniona przez Morze Holsztyńskie, wydłużone równoleżnikowo.

Intensywność i charakter erozji zależą w dużym stopniu od podłoża. Boulton (1979) wyróżniał dwa główne style erozji: pierwszy, kiedy podłoże jest stosunkowo odporne w porównaniu do lodu i zbudowane z litych skał i drugi, kiedy podłoże cechuje się niską spójnością i łatwo podlega deformowaniu. W pierwszym przypadku klasty są erodowane i transportowane wewnątrz lodu (możliwy jest długi transport materiału) - 


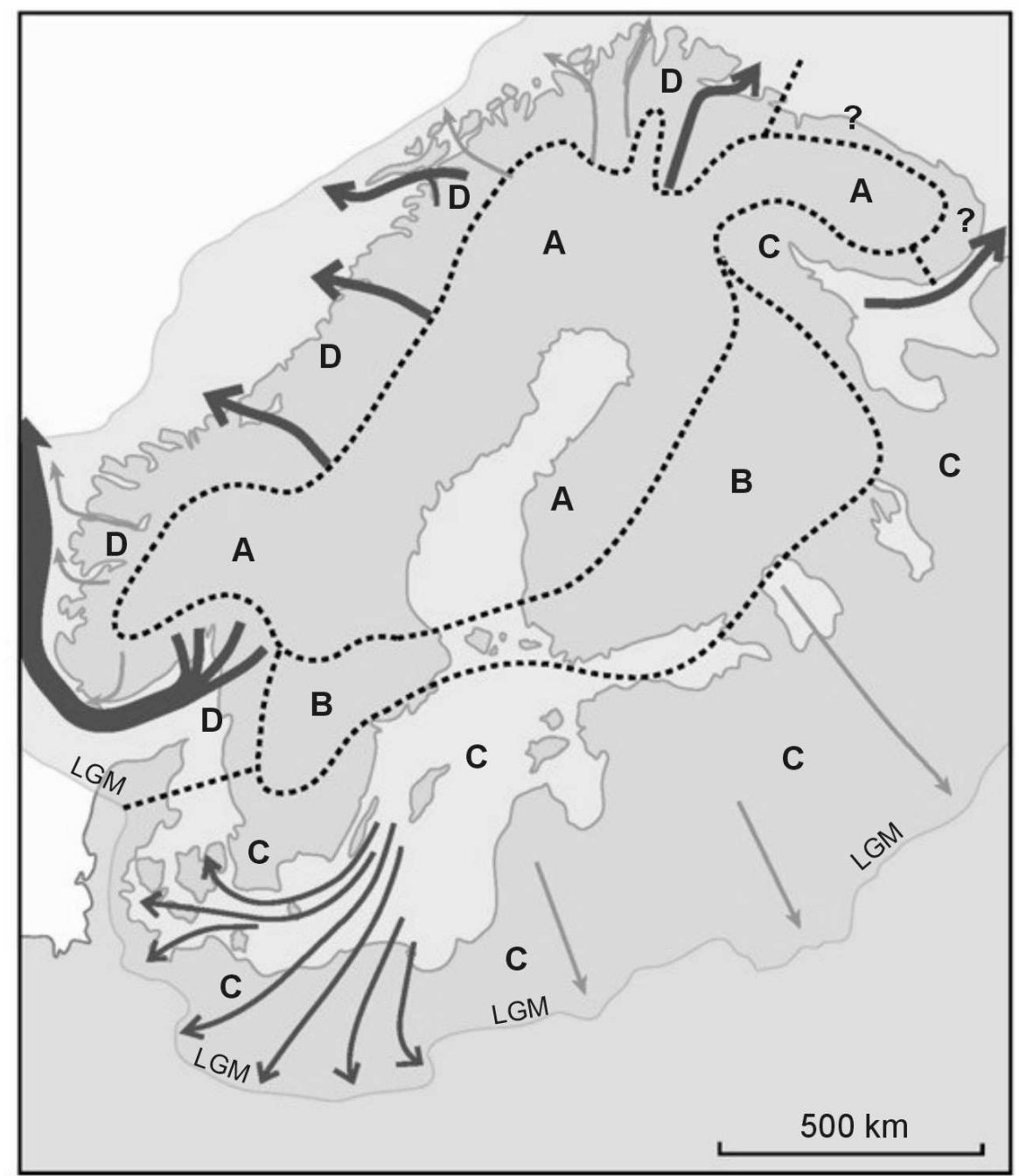

Rys. 8.6. Reżim termiczny podłoża lądolodu fennoskandzkiego w LGM i okresie bezpośrednio poprzedzającym lub następującym (wg Kleman i in., 1997; Kleman i Glasser, 2007; zmodyfikowany); A - zimny reżim podłoża, radialny ruch lodu na zewnątrz czaszy lądolodu, B - podłoże lądolodu na ogół ciepłe, lód rozpływa się promieniście, $\mathrm{C}$ - podłoże ciepłe, obszar formowania się strumieni lodowych uwarunkowanych topografią podłoża, D - dominuje ciepły reżim termalny podłoża, ale na wysoczyznach możliwe duże obszary o zimnym reżimie, ruch lodu kontrolowany w znacznym stopniu przez wyraźną rzeźbę terenu, liczne strumienie lodowe uchodzące do morza

Figure 8.6. First-order Fennoscandian subglacial thermal organization at the LGM or near-LGM stages. Since ice streams operation is time-transgressive, only ice streams inferred to have functioned at the Last Glacial Maximum (LGM) or near-LGM stages are shown; A - sheet flow, predominantly frozen bed, B - sheet flow, mostly thawed bed, C - low-gradient ice streams, topographical control also in low-relief terrain, D - flow pattern controlled by topography, mostly thawed bed, frozen on some uplands, numerous marine-terminating ice streams (after Kleman et al., 1997; Kleman \& Glasser, 2007; modified) 
typowy dla nieskonsolidowanych osadów pod lodem o umiarkowanym reżimie - długi transport glacjalny jest raczej mało prawdopodobny. Zamarznięte nieskonsolidowane podłoże zimnego lodowca może podlegać dowolnemu stylowi erozji - albo włączaniu i przenoszeniu zamarzniętych bloków, albo głównie deformowaniu podłoża. Współczesne lodowce są zwykle podścielone niepodatnymi, zwięzłymi skałami. Okresowo w plejstocenie lodowce wykraczały daleko poza swój podstawowy obszar źródłowy i nasuwały się na obszary zbudowane z miękkich osadów. Utwory te były pierwotnie deformowane, co prowadziło do kompleksowej aktywności depozycyjnej i powstawania zdrumlinizowanego „linearnego” krajobrazu (Boulton, op. cit.).

Obszar północnej i środkowej Polski podlegał mniej intensywnym procesom erozyjnym niż obszar depresji bałtyckiej. Miejscami jednak erozja mogła się nasilać, na co wskazuje wzrost udziału skał lokalnych. Niestety jest to czytelne tylko tam, gdzie w podłożu występują skały starsze od czwartorzędowych. Inkorporacja starszych osadów plejstoceńskich może być zamaskowana zbliżonym rodzajem osadu. Co prawda Lisicki (m.in. 2003) pokazuje liczne przykłady sytuacji, gdzie w obrębie glin (materiał z rdzeni wiertniczych) wyróżnił obce elementy określane przez niego jako porwaki. Poza zauważalną odmiennością składu drobnej frakcji żwirowej nie dostarczył jednak żadnych przekonywujących dowodów obcego pochodzenia wyróżnionych fragmentów glin. Powszechnie przyjęty pogląd o intensywnej egzaracji w pasie wyżyn i średniogórza środkowej Europy wynika raczej z możliwości odczytania śladów tejże na wyeksponowanych powierzchniach skał litych, aniżeli z realnego nasilenia tego procesu (Marks, 1998). Ostatnio coraz częściej wskazywane są przesłanki świadczące o znaczącej erozji również na Niżu Środkowoeuropejskim (Ber, 2000; Wysota, 2002; Wysota i Molewski, 2007).

Niewielka miąższość lądolodu warciańskiego w regionie łódzkim oraz stosunkowo mało urozmaicona rzeźba podłoża osadów warciańskich (w porównaniu do Polski Północnej) wpłynęły na niewielką skalę erozji glacjalnej (Rdzany, 2009). Tę interpretację wspiera powszechne występowanie ciągłego pokładu glin odrzańskich - głównie w obrębie płatów wysoczyznowych oraz umiarkowane zróżnicowanie miąższości glin warciańskich. Wnioski Rdzanego dobrze wpisują się w model warunków termicznych i procesów subglacjalnych przedstawiony przez Klemana i in. (2008). Położenie Polski Środkowej w stosunku do centrum zlodowacenia podczas stadiału warty niewątpliwie odpowiadałoby strefie zewnętrznej powyższego modelu, w której dominują procesy sedymentacyjne. Zauważony przez Rdzanego (op. cit.) nieomal zupełny brak osadów ocieplenia przedwarciańskiego w regionie łódzkim może być wyrazem nie tyle erozji, co raczej braku warunków do ich depozycji - zwłaszcza w świetle nowej interpretacji stratygrafii czwartorzędu Polski, w której warta to tylko stadiał recesywny zlodowacenia odra (m.in. Ber i in., 2007; Lindner i Marks, 2012).

Erozja glacjalna na terenie Polski najintensywniej zachodziła wzdłuż wcześniejszych liniowych obniżeń (doliny rzeczne lub formy o innej genezie) i je pogłębiała. W Polsce Środkowej transgredujący lądolód warciański wykorzystał w ten sposób doliny Prosny, Warty, Widawki i Rawki (por. Różycki, 1972; Krzemiński, 1974, 1997; Goździk, 1980, 
1986; Rdzany, 1997, 2004, 2009; Kobojek, 1997, 2000; Turkowska, 2006). Podobny charakter mogła mieć transgresja i związana z nią erozją lądolodu warty w Polsce Wschodniej. Lądolód wkroczył w południkowy odcinek doliny Bugu i wzdłuż niego utworzył lob wysunięty daleko na południe (Terpiłowski i Dobrowolski, 2004). Obniżenia morfologiczne wykorzystał również lądolód odrzański wkraczający w Góry Świętokrzyskie (Lindner, 1970). Analogicznie zachował się lądolód zlodowacenia wisła w rynnie Gopła (Molewski, 1999, 2007).

Kopalne obniżenia traktowane są przez niektórych badaczy jako dowód glacjalnej erozji podłoża (Drewry, 1986; Marks, 1998). Intensywniej dopływa tam ciepło wnętrza ziemi, szybszy zatem może być ślizg denny. Rynny subglacjalne w Polsce rozpoznał m.in. Niewiarowski (1995) na Pojezierzu Dobrzyńskim i Gnieźnieńskim. Odmienne zdanie reprezentuje Baraniecka (1980), która uważa, że erozji poddane były głównie wyniesienia podłoża. Ten pogląd wydaje się prawidłowy, ale raczej w odniesieniu do pagórków i wysoczyzn przekraczanych przez transgredujący lądolód (poprzecznych do kierunku ruchu).

Erozja i akumulacja w Polsce Środkowej nie były ostro oddzielone ani czasowo, ani przestrzennie. Materiał wyerodowany w jednym miejscu mógł być po krótkiej fazie transportu deponowany w najbliższym nawet sąsiedztwie (Rdzany, 2009). Idąc śladem tej interpretacji należałoby przyjąć, że dużą część osadów glacjalnych stanowi materiał redeponowany, którego odróżnienie od materiału przyniesionego bezpośrednio z obszaru alimentacji lodu jest prawie niemożliwe. Wyjątek stanowiłaby sytuacja, kiedy dno erodowanego obniżenia byłoby pozbawione osadów glacjalnych, a tym bardziej skał czwartorzędowych. Wtedy świadectwem erozji i bliskiej depozycji byłaby podwyższona zawartość skał lokalnych, która w glinach warciańskich KWB „Bełchatów” osiągała wartość 20-30\% (Czubla, 2001). Pośrednim dowodem aktywnej erozji podłoża lądolodów kompleksu środkowopolskiego w Polsce Centralnej jest rzadkie zachowywanie się poziomów glebowych pod glinami. W okolicach Łodzi udało się zidentyfikować zaledwie kilka takich stanowisk (Manikowska, 1966).

Wielkość sumarycznej erozji glacjalnej Fennoskandii w plejstocenie jest bardzo trudna do obliczenia (lub raczej oszacowania). Wykorzystuje się w tym celu głównie metody pośrednie. Jedną z nich jest obliczenie objętości osadów złożonych w obszarze akumulacji glacjalnej i fluwioglacjalnej, a następnie odniesienie ich do wielkości erodowanej powierzchni. W tej metodzie istnieje duże niebezpieczeństwo przeszacowania wielkości erozji na skutek pominięcia wpływu inkorporacji skał lokalnych na sumaryczną objętość osadów. W ten sposób włączane w masę lodu mogą być również starsze osady glacjalne. Prowadzi to do powstawania tzw. glin hybrydowych, które udokumentowano m.in. w Kanadzie (Trommelen i in., 2013). Inkorporowanie starszych osadów glacjalnych zmniejsza wiarygodność badań litostratygraficznych. Z tego punktu widzenia na Niżu Środkowoeuropejskim najbardziej wiarygodne są analizy osadów pierwszego nasunięcia lądolodu na dany obszar, ponieważ wszystkie znalezione skały fennoskandzkie można jednoznacznie przypisać temu właśnie awansowi lądolodu. Jest to możliwe dzięki zupełnie odmiennej budowie geologicznej północnej Polski i Niemiec w zestawieniu 
z obszarami alimentacyjnymi w Fennoskandii. Inna metoda oceny rozmiarów erozji glacjalnej opiera się na rekonstrukcjach rzeźby terenu z okresu preglacjalnego (np. Amantov, 1995).

Fragmentaryczne i w wielu przypadkach tylko szacunkowe dane wykorzystywane do oceny skali erozji glacjalnej Fennoskandii przyczyniły się do bardzo dużej rozpiętości wyników. Rudberg (1978) uważał, że erozja Skandynawii w plejstocenie wyniosła przeciętnie zaledwie 25 metrów. Skrajnie wysokie wartości - maksymalnie nawet do $400 \mathrm{~m}$ - zaproponowali Amantov (1995) i Mojski (1995). Zdaniem ostatniego erozja była bardzo zróżnicowana i wyniosła od 25 m w południowej części Bałtyku przez 200-300 m w północnej Szwecji i Finlandii, aż po 400 m u nasady Półwyspu Kolskiego. Podobnie intensywną erozję (330-420 m) stwierdzono w południowo-zachodniej części szelfu Morza Barentsa (Laberg i in., 2012). Dla obszaru środkowego Bałtyku Tuuling i Flodén (2001) wyliczyli maksymalną sumaryczną wartość erozji glacjalnej na zaledwie około 60 metrów.

Zróżnicowanie wielkości erozji glacjalnej w różnych częściach Fennoskandii niewątpliwie wpłynęło na proporcje eratyków w osadach glacjalnych. Można stąd wnioskować, że odmienne zespoły skał przewodnich, stwierdzone w różnowiekowych osadach glacjalnych, nie muszą być wyrazem jedynie regionalnej migracji strefy alimentacji lądolodu (por. Ehlers, 1983; Ehlers i in., 1984). Mogą również być uwarunkowane zmianami intensywności erozji w Fennoskandii w efekcie, np. wahań zasięgu zimnego i ciepłego reżimu termicznego podłoża (por. Woźniak i Czubla, w druku). 


\section{TRANSPORT ERATYKÓW}

Odmienny w stosunku do otoczenia charakter eratyków na Niżu Środkowoeuropejskim został zidentyfikowany bardzo wcześnie - zanim jeszcze rozwinęła się teoria zlodowaceń kontynentalnych. Dostrzeżono również podobieństwo wielu z nich do skał występujących na północy. Skłoniło to do potraktowania ich jako produktów dalekiego transportu ze Skandynawii. Niejasny był tylko mechanizm transportu. Początkowo dużą popularność zyskała teoria dyluwialna, według której eratyki miały zostać przyniesione przez powodzie (m.in. Buckland, 1823 - fide Hesemann, 1960; Buch, 1811; Staszic, 1805 - fide Jaroszewicz-Kłyszyńska, 1938a, 1938b). Dziś powyższa teoria ma znaczenie jedynie historyczne.

Już w pierwszej połowie XIX wieku pojawiła się nowa teoria dryftowa (Lyell, 1835 fide Jaroszewicz-Kłyszyńska, 1938b). W świetle tej koncepcji Fennoskandia miała być w plejstocenie pokryta czaszą lodową i otoczona morzami, podobnie jak dzisiejsza Antarktyda lub Grenlandia. Wmarznięte w kry i góry lodowe skały skandynawskie miałyby zostać rozwleczone przez wiatr i prądy po całym Niżu Europejskim. Zwolennicy teorii dryftowej (m.in. Kummerow, 1950, 1954) byli aktywni jeszcze do drugiej połowy XX wieku. Należał do nich m.in. Overweel (1977), który zakładał istnienie na przedpolu lądolodu fennoskandzkiego dużego zbiornika wodnego. Na skutek cielenia się lądolodu miały do niego trafiać olbrzymie ilości lodu wraz z wmarzniętym materiałem skalnym. Nowsze badania wykazały, że transport eratyków w krach i górach lodowych rzeczywiście odgrywał i nadal odgrywa znaczącą rolę na obszarach przybrzeżnych, np. w estuarium Rzeki Świętego Wawrzyńca (Dionne, 1972, 1989, 1993, 2003, 2009), u wybrzeży Francji (Guyader, 1977) i Antarktydy (Fitzsimons, 1990). W górach i krach lodowych odprowadzana jest większość materiału skalnego dostarczanego do mórz i jezior przez strumienie lodowe (por. Nygård i in., 2007; Bennett i Glasser, 2009; Winsborrow i in., 2010a).

Interesujących danych dostarczyły badania osadów preglacjalnych (ok. 1,1 do 0,6 Ma BP, tj. MIS 34 - MIS 16) na wybrzeżu wschodniej Anglii. Znaleziono w nich rozproszone eratyki wywodzące się z różnych regionów Szkocji oraz z południowej Norwegii, czyli przyniesione z odległości co najmniej $500 \mathrm{~km}$. Pozwala to wnioskować o wczesnym rozwoju czasz lodowych zarówno na Wyspach Brytyjskich (BIIS - British-Irish Ice Sheet), jak i w Skandynawii (SIS - Scandinavian Ice Sheet). Okresowo miały one osiągać wybrzeże Morza Północnego i umożliwiać w ten sposób daleki transport materiału skalnego tkwiącego w krach i górach lodowych (Larkin i in., 2011).

Kry lodowe aktywnie uczestniczą w transporcie dużych bloków skalnych i w procesach morfogenetycznych na wybrzeżach. Niekiedy mogą też przenosić pakiety zamarzniętych luźnych osadów. W zimie jest to możliwe także w strefie umiarkowanej, co udało się potwierdzić na niemieckim wybrzeżu Bałtyku (Reinhard, 1967), atlantyckim 
wybrzeżu USA i Kanady (Dionne, 2003; Argow i in., 2011), jak również na wybrzeżach jezior (Barnes i in., 1994).

Powszechnie przyjmuje się jednak, że w przypadku kontynentalnych czasz lodowych większość materiału skalnego transportowana jest w lodzie. Dopiero w strefie marginalnej lądolodu nasilają się procesy fluwioglacjalne i dochodzi do przejęcia przez wody materiału transportowanego dotychczas w lodzie. W efekcie ilość osadu odprowadzana przez wody roztopowe może być wielokrotnie wyższa od odłożonej bezpośrednio z lodu (np. Hagen i in., 1983).

\subsection{Transport glacjalny}

Okruchy skalne mogą być włączane w obręb płynącego lodu na wszystkich powierzchniach zewnętrznych. W przypadku lądolodów proces ten zachodzi właściwie tylko w spągu lodu. W strefie marginalnej możliwa jest również dostawa materiału skalnego za pośrednictwem procesów stokowych z nunataków lub zboczy dolin, w które wchodziły loby lodowcowe. Miała ona jednak znikome znaczenie i występowała tylko w przypadku wkraczania lądolodu na obszar o bardzo zróżnicowanej rzeźbie.

Transport materiału morenowego w lądolodzie odbywa się niemal wyłącznie w jego części bazalnej. Morena supraglacjalna stanowi absolutny wyjątek i może się utworzyć tylko w pobliżu wypukłego nunataka. W Polsce taka sytuacja mogła wystąpić jedynie w pasie wyżyn lub pogórza, ale stwierdzenie śladów jej istnienia w osadach glacjalnych jest niemożliwe ze względu na podobieństwo budowy geologicznej potencjalnych nunataków i okolicznego podłoża. Zdaniem Kirkbride’a (2002) morena supraglacjalna może powstawać także w ścisłej strefie marginalnej lądolodu, gdzie materiał skalny inkorporowany w podłożu wędruje ku górze dzięki płynięciu deformacyjnemu lodu. Wydaje się jednak, że ta koncepcja ma charakter raczej teoretyczny i nie znalazła dotychczas potwierdzenia w obserwacjach terenowych.

Większość gruzu skalnego transportowana jest bezpośrednio ponad stopą lodowca. Jego zawartość wynosi zwykle około 25-30\% (m.in. Echelmeyer i Wang, 1987; Ronnert i Mickelson, 1992). Bezpośrednie pomiary przeprowadzone w bazalnej części małego lodowca wypustowego na płaskowyżu Hardangervidda w Norwegii wykazały, że najwięcej materiału skalnego koncentruje się w przydennej warstwie lodu o grubości zaledwie 1-2 m (Hagen i in., 1983). Wyżej jego ilość szybko maleje. Co ciekawe, nawet w strefie przydennej występowały strefy czystego lodu (zawierającego zaledwie $0,03 \mathrm{~kg} / \mathrm{m}^{3}$ ), powiązane z subglacjalnymi kanałami. Autorzy tłumaczą ten fakt wytapianiem „brudnego lodu” i wynoszeniem materiału skalnego przez wodę i napływem w to miejsce czystego lodu z wyższych warstw lodowca. Najwyższa stwierdzona koncentracja materiału skalnego w lodzie wyniosła około $60 \mathrm{~kg} / \mathrm{m}^{3}$, tj. co najmniej czterokrotnie mniej, niż wynika z badań Lawsona (1979). Na wysokości $1 \mathrm{~m}$ stwierdzono zawartość materiału skalnego na poziomie $6-12 \mathrm{~kg} / \mathrm{m}^{3}$. W strefie bazalnej zachodzi też glacjalne ścieranie i rozdrabnianie fragmentów skał (Dreimanis, 1990). Tarcie o podłoże wpływa na spadek prędkości przemieszczania się okruchów skalnych pozostających w kontakcie z podłożem (por. Hagen i in., op. cit.). Spowolnienie zaznacza się również w wyższych 
częściach strefy bazalnej lodowca. Lodowce cechujące się ciepłym reżimem termicznym w stopie, transportują zazwyczaj niewiele materiału skalnego. Warstwa bazalna bogata w materiał skalny ma w nich miąższość rzędu zaledwie centymetrów lub decymetrów ze względu na duży przepływ wód ablacyjnych i odprowadzanie wytopionego materiału (Hambrey i Glasser, 2012). Lodowce politermalne transportują większość materiału skalnego w strefie bazalnej i wewnątrzglacjalnej. Lodowce o zimnym reżimie podłoża transportowały większość materiału skalnego w strefie bazalnej i bardzo mało przerabiały go podczas transportu (Hambrey i Glasser, 2012).

W lądolodzie antarktycznym stwierdzono obecność od 0 do 12\% objętościowych materiału morenowego (Gow i in., 1979; Drewry, 1986), a w grenlandzkiej czaszy lodowej zaledwie około 0,1\% objętościowego (Herron i Langway, 1979). Nierówności podłoża powodują poziome lub pionowe odchylenie toru ruchu klastów. W konsekwencji warstwa bogatego w okruchy skalne lodu staje się grubsza po bokach przeszkody, a nad jej kulminacją cieńsza. Lód regelacyjny w strefie przydennej (bogaty w materiał morenowy) układa się w strumienie „opływające” przeszkody (Jania, 1993).

Powyżej strefy bazalnej bogatej w gruz skalny leży lód czysty lub zawierający tylko nieliczne fragmenty skał. W trakcie płynięcia nasuwczego (compressive flow) bogate w skały dolne warstwy lodu mogą być przeniesione do wyższych warstw lodowca. Jako że rozpad i ścieranie skał w tej strefie są minimalne, skały mogą być transportowane na bardzo duże odległości (Dreimanis, 1976). Wg Ehlersa (2011) może to być droga, na której całe warstwy lodu włącznie z materiałem morenowym mogły nieprzemieszane przywędrować ze Skandynawii do północnych Niemiec. Wśród nich charakterystyczne czerwone gliny, przypisywane późnym etapom nasunięć glacjalnych (Ehlers, 1992), stwierdzono ostatnio również w Polsce (Jasiewicz, 2001, 2007). W przeciwieństwie do innych osadów glacjalnych północnych Niemiec są one złożone ze stosunkowo „czystego" materiału dalekiego transportu i praktycznie nie zawierają narzutniaków lokalnych. Taki skład pozwala założyć, że czerwone gliny rzeczywiście stanowią efekt transportu w górnych warstwach lądolodu (Ehlers, 1992). Dowodów dostarczyły analizy drobnej frakcji żwirowej (Ehlers, 1990b). Wyróżniane w tej frakcji lokalne składniki to głównie kwarc, ale w szerszym znaczeniu mogą do nich być zaliczane także krzemienie i kreda. Tych ostatnich we wspomnianych analizach niemal zupełnie brakuje (Ehlers, 2011). Obecność kwarcu trudno potraktować jako dowód lokalnej inkorporacji skał podłoża, ponieważ odróżnienie kwarcu lokalnego od powstałego z rozpadu fennoskandzkich skał krystalicznych jest w większości przypadków niemożliwe. W sytuacji, kiedy brak skał niewątpliwie lokalnych, obecność samego kwarcu niczego zatem nie dowodzi. W wyższych warstwach lodu transportowane mogą też być wielkie kry glacjalne, np. jurajskie w okolicach Łukowa (Ruszczyńska-Szenajch, 1976, 1987; Gałązka i in., 2009), kredowe w Danii i Polsce, kenozoiczne m.in. w Polsce Północnej (Orłowski, 2008). Gliny utworzone z materiału inglacjalnego opisują m.in. Harrison (1960), Dreimanis i Vagners (1969) oraz Shilts (1973).

Istnieje również możliwość zatrzymania na przeszkodzie morfologicznej dolnej części lodu bogatej w materiał skalny i nasuwania się dalej już tylko wyższych części masy lodowej na drodze ślizgu wewnętrznego (Jania, 1993). Lód taki byłby bardzo ubogi 
w materiał skalny i mógłby nie pozostawiać żadnej wyraźnej moreny (por. Lindner, 1988, 1996, 2009). Ewentualnie pobierałby materiał leżący w podłożu, ale już za przeszkodą i w ten sposób przyjąłby zupełnie obcy skład głazowy, zależny od lokalnej sytuacji geologicznej. W ten sposób część glin tego samego zlodowacenia, odłożona za przeszkodą, mogłaby charakteryzować się zupełnie odmiennym składem głazowym. Należy jednak mieć świadomość, że powyższy proces jest możliwy tylko w stopie ciepłego lodowca. W Polsce podłoże transgredującego lądolodu stanowiły na ogół osady nieskonsolidowane. W związku z tym prawdopodobieństwo wystąpienia przeszkód, które byłyby w stanie zatrzymać bazalną, bogatą w materiał morenowy warstwę lądolodu jest niewielkie. Dużo większą rolę opisywany mechanizm odgrywał na obszarach zbudowanych ze skał litych, np. tarczy kanadyjskiej czy fennoskandzkiej. Lokalne zatrzymanie części bogatego w materiał morenowy lodu na przeszkodzie morfologicznej i pobór nowego po jej dystalnej stronie w Skandynawii raczej nie ma jednak istotnego wpływu na skład osadów glacjalnych odłożonych na Niżu Środkowoeuropejskim w odległości kilkuset km od przeszkody. Na dodatek w Fennoskandii opisywany proces byłby możliwy tylko na początkowym etapie rozwoju czaszy lodowej, kiedy występował tam lód ciepły. Wraz z rozprzestrzenianiem się czaszy lodowej zmieniał się rozkład przestrzenny warunków termicznych i na dużym obszarze Fennoskandii występował zimny reżim termiczny lodu (rys. 8.6) (m.in. Kleman i in., 1997, 2008; Kleman i Glasser, 2007).

Zbliżony mechanizm ruchu lodu, ale uwarunkowany zmiennością przestrzenną termiki lodu i podłoża przedstawiono dla północnego Tajmyru (Alexanderson i in., 2002). Początki rozwoju czaszy lodowej vistulianu na wynurzonym wówczas szelfie Morza Karskiego związane były z występowaniem wieloletniej zmarzliny i funkcjonowaniem zimnego reżimu termicznego. Rosnąca miąższość lodu, strumień cieplny Ziemi oraz tarcie wywołane ruchem lodu doprowadziły do zmiany reżimu w centralnej części czaszy lodowej na ciepły. Strefa marginalna lądolodu cechowała się natomiast zimnym reżimem termicznym z zachowaną wieloletnią zmarzliną w podłożu (efekt małej miąższości lodu i mniejszej ilości ciepła uwalnianego na skutek tarcia wewnętrznego). To sprawiło, że czoło lądolodu było przymarznięte do podłoża i funkcjonowało podobnie jak przeszkoda morfologiczna na drodze lądolodu. Ruch odbywający się w obrębie czaszy lądolodu zachodził głównie na drodze kompresyjnego płynięcia nasuwczego, a lokalnie (w strefie bardziej oddalonej od czoła) także w efekcie deformowania miękkiego podłoża - tam, gdzie miąższość lodu lub/i strumień cieplny podłoża pozwoliły osiągnąć punkt topnienia pod ciśnieniem. Zdaniem cytowanych autorów strefa o zimnym podłożu miała zaledwie 2 do $15 \mathrm{~km}$ szerokości, podczas gdy w obszarze marginalnym lądolodu laurentyjskiego osiągała ona 60 do $200 \mathrm{~km}$ (Cutler i in., 2000). Wieloletnia zmarzlina w podłożu strefy marginalnej lodowca nie tylko zmieniała charakter jego ruchu, ale także blokowała subglacjalny odpływ wód ablacyjnych, uwolnionych w strefach o ciepłym reżimie podłoża. Wieloletnia zmarzlina mogła utrzymać się w podłożu transgredującego lądolodu przez kilkaset do nawet kilku tysięcy lat, blokując odpływ wód i wymuszając ich gromadzenie się pod lodem (ibidem). Możliwe, że podobnie wyglądała strefa marginalna lądolodu fennoskandzkiego na Niżu 
Środkowoeuropejskim. Wątpliwości budzi czas utrzymywania się permafrostu pod transgredującym lądolodem. Jeżeli rzeczywiście wieloletnia zmarzlina jest tak trwała pod czołem lądolodu, to rozwój (a przynajmniej zainicjowanie) strumieni lodowych byłby niemożliwy. Jeżeli strumień lodowy już funkcjonuje, to ciepło uwalniane w efekcie tarcia pozwoliłoby być może utrzymać ciepły reżim jego podłoża.

W ostatnim ćwierćwieczu upowszechniło się przekonanie, że na obszarach zbudowanych z nieskonsolidowanych skał osadowych większość materiału transportowana jest nie w lodzie, a w podłożu lądolodu jako miękka warstwa deformacyjna (np. Boulton, 1979, 1996; Boulton i Hindmarsh, 1987; Iverson i in., 1999; Boulton i in., 2001a). Odkrycie tego mechanizmu transportu pod ciepłym lądolodem bywa nawet traktowane jako jedno z największych osiągnięć współczesnej glacjologii (Eyles, 2006). W świetle tej hipotezy większość osadów glacjalnych Niżu Środkowoeuropejskiego stanowiłby „przerobiony” materiał, pozostawiony przez starsze zlodowacenia. W przypadku, gdyby powyższa koncepcja się potwierdziła, badania litostratygraficzne osadów glacjalnych, w tym skał wskaźnikowych, straciłyby wiarygodność. Wydaje się jednak, że zróżnicowanie składu różnowiekowych osadów glacjalnych (np. Kenig, 1998; Czubla, 2001; Lisicki, 2003; Gałązka, 2004b) zaprzecza dominującej roli tego mechanizmu transportu glacjalnego w Polsce. Analizy sedymentologiczne też wykazują wiele sprzeczności z koncepcją deformowanego podłoża i wskazują na konieczność radykalnego ograniczenia obszaru, na którym mechanizm ten miałby dominować (Beget, 1986; Piotrowski i in., 2001, 2002). Miąższość deformowanej warstwy wynosiła raczej kilka centymetrów, a nie metrów. Zasięg poziomy też był niezbyt wielki. Bardziej prawdopodobny i zgodny z danymi sedymentologicznymi jest wewnątrzglacjalny transport materiału skalnego oraz ruch lądolodu w oparciu głównie o ślizg denny (Piotrowski i in., 2001). Znikomą miąższość deformowanych osadów w podłożu udało się potwierdzić w Polsce w stanowisku Obórki na peryferiach wiślanego strumienia lodowego (Narloch i in., 2012).

Odmienną koncepcję deformowanego podłoża przedstawiono na podstawie badań z zachodniej Syberii (Astakhov i in., 1996). Tamtejsze plejstoceńskie pokrywy lodowe cechowały się najczęściej zimnym reżimem. Subglacjalne, zamarznięte osady zostały zaangażowane w glacjalny system naprężeń. Naprężenia ścinające mogły doprowadzić do powstania w nich powierzchni oddzielności i nasunięć. Stwierdzono również występowanie deformacji ciągłych. W wielu przypadkach doszło do uruchomienia wielkich mas osadów i ich przemieszczenia na znaczne odległości. Płaty zamarzniętych osadów były zatrzymywane przez bariery litologiczne, orograficzne lub termiczne i tworzyły struktury imbrykacyjne. Lód lodowcowy zaangażowany w struktury imbrykacyjne mógł zostać zachowany we współczesnej wieloletniej zmarzlinie. Materiał skalny transportowany przez lodowiec był odkładany głównie przez odwarstwianie w stopie stagnujących płatów brudnego lodu, tworzących w ten sposób subglacjalną zmarzlinę. Na obszarze współczesnej wieloletniej zmarzliny gliny bazalne często zachowały się w pierwotnym zamarzniętym stanie. Stanowią one najbardziej konserwatywny element zlodowacenia kontynentalnego, który przetrwał do interglacjału (Astakhov i in., op. cit.). Wydaje się, że podobny mechanizm mógł funkcjonować w Skandynawii i w ten sposób zwiększać zawartość materiału morenowego w lodzie migrującym na południe. 
Istotną rolę naprężeń ścinających w transporcie eratyków podkreślają również Charbonneau i David (1995). W oparciu o trójwymiarową analizę wachlarzy rozrzutu skał w Quebeku wypracowali model transportu eratyków w lądolodzie poprzez rozpraszanie $w$ efekcie ścinania (shear-diffusion model). Zgodnie $z$ ich ideą deformacje ścięciowe zachodzą w preglacjalnej zwietrzelinie pod lodem i w świeżo powstałej glinie. Ścinanie górnej warstwy regolitu i rozwlekanie najwyższej części gliny prowadzą do rozproszenia materiału skalnego (eratyków).

\subsection{Facje w lodowcach i lądolodach (kriofacje)}

Badania glacjologiczne zmierzają w kierunku uporządkowania opisów lodu lodowcowego i wprowadzenia podziału facjalnego (m.in. Lawson, 1979) na wzór stosowanego w sedymentologii (np. Reading, 1996). Niekiedy w odniesieniu do lodu stosuje się pojęcie kriofacji (cryofacies) (np. Murton i in., 2005; Hubbard i in., 2009), wykorzystywane powszechnie w charakterystyce wieloletniej zmarzliny (m.in. Murton i French, 1994; Stephani i in., 2010).

W oparciu o badania lodowca Matanuska na Alasce wyróżniono strefę bazalną w lodzie, w obrębie której można wyodrębnić fację warstwowaną (stratified) i fację rozproszoną (dispersed). Ponad nią rozciąga się facja wewnątrzglacjalna (englacial) budująca większość masy lodowca (Lawson, 1979) (rys.9.1). Fację warstwowaną rozdzielono na trzy subfacje, tj. stałą (solid) bogatą w materiał morenowy $\left(>500 \mathrm{~g} / \mathrm{dm}^{3}\right)$, nieciągłą (discontinuous), zawierającą drobnoziarnisty materiał morenowy w postaci skupień oraz subfację zawieszoną (suspended), zawierającą rozproszony materiał skalny i jego skupienia $\left(0,2-500 \mathrm{~g} / \mathrm{dm}^{3}\right)$ - Lawson (1979). Najniżej leży warstwowany lód bazalny subfacji stałej. Na zachodnim obrzeżu lądolodu grenlandzkiego zawiera on średnio aż $47 \%$ objętościowych materiału skalnego (Waller i in., 2000). Jeszcze niedawno uważano, że ta subfacja reprezentuje nieskonsolidowany osad przymarznięty do stopy lądolodu w pobliżu strefy marginalnej (Sugden i in., 1987; Waller i in., op. cit.). W związku z tym miałaby występować tylko pod czołem lodowca i szybko cienieć w kierunku pod prąd lodu. Utrzymanie tej koncepcji trudno byłoby jednak pogodzić z niewątpliwym napływem dużej ilości skał fennoskandzkich na obszar Niżu Środkowoeuropejskiego, czy jakimkolwiek dalekim transportem dużej ilości materiału skalnego. Subfacja nieciągła zawiera laminy materiału mineralnego o miąższości 0,5-2 mm, tkwiące w stosunkowo czystym lodzie. Zawartość materiału mineralnego jest w niej około dwukrotnie niższa niż w poprzedniej i wynosi średnio $22 \%$ objętościowych. W górnej części facji warstwowanej występuje subfacja zawieszona, zawierająca liczne wkładki materiału mineralnego, stanowiące w sumie ok. 30\% objętościowych (Waller i in., 2000). Powyższe obserwacje i pomiary subfacji przeprowadzono na obrzeżu Grenlandii, a więc w warunkach nieco zbliżonych do tych, jakie mogły występować w plejstocenie w środkowej Europie.

Sumaryczna miąższość facji warstwowanej lodu bazalnego najczęściej zawiera się w przedziale od kilku cm do 2 metrów, ale zdarza się i do 6 m (Lawson i in., 1998). To w niej koncentruje się większość materiału skalnego transportowanego przez lodowiec - najczęściej od około 4 do 15\% objętościowych lodu bazalnego, ale w skrajnym przy- 
padku aż $44 \%$ objętościowych, czyli ponad $60 \%$ wagowych. Głaziki i większe klasty występowały rozrzucone raczej przypadkowo w lodzie bazalnym, chociaż zdarzały się ich koncentracje na kontakcie warstwowanego lodu bazalnego i czystego lodu glacjalnego. Większość z nich była dobrze obtoczona lub średnio obtoczona i wydawała się być formowana przez transport rzeczny. Generalnie głaziki były nieporysowane (Larson i in., 2010). Obserwacje przeprowadzone w lodowcu Svinafellsjökull (czasza lodowa Vatnajökull na Islandii) wykazały, że frakcja żwirowa ma proporcjonalnie większy udział w materiale skalnym transportowanym w facji rozproszonej, aniżeli w facji warstwowanej (Adam, 2006). Możliwe, że jest to efekt abrazji grubszych ziaren na kontakcie z lodem, o czym mogłaby świadczyć podwyższona zawartość frakcji aleurytowej w facji warstwowanej (rys.9.2), ale przytoczone wcześniej wyniki (Larson i in., 2010) nie potwierdzają intensywnego niszczenia transportowanego w tej facji materiału skalnego.

STREFA

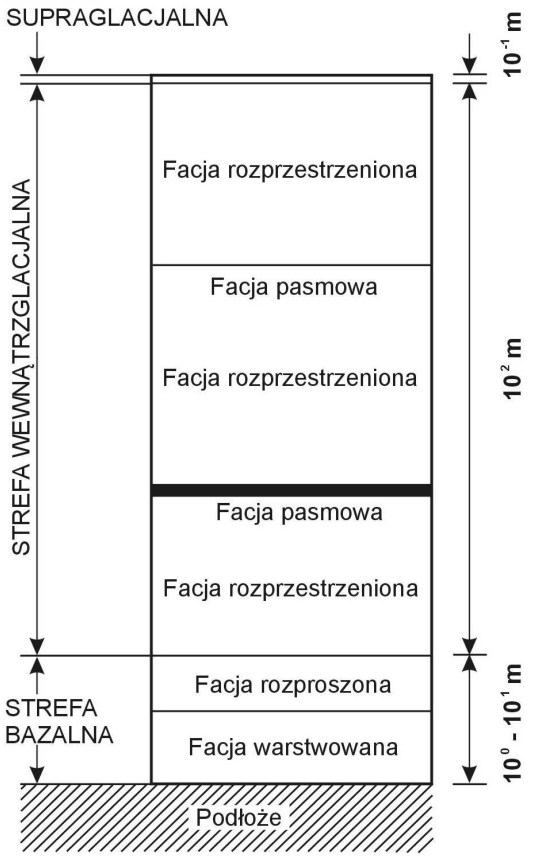

Powyżej facji warstwowanej rozciąga się facja rozproszona (dispersed), zdefiniowana jako cząsteczki skalne i ich agregaty rozproszone w masie czystego lodu bazalnego (Lawson, 1979). Jej miąższość w lądolodzie antarktycznym waha się w granicach od 6 do $12 \mathrm{~m}$ (Christoffersen i in., 2006), na Islandii zaś stwierdzono nawet 25-metrową warstwę lodu w tej facji (Cook i in., 2011). Zawartość materiału skalnego $w$ facji rozproszonej jest niewielka - średnio $38 \mathrm{~g} / \mathrm{dm}^{3}$ (Lawson, 1979) lub poniżej 1\% objętościowego (Waller i in., 2000). W Lodowcu Russela na Grenlandii zaobserwowano występowanie soczewek materiału morenowego o średnicy do $8 \mathrm{~cm}$. Ich koncentracja maleje ku górze, a całkowita zawartość materiału morenowego mieści się w granicach 0,001-8\% wagowych (Knight, 1987; Sugden i in., 1987). Zbliżoną zawartość materiału skalnego stwierdzono w facji rozproszonej lądolodu antarktycznego - do $1 \% \mathrm{w}$ postaci mułowych skupień lub pojedynczych ziaren (Christoffersen i in., 2006) lub około $15 \mathrm{~g} / \mathrm{dm}^{3}$ z przewagą frakcji mułowej (Cuffey i in., 2000b; Samyn i in., 2005).

Rys. 9.1. Schematyczny profil lodowca Matanuska z zaznaczonymi facjami lodu lodowcowego; wysoką zawartością materiału skalnego cechują się facje warstwowana i pasmowa; wg Lawsona (1979)

Figure 9.1. Schematic vertical section through Matanuska Glacier, Alaska, showing the distribution of ice facies. High debris concentrations occur in the banded facies (from supraglacial sources) and in the stratified facies (from subglacial sources) (after Lawson, 1979) 
Ze względu na niską zawartość klastów skalnych, wpływ facji rozproszonej na kształtowanie składu glin wydaje się być co najwyżej drugorzędny. Zaprzeczają jednak temu poglądowi badania lodu bazalnego w lodowcu Svínafellsjökull na Islandii (Cook i in., 2011). Mimo stosunkowo niskiej średniej zawartości materiału mineralnego ok. 1,6\% objętościowego - facja rozproszona przyczynia się w znacznym stopniu do uwalniania materiału skalnego. Dzieje się tak dzięki dużej miąższości (do $25 \mathrm{~m}$ ) tej facji, podczas gdy bogaty w materiał morenowy lód bazalny facji warstwowanej jest tam kilkadziesiąt razy cieńszy. Dodatkowo facja rozproszona występuje powszechnie wzdłuż czoła lądolodu. Te czynniki sprawiły, że w analizowanym przypadku facja rozproszona lodu bazalnego dostarcza około 6,5 razy więcej materiału skalnego niż topniejący warstwowany lód bazalny. Geneza facji rozproszonej jest niejasna. Być może stanowi ona produkt subglacjalnego przemarzania wody i osadów (Christoffersen i in., 2006). Wśród licznych hipotez (m.in. Sugden i in., 1987; Koerner, 1989; Knight i Knight, 1994; Sharp i in., 1994; Hubbard i in., 2000) najbardziej uzasadniona wydaje się być koncepcja, że lód facji rozproszonej powstał w wyniku przekształcenia warstwowanego lodu bazalnego (Hart, 1995). Wnikliwe badania lodowca Svínafellsjökull na Islandii wykazały jednak, że żadna z istniejących teorii nie opisuje w pełni genezy facji rozproszonej lodu bazalnego (Cook i in., 2011).

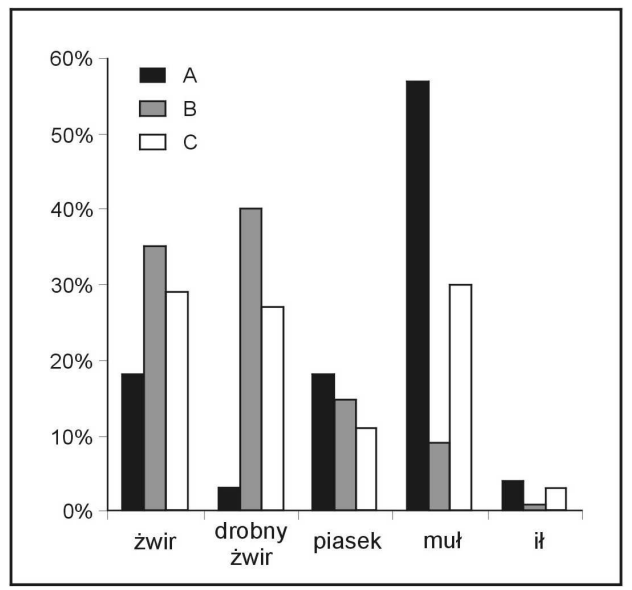

Lód bazalny może zostać przemieszczony do lodu wewnątrzglacjalnego, a nawet do pozycji supraglacjalnej w fałdach powstałych w efekcie silnej kompresji na znaczących nierównościach podłoża (Goodsell i in., 2002). Powyższy mechanizm przyczynia się do wzbogacenia w materiał skalny wyższych warstw głównie w lodowcach górskich, a w przypadku lądolodu fennoskandzkiego mógł wystąpić podczas przekraczania zrębu Bornholmu lub regionu dzisiejszych Wysp Alandzkich.

Rys. 9.2. Rozkład uziarnienia w facjach lodu bazalnego: A - facja warstwowana, B - smugi materiału morenowego w lodzie bazalnym, C - facja rozproszona; frakcje: żwir - 4-64 mm (w źródle brak informacji,

czy w tej kategorii uwzględniono też większe klasty), drobny żwir - 2-4 mm, piasek -0,063-2 mm, muł - 0,004-0,063 mm, ił - <0,004 mm (wg Adama, 2006)

Figure 9.2. Relative proportions of different particle sizes in the stratified (A), debris band (B) and dispersed (C) basal ice facies; fraction: pebble $-464 \mathrm{~mm}$ (in the original work there is no information if bigger clasts were included too or not), granule $-24 \mathrm{~mm}$, sand -0,063 $2 \mathrm{~mm}$, silt $-0,0040,063 \mathrm{~mm}$, clay $-<0,004 \mathrm{~mm}$ (after Adam, 2006)

Transport lodu bazalnego ku górze może nastąpić również podczas przekraczania obniżeń podłoża w strefie terminalnej lodowca. Wkraczający na przeciwny stok lód podlega wyciskaniu ku górze (Spedding i Evans, 2002). Na obszarze Polski było to 
możliwe w pobliżu czoła lądolodu w trakcie przekraczania dolin rzecznych o równoleżnikowym przebiegu lub przy wkraczaniu lądolodu na wyżyny lub pogórza. Występowanie nasunięć tego typu w strefie czołowej lądolodu nie wpływało na istotne przedłużenie drogi transportu materiału skalnego, ponieważ lód i tak wkrótce podlegał ablacji. O wiele cenniejsze byłoby potwierdzenie funkcjonowania analogicznego mechanizmu na obszarze alimentacji lądolodu fennoskandzkiego.

W strefie wewnątrzglacjalnej wyróżniono fację pasmową (banded), zawierającą bogate w kanciaste klasty warstewki lodu o miąższości najczęściej od 2 do $5 \mathrm{~cm}$ oraz fację rozprzestrzenioną (diffused) w zasadzie wolną od materiału morenowego i stanowiącą dominującą część lodu lodowcowego (Lawson, 1979). Smugowate skupienia materiału morenowego w facji pasmowej interpretowane są na ogół jako produkt tektonicznego przemieszczenia do wyższych warstw lodowca lodu bazalnego bogatego w materiał morenowy (facji warstwowanej) lub osadów subglacjalnych (m.in. Hart, 1998; Waller i in., 2000; Swift i in., 2006). Zawartość materiału skalnego w strefie wewnątrzglacjalnej lodowca Watts na Wyspie Baffina wynosi średnio zaledwie 0,0018\% wagowych (Dowdeswell, 1986). Oznacza to, że jej wpływ na kształtowanie składu petrograficznego osadów glacjalnych był znikomy.

Z punktu widzenia badań eratyków szczególnie istotne są facje lodu bazalnego, tj. facja warstwowana i w mniejszym stopniu rozproszona, ponieważ w nich koncentruje się zdecydowana większość transportowanego materiału skalnego. Przeprowadzono już obliczenia wielkości dopływu osadów na skutek ablacji w lodowcu Svínafellsjökull na Islandii (Cook i in., 2011) przy założeniu, że prędkość ruchu lodu wynosi 14,6-29,2 m/rok. Z facji rozproszonej lodu uwalniane jest 0,81 do 1,62 $\mathrm{m}^{3} / \mathrm{m} \cdot$ rok (na metr szerokości czoła lodowca w ciągu roku). Jest to wartość znacznie niższa od obliczonej dla facji warstwowanej lodu bazalnego (Cook i in., 2010), wynoszącej 4,8-9,6 $\mathrm{m}^{3} / \mathrm{m}$.rok (w przypadku przechłodzenia) i $1-2 \mathrm{~m}^{3} / \mathrm{m} \cdot$ rok (gdy za jego powstawanie odpowiedzialna była regelacja). Dla lodowca Russella na Grenlandii wyliczono znacznie wyższą wartość dostawy osadów z facji rozproszonej, bo aż $7,2 \mathrm{~m} / \mathrm{m} \cdot$ rok, ale było to związane ze znacznie grubszą warstwą lodu reprezentującego tę fację (Knight i in., 2002). Wadą powyższych obliczeń, przynajmniej z punktu widzenia badań eratyków wskaźnikowych, jest uwzględnianie całkowitej ilości uwalnianego materiału skalnego, a nie samej frakcji żwirowej. Dodatkowym utrudnieniem w analizach jest nieciągłe występowanie facji warstwowanej oraz bardzo zróżnicowane stosunki miąższości obydwu facji. Może to doprowadzić do wspomnianej już sytuacji, kiedy facja rozproszona dostarczyła znacznie więcej materiału skalnego niż warstwowana (Cook i in., 2011).

\subsection{Transport fluwioglacjalny}

Transport materiału skalnego przy udziale wód ablacyjnych szczególnie intensywnie mógł zachodzić na etapie deglacjacji arealnej, kiedy w szczelinach martwego lodu narzutniaki mogą być transportowane nawet na duże odległości - również w kierunku poprzecznym do pierwotnego ruchu lodu (Schulz, 2003). Przemieszczanie materiału 
w kanałach subglacjalnych i inglacjalnych odbywało się w kierunku na ogół zgodnym z ruchem lodu, ale możliwe były także dość znaczne odchylenia.

Na przedpolu lądolodów na Niżu Środkowoeuropejskim wody roztopowe odprowadzane były głównie na zachód (przynajmniej podczas ostatniego zlodowacenia). Ten kierunek odpływu sprzyjał przenoszeniu materiału wschodniego w krach i bryłach (górach) lodowych na obszar północno-zachodniej Europy. Niemal zupełny brak na terenie Polski skał norweskich zdaje się wskazywać, że i w dawniejszych zlodowaceniach przeważał ten sam kierunek odpływu wód ablacyjnych, a notowany lokalnie drenaż w kierunku Morza Czarnego miał charakter okresowy i był możliwy tylko przy dość dalekim na południe zasięgu lądolodu.

Analiza możliwości transportu frakcji piaszczystej i żwirowej w lodzie oraz w wodach in- lub subglacjalnych wykazała, że długość transportu glacjalnego i fluwioglacjalnego jest zbliżona, ale w drugim przypadku strefa rozrzutu materiału jest zwykle przesunięta o kilka do maksymalnie 25 km zgodnie z kierunkiem ruchu (Cummings i in., 2011 - na podstawie danych: Hellaakoski, 1931; Lee, 1965; Gillberg, 1968; Pertunnen, 1989; Bolduc, 1992; Levasseur i Prichonnet, 1995).

Rdzany (2009) podaje, że zawartość skał lokalnych w osadach fluwioglacjalnych w pobliżu wychodni i na obszarach o płytko zalegającym podłożu przekracza często w Polsce Środkowej 50\%, a niekiedy, zwłaszcza w osadach gruboklastycznych wypełniających tunele subglacjalne i inglacjalne, a niekiedy także koryta supraglacjalne, może sięgać nawet $80-90 \%$. Ten ostatni przykład z Siedlątkowa dowodzi, że erozja w czasie subglacjalnych przepływów mogła dostarczyć znacznie więcej materiału niż bardziej powierzchniowa i płytka erozja glacjalna. Mimo krótkiego transportu, materiał uległ dość szybkiej obróbce (Rdzany, 2009). W glinach warciańskich w Bełchatowie zawartość skał lokalnych sięgała maksymalnie niewiele ponad 30\%, a zwykle była znacznie niższa (Czubla, 2001). Podobne są wyniki badań i obserwacji z Lubelszczyzny. W osadach fluwioglacjalnych zawartość skał lokalnych (przede wszystkim krzemieni i czertów) jest bardzo zmienna i w niektórych stanowiskach bardzo wysoka (R. Dobrowolski, inf. ustna 2014), podczas gdy w przebadanych próbkach osadów glacjalnych Lubelszczyzny i Podlasia skały lokalne występowały w znikomych ilościach. Duży udział w osadach fluwioglacjalnych materiału transportowanego na krótkim odcinku, w Polsce w większości przypadków odłożonego przez wcześniejsze nasunięcia glacjalne, wskazuje na raczej ograniczoną przydatność i wiarygodność badań eratyków przewodnich pobranych z osadów fluwioglacjalnych w stosunku do materiału pobranego bezpośrednio z glin.

\subsection{Długość transportu glacjalnego}

Długość transportu materiału morenowego w lodzie stanowi od dawna przedmiot dyskusji. Maksymalny dystans transportu glacjalnego (pomijając transport po powierzchni oceanu w górach lodowych) jest szacowany przez większość badaczy na 1500 km, choć niektórzy podają nawet do 2500 km (Prest i Nielsen, 1985). Eratyki wywodzące się z Dalarny i Ångermanlandu, znajdowane w Polsce lub w środkowych Niemczech, musiały przebyć około 800 km w linii prostej. Badania w Skandynawii wykazały jednak, że daleki transport (setki km) odgrywa niewielką rolę, dominuje zaś stosunkowo bliski 
(np. Virkkala, 1974; Salonen, 1986, 1987; Donner, 1989; Bouchard i Salonen, 1990). W drodze na obszar Niżu Środkowoeuropejskiego skały skandynawskie musiałyby zatem być kilkakrotnie odkładane i powtórnie inkorporowane przez nasuwający się lądolód. Oznacza to, że skład gliny w dużym stopniu odzwierciedla skład podłoża nie tylko w strefie zasilania, ale i na drodze potoku (strumienia) lodowego. Potwierdził to Lindén (1975) dla liczącego $48 \mathrm{~km}$ południkowego profilu na zachód od Uppsali. Na rys. 9.3 przedstawiono wyraźny związek składu obydwu frakcji z budową podłoża, a to stawia pod znakiem zapytania wyniki badań głazowych. Nasuwa się pytanie, ile razy eratyki były inkorporowane przez lód i następnie deponowane na swojej drodze z Fennoskandii na Niż Środkowoeuropejski. Na wykresie dostrzec też można, że niektóre skały pojawiają się już po proksymalnej stronie wychodni, a to wskazuje na ich wcześniejszy transport na północ w środowisku raczej innym niż glacjalne (bądź na obecność innego obszaru źródłowego tego samego typu petrograficznego). Zdaniem Klemana i in. (2008) długi transport eratyków jest dużo bardziej prawdopodobny na etapie tworzenia się czaszy lądolodu, aniżeli podczas deglacjacji. Pogląd taki wynika z przyjętego przez tego autora modelu termiki lądolodu.

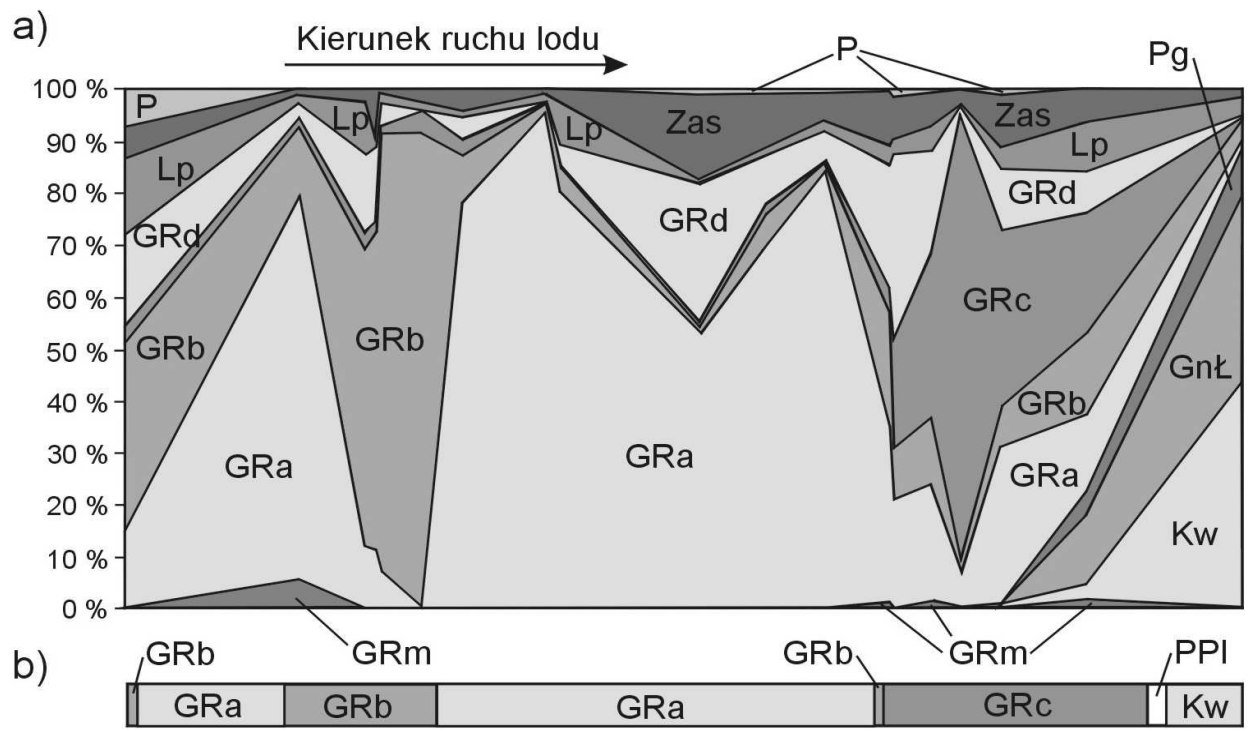

Rys. 9.3. Zależność składu zespołu eratyków frakcji 20-60 mm w glinie od rodzaju podłoża; a) zmienność

składu wraz z przemieszczaniem się lodu po wychodniach w podłożu, b) budowa geologiczna podłoża: GRa - granitoidy bogate w krzemionkę, GRb - granitoidy pośrednie, GRc - granitoidy ubogie w krzemionkę, GRd - granitoidy drobnokrystaliczne, GRm - granity mikroklinowe, PPI - porfiry, Kw - kwarcyty, GnŁ - gnejsy i łupki metamorficzne, Pg - pegmatyty, Lp - leptyty, Zas - skały zasadowe, P - skały pozostałe (rysunek wg Lindéna, 1975 i Ehlersa, 2011, zmieniony)

Figure 9.3. The relationship of the erratic boulders (fraction $20-60 \mathrm{~mm}$ ) in glacial tills to the geology of bedrock; a) the variability of the debris composition against the movement of ice sheet over the outcrops in the bed, b) geology of bedrock: GRa - granitoids rich in silica, GRb - intermediate granitoids, GRC - granitoids poor in silica, GRD - fine-crystalline granitoids, GRM - microcline granite, IBS - porphyries, Kw - quartzites,

GNL - gneisses and schists, Pg - pegmatites, Lp - leptites, Zas - alkaline rocks, P - other rocks

(after Linden, 1975 and Ehlers, 2011, modified) 
Nawet w północnych Niemczech położonych już blisko czoła lądolodu, gdzie raczej przeważała depozycja niż erozja (Kleman i in., 2008), w glinach występuje bardzo dużo skał lokalnych. Narzutniaki skandynawskiego pochodzenia mają znikomy udział w masie gliny. Frakcja ponad $2 \mathrm{~mm}$ stanowi przeciętnie nie więcej niż 3\%. Pozostałe $97 \%$ to piasek, muł i ił, złożone zapewne w przeważającej części z lokalnego materiału. Jako że osady miocenu i pliocenu są tam niemal pozbawione większych ziaren, to nic dziwnego, że wśród grubszej frakcji brak odpowiednich skał lokalnych i dostrzegane są jedynie eratyki fennoskandzkie (Ehlers, 2011). Na wysoki udział materiału bliskiego transportu w glinach północnych Niemiec zwrócono uwagę już ponad sto lat temu (Keilhack, 1896), dużo później podobną opinię przedstawili również Ahrens i in. (1982). Dalej na południe - w Saksonii, Turyngii i Westfalii, gdzie lądolód wkraczał na podłoże zbudowane ze skał litych, skład grubej frakcji w glinach jest wyraźnie inny. Okazuje się, że składniki południowego pochodzenia (lokalne) zdecydowanie przeważają (Ehlers, 2011). Odmienne przykłady przywołuje Meyer (1983), np. żwiry rzeczne południowego pochodzenia przykryte gliną niemal zupełnie wolną od głazików pochodzących z południa.

Bardzo wysoki udział skał pochodzących z Sudetów występuje w stanowiskach na Przedgórzu Sudeckim i - co oczywiste - w samych Sudetach. We frakcji $>20 \mathrm{~mm}$ w glinach i żwirach w Jaroszowie (Przedgórze Sudeckie) na skały lokalne (głównie sudeckie) przypada od 45 do 79\% całkowitej liczby oznaczonych klastów, a w Janowicach Wielkich (Sudety) aż 95\%. Należy jednak pamiętać, że nie wszystkie skały sudeckie i nordyckie dają się jednoznacznie oznaczyć metodami makroskopowymi. Istnieje spora grupa skał - zwłaszcza metamorficznych, które mogą pochodzić zarówno z Sudetów, jak i ze Szwecji i ich przypisanie do jednej bądź drugiej grupy, w oparciu o badania jedynie makroskopowe, obarczone jest znacznym błędem subiektywizmu.

Interesujące dane z Minnesoty, uzasadniające prowadzenie analiz eratyków w osadach glacjalnych, przytacza Jennings (2006). Według niej kolejne nasunięcia lodu o powtarzalnym kierunku zupełnie nie różnią się składem materiału morenowego. Autorka dostrzega też, że skład materiału morenowego ukształtował się bardzo wcześnie, sądząc po pochodzeniu klastów w analizowanych glinach. Tylko w dolnej części pokładu gliny oraz w pobliżu strefy marginalnej daje się zauważyć podwyższony udział materiału lokalnego (ibidem - str. 110).

$\mathrm{Na}$ skutek wielokrotnego deponowania i pobierania eratyki dalekiego transportu ulegają stopniowemu rozproszeniu w osadach glacjalnych, a udział materiału lokalnego systematycznie wzrasta. Powyższą prawidłowość trudno jednak zaobserwować na obszarach zbudowanych wyłącznie z osadów starszych zlodowaceń, ponieważ inkorporowany materiał lokalny jest jakościowo prawie identyczny (w odniesieniu do frakcji żwirowej) z transportowanym bezpośrednio (w jednym cyklu) z północy. Narastający udział skał lokalnych w osadach glacjalnych łatwiej można zidentyfikować na obszarach, gdzie podłoże zbudowane jest ze skał litych, np. w północnych Niemczech. Wówczas inkorporacja starszych osadów glacjalnych wiąże się również z wchłanianiem ziaren skał miejscowych. Prowadzi to do dużego zróżnicowania składu glin, w którym znaczący udział mają składniki transportowane w więcej aniżeli jednym lądolodzie (Ehlers, 2011). Należy przyjąć, że dotyczy to nie tylko Niemiec, ale też dużej części Niżu Środkowo- 
europejskiego. Dowody znaczącego udziału tego procesu w kształtowaniu się składu glin na obszarze Nowej Szkocji przytoczyli Finck i Stea (1995). Osady glacjalne powstałe przy znacznym udziale materiału odłożonego przez starsze lądolody określali jako gliny hybrydowe.

Budowa podłoża podczwartorzędowego Polski Północnej i Środkowej nie sprzyja badaniom udziału skał lokalnych w osadach glacjalnych i fluwioglacjalnych. Kolejne lądolody wkraczały na obszar zbudowany głównie z luźnych skał neogenu i plejstocenu preglacjalnego. Materiał podlegający inkorporacji reprezentował niemal wyłącznie drobne frakcje i w tej postaci był makroskopowo nieodróżnialny od również drobnej frakcji pochodzącej np. z obszaru niecki bałtyckiej. Jedynie frakcja żwirowa daje możliwość określenia długości transportu, ale jej udział w osadach glacjalnych Polski jest znikomy.

\subsection{Długość transportu a frakcja i kształt ziaren}

Materiał morenowy obecny w lodzie lodowcowym podlega obróbce zależnej od miejsca transportu (facji lądolodu). Na przykładzie lodowca Matanuska na Alasce udało się wykazać, że w bazalnej strefie lodu dominują ziarna zaokrąglone i mało zaokrąglone (reprezentujące wysoki stopień obróbki w zastosowanej sześciostopniowej skali), podczas gdy w morenie powierzchniowej przeważały klasty bardzo ostre i ostre (Lawson, 1979). Klasty transportowane w środowisku fluwioglacjalnym również podlegają intensywnej obróbce - obtoczeniu. W oparciu o badania w stopie trzech lodowców Boulton (1978) doszedł do wniosku, że w efekcie abrazji powstają ziarna o rozmiarach zwykle poniżej 0,5 $\mathrm{mm}$, podczas gdy kruszenie dostarcza materiału o rozmiarach większych od tej wartości. Dreimanis i Vagners (1971) potwierdzili dość oczywisty wniosek, że w pobliżu obszaru źródłowego rozkład bimodalny materiału okruchowego cechuje się przewagą grubej frakcji, a wraz z rosnącą odległością stopniowo narasta udział drobnej frakcji. Liczni badacze byli przekonani o istnieniu krańcowej wielkości ziaren transportowanych przez lód, poniżej której dalsze rozdrabnianie już nie zachodzi. To krańcowe rozdrobnienie miałoby być osiągane podczas transportu na odcinku zaledwie $<1,6$ km w New Hampshire (Drake, 1972) i trzykrotnie mniejszym $(0,5 \mathrm{~km})$ na Islandii (Humlum, 1985). Część badaczy powątpiewa jednak w istnienie takiej granicy, np. Haldorsen (1981).

Ziarna transportowane $w$ górnych warstwach lądolodu w zasadzie nie podlegają obróbce podczas transportu. Po części wynika to ze znikomej koncentracji materiału skalnego w lodzie, co znacząco redukuje możliwość kolizji. Wielkość naprężeń ścinających generowanych w tej strefie przez płynięcie nasuwcze lodu jest niewielka i nawet jeśli dojdzie do zetknięcia ziaren, to zwykle nie ulegają one abrazji ani kruszeniu (Kirkbride, 2002).

Nie ma dotychczas jednoznacznej opinii na temat zależności długości transportu glacjalnego od frakcji transportowanego materiału. Część badaczy reprezentuje pogląd, że taka zależność istnieje i grubsze ziarna transportowane są dalej (Gilberg, 1965; Szabo i in., 1975). Inni zaobserwowali odwrotne zjawisko, tj. dłuższy transport materiału 
drobnoziarnistego (np. Virkkala, 1971; Peltoniemi, 1985). Możliwe, że zależność pomiędzy frakcją i długością transportu jest nieznaczna (Pertunnen, 1977). Boulton (1975, 1979) sugeruje, że zależność pomiędzy frakcją i długością transportu nie jest ani wprost, ani odwrotnie proporcjonalna, szybszemu i dłuższemu transportowi podlegają natomiast ziarna z określonego przedziału rozmiarów. Powyższe opinie (zwłaszcza ostatnia) byłyby uzasadnione pod warunkiem, że w środowisku transportu następowałaby selekcja wielkościowa ziaren. W przypadku uwięzienia materiału w lodzie taka selekcja jednak nie zachodzi. Co najwyżej ziarna znajdujące się w części bazalnej lądolodu mogą podlegać przyspieszonemu niszczeniu i rozdrabnianiu. W związku z tym należy uznać za najbliższe rzeczywistości twierdzenie o niezależności długości ruchu cząsteczek w lodzie od ich rozmiarów (Hallet, 1979, 1981). Selekcja wielkościowa, a co za tym idzie i zróżnicowanie długości transportu, następuje natomiast w warunkach fluwioglacjalnych.

Doszukiwano się również związku pomiędzy kształtem ziaren a środowiskiem transportu i depozycji (m.in. Holmes, 1960; Drake, 1972; Boulton, 1975, 1978). Ziarna wyerodowane z podłoża są początkowo transportowane $\mathrm{w}$ bazalnej strefie trakcji, gdzie cząsteczki wchodzą często w kontakt z podłożem i ulegają niszczeniu. Większe okruchy skalne transportowane $\mathrm{w}$ tej strefie podlegają obtoczeniu, kruszeniu oraz rysowaniu i szlifowaniu powierzchni. Duże głazy złożone w glinie typu lodgement wykazują tendencję do ułożenia zgodnie z kierunkiem ruchu lodu i ten sam kierunek wskazują widoczne na nich rysy. Klasty oderwane ze ścian skalnych i nunataków (odnosi się to głównie do lodowców górskich, a nie lądolodów) mają na ogół kanciaste kształty i mogą je zachować, jeżeli transportowane są supraglacjalnie lub inglacjalnie. Ten typ transportu ma zwykle pasywny charakter (Boulton, 1978). Kształt ziaren, ich rozmiary i stopień obtoczenia nie zależą wyłącznie od środowiska i długości transportu, ale w bardzo dużym stopniu również od składu mineralnego oraz cech teksturalnych i strukturalnych skały macierzystej.

Większość eratyków frakcji >20 mm, występujących w osadach glacjalnych Polski, cechuje się dość wysokim stopniem obtoczenia, a to może świadczyć, że przynajmniej część swojej drogi pokonały transportowane w strefie bazalnej lądolodu. Pozostawanie w trakcji dennej musiało być krótkotrwałe - w przeciwnym wypadku głaziki uległyby dalszemu rozdrobnieniu. Możliwe też, że już w momencie pobierania przez lód cechowały się dobrym obtoczeniem, np. w efekcie wcześniejszego transportu w środowisku rzecznym. 


\section{ERATYKI WSKAŹNIKOWE - PRZEWODNIE I POMOCNICZE}

Do eratyków wskaźnikowych zaliczamy wszystkie skały pozostawione przez lądolody ilodowce, które dzięki znajomości miejsca ich pochodzenia (pierwotnej wychodni), mogą posłużyć do określenia strefy alimentacji lądolodu oraz dróg migracji mas lodowych w obrębie lądolodów. Pośrednio mogą też być wykorzystywane do korelacji osadów glacjalnych oraz ustalania ich przynależności stratygraficznej. Należy jednak mieć świadomość, że różnorodność oraz zmienność przestrzenna i czasowa procesów, które doprowadziły do ich złożenia w osadach glacjalnych (por. m.in. Jasiewicz, 2006), bardzo utrudniają, jeśli nie wykluczają, jednoznaczną interpretację. W związku z tym wnioski stratygraficzne lub paleogeograficzne, bazujące na analizach eratyków wskaźnikowych, koniecznie winny być wsparte innymi rodzajami badań (np. Czubla i Forysiak, 2004, 2013; Czubla i in., 2007a, 2010a, 2010b, 2013a, 2013b, Terpiłowski i in., 2012, 2013, 2014; Woźniak i in., 2009, 2013a; Pidek i in., 2013, 2014; Woźniak i Czubla, 2014a, 2014b, w druku).

Wśród eratyków wskaźnikowych wyróżniane są dwie grupy, tj. właściwe eratyki przewodnie i eratyki pomocnicze. Eratyki przewodnie wykazują odrębne właściwości petrograficzne, które pozwalają na ich jednoznaczne odróżnienie od innych typów skał oraz mają ograniczony, dobrze zdefiniowany obszar macierzysty (Lüttig, 1991). Zdaniem Gaigalasa (1971b) eratyki przewodnie powinny również cechować się zbliżoną odpornością na wietrzenie i erozję, co pozwoli na zachowanie stabilnych proporcji pomiędzy nimi, niezależnie od długości i czasu transportu. Eratyki pomocnicze mają na ogół znacznie większe wychodnie źródłowe, w obrębie których może zaznaczać się dość wyraźna zmienność petrograficzna. Wychodnie niektórych skał pomocniczych mogą być porozdzielane na kilka części.

Nie ma jednoznacznego kryterium, które na podstawie wielkości wychodni pozwoliłoby zaklasyfikować skałę jako przewodnią lub pomocniczą. W Niemczech pojawiła się opinia, że o randze skały w badaniach eratyków powinny decydować razem wielkość wychodni i długość transportu glacjalnego do miejsca złożenia osadu. W przypadku długiego transportu (kilkaset $\mathrm{km}$ ) dopuszczalne ma być zakwalifikowanie do skał przewodnich nawet takich, których wychodnie mają powierzchnię ponad $1000 \mathrm{~km}^{2}$. Dla skał, które przebyły najdłuższą drogę z północy, jak np. granit Revsund, przeszkodą w zali-czeniu do tej grupy nie było ani rozczłonkowanie wychodni na kilka izolowanych części, ani jej sumaryczna powierzchnia wynosząca około $6000 \mathrm{~km}^{2}$ (Meyer i Lüttig, 2007). Biorąc jednak pod uwagę frakcję wykorzystywaną przez cytowanych autorów (20-60 mm), dyskusja na temat rangi granitów Revsund wydaje się bezprzedmiotowa, ponieważ te bardzo grubokrystaliczne granity nader rzadko są w niej rozpoznawalne. Niemożność identyfikacji w małych ziarnach większości magmowych skał grubokrystalicznych była zresztą jedną z głównych przesłanek, które skłoniły autora do 
zakwestionowania powszechnie stosowanej górnej granicy rozmiarów analizowanych klastów (Czubla, 2001). W przypadku skał, których droga transportu była znacznie krótsza, rzędu $100 \mathrm{~km}$, wychodnia o powierzchni około $100 \mathrm{~km}^{2}$ może być zdaniem Meyera i Lüttiga (op. cit.) uznana za relatywnie zbyt rozległą.

Współczesnej wychodni analizowanej skały przewodniej nie wolno utożsamiać z istniejącą w plejstocenie (Kummerow, m.in. 1927, 1956). Dotyczy to zwłaszcza skał osadowych o małej miąższości i niewielkim upadzie, które mogły podlegać istotnej denudacji. Jest to pogląd akceptowany również przez Lüttiga (1958), ale z zastrzeżeniem, że nie dotyczy on skał krystalicznych. Przesunięcie wychodni skał magmowych lub metamorficznych w efekcie erozji jest jego zdaniem niewielkie, a w odniesieniu do skał osadowych nawet lepsze jest uwzględnienie w badaniach współczesnej wychodni niż spekulowanie, gdzie centrum wychodni mogło znajdować się podczas rozwoju lądolodu. W opinii autora powyższe rozumowanie Lüttiga (op. cit.) nie prowadzi jednak do żadnego konstruktywnego wniosku, bo TCG (obliczone w oparciu o współrzędne wychodni eratyków) nie jest przecież realnym centrum rozwoju lądolodu i nie przypisujemy mu konkretnego miejsca na mapie. To tylko para liczb, służąca porównaniom z analogicznymi wskaźnikami obliczonymi dla innych osadów glacjalnych. Lokowanie teoretycznego centrum głazowego na mapie Fennoskandii (np. Vinx i in., 1997; Górska, 2000; Górska-Zabielska, 2008; Lipka, 2011) powoduje tylko u czytelnika niepotrzebne złudzenie, jakoby był to realny środek obszaru alimentacji analizowanego lądolodu. W rzeczywistości mogłoby tak być tylko w przypadku, jeśli cały obszar Fennoskandii pokryty byłby równomiernie wychodniami skał przewodnich, a lądolód płynąłby tylko w jednym kierunku. Istnieją jednak olbrzymie obszary, jak np. znaczna część dna Bałtyku, skąd żadne skały przewodnie jak dotychczas nie zostały rozpoznane. Nie należy też przeceniać przesunięcia granic wychodni skał osadowych w plejstocenie. Nawet jeśli pomiędzy poszczególnymi awansami lądolodu miało ono miejsce, to różnica była najprawdopodobniej znikoma - zwłaszcza w kontekście przyjmowanej przez większość autorów niewielkiej skali erozji Fennoskandii (patrz rozdz. 8). Warto mieć na uwadze, że niewielkim zmianom zasięgu mogły ulegać nie tylko wychodnie skał osadowych, ale też wulkanicznych wylewnych, a także niektórych metamorficznych - wszystkie, tworzące formy o niewielkiej miąższości i dużym zasięgu poziomym. Na małą skalę zmian zasięgu wychodni wraz z postępującą erozją wskazują obliczenia, z których wynika, że usunięcie 1 metra skał osadowych w niecce Bałtyku spowodowałaby przesunięcie granic wychodni skał nachylonych pod kątem średnio $0,2^{\circ}\left(0,1-0,3^{\circ}\right.$ wg Noormets i Flodén, 2002) o zaledwie 286,5 metra. Oznacza to, że całkowite przesunięcie granic wychodni skał wyścielających centralny Bałtyk, gdzie erozja zdarła około $60 \mathrm{~m}$ skał osadowych (Tuuling i Flodén, 2001), wyniosłoby co najwyżej niewiele ponad 17 kilometrów na południowy wschód, co w skali rozmiarów dna Bałtyku pozostaje wartością umiarkowaną. Na zmiany położenia granic warstw i powierzchni intruzji nachylonych pod większym kątem, rzędu kilku i więcej stopni, erozja ma wpływ jeszcze mniejszy.

W ciągu ostatnich kilkunastu lat rozgorzała ostra dyskusja na temat szerszego uwzględnienia skał osadowych w analizach eratyków przewodnich. Gorącym orędownikiem tej opcji jest Smed prowadzący badania w Danii (1997, 2000, 2002, 2010), 
a w Polsce w propagowanie tej korekty metodycznej aktywnie zaangażowały się Górska (2003a; Górska-Zabielska, 2008) i Lipka (2011). Położenie Danii w południowo-zachodnim sektorze lądolodu fennoskandzkiego, daleko na zachód od większości wychodni paleozoicznych skał osadowych, być może usprawiedliwia tę korektę metodyki. Większość skał osadowych z basenu Bałtyku ma jednak wychodnie ciągnące się na bardzo długim dystansie i każdy strumień lub potok lodowy, kierujący się nie na zachód w kierunku Cieśnin Duńskich, lecz na południe - w kierunku Polski lub krajów perybałtyckich, musiał je przekroczyć. Ustalenie, w której części wychodni to nastąpiło jest niemożliwe. W związku z tym lokowanie olbrzymiego koła, obrazującego wysoki udział danej skały osadowej w zespole, na mapie kołowej powoduje fałszywe wrażenie dominacji ustalonego przez Smeda $(2000,2010)$ centralnego punktu wychodni danej skały i prowokuje do wyznaczenia przez nie drogi lodu na południe. Mające znacznie mniejsze wychodnie i, w konsekwencji, znacznie słabiej reprezentowane na mapie kołowej skały magmowe sprawiają wrażenie mało istotnych w porównaniu z wyeksponowanymi graficznie skałami osadowymi, podczas gdy w rzeczywistości to one właśnie dostarczają bardziej wiarygodnych informacji. Na ten mankament map kołowych w nowej interpretacji Smeda (op. cit.), uwzględniającej liczne skały osadowe z basenu Bałtyku, zwracają uwagę również Meyer i Lüttig (2007). Ci ostatni autorzy kategorycznie odrzucają stosowanie pojęcia eratyki statystyczne (statistische Leitgeschiebe), logicznie twierdząc, że wszystkie skały przewodnie poddawane są procedurze statystycznej, jaką jest obliczanie teoretycznych ośrodków głazowych. Skały wprowadzane na mapy kołowe przez Smeda mają zbyt duże wychodnie, by mogły być uwzględniane w obliczeniach TCG, a więc z założenia statystycznymi nie są (Lüttig, 2007; Meyer i Lüttig, 2007).

Wielu autorów skoncentrowało się na analizach tylko skał krystalicznych (głównie magmowych), a spośród skał osadowych akceptuje jedynie zlepieńce i piaskowce Digeberga (np. Hesemann, 1936, 1975; Richter, 1933; Schuddebeurs, 1980/1981; Zandstra, 1983a, 1988). Skrajnie ortodoksyjne stanowisko zajmuje Gałązka (2004b), który uwzględnia wyłącznie skały krystaliczne. Niską rangę skałom osadowym przypisują także Gaigalas i Gudelis (1965). Wyróżniają oni trzy kategorie eratyków, tj. główne skały przewodnie, drugorzędne skały przewodnie i skały towarzyszące. W dwóch pierwszych kategoriach znalazły się wyłącznie skały magmowe i dopiero wśród skał towarzyszących zostały wymienione nieliczne skały osadowe. Zdaniem cytowanych autorów wnioski paleogeograficzne można wyciągać wyłącznie w oparciu o analizę głównych skał przewodnich, tj. rapakiwi z masywu Wyborga, porfirów kwarcowych Hogland, diabazów oliwinowych Satakunta, porfirów kwarcowych Alnö ${ }^{5}$, porfirów botnickich, bałtyckich, dalarneńskich i smalandzkich, rapakiwi z południowo-zachodniej Finlandii oraz skał alandzkich. Ten generalnie słuszny dla Litwy, Łotwy lub Estonii wniosek trudno jednak przenieść na obszar Polski, ponieważ spośród wymienionych skał tylko część (od porfirów botnickich po skały alandzkie) występuje w znaczących ilościach w osadach glacjalnych naszego kraju. Należy jednak zaznaczyć, że Gaigalas (1971b) przypisywał różną rangę tego samego typu skale w zależności od analizowanego obszaru, np. diabaz oliwinowy Satakunta w Estonii miał pełnić rolę eratyka głównego, na Litwie zaś już tylko

\footnotetext{
${ }^{5}$ Tak podano w cytowanej publikacji, ale autorom chodziło zapewne o porfir kwarcowy Rödö.
} 
drugorzędnego. Dyskusja na temat rangi poszczególnych skał jako eratyków wskaźnikowych nie jest niczym nowym. Właściwie już od zarania badań głazowych istniały kontrowersje dotyczące sposobu poboru próby, jej wielkości, wykorzystywanej frakcji, metod przeliczania i - przede wszystkim - listy skał uznawanych za przewodnie (np. Milthers, 1934; Hesemann, 1934, 1960) - patrz rozdz. 4 i 5. Szerszą dyskusję metodyczną przedstawiano już kilkakrotnie (m.in. Kummerow, 1954; Lüttig, 1958; Gudelis, 1971; Nunberg, 1971; Schuddebeurs, 1980/1981, 1986; Czubla, 2001; Gałązka, 2004b) i nie będzie ona tu powtarzana.

Strefa alimentacji lądolodów fennoskandzkich miała zasięg zmienny w czasie i w decydującym stopniu uzależniony od reżimu termicznego. Obejmowała całą Skandynawię, Finlandię, nieckę dzisiejszego Morza Bałtyckiego, znaczną część szelfu Morza Barentsa, Półwysep Kolski i zachodnią Karelię. Rozszerzanie strefy zimnego reżimu termicznego powodowało, że inkorporacja materiału skalnego przesuwała się ku zewnętrznym częściom czaszy lodowej. Istniała wtedy możliwość włączania w masę lodu skał ze stopniowo zajmowanych obszarów, np. Europy Środkowej (patrz rozdziały 6-9).

Znaczący wpływ na dostawę materiału skalnego na obszar Niżu Środkowoeuropejskiego miały oscylacje linii podziału lodu - zwłaszcza we wczesnych etapach rozwoju lądolodów, kiedy istniały tam możliwości inkorporacji materiału skalnego i dość szybkiego transportu ku marginalnym strefom rozwijającej się czaszy lodowej. Zdaniem Ehlersa w fazie inicjalnej każdego zlodowacenia linia podziału leżała w pobliżu głównego skandynawskiego działu wodnego (Ehlers, 1981, 1983; Ehlers i Stephan, 1983). Wraz z rozwojem przestrzennym lądolodu miała ona stopniowo przesuwać się na wschód aż po strefę współczesnego wybrzeża zatoki Botnickiej. W schyłkowym okresie zlodowacenia, kiedy zmiany klimatyczne wymuszały postępujące ograniczanie zasięgu lądolodu, dochodziło do powrotu linii podziału na jej pierwotną pozycję w rejonie wododziału Gór Skandynawskich. Skrajne stanowisko na temat migracji linii podziału lodu reprezentują badacze estońscy. W oparciu o interpretację kierunków napływu lodu na terytorium Estonii doszli do wniosku, że centrum zlodowacenia, funkcjonujące początkowo w Górach Skandynawskich, przesuwało się wraz z rozwojem ostatniego lądolodu aż po środkową Finlandię, warunkując południkowy kierunek napływu lodu (Tavast i Raukas, 1982; Raukas, 1995).

Na obszar naszego kraju możliwy był transport glacjalny jedynie tych skał, których wychodnie leżały na południe i południowy wschód od linii podziału lodu. Oznacza to, że w żadnych osadach glacjalnych Polski nie należy spodziewać się obecności eratyków przywleczonych z Karelii, Półwyspu Kolskiego, północnej i środkowej Finlandii i prawie całej Norwegii, skąd skały wynoszone były w zupełnie innych kierunkach. Wyznaczone w Finlandii kierunki transportu glacjalnego podczas ostatniego zlodowacenia (m.in. Salonen, 1987; Rauhaniemi i in., 1999) wykluczają dostawę na obszar Polski również skał południowofińskich. Nie podważa to jednak możliwości okresowej migracji lodu z tamtego kierunku we wcześniejszych zlodowaceniach.

Ta część obszaru alimentacji lądolodu fennoskandzkiego, z której materiał skalny mógł być przenoszony na obszar Polski, zbudowana jest głównie ze skał krystalicznych, wchodzących w skład tarczy fennoskandzkiej. Największą powierzchnię zajmują tam 
gnejsy i mało zróżnicowane granitoidy, wśród których tylko nieliczne mają cechy na tyle charakterystyczne, by dały się przypisać do konkretnego obszaru źródłowego (por. m.in. Simonen, 1960; Meyer, 1985; Smed, 1994, 2002; Lauri i in., 2005; Linnemann i in., 2008). Większe wystąpienia proterozoicznych i paleozoicznych skał osadowych ograniczone są niemal wyłącznie do niecki bałtyckiej (rys. 10.1). Mniejsze wychodnie tych skał występują także w południowej i środkowej Szwecji oraz w Finlandii (por. m.in. Simonen, 1960; Ludwig, 1967; Winterhalter i in., 1981; Błaszczyszyn i in., 1982; Lehtovaara, 1982; Flodén, 1984; Emelyanov i Kharin, 1988; Männil, 1988; Smed, 1994, 2002; Amantov i in., 1995; Mojski, 1995; Kramarska, 1999, 2000; Ūsaitytè, 2000; Stupnicka, 2007; Linnemann i in., 2008; Harff i in., 2011; Šliaupa i Hoth, 2011; Tuuling i in., 2011).

Dotychczas udało się wyróżnić około 200 charakterystycznych typów skał przewodnich, które w postaci eratyków mogły zostać przyniesione przez lód na obszar Niżu Środkowoeuropejskiego (Hesemann, 1936, 1960, 1975; Lüttig, 1958; Smed, 1994, 2002) - rys. 10.2. Większość z nich została wytypowana na wczesnym etapie rozwoju badań eratyków, ale nadal podejmowane są próby wprowadzenia do tej kategorii badań nowych rodzajów skał (Geisler, 1996; Vinx, 1996, 1998, 1999). Spośród tej licznej grupy skał przewodnich pospolicie występuje tylko kilkadziesiąt - 30-40, pozostałe znajdowane są dość rzadko (Schuddebeurs, 1980/1981; Meyer, 1983). W Polsce eratyków reprezentujących pospolite skały jest jeszcze mniej. Głównie za sprawą ominięcia większości obszaru Polski przez masy lodu napływające z Norwegii i zachodniej Szwecji. Wbrew oczekiwaniom nie zastąpiły ich nawet we wschodniej Polsce skały z Finlandii i rosyjskiej Karelii.

Częstotliwość występowania różnych eratyków wskaźnikowych zależy w dużej mierze od pozycji stratygraficznej osadu glacjalnego (np. Meyer, 1983; Czubla, 2001), czyli pośrednio od obszaru alimentacji i drogi transportu materiału morenowego na obszar Niżu Środkoweoeuropejskiego. Nie można jednak pomijać wpływu rozmiarów wychodni w Fennoskandii, rzeźby terenu w obrębie wychodni, odporności skały na procesy wietrzeniowe, gęstości spękań ciosowych w skale pierwotnej, warunkującej rozmiary eratyków, lokalizacji miejsca poboru próby w stosunku do obszaru alimentacji lodu etc. Większość znalezisk rzadkich eratyków przewodnich została dokonana przez hobbystów na plażach bałtyckich lub w żwirach o różnej genezie, a nawet pryzmach kamieni zebranych z pól Niemiec, Danii i Holandii. Nie mają one istotnego znaczenia naukowego i stanowią tylko ciekawostki. W próbach pobieranych dla potrzeb badawczych najczęściej ich nie ma. Powszechnie występują w różnych proporcjach jedynie podstawowe typy skał przewodnich. Zatem do badań głazowych wystarczy umiejętność sprawnego identyfikowania zaledwie kilkudziesięciu (maksymalnie ok. 40) typów najważniejszych rodzajów skał przewodnich i pomocniczych (por. Meyer, 1983). W osadach glacjalnych Niemiec 20-25 rodzajów eratyków przewodnich stanowi zwykle $3 / 4$ składu rozpoznanych w próbce eratyków przewodnich (Meyer, 1985 - str. 80). Przytoczona opinia Meyera i tak opiera się na analizach z obszaru, gdzie zróżnicowanie skał przewodnich jest dużo większe niż w Polsce. W większości stanowisk w naszym kraju na wspomniane $3 / 4$ składu zespołu eratyków przewodnich złożyłoby się raczej 15-20 typów. Ogólne pojęcie o pochodzeniu analizowanej masy lodu może dać według 


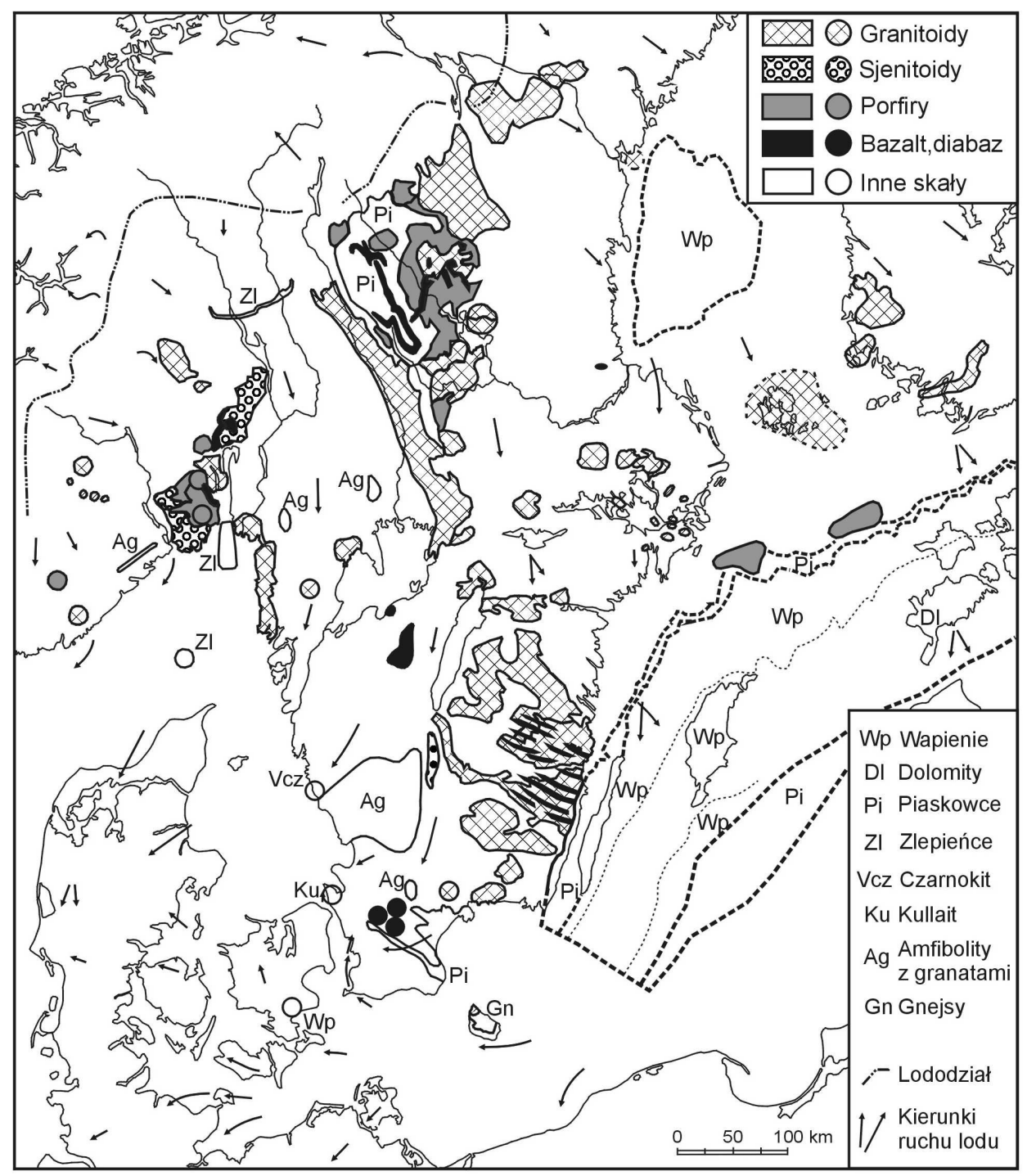

Rys. 10.1. Obszary macierzyste bałtycko-fennoskandzkich skał wskaźnikowych (wg Smeda, 1993, uproszczone; za Czubla, 2001)

Figure 10.1. Source areas of Baltic-Fennoscandian indicator rocks (auxiliary rocks including) (according to Smed, 1993, simplified; after Czubla, 2001) 


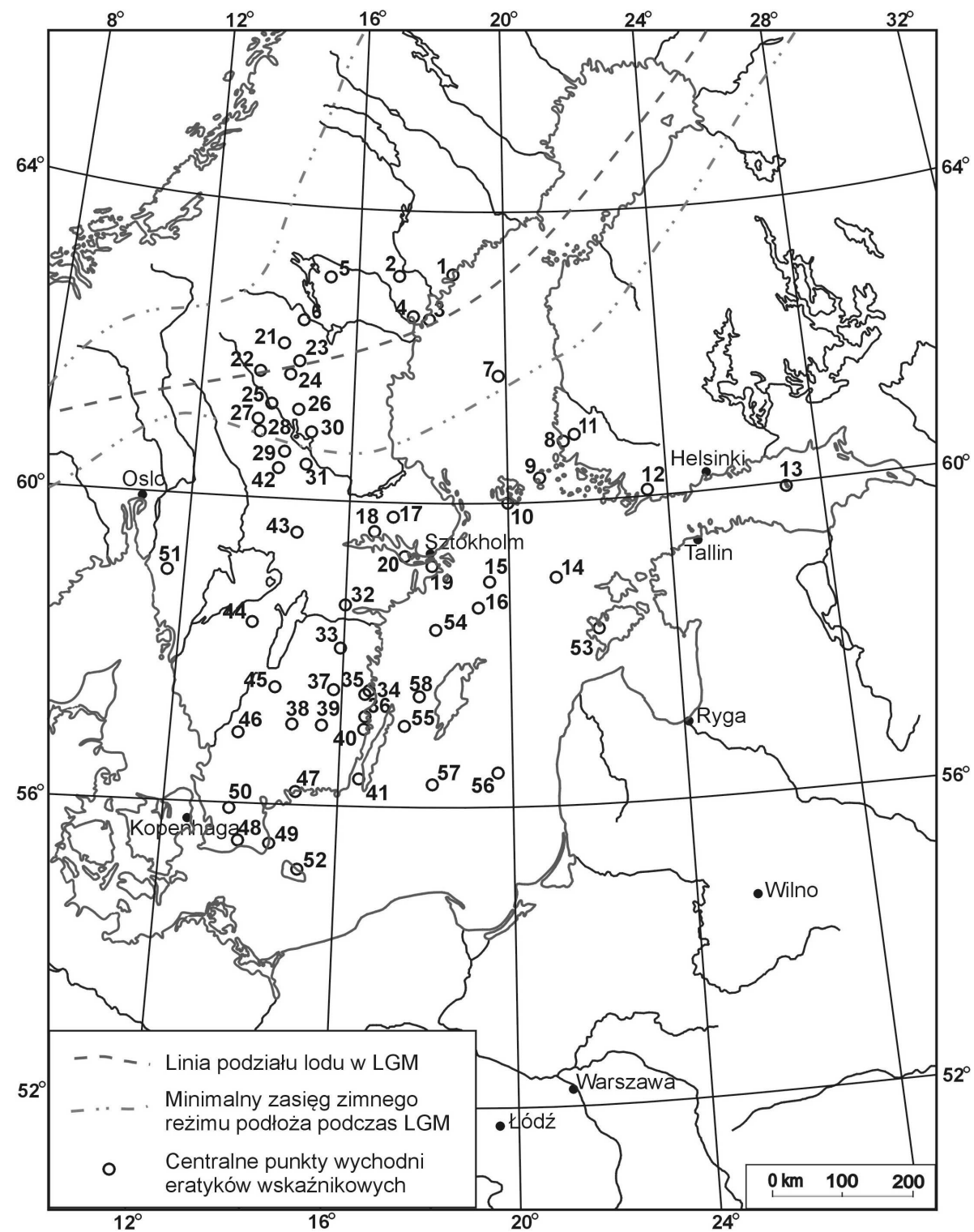

Rys. 10.2. Rozmieszczenie obszarów źródłowych eratyków przewodnich i wybranych eratyków pomocniczych w odniesieniu do przypuszczalnego przebiegu linii podziału lodu w LGM (wg Klemana i Stroevena, 1997) oraz do minimalnego zasięgu strefy występowania w LGM zimnego podłoża lądolodu fennoskandzkiego (wg Klemana i in., 1997); numery centralnych punktów wychodni eratyków wskaźnikowych zgodne z tab. 4.4

Figure 10.2. Location of geographical centers of the source areas of indicator erratics (selected types of auxiliary erratics including) in relation to a supposed ice-divide line (dashed line; according to Kleman \& Stroeven, 1997) and to a minimal range of cold thermal regime of Fennoscandian Ice Sheet during the LGM (dashed and dotted line; according to Kleman et al., 1997); numbers of points (indicator erratics) as in Tab. 4.4 
Ehlersa (2011) rozpoznanie nawet kilku najważniejszych i łatwo rozpoznawalnych skał. Zalicza on do tej grupy porfiry alandzkie, granity rapakiwi z Wysp Alandzkich i Finlandii, porfiry bałtyckie, porfir Påskallavik, smålandzkie granitoidy z niebieskim kwarcem, plamisty gnejs z Västervik, porfir Bredvad i diabaz Kinne.

W zdobyciu umiejętności identyfikacji najważniejszych eratyków, poza kolekcjami referencyjnymi, bardzo pomocne mogą być liczne, bogato ilustrowane atlasy skał przewodnich (Korn, 1927; Gudelis, 1971; Hesemann, 1975; Smed, 1994, 2002; Zandstra, 1999; Schulz, 2003; Rohde, 2007, 2008; Rudolph 2008a, 2008b). Większość wymienionych opracowań przeznaczona jest przede wszystkim dla amatorów - zbieraczy skał narzutowych, ale z powodzeniem można je wykorzystać również dla potrzeb naukowych. Do dziś brakuje jednak polskojęzycznego atlasu skał wskaźnikowych. Tę lukę tylko częściowo wypełnia wspólne opracowanie polskich badaczy skał narzutowych (Czubla i in., 2006). Ze względu na szczegółowe charakterystyki i liczne fotografie eratyków przedstawione $w$ wymienionych powyżej atlasach zbędne jest powielanie dokładnych opisów skał i metod ich rozpoznawania w niniejszej publikacji. Autor uznał za o wiele istotniejsze skoncentrowanie się na rozmieszczeniu przestrzennym i czasowym (w różnowiekowych osadach glacjalnych) poszczególnych rodzajów eratyków w Polsce. Ze względu na niejasną pozycję stratygraficzną bardzo wielu analizowanych pokładów glin, autor uznał za niegwarantujące pełnego obiektywizmu przyporządkowywanie ich do konkretnych faz i stadiałów i ograniczył się do wyróżniania osadów glacjalnych przypisywanych tylko trzem głównym kompleksom glacjalnym plejstocenu Polski (sensu Ber i in., 2007; Lindner i Marks, 2012; Lindner i in., 2013).

W miarę możliwości własne dane na temat dystrybucji eratyków w Polsce uzupełnione zostały informacjami opublikowanymi przez innych badaczy czwartorzędu. Obszar Polski północno-wschodniej został przebadany przez Gałązkę (2004b), a Polski północno-zachodniej i zachodniej przez Górską (2000; Górska-Zabielska, 2008) i Lipkę (2011), nie licząc licznych starszych prac geologów niemieckich. Bardzo skromnie na tym tle wypada Polska Południowa, ponieważ w okresie powojennym prowadzili tam badania właściwie tylko Konieczny (1956; Konieczny i Wdowiak, 1971) i Dudziak (np. 1973, 1978, 1980), ale uzyskane przez nich wyniki są trudne do wykorzystania ze względu na zastosowaną metodykę. Obszerny przegląd historii badań eratyków na terenie Polski był już publikowany (m.in. Jaroszewicz-Kłyszyńska, 1938b; Nunberg, 1971; Czubla, 2001; Gałązka, 2004b) i niecelowe jest jego powtarzanie w niniejszym opracowaniu.

\subsection{Eratyki z Ångermanlandu i krain przyległych - północna Szwecja}

Wśród skał z północnej Szwecji udało się wyróżnić stosunkowo niewiele eratyków przewodnich. Należą do nich granity Revsund (fot. 10.1), Ragunda (fot. 10.2), Björna, alnöit (fot. 10.3), granity i granitognejsy Ångermanland oraz cały zespół skał Rödö. Nie ma jednoznacznej opinii na temat ich znaczenia jako skał przewodnich. Gaigalas i Gudelis jedynie skały Rödö zaliczają do głównych skał przewodnich, pozostałe zaś lokują w grupie skał drugorzędnych - granity Ragunda i Revsund, bądź ledwie towarzyszących 
- porfiry Ragunda oraz granity i gnejsy z Ångermanland (Gaigalas i Gudelis, 1965; Gaigalas, 1971b). Inni badacze traktują je jako typowe skały przewodnie (Lüttig, 1958; Hesemann, 1975; Smed, 1994 (oprócz granitów i granitognejsów Ångermanland); Zandstra, 1999; Gałązka, 2004b).

Wątpliwości budzi przede wszystkim położenie wychodni skał północnoszwedzkich w stosunku do linii podziału lodu. Kleman i Stroeven (1997) przedstawili hipotetyczny przebieg tej linii dla ostatniego zlodowacenia. Ich zdaniem prowadziła ona od centrum południowej Norwegii prawie równoleżnikowo na północne peryferie Dalarny, stamtąd kierowała się bardziej na północny wschód, przechodziła przez północną część Botniku Południowego, a następnie przez wschodni Botnik Północny (rys. 10.2). Gdyby ten model był prawdziwy i stabilny w czasie, na Niżu Środkowoeuropejskim nie powinno być żadnych skał północnoszwedzkich, a i skały z Dalarna winny występować stosunkowo rzadko. Nawet jeżeli linia podziału przebiegała w rzeczywistości na północ lub północny zachód od wychodni tych skał, to bardzo powolny ruch lodu, typowy dla obszarów położonych w pobliżu tej linii (m.in. Donner, 1989), powinien w znacznym stopniu utrudnić ich rozprzestrzenianie się (patrz rozdz. 6). Poza tym, podczas maksimum ostatniego zlodowacenia większość wychodni eratyków północnoszwedzkich znalazła się w strefie zimnego reżimu podłoża (Kleman i in., 1997), gdzie pobór materiału był bliski zeru. Nawet zmiana reżimu na ciepły na etapie deglacjacji nie mogła już nic zmienić w składzie zespołów eratyków w glinach vistulianu w Polsce, ponieważ niewielka prędkość lodu blisko linii podziału oraz ograniczone ramy czasowe tego etapu nie pozwalały na daleki transport materiału skalnego. Co najwyżej mogło wówczas dojść do przemieszczenia eratyków z Dalarny i Ångermanlandu bardziej na południe i południowy wschód, skąd mogłyby być inkorporowane podczas kolejnego awansu lądolodu.

Dodatkowy problem stanowi oznaczanie niektórych typów skał z północnej Szwecji. Granity Revsund i Björna są bardzo grubokrystaliczne i w osadach glacjalnych zachowują się najczęściej w postaci pojedynczych kryształów skaleni i kwarcu lub ich fragmentów. W związku z tym szanse ich prawidłowej identyfikacji są znikome. Niewiele lepiej wygląda rozpoznawanie skał Rödö. Porfiry Rödö różnią się od swoich alandzkich odpowiedników właściwie tylko nieco jaśniejszym kwarcem, ale wśród porfirów z Wysp Alandzkich występuje dość duże zróżnicowanie zabarwienia fenokryształów kwarcu. Granity Rödö cechują się obecnością niewielkich skupień kalcytu, którym nawet zawdzięczają drugą nazwę „granity wapienne” (Kalkgranite - Hesemann, 1975), ale kalcyt dość rzadko występuje w małych głazikach tej skały. Klasty pozbawione domieszki kalcytu są bardzo trudne, o ile w ogóle możliwe, do makroskopowej identyfikacji. Dobre opisy zaprezentowane przez Korna (1927) i Hesemanna (1975) odwołują się w znacznej części do cech rozpoznawalnych tylko mikroskopowo, jak np. specyficzne, faliste wygaszanie światła przez kwarc w granicie rapakiwi Rödö, będące trwałym wynikiem naprężeń deformujących kiedyś skałę. Alnöity są łatwo rozpoznawalne, ale ze względu na liczne i duże blaszkowe kryształy biotytu szybko ulegają wietrzeniu i w konsekwencji rozpadowi na małe fragmenty, co nie sprzyja ich przetrwaniu w grubożwirowej frakcji osadów glacjalnych. Problemy, jakie sprawiało odróżnianie skał z północnej Szwecji od 


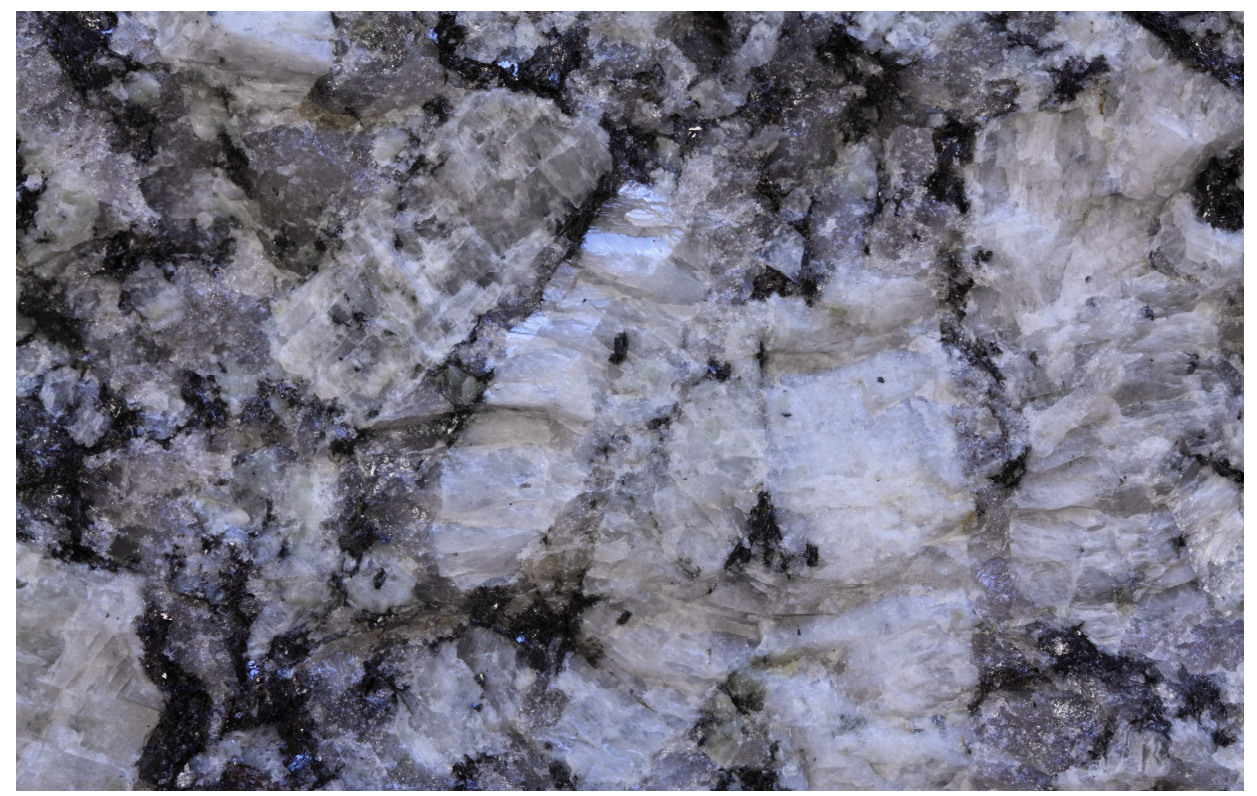

Fot. 10.1. Granit Revsund, Valla - Ragunda, środkowa Szwecja; rozmiar dłuższego boku 80 mm; fot. P. Czubla 2015

Photo 10.1. Revsund granite, Valla - Ragunda, Central Sweden; picture width $80 \mathrm{~mm}$. Photo P. Czubla 2015

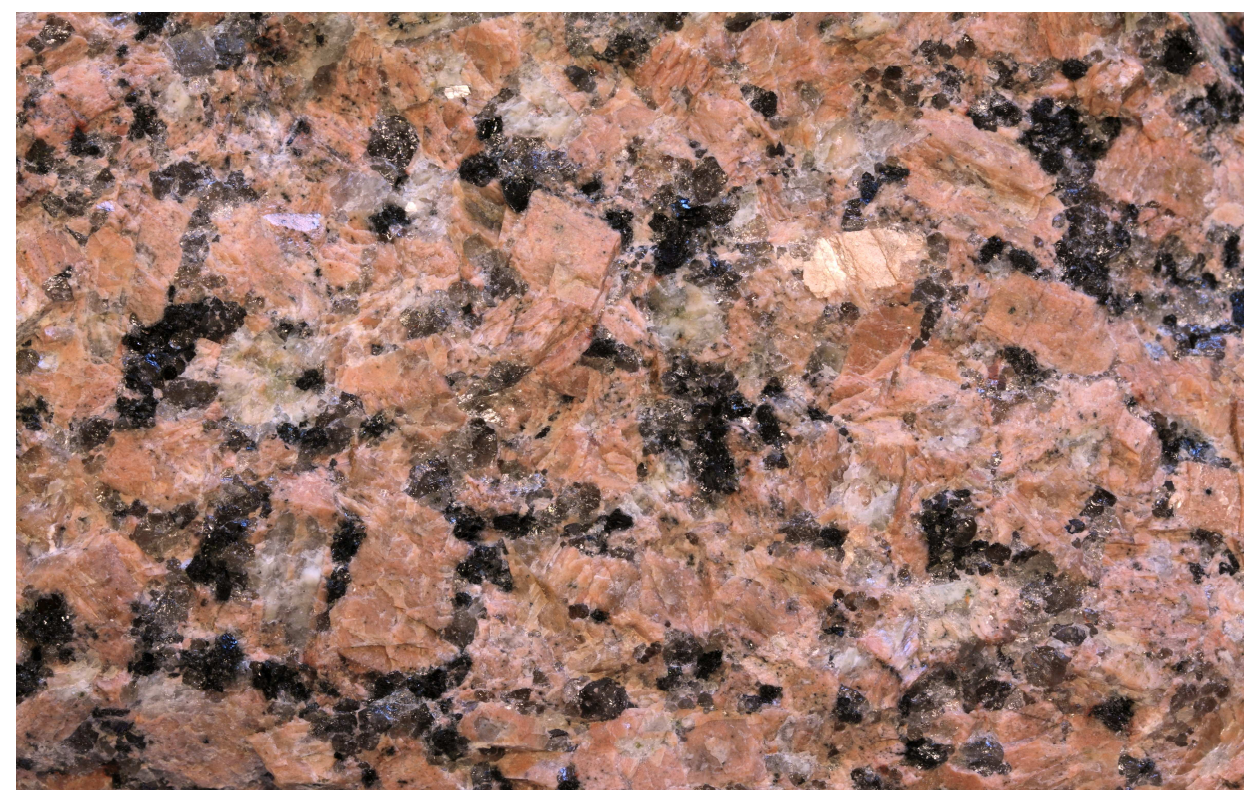

Fot. 10.2. Granit Ragunda, Ragunda, środkowa Szwecja; rozmiar dłuższego boku 65 mm; fot. P. Czubla 2015

Photo 10.2. Ragunda granite, Ragunda, Central Sweden; picture width 65 mm. Photo P. Czubla 2015 


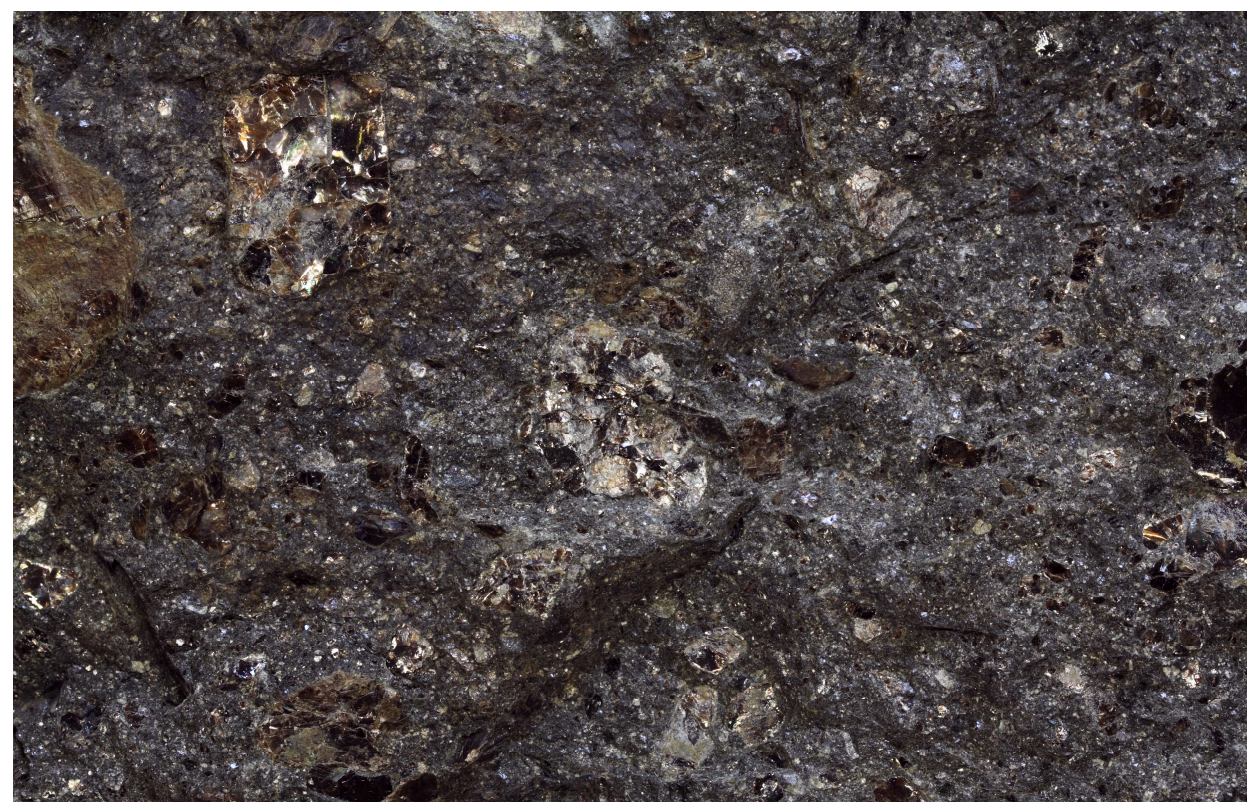

Fot. 10.3. Alnöit, Näset, środkowa Szwecja; rozmiar dłuższego boku 102 mm; fot. P. Czubla 2015

Photo 10.3. Alnöite, Näset, Central Sweden; picture width $102 \mathrm{~mm}$. Photo P. Czubla 2015

zbliżonych skał z dna zatoki Botnickiej i z Wysp Alandzkich skłoniły Zandstrę (1983a, 1983b) do odstąpienia od wyróżniania oddzielnej grupy skał północnoszwedzkich w zaproponowanym podziale regionalnym zespołów eratyków w Holandii i ujęcia ich razem ze skałami alandzkimi i południowofińskimi.

W przebadanych próbach udało się autorowi zidentyfikować zaledwie 9 ziaren granitów Revsund i Björna. Najwięcej w glinach kompleksu południowopolskiego i stopniowo coraz mniej w młodszych osadach plejstocenu Polski. Większość znalezisk została dokonana w Polsce Środkowej, a tylko po jednym okazie rozpoznano w próbach z Kujaw i Pomorza. Nieco liczniejsze były eratyki skał Rödö (w sumie 22 w osadach glacjalnych i 3 w żwirach) oraz granitoidy i granitognejsy Ångermanland - odpowiednio 49 i 7 klastów. Skały te występują rozproszone dość równomiernie w różnowiekowych osadach glacjalnych, z niewielkim tylko przyrostem udziału w osadach kompleksu środkowopolskiego. Obecne są w osadach wszystkich przetestowanych obszarów badawczych Polski. Skał z Alnö nie udało się stwierdzić w żadnej analizowanej próbce. Nawet zlokalizowanie i pobór prób referencyjnych tej skały w wychodni w okolicach Sundsvall w Szwecji wiązały się ze sporymi trudnościami - wynik dość wysokiego stopnia zwietrzenia skały, małych rozmiarów stanowiska i braku wyraźnej formy morfologicznej. Tym bardziej nie należy się dziwić brakowi tej skały w przebadanych osadach glacjalnych Polski. 
Sumaryczny udział skał północnoszwedzkich w zespołach eratyków przewodnich przebadanych osadów glacjalnych Polski wyniósł zaledwie 1,4\%, a w żwirach 1,6\%. Największy udział został zanotowany w osadach kompleksu południowopolskiego $1,7 \%$, w glinach kompleksu środkowopolskiego 1,4\%, północnopolskiego zaś 1,2\%. Podwyższona rola skał północnoszwedzkich w osadach najstarszego kompleksu glacjalnego może wskazywać na inkorporację przez lądolód zwietrzeliny zalegającej na powierzchni wychodni, a być może nawet w większym stopniu otoczaków rozwleczonych na południe i południowy wschód przez preglacjalne systemy rzeczne Fennoskandii. Ta hipoteza dość dobrze wyjaśniałaby zarówno napływ do Polski skał z obszaru położonego w najbliższym sąsiedztwie lododziału, jak i stopniowy spadek zawartości skał z tamtego regionu w osadach kolejnych nasunięć glacjalnych.

Górska-Zabielska (2008) w vistuliańskich glinach lobu Odry nie znalazła eratyków północnoszwedzkich, a w żwirach tego wieku wykazała ich udział zaledwie $0,2 \%{ }^{6}$. Osady ostatniego zlodowacenia środkowej i zachodniej Wielkopolski oraz Ziemi Lubuskiej okazały się również wolne od skał pochodzących z analizowanego regionu Fennoskandii (Górska, 2000; Lipka, 2011). Do podobnego rezultatu (niestwierdzenia obecności skał północnoszwedzkich) doprowadziły badania Dudziaka (1970), którymi objęte zostały liczne duże głazy południowej, zachodniej i północnej Polski. Zupełnie odmienne wyniki relacjonuje Gałązka (2004b). Z jego badań przeprowadzonych w Polsce Środkowej i Wschodniej wynika, że skały z Ångermanlandu stanowią około 5-6\% eratyków przewodnich w glinach sanu i odry (w tradycyjnym rozumieniu wydzieleń stratygraficznych), uzyskują udział średnio ponad $20 \%$ w glinach warty, by spaść do około $12-15 \%$ w osadach ostatniego zlodowacenia. Co ciekawe, dalej na wschód, na terenie Białorusi Astapova (1987) wykazuje już tylko od 0,6\% do 13,1\% skał północnoszwedzkich, ale w większości analizowanych przez nią obszarów zawartość eratyków opisywanej grupy nie przekroczyła 5\%. Udział skał północnoszwedzkich w zespołach eratyków w Holandii bardzo rzadko przewyższa 3\% (Schuddebeurs, 1980/1981). Skały Rödö należą do rzadko występujących eratyków również na Litwie, Łotwie i w Estonii (Tarvydas, 1971c) oraz w środkowych Niemczech (Hoffmann i Meyer, 1997, 1999). Marginalny udział skał północnoszwedzkich stwierdzono także w północnych Czechach (Víšek i Nývlt, 2006), aczkolwiek w rejonie Jesenika (Jindřichov) skały z Rödö wyjątkowo stanowiły ponad $10 \%$ rozpoznanych eratyków przewodnich (Hanáček i Nývlt, 2009). Duże rozbieżności w ocenie udziału skał z Ångermanlandu w osadach glacjalnych Polski, włącznie z odbiegającymi bardzo w górę od analiz przeprowadzonych w krajach ościennych, wskazują na konieczność rewizji oznaczeń z uwzględnieniem zweryfikowanych okazów referencyjnych. W przypadku potwierdzenia wysokiego udziału skał północnoszwedzkich w osadach glacjalnych Polski, należałoby zweryfikować modele termiczne lądolodu fennoskandzkiego i znacznie ograniczyć przyjmowany zasięg zimnego reżimu termicznego stopy lądolodu.

\footnotetext{
${ }^{6}$ Podane wartości zostały obliczone w oparciu o surowe dane zamieszczone w pracy Górskiej-Zabielskiej (2008), ujednolicone z metodyką badawczą zastosowaną w niniejszym opracowaniu.
} 


\subsection{Zatoka Botnicka i Wyspy Alandzkie}

Skały przewodnie pochodzące z regionu Wysp Alandzkich i, w mniejszym stopniu, z dna Zatoki Botnickiej stanowią bardzo ważny składnik osadów glacjalnych w Polsce. Najliczniej występują granitoidy alandzkie w różnych odmianach: typowe rapakiwi z owoidami skaleniowymi (fot. 10.4), pyterlity i granity aplitowe; znacznie rzadziej znajdowane są granity Haga (fot. 10.5) i Kökar. Nieco mniejszy udział mają ich wulkaniczne i subwulkaniczne odpowiedniki, tj. alandzkie porfiry kwarcowe i granitoporfiry (fot. 10.6). Dno Zatoki Botnickiej reprezentują głównie skały wulkaniczne i subwulkaniczne. Przewodnie znaczenie skał alandzkich nie budzi większych wątpliwości (Hesemann, 1975; Gaigalas, 1971a, 1971b; Meyer, 1983; Smed, 1994, 2002; Zandstra, 1999; Gałązka, 2004b; Czubla i in., 2006). Co najwyżej mogą wystąpić problemy z odróżnieniem niektórych ich odmian od analogicznych skał pochodzących z kontynentalnej części Finlandii. Dotyczy to przede wszystkim granitu Kökar z południowej części archipelagu, który jest bardzo podobny do wyborgitów ze wschodniej Finlandii. Zdaniem niektórych badaczy fińskie wyborgity znajdowane sporadycznie w Niemczech (włącznie z obszarem Prus Wschodnich) to właśnie błędnie rozpoznane skały z południowej części Wysp Alandzkich (Postelmann, 19367 ; Kummerow, 1954). Opinie na temat przewodniego charakteru skał botnickich nie są jednoznaczne. Część badaczy skłonna jest uznać za przewodnie tylko niektóre odmiany subjotnickich porfirów kwarcowych z tego rejonu (np. Eskola, 1934; Hesemann, 1939; Viiding, 1957; Schuddebeurs, 1980/1981). Według Tarvydasa (1971a) przewodnie znaczenie skał z dna Zatoki Botnickiej nie zostało jednoznacznie potwierdzone. W niniejszym opracowaniu do skał przewodnich zostały zaliczone wszystkie skały alandzkie oraz porfiry botnickie.

W osadach glacjalnych Polski skały alandzkie należą do najliczniej notowanych eratyków przewodnich. Ich zasięg wykracza również daleko na zachód, bo aż po Holandię (Schuddebeurs, 1980/1981) i na wschód, gdzie skały alandzkie znane są ze wszystkich krajów perybałtyckich i Obwodu Kaliningradzkiego (Eskola, 1933; Gaigalas, 1971a) oraz z Białorusi (Astapova, 1987). Skały alandzkie w plejstoceńskich osadach Polski mają nierzadko bardzo duże rozmiary. Dotyczy to nawet porfirów, które teoretycznie, już w wychodni powinny być pocięte gęstą siecią spękań ciosu termicznego, uniemożliwiającą zachowanie się dużych eratyków. Porfiry botnickie osiągają zdecydowanie mniejsze rozmiary. Większość okazów rozpoznanych przez autora nie przekraczała $5 \mathrm{~cm}$, chociaż w osadach glacjalnych krajów perybałtyckich mają występować obtoczone klasty o średnicy nawet do $40 \mathrm{~cm}$ (Tarvydas, 1971a). Rozmiary eratyków porfirów botnickich znalezionych w Holandii nie zostały niestety sprecyzowane (Schuddebeurs, 1980/1981). Skałom alandzkim i botnickim często towarzyszą jotnickie piaskowce. Generalnie są to skały mające bardzo liczne wychodnie w różnych częściach Fennoskandii i pozbawione cech, które pozwoliłyby przypisać je do ściśle określonego miejsca pochodzenia (Meyer

\footnotetext{
${ }^{7}$ Postelmann zweryfikował jako granit Kökar rzekomy fiński wyborgit, wykorzystany we wzniesionym pomiędzy dzisiejszym Olsztynkiem i Sudwą Mauzoleum Hindenburga. Mauzoleum już nie istnieje. Zostało wysadzone przez wycofujące się niemieckie wojska, a pozostałości rozebrano pod koniec lat 40. XX wieku i wywieziono jako materiał budowlany m.in. do Warszawy.
} 


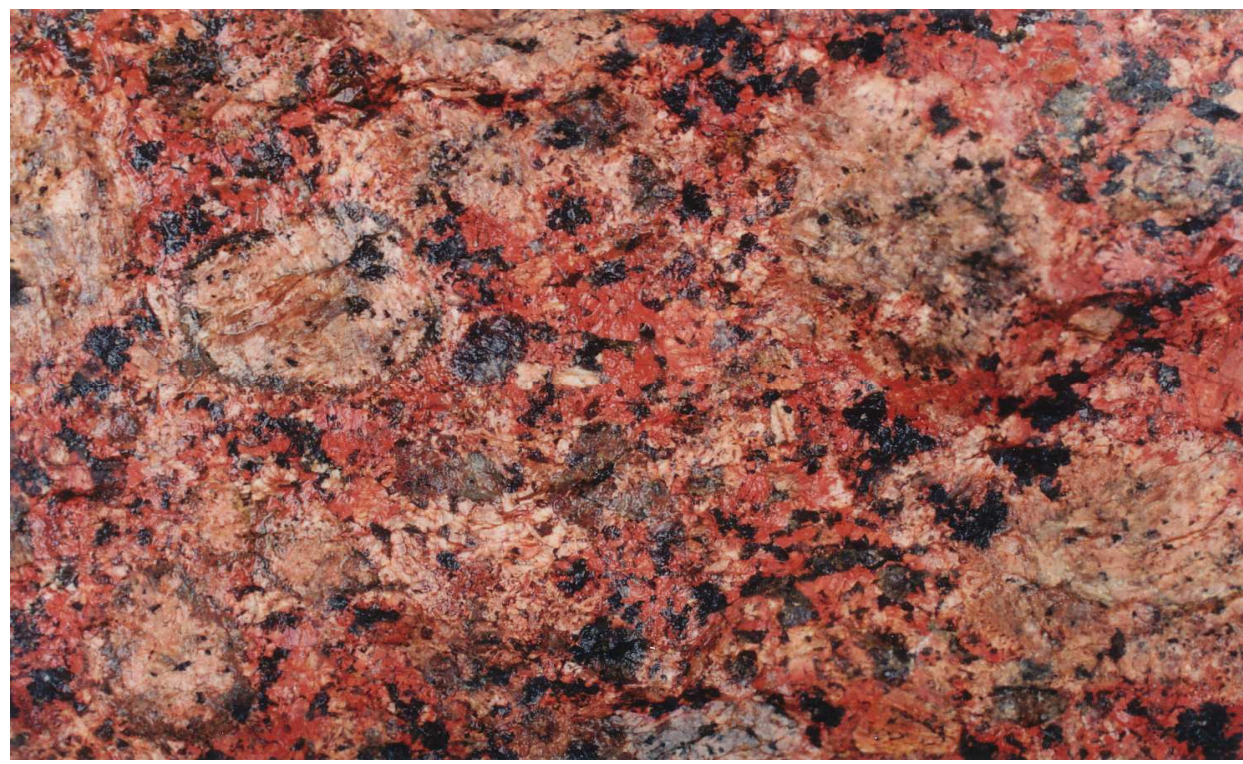

Fot. 10.4. Alandzki granit rapakiwi, eratyk - odkrywka KWB Bełchatów; rozmiar dłuższego boku 83 mm; fot. P. Czubla i Z. Machnicki 1999

Photo 10.4. Åland rapakivi granite, erratic - Bełchatów outcrop; picture width $83 \mathrm{~mm}$. Photo P. Czubla \& Z. Machnicki 1999

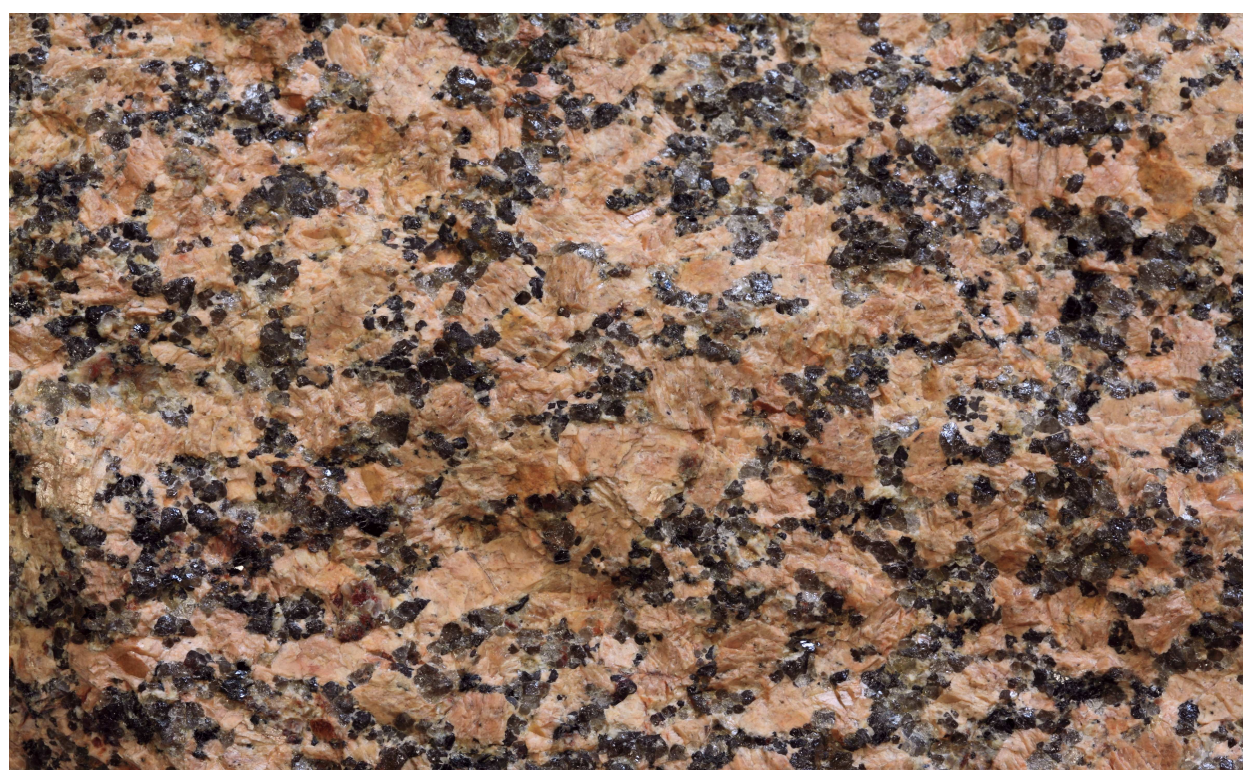

Fot. 10.5. Granit Haga, eratyk - odkrywka KWB Bełchatów; rozmiar dłuższego boku 112 mm; fot. P. Czubla 2015

Photo 10.5. Haga granite, erratic - Bełchatów outcrop; picture width 112 mm. Photo P. Czubla 2015 


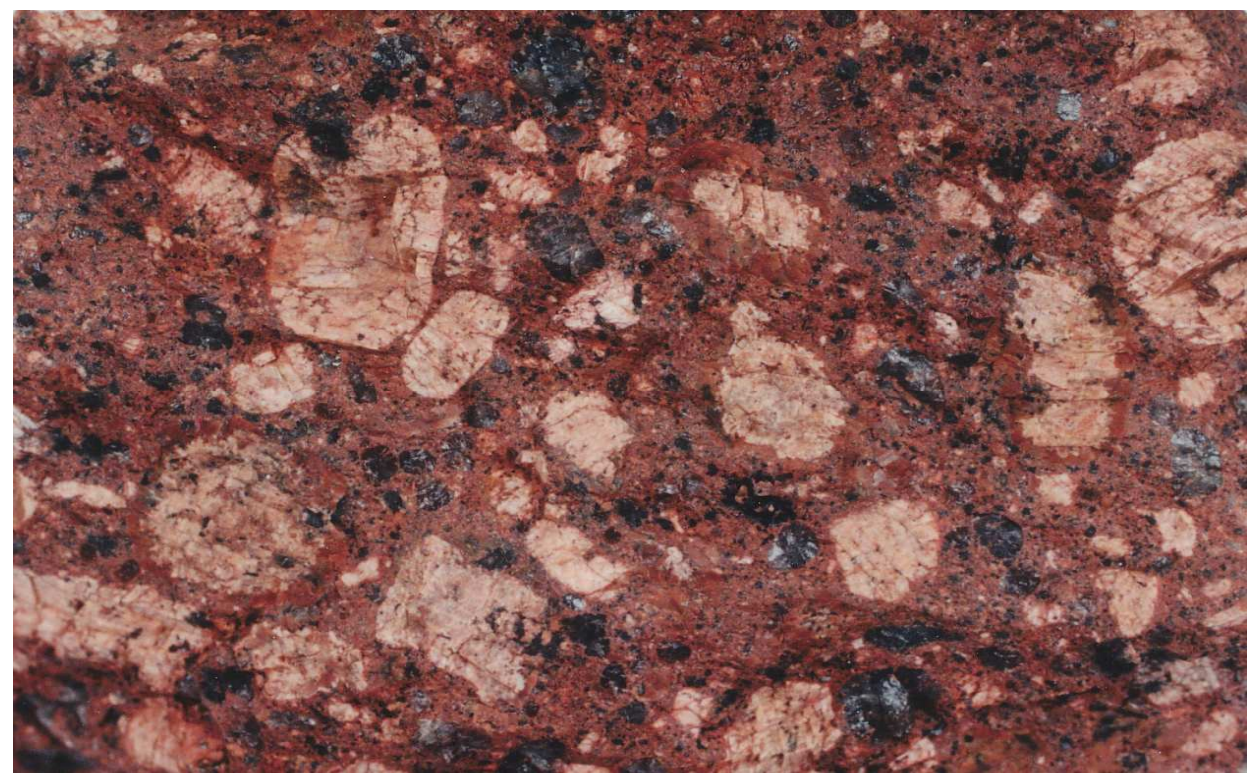

Fot. 10.6. Granitoporfir alandzki, eratyk - odkrywka KWB Bełchatów; rozmiar dłuższego boku $92 \mathrm{~mm}$; fot. P. Czubla i Z. Machnicki 1999

Photo 10.6. Åland granite porphyry, erratic - Bełchatów outcrop; picture width $92 \mathrm{~mm}$. Photo P. Czubla \& Z. Machnicki 1999

i Lüttig, 2007), a więc pozbawione znaczenia wskaźnikowego. W przypadkach jednak, kiedy towarzyszą jednoznacznie zidentyfikowanym skałom przewodnim, można założyć, że pochodzą z dokładnie tego samego regionu. Przykłady takich interpretacji opisane są z wybrzeża Rugii i z Dolnej Saksonii (Meyer i Lüttig, op. cit.).

W przeanalizowanych osadach zaznaczyła się duża dysproporcja pomiędzy liczbą eratyków wywodzących się z dna zatoki Botnickiej oraz z regionu Wysp Alandzkich. Nie jest ona związana z kierunkiem napływu lodu, ponieważ obydwa obszary znalazły się najprawdopodobniej na drodze tych samych mas lodu, o czym świadczy ich powszechne współwystępowanie w osadach glacjalnych. Do głównych przyczyn wspomnianej różnicy należy raczej zaliczyć znacznie większą powierzchnię wychodni skał alandzkich oraz ich usytuowanie na elewacji rzeźby w stosunku do porfirów botnickich. Współcześnie Wyspy Alandzkie wznoszą się na wysokość do 129 m n.p.m., podczas gdy w cieśninie Södra Kvarken, oddzielającej archipelag od Szwecji, głębokość znacznie przekracza 200 metrów - maksymalnie 285 m p.p.m. Średnia głębokość Botniku Południowego, na dnie którego znajdują się niewielkie wychodnie różnorodnych skał wulkanicznych (Eskola, 1934; Veltheim, 1962), wynosi około 62 metry. Znaczenie nierówności terenu w inkorporacji materiału skalnego z podłoża podkreślał m.in. Puranen (1990). Zgodnie z jego modelem, dzisiejsze Wyspy Alandzkie, tworzące elewację wzniesioną na ponad 100 metrów w stosunku do otaczającego podłoża lądolodu, dostarczały materiału skalnego bezpośrednio do wyższych warstw lodu, które przemieszczały się 
szybciej i mogły przetransportować materiał morenowy na większą odległość. Należy również uwzględnić kruszenie i abrazję materiału skalnego w facjach bazalnych lądolodu, które szybko redukowały rozmiary transportowanych w stopie lądolodu lub tuż ponad nią, głazików. Tym procesom w znacznie większym stopniu podlegały zapewne skały botnickie niż alandzkie, co tłumaczy ich występowanie w postaci najczęściej bardzo małych eratyków. Do ograniczenia udziału skał botnickich mogło również przyczynić się istnienie bariery, jaką stanowił próg alandzki. Niższe, bogate w skały botnickie warstwy lodu mogły zatrzymywać się na przeszkodzie, a dalej płynęły już tylko wyższe warstwy lodu, uboższe w materiał skalny i pobierające fragmenty skał z masywu alandzkiego. Było to jednak możliwe tylko pod warunkiem występowania w tym okresie ciepłego reżimu podłoża w stopie lądolodu fennoskandzkiego w omawianym regionie. W analogiczny sposób Lindner $(1996,2009)$ starał się wyjaśnić brak osadów glacjalnych kompleksu środkowopolskiego w niektórych stanowiskach na Podlasiu.

Średnia zawartość porfirów botnickich w osadach glacjalnych ${ }^{8}$ przebadanych przez autora wynosiła zaledwie 0,40\%, a w żwirach tylko 0,24\%. W związku z tym wyciąganie jakichkolwiek wniosków na temat rozmieszczenia tego typu skały w różnowiekowych osadach i w różnych regionach Polski byłoby zupełnie bezzasadne. Górska-Zabielska (2008) nie znalazła w lobie Odry żadnych skał botnickich, a w osadach glacjalnych Wielkopolski natrafiła na porfir botnicki we Włoszakowicach ${ }^{9}$ (Górska, 2000). Ujęcie przez Gałązkę (2004b) porfirów botnickich razem ze skałami alandzkimi i brak surowych danych nie pozwalają na żadne analizy odnoszące się bezpośrednio do udziału tych skał. W zestawieniach wyników badań w Holandii widoczne są proporcje skał alandzkich i botnickich, podobne do zaobserwowanych w Polsce, tzn. kilkadziesiąt razy mniejszy odsetek tych drugich (Schuddebeurs, 1980/1981).

W stanowiskach przebadanych przez autora na skały alandzkie przypada średnio $32,6 \%$ eratyków przewodnich zidentyfikowanych w glinach i 39,4\% w żwirach. Najliczniej skały alandzkie występują w osadach kompleksu środkowopolskiego - średnio aż $38,3 \%$. Ich udział w glinach kompleksu południowopolskiego i północnopolskiego jest o około $1 / 3$ niższy - odpowiednio $26,7 \%$ oraz $29,0 \%$. Większe zróżnicowanie notowane było $w$ różnowiekowych osadach Polski Środkowej (Czubla, 2001), ale wynikało to z ograniczonych rozmiarów obszaru badań, co zredukowało wpływ zmienności przestrzennej składu zespołów głazowych na wartości średnie wyliczane dla kolejnych lądolodów. Na porfiry alandzkie przypada niewiele ponad 1\% zidentyfikowanych skał przewodnich bez względu na wiek i fację osadów. Proporcje pomiędzy różnymi skałami alandzkimi są zmienne. W części prób dominują drobnokrystaliczne granity aplitowe, w innych nierównokrystaliczne i grubokrystaliczne granity rapakiwi. Na ogół wśród klastów bliskich minimalnym rozmiarom analizowanej frakcji (np. 20-30 mm) przeważają odmiany drobnokrystaliczne. Nie jest to jednak cecha pierwotna zespołu głazo-

\footnotetext{
${ }^{8}$ Zawartość procentowa w analizach rozmieszczenia poszczególnych typów eratyków przewodnich odnosi się do całkowitej liczby eratyków przewodnich zidentyfikowanych w osadach badanego wieku lub stanowiska. W przypadku eratyków pomocniczych podawany udział odnosi się do całkowitej liczby eratyków fennoskandzkich, bądź wymienionej grupy.

${ }^{9}$ Wniosek oparty na rys. 4.9 ze strony 47 , bo w tekście brak informacji na jego temat.
} 
wego przywleczonego przez lądolód, lecz raczej wtórny efekt wietrzenia fizycznego. Rozpad grubokrystalicznych pyterlitów i granitów rapakiwi prowadzi często do odspojenia pojedynczych kryształów lub ich fragmentów, których zakwalifikowanie jako produktu rozpadu konkretnych skał przewodnich jest niemożliwe.

W glinach kompleksu południowopolskiego bardzo wyraźnie zaznacza się wzrost udziału skał alandzkich przy przesuwaniu się z zachodu na wschód od zaledwie kilkunastu procent na Dolnym Śląsku (w Mokrzeszowie tylko $8,0 \%$ ), po około $50 \%$ na Podlasiu i Lubelszczyźnie (rys. 10.3). Maksymalny udział eratyków alandzkich zaobserwowano w Kocianowie koło Nałęczowa, gdzie wyniósł on aż 50,9\%. Analogiczną sytuację, ale na mniejszym obszarze (brak prób odpowiedniego wieku z Dolnego Śląska) można zaobserwować również w osadach kompleksu środkowopolskiego. W stanowiskach wysuniętych najdalej na zachód na skały alandzkie przypada poniżej $20 \%$ eratyków przewodnich, np. w Dębówku Nowym 11,1\%. Przy wschodniej granicy Polski wartość ta rośnie do ponad 50\%; w skrajnym przypadku w Neplach 66,7\% (rys. 10.4). Za to zróżnicowanie odpowiada głównie promienisty lub podobny układ indywidualnych prądów lodowych w obrębie ówczesnych lądolodów.

Poszukiwanie podobnej zmienności w osadach ostatniego zlodowacenia wymagało sięgnięcia po prace innych badaczy (Górska, 2000; Gałązka, 2004b; Górska-Zabielska, 2008; Lipka, 2011), ponieważ odpowiednie stanowiska opracowane przez autora układały się mniej więcej południkowo, a więc zgodnie z uogólnionym kierunkiem napływu lodu (rys. 10.3). Udział skał alandzkich w glinach lobu Odry (27,4\% - Górska-Zabielska, 2008) okazał się tylko nieznacznie niższy od stwierdzonego przez autora na obszarze od Pomorza Gdańskiego po południowe Kujawy - 29,0\%. Zastanawiający jest, zwłaszcza w kontekście sugerowanej przez autorkę równoważności badań petrograficznych glin i żwirów fluwioglacjalnych, ponad półtorakrotnie wyższy udział skał alandzkich w glinach aniżeli w żwirach lobu Odry - 27,4\% wobec 16,6\%. Na obszarze Wielkopolski w glinach leszczyńskich we Włoszczakowicach oraz w Ujściu udział skał alandzkich określono na 17-18\% (Górska, 2000), tj. na poziomie niższym od danych autora. Jeszcze mniejszy udział skał alandzkich znany jest z Wysoczyzny Lubuskiej (Lipka, 2011), ale brak surowych danych i odmienna metodyka bardzo utrudniają wiarygodne porównania $z$ danymi autora.

Bardzo interesujące jest zestawienie wyników z rezultatami badań Gałązki (2004b). Co prawda Gałązka ujmował skały alandzkie razem z botnickimi, ale ze względu na znikomy udział tych ostatnich, ich wpływ na sumaryczny udział całej grupy był prawie pomijalny. Okazało się, że w glinach zlodowacenia sanu średni udział skał alandzkich wyniósł 45,8\%, czyli był niemal identyczny ze stwierdzonym przez autora na Podlasiu i Lubelszczyźnie. Gliny warciańskie na obszarze badanym przez Gałązkę zawierały w zależności od poziomu od 23 do ponad 30\% skał alandzkich wśród eratyków przewodnich, a gliny zlodowacenia wisły od 23,5 do $28 \%$. Ten ostatni wynik tylko nieznacznie różni się od wartości wyliczonych dla glin kompleksu północnopolskiego na Kujawach, Powiślu i Pomorzu. 


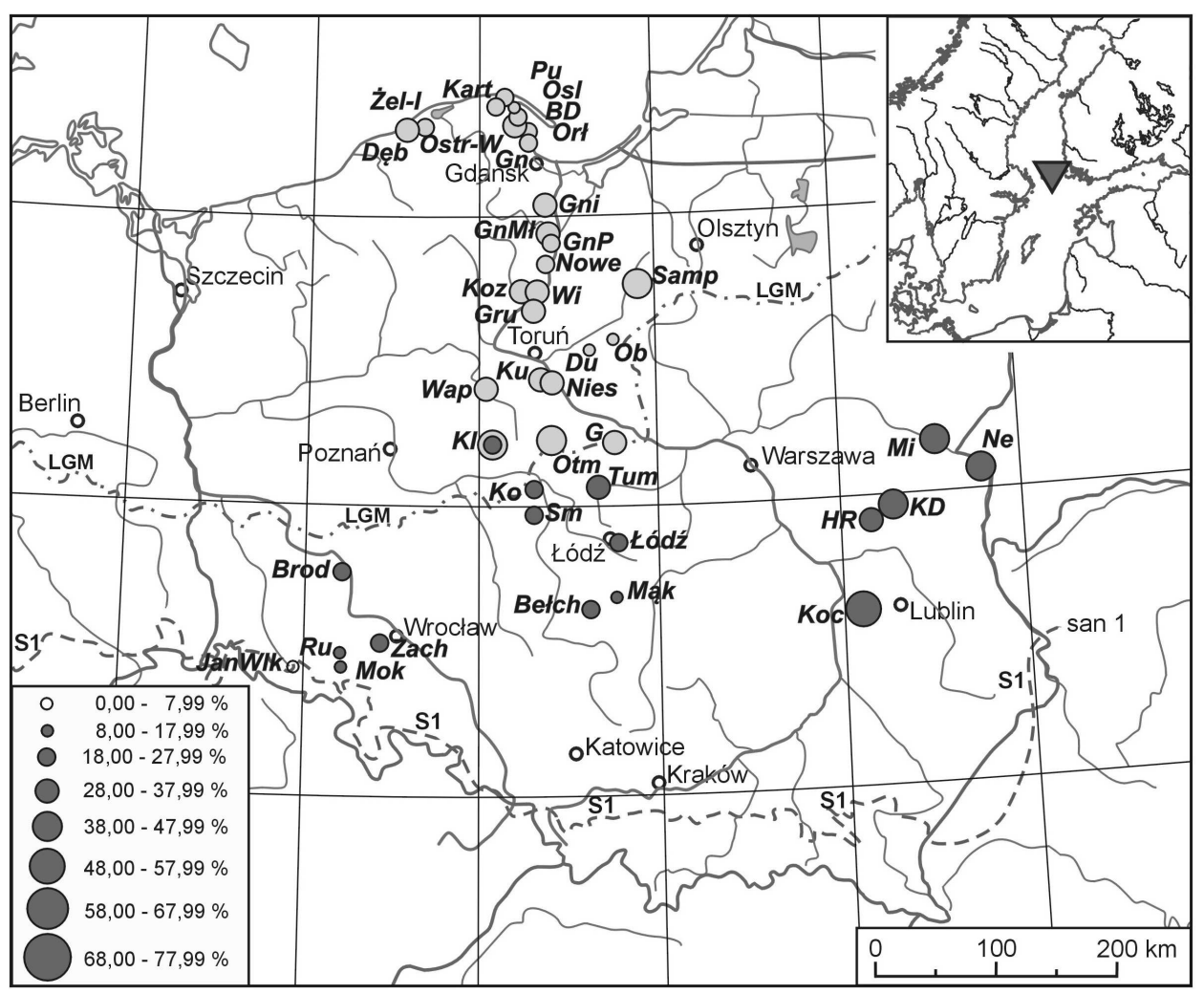

Rys. 10.3. Rozmieszczenie skał alandzkich w przebadanych osadach glacjalnych kompleksu południowo-polskiego (ciemne koła) i północnopolskiego (jasne koła) - udział poniżej 8,00\% (puste koło jako symbol stanowiska w Janowicach Wielkich) oznacza brak danej skały. Obszar źródłowy prezentowanych eratyków zaznaczono na mapce w prawym górnym rogu rysunku. Skróty na mapach odnoszą się do stanowisk, a nie do próbek. W przypadku analizy kilku prób tego samego wieku z jednego stanowiska, na mapie prezen-towane

są dane uśrednione. Poniższe wyjaśnienia skrótów odnoszą się do wszystkim map zamieszczonych w niniejszej pracy: Bar - Barcin, BD - Babie Doły, Bełch - Bełchatów, Bes - Besiekierz, Br - Brzeziny-Paprotnia,

Brod - Brodowice, Cho - Chociw, Dan - Daniszewice, Dęb - Dębina, DębN - Dębówko Nowe, Du - Dulsk, G - Gostynin-Lisica, Gn - Gnieżdżewo, Gni - Gniszewo, GnMł - Gniewskie Młyny, GnP - Gniew-Piaskownia,

Gru - Grubno, HR - Huta Radoryska, JanWlk - Janowice Wielkie, Kacz - Kaczory, Kart - Kartoszyno,

KD - Kolonia Domaszewska, KI - Kleczew, Ko - Koźmin i Koźmin-Północ, Koc - Kocianów, Koz - Kozłowo,

Kr - Kruszów, Ku - Kuczek, Lewk - Lewkówka, Łazy - Łazy Duże, Łódź - Łódź, ŁW - Łaznowska Wola, Masł - Masłowice, Mąk - Mąkolice, Mi - Mielnik, Mło - Młodocin, Mok - Mokrzeszów, Mosz - Moszczenica,

$\mathrm{Ne}$ - Neple, Nies - Nieszawa, Nowe - Nowe nad Wisłą, Ob - Obórki, Orł - Orłowo, Osl - Osłonino, Ostr-W - Ostrowo Zachód, Otm - Otmianowo, Pu - Puck, Ru - Rusko, Samp - Sampława, Si - Siedlątków, Sm - Smulsko, Tum - Tum, Wap - Wapienno, War - Warka, Wi - Wiąg, Wyrz - Wyrzysk, WZag - Wólka Zagórna (Kózki), Zach - Zachowice, Żel-I - Żelazo 
Na mapie przedstawiającej udział skał alandzkich w glinach vistulianu (rys. 10.3) można zauważyć niewielki wzrost ich znaczenia w stanowiskach położonych w pobliżu linii maksymalnego zasięgu ostatniego lądolodu, np. Kleczew, Otmianowo, Gostynin, Sampława. Nietypowo niski udział skał tej grupy w Obórkach, położonych również na bliskim zapleczu strefy marginalnej lądolodu, może być wyrazem dość wysokiego stopnia zwietrzenia opróbowanych osadów, co doprowadziło do rozpadu wrażliwych na wahania temperatury skał grubokrystalicznych, w tym większości alandzkich. Na słuszność tego przypuszczenia może wskazywać fakt, że stanowiska z minimalnym i maksymalnym udziałem eratyków alandzkich w przebadanych glinach vistulianu (Obórki i Sampława - odpowiednio $11,2 \%$ oraz $43,4 \%$ ) położone są w najbliższym sąsiedztwie. Mimo niewielkiej odległości dzielącej wspomniane stanowiska, występujące w nich osady zostały odłożone przez odrębne loby lądolodu wisły - Obórki znalazły się w strefie objętej lobem wiślanym o dużym udziale eratyków ze Smålandu, a Sampława w zasięgu lobu małdyckiego, zdominowanego przez skały alandzkie (Gałązka, 2004a, 2004b; Gałązka i in., 2006). Odłożenie glin w Sampławie i Obórkach przez odrębne loby nie wyjaśnia jednak w sposób wystarczający zaobserwowanego zróżnicowania petrograficznego, ponieważ stanowiska zlokalizowane niewątpliwie w obrębie lobu wiślanego, również cechują się bardzo dużym zróżnicowaniem udziału skał alandzkich.

Analiza zawartości skał alandzkich wśród eratyków przewodnich Polski i Białorusi wskazuje na wyraźną prawidłowość. W Polsce w przekroju równoległym do czoła lądolodu następuje systematyczny wzrost roli skał alandzkich wraz z przesuwaniem się na wschód. Maksymalny ich udział zanotowano na Podlasiu i Lubelszczyźnie. Na terenie Białorusi tendencja jest odwrotna i od okolic Grodna na wschód stopniowo zawartość skał tej grupy maleje (Astapova, 1987). Można mieć wątpliwości co do stosowanej tam metody (pobór eratyków z powierzchni pól, a nie z konkretnej warstwy osadów), ale ogólny obraz jest dość przejrzysty. Pozyskane dane świadczą o tym, że w regionie

$\leftarrow$ Figure 10.3. The distribution of Åland rocks in glacial deposits of the South-Polish Complex (dark circles) and of the North-Polish Complex (light circles) - share below 8,00\% (empty circle as a site symbol for

Janowice Wielkie) means a lack of the presented rock (or group) in the site. The source area of given indicator erratic is presented in the small map placed in the upper right corner. Abbreviations refer to sites and not to the individual samples. In case of analysis of several samples of the same age from one site averaged data are presented. The following explanations refer to all the erratics maps included in the study: Bar - Barcin,

BD - Babie Doły, Bełch - Bełchatów, Bes - Besiekierz, Br - Brzeziny-Paprotnia, Brod - Brodowice,

Cho - Chociw, Dan - Daniszewice, Dęb - Dębina, DębN - Dębówko Nowe, Du - Dulsk, G - Gostynin-Lisica,

Gn - Gnieżdżewo, Gni - Gniszewo, GnMł - Gniewskie Młyny, GnP - Gniew-Piaskownia, Gru - Grubno,

HR - Huta Radoryska, JanWlk - Janowice Wielkie, Kacz - Kaczory, Kart - Kartoszyno, KD - Kolonia

Domaszewska, KI - Kleczew, Ko - Koźmin i Koźmin-Północ, Koc - Kocianów, Koz - Kozłowo, Kr - Kruszów,

Ku - Kuczek, Lewk - Lewkówka, Łazy - Łazy Duże, Łódź - Łódź, ŁW - Łaznowska Wola, Masł - Masłowice,

Mąk - Mąkolice, Mi - Mielnik, Mło - Młodocin, Mok - Mokrzeszów, Mosz - Moszczenica, Ne - Neple,

Nies - Nieszawa, Nowe - Nowe nad Wisłą, Ob - Obórki, Orł - Orłowo, Osl - Osłonino, Ostr-W - Ostrowo

Zachód, Otm - Otmianowo, Pu - Puck, Ru - Rusko, Samp - Sampława, Si - Siedlątków, Sm - Smulsko,

Tum - Tum, Wap - Wapienno, War - Warka, Wi - Wiąg, Wyrz - Wyrzysk, WZag - Wólka Zagórna (Kózki), Zach - Zachowice, Żel I - Żelazo 


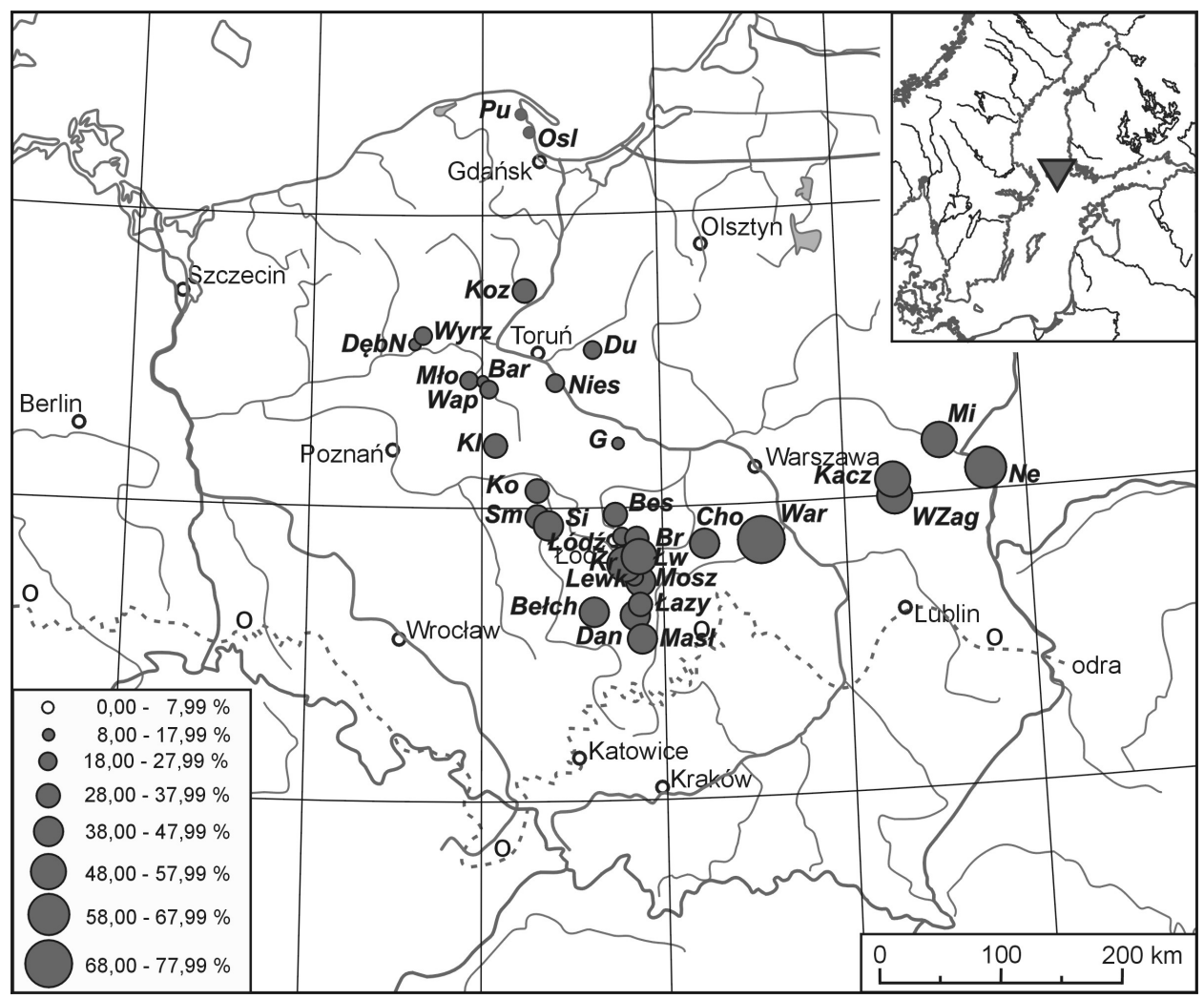

Rys. 10.4. Rozmieszczenie skał alandzkich w przebadanych osadach glacjalnych kompleksu środkowopolskiego

Figure 10.4. The distribution of Åland rocks in glacial deposits of the Middle-Polish Complex

pogranicza polsko-białoruskiego przebiega strefa maksymalnego rozrzutu skał alandzkich, czyli jest to zapewne osiowa część wachlarza rozrzutu tych skał. Na wschodzie Białorusi zawartość skał z Wysp Alandzkich maleje do kilku procent (Astapova, op. cit.). Powyższy kierunek transportu skał alandzkich potwierdzają analizy strefy rozrzutu piaskowców jotnickich, posiadających rozległe wychodnie na dnie Zatoki Botnickiej (Salonen, 1991). Okazało się, że w osadach ostatniego zlodowacenia w Finlandii tworzą one dość wąską strefę rozrzutu, przebiegającą niemal równolegle do hipotetycznego kierunku ruchu lodu, który doprowadził do koncentracji skał alandzkich w osadach starszych zlodowaceń w strefie granicznej Polski i Białorusi.

Tak gwałtowny spadek znaczenia eratyków alandzkich nie jest obserwowany w zachodniej części wachlarza rozrzutu tych skał. Z zachodnich Czech, Niemiec, a nawet z Holandii znane są zespoły eratyków bałtyckiego pochodzenia, w których udział tej grupy skał wynosi około $25 \%$, a w skrajnych przypadkach nawet 30 do $40 \%$ (Schuddebeurs, 1980/1981; Meyer, 1983; Višek i Nývlt, 2006). W glinie typu Emmen (saale, 
Holandia) Zandstra (1976) zidentyfikował aż 60\% eratyków alandzkich w grupie skał przewodnich. Potwierdza to postawioną wcześniej tezę, że zarówno transport preglacjalny, jak też fluwioglacjalny i fluwialny, sprzyjał przemieszczaniu się skał fennoskandzkich w kierunku zachodnim - zgodnie ze zgeneralizowanym nachyleniem terenu.

\subsection{Południowa Finlandia i wyspa Hogland (Rosja)}

Skały z południowej Finlandii występują stosunkowo rzadko w osadach glacjalnych Polski. W przeanalizowanych pokładach zidentyfikowane zostały przewodnie granitoidy Ytö (fot. 10.7 i 10.8), Nystad, Lellainen i Perniö, pyterlity (fot. 10.9) oraz porfiry Hogland. Stosunkowo licznie występują również granity plamiste (Prick) - fot. 10.10, mające ograniczone znaczenie wskaźnikowe (eratyki pomocnicze), ponieważ w bardzo podobnym wykształceniu występują we wszystkich masywach rapakiwi Finlandii włącznie z Wyspami Alandzkimi (Gaigalas, 1971b; Hesemann, 1975). Klasycznych wyborgitów (fot. 10.11), wschodniofińskich pyterlitów, diabazów Satakunta, ani helsinkitów (sjenitów mikroklinowych - Zandstra, 1999) w przebadanych próbkach nie było. Nie oznacza to, że wszystkie wymienione skały w Polsce zupełnie nie występują. Grubokrystaliczna tekstura wyborgitów sprawia, że w postaci drobnych, kilkucentymetrowych klastów są one makroskopowo zupełnie nierozpoznawalne. Skały grubokrystaliczne są bardzo podatne na wietrzenie fizyczne, zwłaszcza w efekcie insolacji. Zmiany rozmiarów kryształów, zachodzące w efekcie rozszerzalności cieplnej, generują duże naprężenia na stykach ziaren i prowadzą do szybkiego rozpadu granularnego skały. Opinię o wysokiej podatności wschodniofińskich granitów rapakiwi (wyborgitów i pyterlitów) na wietrzenie wyraził Dudziak (1974, 1985), który uważał, że te wielkokrystaliczne skały zostały kompletnie wyeliminowane z frakcji do $100 \mathrm{~mm}$. Przeprowadzone badania potwierdziły w pełni ten pogląd. Wyborgity najłatwiej znaleźć w żwirowniach i na pryzmach kamieni zebranych z pól. Duże eratyki wyborgitów autor zebrał w okolicach Gołdapi, w odkrywce KWB Bełchatów (fot. 10.12) i w kilku stanowiskach w Polsce Wschodniej, ale ze względu na niemożność ustalenia osadu źródłowego, nie mogły one zostać uwzględnione $\mathrm{w}$ badaniach. Stanowiły natomiast, obok próbek skał pobranych w wychodniach, dobre okazy referencyjne.

Wskaźnikowe znaczenie poszczególnych skał omawianego regionu bywa różnie interpretowane. W krajach perybałtyckich do głównych skał przewodnich zaliczane są wyborgity i pyterlity ze wschodniej Finlandii (pogranicze z Rosją), porfiry uralitowe Tammela i Pellinge (Pellinki), rapakiwi Laitila (Lellainen) i Vehmaa oraz kwarcowe porfiry Hogland (Gaigalas, 1971b; Raukas, 1971). Dość liczna jest również grupa drugorzędnych skał przewodnich, wśród których wymienione zostały nie tylko skały magmowe, ale i metamorficzne. Zdaniem Gaigalasa (1971b) granity plamiste (Prick), aplitowe granity rapakiwi, granity Perniö i Nystad zasługują tylko na miano skał towarzyszących, na równi z występującymi w rejonie Zatoki Fińskiej piaskowcami jotnickimi. Viiding (1971a, 1971b, 1971c) kwestionuje nawet znaczenie przewodnie granitów (granodiorytów) Nystad w oparciu o znaleziska identycznej skały w północno-wschodniej części obszaru perybałtyckiego. Uważa, że dowodzi to występowania identycznej skały gdzieś we 


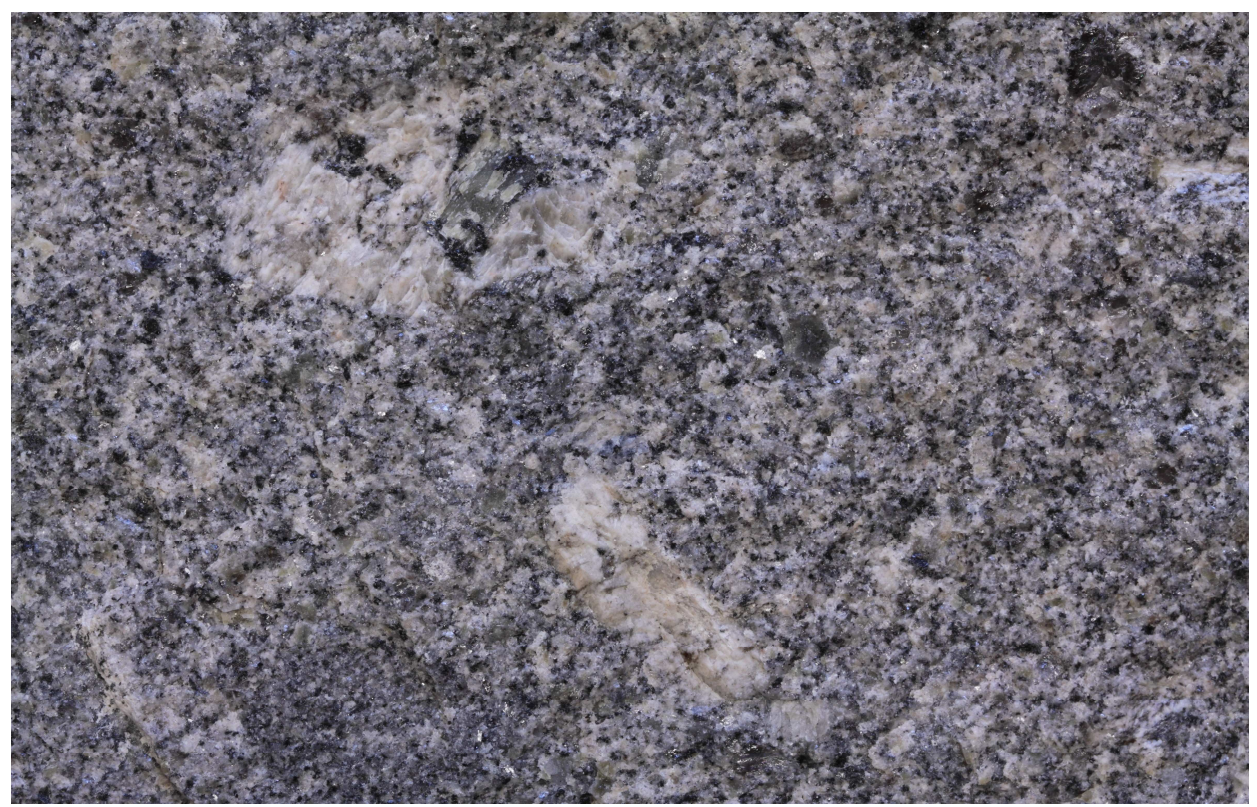

Fot. 10.7. Granit Ytö, Ytö k/Laitilla, zachodnia Finlandia; rozmiar dłuższego boku 87 mm; fot. P. Czubla 2015

Photo 10.7. Ytö granite, Ytö near Laitilla, western Finland; picture width 87 mm. Photo P. Czubla 2015

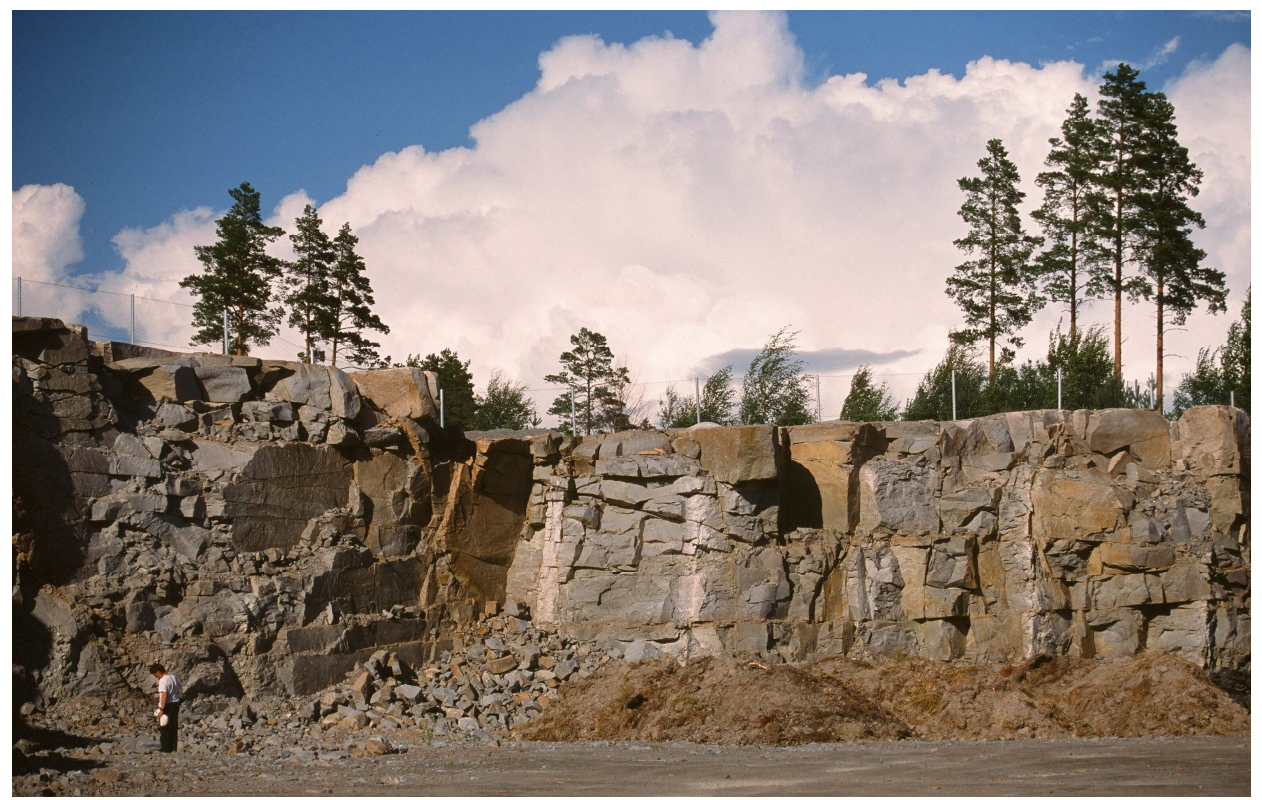

Fot. 10.8. Kamieniołom granitów w Ytö, Katinhäntä (na zachód od Laitila); fot. P. Czubla 2003 Photo 10.8. Granite quarry in Ytö, Katinhäntä (west of Laitila). Photo P. Czubla 2003 


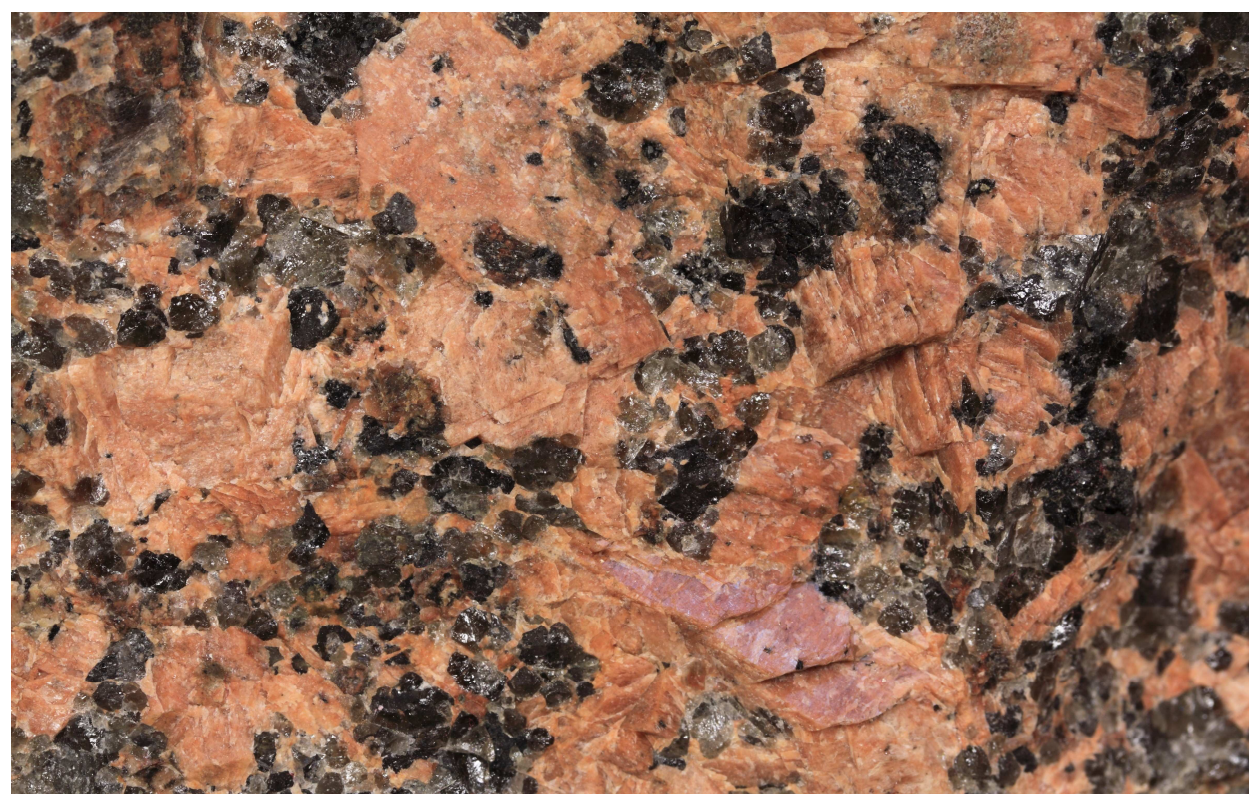

Fot. 10.9. Fiński pyterlit, eratyk - Smulsko; rozmiar dłuższego boku 74 mm; fot. P. Czubla 2015 Photo 10.9. Pyterlite from Finland, erratic - Smulsko outcrop; picture width $74 \mathrm{~mm}$. Photo P. Czubla 2015

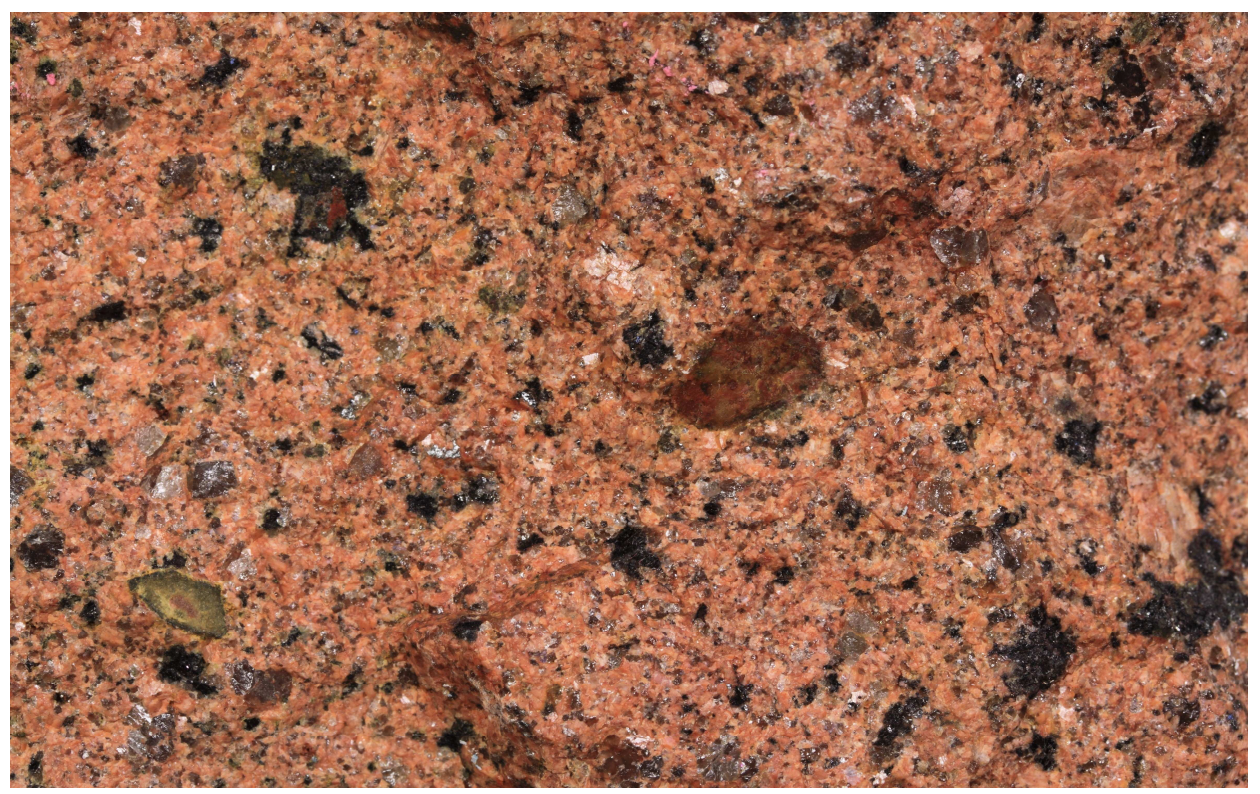

Fot. 10.10. Granit Prick, eratyk - odkrywka KWB Bełchatów; rozmiar dłuższego boku 61 mm; fot. P. Czubla 2015

Photo 10.10. Prick granite, erratic - Bełchatów outcrop; picture width $61 \mathrm{~mm}$. Photo P. Czubla 2015 


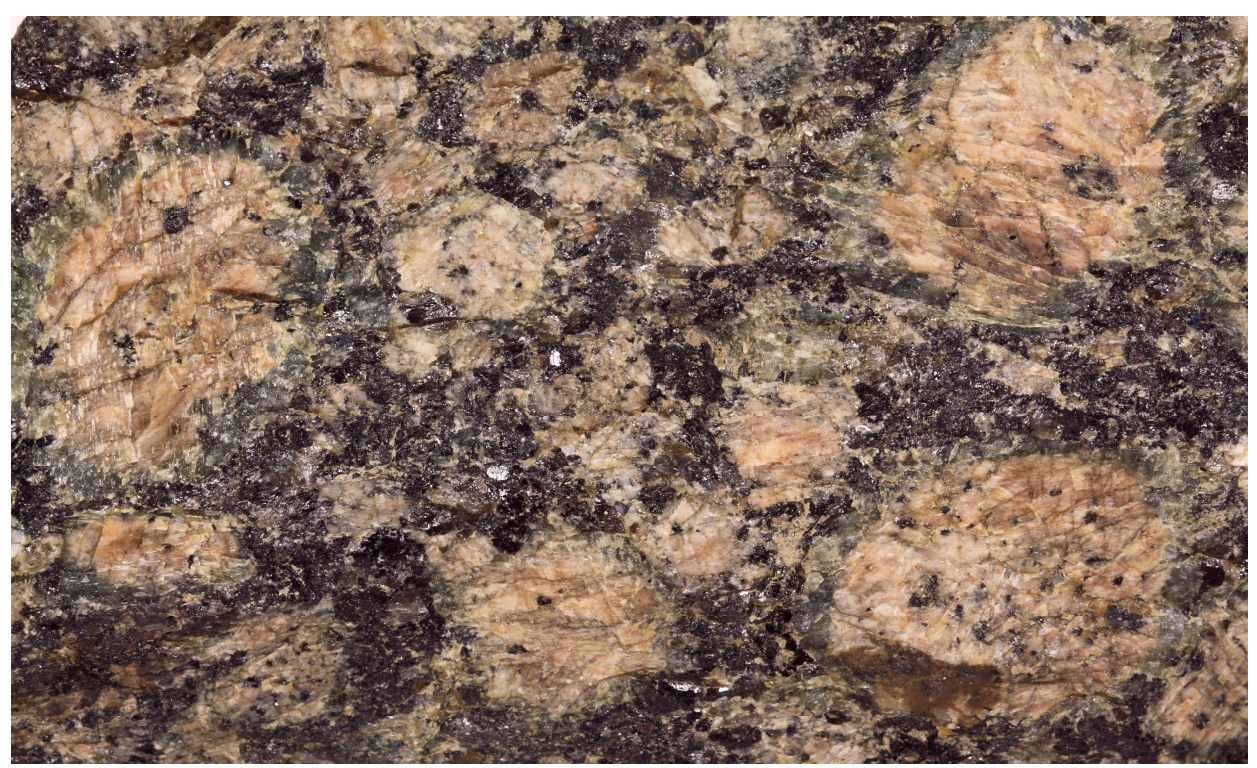

Fot. 10.11. Wyborgit (granit rapakiwi), Ylämaa, wschodnia Finlandia; rozmiar dłuższego boku 99 mm; fot. P. Czubla 2015

Photo 10.11. Vyborgite (rapakivi granite), Ylämaa, eastern Finland; picture width $99 \mathrm{~mm}$. Photo P. Czubla 2015

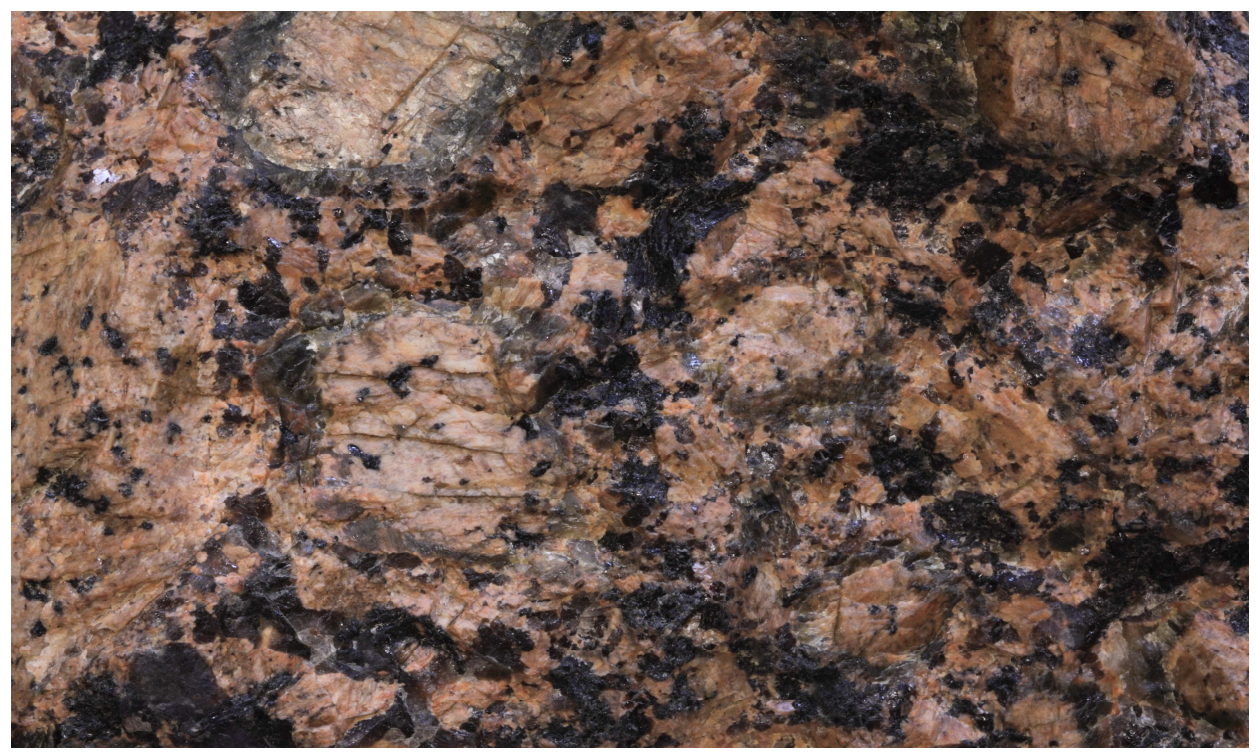

Fot. 10.12. Wyborgit (fiński granit rapakiwi), eratyk - odkrywka KWB Bełchatów; rozmiar dłuższego boku 86 mm; fot. P. Czubla 2015

Photo 10.12. Vyborgite (rapakivi granite), erratic - Bełchatów outcrop; picture width $86 \mathrm{~mm}$. Photo P. Czubla 2015 
wschodniej Finlandii. Jego opinia wydaje się jednak niezbyt zasadna, ponieważ zakres zmienności kierunków rozprzestrzeniania się lądolodów plejstoceńskich był stosunkowo duży i sama obecność eratyków dalej na wschodzie nie musi świadczyć o innym źródle zasilania. Tym bardziej, że analizy eratyków krótkiego transportu w vistulianie w Finlandii, wsparte dowodami geomorfologicznymi (m.in. przebiegiem moren Salpausselkä), wykazały dominację kierunków napływu na wschód i południowy wschód (Salonen, 1986, 1987, 1991). Gałązka (2004b) wykorzystuje do obliczeń teoretycznych ośrodków głazowych i konstruowania wykresów frekwencji skał w osadach glacjalnych niemal wszystkie skały wymienione przez Gaigalasa wśród eratyków głównych i drugorzędnych, a dodatkowo zalicza do przewodnich także dość szeroko rozpowszechniony plamisty granit Prick. Nie sposób określić, które skały z bardzo długiej listy eratyków fińskich udało się Gałązce (op. cit.) rozpoznać w analizowanych próbach, ponieważ przedstawia on wyłącznie zestawienia zbiorcze. Badacze niemieccy i holenderscy poświęcają znacznie mniej uwagi skałom fińskim, co wynika z raczej marginalnej roli eratyków ze wschodu w osadach czwartorzędowych Europy Zachodniej. Wybrane skały fińskie uwzględnili m.in. Lüttig (1958), Schuddebeurs (1980/1981), Smed (1994, 2002) i Zandstra (1999).

Strefa zasięgu skał wschodnio- i południowofińskich obejmuje właściwie tylko północno-wschodnią Polskę (Tarvydas, 1957, 1960; Gaigalas, 1971b). Przedłużenie proponowanych stref rozrzutu spowodowałoby objęcie nią również Podlasia, Lubelszczyzny i części Podkarpacia oraz Małopolski. Pozostałe obszary Polski leżą na zachód od strefy rozrzutu tych skał, co potwierdza bardzo niski udział skał z tej części Finlandii w przeanalizowanych zespołach eratyków. Bardzo podobną zachodnią granicę zasięgu fińskich wyborgitów i porfirów Hogland, przebiegającą od środkowej Estonii po Tylżę u ujścia Niemna, wyznaczył Kraus (1934). Niestety Kraus bazował na bardzo małych, niereprezentatywnych zespołach eratyków - poniżej 10 okazów z każdego z przebadanych 29 stanowisk - i jego wyniki są mało precyzyjne.

W centralnej Polsce (w glinie warciańskiej w Moszczenicy) autor zidentyfikował jeden głazik porfiru Hogland (Czubla, 2001), a Baudenbacher (1986) informuje nawet o występowaniu tego porfiru w dwóch stanowiskach w okolicach Lipska. Nasuwa się jednak pytanie, na ile możliwa jest jednoznaczna identyfikacja tej skały. Wątpliwości wyraził już Eskola (1933), wskazując na występowanie bardzo podobnych skał w postaci narzutniaków w zachodniej Finlandii, a to świadczyłoby o istnieniu wychodni łudząco podobnej skały gdzieś dużo dalej na północny zachód. Wychodnia na wyspie Suursaari (Hogland) jest obecnie niedostępna ze względów obronnych Rosji i pozyskanie próbek referencyjnych jest niemożliwe. Nawet na wybrzeżu Zatoki Fińskiej w Estonii, w odległości zaledwie kilkudziesięciu kilometrów na południe od wychodni, porfiry Hogland o typowym wykształceniu występują stosunkowo rzadko. W sprzeczności z powyższą obserwacją pozostają wyniki analiz eratyków w Białorusi, gdzie na południowy wschód od Mińska zlokalizowano zespoły głazowe zawierające nawet około 25\% porfirów Hogland (Astapova, 1987). Jedynym logicznym wyjaśnieniem nadreprezentacji tej skały (poza oczywiście nieprawidłową identyfikacją) jest istnienie do zlodowacenia saale znacznie większej wychodni omawianych porfirów w postaci cienkiej pokrywy lawowej. 
Jej zniszczenie (do eemu mógł np. zachować się jedynie komin wulkaniczny - nek) spowodowało, że w osadach vistulianu eratyki tej skały występują bardzo rzadko. Do odosobnionych przypadków przeniesienia skał wschodniofińskich daleko na zachód mógł przyczynić się transport w krach lodowych wzdłuż czoła lądolodu - dzięki obecności jezior proglacjalnych oraz rzek odprowadzających pradolinami wody ablacyjne.

Skały wywodzące się ze wschodniej Fennoskandii okazały się bardzo nieliczne w przebadanych przez autora osadach. Ich udział w osadach zlodowaceń południowopolskich wyniósł $2,3 \%$, w środkowopolskich 3,5\%, a w glinach vistulianu 1,6\%. Średnia zawartość omawianych skał w żwirach była bardzo podobna - odpowiednio 2,6\% oraz $3,2 \%$ (z osadów kompleksu północnopolskiego nie pobierano próbek żwirowych). Odpowiada to obecności zaledwie 1 lub 2, a co najwyżej 3 eratyków z analizowanego obszaru w pojedynczej przebadanej próbce.

Udział skał z kontynentalnej części Finlandii byłby znacznie większy, gdyby uwzględnić w nich również pyterlity o niepewnym pochodzeniu - alandzkie lub Nystad. Cechy tych skał nie pozwalają jednak na jednoznaczne przyporządkowanie ich do któregoś z powyżej wymienionych obszarów alimentacyjnych. Na dodatek obszar pochodzenia mógł być różny w zależności od wieku analizowanych osadów. Nie ma to jednak znaczenia w przypadku obliczania teoretycznych ośrodków głazowych, ponieważ uwzględniono tam uśrednione współrzędne obydwu potencjalnych obszarów źródłowych tych pyterlitów. Ciekawie kształtuje się rozkład pozostałych skał z rejonu Nystad w różnowiekowych osadach glacjalnych - maleje od $0,7 \% \mathrm{w}$ glinach zlodowaceń południowopolskich przez $0,3 \% \mathrm{w}$ glinach zlodowaceń środkowopolskich do zaledwie $0,1 \% \mathrm{w}$ glinach vistulianu. Mała liczba eratyków nie pozwala niestety stwierdzić, czy nie jest to rozrzut przypadkowy. Na nieprzypadkowy charakter koncentracji eratyków Nystad w najstarszych glinach wskazuja jednak badania w południowo-wschodniej Polsce w brzeżnej części Karpat pomiędzy dolinami Wisły i Sanu (Dudziak, 1970). Wysoki udział skał fińskich został tam nawet potraktowany jako cecha charakterystyczna osadów zlodowaceń południowopolskich.

Niewielka liczba zidentyfikowanych skał fińskich nie pozwala również na szczegółowe prześledzenie zmienności przestrzennej ich udziału. Mimo to można dostrzec wyraźnie podwyższony udział eratyków wschodniej proweniencji w glinach zlodowaceń południowopolskich na Podlasiu i Lubelszczyźnie, np. w Hucie Radoryskiej 6,1\%, a w Kocianowie 5,5\%. Znacznie mniej czytelne jest zróżnicowanie w osadach kompleksu środkowopolskiego, ale maksymalny udział skał fińskich znowu rozpoznano we wschodniej Polsce - 11,9\% w Mielniku (z pyterlitami alandzkimi lub Nystad nawet 16,7\%), tj. ponad trzykrotnie powyżej średniej dla osadów glacjalnych tego wieku. W glinach vistulianu udział eratyków fińskich jest zbyt mały, żeby wysnuć wiarygodne wnioski na temat ich rozmieszczenia na przebadanym obszarze.

W osadach lobu Odry Górska-Zabielska (2008) zidentyfikowała tylko jedno ziarno skały wywodzącej się z kontynentalnej części Finlandii, tj. granit Lellainen. W środkowej i zachodniej Wielkopolsce oraz na Wysoczyźnie Lubuskiej (Ziemi Lubuskiej) nie udało się potwierdzić obecności skał fińskich, pomimo wcale niemałej zawartości skał alandzkich 
(Górska, 2000; Lipka, 2011). Badania przeprowadzone w środkowych Niemczech wykazały brak w tamtejszych osadach skał z kontynentalnej części Finlandii (Hoffmann i Meyer, 1997, 1999). Pojedyncze skały z analizowanego regionu zostały znalezione w zachodnich Czechach (Víšek i Nývlt, 2006). Znacznie liczniej skały południowofińskie występują we wschodniej Polsce (Gałązka, 2004b). Ich sumaryczna ${ }^{10}$ zawartość wynosiła blisko $7 \%$ dla zlodowacenia sanu, 9,0\% w osadach warciańskich i od 0 do $15 \%$ w różnych poziomach glin vistulianu. Tę ostatnią wartość trudno pogodzić z danymi Salonena (1987), który ustalił kierunki ruchu ostatniego lądolodu w Finlandii, wykluczające dostawę skał z tamtego obszaru na południe od Bałtyku.

Przedstawione wyniki nie potwierdzają opinii Korna $(1895,1917)$ o licznym występowaniu skał fińskich włącznie z wyborgitami w Prusach Wschodnich. Nasuwają się raczej wątpliwości, w jaki sposób Korn identyfikował wyborgity, skoro znaczna część jego badań bazowała na materiale z wierceń. Należałoby raczej skłaniać się ku poglądom Eskoli (1933), który podkreślał zaskakująco nieliczne występowanie skał fińskich na tym samym obszarze. Do rozstrzygnięcia pozostaje jeszcze sprzeczność pomiędzy niebudzącą wątpliwości obecnością skał fińskich w osadach ostatniego lądolodu w Polsce, a kierunkami ruchu lodu określonymi w Finlandii w oparciu o rysy glacjalne, struktury w glinach oraz wachlarze rozrzutu eratyków (Salonen, 1987; Rauhaniemi i in., 1999). Jedynym wiarygodnym rozwiązaniem jest uwzględnienie czasu w rozważaniach. Skład gliny i obecność w niej materiału z dowolnego regionu Fennoskandii jest uśrednionym wynikiem długiego cyklu procesów, zakończonych depozycją materiału morenowego. Kierunki napływu lodu bazujące na rysach glacjalnych podłoża oraz właściwościach strukturalnych i petrograficznych glin w Fennoskandii dokumentują jedynie końcowy etap istnienia czaszy lodowej, w którym mogło dojść do radykalnej zmiany kierunku transportu glacjalnego, uwarunkowanej chociażby postępującym rozpadem czaszy lądolodu.

Na terenie Białorusi sumaryczna zawartość skał południowofińskich systematycznie wzrasta wraz z przesuwaniem się na wschód. W okolicach Grodna wynosi około $20 \%$, co i tak znacznie przekracza wartości obserwowane po polskiej stronie granicy. Dalej na wschód maleje udział skał zachodniofińskich, ale spadek rekompensuje szybki przyrost udziału skał wschodniofińskich, co sprawia, że na wschodzie kraju sumaryczna zawartość skał fińskich wynosi około 80\% (Astapova, 1987). Do tego należałoby jeszcze doliczyć porfiry Hogland, ale ich zawartość nie jest tam duża. Blisko granicy z Polską udział jest bliski zeru - w rejonie Grodna nie znaleziono ich wcale. Przy granicy z Rosją odsetek wulkanitów Hogland przekracza 10\%, najbogatsze zaś w tę skałę zespoły eratyków zaobserwowano na południowy wschód od Mińska - porfiry Hogland stanowiły tam około $25 \%$, a skały z południowo-wschodniej Finlandii cechowały się udziałem ponad $60 \%$. Na wschodzie Białorusi w składzie zespołów głazowych dość istotną rolę (do około 25\%) odgrywają też skały z Karelii (Gurski i in., 1993), których w Polsce nie udało się dotychczas zidentyfikować.

\footnotetext{
${ }^{10}$ Gałązka (2004b) oddzielnie liczył eratyki z południowo-zachodniej i południowo-wschodniej Finlandii.
} 


\subsection{Dalarna i Värmland - środkowa Szwecja}

Skały ze środkowej Szwecji należą do eratyków najliczniej występujących w osadach glacjalnych Polski. Przewodnie znaczenie pochodzących z tamtego regionu skał plutonicznych (granity Järna, Siljan i rapakiwi Siljan, Garberg - fot. 10.13, Rätan, Filipstad, Kristinehamn) i wulkanicznych (porfiry Åsen, Blyberg, Bredvad - fot. 10.14, Glöte, Grönklitt, Heden, Kåtilla, Klittberg, Månsta, Särna, Tandsjöborg - fot. 10.15, Venjan, ignimbryty Blyberg, Klittberg, Orrlok, Rännås, Särna - fot. 10.16) jest akceptowane przez większość autorów (Lüttig, 1958; Hesemann, 1975; Meyer, 1983; Smed, 1994, 2002; Gałązka, 2004b; Czubla i in., 2006). Do wyjątkowych należy podejście Tarvydasa (1971d), który kwestionuje przewodni charakter granitów Siljan i Järna. Informuje on również o występowaniu w Jämtlandzie, Härjedalen i w innych stanowiskach skał bardzo podobnych do dalarneńskiego porfiru Bredvad (powołując się na pracę Högboma z 1920). Wbrew powyższej informacji nie podważa jednak przewodniej roli tej skały.

Zdecydowanie mniej jednoznaczne jest stanowisko wobec skał żyłowych - głównie diabazów. Zdaniem Meyera (1983) diabazy Öje i Åsby mogą w bardzo podobnym wykształceniu występować w wielu stanowiskach. Na podobieństwo diabazów odsłaniających się w Szwecji i w Finlandii zwracał uwagę już Mende (1926). Tarvydas (1971d) zdyskwalifikował diabaz Åsby jako skałę przewodnią w krajach perybałtyckich ze względu na pobliskie występowanie diabazów Satakunta - trudno- lub zupełnie nieodróżnialnych od Åsby. Jako dodatkowy argument przeciwko przypisywaniu temu diabazowi roli przewodniej przytoczył dodatkowe miejsca występowania bardzo podobnych skał na zachodnim brzegu Zatoki Botnickiej, na Wyspach Alandzkich oraz w prowincjach Södermanland i Jämtland. Negatywną opinię na temat roli diabazów podziela również Schuddebeurs (1980/1981), odwołując się do nieopublikowanych materiałów Groetznera. Niejasne są w tym kontekście przesłanki, które skłoniły Gałązkę (2004b) do uwzględniania w swoich badaniach diabazu Öje, a odrzucania Åsby. Jedyną skałą żyłową z prezentowanego regionu, możliwą do jednoznacznego zidentyfikowania i przypisania do konkretnej wychodni, jest tinguait Särna bardzo rzadko występujący w Polsce zaledwie 5 głazików, w tym wątpliwe, na około 8000 zidentyfikowanych krystalicznych eratyków przewodnich (fot. 10.17).

Ostatnio, za sprawą publikacji Smeda (1997, 2000, 2002, 2010), nasiliła się dyskusja dotycząca wykorzystania w badaniach skał osadowych, w tym jotnickich piaskowców z Dalarny (fot. 10.18 i 10.19). W odróżnieniu od pozostałych piaskowców jotnickich określane są jako piaskowce Dala, ale poza nazwą nic ich nie wyróżnia spośród innych piaskowców tego wieku, nagromadzonych w zagłębieniach subjotnickiej penepleny. Część badaczy uważa, że wyznacznikiem dalarneńskiego pochodzenia piaskowców jotnickich jest występowanie fioletowawego zabarwienia z niewielkimi jasnymi (jasnoszarymi lub beżowożółtymi) plamkami odbarwieniowymi (Bennhold, 1932; Schuddebeurs, 1980/1981; Smed, 1994, 2002). Mają one powstawać w wyniku rozkładu kryształów pirytu, wchodzących w skład skały, a następnie reakcji produktów rozkładu tego minerału z hematytem, zawartym w spoiwie i pierwotnie nadającym skale czerwonawe 
zabarwienie (Schulz, 2003). Nic zatem dziwnego, że tego typu plamy z odbarwienia i fioletowawa kolorystyka znane są ze wszystkich wychodni piaskowców jotnickich oraz występują w wielu innych skałach psamitowych (Meyer i Lüttig, 2007). W spągu piaskowców jotnickich najczęściej występują zlepieńce, często arkozowe, przechodzące ku górze w typowe ceglastoczerwone do ciemnoczerwonych piaskowce o bardzo dużej miąższości.

Pierwotny zasięg piaskowców jotnickich obejmował zapewne dużą część Fennoskandii. Współcześnie zachowały się tylko w obniżeniach, np. na powierzchni batolitów granitoidowych w południowej Finlandii i na Wyspach Alandzkich oraz w Zatoce Botnickiej (Winterhalter i in., 1981; Flodén, 1984). Sprzyjające warunki do przetrwania piaskowców jotnickich istniały również w rowach tektonicznych po obydwu stronach Zatoki Botnickiej, tj. na zachód od Sztokholmu w okolicach jeziora Mälar (piaskowiec Mälar albo Ekerö), w rejonie Nordingrå i Gävle w Szwecji oraz Oulu-Muhos i Pori w Finlandii. Przy pomocy badań sejsmicznych Flodén $(1973,1984)$ udokumentował duże wystąpienia piaskowców jotnickich na dnie Bałtyku na południe od Wysp Alandzkich i na północny zachód od Gotlandii. W środkowej Skandynawii piaskowce jotnickie zajmują około 30 tys. $\mathrm{km}^{2}$ i osiągają maksymalną miąższość do 800 metrów (Schulz, 2003). Ich wychodnie ciągną się przez dużą część Dalarny i przedłużają na drugą stronę granicy z Norwegią (Meyer i Lüttig, 2007). Groetzner (1972) opisał piaskowce Dala jako przewodnie, ale z zastrzeżeniem, że bardzo podobne piaskowce jotnickie oglądał w południowo-zachodniej Finlandii w pobliżu elektrowni Kahjavalta. Sumaryczny obszar zajęty przez piaskowce jotnickie jakoby wynosi aż 0,5 mln km² (Meyer i Lüttig, 2007 str. 110). Nawet jeśli podana wielkość jest wielokrotnie zawyżona, to i tak obszar źródłowy tych skał jest bardzo duży (rys. 10.5), a to sprawia, że piaskowce jotnickie należą do najpospolitszych eratyków na Niżu Środkowoeuropejskim i nie mogą pełnić roli przewodniej. Mimo to Górska-Zabielska wyznacza trzy różne punkty centralne wychodni piaskowców jotnickich: jeden w Dalarnie i dwa na dnie Bałtyku na północ i południe od Wysp Alandzkich (2008 - str. 60). Brak jednak informacji, w jaki sposób punkty te zostały wyznaczone oraz jakie kryterium ma decydować o wyborze jednego z nich.

Pomimo tak rozległej i rozczłonkowanej wychodni, w wielu stanowiskach Holandii, Danii i Niemiec zaobserwowano znacznie liczniejsze występowanie piaskowców jotnickich, niż gdzie indziej (Meyer i Lüttig, 2007). W takich przypadkach bywa możliwe powiązanie piaskowca jotnickiego z konkretną wychodnią na podstawie towarzyszących mu typowych skał przewodnich. W ten sposób „Trebuser Sandstein"11 (Bennhold, 1931, 1932), dzięki licznej współobecności brunatnych porfirów bałtyckich i skał alandzkich, a znikomej eratyków dalarneńskich, mógł zostać powiązany z wychodnią na dnie Bałtyku (Schuddebeurs i Zwenger, 1992; Meyer, 2000; Zwenger, 2010). Jak widać przypisanie tamtejszych piaskowców do Dalarny, na podstawie licznego występowania plam odbarwieniowych - zgodnie z ideą Smeda (1994, 2002), doprowadziłoby do

\footnotetext{
${ }^{11}$ Piaskowiec jotnicki znajdowany w masowych ilościach w okolicach Trebus na północ od Fürstenwalde w Niemczech.
} 


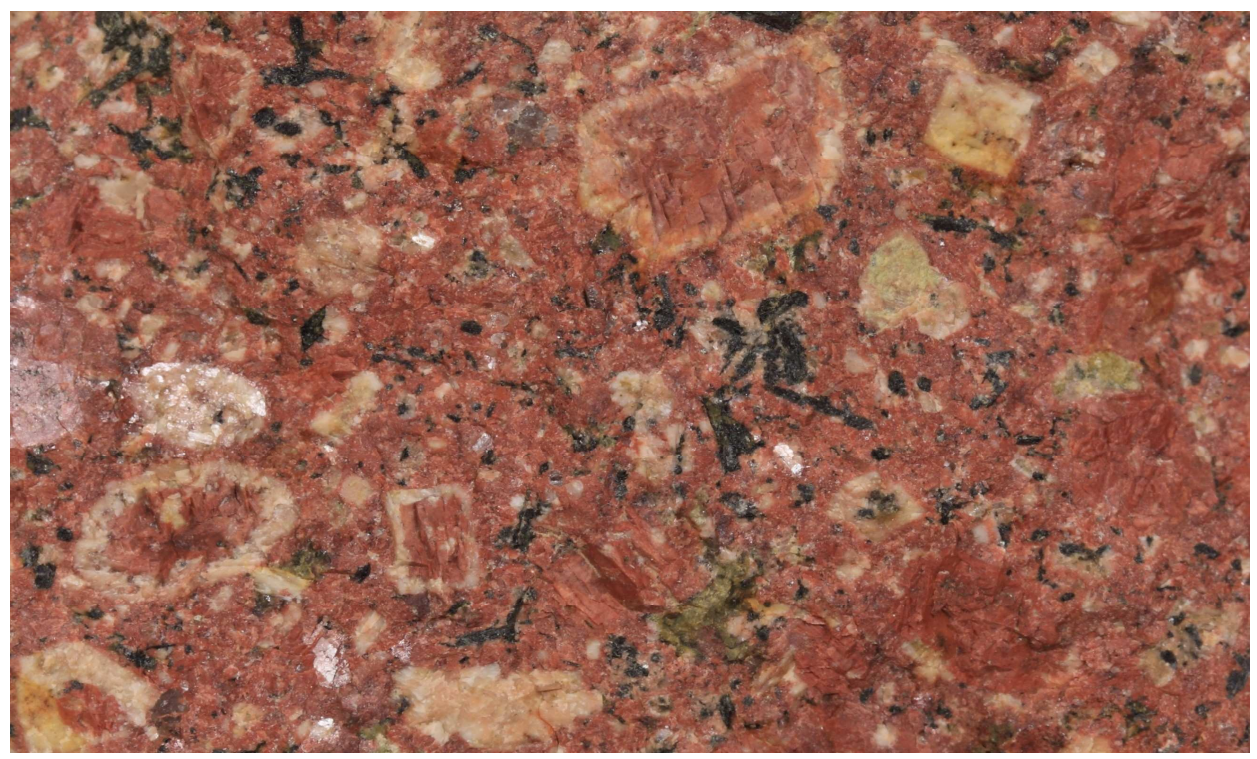

Fot. 10.13. Granit Garberg, eratyk - Moszczenica k/Piotrkowa Trybunalskiego; rozmiar dłuższego boku $44 \mathrm{~mm}$; fot. P. Czubla 2015

Photo 10.13. Garberg granite, erratic - Moszczenica near Piotrków Trybunalski; picture width $44 \mathrm{~mm}$. Photo P. Czubla 2015

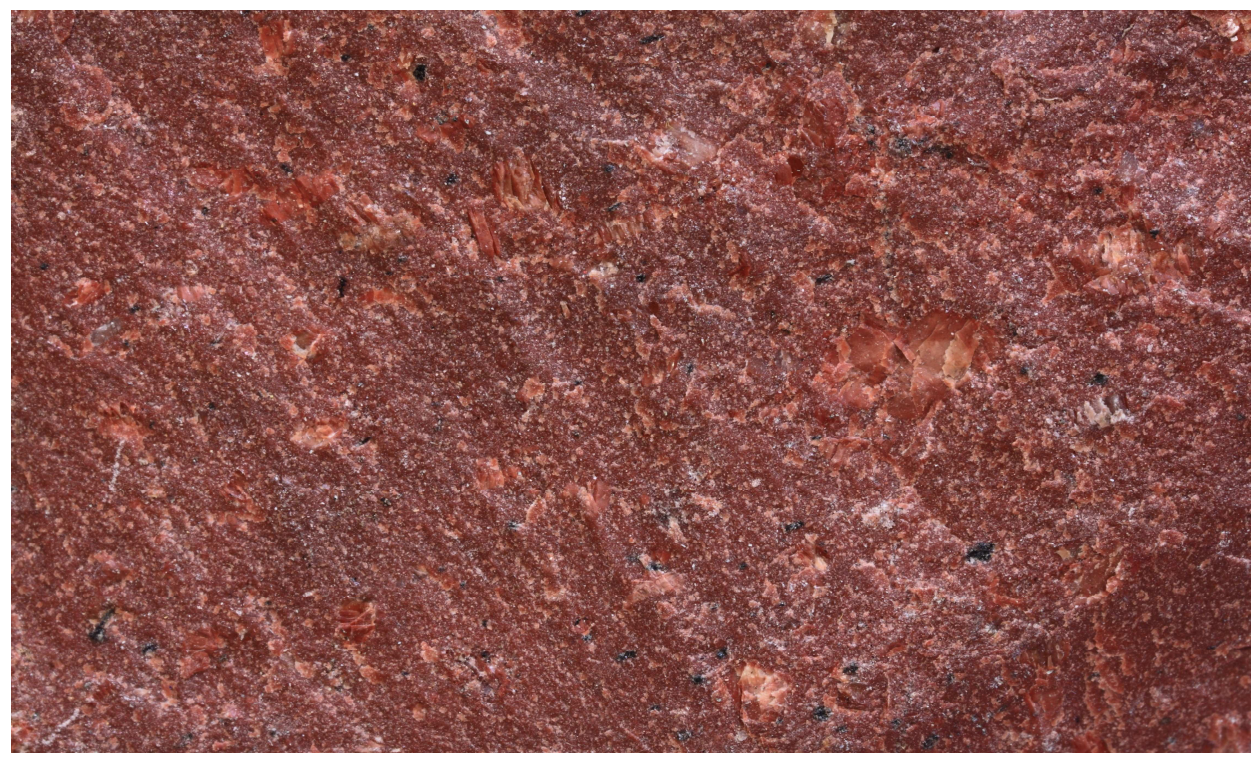

Fot. 10.14. Porfir Bredvad, okolice zapory Trängslet, Dalarna, środkowa Szwecja; rozmiar dłuższego boku $45 \mathrm{~mm}$; fot. P. Czubla 2015

Photo 10.14. Bredvad porphyry, near the Trängslet dam, Dalarna, Central Sweden; picture width $45 \mathrm{~mm}$. Photo P. Czubla 2015 


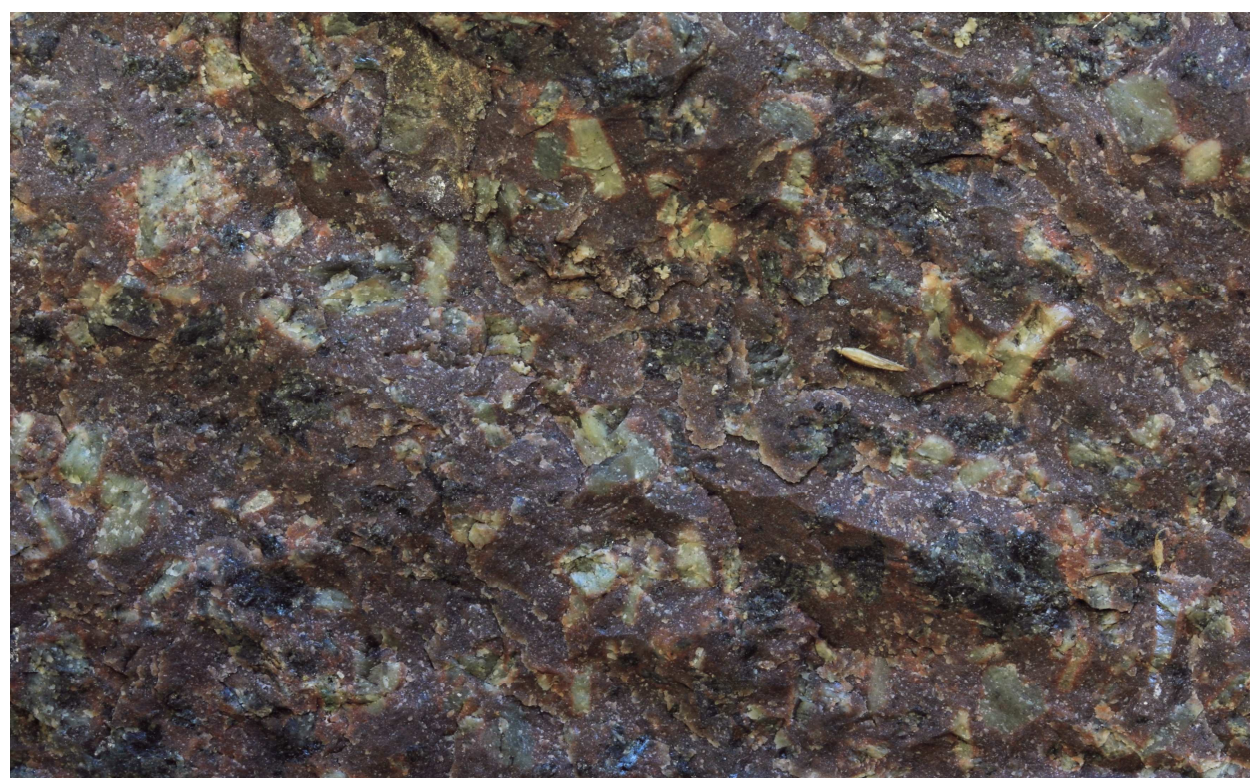

Fot. 10.15. Porfir Tandsjöborg, Tandsjöborg, Dalarna, środkowa Szwecja; rozmiar dłuższego boku 39 mm; fot. P. Czubla 2015

Photo 10.15. Tandsjöborg porphyry, Tandsjöborg, Dalarna, Central Sweden; picture width $39 \mathrm{~mm}$. Photo P. Czubla 2015

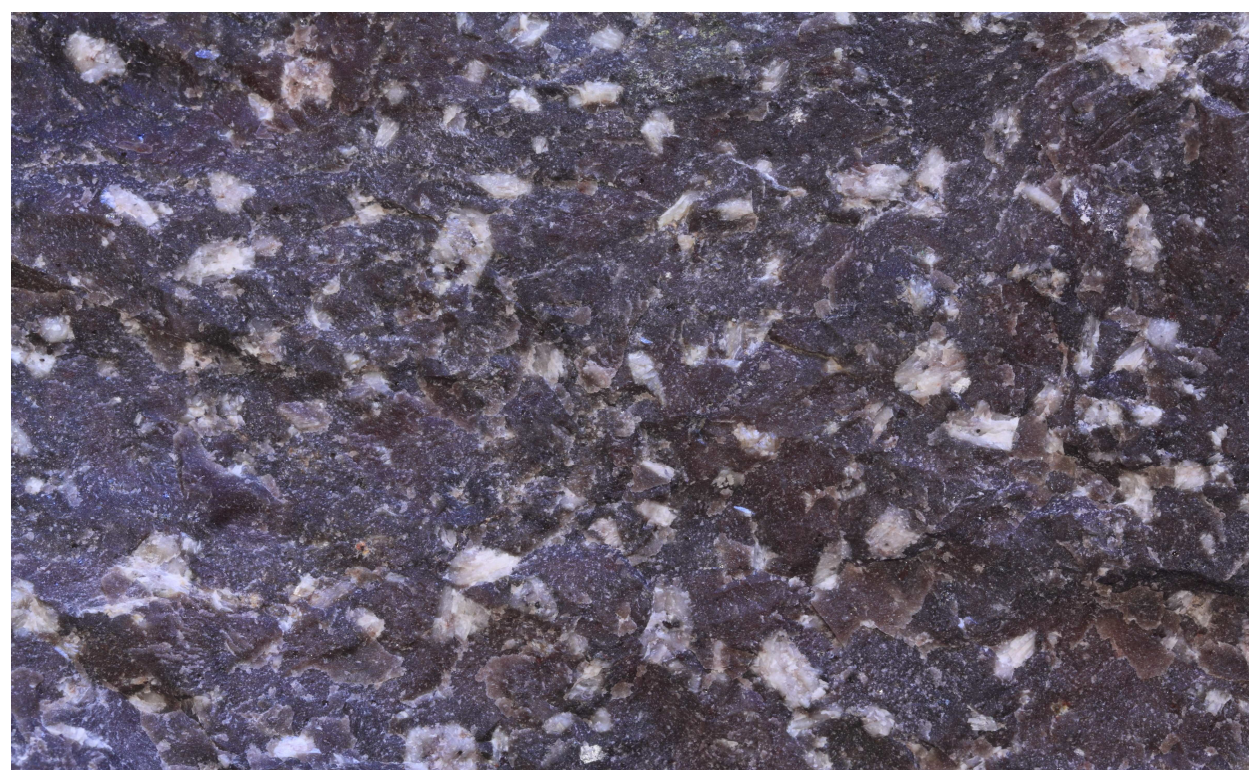

Fot. 10.16. Ignimbryt Särna (fioletowy), Särna, środkowa Szwecja; rozmiar dłuższego boku $81 \mathrm{~mm}$; fot. P. Czubla 2015

Photo 10.16. Särna ignimbrite (violet), Särna, Central Sweden; picture width 81 mm. Photo P. Czubla 2015 


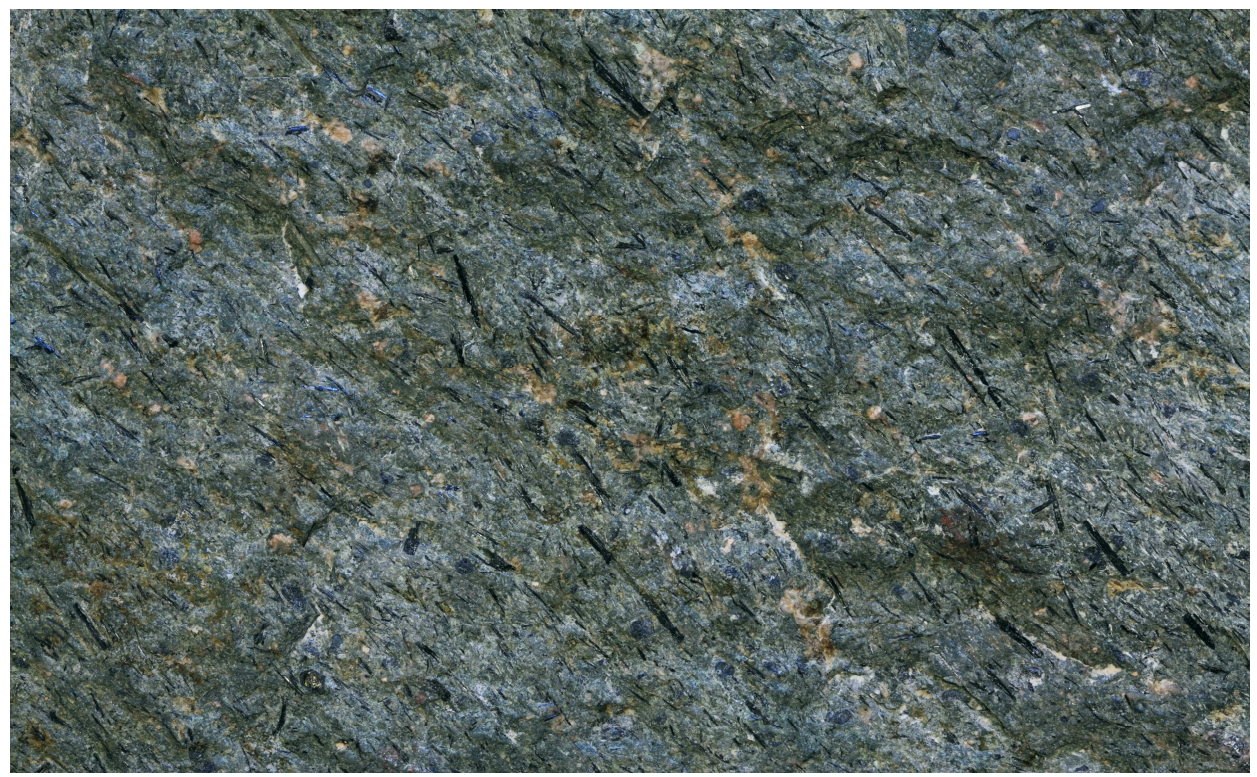

Fot. 10.17. Tinguait (särnait), Siksjöberget k/Bergswallen, środkowa Szwecja; rozmiar dłuższego boku $98 \mathrm{~mm}$; fot. P. Czubla 2015

Photo 10.17. Särna tinguaite (särnaite), Siksjöberget near Bergswallen, Central Sweden; picture width 98 mm. Photo P. Czubla 2015

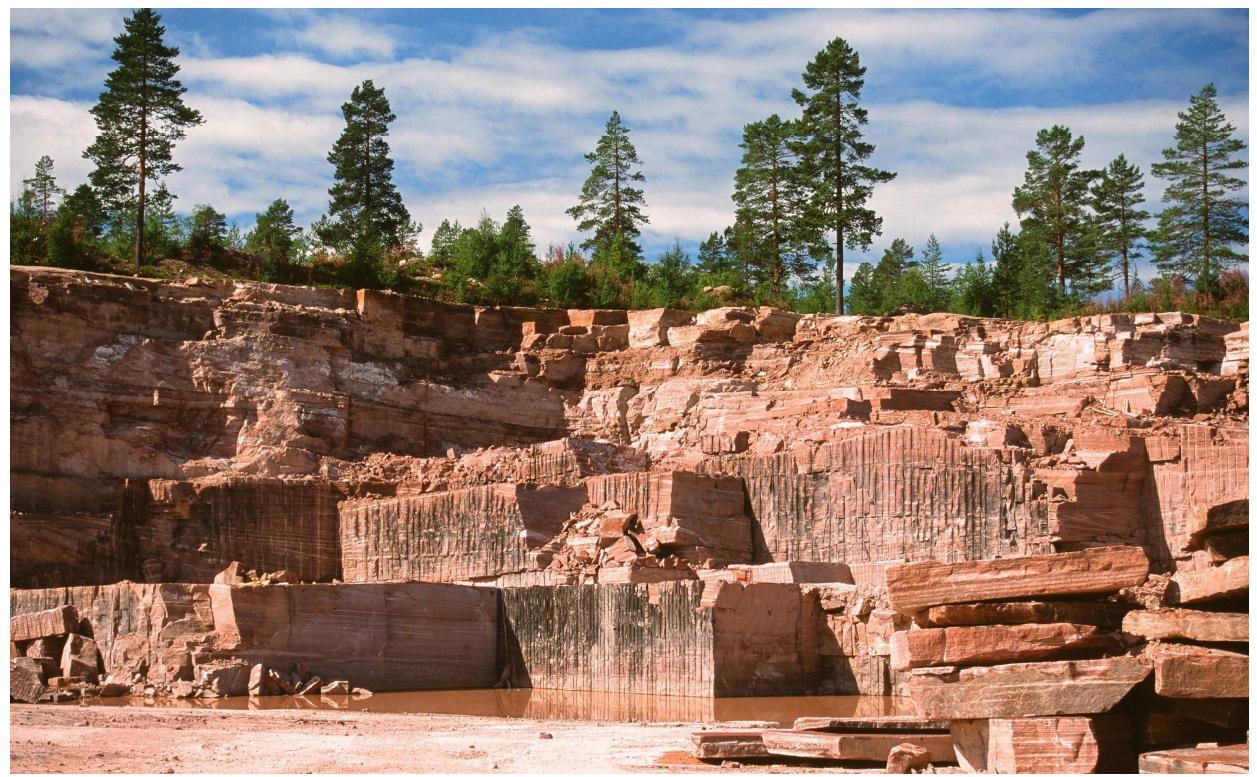

Fot. 10.18. Kamieniołom piaskowców jotnickich, Mångsbodarna, Dalarna, środkowa Szwecja; fot. P. Czubla 2003

Photo 10.18. Jotnian sandstone quarry, Mångsbodarna, Dalarna, Central Sweden. Photo P. Czubla 2003 


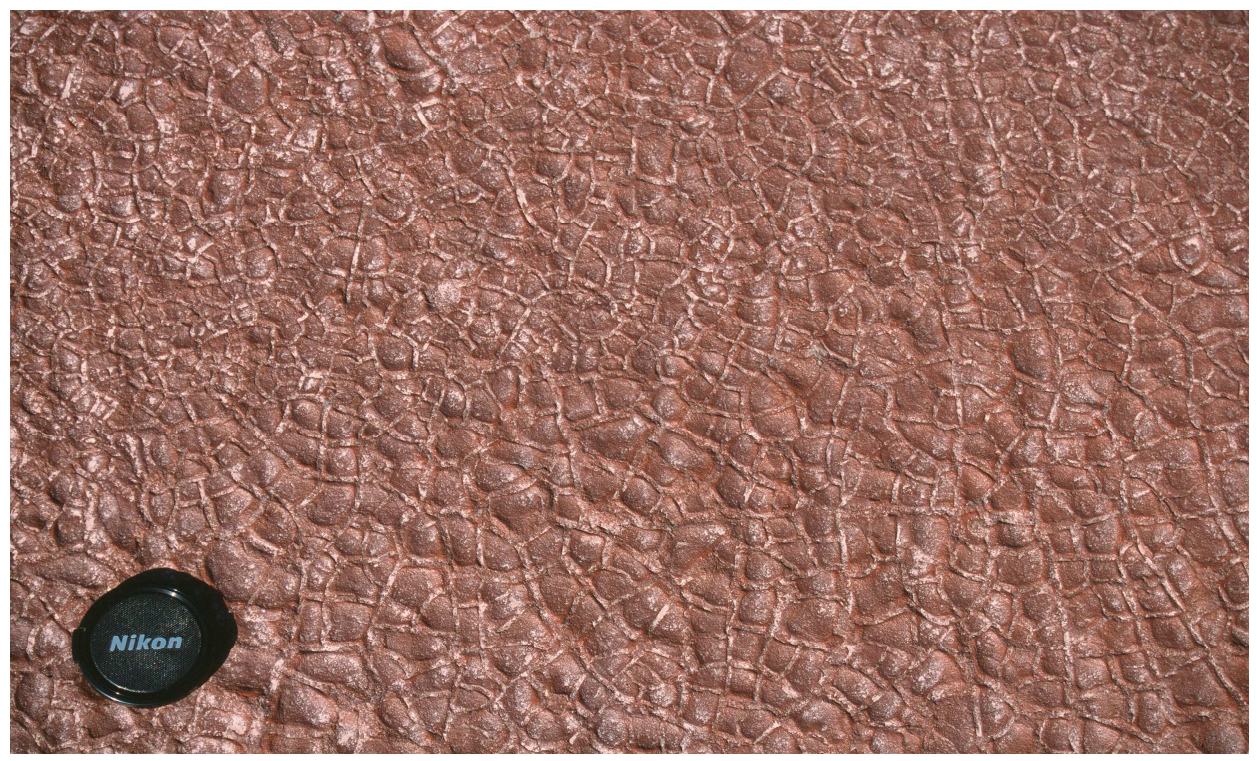

Fot. 10.19. Odlewy szczelin z wysychania w piaskowcu jotnickim, Mångsbodarna, Dalarna, środkowa Szwecja; rozmiar dłuższego boku $550 \mathrm{~mm}$; fot. P. Czubla 2003

Photo 10.19. Castings of drying cracks in Jotnian sandstone, Mångsbodarna, Dalarna, Central Sweden; picture width $550 \mathrm{~mm}$. Photo P. Czubla 2003

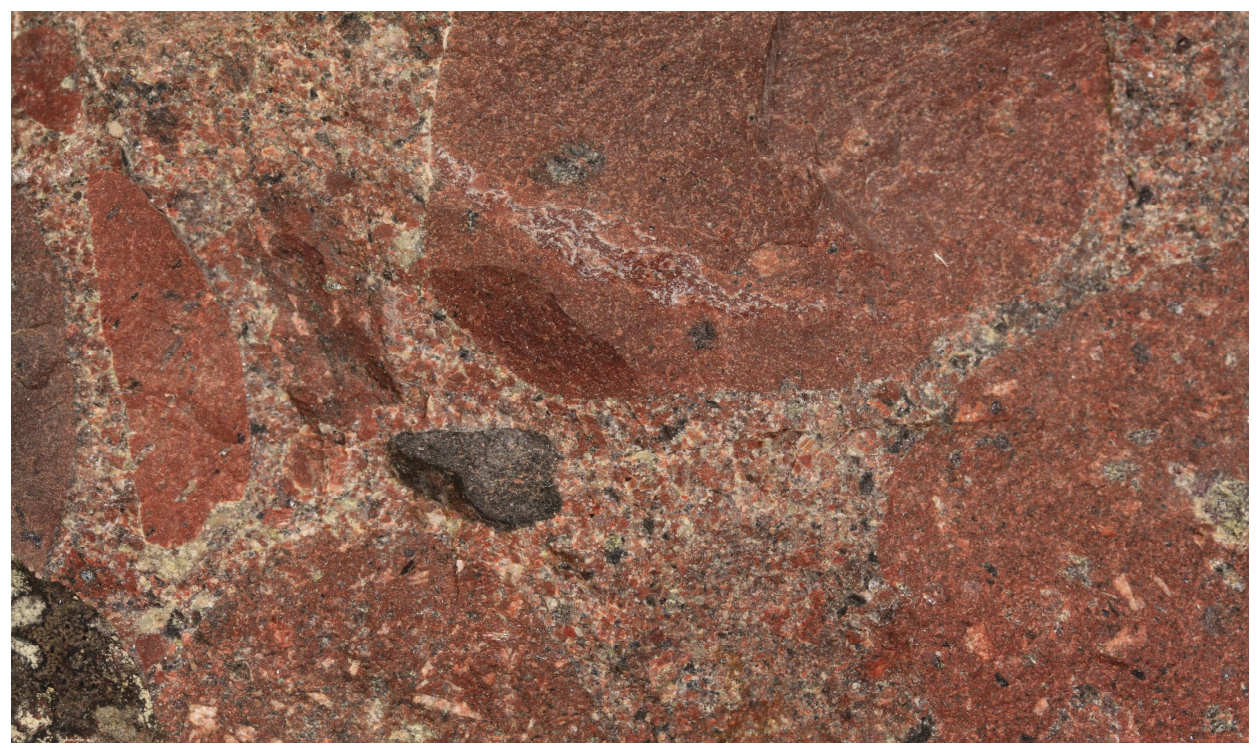

Fot. 10.20. Zlepieniec Digeberga, Höghed, Dalarna, środkowa Szwecja; rozmiar dłuższego boku $66 \mathrm{~mm}$; fot. P. Czubla 2015

Photo 10.20. Digeberga conglomerate, Höghed, Dalarna, Central Sweden; picture width $66 \mathrm{~mm}$. Photo P. Czubla 2015 


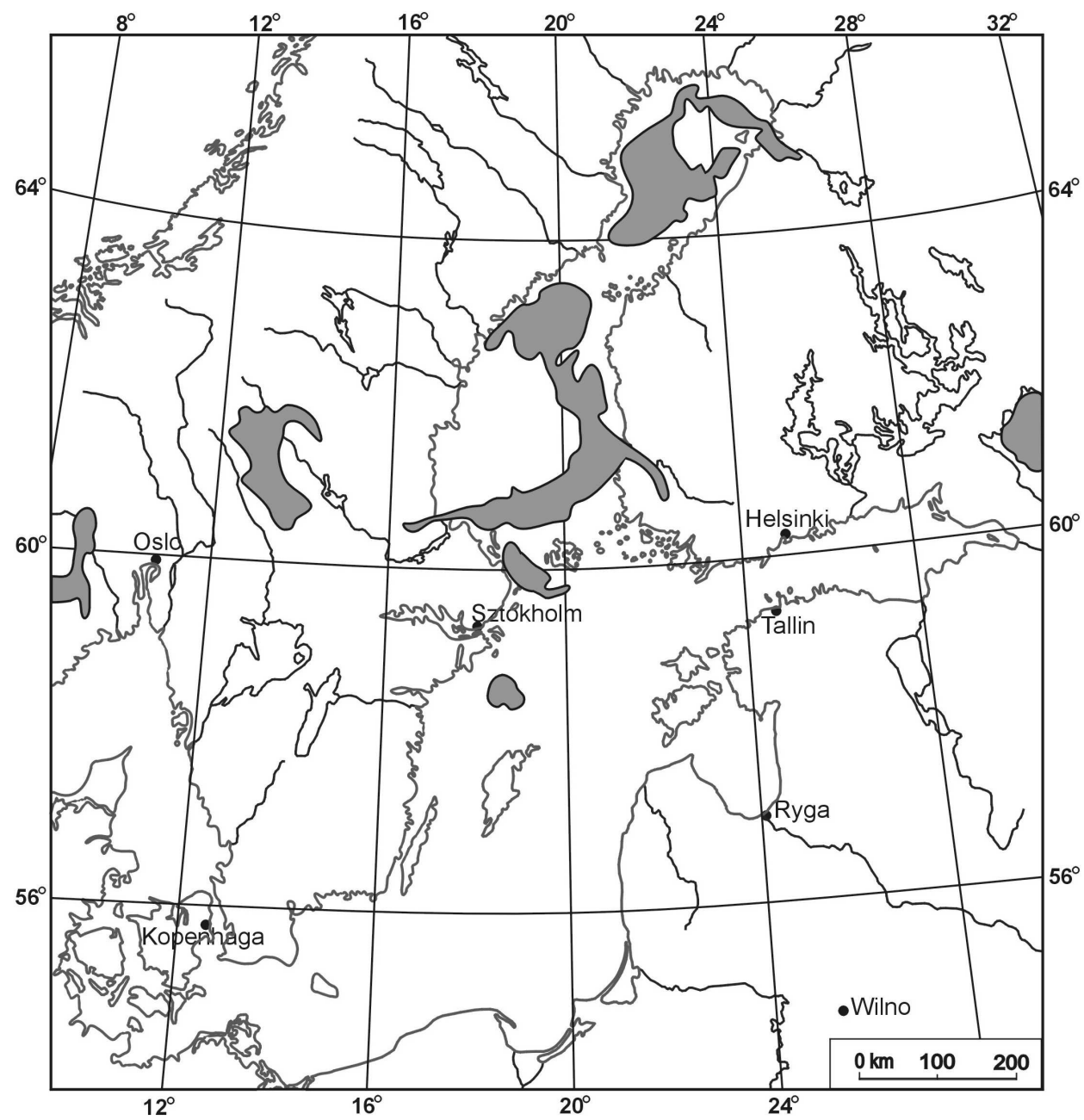

Rys. 10.5. Występowanie piaskowców jotnickich w Fennoskandii (wg Zwengera, 2010; uproszczone)

Figure 10.5. The occurrence of Jotnian sandstones in Balto-Fennoscandia (according to Zwenger, 2010 - Fig. 2, simplified)

błędnych wniosków. Podobne przypadki stowarzyszenia piaskowców jotnickich ze skałami alandzkimi, a nie dalarneńskimi znane są z Rugii oraz z Dolnej Saksonii (Meyer i Lüttig, 2007).

Jedynymi skałami osadowymi z analizowanego obszaru, które mogą być wykorzystywane jako eratyki przewodnie, pozostały zatem piaskowce i zlepieńce Digeberga (fot. 10.20). Zlepieńce są bardzo łatwo rozpoznawalne dzięki obecności w ich składzie otoczaków porfirów dalarneńskich (Meyer, 1983; Smed, 1994, 2002). Ich wadą jest jednak bardzo rzadkie występowanie w osadach glacjalnych Niżu Środkowoeuropejskiego. Tufowate piaskowce Digeberga są znacznie trudniejsze do identyfikacji i istnieje 
wysokie prawdopodobieństwo pomylenia ich podczas makroskopowej identyfikacji ze zwykłymi jotnickimi piaskowcami arkozowymi o podobnej budowie wewnętrznej i bliżej nieustalonym pochodzeniu.

Skały z Dalarny i Värmlandu stanowią drugą pod względem liczebności, po skałach alandzkich, grupę eratyków przewodnich wyróżnionych w osadach glacjalnych w Polsce. Średnia zawartość skał tej grupy w glinach zlodowaceń południowopolskich wynosi $23,9 \%$, w środkowopolskich spada do $19,6 \%$, by w osadach ostatniego zlodowacenia powtórnie wzrosnąć do 21,0\%. Dość wyraźnie zaznacza się zmienność przestrzenna udziału skał dalarneńskich w osadach glacjalnych. Najwięcej eratyków przewodnich z analizowanego regionu Fennoskandii w glinach zlodowaceń południowopolskich zidentyfikowano na Dolnym Śląsku (w dolnej glinie w Rusku 45,0\%, a w Mokrzeszowie $36,0 \%$ ) oraz w środkowej Polsce (Bełchatów B17 40,6\%, Mąkolice 38,5\%). Najniższy udział tych skał stwierdzono na Podlasiu: w Mielniku 7,1\% oraz w Neplach 7,6\% (rys. 10.6). Eratyki dalarneńskie w osadach zlodowaceń środkowopolskich krzny i odry/ warty najliczniej występują w glinie T5 (krzna?) w Bełchatowie - maks. 39,2\% oraz na Pomorzu w Pucku 38,9\% i w sąsiednim Osłoninie 38,0\%. Podobnie jak w starszych osadach, minimalną zawartością skał dalarneńskich cechowały się gliny na Podlasiu 3,7\% w Kaczorach koło Siedlec i 4,5\% w Neplach nad Bugiem (rys. 10.7). Spadek znaczenia skał dalarneńskich przy przesuwaniu się na wschód na obszarze Polski zaobserwowano po raz pierwszy już w okresie międzywojennym, kiedy przeprowadzono pierwsze systematyczne badania eratyków (Milthers i Milthers, 1938). Mankamentem ówczesnych badań był jednak pobór skał z powierzchni terenu, co uniemożliwiło wiarygodne przyporządkowanie stratygraficzne opracowywanych stanowisk.

Obszar badań glin vistulianu ma małą rozciągłość równoleżnikową (rys. 10.6). W związku z tym zmienność przestrzenna udziału skał dalarneńskich jest, w przeciwieństwie do starszych osadów, trudna do przeanalizowania. Najwyższy udział tych skał stwierdzono w Osłoninie koło Pucka $(32,3 \%)$ i w pobliskim Ostrowie $(31,4 \%)$, a najniższe w Wiągu nad Wisłą $(7,1 \%)$ i w środkowej glinie w Kozłowie koło Świecia $(9,1 \%)$. Podkreślić należy, że obydwie gliny z minimalnym udziałem skał dalarneńskich mogą być interpretowane jako osad stadiału Świecia (Czubla, 2011).

Odmienne zróżnicowanie stratygraficzne udziału skał dalarneńskich przedstawił Gałązka (2004b). Według jego badań w glinach zlodowacenia sanu udział ten wynosi zaledwie $14,9 \%$, w glinach odry $27,5 \%$, warty $13,4 \%$ do $19,7 \%$, w trzech zaś wyróżnianych poziomach glacjalnych vistulianu najwyższy zanotował w najstarszym (glina Świecia) 32,3\%, w kolejnych zauważalny jest spadek do $21,8 \%$ i wreszcie $16,8 \%$ w najmłodszym, korelowanym z fazą pomorską. Podkreślić należy, że badania Gałązki odniesione zostały do tradycyjnego podziału stratygraficznego, tzn. sprzed wprowadzenia zmian proponowanych przez Bera i in. (2007). Utrudnia to obiektywne porównanie wyników. Po uwzględnieniu reinterpretacji wieku glin w Bełchatowie i odstąpieniu od rozdzielania poziomów morenowych w obrębie poszczególnych kompleksów stratygraficznych, wyniki Gałązki prawie nie odbiegają od danych autora. 


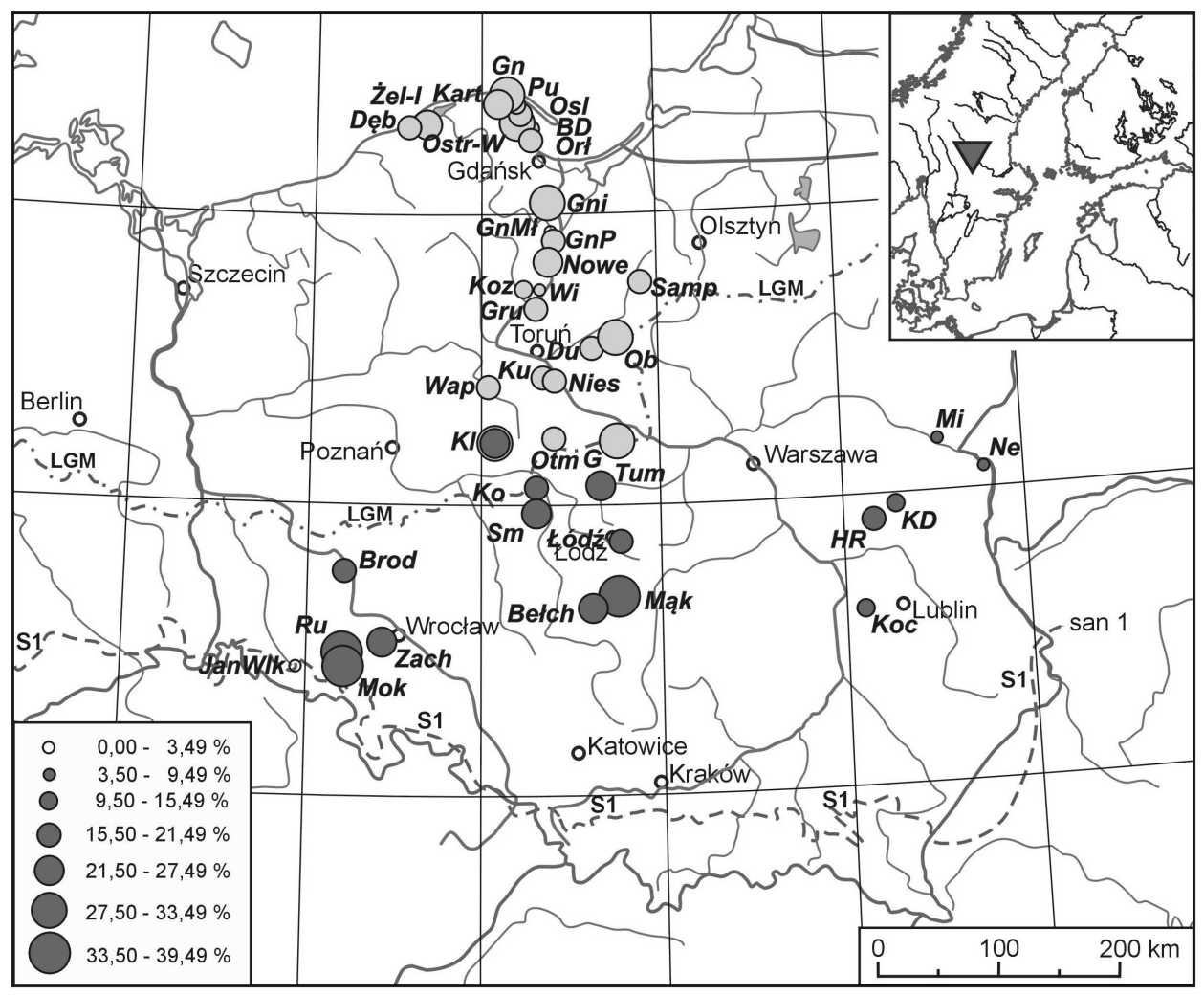

Rys. 10.6. Rozmieszczenie skał z Dalarny i Värmlandu w przebadanych osadach glacjalnych kompleksu południowopolskiego (ciemne koła) i północnopolskiego (jasne koła) - udział poniżej 3,50\% (puste koło jako symbol stanowiska) oznacza brak danej skały

Figure 10.6. The distribution of Dalarna and Värmland rocks in glacial deposits of the South-Polish Complex (dark circles) and of the North-Polish Complex (light circles) - share below 3,50\% (empty circle as a site symbol) means a lack of the presented erratics in the site

W żwirach skały dalarneńskie występują nieco liczniej niż w glinach - odpowiednio $23,6 \%$ wobec $21,1 \%$. To zróżnicowanie może wynikać z dominującej roli odpornych na wietrzenie skał wulkanicznych wśród eratyków przewodnich z tego obszaru. Takie skały nawet wystawione przez bardzo długi okres na działanie intensywnego wietrzenia ulegają stosunkowo niewielkim zmianom i nadal są rozpoznawalne. $\mathrm{Na}$ wtórne podwyższenie zawartości dalarneńskich wulkanitów w osadach zalegających na powierzchni oraz w żwirach zwrócił uwagę również Dudziak (1974, 1985). Zarówno w glinach, jak i w żwirach wulkaniczne i subwulkaniczne skały z Dalarny są liczniejsze od swoich plutonicznych odpowiedników. Ta dysproporcja nasila się wraz z wietrzeniem (Czubla, 2001). W zespołach głazowych, pobranych z na ogół mocno już zwietrzałych osadów glacjalnych w Holandii, udział samego porfiru Bredvad może przekraczać $20 \%$ (Schuddebeurs, 1980/1981). Do przeciwnego wniosku mogłaby prowadzić interpretacja 
badań Górskiej-Zabielskiej (2008), która w lobie Odry stwierdziła większy udział skał z Dalarny w glinach, aniżeli w żwirach - 20,4\% wobec $18,3 \%$. Te wyniki trudno jednak uznać za ostateczne ze względu na zbyt małą liczbę krystalicznych eratyków przewodnich rozpoznanych w przebadanych osadach - zwłaszcza w glinach.

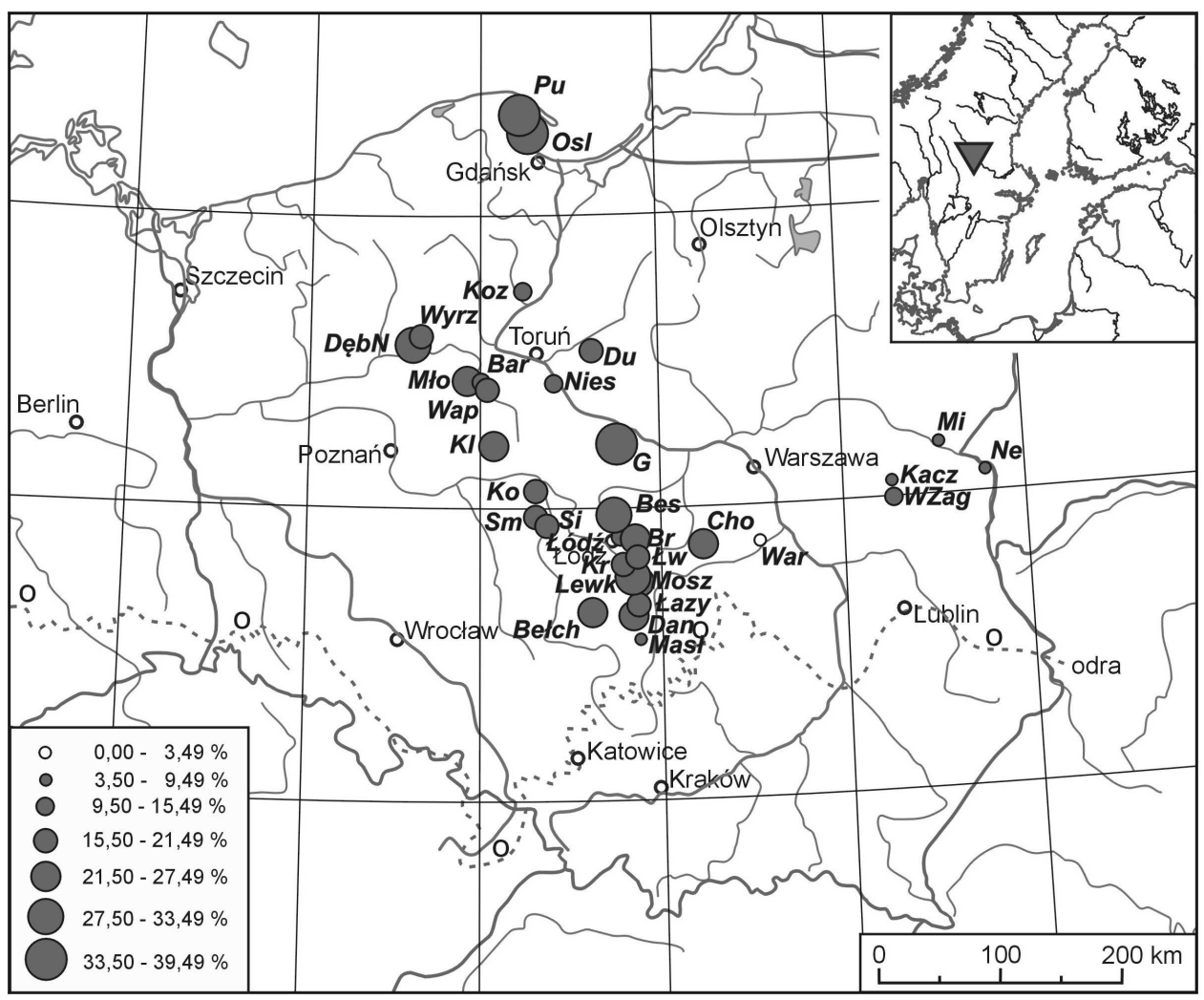

Rys. 10.7. Rozmieszczenie skał z Dalarny i Värmlandu w przebadanych osadach glacjalnych kompleksu środkowopolskiego - udział poniżej 3,50\% (puste koło jako symbol stanowiska) oznacza brak danej skały Figure 10.7. The distribution of Dalarna and Värmland rocks in glacial deposits of the Middle-Polish Complex share below $3,50 \%$ (empty circle as a site symbol) means a lack of the presented erratics in the site

Najliczniej występującą skałą z Dalarny jest porfir Bredvad, który w przebadanych zespołach głazowych miał udział od 5,8\% w glinach kompleksu środkowopolskiego przez 6,1\% w kompleksie południowopolskim, aż po 6,9\% w glinach vistulianu. Wyraźnie zaznaczyła się również różnica udziału tej skały w glinach $(6,2 \%)$ oraz żwirach (7,3\%). Na obszarze badań Górskiej-Zabielskiej (2008) całkowity udział porfirów Bredvad był znacznie mniejszy od wyznaczonego przez autora, a dysproporcja pomiędzy żwirami i glinami zaznaczyła się dużo bardziej - 2,7\% wobec 4,3\% i w odwrotnym kierunku, tzn. udział eratyków tej skały był wyższy w glinach. Na Litwie i Łotwie porfiry Bredvad występują w osadach wszystkich zlodowaceń, ale najliczniej w dwóch ostatnich 
(Tarvydas, 1971d). Bardzo wysoki udział tej skały został stwierdzony w osadach zlodowacenia elstera w zachodnich Czechach - nawet ponad 25\% (Víšek i Nývlt, 2006), ale należy tu uwzględnić fakt, że większość prób eratyków analizowanych w Czechach pochodzi z osadów fluwioglacjalnych, które mogą zawierać materiał skalny wstępnie przeselekcjonowany przez wietrzenie.

Zróżnicowanie przestrzenne udziału porfirów Bredvad w zespołach głazowych Polski jest niewielkie. Najwyższy udział tej skały w osadach zlodowaceń południowopolskich zaobserwowano w stosunkowo mocno zwietrzałych glinach w Łodzi (10,5\%) i w Tumie koło Łęczycy (10,4\%). Bardzo wysokie wskaźniki zanotowano również na Dolnym Śląsku: 9,7\% w dolnej glinie w Rusku i 8,6\% w Brodowicach. Najbogatsze w porfiry Bredvad osady zlodowaceń środkowopolskim występują na północy kraju: w Pucku 14,8\% oraz w Wyrzysku 10,3\%. W przebadanych osadach obydwu starszych kompleksów glacjalnych zauważalny jest spadek ich zawartości w Polsce Wschodniej (rys. 10.8). W osadach vistulianu możliwości interpretacyjne są bardzo ograniczone ze względu na brak danych z północno-wschodniej Polski - Gałązka (2004b) nie zamieścił surowych danych, lecz wyłącznie zestawienia zbiorcze. W lobie Odry udział omawianej skały (4,3\%) jest znacznie niższy (Górska-Zabielska, 2008) od stwierdzonego przez autora w lobie wiślanym (6,9\%). Maksymalna zawartość porfirów Bredvad została jednak stwierdzona w strefie interlobalnej w stanowisku Żelazo na środkowym Pomorzu - 14,0\%. Bardzo wysoki udział rozpoznano również w Ostrowie koło Władysławowa (12,8\%) oraz w Gostyninie na zapleczu strefy marginalnej ostatniego zlodowacenia $-12,5 \%$.

Zarówno w glinach, jak i w żwirach Polski porfiry Bredvad były prawie dwukrotnie liczniejsze od porfirów Grönklitt. Podobne proporcje stwierdzone zostały w zachodniej części Czech (Víšek i Nývlt, 2006). Wspomniana przez Tarvydasa (1971d) przewaga liczbowa czerwonych porfirów Grönklitt nad szarymi na Litwie i Łotwie, potwierdziła się również w osadach glacjalnych Polski.

Sumaryczna zawartość skał z Dalarny i Värmlandu (około 20\%) jest stosunkowo mało zróżnicowana na przebadanym obszarze. Zaznacza się jedynie dość wyraźny spadek ich udziału w osadach przedvistuliańskich zlodowaceń w Polsce Wschodniej. Trudny do wyjaśnienia jest fakt, że spadek ten jest zauważalny jedynie w grupie dalarneńskich wulkanitów (rys. 10.9), podczas gdy udział skał plutonicznych na terenie Polski od Dolnego Śląska aż po Podlasie wydaje się raczej wyrównany. Dość duże zróżnicowanie odsetka środkowoszwedzkich granitoidów zaznacza się w osadach ostatniego zlodowacenia, ale nie sposób dopatrzeć się w nim jakiejś regularności przestrzennej (rys. 10.10).

Zadziwiające dane przedstawili Milthers i Milthers (1938), którzy w rejonie Włodawy nad Bugiem stwierdzili obecność w przeanalizowanym zespole aż 59\% skał dalarneńskich i $41 \%$ alandzkich, czyli ponad trzykrotnie więcej niż w próbach przebadanych przez autora. Nietypowy skład można w jakiejś części złożyć na karb metodyki poboru prób oraz wykorzystywania tylko wybranych, bardzo nielicznych typów skał przewodnich. Wyniki Milthersów potwierdza jednak znacznie nowsza analiza, w której podano aż 75\% udział skał dalarneńskich po drugiej stronie Bugu w Rostani na Ukrainie (Bogucki i in., 1998). 


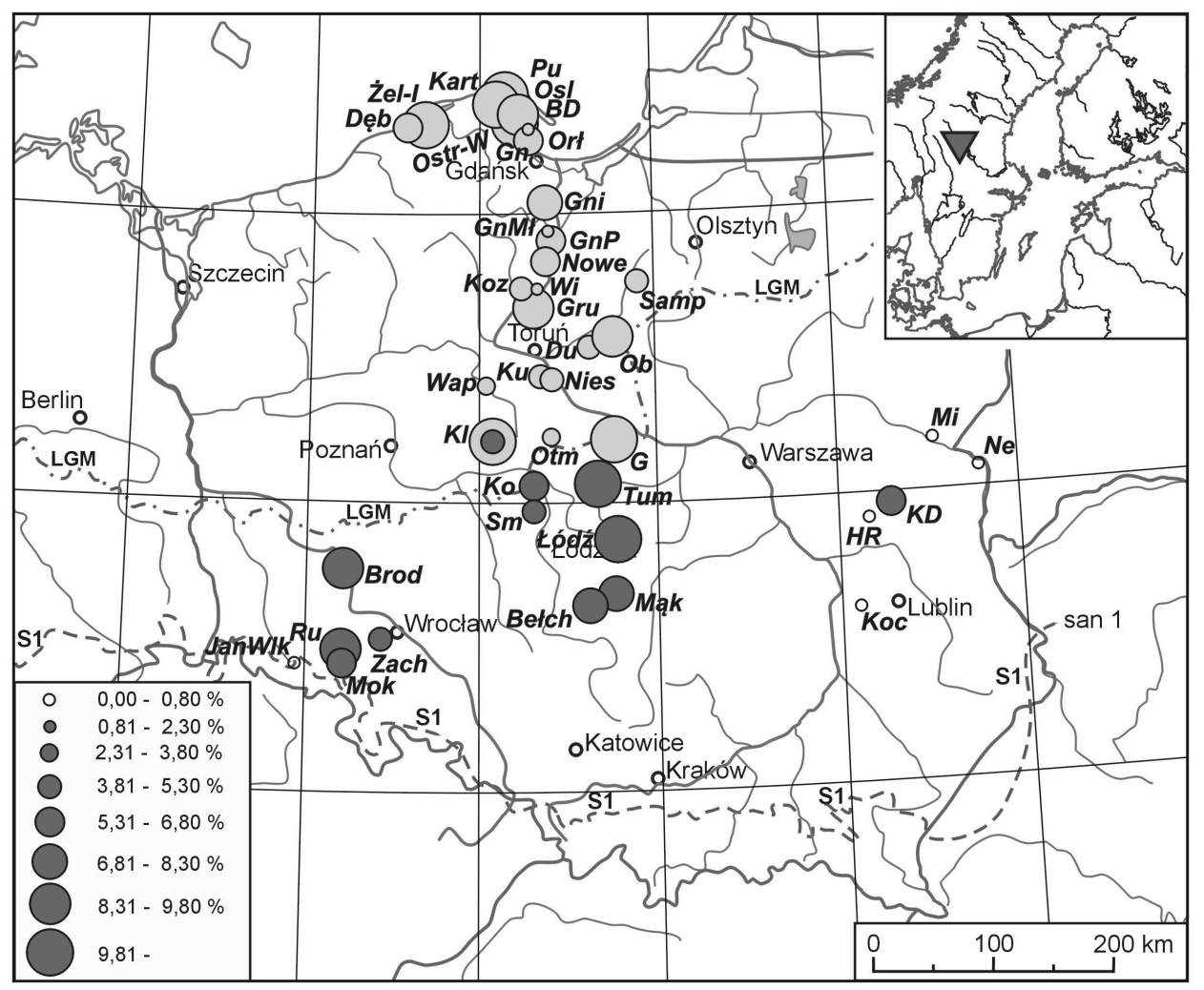

Rys. 10.8. Rozmieszczenie porfirów Bredvad w przebadanych osadach glacjalnych kompleksu południowopolskiego (jasne koła) i północnopolskiego (ciemne koła) - udział poniżej 0,81\% (puste koło jako symbol stanowiska) oznacza brak danej skały

Figure 10.8. The distribution of Bredvad porphyry in glacial deposits of the South-Polish Complex (dark circles) and of the North-Polish Complex (light circles) - share below $0,81 \%$ (empty circle as a site symbol) means a lack of the presented erratics in the site

Odmiennie kształtują się wyniki analiz przeprowadzonych przez Gałązkę (2004b). Co prawda jego dane wskazują zwykle na nieco wyższy udział skał dalarneńskich w glinach na Podlasiu, aniżeli uzyskany przez autora, ale jest to najczęściej od kilkunastu do dwudziestu kilku procent w zależności od stanowiska, czyli 2-3 razy mniej niż w przytoczonych badaniach Milthersów (op. cit.) oraz Boguckiego i in., (op. cit.). Przebadane przez Dudziaka (1978) osady glacjalne zlodowaceń sanu i odry na przedpolu Karpat różnią się wyraźnie zawartością skał dalarneńskich. Osady starszego lądolodu są tam stosunkowo ubogie w eratyki z zachodniej Fennoskandii (w tym dalarneńskie), podczas gdy w glinach odrzańskich ich zawartość jest dużo wyższa i na ogół przekracza $20 \%$. W tym przypadku nie można jednak uznać udziału skał z Dalarny jako różnicującego osady glacjalne kolejnych zlodowaceń, ponieważ próby z młodszych glin pobierane były tylko w zachodniej części przedpola Karpat, a ze starszych na wschodzie. Nie sposób 


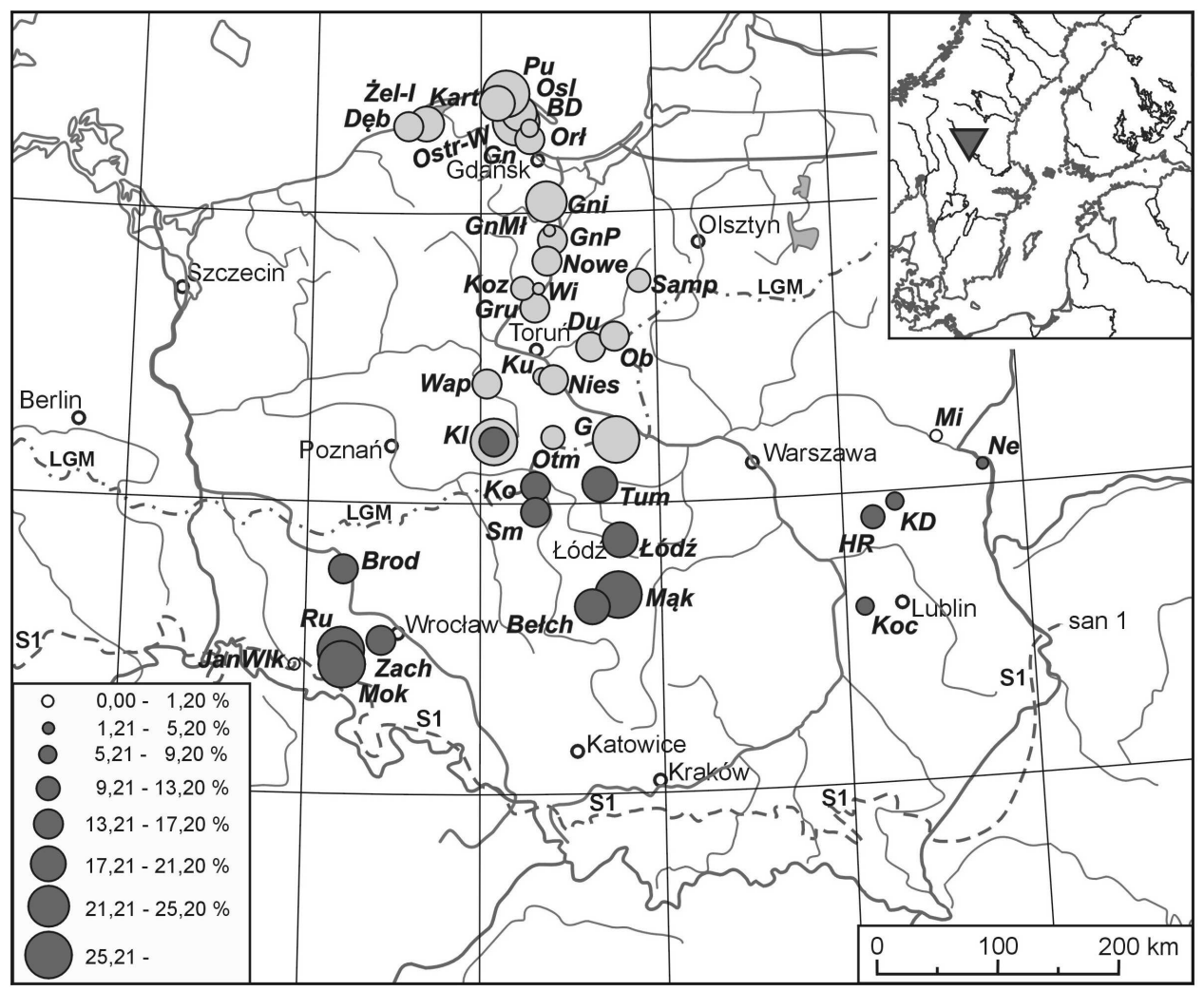

Rys. 10.9. Rozmieszczenie skał wulkanicznych z Dalarny i Värmlandu w przebadanych osadach glacjalnych kompleksu południowopolskiego (ciemne koła) i północnopolskiego (jasne koła) - udział poniżej 1,21\% (puste koło jako symbol stanowiska) oznacza brak danej skały

Figure 10.9. The distribution of Dalarna and Värmland volcanic rocks in glacial deposits of the South-Polish Complex (dark circles) and of the North-Polish Complex (light circles) - share below 1,21\%

(empty circle as a site symbol) means a lack of the presented erratics in the site

zatem ocenić, na ile ta różnica jest wynikiem przestrzennego, a na ile wiekowego zróżnicowania składu materiału morenowego. Badania przeprowadzone w Kotlinie Kłodzkiej wykazały również dość wysoki, bo ponad 30\% udział eratyków dalarneńskich w osadach przypisywanych zlodowaceniu środkowopolskiemu (Konieczny i Wdowiak, 1971), co byłoby zgodne z przytoczonymi powyżej rezultatami analiz Dudziaka. W niektórych stanowiskach osadów zlodowacenia elstery, położonych w zachodnich Czechach odsetek skał z Dalarny przewyższa nawet $40 \%{ }^{12}$ (Víšek i Nývlt, 2006). Trudno włączyć do prezentowanego zestawienia dane Astapovej, ponieważ potraktowała skały dalarneńskie razem z upplandzkimi. Nawet jednak ta sumaryczna wartość w przygranicznych obwodach Białorusi wynosi zaledwie kilkanaście procent i szybko maleje wraz

\footnotetext{
${ }^{12}$ Obliczenia własne w oparciu o surowe dane zamieszczone przez cytowanych autorów.
} 
z przesuwaniem się na wschód, by w okolicach Mińska spaść do ok. 1-3\% (Astapova, 1987). Wyniki analiz głazowych prowadzonych na dużą skalę w Niemczech prezentowane są najczęściej już w postaci gotowego wyniku, tj. teoretycznego ośrodka głazowego (np. Lüttig, 2005). Brak danych wyjściowych nie pozwala w takim przypadku precyzyjnie ocenić udziału poszczególnych regionów Fennoskandii w zasilaniu lądolodu w materiał morenowy. Przedstawione w niektórych publikacjach mapy kołowe (Hoffmann i Meyer, 1997, 1999) lub spisy oznaczonych eratyków (Meyer, 1983) pozwalają jednak uznać udział skał dalarneńskich w zespołach głazowych Niemiec za stosunkowo wysoki i porównywalny z przytoczonymi danymi z Polski Zachodniej. W holenderskich zespołach głazowych skały środkowoszwedzkie reprezentowane są niemal wyłącznie przez różne wulkanity. Granitoidy z omawianego regionu występują tam co najwyżej w postaci pojedynczych klastów (Schuddebeurs, 1980/1981).

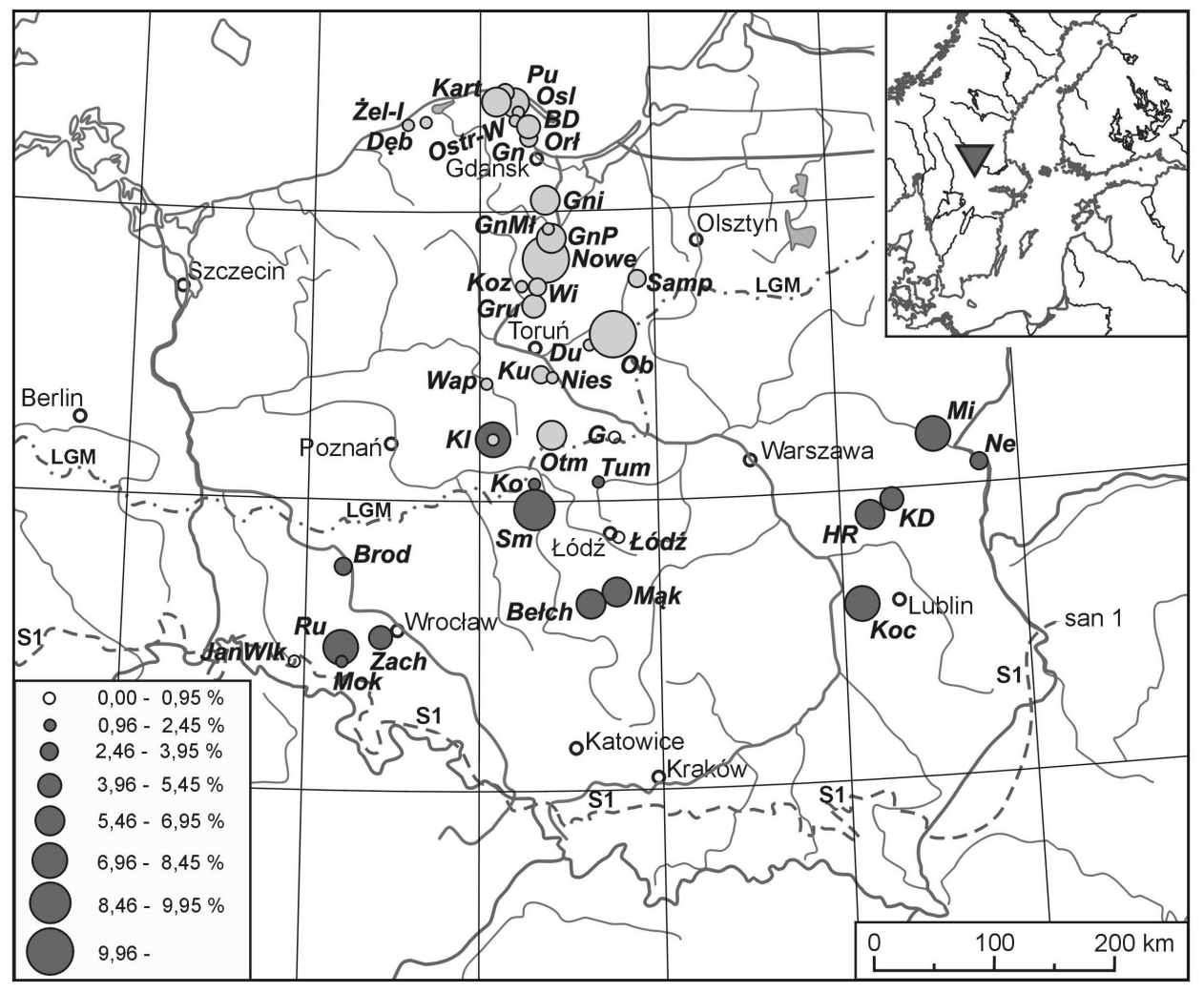

Rys. 10.10. Rozmieszczenie skał plutonicznych z Dalarny i Värmlandu w przebadanych osadach glacjalnych kompleksu południowopolskiego (ciemne koła) i północnopolskiego (jasne koła) - udział poniżej 0,96\% (puste koło jako symbol stanowiska) oznacza brak danej skały

Figure 10.10. The distribution of Dalarna and Värmland plutonic rocks in glacial deposits of the South-Polish Complex (dark circles) and of the North-Polish Complex (light circles) - share below 0,96\%

(empty circle as a site symbol) means a lack of the presented erratics in the site 
Udział skał środkowoszwedzkich w osadach vistulianu lobu wiślanego i w jego najbliższym sąsiedztwie $(21,0 \%)$ okazał się niemal identyczny ze stwierdzonym przez Górską-Zabielską (2008) w glinach lobu odrzańskiego - 20,4\%. Podobne wartości prezentuje również Gałązka (2004b), ale rozbija je na trzy wyróżniane gliny zlodowacenia wisły, w których w kolejności od najstarszej omawiane skały stanowią 32,3\%, 21,8\% i 16,8\%. Dane Górskiej (2000) z Wielkopolski okazały się znacznie wyższe od uzyskanych przez tę samą autorkę w lobie odrzańskim. W skrajnym przypadku w glinie leszczyńskiej we Włoszakowicach zidentyfikowała aż 70\% eratyków z Dalarna, podczas gdy w również leszczyńskiej glinie w Ujściu tylko 24\%. Na Wysoczyźnie Lubuskiej eratyki dalarneńskie stanowią najczęściej od 12 do $25 \%$ zespołów eratyków opisanych w glinach ostatniego zlodowacenia (Lipka, 2011). Wśród dużych głazów z różnych regionów Polski przeanalizowanych przez Dudziaka (1970) nie udało się zidentyfikować żadnej skały z Dalarna, a skały szwedzkie występowały rzadko.

Wysoka zawartość eratyków dalarneńskich, notowana w niemal wszystkich osadach plejstoceńskich Polski, a także na obszarze pozostałych krajów położonych na południe od Bałtyku (m.in. Tarvydas, 1971d; Meyer, 1983), jest sprzeczna z modelami dynamiki lądolodu fennoskandzkiego, które w najbliższym sąsiedztwie Dalarny lokują linię podziału lodu (np. Donner, 1989; Kleman i Stroeven, 1997 - patrz rys. 10.2). Powolne tempo ruchu lodu w najbliższym sąsiedztwie lododziału (Donner, 1989; Bennett i Glasser, 2009) powinno uniemożliwić jednoetapowy transport skał dalarneńskich na obszar Niżu Środkowoeuropejskiego oraz znacznie ograniczyć transport wieloetapowy. Wyniki badań eratyków wskazują zatem na potrzebę rewizji istniejących modeli termodynamicznych lądolodu.

\subsection{Uppland i Södermanland - środkowo-wschodnia Szwecja}

Środkowo-wschodnia Szwecja stanowi obszar źródłowy znajdowanych na Niżu Środkowoeuropejskim granitoidów sztokholmskiego (fot. 10.21), Sala (fot. 10.22), Uppsala (fot. 10.23), Vänge (fot. 10.24), Arnö, czerwonego i brunatnego granitu Graversfors oraz porfiru Mälar. Traktowanie tych skał jako eratyków przewodnich nie budzi poważniejszych wątpliwości (Hesemann, 1975; Meyer, 1983; Smed, 1994, 2002; Zandstra, 1999; Gałązka, 2004b; Czubla i in., 2006). Wyjątek stanowią granity sztokholmskie i Uppsala. Korn (1927) informuje o wychodniach skał bardzo podobnych do granitów sztokholmskich, odsłaniających się na zachodnim wybrzeżu Szwecji w Bohuslänie, pomiędzy Strömstad i Göteborgiem, a także wspomina o licznych żyłach podobnych mikrogranitów, występujących w środkowej Szwecji. Schuddebeurs (1980/1981) dodaje do tego wychodnie na Wyspach Alandzkich i w Laponii. O ile Laponia i Bohuslän znalazły się poza szlakami migracji lodu w kierunku Polski, to Wyspy Alandzkie i środkowa Szwecja z całą pewnością były źródłem materiału skalnego przywleczonego na obszar naszego kraju i to w znacznych ilościach. Oszacowanie wpływu tych wychodni na skład zespołów głazowych w Polsce wymagałoby szczegółowej analizy powierzchni odsłonięć w stosunku do zajmowanej przez typowe granity sztokholmskie oraz ścisłego określenia dynamiki lądolodu fennoskandzkiego i jej czasowej zmienności, co na obecnym etapie badań 
plejstocenu jest niemożliwe. Problemy identyfikacyjne mogą też sprawiać granity Uppsala. Jednoznacznie rozpoznawalne są wyłącznie ich odmiany zawierające niebieskawy kwarc (Dudziak, 1970 - str. 22; Smed, 1994, 2002). Tym niemniej niektórzy autorzy zaliczają do granitów Uppsala również skały zawierające jedynie szary kwarc (np. Meyer, 1983). Takie skały są jednak nieodróżnialne od fińskich granitów z okolic Vaasa (Veltheim, 1962).

$\mathrm{Na}$ terenie Polski dodatkowy problem mogą stanowić granodioryty strzelińskie, makroskopowo prawie identyczne z granitami sztokholmskimi, ale ich potencjalny zasięg w osadach glacjalnych ograniczony jest wyłącznie do Dolnego śląska. Jest to obszar położony w strefie marginalnej lądolodu fennoskandzkiego, w której dominowała sedymentacja, a erozja mogła odgrywać tylko niewielką rolę (patrz rys. 8.5), co dodatkowo zmniejsza możliwość inkorporacji tej skały. W przebadanych osadach z tamtego regionu nie udało się autorowi zidentyfikować ani jednego niewątpliwego granodiorytu strzelińskiego, a udział granitów sztokholmskich (włącznie z ewentualnymi błędnie oznaczonymi skałami wywodzącymi się z intruzji Strzelina i Żulovej) był o około 1/4 niższy od średniej zawartości stwierdzonej w glinach zlodowaceń san 1 i san 2 na terenie Polski $(5,26 \%$ wobec $7,17 \%)$. Na dodatek granodiorytów strzelińskich należałoby się spodziewać głównie w próbkach bogatych w inne skały dolnośląskie. Jeśli jednak tych ostatnich jest w analizowanym zespole eratyków bardzo mało lub brak ich zupełnie, to wątpliwe drobnokrystaliczne szare granitoidy pochodzą zapewne z północy. Dodatkową cechą ułatwiającą odróżnienie skał dolnośląskich od ich odpowiedników z Fennoskandii jest stopień zwietrzenia. Detrakcja pozwalała na włączanie w masę lodu skał fennoskandzkich niemal zupełnie świeżych, niezwietrzałych. Skały sudeckie przed potencjalną inkorporacją przez lądolód podlegały długotrwałemu wietrzeniu i często również transportowi w środowisku rzecznym. W związku z tym w osadach glacjalnych występują w postaci mocno zwietrzałych ziaren - granodioryty strzelińskie przyjmują wówczas żółtobrązowawe zabarwienie (J. Badura, 2013 - inf. ustna), uwarunkowane rozkładem minerałów maficznych. Tak zabarwione klasty nie mogły zostać uznane za granity sztokholmskie.

W przebadanych osadach napotkano tylko jeden eratyk porfiru Mälar. Do bardzo rzadkich znalezisk należy również granit Arnö, ale w tym przypadku istotną przyczyną takiego stanu mogła być niemożność rozpoznania tej skały w małych ziarnach. Trochę liczniej występują granity Graversfors (głównie czerwone), ale na ogół jako pojedyncze głaziki w próbce. Nie pozwala to na wyciąganie wniosków na temat ich przestrzennej i czasowej dystrybucji. Granity sztokholmskie, Sala, Uppsala i Vänge występują dość licznie w osadach glacjalnych Polski. Ich obecność wyraźnie zaznacza się również w osadach wszystkich zlodowaceń południowej części obszaru perybałtyckiego (Tarvydas, 1971d). Ten sam badacz zaobserwował również rzadsze występowanie eratyków granitu Sala aniżeli sztokholmskiego i Uppsala. W osadach przebadanych przez autora proporcje pomiędzy poszczególnymi typami eratyków układają się inaczej. Dominują granity sztokholmskie (średnio 8,17\% w glinach), dwukrotnie mniej liczne - po około 4\% - są zaś zarówno granity Sala, jak i Uppsala. Większość typów skał z analizowanego 


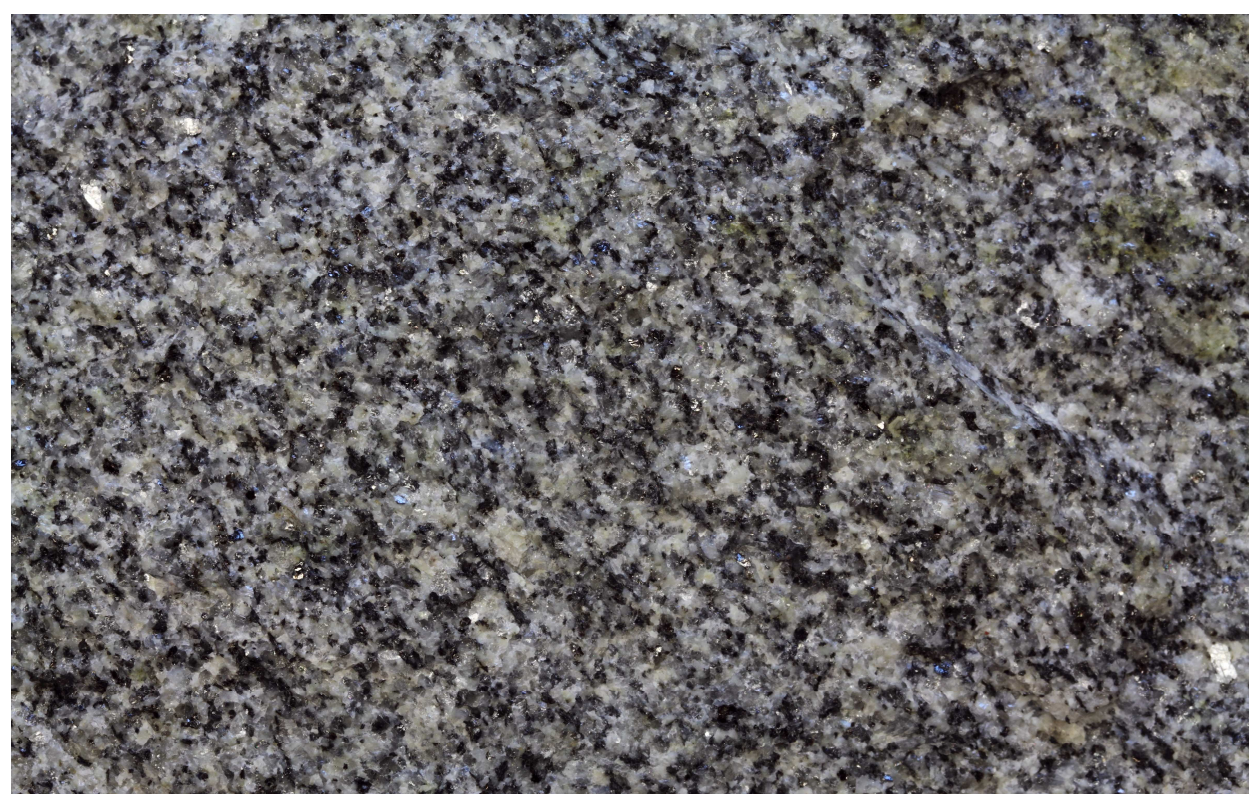

Fot. 10.21. Granit sztokholmski, Sånga na północ od Stenhamra, środkowa Szwecja; rozmiar dłuższego boku $88 \mathrm{~mm}$; fot. P. Czubla 2015

Photo 10.21. Stockholm granite, Sånga, North of Stenhamra, Central Sweden; picture width $88 \mathrm{~mm}$. Photo P. Czubla 2015

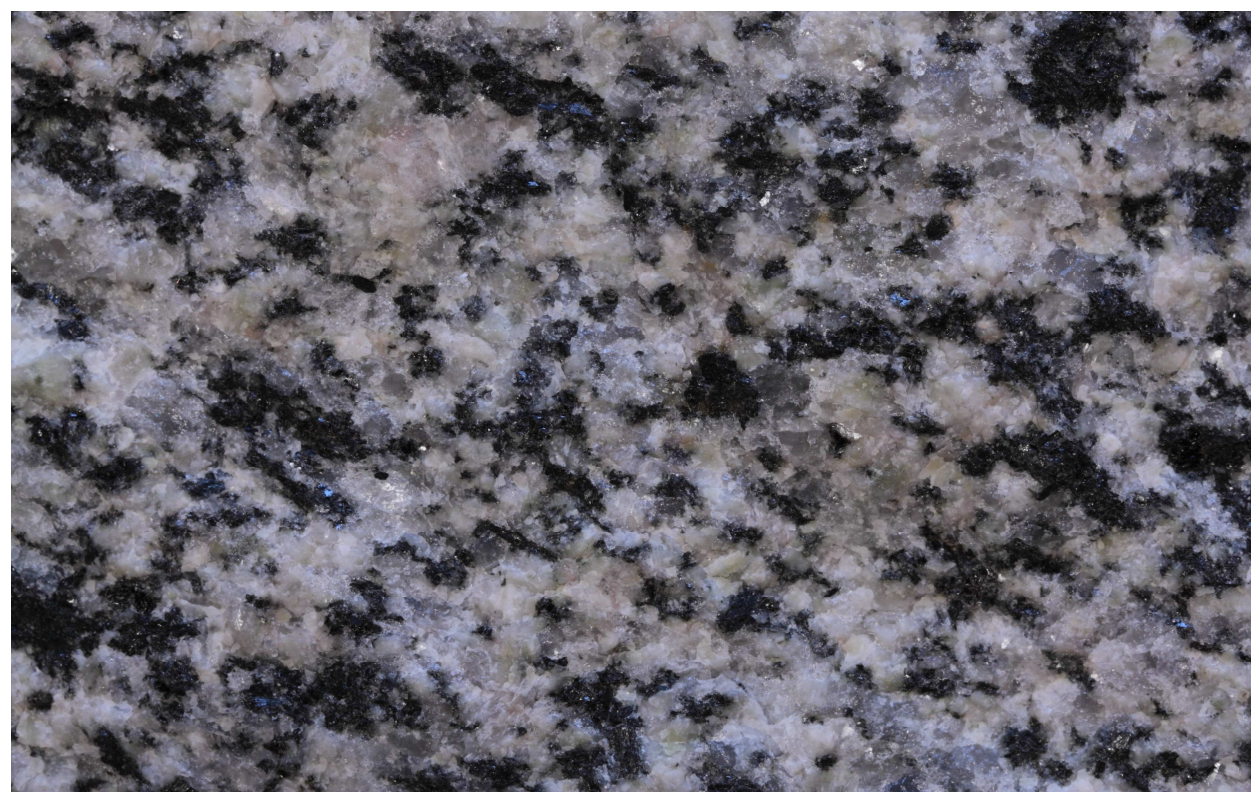

Fot. 10.22. Granit Sala, Heby, środkowa Szwecja; rozmiar dłuższego boku 77 mm; fot. P. Czubla 2015 Photo 10.22. Sala granite, Heby, Central Sweden; picture width 77 mm. Photo P. Czubla 2015 


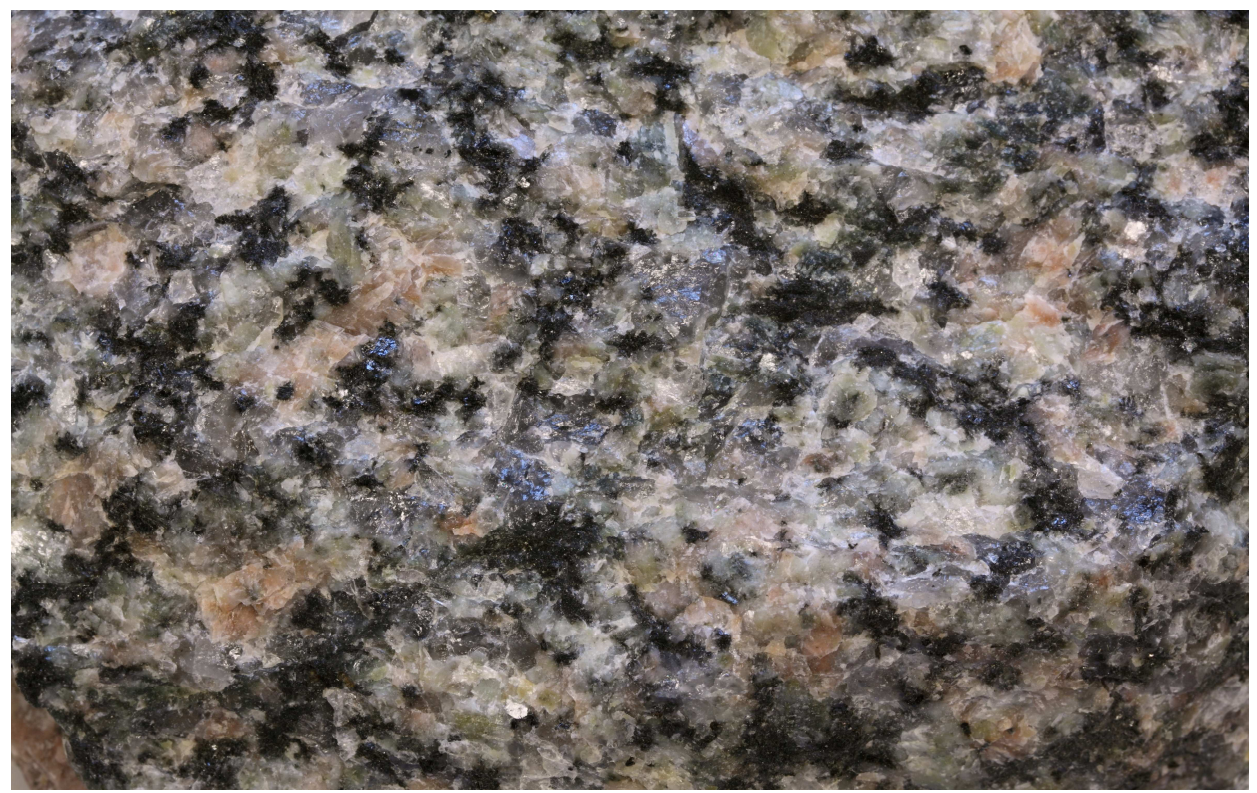

Fot. 10.23. Granit Uppsala, Berga, środkowa Szwecja; rozmiar dłuższego boku 78 mm; fot. P. Czubla 2015 Photo 10.23. Uppsala granite, Berga, Central Sweden; picture width 78 mm. Photo P. Czubla 2015

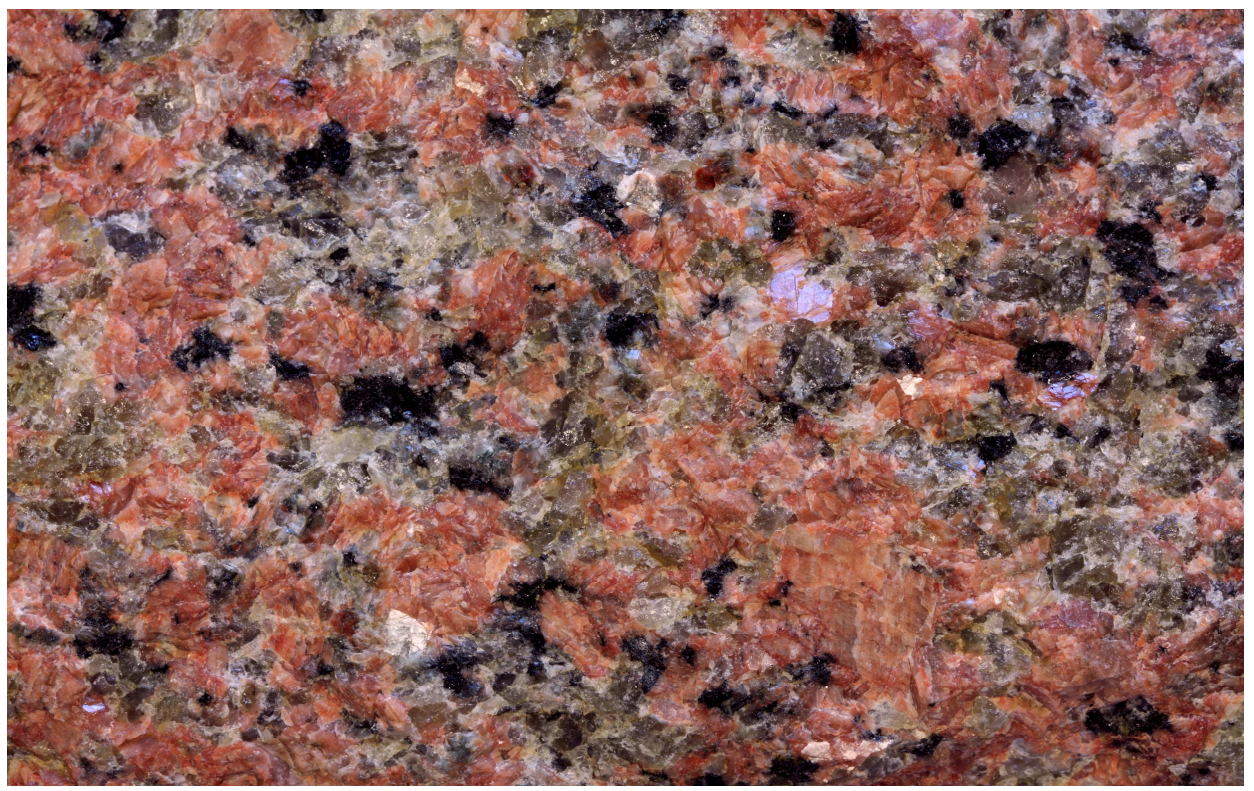

Fot. 10.24. Granit Vänge, Kristineberg k/Laby, środkowa Szwecja; rozmiar dłuższego boku 92 mm; fot. P. Czubla 2015

Photo 10.24. Vänge granite, Kristineberg near Laby, Central Sweden; picture width $92 \mathrm{~mm}$. Photo P. Czubla 2015 
obszaru, zwłaszcza granity sztokholmskie i Sala, dość łatwo ulega wietrzeniu (Marczinski, 1968b; Czubla, 2001). W konsekwencji bardzo wyraźnie zaznacza się spadek ich sumarycznego udziału w żwirach w stosunku do glin - odpowiednio 11,15\% i 17,05\%. Niska odporność granitów Sala i sztokholmskich na procesy wietrzeniowe prowadzi do prawie dwukrotnego (w stosunku do glin) spadku ich zawartości w żwirach: Sala do około 2,7\%, a sztokholmskich do 4,5\%. Zależność udziału skał Uppsala, Vänge i Arnö od typu litologicznego osadu zaznacza się zdecydowanie słabiej.

Skały ze środkowo-wschodniej Szwecji stanowią około 17,17\% eratyków zidentyfikowanych w glinach kompleksu południowopolskiego. W glinach kompleksu środkowopolskiego ich zawartość obniża się do $16,23 \%$, by w osadach ostatniego zlodowacenia wzrosnąć do $18,20 \%$. W osadach kompleksu południowopolskiego maksymalny udział skał z Upplandu i okolic Sztokholmu zaobserwowano w Polsce Środkowej (ekstremalne zespoły: Smulsko 37,3\%, Koźmin 33,3\%, Bełchatów B9c 25,8\%), a wraz z przesuwaniem się tak na zachód, jak i na wschód zauważalny jest spadek ich zawartości (skrajnie niski udział zanotowano w Kolonii Domaszewskiej koło Łukowa 6,4\% oraz w Rusku na Dolnym Śląsku 8,1\%). Na zaprezentowanej mapie (rys. 10.11) widoczny jest co prawda wyjątkowo wysoki udział skał z Upplandu w Janowicach Wielkich, ale wynika on ze znikomej liczby zidentyfikowanych tam skał wskaźnikowych (za tę anomalię na kartodiagramie odpowiada pojedynczy klast granitu Vänge). Przedstawiona tendencja zanika w osadach młodszych zlodowaceń.

Najniższy odsetek granitów sztokholmskich w najstarszych osadach glacjalnych został odnotowany na Dolnym Śląsku, a znacznie wyższe stwierdzono w Polsce Centralnej oraz na Podlasiu (rys. 10.12). Trudny do wyjaśnienia jest fakt, że obydwie ekstremalne zawartości zaobserwowano w sąsiednich stanowiskach na Południowym Podlasiu: 18,8\% w Hucie Radoryskiej i 2,2\% w Kolonii Domaszewskiej. W glinach kompleksu środkowopolskiego żadne wyraźnie zaznaczone zróżnicowanie nie występuje, podczas gdy w osadach ostatniego zlodowacenia można dostrzec spadek zawartości granitu sztokholmskiego na bliskim zapleczu strefy marginalnej ówczesnego lądolodu. W trochę mniejszym stopniu (z wyjątkiem stanowiska Otmianowo) ta sama tendencja zaznacza się również wśród pozostałych skał z Upplandu.

Badania Górskiej-Zabielskiej (2008) w lobie Odry wykazały znacznie niższy udział skał $\mathrm{z}$ analizowanego obszaru $\mathrm{w}$ osadach ostatniego zlodowacenia. W glinach wyniósł on niecałe $8 \%$, a w żwirach o $2 \%$ mniej, co podkreśla wspomniany już wcześniej wpływ wietrzenia na redukcję zawartości skał z Upplandu i okolic. W lobie odrzańskim zawartość granitów sztokholmskich (5,31\% w glinach i 4,18\% w żwirach) przewyższa co najmniej dwukrotnie udział skał z pozostałych obszarów Upplandu - odpowiednio 2,65\% i 1,77\% (Górska-Zabielska, 2008). W próbach przebadanych przez autora przewaga granitów sztokholmskich zaznaczała się znacznie słabiej - stanowiły one na ogół mniej niż połowę eratyków ze środkowo-wschodniej Szwecji. Na Wysoczyźnie Lubuskiej skały z Upplandu Lipka (2011) zidentyfikowała tylko w glinach ostatniego zlodowacenia i to w ilości zaledwie kilku procent oraz w jednej próbie ze żwiru. Zapewne pierwotna zawartość tych skał była wyższa, ale duża ich część została wyeliminowana przez 
wietrzenie. Do podobnych wniosków prowadzi interpretacja danych z Wielkopolski. Na obszarze przebadanym przez Górską (2000) skały z Upplandu były obecne tylko w glinie warciańskiej w Ujściu i stanowiły tam jedynie 13\% eratyków oznaczonych w próbce.

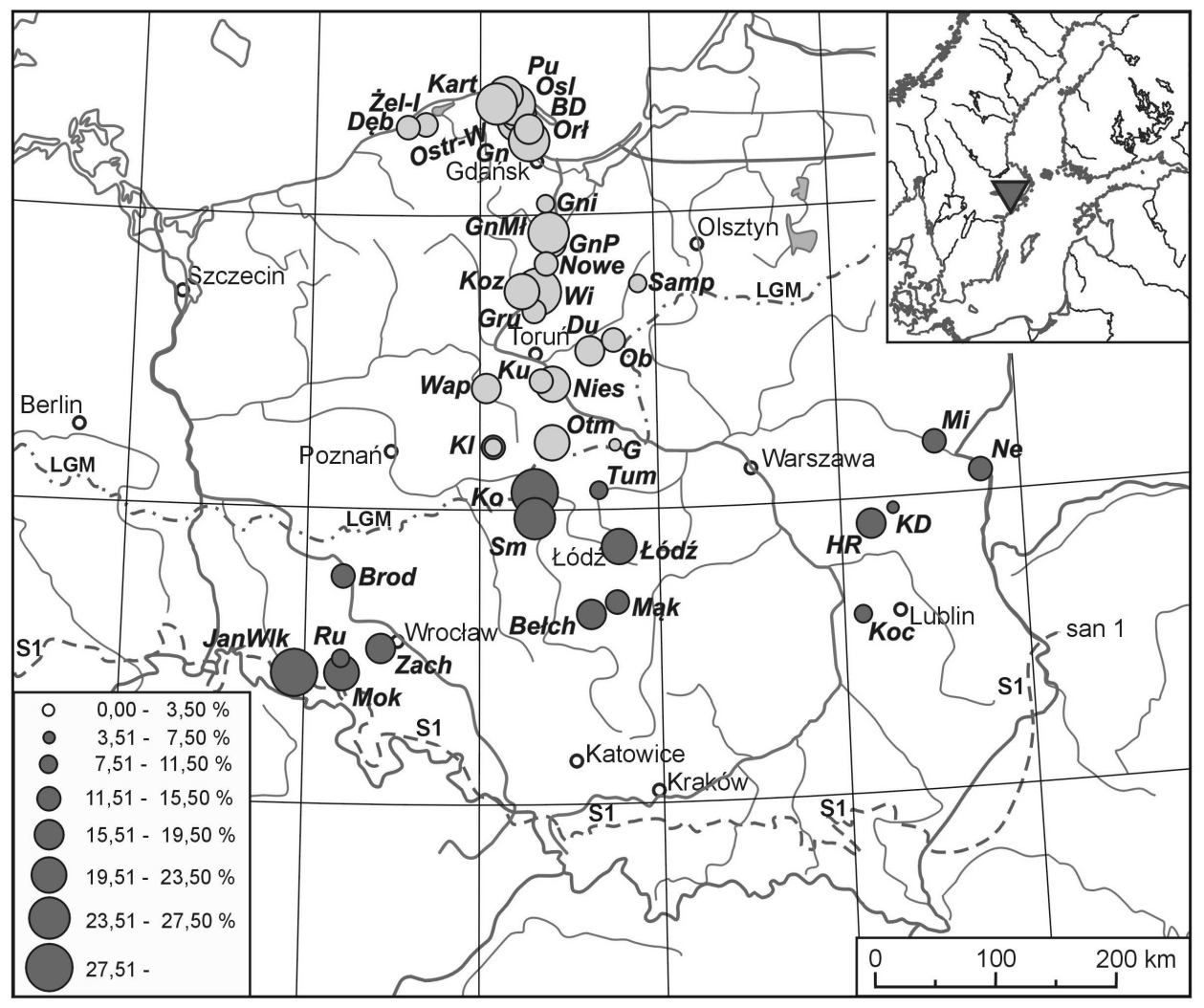

Rys. 10.11. Rozmieszczenie skał z Upplandu i okolic Sztokholmu w przebadanych osadach glacjalnych kompleksu południowopolskiego (ciemne koła) i północnopolskiego (jasne koła)

Figure 10.11. The distribution of Uppland and Stockholm rocks in glacial deposits of the South-Polish Complex (dark circles) and of the North-Polish Complex (light circles)

Z badań Gałązki (2004b) wynika stopniowy wzrost udziału skał upplandzkich wraz z malejącym wiekiem osadów glacjalnych. W glinach zlodowacenia sanu było ich tylko $2,5 \%$, odry (w tradycyjnym rozumieniu) $9,8 \%$, a w osadach zlodowacenia warty $10,2 \%$ w dolnej glinie i 12,6\% w górnej. Maksymalną wartość Gałązka wykazał dla gliny V3 (stadiał Świecia) - 17,3\%, a w kolejnych, tj. w stadiale głównym w fazie leszczyńsko-poznańskiej zanotował spadek do 14,6\%, w pomorskiej natomiast nawet do 7,6\%. W niektórych stanowiskach granity Uppsala miały być nawet liczniejsze od pospolitych porfirów Bredvad, czego nie da się wyjaśnić w inny od wyżej zasugerowanego sposób. Można oczywiście też spekulować, że w Bohuslän lub gdzieś indziej na drodze lodu do Holandii, znajdowała się mała intruzja skały łudząco podobnej do granitu Uppland, 
która uległa w plejstocenie całkowitej egzaracji. W zespołach głazowych określanych w Holandii i Niemczech jako wschodniobałtyckie proporcje pomiędzy poszczególnymi skałami z Upplandu i okolic są już zbliżone do obserwowanych w Polsce.

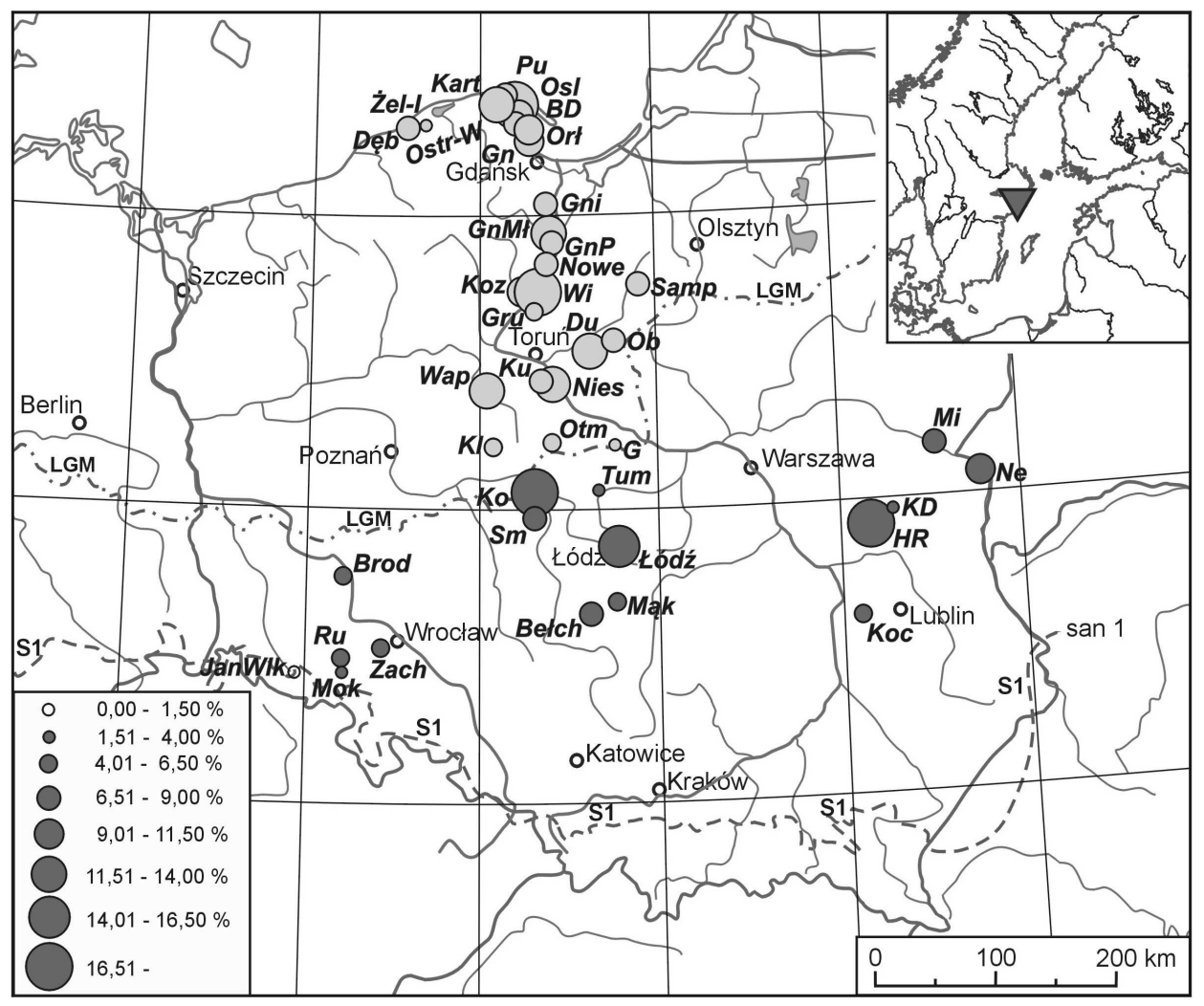

Rys. 10.12. Rozmieszczenie granitów sztokholmskich w przebadanych osadach glacjalnych kompleksu południowopolskiego (ciemne koła) i północnopolskiego (jasne koła) - udział poniżej 1,51\% (puste koło jako symbol stanowiska) oznacza brak danej skały

Figure 10.12. The distribution of Stockholm granite in glacial deposits of the South-Polish Complex (dark circles) and of the North-Polish Complex (light circles) - share below 1,51\% (empty circle as a site symbol) means a lack of the presented erratic in the site

Miarodajna ocena liczebności skał ze środkowo-wschodniej Szwecji na terenie Białorusi jest bardzo utrudniona, ponieważ Astapova (1987) ujmuje je razem ze skałami dalarneńskimi. Można co najwyżej przyjąć, że, podobnie jak w przypadku tych ostatnich, ich zawartość maleje wraz z przesuwaniem się na wschód. W osadach glacjalnych i fluwioglacjalnych zachodnich Czech skały z Upplandu rozpoznawane były wyjątkowo rzadko (Višek i Nývlt, 2006), do czego mogła przyczynić się ich wysoka podatność na wietrzenie. 


\subsection{Dno środkowego Bałtyku włącznie z wyspami Szwecji i Estonii}

Dno środkowego Bałtyku, Gotlandia, Olandia i Archipelag Zachodnioestoński zbudowane są głównie ze skał osadowych starszego paleozoiku, tworzących rozległe wychodnie. Tylko lokalnie występują skały magmowe (por. m.in. Amantov, 1996; Ūsaitytė, 2000; Šliaupa i Hoth, 2011; Tuuling i in., 2011). W związku z tym jedynie nieliczne skały bałtyckie mogą być traktowane jako typowe skały przewodnie - przede wszystkim brunatny (fot. 10.25) i czerwony (fot. 10.26) porfir bałtycki (m.in. Gaigalas i Gudelis, 1965) oraz bałtycki diabaz melafirowy (liczne odmiany), traktowany przez cytowanych autorów jako skała przewodnia, drugorzędna. Do eratyków przewodnich zaliczane są zazwyczaj także najbardziej charakterystyczne skały okruchowe, tj. piaskowiec Tessini (fot. 10.27) i z pewnymi zastrzeżeniami piaskowiec Kalmarsund - fot. 10.28 (Lüttig, 1958; Meyer, 1983; Smed, 1994, 2002; Czubla i in., 2006; Meyer i Lüttig, 2007). Ten pogląd kwestionuje Gałązka (2004b), który z założenia wyklucza wykorzystywanie jakichkolwiek skał osadowych w charakterze eratyków przewodnich i dyskwalifikuje nawet najbardziej wśród nich charakterystyczny piaskowiec Tessini.

Pozostałe skały bałtyckie (czerwone piaskowce kambryjskie, wapienie paleoporellowe - fot. 10.29, krynoidowe - fot. 10.30, beyrichiowe, ortocerasowe, czerwone wapienie ordowickie, wschodniobałtyckie wapienie Wesenberga, „tłuste” pelitowe wapienie bałtyckie i dolomity) mają charakter wyłącznie pomocniczy i nie mogą być uwzględniane w obliczeniach teoretycznych ośrodków głazowych.

Analiza rozprzestrzenienia eratyków obydwu odmian porfirów bałtyckich umożliwiła już w pierwszej połowie XX wieku wysunięcie przypuszczenia, że ich wychodnia winna znajdować się na dnie Bałtyku pomiędzy Wyspami Alandzkimi, Gotlandią i Hiumą (Milthers, 1909, 1933). Stosunki ilościowe brunatnych porfirów bałtyckich oraz skał botnickich, określone na zachodnim wybrzeżu Finlandii oraz na Łotwie, pozwoliły doprecyzować lokalizację ich wychodni na dnie Bałtyku (Eskola, 1934). Bardziej zachodnią lokalizację wychodni brunatnych porfirów w stosunku do czerwonych potwierdziły badania eratyków na Gotlandii, gdzie czerwone porfiry są rzadkie (przy dość dużym udziale drugiej odmiany), a na północnym zachodzie wyspy brak ich zupełnie (Königsson i Svantesson, 1975). W Niemczech zaobserwowano współwystępowanie czerwonych porfirów bałtyckich ze skałami zachodniofińskimi i alandzkimi, brunatnych zaś z eratykami z Upplandu i północnej Szwecji (Schulz, 2003). Analogiczna prawidłowość w odniesieniu do czerwonej odmiany porfirów bałtyckich występuje również na terenie Polski. Korelacja brunatnych porfirów ze skałami z Upplandu nie dała się jednak zaobserwować, głównie ze względu na stosunkowo małe zróżnicowanie udziału tych skał w różnowiekowych osadach glacjalnych kraju.

$\mathrm{Na}$ terenie Niemiec obydwa porfiry bałtyckie są pospolite (Rudolph, 2008a), ale brunatny znajdowany jest częściej (np. Baudenbacher, 1986; Meyer i Lüttig, 2007). W północnych Niemczech brunatny porfir bałtycki występuje nawet około 10 razy liczniej niż czerwony (Schulz, 2003). W Polsce ich udział wśród eratyków przewodnich różni się niewiele i to na korzyść czerwonego porfiru: 1,79\% wobec 1,69\% klastów brunatnego. W przebadanych żwirach czerwone porfiry bałtyckie są półtorakrotnie liczniejsze 


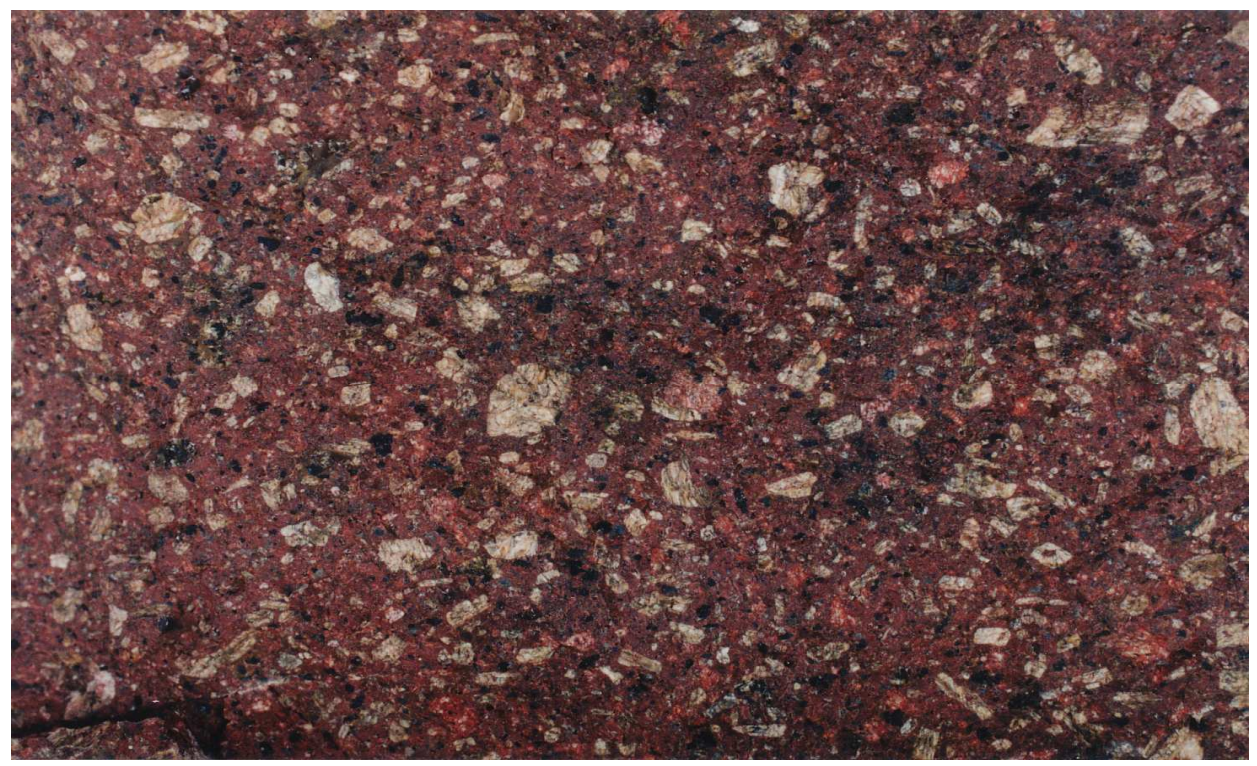

Fot. 10.25. Brunatny porfir bałtycki, eratyk - Moszczenica; rozmiar dłuższego boku $100 \mathrm{~mm}$; fot. P. Czubla i Z. Machnicki 1999

Photo 10.25. Brown Baltic quartz porphyry, erratic - Moszczenica; picture width $100 \mathrm{~mm}$. Photo P. Czubla \& Z. Machnicki 1999

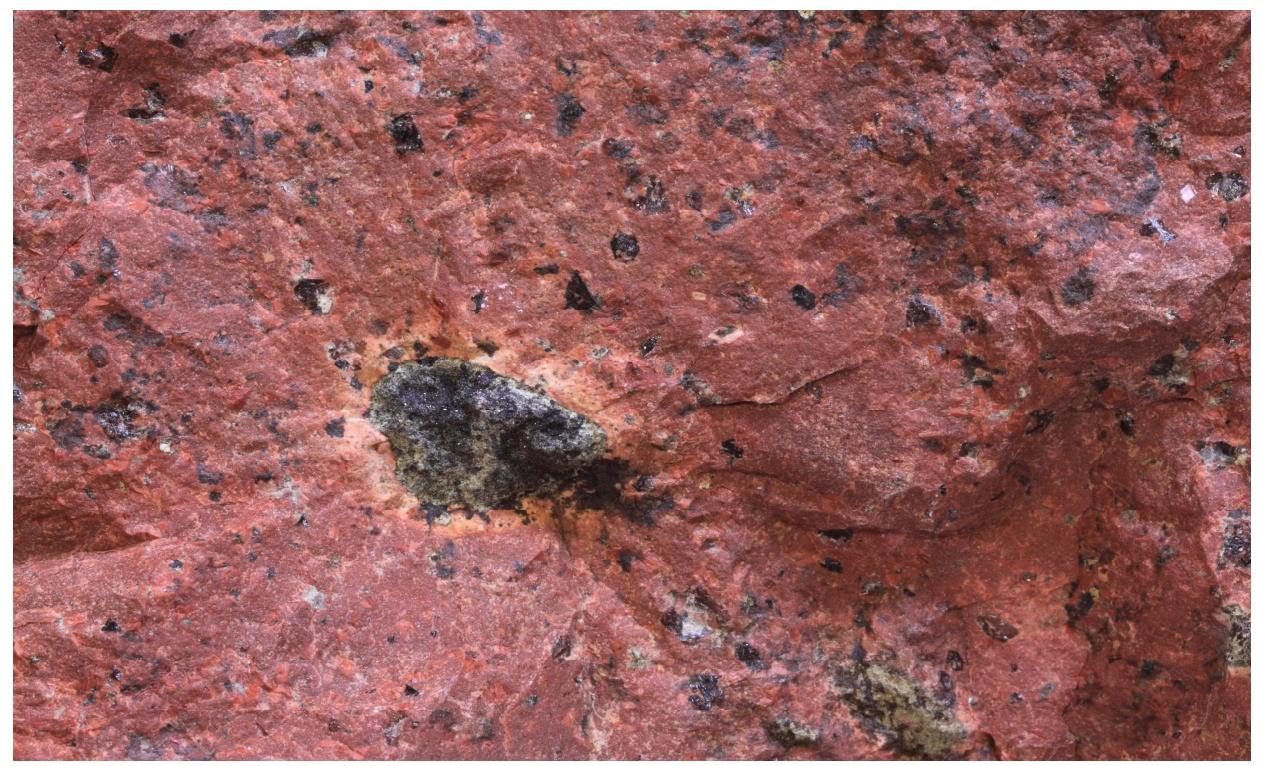

Fot. 10.26. Czerwony porfir bałtycki, eratyk - Siedlątków nad Wartą; rozmiar dłuższego boku 67 mm; fot. P. Czubla 2015

Photo 10.26. Red Baltic quartz porphyry, erratic - Siedlątków on the Warta river; picture width $67 \mathrm{~mm}$. Photo P. Czubla 2015 


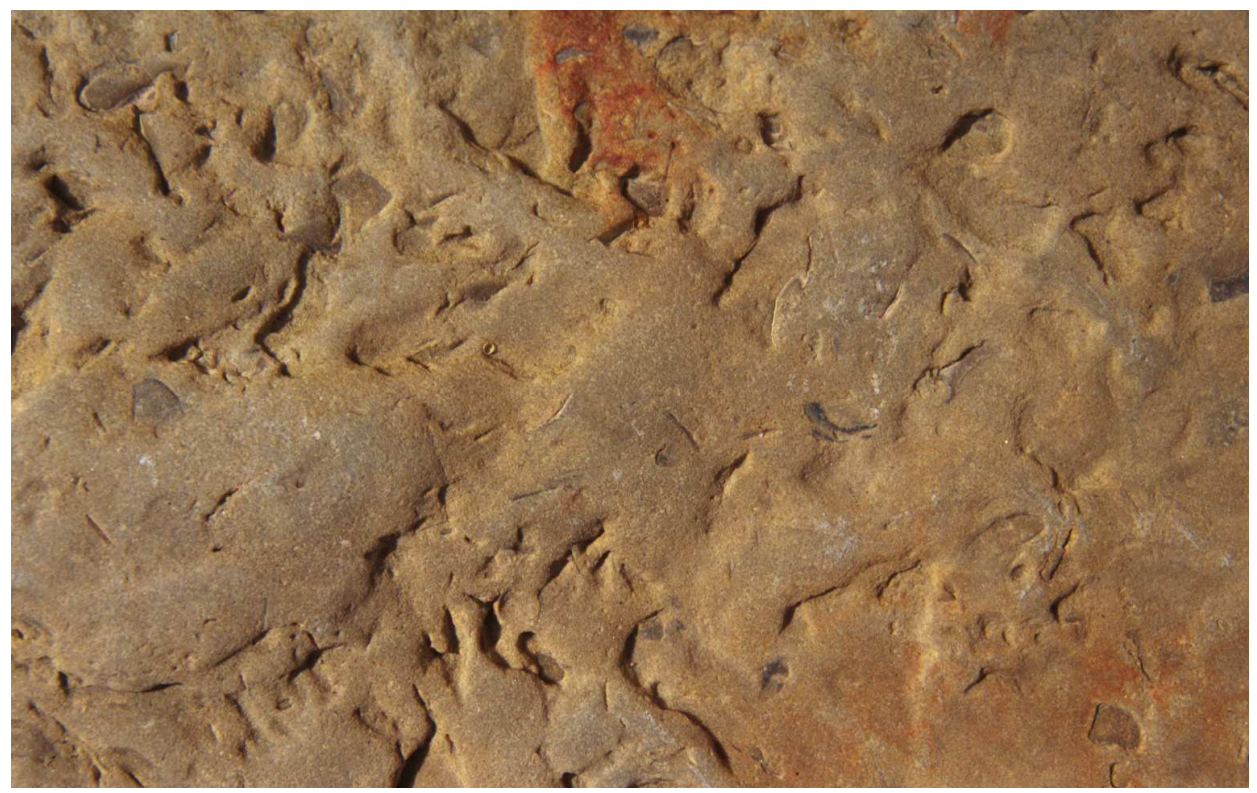

Fot. 10.27. Piaskowiec tessini, Äleklinta, Olandia, rozmiar dłuższego boku 84 mm; fot. P. Czubla 2010

Photo 10.27. Tessini sandstone, Äleklinta, Öland Island; picture width $84 \mathrm{~mm}$. Photo P. Czubla 2010

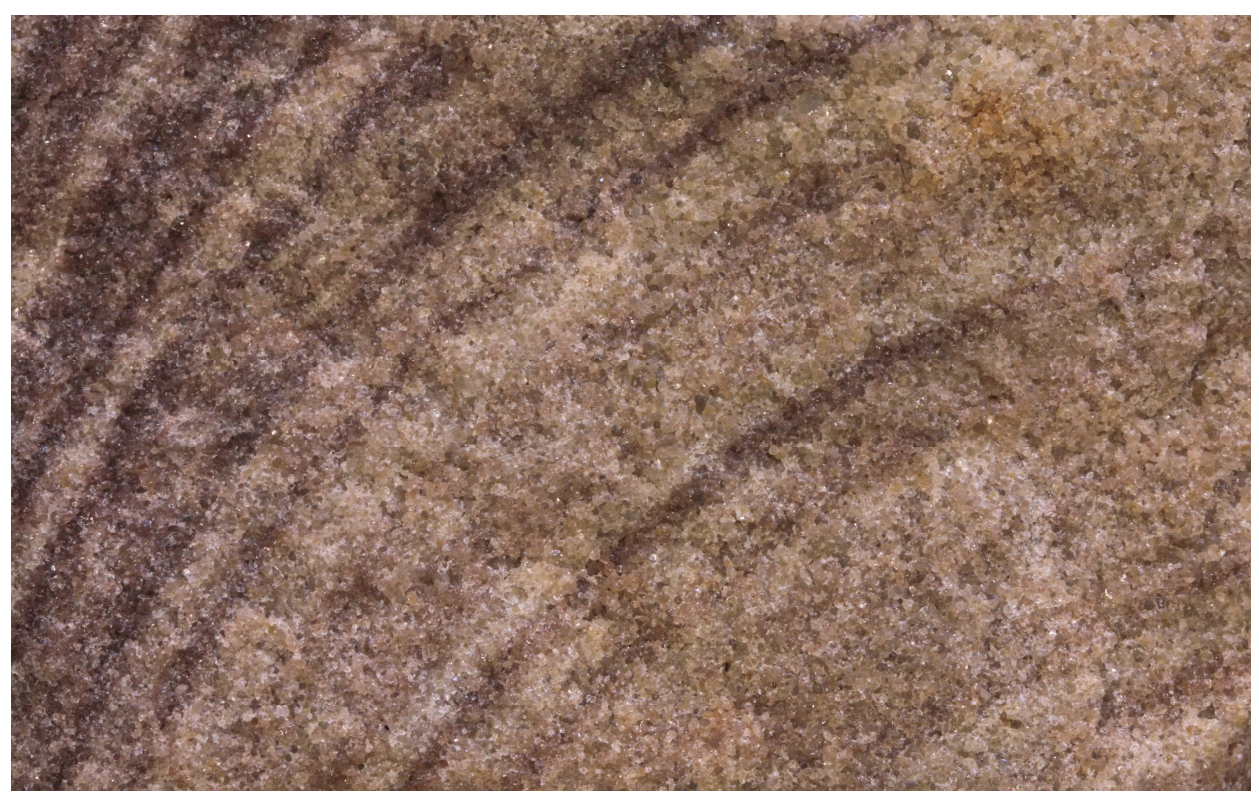

Fot. 10.28. Piaskowiec Kalmarsund, Värsnäs k/Kalmaru, południowa Szwecja; rozmiar dłuższego boku 60 mm; fot. P. Czubla 2015

Photo 10.28. Kalmarsund sandstone, Värsnäs near Kalmar, Southern Sweden; picture width $60 \mathrm{~mm}$. Photo P. Czubla 2015 


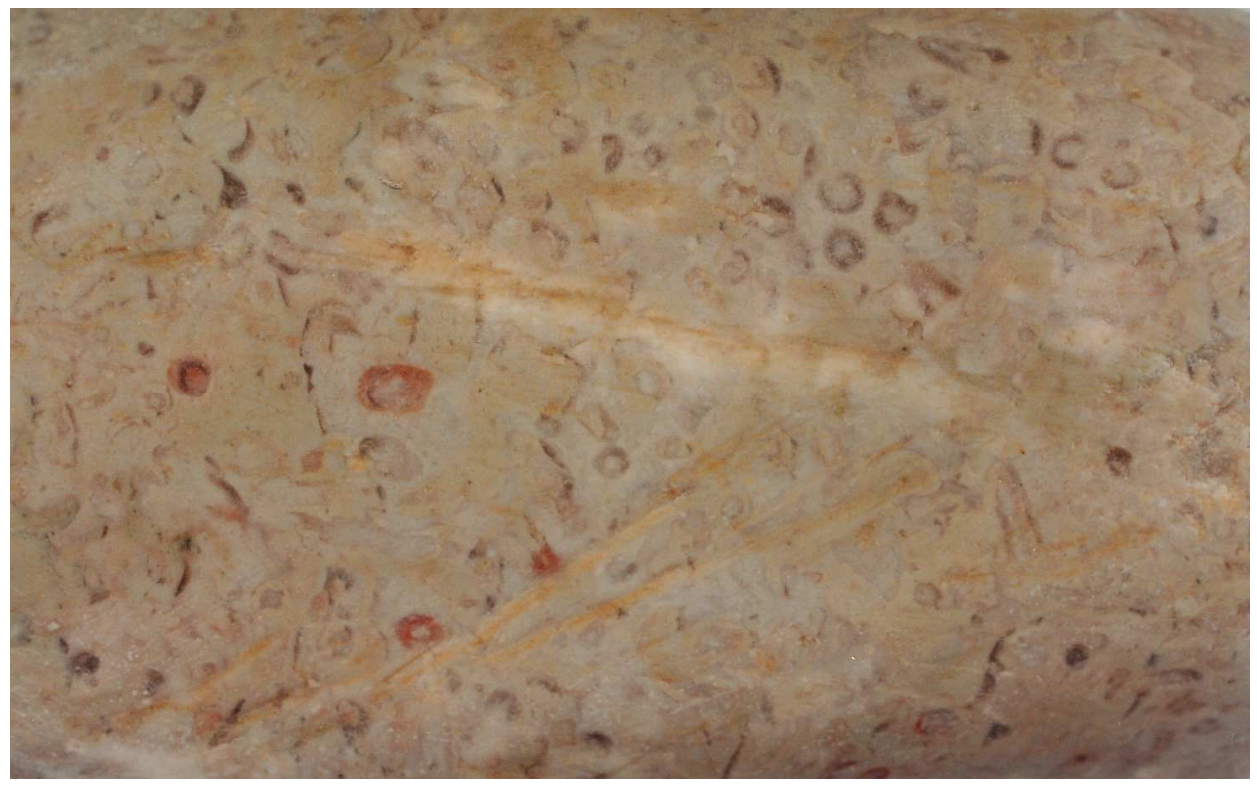

Fot. 10.29. Wapień paleoporellowy, eratyk - Smulsko; rozmiar dłuższego boku $76 \mathrm{~mm}$; fot. P. Czubla i Z. Machnicki 1999

Photo 10.29. Paleoporella limestone, erratic - Smulsko outcrop; picture width $76 \mathrm{~mm}$. Photo P. Czubla \& Z. Machnicki 1999

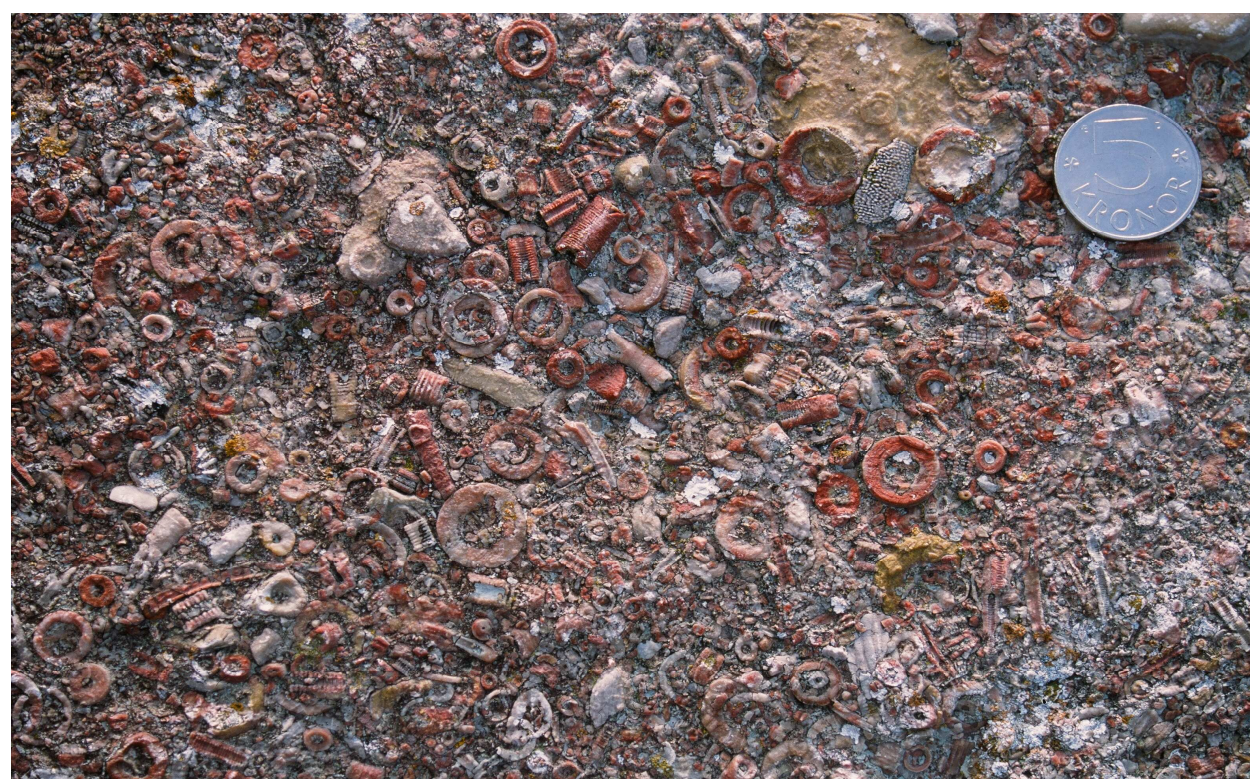

Fot. 10.30. Wapień krynoidowy, klif Hoburgen, Gotlandia; rozmiar dłuższego boku $240 \mathrm{~mm}$ (średnica monety $29 \mathrm{~mm}$ ); fot. P. Czubla 2003

Photo 10.30. Crinoidea limestone, Hoburgen Cliff, Gotland Island; picture width $240 \mathrm{~mm}$ (the diameter of the coin is $29 \mathrm{~mm}$ ). Photo P. Czubla 2003 
(2,3\% wobec $1,45 \%$ brunatnych), ale to zapewne wynika z łatwiejszej identyfikacji czerwonego porfiru nawet w postaci drobnych ziaren, a być może częściowo także z jego większej odporności na wietrzenie. Powyższy wniosek potwierdzają dane prezentowane przez Górską-Zabielską (2008) dla lobu Odry, gdzie w glinach czerwone porfiry są sześciokrotnie mniej liczne od brunatnych (odpowiednio 0,37\% i 2,23\%), w żwirach zaś ich udział - 2,66\% znacznie przewyższa odsetek brunatnych porfirów wynoszący $1,77 \%$. Obserwacje na Wołyniu wykazały dużą przewagę liczebną czerwonych porfirów nad brunatnymi (Gagel i Korn, 1918), ale metoda poboru prób (zbiór kamieni leżących na powierzchni ziemi) niewątpliwie faworyzowała skałę odporniejszą na wietrzenie.

Eratyki porfirów bałtyckich znajdowane w Danii i Niemczech mają najczęściej dość duże rozmiary, tj. od 6 do $14 \mathrm{~cm}$ (w Meklemburgii do $16 \mathrm{~cm}$ ) - Gry (1974), Schulz (2003). Odmienną opinię wyraził Richter (1933), który zwrócił uwagę na zazwyczaj niewielkie (mniejsze od kurzego jaja) eratyki porfirów bałtyckich w północnych Niemczech. Eratyki czerwonych porfirów bałtyckich znajdowane w Polsce cechują się najczęściej średnicą do około 5-6 cm, brunatne bywają natomiast na ogół większe. Jedną z przyczyn liczebnej przewagi czerwonych porfirów w drobniejszej frakcji może być łatwość ich rozpoznania nawet w małych klastach, podczas gdy małe ziarna brunatnego porfiru są trudne do makroskopowej identyfikacji.

Milthers (1934, 1936, 1939, 1950; Milthers i Milthers, 1938) próbował wykorzystać brunatny porfir bałtycki jako eratyk homochroniczny dla osadów lądolodu warciańskiego. Strefa rozrzutu tej skały na Niżu Środkowoeuropejskim miała być tożsama z maksymalnym zasięgiem tego zlodowacenia i obejmować obszar od Jäderen w południowo-zachodniej Norwegii, przez Anglię (?), Holandię, Niemcy, Polskę i sięgać na wschód aż po W-Rosję i południową część krajów nadbałtyckich. Zbliżony udział tej skały notowany był w osadach warciańskich na odcinku około $1200 \mathrm{~km}$ aż po Białowieżę. Dalej na wschód brunatny porfir bałtycki występuje już na tyle nielicznie, że nie jest już możliwe określenie na jego podstawie dalszego przebiegu zasięgu warty (Milthers, 1939). Tezę Milthersa potwierdzili w Polsce Zachodniej Konieczny i Wdowiak (1971). W opozycji do poglądów Milthersa występował natomiast Ladwig (1938), który nie dostrzegł żadnej regularności w rozmieszczeniu brunatnych porfirów na środkowym Pomorzu i uważał, że każdy spływający w tym kierunku potok/strumień lodowy musiał przekroczyć wychodnię tej skały. W Polsce Środkowej pogląd Milthersa zakwestionował Różycki (1965, 1967), rozszerzając strefę rozrzutu brunatnego porfiru bałtyckiego pomiędzy $19^{\circ} \mathrm{E}$ i $22^{\circ} \mathrm{E}$ aż po granicę zasięgu stadiału Radomki. Poza tą strefą Różycki potwierdził zgodność występowania brunatnego porfiru z zasięgiem lądolodu warciańskiego. Wyniki Różyckiego zostały początkowo potwierdzone przez Dudziaka (1978), który na przedpolu Karpat nie znalazł zupełnie brunatnych porfirów bałtyckich w osadach kompleksu południowopolskiego, ale w dalszych badaniach okazało się, że skała ta jednak występuję w osadach starszych od środkowopolskich (Dudziak, 1980). Badania przeprowadzone w odkrywce bełchatowskiej doprowadziły do zanegowania tezy Różyckiego o rozszerzeniu zasięgu brunatnego porfiru bałtyckiego na południe, ponieważ w osadach glacjalnych formacji Ławki, interpretowanej jako zdeponowane przez lądolód odrzański (pozycja stratygraficzna odpowiadająca przywoływanemu stadiałowi 
Radomki) (m.in. Krzyszkowski, 1995), nie znaleziono ani jednego głazika tej skały (Czubla, 2001). Odmienną interpretację przedstawiła Turkowska, która założyła, że teza Różyckiego jest prawidłowa, a skoro tak, to interpretacja formacji Ławki w odkrywce „Bełchatów” jako odrzańskiej jest sprzeczna z jej składem petrograficznym (2006 str. 111). W świetle nowszych badań (Balwierz i in., 2006, 2008) dotychczas powszechnie akceptowana interpretacja stratygrafii osadów w odkrywce KWB „Bełchatów” jest rzeczywiście trudna do utrzymania i formację Ławki należy wiązać ze zlodowaceniem san 2 (por. Lindner i Marks 2012; Pawłowska i in., 2014) i tak jest to przyjęte w niniejszej pracy.

Utożsamianie występowania brunatnych porfirów bałtyckich z zasięgiem lądolodów środkowopolskich nie znajduje potwierdzenia w nowych analizach petrograficznych. Pozorny brak tej skały poza zasięgiem zlodowaceń środkowopolskich wynikał zapewne z jej bardzo małego udziału w osadach kompleksu południowopolskiego - 0,54\% i znacznego wzrostu jej liczebności w młodszych osadach glacjalnych - 1,22\% w kompleksie środkowopolskim i 3,34\% w północnopolskim (rys. 10.13 i 10.14). Powyższy przyrost można zinterpretować jako efekt systematycznego powiększania się wychodni porfirów wraz z erozją przykrywających je innych skał. Oznaczałoby to, że brunatne porfiry bałtyckie tworzyły najprawdopodobniej subwulkaniczną intruzję o kształcie lakkolitu i stopniowo odsłaniane były jej coraz głębsze, a jednocześnie szersze partie.

Czerwone porfiry bałtyckie w osadach kompleksu południowopolskiego są prawie trzykrotnie liczniejsze od brunatnych $-1,45 \%$, ale najwyższy udział mają w glinach zlodowaceń środkowopolskich - 2,08\%. W osadach vistulianu ich odsetek maleje do $1,64 \%$, co oznacza, że jest on ponad dwukrotnie niższy od zawartościporfirów brunatnych.

Sumaryczna zawartość porfirów bałtyckich rośnie w coraz to młodszych osadach glacjalnych głównie za sprawą wspomnianego przyrostu udziału jego brunatnej odmiany. Nie udało się natomiast wykazać występowania wyraźnej zmienności przestrzennej udziału tej grupy jako całości w przebadanych osadach. Taka zmienność jest za to czytelna w rozmieszczeniu czerwonych porfirów bałtyckich, których zawartość w osadach obydwu starszych kompleksów plejstocenu Polski wzrasta wraz z przesuwaniem się na wschód. W glinach południowopolskich maksymalna zawartość tej skały wyniosła 5,4\% w Kolonii Domaszewskiej koło Łukowa (rys. 10.15), a w glinach środkowopolskich, w których zmienność przestrzenna jest słabiej czytelna, 4,9\% w Kaczorach koło Siedlec i aż 6,9\% w Wyrzysku na krawędzi doliny Noteci (rys. 10.16). Uwzględnienie wyników badań innych autorów pozwala wykazać tę samą prawidłowość również w osadach ostatniego zlodowacenia. W lobie odrzańskim czerwone porfiry bałtyckie stanowią średnio 0,37\% krystalicznych eratyków przewodnich (Górska-Zabielska, 2008). W lobie wiślanym ich zawartość jest ponad czterokrotnie wyższa - 1,64\%. Udział brunatnych porfirów bałtyckich zmienia się odwrotnie. Górska-Zabielska (op. cit.) wykazała obecność 2,23\% eratyków tej skały w lobie odrzańskim, podczas gdy w lobie wiślanym stanowią one około 1,64\%. Powyższe stosunki ilościowe pomiędzy porfirami bałtyckimi w lobach Odry i Wisły odzwierciedlają rozmieszczenie ich wychodni na dnie Bałtyku (rys. 10.1 i 10.2) i zdają się świadczyć o równoległym ruchu sąsiednich mas (potoków) lodowych na południe i południowy zachód. 


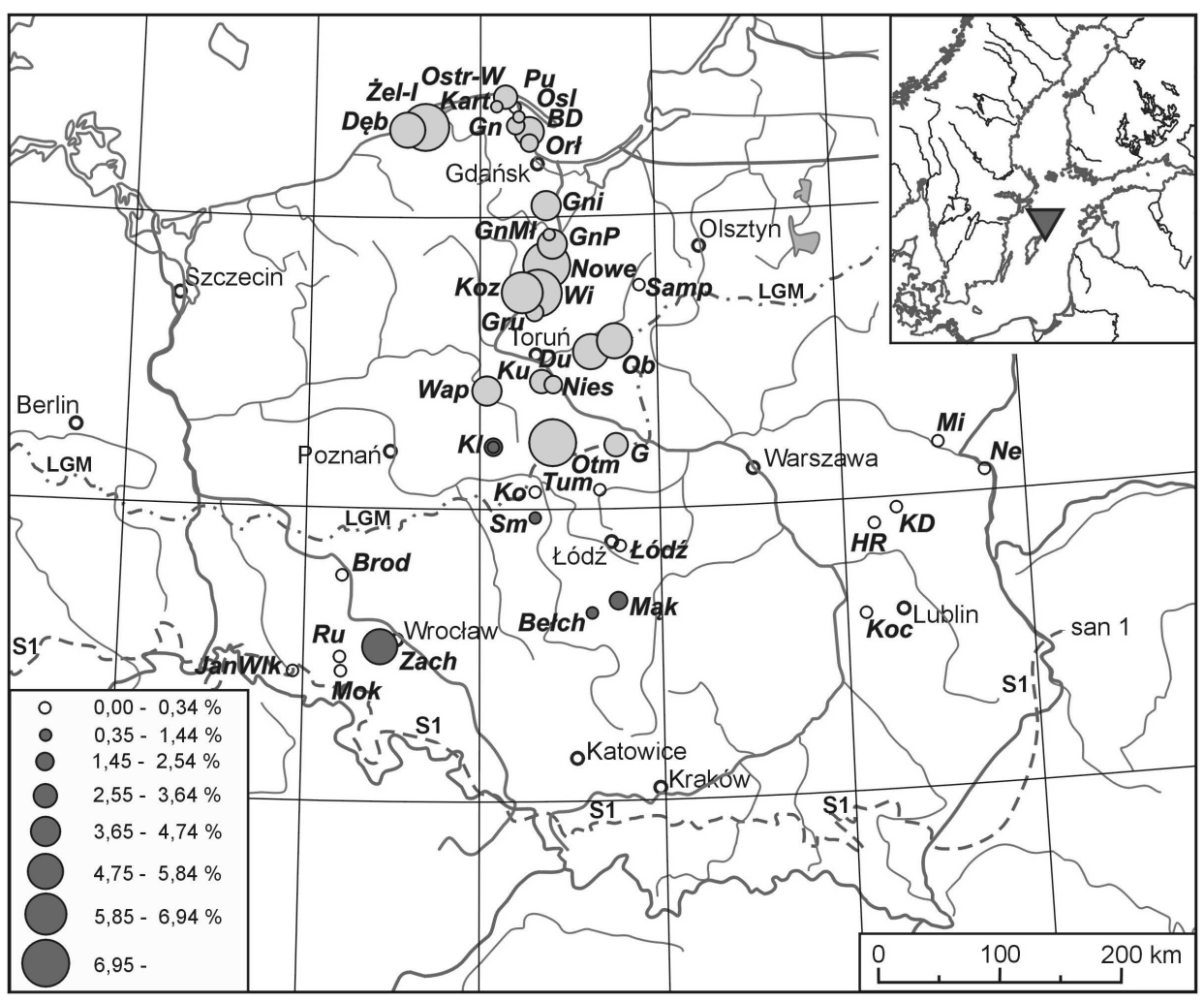

Rys. 10.13. Rozmieszczenie brunatnych porfirów bałtyckich w osadach kompleksu południowopolskiego (ciemne koła) i północnopolskiego (jasne koła) - udział poniżej 0,35\% (puste koło jako symbol stanowiska) oznacza brak danej skały

Figure 10.13. The distribution of brown Baltic porphyry in glacial deposits of the South-Polish Complex (dark circles) and of the North-Polish Complex (light circles) - share below 0,35\% (empty circle as a site symbol) means a lack of the presented porphyry in the site

Sumaryczny udział porfirów i diabazów bałtyckich rozpoznanych w osadach vistulianu lobu wiślanego wyniósł 5,4\%. Identyczną wartość dla glin stadiału głównego przedstawił Gałązka (2004b). Na terenie Wielkopolski Górska (2000) w ogóle nie znalazła porfirów bałtyckich, w glinach lobu odrzańskiego zaś określiła ich sumaryczny udział na 2,6\% (Górska-Zabielska, $2008^{13}$ ). Nieliczne skały z dna Bałtyku rozpoznano na Wysoczyźnie Lubuskiej (Lipka, 2011), ale sposób przedstawienia wyników uniemożliwia określenie, jakie konkretnie skały autorka zidentyfikowała.

Porównanie wyników z danymi prezentowanymi przez Gałązkę dla glin sanu i odry jest niecelowe, ponieważ znaczna część jego danych dotyczących glin odrzańskich została pozyskana w oparciu o analizy osadów formacji Ławk w Bełchatowie (2004b).

${ }^{13}$ Dane Górskiej-Zabielskiej (2008) zostały przeliczone zgodnie z metodyką przyjętą w niniejszej pracy. Autorka przytoczonych wartości procentowych bezpośrednio nie podawała. 


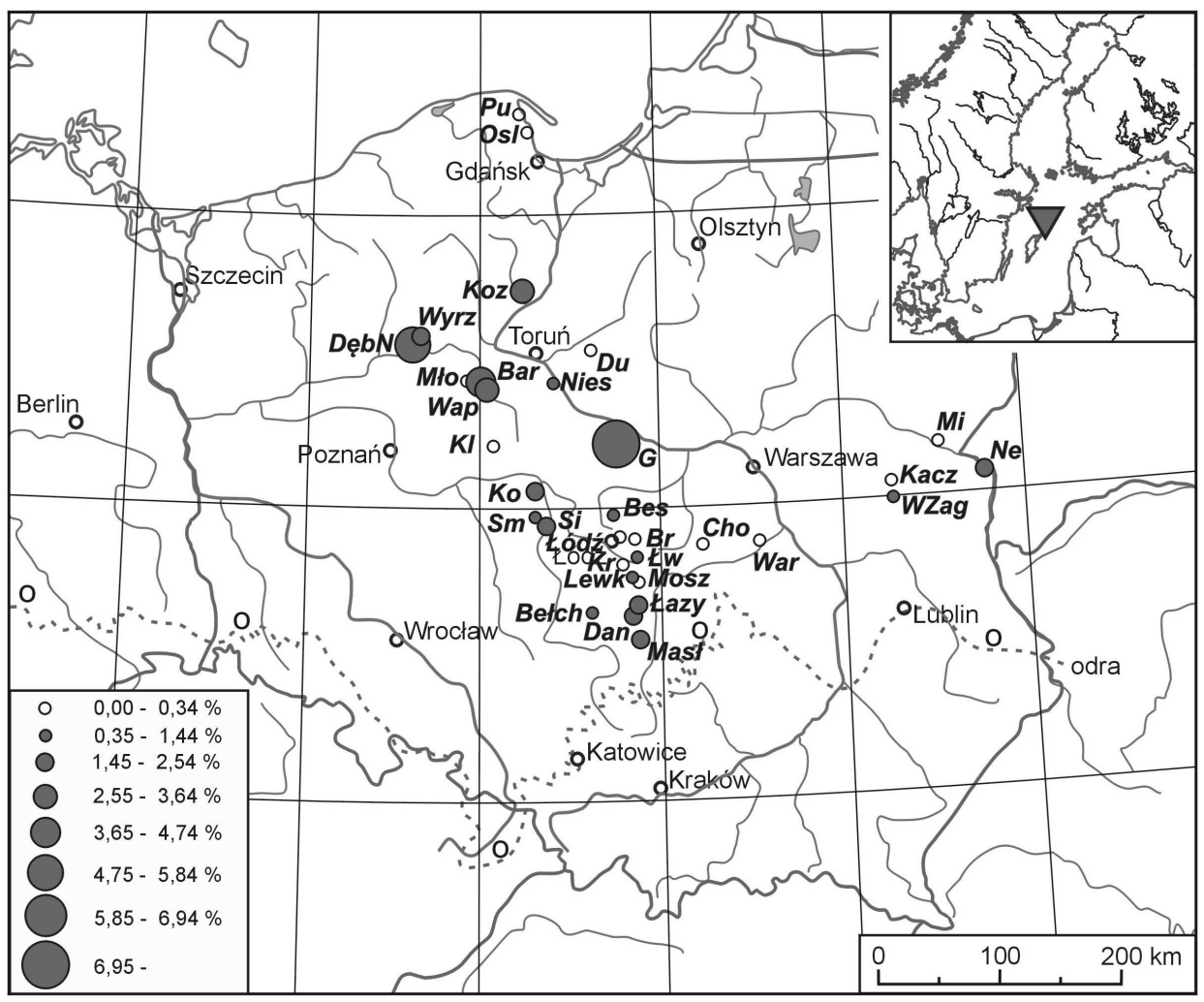

Rys. 10.14. Rozmieszczenie brunatnych porfirów bałtyckich w osadach kompleksu środkowopolskiego udział poniżej 0,35\% (puste koło jako symbol stanowiska) oznacza brak danej skały

Figure 10.14. The distribution of brown Baltic porphyry in glacial deposits of the Middle-Polish Complexshare below $0,35 \%$ (empty circle as a site symbol) means a lack of the presented erratic in the site

Podobnie dawniejsze badania autora (m.in. Czubla, 2001) oparte były na powszechnie akceptowanej wówczas interpretacji tej formacji jako odrzańskiej. Odrębnego komentarza wymagają wyniki uzyskane w Holandii. W skrajnym przypadku, w zespole głazowym w Nunspeet zidentyfikowano aż 40,3\% (48 na 119 rozpoznanych klastów) brunatnych porfirów bałtyckich. W zespołach głazowych bogatych w skały alandzkie i bałtyckie, określanych w Holandii jako wschodniobałtyckie, brunatny porfir bałtycki występuje już dość rzadko, znacznie liczniejszy jest jego czerwony odpowiednik, który np. w Lheebroek stanowił ponad $14 \%$ zespołu, a w Veenhuizen nawet prawie $28 \%$ i to we frakcji >25 mm (Schuddebeurs, 1980/1981, 1981). Skrajnie wysoką zawartość czerwonego porfiru bałtyckiego, wynoszącą około 39\%, tj. ponad pięciokrotnie wyższą od maksymalnej stwierdzonej przez autora w Polsce (Wiąg - 7,1\%; rys. 10.15), stwierdzono w stanowisku Zwiggelte (Zandstra, 1974). Do tak wysokiego udziału tej skały wśród rozpoznanych eratyków z całą pewnością przyczyniły się procesy wietrzeniowe, które wyeliminowały większość skał mniej odpornych, bądź znacznie 
ograniczyły możliwości ich identyfikacji. Jak już wcześniej wspomniano, czerwone porfiry bałtyckie należą do skał bardzo odpornych na wietrzenie, a większość osadów glacjalnych Holandii cechuje się znacznym stopniem zaawansowania tego procesu (Schuddebeurs, op. cit.). W podobny sposób można wyjaśnić dość wysoki udział porfirów bałtyckich, a zwłaszcza czerwonej odmiany w zespołach głazowych zachodnich Czech, stwierdzony przez Víšeka i Nývlta (2006).

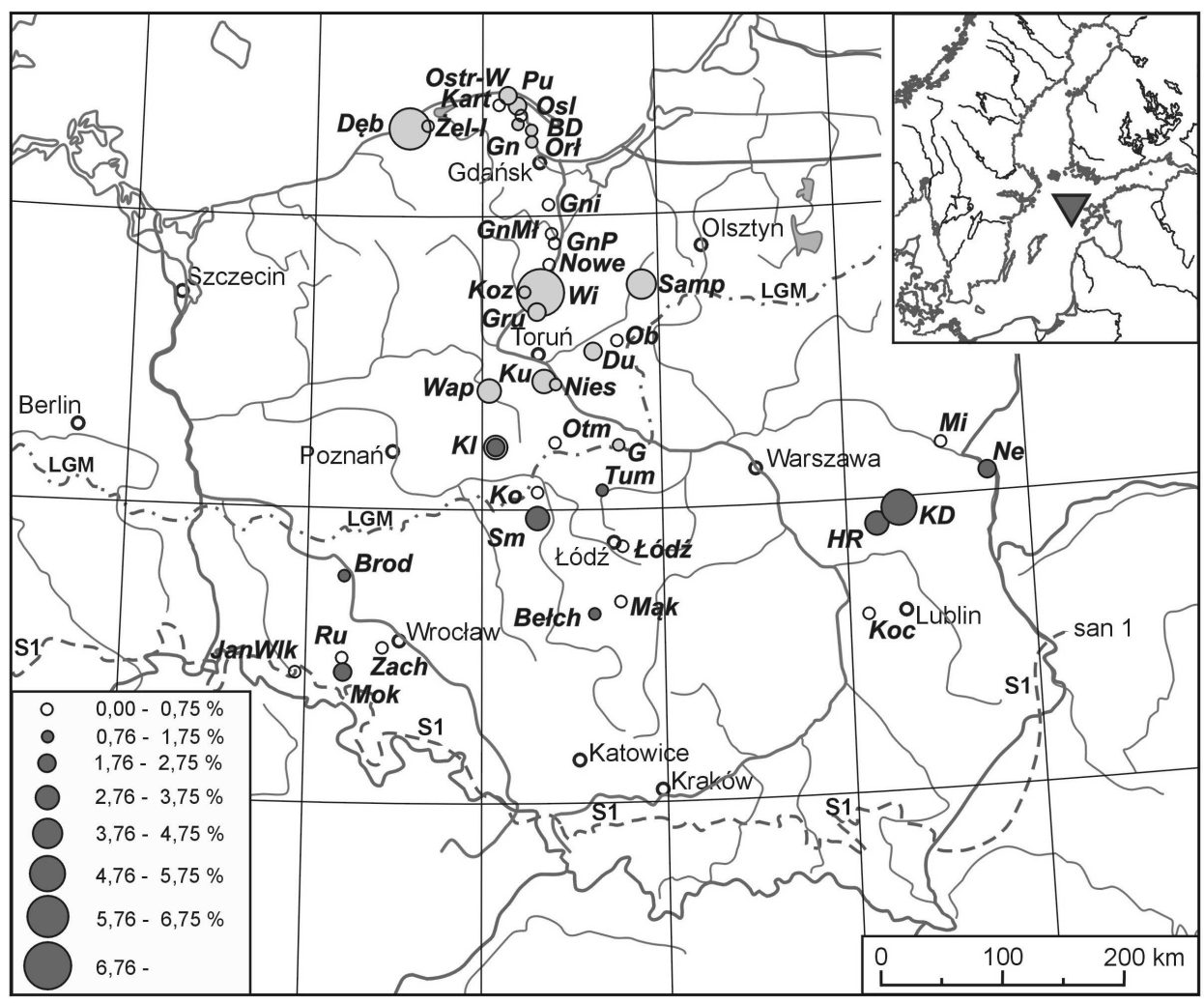

Rys. 10.15. Rozmieszczenie czerwonych porfirów bałtyckich w osadach kompleksu południowopolskiego (ciemne koła) i północnopolskiego (jasne koła) - udział poniżej 0,76\% (puste koło jako symbol stanowiska) oznacza brak danej skały

Figure 10.15. The distribution of red Baltic porphyry in glacial deposits of the South-Polish Complex (dark circles) and of the North-Polish Complex (light circles) - share below 0,76\% (empty circle as a site symbol) means a lack of the presented porphyry in the site

Na terenie Białorusi Astapova (1987) stwierdziła obecność od 0,4 do ponad 11\% porfirów bałtyckich wśród oznaczonych eratyków. Są to wartości nadspodziewanie wysokie, ponieważ analizowana przez nią frakcja $(10-15 \mathrm{~cm})$ zawiera już stosunkowo niewiele skał wulkanicznych - zwłaszcza czerwonych porfirów bałtyckich. Największą zawartość porfirów bałtyckich Astapova zanotowała w rejonie Nowogródka i Grodna, dalej na wschód ich udział dość wyraźnie malał. Na wschód od Mińska występowały już tylko sporadycznie. 


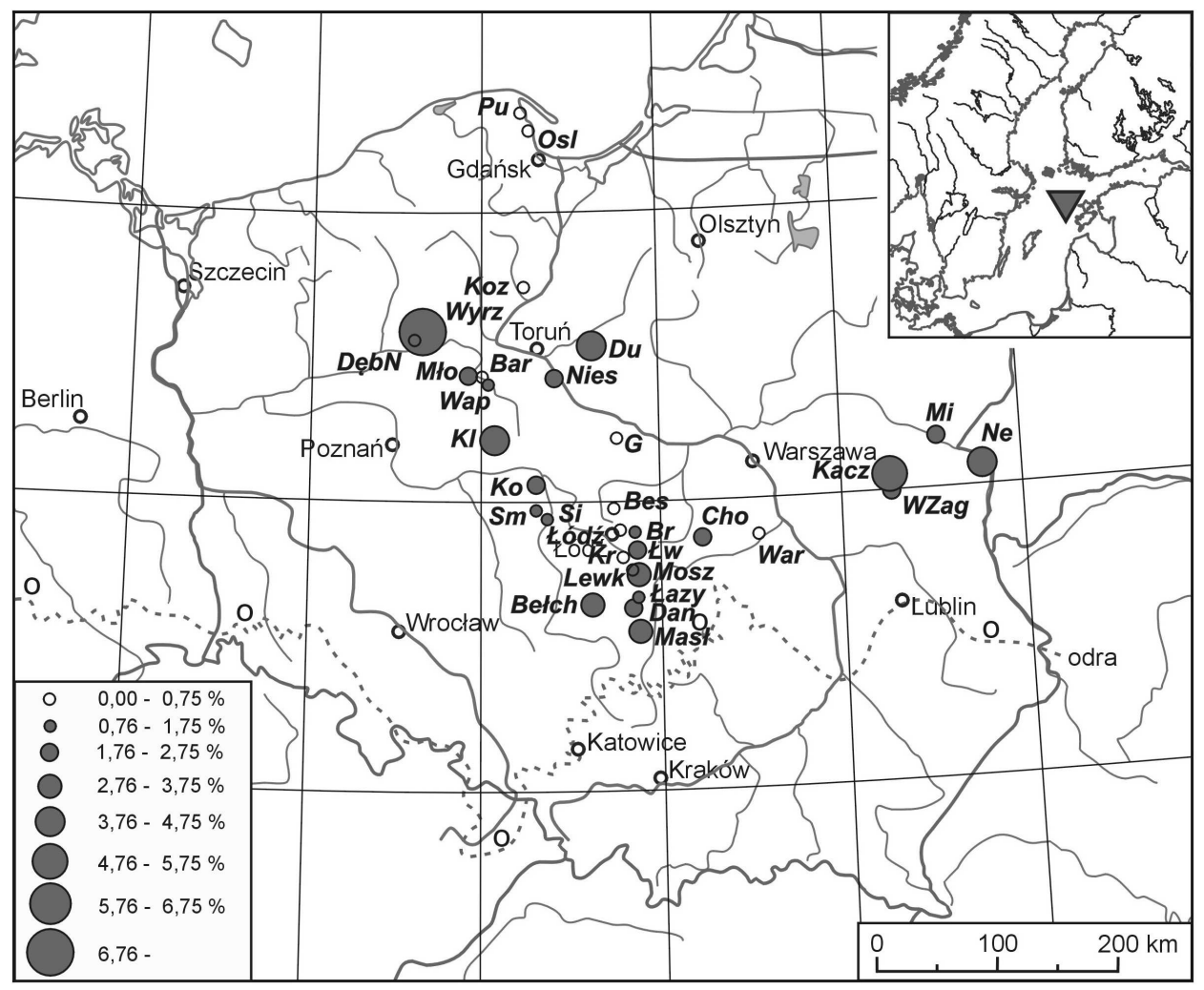

Rys. 10.16. Rozmieszczenie czerwonych porfirów bałtyckich w osadach kompleksu środkowopolskiego udział poniżej 0,76\% (puste koło jako symbol stanowiska) oznacza brak danej skały

Figure 10.16. The distribution of red Baltic porphyry in glacial deposits of the Middle-Polish Complex-share below $0,76 \%$ (empty circle as a site symbol) means a lack of the presented porphyry in the site

Wykorzystywane jako eratyki przewodnie piaskowce Kalmarsund (Chiasma) i Tessini mają na tyle jednoznaczne cechy rozpoznawcze, że ich pomylenie z innymi skałami okruchowymi jest bardzo mało prawdopodobne. Kalmarsund ma wyraźne brunatno-czerwone pasma krzyżujące się z warstwowaniem i jako taki wyraźnie odróżnia się od równowiekowego piaskowca Nexö z Bornholmu oraz czerwonego piaskowca bałtyckiego (Meyer, 1983; Smed, 1994; Meyer i Lüttig, 2007). Żelazista mineralizacja przebiegająca niezgodnie ze strukturą (warstwowaniem i uziarnieniem) skały jest jednak zjawiskiem dość rzadkim i piaskowce Kalmarsund w typowym wykształceniu były bardzo nieliczne w próbach przeanalizowanych przez autora - na jedną próbkę przypadało średnio zaledwie pół eratyka tej skały. Uniemożliwia to wyciągnięcie wiarygodnych wniosków na temat dystrybucji przestrzennej i czasowej piaskowców Kalmarsund w osadach glacjalnych Polski. 
Znacznie częściej występują piaskowce Tessini. Wbrew nazwie są to raczej mułowce (mułowiec paradoxissimus - Martinsson, 1965), rzadziej drobnoziarniste piaskowce, szarozielonkawo zabarwione, oddzielające się w postaci cienkich płytek. W miarę wietrzenia zmieniają natomiast zabarwienie na żółtozielonkawe do szaro brązowawego (fot. 10.27). Wśród składników ziarnistych przeważa słabo obtoczony kwarc i glaukonit, a w skład spoiwa wchodzi głównie krzemionka z domieszką węglanu wapnia. Niekiedy piaskowce Tessini bywają ubogie w węglany, a nawet bezwęglanowe (Groetzner, 1972). Podobnie wykształcone bywają niektóre warstwy piaskowców Mickwitzia w Västergötland i ich odpowiedniki w Skanii i Estonii, ale ich udział (skał na tyle podobnych do Tessini, że mogą być z nim mylone) w tamtejszych wychodniach jest znikomy, a zatem prawdopodobieństwo popełnienia błędu niewielkie (Groetzner, op. cit.). Najłatwiej byłoby rozpoznać ten piaskowiec/mułowiec po skamieniałościach trylobitów, którym zresztą zawdzięcza swoją drugą nazwę, niestety w rzeczywistości występują one bardzo rzadko. Identyfikacja tej skały bazuje zatem na bardzo drobnej frakcji, zabarwieniu oraz masowym występowaniu hieroglifów zarówno nieorganicznych (np. wleczeniowych), jak i biogenicznych. Piaskowce Tessini uznają za przewodnie m.in. Marczinski (1968a), Groetzner (1972), Meyer (1983), Smed (1994, 2002), Lüttig (Meyer i Lüttig, 2007). Niejasne jest stanowisko Schuddebeursa (1980/1981, 1986), który generalnie kwestionuje wykorzystywanie skał osadowych jako eratyków przewodnich, ale głównie z uwagi na ich znikomy udział w holenderskich zespołach głazowych (piaskowiec Tessini napotkał tylko w 3 stanowiskach i tylko po jednym okazie). W Polsce piaskowiec Tessini występuje niezbyt licznie. Najbogatsze w tę skałę są osady glacjalne kompleksu południowopolskiego Dolnego Śląska i Polski Środkowej, na wschodzie zaś jej zawartość wyraźnie maleje. Wraz z malejącym wiekiem osadów glacjalnych udział piaskowców Tessini systematycznie się obniża.

We wszystkich próbach pobranych z niezwietrzałych osadów glacjalnych bardzo licznie występują wapienie paleozoiczne (ordowik i sylur). Mają one olbrzymie wychodnie macierzyste - w niektórych przypadkach rozczłonkowane. W związku z tym mogą być traktowane tylko jako eratyki pomocnicze. Próby włączenia niektórych typów wapieni do obliczeń teoretycznych ośrodków głazowych (Vinx i in., 1997; Czubla, 2001) prowadziły do większego rozproszenia współrzędnych uzyskanych dla równowiekowych osadów glacjalnych. Na utrudnienie interpretacji uzyskanych tą drogą teoretycznych ośrodków głazowych wpłynęła również duża wrażliwość skał węglanowych na wietrzenie.

Smed $(2000,2002,2010)$ rozszerzył znacznie liczbę wapieni wykorzystywanych do tworzenia map kołowych - dodatkowo uwzględnił wapień beyrichiowy, gotlandzki wapień koralowcowy i krynoidowy (fot. 10.30), wapień paleoporellowy (fot. 10.29), czerwono-biały wapień bałtycki, czerwony wapień z Olandii, dolomity oraz narzutniaki dewońskie. W ten sposób zwiększył rangę tych skał w wyznaczaniu obszarów alimentacji i kreśleniu dróg migracji potoków lodowych. W oparciu o nowe materiały kartograficzne (głównie Fredén, 1994) wyznaczył dla nich centralne punkty wychodni niezbędne do sporządzania map kołowych. W przypadku wapienia beyrichiowego zostały 
ustalone nawet dwa alternatywne „środki” wychodni (Smed, 2002). Górska-Zabielska (2008) dołączyła jeszcze do tej grupy „tłusty” wapień bałtycki, dla którego „środek” wychodni wyznaczyła na zachód od Hiumy. Nieznane są jednak przesłanki, które zadecydowały o akurat takiej lokalizacji tego punktu. Bardzo krytycznie do powyższej koncepcji Smeda odnoszą się Meyer i Lüttig (2007). Jako kontrargument przytoczyli czerwony wapień przypisywany przez Smeda (2000) do wychodni na Olandii. Okazało się, że w próbie z Lieth koło Elmshorn wapień ten towarzyszy licznym skałom norweskim i zachodnioszwedzkim, a skały alandzkie są w niej zupełnie nieobecne. Świadczy to o pochodzeniu wapieni z Västergötland, a nie z Olandii (Meyer i Lüttig, op.cit.). Uwzględnianie czerwonych wapieni ordowickich na mapach kołowych prowadzić może zatem do błędnej interpretacji obszaru alimentacyjnego analizowanego osadu. Analogiczne problemy mogą wystąpić również w przypadku wapieni beyrichiowych, paleoporellowych i "tłustych" wapieni wschodniobałtyckich, które mają słabiej rozpoznane i rozczłonkowane wychodnie, rozrzucone na dużym obszarze. W próbkach, gdzie skały węglanowe stanowiłyby 30-60\% skał wskaźnikowych, łatwo mogłoby dochodzić do dużych rozbieżności w wynikach (Meyer i Lüttig, 2007). Precyzyjne ustalenie lokalizacji niektórych spośród wymienionych wapieni bywa niekiedy możliwe przy wsparciu pracoi czasochłonnych metod mikropaleontologicznych (por. Schallreuter, 1997; Meyer i Lüttig, 2007), które jednak w szeroko zakrojonych badaniach osadów czwartorzędowych są trudne do zaakceptowania.

Znaczący wpływ na wyniki badań eratyków, w których uwzględniono skały węglanowe, może wywrzeć wietrzenie. W efekcie wietrzenia fizycznego może dojść do wtórnego wzrostu liczby oraz zmniejszenia rozmiarów wapiennych klastów, wietrzenie chemiczne zaś może doprowadzić do kompletnej eliminacji wapieni $z$ analizowanych osadów. To zapewne przyczyniło się do pojawienia się opinii o braku perspektyw wykorzystania skał węglanowych w badaniach eratyków w Holandii (Zandstra, 2002). Lüttig również wielokrotnie $(1954,1995,1997)$ podkreślał, że odwapnienie osadów uniemożliwia późniejsze porównania - zwłaszcza w przypadku uwzględniania w analizach skał węglanowych.

Dodatkowy problem mogłoby stanowić słabe opróbowanie glin bogatych w klasty wapienne, ponieważ osiągnięcie minimalnej liczby głazików w próbie nie gwarantowałoby obecności w niej dostatecznej liczby jednoznacznie oznaczalnych krystalicznych eratyków przewodnich (Meyer i Lüttig 2007). Można tego jednak łatwo uniknąć, kontrolując pobieżnie skład próbki już $w$ terenie i w przypadku wysokiego udziału skał węglanowych, zwiększając jej liczebność (por. Czubla, 2001). Pomimo wszystkich powyższych zastrzeżeń, autor przychyla się do opinii Meyera i Lüttiga (2007), że poszczególne typy wapieni powinny być wyróżniane w analizach eratyków. Nawet jeżeli nie zostaną wykorzystane do kreślenia map kołowych, to dostarczą dodatkowych informacji, np. o drogach migracji lodu lub o procesach, jakim osad glacjalny podlegał już po depozycji.

W związku z powyższym założeniem we wszystkich analizowanych próbach wyróżniano najważniejsze typy wapieni i określano ich udział wśród fennoskandzkich skał 
węglanowych. Okazało się, że udział wapieni wschodniobałtyckich, tzn. „tłustych” wapieni pelitowych i plamistych „Wesenberga” zmienia się w sposób niemal identyczny z udziałem skał alandzkich, czyli osiąga maksimum w glinach kompleksu środkowopolskiego (tab. 10.1). Wynika to z niewielkiej odległości dzielącej ich wychodnie w środkowej Fennoskandii, a zatem migracji w obrębie tego samego potoku lodowego. Podobny związek można zaobserwować pomiędzy czerwonymi wapieniami ordowickimi i skałami krystalicznymi ze Smålandu, które największy udział osiągają w glinach kompleksu południowopolskiego. Obecność niektórych typów wapieni pozwala zatem potwierdzić i uzupełnić wnioski oparte na analizie typowych skał przewodnich.

Tab. 10.1. Udział wybranych typów wapieni fennoskandzkich w całkowitej liczbie eratyków fennoskandzkich skał węglanowych (ujęto w tej grupie wszystkie typy paleozoicznych wapieni, dolomity, margle i margle dolomityczne)

Table 10.1. Shares of selected types of Fennoscandian limestone erratics in the total number of Nordic carbonate rocks (Paleozoic limestones, dolomites, marls and dolomitic marls are included in this group)

\begin{tabular}{|l|c|c|c|c|}
\hline \multirow{2}{*}{$\begin{array}{c}\text { Rodzaj wapieni } \\
\text { fennoskandzkich }\end{array}$} & \multicolumn{3}{|c|}{$\begin{array}{c}\text { Udział wapieni fennoskandzkich w grupie skał węglanowych } \\
\text { (w \%) }\end{array}$} \\
\cline { 2 - 5 } & $\begin{array}{c}\text { Gliny kompleksu } \\
\text { południowopolsk. }\end{array}$ & $\begin{array}{c}\text { Gliny kompleksu } \\
\text { środkowopolsk. }\end{array}$ & $\begin{array}{c}\text { Gliny kompleksu } \\
\text { północnopolsk. }\end{array}$ & Żwiry \\
\hline Wapienie paleoporellowe & 0,83 & 1,28 & 2,03 & 1,44 \\
\hline Wapienie beyrichiowe & 3,16 & 2,96 & 3,43 & 3,16 \\
\hline Wapienie krynoidowe & 1,74 & 2,20 & 1,60 & 1,89 \\
\hline $\begin{array}{c}\text { "Tłuste" wapienie bałtyckie } \\
\text { i „Wesenberga” }\end{array}$ & 10,20 & 13,87 & 8,86 & 11,34 \\
\hline $\begin{array}{c}\text { Czerwone wapienie } \\
\text { ordowickie }\end{array}$ & 4,62 & 2,60 & 2,49 & 3,00 \\
\hline
\end{tabular}

Dolomity oraz margle dolomityczne występują w osadach syluru i dewonu, leżących bezpośrednio pod czwartorzędem w południowo-wschodniej i wschodniej części niecki Bałtyku oraz na przyległych obszarach Łotwy i Estonii (Ludwig, 1967; Cepek, 1969; Flodén, 1984; Amantov, 1996; Raukas i Teedumäe, 1997; Ūsaitytė, 2000; Šliaupa i Hoth, 2011; Tuuling i in., 2011). Lokalizacja podczwartorzędowych wychodni pozwala uznać te skały za wskaźnik wschodniego pochodzenia osadów glacjalnych. Ze względu na bardzo rozległe wychodnie dolomity nie mają rangi skał przewodnich, lecz tylko pomocniczych. Nie przeszkadza to jednak w wykorzystywaniu dolomitów w konstruowaniu map kołowych (Smed, 2000, 2002, 2010; Czubla, 2001; Górska-Zabielska, 2008). Należy jednak mieć świadomość, że inkorporacja dolomitów mogła nastąpić w różnych częściach wschodniego lub centralnego Bałtyku, bądź nawet na terenie dzisiejszej Łotwy lub Estonii - ostatnia opcja raczej nierealna w odniesieniu do glin na terenie Polski. W związku z tym obecność dolomitów w osadach glacjalnych nie pozwala na precyzyjne odtworzenie drogi migracji lodu, odpowiedzialnego za ich odłożenie.

Dolomity są stosunkowo łatwo rozpoznawalne na podstawie reakcji z rozcieńczonym 10\% kwasem chlorowodorowym. Najczęściej cechują się skrytoziarnistą lub drobnoziarnistą („cukrowatą") teksturą; niekiedy porowatą i „drobnokomórkową" 
(Cepek, 1969). Na obecność porowatej tekstury w dolomitach wpływa głównie ich geneza. Diagenetyczna lub, częściej, epigenetyczna dolomityzacja pierwotnej skały wapiennej prowadzi do redukcji objętości i pojawienia się wolnych przestrzeni w skale. Te porowate dolomity mogą reagować z kwasem niewiele słabiej niż masywne wapienie, co czasami prowadzi do błędnej identyfikacji. Dolomityzacja może być częściowa lub całkowita. Skały tylko częściowo przekształcone w dolomit, na podstawie intensywnej reakcji z kwasem zachowanych w niezmienionej postaci cząsteczek kalcytu, również mogą zostać błędnie zaklasyfikowane jako zwykłe wapienie paleozoiczne. Obydwa potencjalne błędy nie mają jednak istotnego wpływu na wyniki analiz i ich interpretację, ponieważ takie wątpliwe eratyki i tak pochodzą w przytłaczającej większości ze wschodniej części niecki bałtyckiej. Obecność stosunkowo licznych częściowo tylko zdolomityzowanych bałtyckich wapieni została dostrzeżona nawet na zachodnich krańcach zasięgu lądolodów fennoskandzkich w Holandii (Schuddebeurs, 1980/1981).

W zespołach głazowych Polski dolomity i margle dolomityczne najczęściej towarzyszą skałom alandzkim, a ich udział wśród skał nordyckich, w przeciwieństwie do alandzkich plutonitów i wulkanitów osiągających najwyższą koncentrację na wschodzie, cechuje się podobnie wysokimi wartościami w próbach pochodzących zarówno ze wschodniej, jak i centralnej części kraju. Bardzo niski jest natomiast odsetek dolomitów w osadach glacjalnych Dolnego Śląska. W wielu przypadkach dostrzegalna jest także redukcja udziału dolomitów w zwietrzałych glinach (patrz rozdział 12). Podatność na wietrzenie jest drugim, obok rozległych obszarów źródłowych, czynnikiem dyskwalifikującym dolomity w obliczeniach teoretycznych ośrodków głazowych. Analogiczną opinię reprezentują badacze niemieccy, którzy zaobserwowali znaczne wahania zawartości dolomitów w Dolnej Saksonii (Meyer i Lüttig, 2007). Margle dolomityczne udało się autorowi zidentyfikować wyłącznie w próbach z Polski Wschodniej.

Udział dolomitów i margli dolomitycznych wśród skał fennoskandzkich w glinach kompleksu południowopolskiego wynosi średnio około 3,74\%, najwyższą uśrednioną wartość uzyskuje w glinach środkowopolskich - 4,90\% i obniża się do 3,53\% w glinach ostatniego zlodowacenia (rys. 10.17). Maksymalną zawartość dolomitów w osadach zlodowaceń środkowopolskich stwierdzono w górnej glinie w odkrywce Koźmin Północ 19,16\% oraz w dolnej glinie w Nieszawie - 9,83\% i w środkowej glinie w Smulsku 9,70\% (rys. 10.18). Jeszcze wyższy udział dolomitów, sięgający nawet $25 \%$, ale przy znacznym zróżnicowaniu przestrzennym, odnotowano w glinach młodszego Saalianu (Warthe) w Dolnej Saksonii (Gauger i Meyer, 1970). Maksymalne zawartości dolomitów w na ogół uboższych w ten typ skały osadach glacjalnych kompleksu południowopolskiego i północnopolskiego są zbliżone do zaobserwowanych w Nieszawie i Smulsku, co w zestawieniu z podanymi powyżej średnimi wartościami, wskazuje na bardzo duże zróżnicowanie roli tej skały w zależności od stanowiska, a nie od wieku gliny. W najstarszej (południowopolskiej) glinie w Kleczewie koło Konina udział dolomitów sięgnął aż 9,44\%, a w Wiągu, w glinach przypisywanych stadiałowi Świecia ostatniego zlodowacenia (Olszewski, 1974), wyniósł 9,39\% (rys. 10.17). 


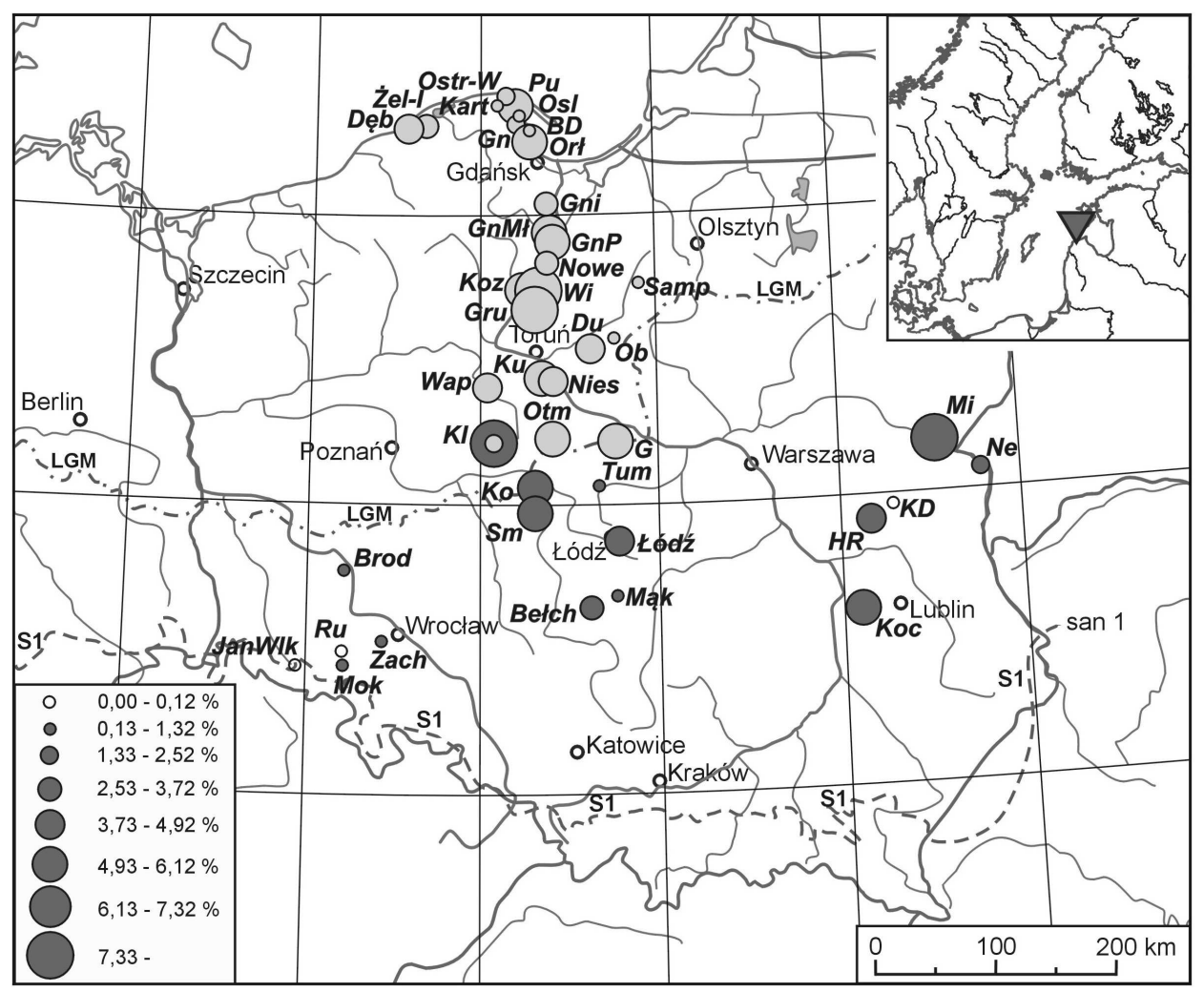

Rys. 10.17. Udział dolomitów w grupie skał fennoskandzkich w osadach kompleksu południowopolskiego (ciemne koła) i północnopolskiego (jasne koła); dla stanowisk, gdzie pobrano wiele próbek z osadów tego samego wieku, dane zostały uśrednione - udział poniżej $0,13 \%$ (puste koło jako symbol stanowiska) oznacza brak dolomitów

Figure 10.17. The percentage of dolomites among Fennoscandian rocks in the tills of the South-Polish Complex (dark circles) and of the North-Polish Complex (light circles); for research sites, where multiple samples were taken from sediments of the same age, the data were averaged - share below $0,13 \%$ (empty circle as a site symbol) means a lack of dolomites in the site

Rozkład przestrzenny udziału dolomitów wśród skał węglanowych (rys. 10.19) jest niemal identyczny z ich udziałem wśród skał fennoskandzkich (rys. 10.17). Jedyną wyraźną różnicą jest niewielki względny spadek znaczenia dolomitów w grupie skał węglanowych Polski Wschodniej. W tej sytuacji można wysunąć przypuszczenie, że dolomity są nawet nieco słabszym wskaźnikiem wschodniego pochodzenia osadów glacjalnych, aniżeli wapienie. Do eratyków potwierdzających wschodnie obszary źródłowe materiału morenowego należą również piaskowce Old-Redu. Są one jednak dość miękkie i wielokrotnie rzadziej od dolomitów zachowują się w identyfikowalnej postaci w osadach glacjalnych. Silnie zwietrzałe piaskowce dewońskie (poza bardzo charakterystycznym „piaskowcem kulkowym” - Kugelsandstein) mogą być błędnie rozpoznawane jako piaskowce mezozoiczne. 


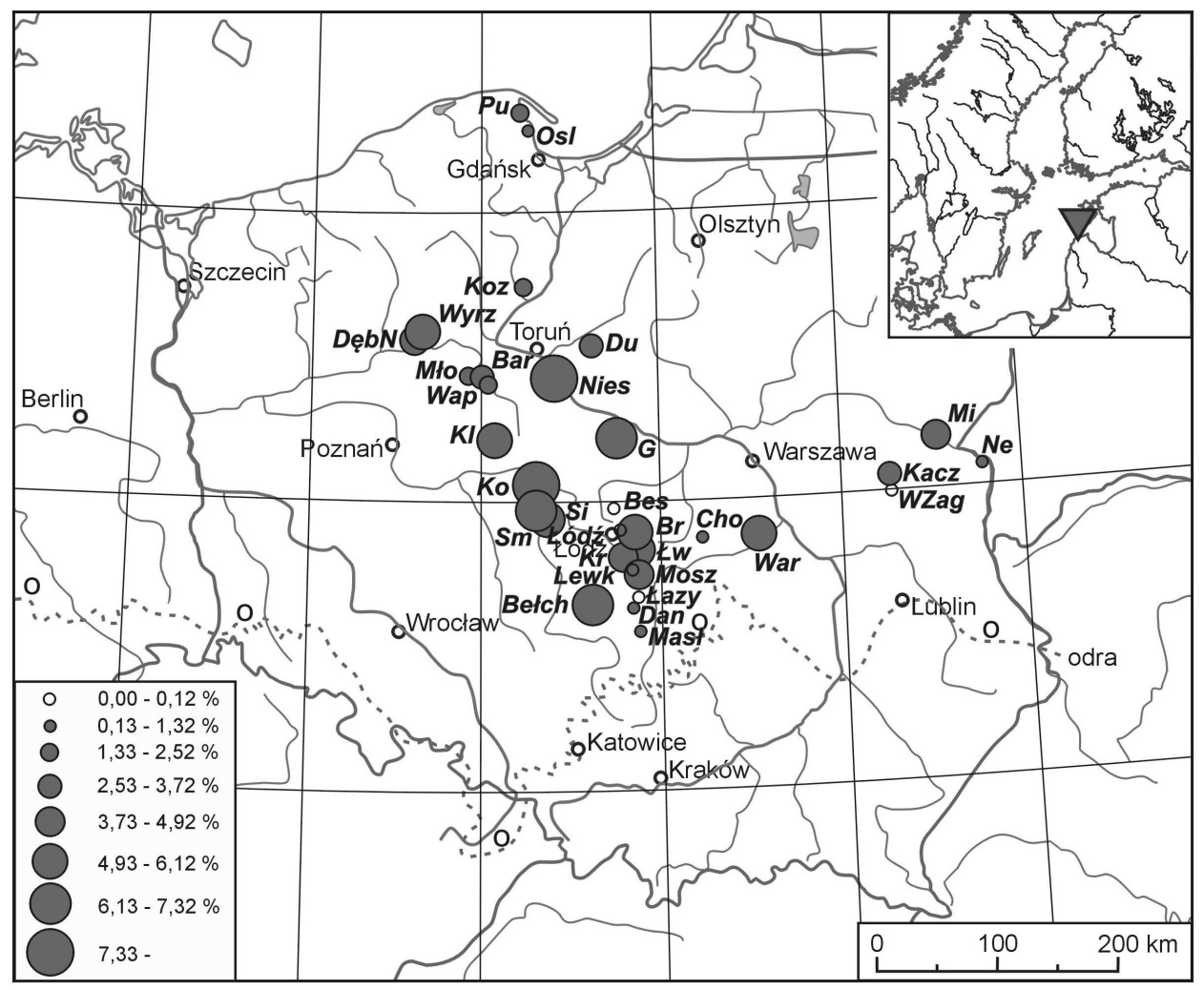

Rys. 10.18. Udział dolomitów w grupie skał fennoskandzkich w osadach kompleksu środkowopolskiego; dla stanowisk, gdzie pobrano wiele próbek z osadów tego samego wieku, dane zostały uśrednione - udział poniżej 0,13\% (puste koło jako symbol stanowiska) oznacza brak dolomitów

Figure 10.18. The percentage of dolomites among Fennoscandian rocks in the tills of the Middle-Polish Complex; for research sites, where multiple samples were taken from sediments of the same age, the data were averaged - share below $0,13 \%$ (empty circle as a site symbol) means a lack of dolomites in the site

Szczególnie licznie dolomity występują we frakcji drobnożwirowej w glinach zlodowaceń południowopolskich dorzecza Rospudy, co pozwoliło Czerwonce i Krzyszkowskiemu na wyróżnienie tzw. „traktu dolomitowego” w północno-wschodniej Polsce (app. B, ark. Wieliczki i Augustów SMGP 1:50 000 - fide Lisicki, 2003 - str. 43). W glinie typu Golubie 1 k11 przywoływani autorzy wyróżnili średnio aż 40\% ziaren dolomitowych, a Lisicki (2003) w otworze Płomieniec w dorzeczu Świdra podaje ekstremalną wartość aż 49\% dolomitów i wysnuwa wniosek, że tu mógł kończyć się jeden ze „szlaków dolomitowych" ciągnących się ze skrajnie północno-wschodniej Polski. Lisicki twierdzi nawet (2003 - str. 63), że w dorzeczu Rospudy i generalnie w całym sektorze „L", który obejmuje Pojezierze Suwalskie i Równinę Augustowską, gliny litotypów G1 i G2, przypisywane zlodowaceniu san 2, zawierają więcej dolomitów niż wapieni. Na obszarze 
przebadanym przez autora nigdzie dolomity nie występowały tak licznie, jak w podanym powyżej obszarze, chociaż bezpośrednie porównanie utrudnia odmienna frakcja (Lisicki analizował ziarna o rozmiarach od 5 do $10 \mathrm{~mm}$ ).

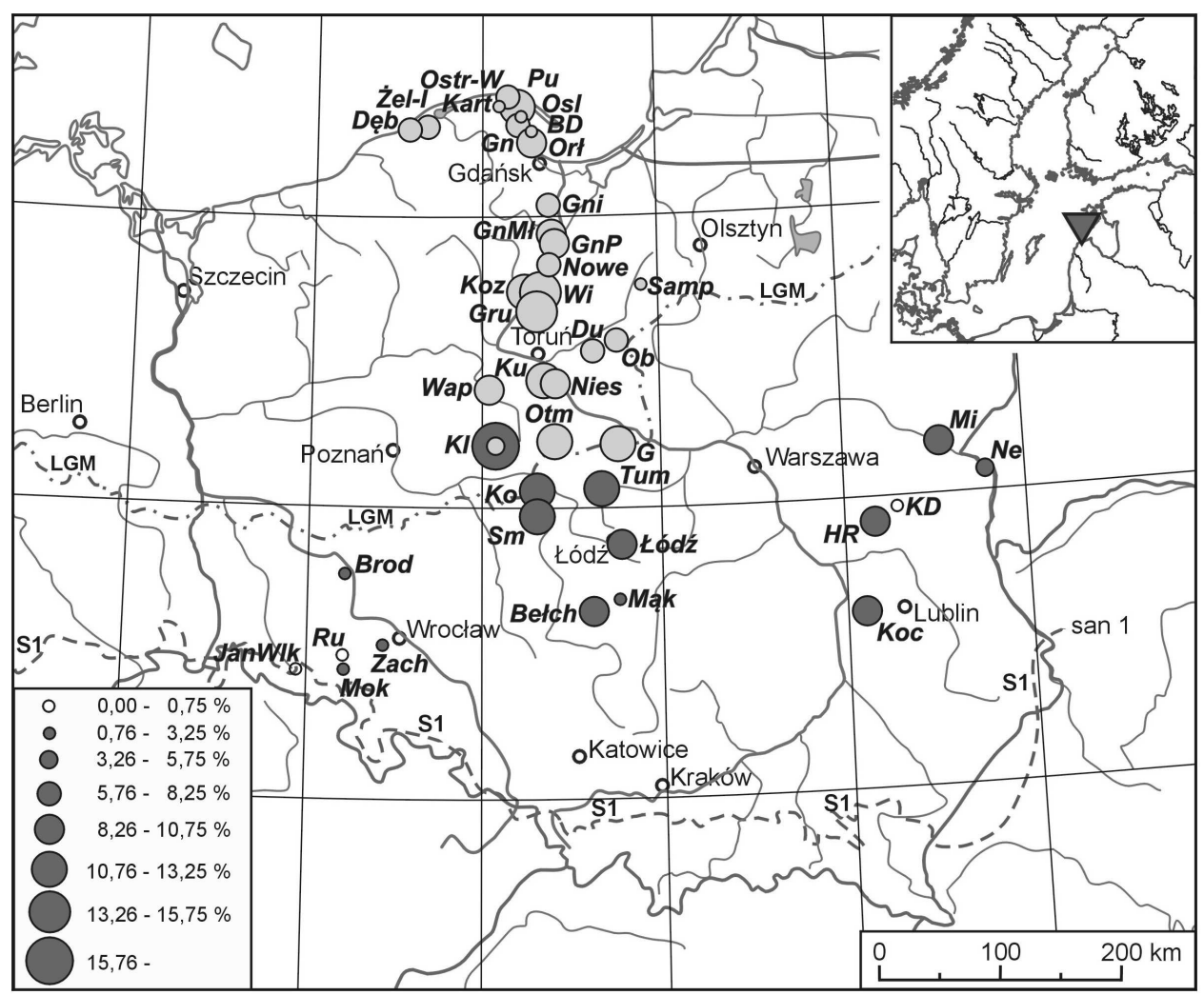

Rys. 10.19. Udział dolomitów w grupie skał węglanowych w osadach kompleksu południowopolskiego (ciemne koła) i północnopolskiego (jasne koła) - udział poniżej 0,76\% (puste koło jako symbol stanowiska) oznacza brak dolomitów

Figure 10.19. The percentage of dolomites among Nordic carbonate rocks in the tills of the South-Polish Complex (dark circles) and of the North-Polish Complex (light circles) - share below 0,76\% (empty circle as a site symbol) means a lack of dolomites in the site

Szlaki dolomitowe miały stanowić wyraz lokalnej zmienności kierunków nasuwania się lądolodu (Ber i in., 1998). Nadzwyczaj wysoki udział dolomitów Lisicki (2003 str. 63) tłumaczy pokonywaniem przez lądolód bardzo długiego odcinka po wychodniach skał węglanowych - na wschodzie miało to być nawet do $500 \mathrm{~km}$. Do tego prezentuje rycinę, z której wynika, że podczas zlodowaceń san 2, warta i wisła lądolód nasunął się na Polskę Wschodnią z Finlandii. Gdyby jego założenie było prawidłowe, to w osadach wymienionych zlodowaceń eratyków szwedzkich w ogóle być nie powinno, a w grupie skał krystalicznych dominować winny eratyki wyborgitów i pyterlitów z Finlandii. W rzeczywistości skał szwedzkich w nich nie brakuje, a typowe skały fińskie (poza alandzkimi) należą do raczej rzadkich znalezisk. 


\subsection{Południowa Szwecja - Småland, Blekinge i Skania}

Krystaliczne skały przewodnie z południowej i południowo-wschodniej Szwecji (granity Kinda, Vånevik - fot. 10.31, Uthammar - fot. 10.32, Flivik, Virbo, Marianelund, różowy Växjö, Vislanda, Karlshamn - fot. 10.33, Spinkamåla (Halen), czerwone granity Småland, porfiry Emarp, Fagerhult, Lönneberga, Nymåla, Påskallavik, Sjögelö, bazalty ze Skanii fot. 10.34) są akceptowane przez większość badaczy eratyków (np. Hesemann, 1936, 1975; Meyer, 1983; Smed, 1994, 2002; Zandstra, 1999; Gałązka, 2004b; Czubla i in., 2006). Co prawda Hesemann (1975) miał wątpliwości co do możliwości odróżnienia niektórych średniokrystalicznych granitów z Blekinge od pewnych odmian granitu Bohus, ale potraktował to jako problem o znikomym znaczeniu, ponieważ w jego badaniach Blekinge i Bohuslän i tak były ujęte we wspólnym obszarze badawczym. Dla obszaru Polski możliwość pomylenia wspomnianych skał też nie ma większego znaczenia, ponieważ skały z Blekinge występują stosunkowo rzadko i to głównie w Polsce Zachodniej, a granitoidy z Bohuslän należą do wyjątkowych znalezisk. Problematyczne bywa wyróżnianie szarego granitu Växjö. Schuddebeurs (1980/1981) traktował tę skałę jako przewodnią, ale napotkał ją tylko w kilku stanowiskach w Holandii w postaci pojedynczych klastów i jedynie w dwóch stanowiskach jej udział był dość wysoki: $12 \%$ oraz $14,5 \%$. Smed $(1989,1994)$ początkowo umieścił ją w swoim atlasie skał wskaźnikowych, by w kolejnym niemieckojęzycznym wydaniu (2002) zupełnie ją pominąć. Zdaniem autora cechy rozpoznawcze tego granitu nie są jednoznaczne i nie pozwalają na jego wiarygodną identyfikację.

Najprostszą cechą rozpoznawczą, pozwalającą bardzo łatwo zidentyfikować liczne typy skał przewodnich (zarówno plutonicznych, jak i wulkanicznych) ze Smålandu, jest występowanie szaroniebieskawego, jasnoniebieskiego aż do jaskrawoniebieskiego kwarcu (np. Richter, 1958; Marczinski, 1968a). Nawet w skałach okruchowych możliwe jest stwierdzenie obecności produktów wietrzenia skał smålandzkich dzięki obecności łatwo identyfikowalnych, dobrze obtoczonych ziaren kwarcu o niebieskawym zabarwieniu. Najczęściej tkwiły one, scementowane fosforanami, w konkrecjach fosforytowych. Wśród granitoidów ze Smålandu wyróżnianych jest szereg odmian lokalnych, które można bardzo precyzyjnie przypisać do konkretnej wychodni w Szwecji. Należą do tej grupy m.in. granity Götemar, Jungfrun, Mariannelund, Uthammar, Virbo i Vånevik, ale tylko ostatni z nich występuje w Polsce stosunkowo często.

Nieco mniej jednoznaczna jest identyfikacja bazaltów ze Skanii. Zdaniem Meyera (1983) podobne do nich diabazy mają zawsze zielonkawy odcień, podczas gdy typowe bazalty ze Skanii są czysto czarne z rdzawobrunatną pokrywą wietrzeniową (fot. 10.34). Bazalty z rowu Oslo mają niebieskawoszarą lub czerwonawobrunatną masę podstawową z licznymi fenokryształami augitu i plagioklazów. Obecność skał norweskich na terenie Polski jest jednak bardzo mało prawdopodobna i dlatego wszystkie bazalty można wstępnie przypisać do obszaru źródłowego w Skanii. Wątpliwości może budzić dość liczne występowanie tego typu skały w osadach glacjalnych Dolnego Powiśla oraz znajdowanie pojedynczych klastów jeszcze dalej na wschód, tj. na Podlasiu. Wydaje się to wskazywać na istnienie wychodni bardzo podobnej skały gdzieś w rejonie środkowego Bałtyku. Jeżeli to przypuszczenie uda się potwierdzić, to bazalty ze Skanii powinny 
zostać wykluczone z grona eratyków przewodnich. Na Dolnym Śląsku można dodatkowo spodziewać się obecności w osadach glacjalnych kenozoicznych bazaltoidów, występujących w ponad 300 stanowiskach w południowo-zachodniej Polsce (Sawicki, 1995, 1997a, 1997b; Pawlak, 1997). Makroskopowo są one nieodróżnialne od swoich jurajskich odpowiedników ze Skanii. Wbrew wstępnym przypuszczeniom, bazalty okazały się jednak na terenie Dolnego Śląska bardzo rzadkimi eratykami, co każe powątpiewać w znaczącą rolę inkorporowania skał lokalnych tego typu.

Kontrowersyjne wydaje się traktowanie kwarcytów Västervik jako skały przewodniej. Co prawda, większość badaczy uznaje je za ważny wskaźnik pochodzenia osadów glacjalnych (np. Lüttig, 1958; Meyer, 1970, 1983; Schuddebeurs, 1980/1981; Vinx i in., 1997; Gába, 2006; Višek i Nývlt, 2006; Górska-Zabielska, 2008). Podobnego zdania był również autor (Czubla, 2001), dopóki nie odwiedził wychodni opisywanych skał w południowo-wschodniej Szwecji. Okazało się, że w bezpośrednim sąsiedztwie występują tam kwarcyty o zróżnicowanym stopniu rekrystalizacji i o bardzo różnych zabarwieniach. W oparciu o powyższe obserwacje należałoby właściwie wszystkie kwarcyty znalezione w osadach glacjalnych Niżu Środkowoeuropejskiego określać jako Västervik. To zaprzeczałoby zasadniczo definicji eratyka przewodniego, dlatego autor odstąpił od wyróżniania tej skały w analizowanych próbach. Znaczenie kwarcytów Västervik negowali już wcześniej m.in. Hesemann (1975) i Gałązka (2004b), a ostatnio zdanie na temat ich przydatności zmienił również Nývlt (Hanáček i Nývlt, 2009 - str. 203).

Zastrzeżenia budzi również wykorzystywanie kwarcytycznych piaskowców Hardeberga w charakterze eratyków przewodnich. Zdaniem Schuddebeursa (1980/1981) nie mają one żadnych jednoznacznych cech pozwalających na wiarygodną identyfikację. Wychodnie piaskowców Hardeberga występujące w Skanii przedłużają się pod dnem Bałtyku i sięgają aż po Bornholm, gdzie znane są pod lokalną nazwą piaskowców Balka, oraz na Hallandsås (Meyer, 1983; Meyer i Lüttig, 2007). Zdaniem przywoływanych autorów duże rozmiary wychodni nie dyskwalifikują jednak tej białawojasnoszarej, drobnolub średnioziarnistej skały jako przewodniej. W przypadku badań prowadzonych na Zelandii ma to nie wpływać na wynik analiz uwzględniających ten typ piaskowca. Piaskowce dolnokambryjskie odsłaniające się w Västergötland i na dnie Botniku Południowego na północ od Wysp Ålandzkich są zdaniem Meyera i Lüttiga (2007) na tyle odległe i odmienne od piaskowców Hardeberga, że nie powinny zakłócać prowadzonych w Niemczech analiz. Dodatkowym argumentem na rzecz wykorzystania piaskowców Hardeberga w analizach głazowych ma być ich liczne występowanie w osadach glacjalnych - wielokrotnie liczniejsze aniżeli wszystkich skał przewodnich ze Skanii razem wziętych (Meyer i Lüttig, op. cit.). W Polsce również pojawiają się opinie o potrzebie uwzględniania tego piaskowca wśród skał przewodnich (np. Górska, 2000; Górska-Zabielska, 2008). Piaskowce Hardeberga zostały zidentyfikowane w niemal wszystkich zespołach głazowych przeanalizowanych w Polsce - zarówno zachodniofennoskandzkich, jak i wschodniobałtyckich (Czubla, 2001). Nie brak ich również w próbach ze wschodniej Polski, gdzie żadnych innych skał ze Skanii i Blekinge nie znaleziono. Pozwala to przypuszczać, że identyczne kambryjskie piaskowce mogą występować również gdzieś w północnej części wielkiej wychodni skał kambryjskich, 


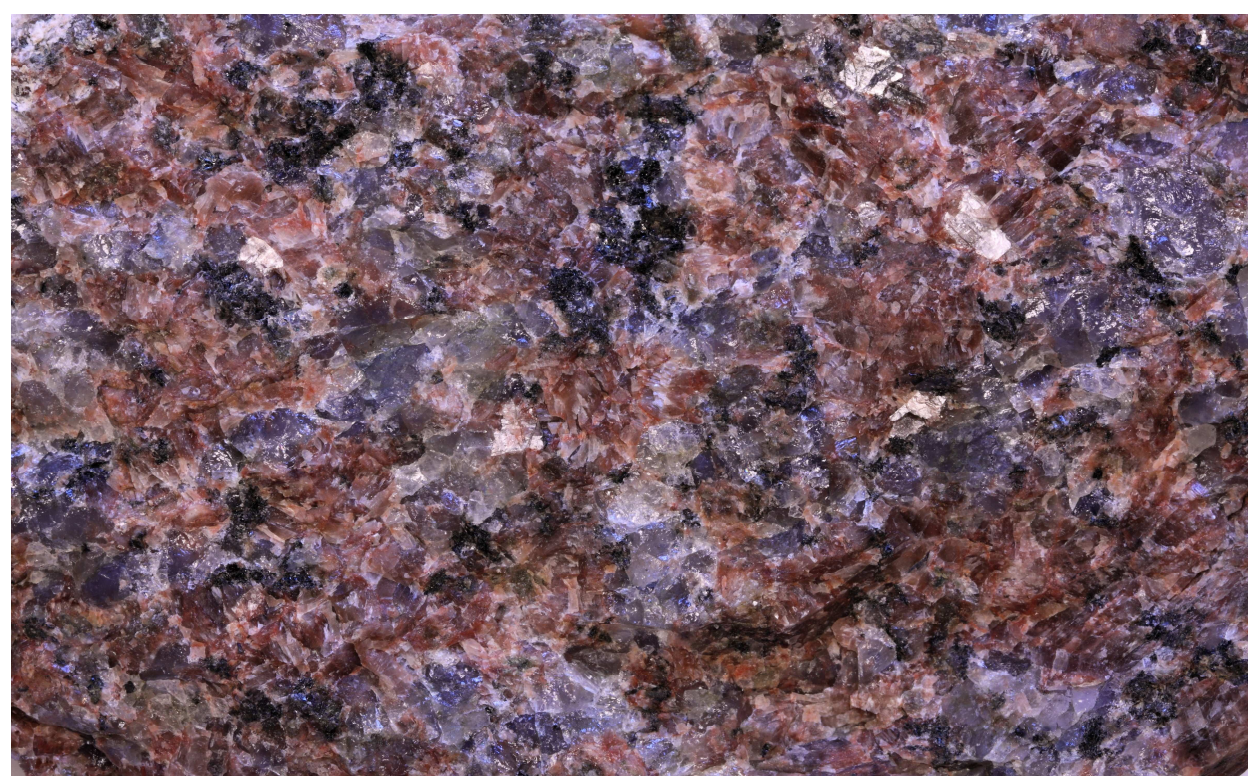

Fot. 10.31. Granit Vånevik, Vånevik, Småland, południowa Szwecja; rozmiar dłuższego boku 92 mm; fot. P. Czubla 2015

Photo 10.31. Vånevik granite, Vånevik, Småland, Southern Sweden; picture width 92 mm. Photo P. Czubla 2015

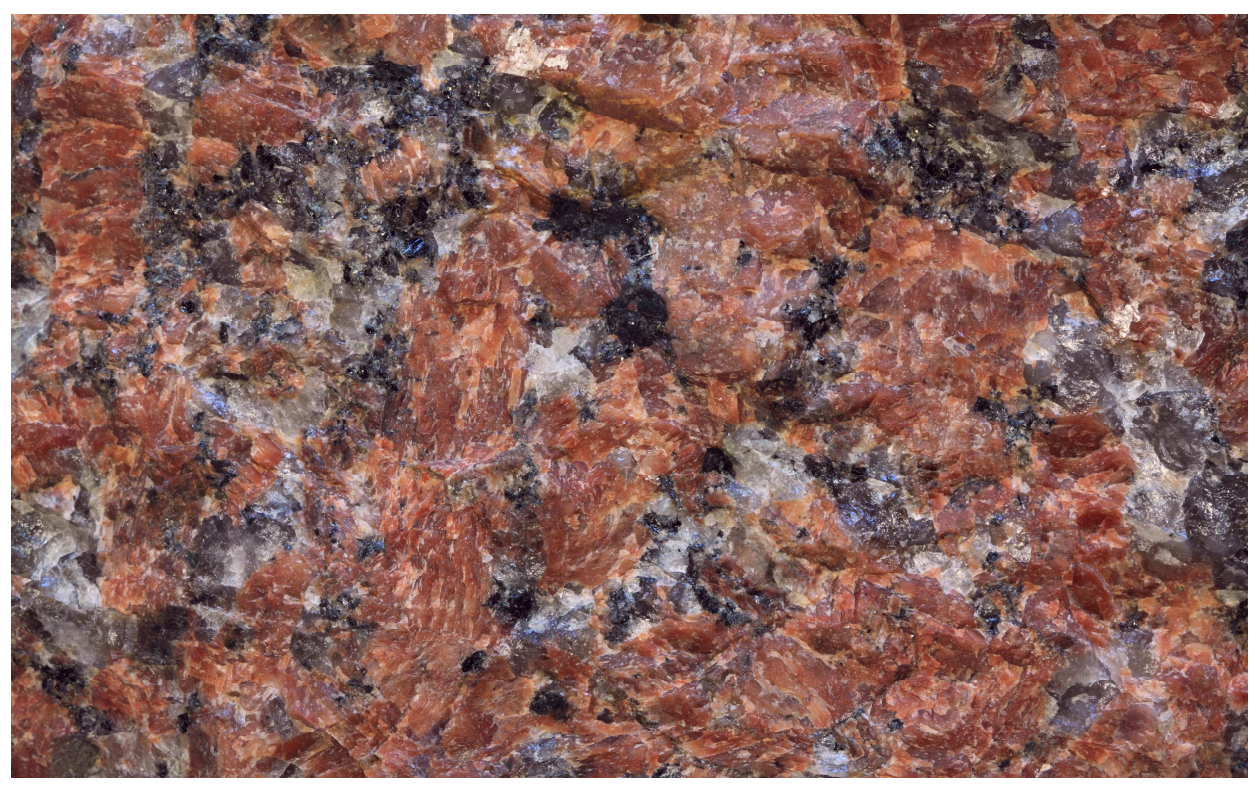

Fot. 10.32. Granit Uthammar, Uthammar, Småland, południowa Szwecja; rozmiar dłuższego boku $96 \mathrm{~mm}$; fot. P. Czubla 2015

Photo 10.32. Uthammar granite, Uthammar, Småland, Southern Sweden; picture width 96 mm. Photo P. Czubla 2015 


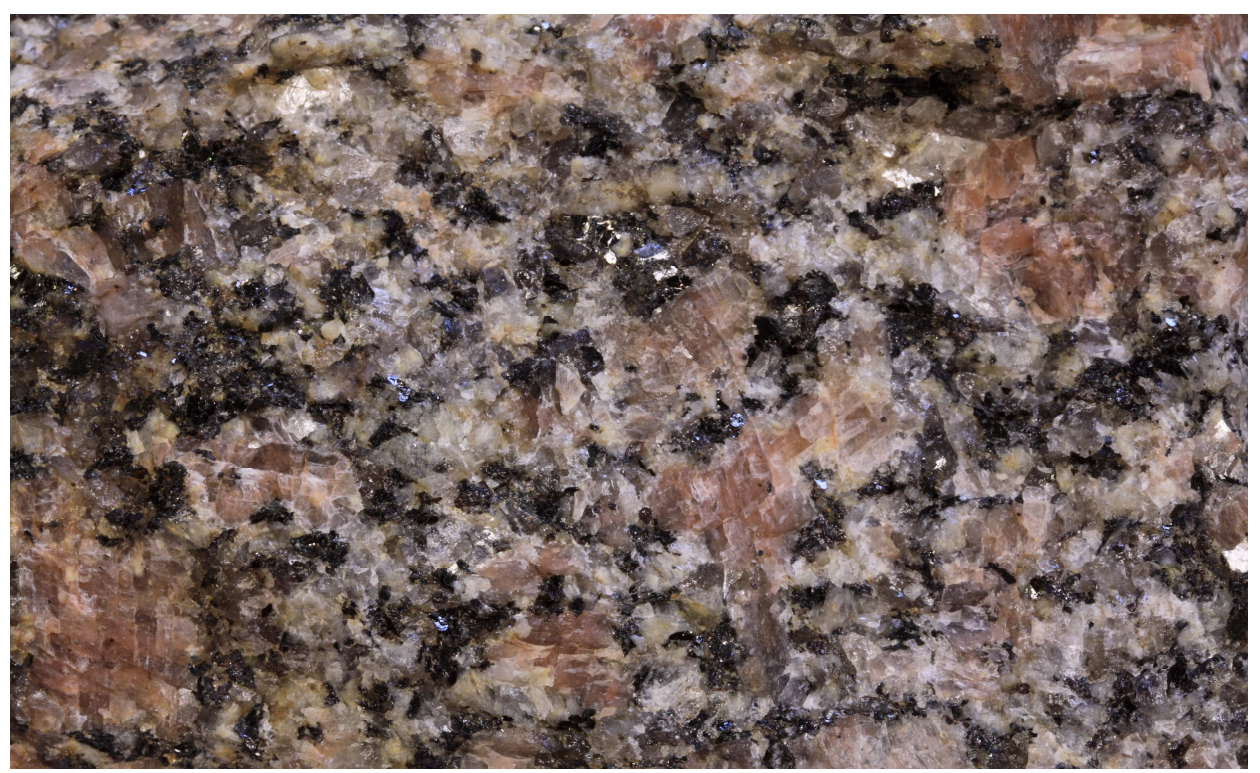

Fot. 10.33. Granit Karlshamn, Hällaryd, Blekinge, południowa Szwecja; rozmiar dłuższego boku $65 \mathrm{~mm}$; fot. P. Czubla 2015

Photo 10.33. Karlshamn granite, Hällaryd, Blekinge, Southern Sweden; picture width 65 mm. Photo P. Czubla 2015

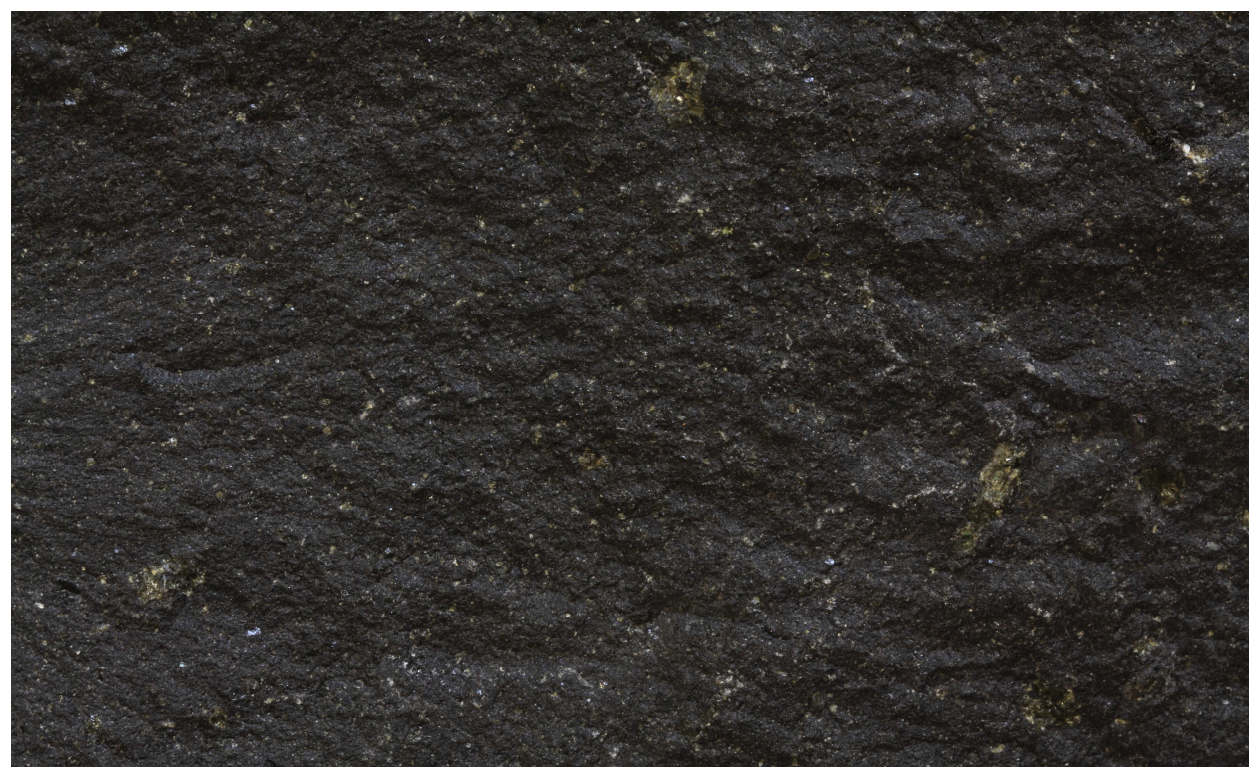

Fot. 10.34. Bazalt, Vägashed, Skania, południowa Szwecja; rozmiar dłuższego boku 63 mm; fot. P. Czubla 2015

Photo 10.34. Skåne basalt, Vägashed, Skåne, Southern Sweden; picture width 63 mm. Photo P. Czubla 2015 
rozciągającej się z południowego zachodu na północny wschód, na dnie Bałtyku - być może w obrębie wspomnianego wcześniej stanowiska zlokalizowanego na dnie Botniku Południowego. Rozczłonkowanie wychodni na odlegle od siebie części, z których co najmniej jedna ma duże i nieznane rozmiary, dyskwalifikuje zdaniem autora rozpatrywaną skałę jako eratyk przewodni. Nie do końca jasne są przesłanki, które skłoniły również Smeda (2010) do zakwestionowania przydatności piaskowców Hardeberga w kreśleniu map kołowych. Co prawda podkreślał on występowanie tej skały również w zespołach głazowych zupełnie pozbawionych skał ze Skanii oraz przytaczał rozległy zasięg jej wychodni aż po Zatokę Botnicką, ale jednocześnie uwzględniał w swoich badaniach piaskowce jotnickie oraz paleozoiczne wapienie o jeszcze większych obszarach źródłowych.

Smed (2010) neguje również przydatność w badaniach piaskowca Höör, który ma różnić się od swoich kambryjskich i proterozoicznych odpowiedników jedynie bardziej porowatą teksturą, ale zgodnie z przywoływaną opinią Vinxa ta cecha nie jest wiarygodna. Na obszarze Polski istnieje duże ryzyko pomylenia go z lokalnymi piaskowcami liasu. Analogiczny problem występuje w przypadku kredowych piaskowców Köpinge ze Skanii. Te jasnoszare, drobnoziarniste piaskowce wapniste z domieszką glaukonitu (Schulz, 2003) mogą łatwo zostać pomylone ze swoimi górnokredowymi lub paleogeńskimi odpowiednikami lokalnego pochodzenia. W związku z tym wszystkie miękkie i porowate oraz wapniste piaskowce napotkane $w$ analizowanych próbach były zaliczane do skał lokalnych i pomijane w obliczeniach TCG oraz w konstruowaniu map kołowych.

Skały południowoszwedzkie występują we wszystkich osadach glacjalnych przebadanych przez autora. Ich średnia zawartość wyniosła $20,59 \%$ w glinach i o około $2 \%$ mniej w żwirach (18,55\%). Najliczniej prezentowane skały występują w glinach kompleksu południowopolskiego - 24,16\%, najniższą zaś wartość odnotowano w glinach zlodowaceń środkowopolskich - 18,07\%. Osady glacjalne kompleksu północnopolskiego cechują się pośrednim udziałem skał południowoszwedzkich, wynoszącym $21,44 \%$. Wyniki Gałązki (2004b) wskazują na najwyższy udział skał z tego regionu w glinach odrzańskich - 33,9\%, ale były to badania oparte na obowiązującym do niedawna założeniu (m.in. Krzyszkowski, 1995), że formacja Ławki w Bełchatowie reprezentuje osady tego wieku. Przytoczone dane były zbieżne z rezultatami badań autora w glinach tej samej formacji - 29,11\% (Czubla, 2001). Po korekcie wieku formacji Ławki na zlodowacenie san 2 dane Gałązki byłyby zbliżone do osiągniętych przez autora, tzn. największy udział skał ze Smålandu, Skanii i Blekinge byłby typowy dla zlodowaceń południowopolskich. Niewielka nadwyżka skał tej grupy wykazywana przez Gałązkę (2004b) może być częściowo uwarunkowana włączeniem do niej dodatkowych skał, tj. diabazów Kinne, amfibolitów z granatami oraz sjenitów Vaggeryd, ujmowanych w niniejszej pracy w grupie skał zachodnioszwedzkich.

W osadach kompleksu południowopolskiego zaznacza się dość wyrównany udział skał z analizowanego obszaru alimentacyjnego na obszarze od Dolnego Śląska aż po Podlasie (rys. 10.20). Dopiero w glinach zlodowaceń środkowopolskich zauważalny jest bardzo wyraźny spadek wraz z przesuwaniem się na wschód. Ich udział na Kujawach i w północnej Wielkopolsce jest bardzo wysoki, a najniższy na Podlasiu i Lubelszczyźnie 
(rys. 10.21). W sąsiedniej Białorusi opisywanych skał już nie znaleziono (Astapova, 1987). Wyraźny wzrost roli skał południowoszwedzkich w zachodniej części Polski można odczytać z materiałów Górskiej-Zabielskiej (2008), która w vistuliańskich glinach lobu Odry udokumentowała aż 37,2\% skał tej grupy, a w żwirach wartość prawie półtorakrotnie wyższą - 53,0\%. Jeszcze wyższy udział został stwierdzony w stanowiskach Ziemi Lubuskiej - od około 40 do aż 80\% skał ze Smålandu wśród oznaczonych eratyków przewodnich (Lipka, 2011). Bezpośrednie porównanie prezentowanych danych z wynikami Lipki nie jest jednak możliwe, ponieważ skały z Blekinge i Skanii ujęła ona razem z bornholmskimi i nie podała surowych danych. Nieco niższy udział skał ze Smålandu odnotowała Górska (2000) w Wielkopolsce - od 11 do 62\%, ale wartość maksymalna oparta była na zaledwie 13 eratykach przewodnich (w tym 8 ze Smålandu).

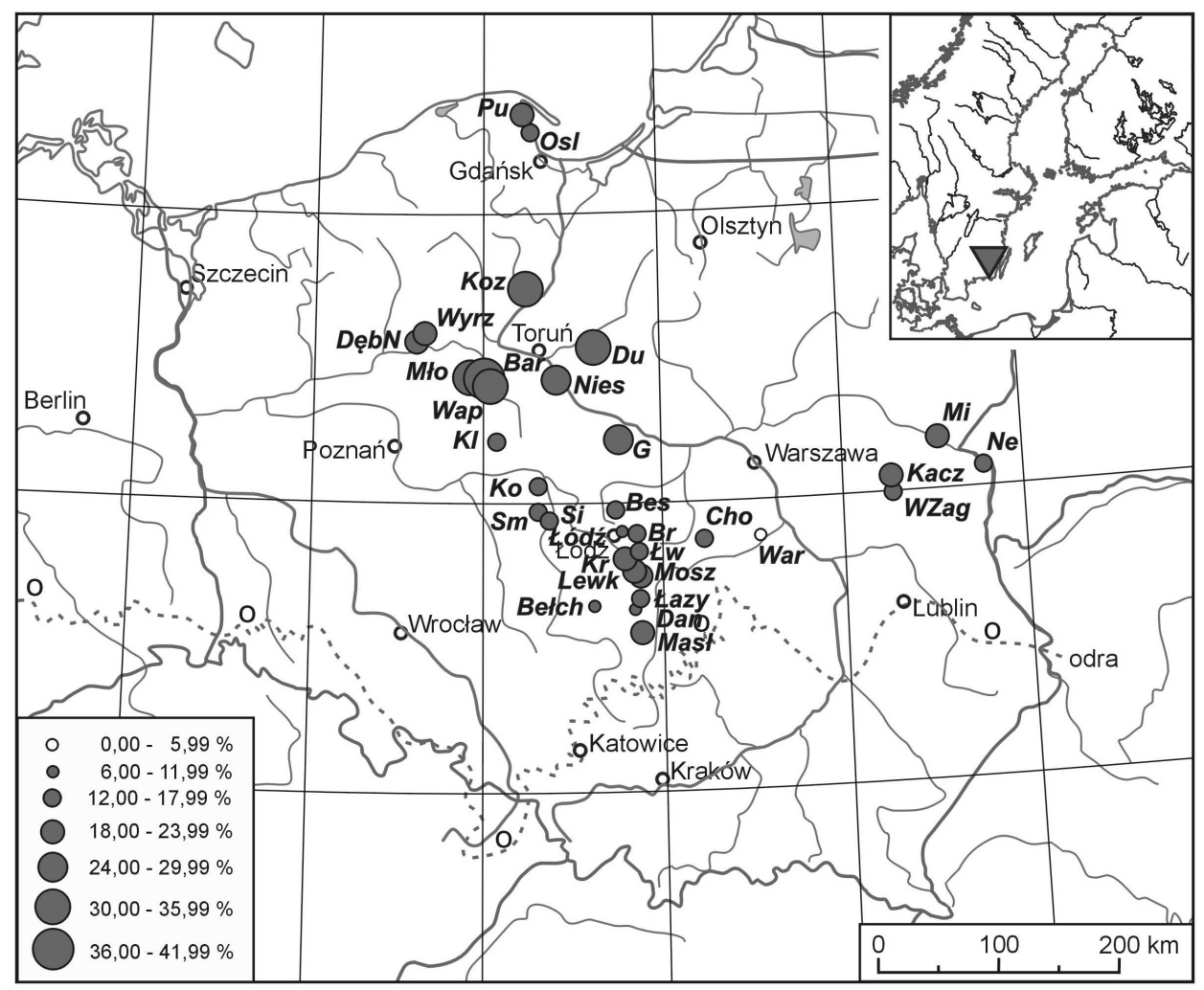

Rys. 10.20. Rozmieszczenie eratyków ze Smålandu, Skanii i Blekinge w osadach kompleksu południowopolskiego (ciemne koła) i północnopolskiego (jasne koła); dla stanowisk, gdzie pobrano wiele próbek z osadów tego samego wieku, dane zostały uśrednione-udział poniżej 6,00\% (puste koło jako symbol stanowiska - Janowice Wielkie) oznacza brak eratyków południowoszwedzkich

Figure 10.20. The distribution of Småland, Skåne and Blekinge erratics in glacial deposits of the South-Polish Complex (dark circles) and of the North-Polish Complex (light circles); for research sites, where multiple samples were taken from sediments of the same age, the data were averaged - share below $6,00 \%$ (empty circle as a site symbol - Janowice Wielkie) means a lack of South Swedish erratics in the site 
Opisywane zróżnicowanie przestrzenne potwierdzają badania Gałązki (2004b), który dla kolejnych trzech nasunięć lądolodu wisły w Polsce Środkowej i Wschodniej wyznaczył zawartość skał południowoszwedzkich, licząc od najstarszego, na 22,0\%, 20,0\% i 13,5\%. Spadek zawartości skał z południowej Szwecji przy posuwaniu się na wschód dobrze dokumentują również badania na obszarze perybałtyckim. Granity i porfiry ze Smålandu oraz bazalty ze Skanii znaleziono tam jedynie w Obwodzie Kaliningradzkim (Tarvydas, 1971b). Skały ze Smålandu, Skanii i Blekinge dość licznie występują w osadach Elsterianu i Saalianu środkowych Niemiec (Hoffmann i Meyer, 1999), jak też w różnowiekowych osadach północno-zachodnich Niemiec (Meyer, 1983). Bardzo duże zróżnicowanie udziału skał południowoszwedzkich zanotowano w Holandii. Wahał się on w granicach od kilku do około 50\%, a w skrajnym przypadku nawet około 85\% (stanowisko

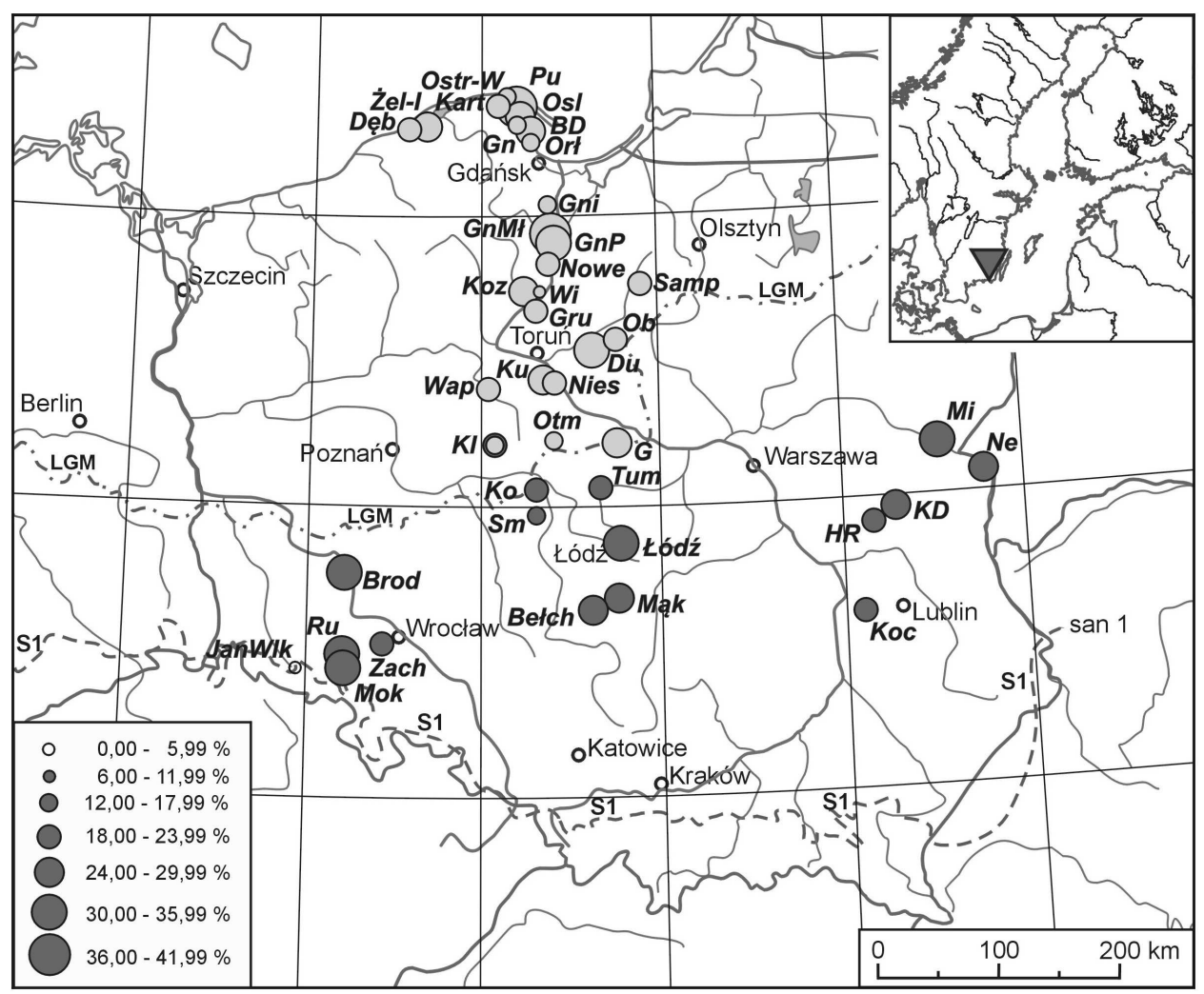

Rys. 10.21. Rozmieszczenie eratyków ze Smålandu, Skanii i Blekinge w osadach kompleksu środkowopolskiego; dla stanowisk, gdzie pobrano wiele próbek z osadów tego samego wieku, dane zostały uśrednione - udział poniżej 6,00\% (puste koło jako symbol stanowiska - Warka) oznacza brak eratyków południowoszwedzkich

Figure 10.21. The distribution of Småland, Skåne and Blekinge erratics in glacial deposits of the Middle-Polish Complex; for research sites, where multiple samples were taken from sediments of the same age, the data were averaged - share below $6,00 \%$ (empty circle as a site symbol - Warka) means a lack of South Swedish 
Garijp) - Schuddebeurs (1980/1981). Metodyka poboru prób przez Schuddebeursa każe jednak z rezerwą podchodzić do tych wyników. W wielu przypadkach eratyki zbierane były z powierzchni ziemi, bądź wybierane z pojemników kombajnów ziemniaczanych, co też sprowadzało się do poboru materiału powierzchniowego - przemieszanego i zwietrzałego. Znacznie niższa (maksymalnie ok. 14\%) jest zawartość skał z południowej Szwecji w osadach północnych Czech (Višek i Nývlt, 2006).

Wyjątkowo nieliczne okazały się skały ze Smålandu i Blekinge wśród dużych głazów narzutowych opisanych przez Dudziaka (1970). Spośród 134 eratyków, których obszar źródłowy udało mu się ustalić, tylko 3 pochodziły ze Smålandu i 1 prawdopodobnie z Blekinge (lub z Bohuslän).

Na podstawie obecności eratyków ze Smålandu w glinach (odrzańskich?), zawierających kry jurajskie regionu Łukowa, Gałązka i in. (2009) wykluczyli możliwość odłożenia tych glin przez ryski lob lodowcowy, ponieważ w tym ostatnim nie stwierdzono występowania południowoszwedzkich eratyków przewodnich (Halicka, 1986; Astapova, 1993). Ma to wskazywać na osiągnięcie okolic Łukowa przez mazurski potok lodowy (Gałązka i in., op. cit.).Najliczniejszą skałą przewodnią z analizowanego obszaru był we wszystkich przeanalizowanych próbach czerwony granit Småland (włącznie z granitem Vislanda). Część badaczy utożsamia go z czerwonym granitem Växjö (fide Meyer, 1983). Dla ułatwienia porównań z badaniami prowadzonymi poza Polską obydwie skały zostały ujęte razem. Rozmieszczenie omawianych skał w różnowiekowych osadach glacjalnych nie odbiega od przedstawionego powyżej dla całego zespołu skał południowoszwedzkich: w kolejności od najstarszego do najmłodszego kompleksu glacjalnego - 18,43\%, $13,55 \%$ i 15,65\%. Przestrzenne rozmieszczenie czerwonych granitów również pokrywa się z przedstawionym wcześniej schematem. Nie jest to niczym zaskakującym, ponieważ omawiane granity stanowią aż około $80 \%$ zespołu skał południowoszwedzkich.

Analogiczna analiza najliczniejszego w osadach glacjalnych eratyka smålandzkiego o precyzyjnie określonym obszarze źródłowym, tj. granitu Vånevik, nie przyniosła już tak jednoznacznych wyników. Co prawda w glinach zlodowaceń południowopolskich dostrzegalny jest spadek jego udziału przy przesuwaniu się od Dolnego Śląska przez Polskę Środkową aż po Podlasie (rys. 10.22), ale już w osadach kompleksu środkowopolskiego najwyższy udział tej skały został stwierdzony w zlewni środkowej i dolnej Wisły (Dulsk, Gostynin, Kozłowo) - rys. 10.23. W tym samym regionie rozlokowane są stanowiska z ekstremalnie wysokim udziałem granitu Vånevik w glinach ostatniego zlodowacenia Kozłowo, Gostynin, Nieszawa, Gniew. Rozmieszczenie prezentowanej skały przewodniej w różnowiekowych osadach odbiega nieco od zaprezentowanego dla całej grupy. W glinach południowopolskich stanowi on 1,57\% eratyków przewodnich, by w środkowopolskich osiągnąć minimalny udział 1,32\%. Najbogatsze w granit Vånevik są osady ostatniego zlodowacenia, w których stanowi on 2,04\%. Znacznie niższy jest średni udział tej skały w różnowiekowych żwirach. Wyniósł on zaledwie 1,21\%, co zdaje się wskazywać na przyspieszone niszczenie podczas transportu, gdyż podany udział jest niższy nawet od stwierdzonego w najuboższych w omawiany typ granitu glinach środkowopolskich. 


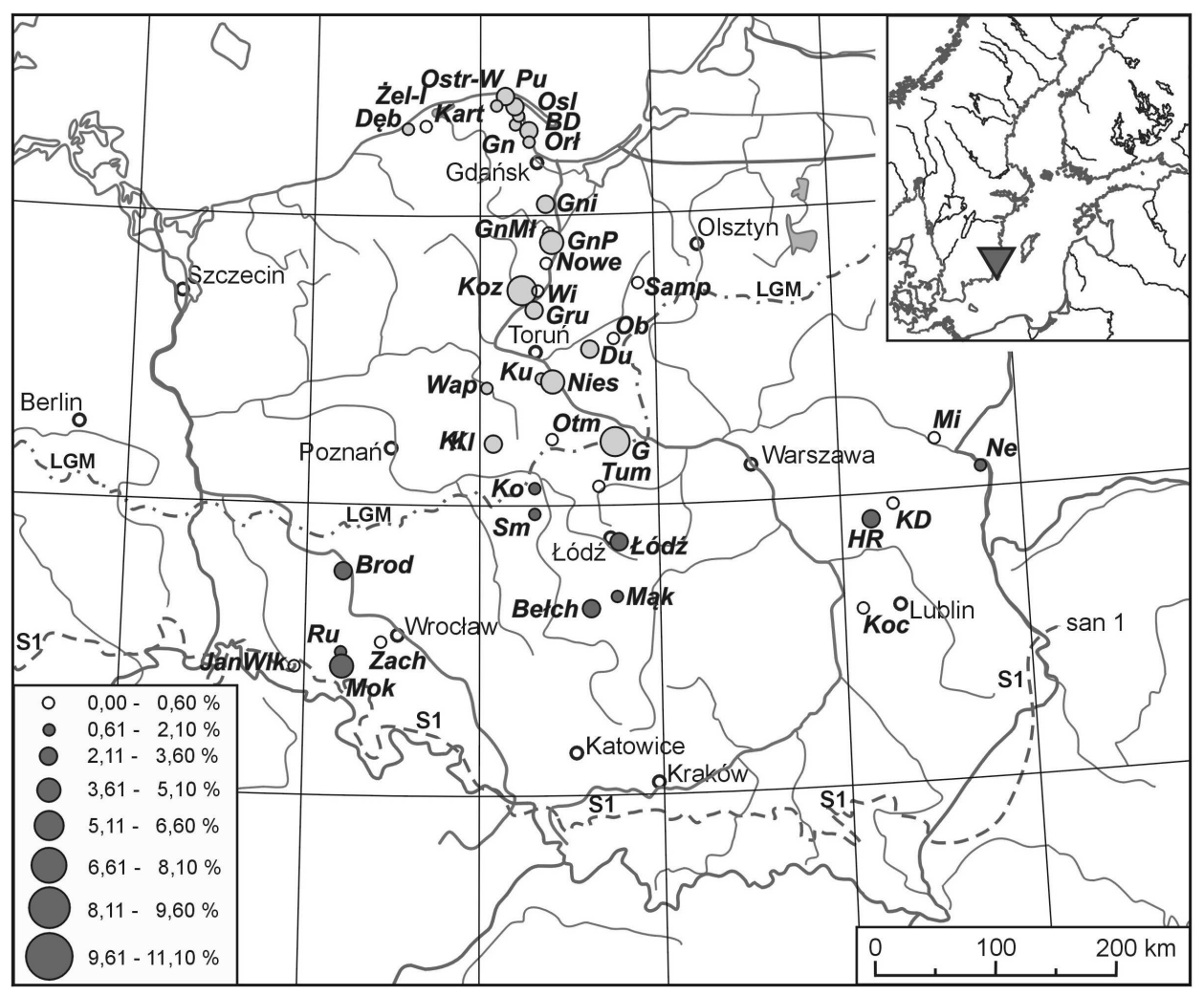

Rys. 10.22. Rozmieszczenie eratyków granitu Vånevik w osadach kompleksu południowopolskiego (ciemne koła) i północnopolskiego (jasne koła); dla stanowisk, gdzie pobrano wiele próbek z osadów tego samego wieku, dane zostały uśrednione - udział poniżej 0,61\% (puste koło jako symbol stanowiska) oznacza brak eratyków granitu Vånevik

Figure 10.22. The distribution of Vånevik granite in glacial deposits of the South-Polish Complex (dark circles) and of the North-Polish Complex (light circles); for research sites, where multiple samples were taken from sediments of the same age, the data were averaged - share below $0,61 \%$ (empty circle as a site symbol) means a lack of Vånevik granite in the site

Pozostałe granitoidy z południowej Szwecji występują znacznie rzadziej w osadach glacjalnych Polski. Wśród nich stosunkowo najliczniejsze były granity Kinda, Uthammar i Spinkamåla, reprezentowane po kilkanaście do dwudziestu kilku ziaren w całym przebadanym materiale. Granity Flivik, Marianelund i Karlshamn zdarzały się tylko sporadycznie.

W przebadanych osadach zidentyfikowanych zostało 111 głazików bazaltów ze Skanii. Oznacza to, że na jedną próbkę przypadło średnio około 0,8 eratyka tej skały. Tak mały udział nie pozwala na wiarygodną analizę jej przestrzennego rozmieszczenia. Dostrzegalna jest jednak obecność pojedynczych głazików bazaltów aż po wschodnie 


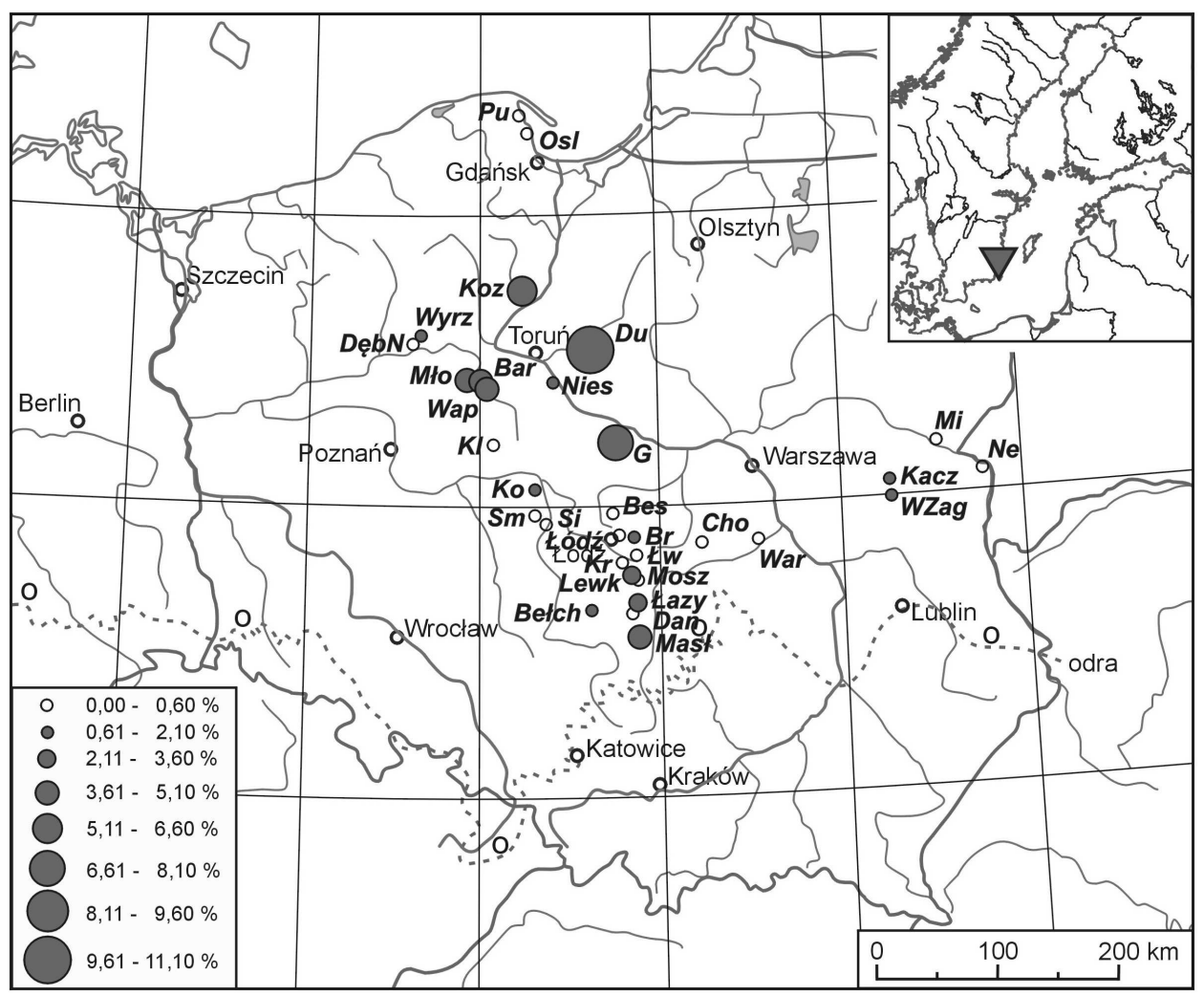

Rys. 10.23. Rozmieszczenie eratyków granitu Vånevik w osadach kompleksu środkowopolskiego; dla stanowisk, gdzie pobrano wiele próbek z osadów tego samego wieku, dane zostały uśrednione - udział poniżej 0,61\% (puste koło jako symbol stanowiska) oznacza brak eratyków granitu Vånevik

Figure 10.23. The distribution of Vånevik granite in glacial deposits of the Middle-Polish Complex; for research sites, where multiple samples were taken from sediments of the same age, the data were averaged - share below 0,61\% (empty circle as a site symbol) means a lack of Vånevik granite in the site

granice kraju (rys. 10.24), a Tarvydas (1971b) informuje o znajdowaniu eratyków bazaltowych również w Obwodzie Kaliningradzkim. Przeciwnego zdania był Korn (1927), który wschodnią granicę zasięgu skał ze Skanii lokował w przybliżeniu wzdłuż zachodnich granic dzisiejszej Polski. Jego pogląd wsparł Hesemann (1930), który eratyki bazaltów notował jedynie na zachód od Odry. Transport bazaltów na obszar Polski pozostaje też w sprzeczności z poglądami Gry (1932), który twierdził, że potoki lodowe przekraczały Skanię ze wschodu lub północnego wschodu na zachód i południowy zachód i w ten sposób wynosiły bazalty w kierunku Danii oraz północnych Niemiec. Według współczesnych badań kierunki napływu lodu w poszczególnych fazach stadiału głównego vistulianu znacząco się różniły i we wcześniejszych dominował ruch na południowy zachód, a tylko w ostatniej wyraźnie zaznaczył się kierunek prawie równoleżnikowy (Kjær i in., 2003). To właśnie ostatnią fazę dokumentują obserwacje terenowe w Skanii, gdzie eratyki bazaltów na ogół znajdowane były na zachód od wychodni, 
podczas gdy na południe od nich należały do rzadkości (Gry, 1932). Powyższe fakty skłaniają do zastanowienia, czy w małych klastach, a takie dominują w próbach pobieranych z glin w Polsce, nie dochodzi jednak do błędnego zaklasyfikowania melafiru bałtyckiego lub innego wulkanitu o nieznanej jeszcze wychodni jako bazaltu ze Skanii. Możliwość istnienia nieznanych dużych wychodni skał efuzywnych gdzieś na dnie Bałtyku zakładał już Kummerow (1930). Jego hipoteza uzasadniałaby obecność eratyków bazaltowych w glinach różnych regionów Polski aż po Podlasie oraz w Obwodzie Kaliningradzkim. Pospolite występowanie nordyckich bazaltów w Niemczech pozostaje w sprzeczności z bardzo małymi rozmiarami wychodni skał efuzywnych w Skanii (Schulz, 2003). Schulz wyjaśnia to ewentualną erozją glacjalną większej objętości bazaltów, aniżeli zachowana do dzisiaj w południowej Szwecji. Byłoby to możliwe w przypadku, gdyby w Skanii w okresie preglacjalnym istniały jurajskie pokrywy lawowe, które zostały całkowicie zniszczone jeszcze w plejstocenie. Koncepcja Schulza, wiarygodna dla obszaru Niemiec, nie sprawdza się jednak w odniesieniu do Polski, ponieważ nadal nie

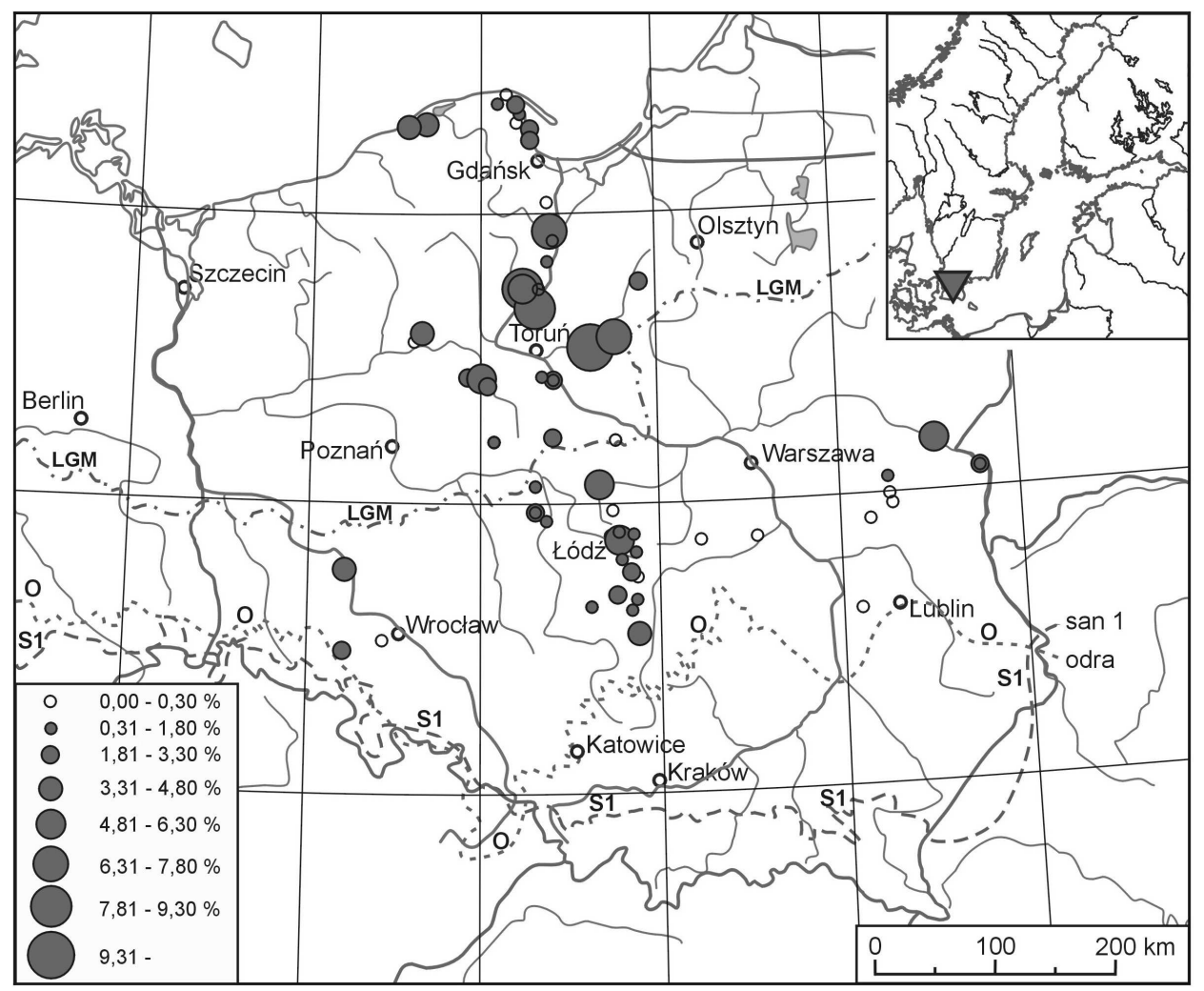

Rys. 10.24. Rozmieszczenie eratyków bazaltu ze Skanii w osadach glacjalnych Polski - udział poniżej 0,31\% (puste koło jako symbol stanowiska) oznacza brak eratyków bazaltu

Figure 10.24. The distribution of Skåne basalts in glacial deposits of Poland - share below 0,31\% (empty circle as a site symbol) means a lack of Skåne basalts in the site 
wyjaśnia obecności bazaltów daleko na wschodzie. Być może dość wysoka zawartość bazaltów, np. w niektórych próbkach z Pomorza, jest wyrazem kilkuetapowego transportu, w którym brał udział również inny czynnik niż tylko glacjalny. Transport bazaltów na południowy wschód mógł też wynikać ze zmienności warunków termodynamicznych w lądolodzie fennoskandzkim, co mogłoby przejawiać się okresowym inicjowaniem lub wygasaniem (słabnięciem) strumieni lodowych i zastępowaniem ich przez radialne rozpływanie się lodu w kierunku Niżu Środkowoeuropejskiego (por. Woźniak i Czubla, 2014a, w druku).

Najliczniej eratyki bazaltów występują w osadach ostatniego zlodowacenia, w których stanowią 2,19\% klastów skał przewodnich. Bardzo mało bazaltów ze Skanii (w sumie zaledwie 3 klasty) rozpoznała Górska-Zabielska (2008) w lobie Odry. Dość ubogie w tę skałę są również osady glacjalne Niemiec (Meyer, 1983; Hoffmann i Meyer, 1999), chociaż Schulz (2003) jest odmiennego zdania. Częściej bazalty spotykane są w plejstoceńskich osadach północnej Holandii, w środkowej zaś części tego kraju dołączają do nich bazalty południowego pochodzenia, określane jako narzutniaki Renu. Brak możliwości makroskopowego rozróżnienia powyższych bazaltów umniejsza przewodnią rolę bazaltów ze Skanii w środkowej Holandii (Schuddebeurs, 1980/1981). Należy też uwzględnić możliwą obecność w Holandii bazaltów norweskich.

Skały wulkaniczne ze Smålandu najczęściej reprezentowane były w przebadanych glinach przez porfiry Påskallavik i Sjögelö. Znacznie rzadziej występowały porfiry Emarp, Fagerhult, Lönneberga, Nymåla. Sumaryczny udział wszystkich skał wulkanicznych z tego obszaru był najwyższy w glinach kompleksu południowopolskiego, gdzie wynosił $1,69 \%$ wszystkich eratyków przewodnich. W środkowopolskich osadach glacjalnych zmalał do 0,96\%, a minimalną wartość osiągnął w glinach vistulianu - 0,55\%. Do wyjątkowo rzadkich eratyków przewodnich należy kullait. Tworzy on tylko niewielkie żyły wśród gnejsów w dwóch stanowiskach w Skanii (Smed, 1994). Z północnych Niemiec znane są tylko dwa znaleziska kullaitów (Obst, 2001; www.kristallin.de). Jedyny okaz znaleziony na terenie Polski pochodzi z rzecznych żwirów formacji Chojny w Bełchatowie, utożsamianych dawniej z ociepleniem pomiędzy zlodowaceniami odra i warta (np. Brodzikowski, 1987; Krzyszkowski, 1990, 1995; Zieliński i Goździk, 2001), a ostatnio przesuwanych raczej na początek kompleksu środkowopolskiego - interglacjał mazowiecki lub zbójeński (Balwierz i in., 2006, 2008; Lindner i Marks, 2012; Pawłowska i in., 2014). W zwiazku z tym można przypuszczać, że znaleziony okaz pochodził najprawdopodobniej z rozmywanych starszych osadów glacjalnych - glin kompleksu południowopolskiego.

Piaskowce Hardeberga nie zostały wliczone do skał przewodnich, lecz do pomocniczych i dlatego ich udział odnoszony jest do całkowitej liczby nordyckich skał okruchowych w próbce. Większość skał osadowych okruchowych występujących w osadach glacjalnych Polski wywodzi się z zachodniej części niecki bałtyckiej i przyległych obszarów Szwecji. Tylko nieliczne mogą pochodzić z dna wschodniego Bałtyku. Udział tych ostatnich jest zapewne większy w Polsce Wschodniej, co może wpływać na względny spadek udziału piaskowca Hardeberga wśród skał okruchowych Podlasia i Lubelszczyzny 
(rys. 10.25 i 10.26). Zawartość omawianej skały w różnowiekowych osadach glacjalnych jest prawie jednakowa i wynosi 3,11\% eratyków skał okruchowych w glinach południowopolskich, 3,42\% w środkowopolskich i 3,41\% w osadach glacjalnych vistulianu. Brak pełnych danych o składzie przeanalizowanych prób uniemożliwia obliczenie odpowiedniego współczynnika dla osadów w lobie Odry, badanych przez Górską-Zabielską (2008), ale duża liczba piaskowców Hardeberga w każdej próbce (w sumie prawie 300 głazików) pozwala przypuszczać, że ich udział był tam znacznie wyższy (szacunkowo około 10\% skał okruchowych) aniżeli na obszarze przebadanym przez autora.

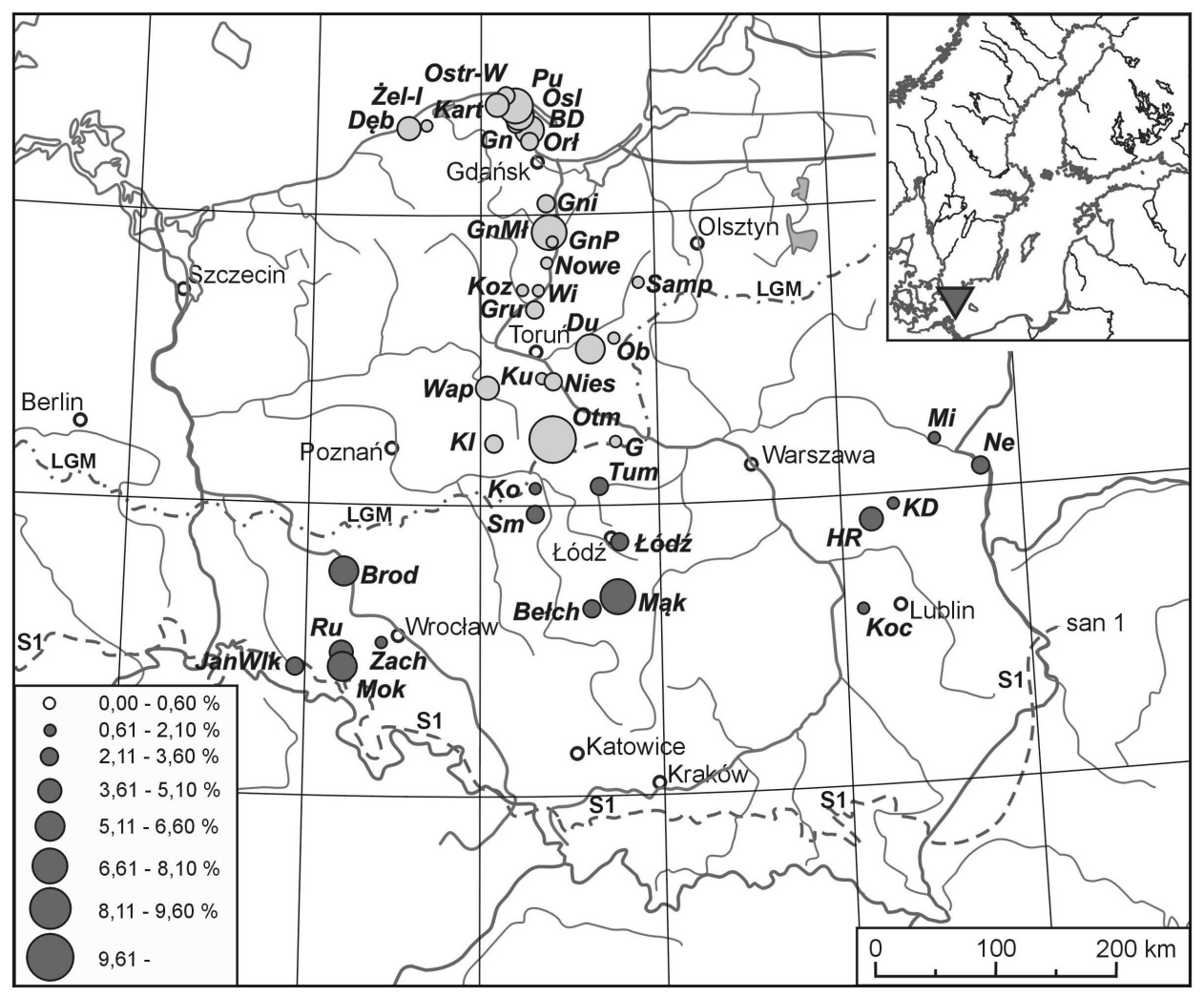

Rys. 10.25. Rozmieszczenie eratyków piaskowca Hardeberga w osadach glacjalnych Polski: kompleks południowopolski - ciemne koła, kompleks północnopolski - jasne koła (podana wartość stanowi udział procentowy opisywanej skały w grupie okruchowych skał północnych)

Figure 10.25. The distribution of Hardeberga sandstone in glacial deposits of the South-Polish Complex (dark circles) and of the North-Polish Complex (light circles); the given value is a percentage in the group of Nordic detrital rocks

Zaliczane niekiedy do skał przewodnich piaskowce skolitusowe (np. Meyer, 1983; Górska-Zabielska, 2008) zostały uznane za eratyki o znaczeniu jedynie pomocniczym. Przewodnie znaczenie tej skały zakwestionował już Schuddebeurs (1980/1981), który dopatrywał się łudzącego podobieństwa do piaskowców kwarcytowych (Pfeifenquarzit 


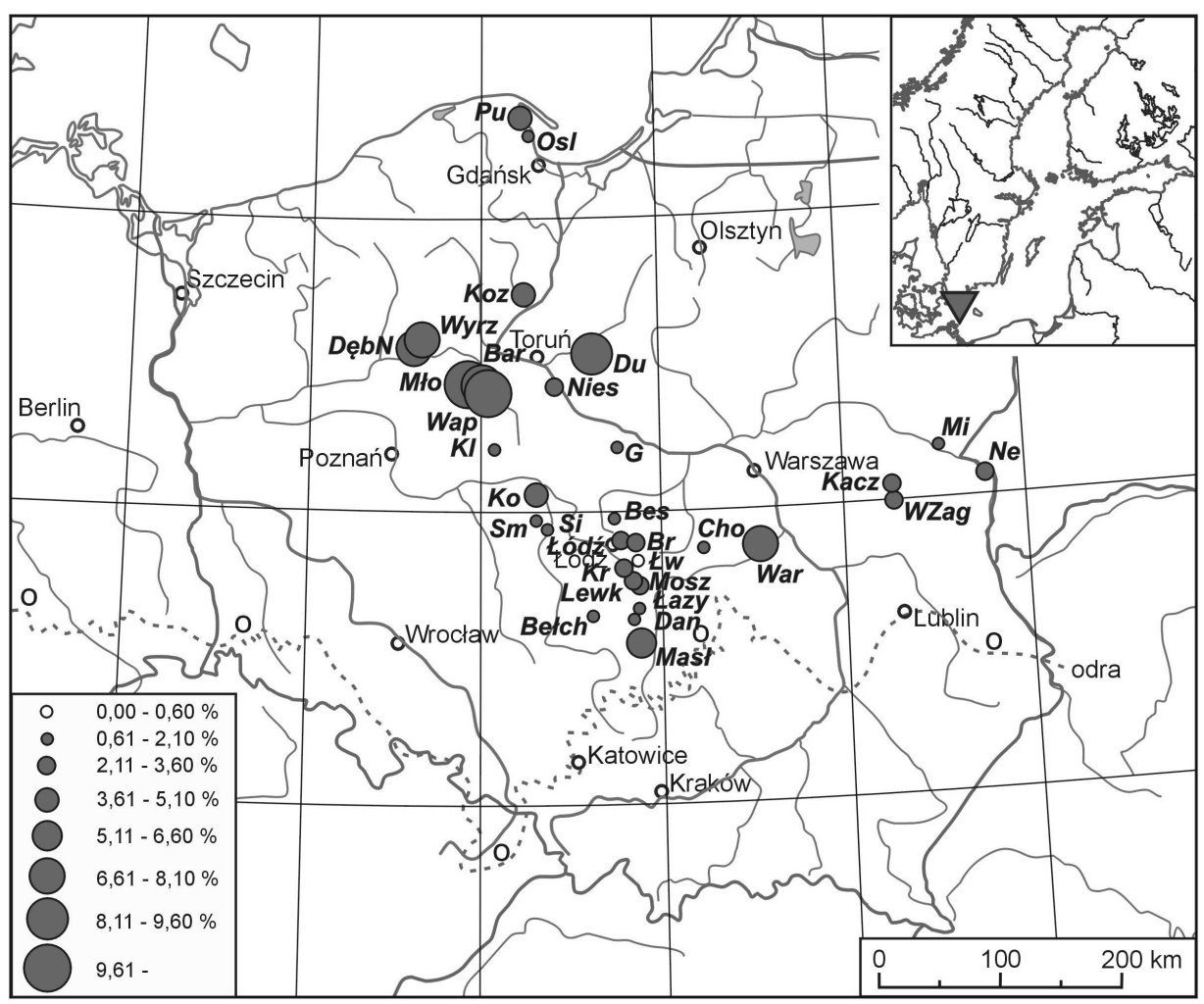

Rys. 10.26. Rozmieszczenie eratyków piaskowca Hardeberga w osadach glacjalnych kompleksu środkowopolskiego (podana wartość stanowi udział procentowy opisywanej skały w grupie okruchowych skał północnych) - udział poniżej 0,61\% (puste koło jako symbol stanowiska - Łaznowska Wola) oznacza brak eratyków tego piaskowca

Figure 10.26. The distribution of Hardeberga sandstone in glacial deposits of the Middle-Polish Complex; the given value is a percentage in the group of Nordic detrital rocks - share below $0,61 \%$ (empty circle as a site symbol - Łaznowska Wola) means a lack of Hardeberga sandstone in the site

- dosł. kwarcyt piszczałkowy), występujących na wyspie Hailuoto u wybrzeży Finlandii i w przyległej części dna Zatoki Botnickiej. W przebadanych zespołach głazowych piaskowce skolitusowe występowały bardzo rzadko. W sumie udało się zidentyfikować zaledwie 9 klastów. Ten rezultat wydaje się być sprzeczny z pobieżnymi obserwacjami dokonywanymi na wybrzeżu Bałtyku lub w żwirowniach centralnej Polski, gdzie piaskowce skolitusowe spotyka się dość często. Różnica wynika zapewne z faktu, że skały te można bez trudu rozpoznać, jeśli występują w postaci dość dużych klastów o łatwo dostrzegalnej fakturze powierzchni. W małych ziarnach mogą być błędnie zidentyfikowane jako piaskowce Hardeberga, od których w rzeczywistości różnią się tylko obecnością pozostałości rurek mieszkalnych wieloszczetów. 


\subsection{Zachodnia Szwecja i wschodnia Norwegia}

Skały zachodnioszwedzkie (granit Bohuslän, diabaz Kinne, sjenit Vaggeryd, granitognejs Åmål, czarnokit Varberg) i norweskie (porfiry i bazalty z rowu Oslo, nordmarkit, larvikit, lardalit, sjenit nefelinowy) są powszechnie akceptowane jako eratyki przewodnie (m.in. Lüttig, 1958; Hesemann, 1975; Meyer, 1983; Smed, 1994, 2002; Zandstra, 1999). Warunki termodynamiczne w kolejnych lądolodach fennoskandzkich decydowały o wynoszeniu tamtejszego materiału głównie w kierunku Danii i Morza Północnego aż po Wyspy Brytyjskie i Szetlandy (Ehlers, 2011). Umniejsza to znacznie potencjalne znaczenie tych skał w badaniach osadów glacjalnych Polski.

Diabaz Kinne (fot. 10.35) jest uważany za jedyny spośród diabazów o niewątpliwie przewodnim znaczeniu, pozostałe zaś mogą w bardzo podobnym wykształceniu występować w wielu stanowiskach, co dyskwalifikuje je jako eratyki przewodnie (Meyer, 1983). Zdaniem Hesemanna (1936) jednoznaczna identyfikacja diabazu Kinne jest możliwa dopiero w oparciu o metody mikroskopowe. W materiale przeanalizowanym przez autora udało się rozpoznać tylko dwa eratyki tej skały ${ }^{14}$. Sporadyczne występowanie diabazu Kinne w Polsce potwierdza koncepcję Ehlersa (2011), że stanowi on skałę typową dla napływu lodu z pominięciem depresji bałtyckiej. Zastanawiające jest w tym kontekście znalezisko dużego (kilkunastocentymetrowego) eratyka tej skały w okolicach Gołdapi na Mazurach. Miało ono miejsce w obecności autora w 2010 roku podczas wycieczki konferencyjnej, a znalazcą był niemiecki geolog $O$. Juschus.

Istotne wątpliwości pojawiają się w odniesieniu do znaczenia amfibolitów z granatami. Skały te występują $w$ wielu stanowiskach rozrzuconych $w$ różnych regionach Fennoskandii (Rudolph, 2008a), co podważa ich przewodnią rolę. Odmiana z białymi szlirowatymi skupieniami plagioklazów jest jednak charakterystyczna dla południowo-zachodniej Szwecji i południowej Norwegii (Smed, 2002; Rudolph, op. cit.). Pojawiła się również opinia, że obecność w osadach glacjalnych licznych amfibolitów nawet bez granatów wyraźnie wskazuje na południowo-zachodnią Szwecję lub południowo-wschodnią Norwegię jako obszar źródłowy, mimo że skały tego typu znane są z wielu regionów Fennoskandii (Vinx i in., 1997). O występowaniu amfibolitów również w środkowej i wschodniej Fennoskandii może świadczyć dość liczna ich obecność w zespołach głazowych Polski. Ich liczba jest kilkakrotnie wyższa, aniżeli wszystkich skał zachodnioszwedzkich wykrytych w analizowanych próbkach razem wziętych. Najliczniej amfibolity reprezentowane były $\mathrm{w}$ glinach kompleksu południowopolskiego, w których bardzo wysoki był także udział skał z południowej Szwecji. Pozostałe skały zachodnioszwedzkie w osadach glacjalnych Polski reprezentowane są przez nieliczne okazy granitu Bohuslän, a sjenitu Vaggeryd, granitognejsu Åmål i czarnokitu Varberg nie udało się zidentyfikować w przebadanych próbach.

\footnotetext{
${ }^{14}$ Znacznie większy udział zaprezentowany na mapach w pracy na temat wschodniej Wielkopolski (Czubla, 2006) wynikał z błędu w procedurze obliczeniowej i nie miał odniesienia do rzeczywistości.
} 


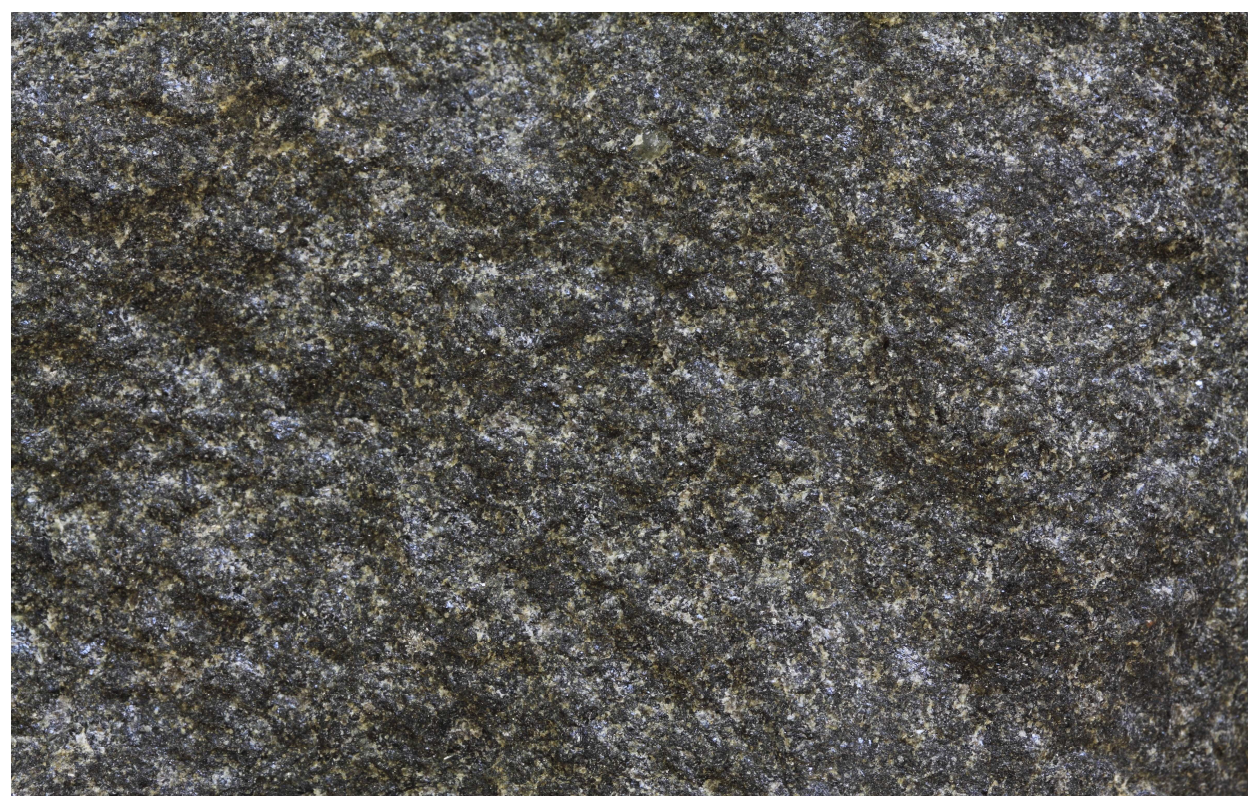

Fot. 10.35. Diabaz Kinne, Kinnekule, zachodnia Szwecja; rozmiar dłuższego boku 98 mm; fot. P. Czubla 2015

Photo 10.35. Kinne diabase, Kinnekule, western Sweden; picture width 98 mm. Photo P. Czubla 2015

Skały norweskie były odprowadzane przez lądolód na zachód i południowy zachód, co znacznie obniżało prawdopodobieństwo ich przywleczenia na teren Polski. Nawet na obszarze Niemiec występują one nielicznie (Meyer, 1983; Ehlers, 2011). Tylko w niektórych pokładach morenowych zdarzają się nieco częściej - np. w glinach Elsterianu w północno-zachodnich Niemczech (Meyer, 1970). Na terytorium dzisiejszej Polski skały norweskie były znajdowane niemal wyłącznie na zachodzie (por. Korn, 1920, 1927; Bennhold, 1928; Casper, 1931; Konieczny i Wdowiak, 1971; Schulz, 1973, Czubla, 2001; Górska, 2003b; Lipka, 2011). Znaczna część okazów pochodzi ze znalezisk powierzchniowych i nie daje się przypisać do konkretnych osadów (np. Casper, 1931; Konieczny i Wdowiak, 1971; Czubla, 2001; Górska, 2003b). Zwykle znajdowane były jedynie najbardziej charakterystyczne i najłatwiejsze do rozpoznania porfiry rombowe. Znaleziska w hanzeatyckich miastach portowych mogą być wyrazem ówczesnych kontaktów handlowych, a nie skutkiem transportu glacjalnego, ponieważ skały norweskie były często wykorzystywane jako balast okrętowy (Schulz, 1973). Powyższa hipoteza nie tłumaczy jednak obecności w odkrywce w Bełchatowie pojedynczego okazu porfiru rombowego, znalezionego przez autora. Głazik leżał luzem na dnie odkrywki (na powierzchni osuwiska) kilkadziesiąt metrów poniżej pierwotnej powierzchni terenu i jego przypisanie do konkretnej warstwy było niemożliwe (Czubla, 2001). Eratyki porfirów rombowych sporadycznie występują również w Czechach. Znaleziono je w okolicach Žulovej i w rejonie Jesenika na Czeskim Śląsku (Gába, 1974a, 1974b, 1977; Gába i Matyásek, 1997). 
Bazalty z rowu Oslo w północnych Niemczech znajdowane były stosunkowo rzadko (Meyer, 1983). Być może przyczyną tego stanu rzeczy były trudności w odróżnieniu bazaltów norweskich od ich odpowiedników ze Skanii. Różnią się one właściwie tylko zabarwieniem afanitowej masy podstawowej, która w przypadku skał norweskich jest niebieskawoszara lub czerwonawobrunatna, podczas gdy w wulkanitach ze Skanii czarna (Meyer, 1983). Tym bardziej godne uwagi jest niedawne znalezisko dwóch okazów tej skały (oraz jednego eratyka porfiru rombowego) w Owczarach na Ziemi Lubuskiej (Lipka, 2011 - str. 41). Pozostałych skał norweskich (nordmarkitu, larvikitu, lardalitu, sjenitu nefelinowego) nie udało się jak dotąd odnotować na terenie Polski.

Udział skał z omawianego regionu Fennoskandii w przebadanych przez autora zespołach głazowych był znikomy. W glinach kompleksu południowopolskiego wyniósł 1,15\%, co odpowiada mniej niż 1 eratykowi w próbce. W młodszych osadach był jeszcze mniejszy: w glinach kompleksu środkowopolskiego $0,66 \%$, a w północnopolskich $0,75 \%$. W przebadanych żwirach (bez względu na ich wiek) nie znaleziono ani jednego eratyka, który można byłoby powiązać z zachodnią Fennoskandią. Śladowe ilości eratyków zachodnioszwedzkich odnotowała Górska-Zabielska (2008) i to tylko w żwirach lobu Odry, w glinach nie znalazła ich w ogóle. Jedyne znalezione przez nią eratyki norweskie pochodzą z plaży u podnóża klifu na Wolinie i ich przypisanie do konkretnych osadów było niemożliwe (Górska, 2003b). Gałązka (2004b) nie rozpoznał w przebadanych przez siebie osadach żadnych skał norweskich, a precyzyjne ustalenie, czy i w jakiej liczbie w przebadanym materiale były obecne skały z zachodniej Szwecji nie było możliwe, ponieważ większość z nich (oprócz granitu Bohuslän, dla którego stworzył odrębną grupę) ujął w jednej grupie razem z eratykami ze Smålandu, Skanii i Blekinge. Pojedyncze eratyki z Bohuslänu udało mu się znaleźć w glinach vistulianu i zlodowacenia warty, a nieco większą ich liczbę zidentyfikował w osadach interpretowanych do niedawna jako odrzańskie. Podany przez niego udział (1,7\%) (Gałązka, op. cit.) jest tylko nieznacznie wyższy od wyznaczonego w niniejszej pracy odsetka skał zachodnioszwedzkich w glinach kompleksu południowopolskiego. Weryfikacja stratygrafii oraz ujednolicenie składu wyróżnianych grup doprowadziłoby do niemal idealnego pokrycia się wyników Gałązki i autora. Dalej na wschód, na terenie Białorusi żadnych skał z zachodniej Fennoskandii nie udało się znaleźć (Astapova, 1987).

\subsection{Bornholm i dno zachodniego Bałtyku}

Położenie geograficzne Bornholmu spowodowało, że wywodzące się z tej wyspy skały stanowią ważne eratyki przewodnie głównie w Europie Zachodniej. Podstawowe znaczenie w badaniach głazowych mają bornholmskie granity (Hammer - fot. 10.36, Vang, Svaneke) oraz gnejsy (por. Hesemann, 1930, 1975; Lüttig, 1958; Meyer, 1983; Smed, 1994, 2002; Zandstra, 1999). Granity, budujące znaczną część Bornholmu, cechują się niepowtarzalnym rubinowoczerwonym zabarwieniem kwarcu (fot. 10.37) oraz występowaniem różnej wielkości plamek w tym samym kolorze (Hesemann, 1930). Jest to cecha bardzo ułatwiająca ich identyfikację. Daje się rozpoznać nawet w bardzo małych ziarnach wyodrębnionych z osadów. Analogiczne czerwone (koralowe) plamki występują również w bornholmskich gnejsach (Smed, 2002). 


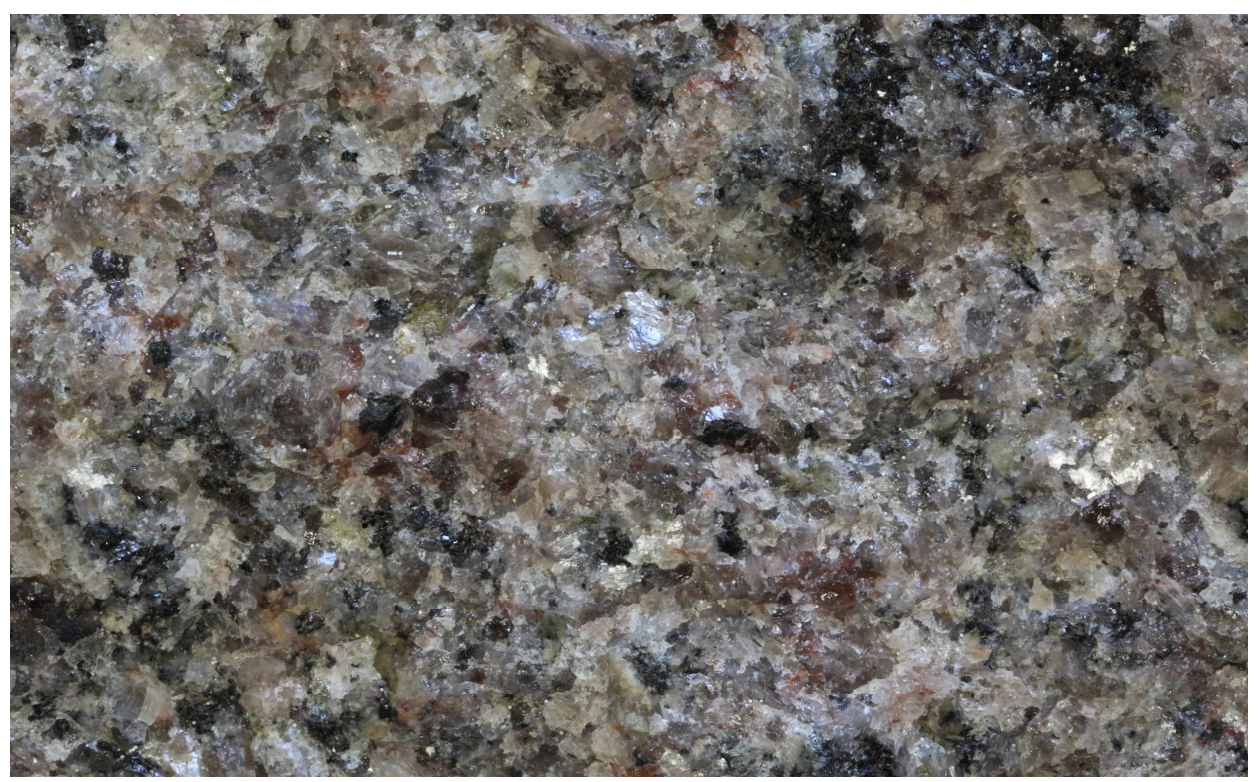

Fot. 10.36. Granit Hammer, Moaselökken na półwyspie Hammeren, Bornholm; rozmiar dłuższego boku 64 mm; fot. P. Czubla 2015

Photo 10.36. Hammer granite, Moaselökken on the Hammeren Peninsula, Bornholm; picture width $64 \mathrm{~mm}$. Photo P. Czubla 2015

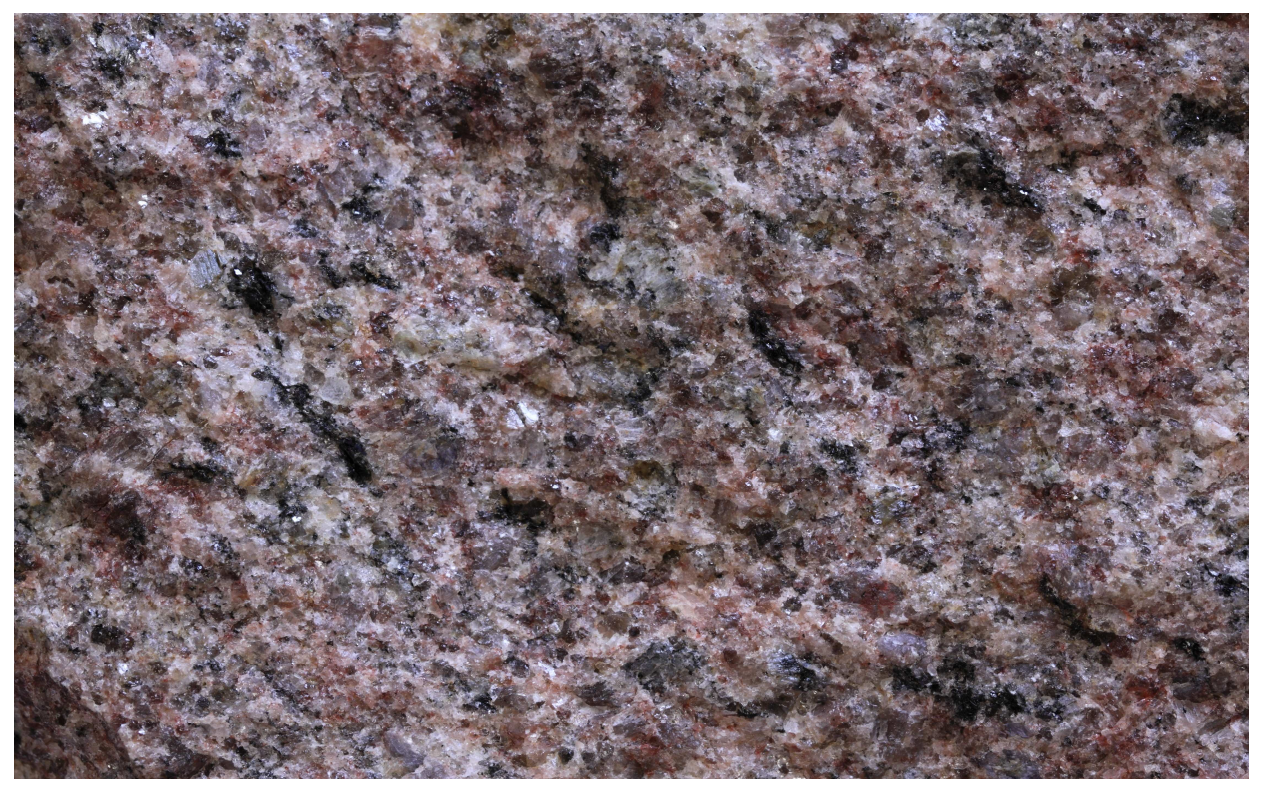

Fot. 10.37. Granit Alminding, kamieniołom w Bjergbakke, Almindingen, Bornholm; rozmiar dłuższego boku $85 \mathrm{~mm}$; fot. P. Czubla 2015

Photo 10.37. Alminding granite, Bjergbakke quarry, Almindingen, Bornholm; picture width $85 \mathrm{~mm}$. Photo P. Czubla 2015 
Przed pochopnym zaliczaniem pegmatytów zawierających czerwone kryształy kwarcu do skał bornholmskich przestrzega jednak Schuddebeurs (1980/1981). Gdyby rzeczywiście takie pegmatyty pochodziły z Bornholmu, to w zespołach głazowych powinny występować razem z innymi skałami bornholmskimi. Tymczasem w Hondsrug towarzyszą im liczne skały alandzkie, a nie ma żadnych bornholmskich (Schuddebeurs, op. cit.). Stąd można wnioskować o raczej północnobałtyckim (zapewne alandzkim) pochodzeniu tych pegmatytów. Potwierdzają ten wniosek obserwacje w odkrywce KWB „Bełchatów”. Liczne pegmatyty z czerwonym kwarcem zostały tam znalezione wśród dużych głazów (średnicy powyżej $1 \mathrm{~m}$ ), wypreparowanych z nadkładu i przeznaczonych do rozsadzenia w celu ułatwienia załadunku i transportu. Okoliczności znalezienia uniemożliwiły powiązanie powyższych skał z konkretnymi osadami plejstoceńskimi. W żadnych jednak osadach glacjalnych Polski Środkowej skały bornholmskie nie występują w większej ilości. Podobnie w miejscu obserwacji przedstawionych pegmatytów, granitoidów ani gnejsów z Bornholmu nie było, licznie występowały natomiast duże eratyki alandzkie oraz inne skały o nieustalonym obszarze źródłowym.

Wykorzystywanie w charakterze eratyków przewodnich bornholmskich piaskowców Nexö (np. Lüttig, 1958; Górska-Zabielska, 2008), jest raczej dyskusyjne (fot. 10.38). Bardzo podobnie wykształcone mogą być inne piaskowce kambryjskie, często zlepieńcowate i/lub arkozowe, odsłaniające się w różnych częściach dna zachodniego i północnego Bałtyku. Zdaniem Bilza (1995) piaskowiec Nexö różni się od proterozoicznych piaskowców jotnickich (Dala) kaolinowym spoiwem, będącym pozostałością po zwietrzałych skaleniach, ale to nie wyjaśnia, jak go odróżnić od innych piaskowców kambryjskich. Schuddebeurs (1980/1981) podkreśla, że omawiany piaskowiec nie ma żadnych jednoznacznych cech charakterystycznych. Obserwacje autora podczas pobytu na Bornholmie również nie pozwoliły na wyznaczenie pewnych cech rozpoznawczych piaskowca Nexö. W związku z tym w niniejszej pracy skała ta jest traktowana wyłącznie jako pomocnicza.

Duże obszary dna zachodniego Bałtyku zajmują wychodnie kredy, zawierającej liczne konkrecje krzemionkowe: czerty, krzemienie i rogowce (Kramarska, 1999; Schulz, 2003; Tuuling i in., 2011). Zawartość konkrecji znacząco jednak maleje w kierunku wschodnim i począwszy od Wolina kreda bałtycka jest już w nie bardzo uboga (Schulz, op. cit.). Wpływa to na dużą dysproporcję udziału krzemieni w osadach glacjalnych Europy Zachodniej i Środkowo-Wschodniej. W Niemczech krzemienie występują tak powszechnie w osadach glacjalnych, że granica ich zasięgu, określana jako „linia krzemieni” (Feuersteinlinie) utożsamiana jest z maksymalnym zasięgiem zlodowaceń skandynawskich (Wagenbreth, 1978). Na terenie Polski Środkowej i Wschodniej krzemienie i czerty występują w osadach w niewielkiej ilości i większość z nich jest pochodzenia lokalnego, a sporadycznie mogą występować także konkrecje krzemionkowe pochodzące z północy - z dolnopaleozoicznych osadów węglanowych w niecce bałtyckiej. Co prawda próbuje się rozciągać wskaźnikową rolę linii krzemieni aż po okolice Krakowa (Schulz, 2003), ale jest to koncepcja błędna i wynikająca zapewne z pominięcia w rozważaniach lokalnych krzemieni z mezozoicznego obrzeżenia Gór Świętokrzyskich i innych stanowisk w obrębie antyklinorium środkowopolskiego oraz w pasie Wyżyn 
Polskich. Przeciwko wykorzystaniu krzemieni w analizach obszarów alimentacyjnych lądolodów fennoskandzkich przemawia także brak możliwości odróżnienia większości konkrecji lokalnego pochodzenia od ich odpowiedników z mezozoicznych osadów na dnie Bałtyku i w Skanii. Próby rozróżniania krzemieni w oparciu o ich zabarwienie mogą być mylące, ponieważ świeże (niezwietrzałe) krzemienie zarówno jurajskie ze stanowisk w Polsce, jak i kredowe różnego pochodzenia mogą być ciemnoszare do czarnych, a spotykane często brązowe, czerwonawe lub żółte zabarwienie stanowi rezultat procesów wietrzeniowych (Marczinski, 1968a; Schuddebeurs, 1980/1981; Smed, 2002). Kolejnym argumentem przeciwko wykorzystywaniu krzemieni jest wyraźnie zaznaczająca się korelacja pomiędzy udziałem skał lokalnych i krzemieni w przebadanych osadach. Wskazuje ona na lokalne pochodzenie większości z nich, o czym już dawno pisał Różycki (1965). Z tego samego względu negatywny wynik przyniosła próba wykorzystania wskaźnika F/K (krzemienie i czerty/skały krystaliczne) do rozpoziomowania osadów glacjalnych w Polsce (Czubla, 2001). Wskaźnik ten z powodzeniem wykorzystywany jest jednak od wielu lat w badaniach osadów plejstoceńskich w Niemczech (np. Richter, 1933; Gauger, 1980). Już wczesne badania eratyków dowiodły, że udział krzemieni jest odwrotnie proporcjonalny do udziału skał wschodniofennoskandzkich (Hesemann, 1931b). Ten wniosek został potwierdzony również współczesnymi badaniami, opartymi na odmiennej metodyce (Hoffmann i Meyer, 1997). W Polsce taka zależność nie jest czytelna.

Schuddebeurs (1958, 1980/1981) kwestionuje sens liczenia krzemieni razem ze skałami krystalicznymi, ponieważ pierwsze szybko rozpadają się na kawałki i wtedy kilkanaście odłupków staje się rzeczywistym odpowiednikiem jednego klastu skały krystalicznej, np. granitu. Prowadzi to do zakłócenia proporcji pomiędzy tymi typami skał w osadach. Na dodatek wraz z długością transportu maleją rozmiary krzemieni, co potwierdza wyrażone powyżej zastrzeżenie (Schuddbeurs, 1980/1981). Smed (2010), pomimo uwzględnienia na swoich mapach kołowych licznych bałtyckich wapieni, dolomitów i skał dewońskich, posiadających olbrzymie wychodnie, zupełnie pominął zachodniobałtyckie krzemienie i czerty. Można tylko domyślać się, że przyczyną było masowe występowanie tych skał również w Danii (fot. 10.39), gdzie np. u podnóża Stevns Klint stanowią dominujący typ otoczaków wyścielających plażę. W konsekwencji ich włączenie jedynie zakłóciłoby analizę. Krzemienie znalazły się jednak na mapach kołowych sporządzanych przez Lipkę (2011) i nawet zdominowały obraz na wielu z nich, ponieważ liczba krzemieni w wielu próbkach znacznie przewyższała liczbę niewątpliwie przewodnich eratyków krystalicznych.

Mała liczba eratyków przewodnich z Bornholmu w przeanalizowanych próbkach utrudnia ich analizę przestrzenną. W osadach starszych zlodowaceń daje się jednak zauważyć niewielki spadek udziału tej grupy skał przy przesuwaniu się na wschód (rys. 10.27). Mała rozciągłość równoleżnikowa obszaru, w którym badane były gliny vistulianu, uniemożliwia analogiczną interpretację osadów ostatniego zlodowacenia, ale zestawienie z danymi Górskiej-Zabielskiej (2008) z lobu Odry wskazuje na występowanie podobnej zmienności. W przeanalizowanych przez nią glinach skały z Bornholmu 


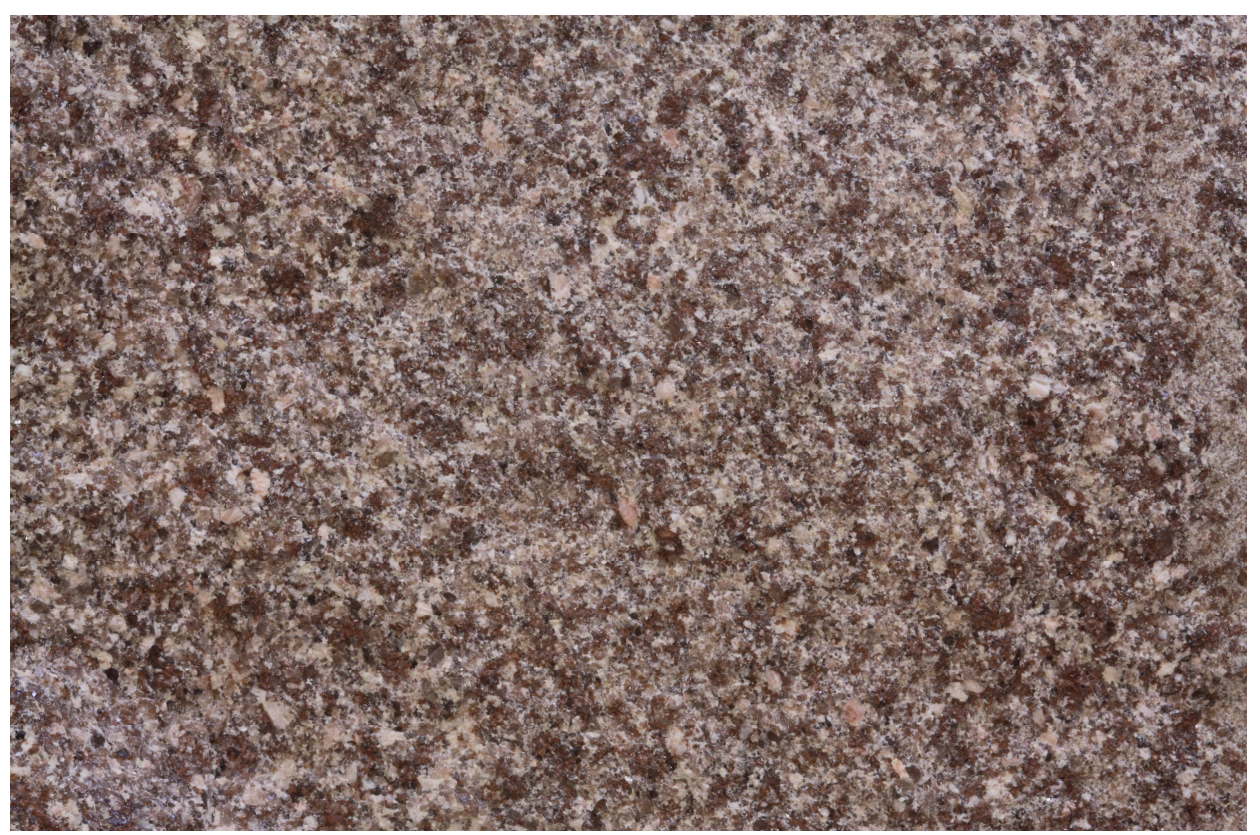

Fot. 10.38. Piaskowiec Nexö, Nexö, Bornholm, rozmiar dłuższego boku 90 mm; fot. P. Czubla 2015

Photo 10.38. Nexö sandstone, Nexö, Bornholm; picture width 90 mm. Photo P. Czubla 2015

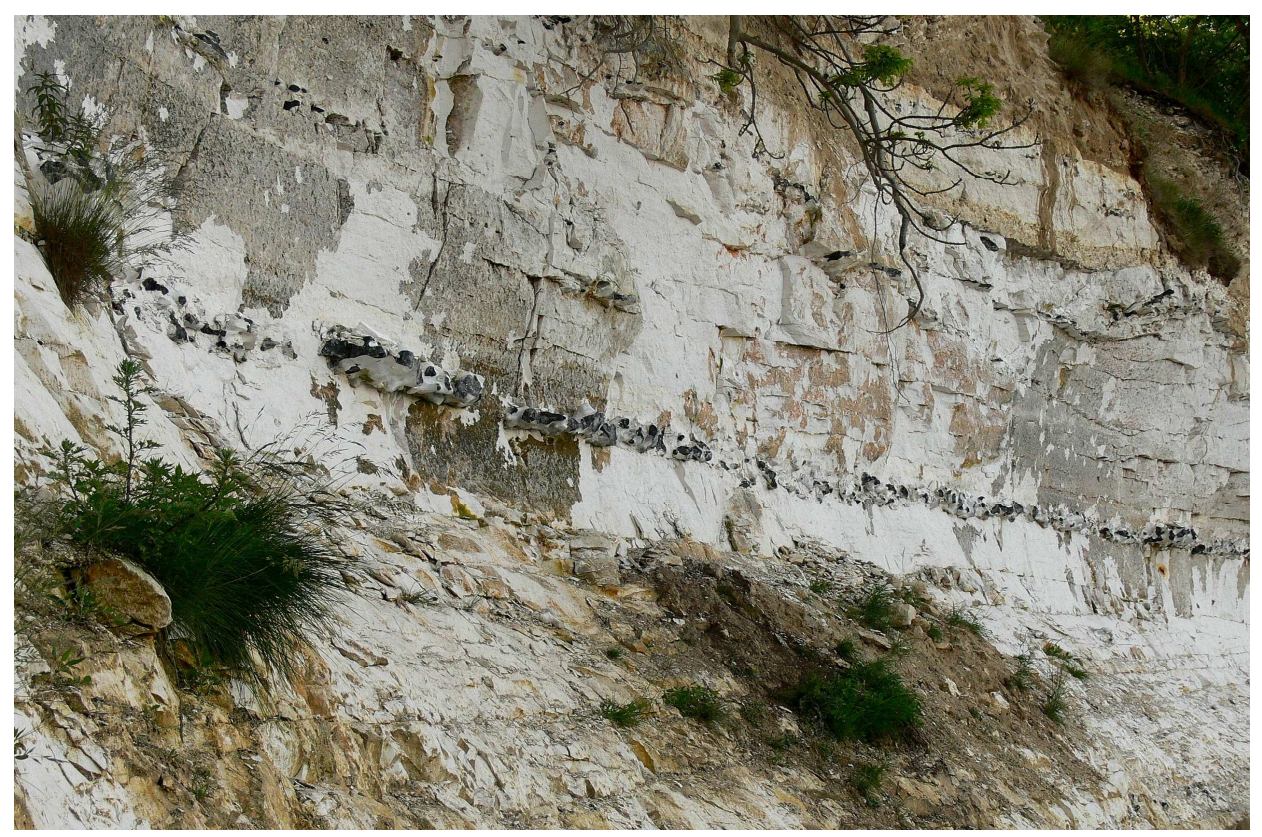

Fot. 10.39. Kreda pisząca z warstwą krzemieni, Stevns Klint, Dania; fot. O. Czubla 2009 Photo 10.39. Cretaceous chalk with a layer of flints, Stevns Klint, Denmark. Photo O. Czubla 2009 
stanowiły 2,66\% krystalicznych eratyków przewodnich. Udział skał z Bornholmu w próbkach opracowanych przez Gałązkę (2004b) był znikomy. W glinach zlodowacenia sanu zabrakło ich zupełnie. W glinach odrzańskich Gałązka rozpoznał ich najwięcej bo aż $3,9 \%$, ale w świetle rewizji stratygrafii Bełchatowa konieczna będzie reinterpretacja tego wyniku - raczej w kierunku gliny południowopolskiej. Gliny warciańskie badane przez Gałązkę były nieomal całkowicie wolne od tej grupy skały - poniżej 0,1\%, w osadach vistulianu zaś udział skał bornholmskich malał zgodnie z następstwem stratygraficznym: w glinie Świecia 0,7\%, leszczyńsko-poznańskiej 0,4\%, a w pomorskiej brakowało ich zupełnie (Gałązka, 2004b). Dalej na wschód, tj. na obszarze Białorusi skał z Bornholmu nie znaleziono (Astapova, 1987).

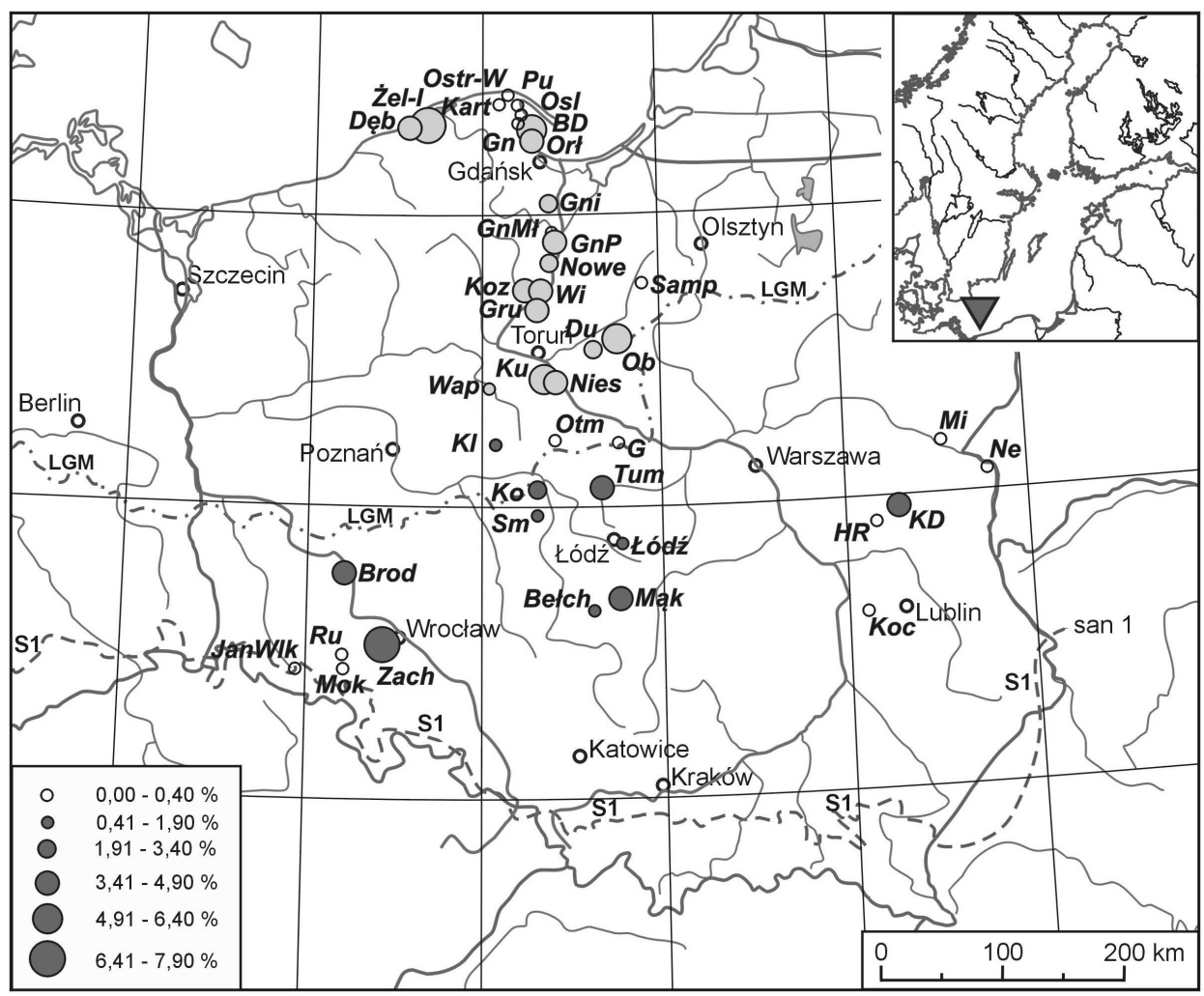

Rys. 10.27. Rozmieszczenie eratyków skał z Bornholmu w osadach kompleksu południowopolskiego (ciemne koła) i północnopolskiego (jasne koła); dla stanowisk, gdzie pobrano wiele próbek z osadów tego samego wieku, dane zostały uśrednione - udział poniżej 0,41\% (puste koło jako symbol stanowiska) oznacza brak eratyków skał bornholmskich

Figure 10.27. The distribution of Bornholm erratics in glacial deposits of the South-Polish Complex (dark circles) and of the North-Polish Complex (light circles); for research sites, where multiple samples were taken from sediments of the same age, the data were averaged - share below $0,41 \%$ (empty circle as a site symbol) means a lack of Bornholm rocks in the site 
Udział granitoidów i gnejsów bornholmskich wśród skał przewodnich pozyskanych z osadów glacjalnych w Polsce był stosunkowo mały - 1,63\%, a w żwirach jeszcze około dwukrotnie niższy $-0,85 \%$. W osadach kompleksu południowopolskiego na skały z tego obszaru przypada około $1,81 \%$ eratyków przewodnich. Najmniej licznie krystaliczne skały bornholmskie występują w osadach kompleksu środkowopolskiego, gdzie stanowią zaledwie $1,06 \%$, a maksimum osiągają w osadach vistulianu 2,34\%. Również w glinach vistulianu obserwowany jest najwyższy udział piaskowców typu Nexö ${ }^{15}$, ale w starszych osadach są one już tak rzadkie, że ewentualna analiza ich rozmieszczenia byłaby niewiarygodna.

W plejstoceńskich osadach Niemiec udział eratyków z Bornholmu jest zwykle niewielki (np. Meyer, 1983; Vinx i in., 1997; Hoffmann i Meyer, 1999). Dość często eratyki bornholmskie znajdowane są natomiast w Holandii. Występują one w niemal wszystkich przeanalizowanych zespołach głazowych (Schuddebeurs, 1980/1981). W skrajnych przypadkach stanowią nawet 12 do $16 \%$ ogólnej liczby przewodnich skał krystalicznych (Zandstra, 1974). Budzi to wątpliwości (Schuddebeurs, 1980/1981), ponieważ powierzchnia egzaracji tych skał na Bornholmie wynosi zaledwie około $300 \mathrm{~km}^{2}\left(400 \mathrm{~km}^{2}\right.$ według Meyera, 1983), a po doliczeniu, zgodnie z przypuszczeniami Hesemanna (1975), również podmorskich wychodni tych skał wzrasta około trzykrotnie do zaledwie 800-1 $000 \mathrm{~km}^{2}$. Nadal jest zatem ponad trzykrotnie mniejsza od powierzchni zajmowanej przez granity Bohuslän (3000 km²), które mają znacznie mniejszy udział w holenderskich zespołach głazowych (Schuddebeurs, op. cit.). Nasuwa się tylko wątpliwość, na ile skały ze szwedzko-norweskiego pogranicza lądolód przenosił do Holandii, a nie na obszar Morza Północnego, co mogłoby tłumaczyć tę pozorną sprzeczność.

Nadreprezentacja skał bornholmskich w Holandii może też być uwarunkowana eksponowanym położeniem Bornholmu na trasie lodu wypływającego z niecki bałtyckiej i inkorporowaniem materiału skalnego bezpośrednio do wyższych partii lodu (podobnie, jak w przypadku skał alandzkich), co znacznie ułatwiało daleki transport. Sprzyjałoby temu wynoszenie Bornholmu jako tektonicznego zrębu już od późnej jury (Graversen, 2009). Tylko jurajskie wznoszenie szacowane jest na co najmniej $335 \mathrm{~m}$, a sumaryczne wypiętrzenie po wczesnej kredzie na około 290-300 m (Petersen i in., 2003; Graversen, 2004). Obecnie Bornholm wznosi się na wysokość do 162 m n.p.m., podczas gdy otaczające morze ma głębokość sięgającą do 105 metrów w Głębi Bornholmskiej, a więc po proksymalnej stronie potoku lodowego wypływającego z obszaru bałtyckiego. Ponad dwustumetrowa różnica wysokości pozwala na ten sam efekt, jaki przedstawiony został wcześniej przy opisie eratyków z Wysp Alandzkich. Należy jednak zastrzec, że jego potencjalny wpływ na dostawę skał bornholmskich na obszar Polski był bardzo ograniczony dominacją odpływu lodu na zachód (przynajmniej w ostatnim zlodowaceniu) (np. Boulton i in., 2001b; Kjær i in., 2003; Marks, 2005).

\footnotetext{
${ }^{15}$ Ze względu na brak jednoznacznych cech do piaskowców Nexö mogły zostać błędnie zaliczone czerwone arkozowe piaskowce kambryjskie z dna Bałtyku. Dlatego użyto bardziej ogólnego określenia „piaskowce typu Nexö".
} 


\subsection{Dno południowego Bałtyku}

Dno południowego Bałtyku budują skały analogiczne do występujących w północnej Polsce. Późnokredowa transgresja zapoczątkowała sedymentację okruchową (Kramarska, 1999). Wzrost zasięgu kredowego morza i oddalenie od erodowanych lądów spowodowały, że ku górze profilu stopniowo wzrastał udział węglanów, co przyczyniło się do powstawania opok, gez i margli, aż po kredę piszącą, lokalnie bogatą w krzemionkowe konkrecje. Wysoka zawartość krzemieni i czertów jest charakterystyczna dla górnej kredy w zachodniej części depresji bałtyckiej i w Danii, podczas gdy na wschód od Odry konkrecje krzemionkowe występują rzadko, a na dodatek sama kreda na znacznym obszarze została odizolowana od stopy lądolodu osadami paleogenu i neogenu (Schulz, 2003). Tylko w zachodniej części dna Bałtyku (na zachód od Darłowa) oraz w Zatoce Gdańskiej bezpośrednio pod plejstocenem leżą skały kredowe, a w rejonie Kołobrzegu i Kamienia Pomorskiego podczwartorzędową powierzchnię budują wypiętrzone skały jurajskie antyklinorium środkowopolskiego (Mojski, 1995; Kramarska, 1999, 2000; Stupnicka, 2007).

Wspomniane powyżej podobieństwo skał południowego Bałtyku i północnej Polski wyklucza ich wykorzystanie jako eratyków przewodnich. Opoki, gezy, margle, mułowce wapniste z glaukonitem, wapniste piaskowce, krzemienie i czerty mogą pochodzić z obydwu przytoczonych obszarów źródłowych. Brak możliwości makroskopowego odróżnienia skał mezozoicznych i kenozoicznych, pochodzących z dna Bałtyku od ich równowiekowych odpowiedników, mających swoje podczwartorzędowe wychodnie w Polsce, skłonił do ujęcia ich razem jako skał bliskiego transportu.

W niemal każdej analizowanej próbie obecne są konkrecje fosforytowe. Najliczniej występują w glinach vistulianu, gdzie stanowią prawie 1\% całkowitej liczby eratyków fennoskandzkich. Zazwyczaj tworzą kilkucentymetrowe bulaste skupienia o obłych, rzadziej nieregularnych kształtach. Często występują w nich dobrze obtoczone ziarna kwarcu - nierzadko również niebieskiego, co zdaje się wskazywać na bliski związek ze Smålandem.

Na obszarze alimentacji lądolodów fennoskandzkich fosforyty opisywane są z osadów starszego paleozoiku, młodszego mezozoiku i paleogenu. Konkrecje fosforytowe występują również na obszarze Polski - głównie w osadach kredy i paleogenu. Obecność dość dużych ziaren kwarcu (w skrajnych przypadkach nawet do $1 \mathrm{~cm}$ ) wyklucza pochodzenie konkrecji fosforytowych z kredowej kredy piszącej, opok lub margli, ponieważ wymienione skały tworzą się w środowisku o małej dynamice, dość odległym od wybrzeża - w miejscu, do którego ziarna piasku raczej nie mogłyby dotrzeć. Samo powstawanie fosforytów wymaga spokojnej sedymentacji i ich powiązanie z wysokoenergetyczną dostawą grubego piasku, a nawet drobnego żwiru wymaga założenia, że ta dostawa miała charakter efemeryczny. Na dodatek konkrecje fosforytowe obecne w osadach kredy w Polsce (np. w Mielniku) są zabarwione glaukonitem na zielono, podczas gdy z przebadanych próbek pochodzą fosforyty czarne lub czarnobrunatne. 
Dowodem na północne pochodzenie konkrecji fosforytowych może być wspomniane wcześniej występowanie w nich obtoczonych ziaren niebieskiego kwarcu. Konkretnego obszaru źródłowego nie udało się jednoznacznie ustalić. W południowej Fennoskandii konkrecje fosforytowe występują w osadach kambru i wczesnego ordowiku (Brasier, 1980; Nielsen i Schovsbo, 2007; Baturin i llyin, 2013), skąd razem z innymi skałami starszego paleozoiku mogły być przynoszone na obszar Niżu Środkowoeuropejskiego. Młodsze koncentracje fosforytów znane są z południowego Bałtyku i przyległych obszarów lądowych, gdzie obecne są w osadach jury, kredy i paleogenu. Najczęściej związane są z morskimi osadami węglanowymi późnej kredy oraz skałami terygenicznymi paleocenu i eocenu (Kharin i Zagorodnykh, 2011). Strefa występowania konkrecji fosforytowych rozciąga się od Bornholmu na zachodzie, przez okolice Gdańska, Obwód Kaliningradzki i przyległy obszar dna Bałtyku aż po terytorium Litwy na wschodzie. Konkrecje napotkano zarówno w wierceniach, jak i w odsłonięciach (Kharin, 2009). W Obwodzie Kaliningradzkim i na Litwie fosforyty są najczęściej czarne lub ciemnozielone i osiągają rozmiary do kilku cm - maksymalnie około $20 \mathrm{~cm}$. Konkrecje paleogeńskie są reprezentowane przez dwa typy morfologiczne. Pierwszy z nich cechuje się wrzecionowatym kształtem oraz zbitą i zwięzłą budową wewnętrzną. Do drugiego typu zaliczane są porowate konkrecje o nieregularnych formach (Kharin, op. cit.). Żaden z powyższych typów morfologicznych nie występował w analizowanym materiale. Przyczyną braku porowatych konkrecji mogło być ich zniszczenie w trakcie erozji glacjalnej lub już podczas transportu. Trudniej wyjaśnić brak zbitych i wydłużonych skupień fosforytów, którym erozja i transport niewiele mogły zaszkodzić. Wydaje się jednak, że przyczyniło się do tego położenie większych podczwartorzędowych wychodni zawierających je skał (paleogen) dość daleko na wschodzie (Ūsaitytė, 2000), skąd materiał skalny wynoszony był raczej w kierunku Litwy i Białorusi. Z dynamiką lądolodu fennoskandzkiego sprzeczna jest również koncepcja Gałązki (2004b) o dostawie fosforytów z wystąpień opisanych przez Tokarskiego (1932) w okolicach Grodna. Powszechne występowanie konkrecji fosforytowych w osadach glacjalnych Pomorza i Powiśla, tj. na północny zachód od potencjalnych obszarów źródłowych w rejonie Grodna, zupełnie wyklucza transport glacjalny. Tamtejsze fosforyty mogłyby ewentualnie zostać zawleczone tylko na obszar Podlasia. Na fosforyty natrafiono również w oligoceńskiej krze glacjalnej w Krzywaniu na południowy wschód od Słupska (Wawryk, 1961; Orłowski, 2008).

W osadach kompleksu południowopolskiego fosforyty są rozmieszczone dość równomiernie w stanowiskach od Dolnego Śląska aż po Podlasie. Bardzo mała liczba eratyków tego typu stawia jednak pod znakiem zapytania wiarygodność powyższego wniosku. To samo dotyczy zespołów głazowych kompleksu środkowopolskiego. Dopiero w osadach vistulianu fosforytów jest znacznie więcej, ale tym razem na przeszkodzie analizie przestrzennej stoi mały obszar badań. Mimo to wyraźnie zaznacza się podwyższona koncentracja konkrecji fosforytowych wzdłuż doliny dolnej Wisły (rys. 10.28). Jest ona czytelna głównie w glinach bogatych w składniki lokalne, ale zauważalna jest 
również w niektórych glinach ubogich w skały bliskiego transportu. Pozwala to wnioskować, że przynajmniej część fosforytów była transportowana na dość długim dystansie i te należałoby dowiązać do typowych skał skandynawskich. Brak informacji o zawartości fosforytów w osadach lobu odrzańskiego (Górska-Zabielska, 2008) nie pozwala na prześledzenie zmienności równoleżnikowej udziału tego składnika. Jeżeli jednak brak wzmianki na ten temat u Górskiej-Zabielskiej był wyrazem nieobecności tej skały w lobie Odry, to można wnosić, że obszar źródłowy zlokalizowany był na dnie środkowego Bałtyku w rejonie położonym na północ od Gdańska i egzarowany na większą skalę dopiero podczas ostatniego zlodowacenia.

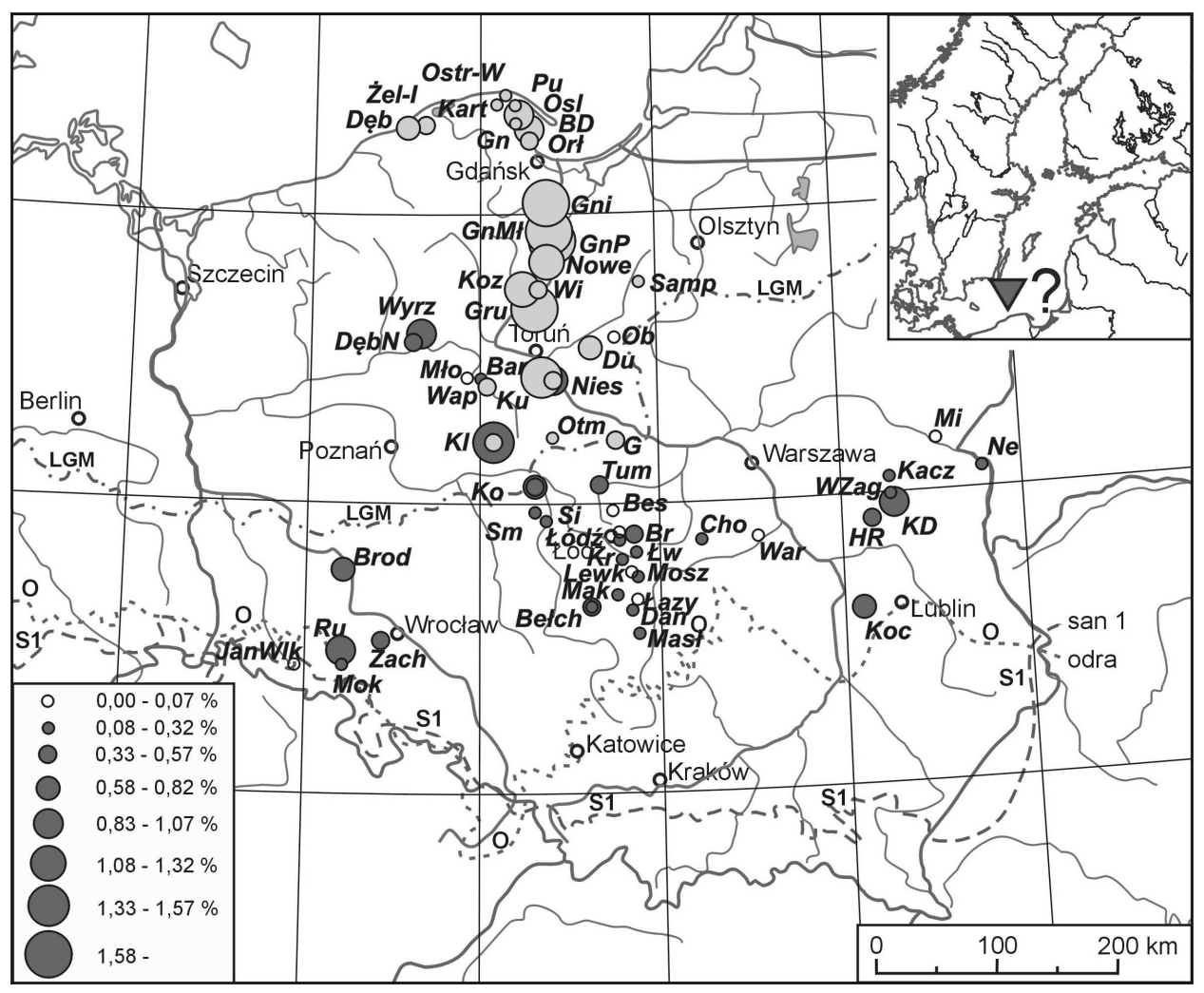

Rys. 10.28. Rozmieszczenie konkrecji fosforytowych w osadach glacjalnych Polski; jasne koła oznaczają stanowiska z osadami ostatniego zlodowacenia, ciemne lokują osady starszych kompleksów glacjalnych - udział poniżej 0,08\% (puste koło jako symbol stanowiska) oznacza brak konkrecji fosforytowych w przebadanych próbkach

Figure 10.28. The distribution of phosphorite nodules in glacial deposits of both the South and the Middle-Polish Complexes (dark circles) and of the North-Polish Complex (light circles) - share below 0,08\% (empty circle as a site symbol) means a lack of phosphorite nodules in the site 
Sfosfatyzowany okaz ostrakodermy, znaleziony w glinie z doliny dolnej Wisły, czyni pochodzenie fosforytów jeszcze bardziej niejasnym. Ostrakodermy to bezszczękowce, które pojawiły się w ordowiku, szczyt rozwoju osiągnęły w sylurze i wymarły pod koniec dewonu. Okres ich panowania w morzach przypada akurat na lukę pomiędzy etapami nasilonej depozycji fosforytów w Fennoskandii. Możliwe jednak, że przepojenie skamieniałości fosforanami nastąpiło już po jej redepozycji i w takim przypadku ostrakoderma mogła znaleźć się na wtórnym złożu w osadach kredy lub paleogenu.

Bardzo rzadko w osadach glacjalnych znajdowane są ziarna bursztynu - zwłaszcza we frakcji ponad $20 \mathrm{~mm}$. Jedną z przyczyn był niewątpliwie dwuetapowy transport, w trakcie którego miękki bursztyn szybko ulegał wietrzeniu i abrazji. W pierwszym etapie w późnym eocenie i we wczesnym oligocenie bursztyn był przynoszony przez rzeki z północy Skandynawii i osadzany w drobnoklastycznych osadach tzw. delty gdańskiej w rejonie dzisiejszej Zatoki Gdańskiej i Półwyspu Sambia (Kosmowska-Ceranowicz, 1989, 2003). Następnie paleogeńskie osady wraz z bursztynem były egzarowane przez lądolody i rozwłóczone na południe aż po granice ich maksymalnego zasięgu (Krause, 1997; Schulz, 1999), czego dowodzą chociażby duże złoża na Kurpiach, eksploatowane na znaczną skalę przez kilka wieków (Kosmowska-Ceranowicz, 2002). Podwyższona liczba znalezisk bursztynu w glinach kompleksu środkowopolskiego jest zgodna z wynikami badań skał przewodnich, które wykazały dominację w tym okresie transportu z północnego wschodu. Na drodze lodu w kierunku Polski Środkowej znalazły się osady eoceńskie lub oligoceńskie Obwodu Kaliningradzkiego i przyległego dna Bałtyku. Tę hipotezę potwierdzają również drobne ziarna bursztynu znalezione w glinach warciańskich w okolicach Łukowa (Gałązka, 2004b). 


\section{WACHLARZE ROZRZUTU ERATYKÓW}

Początkowo badania eratyków na obszarach depozycji osadów glacjalnych koncentrowały się w wielu przypadkach na analizie regionalnego rozprzestrzenienia charakterystycznych typów skał i wyznaczaniu tzw. stożków lub wachlarzy rozrzutu (Beschüttungskegel, Streufächer) (m.in. Gottsche, 1883; Sederholm, 1911; Hausen, 1912, 1913, 1921; Korn, 1927; Kraus, 1934). Określano w ten sposób obszar występowania konkretnego eratyka w osadach. Wachlarze rozrzutu zapoczątkowane są w obrębie wychodni danej skały i stopniowo, mniej lub bardziej regularnie, rozszerzają się w kierunku zgodnym z napływem lodu. Początkowa szerokość wachlarza rozproszenia wynika z wielkości wychodni. Na ogół drogi i pola rozrzutu różnych skał nakładają się na siebie i nieraz krzyżują zależnie od dynamiki kolejnych lądolodów. Wachlarze rozrzutu konstruowane były w oparciu o materiał zebrany na powierzchni (Sederholm, op. cit.; Hausen, op. cit.). W efekcie mają one charakter zbiorczy i obejmują efekty działania wszystkich zlodowaceń, jakie wkroczyły na dany obszar, choćby nawet kierunki ich transgresji różniły się radykalnie (por. Woldstedt, 1954). Nie sposób wykluczyć udziału także innych środowisk transportu (fluwioglacjalnego, fluwialnego) w kształtowaniu wachlarzy rozrzutu skał nordyckich.

Określenie „stożek rozrzutu” (używane nawet w najnowszych opracowaniach, np. Czubla, 2001; Górska-Zabielska; 2008) obecnie już jest raczej trudne do utrzymania, ponieważ sugeruje wybitnie przestrzenny (trójwymiarowy) charakter strefy występowania skał fennoskandzkich na Niżu Środkowoeuropejskim, czy jakichkolwiek eratyków w osadach glacjalnych. W rzeczywistości pionowy zasięg występowania eratyka (poza wychodnią) może wynosić co najwyżej kilkaset metrów w głębokich rynnach subglacjalnych wypełnionych później osadami, podczas gdy zasięg poziomy obejmuje w Europie setki, a w skrajnych przypadkach nawet ponad tysiąc kilometrów. W Ameryce Północnej eratyki inkorporowane w Zatoce Hudsona mogły przebyć nawet do 2500 km (Prest i Nielsen, 1985). W związku z tym o wiele bardziej uzasadnione jest stosowanie określeń wachlarz rozrzutu lub strefa rozprzestrzenienia (rozproszenia).

Początkowe wyniki analiz wachlarzy rozrzutu zdawały się wskazywać na ograniczenie występowania niektórych typów eratyków do pojedynczych nasunięć glacjalnych. Taką rolę przypisywano brunatnemu porfirowi bałtyckiemu dla osadów lądolodu warciańskiego (Milthers, 1934, 1936, 1939, 1950; Milthers i Milthers, 1938). Pogląd ten został jednak bardzo szybko zakwestionowany (Richter, 1937; Różycki, 1965) - por. rozdz. 10. Teoretycznie istnieje możliwość występowania określonego typu eratyka w osadach tylko jednego nasunięcia glacjalnego, ale wymagałaby ona założenia całkowitej erozji wychodni tej skały w ciągu tego właśnie pojedynczego awansu lądolodu oraz braku redepozycji osadów glacjalnych w kolejnych nasunięciach. Są to warunki zupełnie sprzeczne z budową i historią geologiczną północnej Europy. 
Wyznaczanie kierunków nasuwania się lodu w oparciu o analizę wachlarzy rozrzutu eratyków ma sens tylko w odniesieniu do najbliższego sąsiedztwa wychodni (Sauramo, 1924; Woldstedt, 1954). Określone tą metodą kierunki ruchu lodu nie zawsze są zgodne z rysami glacjalnymi, ale rysy zazwyczaj dokumentują tylko ostatni etap ruchu lodu, a skały narzutowe również wcześniejsze jego etapy. W marginalnej strefie lądolodu może dojść do istotnego wtórnego przemieszczenia eratyków wzdłuż czoła lądolodu na skutek procesów fluwioglacjalnych. Zwraca na to uwagę m.in. Schulz (2003), podkreślając możliwość dalekiego transportu w szczelinach martwego lodu, równoległych do czoła lądolodu. Sauramo (op. cit.) podkreśla też możliwość tworzenia się wtórnych stref rozrzutu po rozpadzie większego eratyka. Tego typu smugowe koncentracje eratyków jednego typu nazwano wtórnymi wachlarzami rozrzutu (Hucke, 1926 - str. 34) lub eratykami szrapnelowymi (Schrappnelgeschiebe) (Eskola, 1933). W Holandii określano takie koncentracje jako szliry, przejmując pojęcie wywodzące się z petrografii skał magmowych (Schuddebeurs, 1980/1981). Występowanie eratyków szrapnelowych może znacząco zmienić wyniki lokalnej analizy głazowej, ale nie ma wpływu na zasięg wachlarzy rozrzutu, ponieważ odbywa się w strefie występowania danej skały i nie powoduje zmiany składu jakościowego osadów morenowych. Z przeprowadzonych na terenie Polski badań wynika, że w rzeczywistości wtórne wachlarze rozrzutu występują nadzwyczaj rzadko i przy procedurze poboru prób stosowanej przez autora nie udało się zidentyfikować żadnego jednoznacznego przypadku tego typu zjawiska. Być może taki charakter ma wyjątkowo bogata w skały alandzkie czerwona morena fazy gardnieńskiej, opisywana przez Jasiewicza (2007), ale i jego zdaniem jest to koncepcja w analizowanym przypadku mało prawdopodobna.

Nowsze badania wachlarzy rozrzutu odnoszą się niemal wyłącznie do materiału krótkiego transportu (np. Gilberg, 1965) i wykonywane są najczęściej w ramach poszukiwań złóż surowców i kartowania geochemicznego (por. m.in. Kujansuu i Saarnisto, 1990; McClenaghan i in., 2001; Cummings i in., 2011). Większość stref rozrzutu opisywanych w Szwecji i Finlandii ma stosunkowo mały zasięg, wynoszący najczęściej kilka do kilkudziesięciu kilometrów (Gilberg, 1965; Salonen, 1986, 1987).

Sektor zajmowany przez pojedynczy wachlarz rozrzutu ma na ogół kąt rozwarcia około $10^{\circ}$ (Salonen, 1986). Szersze kąty rozwarcia, sięgające nawet ponad $90^{\circ}$, powstają w wyniku nakładania się stref rozrzutu powstałych w kilku epizodach ruchu lodu o zróżnicowanych kierunkach. W niektórych przypadkach dostrzegalny jest wzrost kąta rozwarcia wraz z rosnącą odległością od wychodni. Taki charakter mają wachlarze rozrzutu przedstawione przez Korna (1927) - zwłaszcza strefa rozprzestrzenienia eratyków skał wulkanicznych ze Smålandu i Dalarny. Wydaje się, że wynika to przynajmniej w części z przyjętej metody badawczej, tj. dokumentacji rozmieszczenia konkretnych znalezisk eratyków w terenie i nieproporcjonalnego rozkładu stanowisk badawczych. Potwierdzenie stanowi wachlarz rozrzutu skał z rowu Oslo, który jest wyraźnie „powcinany". Omija np. Meklemburgię i Pomorze Zachodnie, a wchodzi daleko na wschód w głąb Wielkopolski, aż po okolice Poznania i na Dolny Śląsk po Wrocław. Znacznie bardziej regularne strefy rozrzutu, obejmujące prawie całe terytorium dzisiejszej Polski, Korn przypisał granitoidom z Dalarny, Upplandu i Smålandu oraz porfirom z Dalarny 
i Smålandu. Rozszerzanie się wachlarzy rozrzutu w południowej Fennoskandii może stanowić wyraz narastającej zmienności kierunków ruchu lodu oraz nasilającego się wpływu innych czynników transportu. Na południu właściwie wszystkie skały mogły być transportowane na zachód przez pre- lub interglacjalne rzeki, a to dodatkowo zwiększato ich zasięg równoleżnikowy. Udział bardzo różnych środowisk transportu (glacjalnego, fluwioglacjalnego, rzecznego) w kształtowaniu się stref rozrzutu wykazano już wielokrotnie (np. Cummings i in., 2011, por. również rozdz. 8 i 9). Konstruując dla północnej Polski schemat analogiczny do przedstawionego na rys. 4.2 należałoby dodatkowo uwzględnić jeszcze transport morski.

Według Korna (1927) skały o wychodniach położonych w południowej Fennoskandii mają szersze wachlarze rozrzutu (większy kąt rozwarcia), aniżeli eratyki wywodzące się z odsłonięć leżących dalej na północ, np. w Dalarnie. Logika i analiza dynamiki czaszy lodowej nakazywałyby raczej rozszerzenie wachlarza rozrzutu skał z Dalarny, gdyż bliżej linii podziału lodu możliwa jest większa zmienność kierunków ruchu, uwarunkowana np. przemieszczaniem się tej linii na skutek zmian klimatycznych. Powyższy pogląd potwierdzają badania przeprowadzone w Szkocji, z których wynika, że mikrogranity o wychodni zlokalizowanej w strefie dawnej linii podziału lodu mają bardzo szeroki wachlarz rozrzutu, bo obejmujący aż $90^{\circ}$ (Cornish, 1983). Duża zmienność warunków przestrzenno-termicznych w strefie bliskiej linii podziału lodu może doprowadzić do ukształtowania się bardzo nieregularnych stref rozrzutu eratyków, jakie opisano w Kanadzie (Trommelen i in., 2013) - rys. 11.1. Uzyskane przez Trommelen i in. (op. cit.) strefy mają „amebowaty” kształt, co po części zgodne jest z przytoczonymi wcześniej starszymi badaniami. Powyższe analizy odnoszą się - co prawda - do eratyków bliskiego transportu, ale stwierdzona zmienność kierunków z pewnością wpłynęła również na daleki transport materiału skalnego. Wskazują na to kształty wachlarzy rozrzutu w lądolodzie laurentyjskim zestawione przez Cummingsa i in. (2011).

Analogicznie możemy wnioskować, że nawet niewielka zmiana kierunku ruchu lodu w środkowej Szwecji (blisko linii podziału lodu) powinna była spowodować bardzo duże rozszerzenie kąta rozwarcia strefy rozrzutu, podczas gdy identyczna zmiana na południu Skandynawii, a tym bardziej w północnej Polsce, miałaby znikomy wpływ na ten kąt. Korn (1927) łączył graficznie szerokie strefy występowania konkretnych eratyków na Niżu Środkowoeuropejskim z ich wychodniami w Fennoskandii. W rezultacie mniejszy kąt rozwarcia strefy rozrzutu eratyków wywodzących się ze środkowej Fennoskandii stanowi tylko geometryczny wyraz większej odległości pomiędzy miejscem alimentacji i obszarem depozycji, aniżeli w przypadku skał południowoszwedzkich.

Wachlarze rozrzutu Korna były obarczone błędem wynikającym z bardzo zróżnicowanej częstotliwości występowania różnych typów skał. Symptomatyczne jest rysowanie zasięgu skał norweskich daleko w głąb dzisiejszego terytorium Polski, podczas gdy strefa rozrzutu bazaltów ze Skanii miała sięgać tylko po ciągnące się wzdłuż zachodniej granicy Polski części Pomorza Zachodniego i Ziemi Lubuskiej. Współczesny stan wiedzy każe zweryfikować te poglądy, ponieważ przemieszczone bez udziału człowieka narzutniaki norweskie nie sięgają tak daleko (np. Schulz, 1973; Czubla, 2001; Górska, 2003b), podczas gdy bazalty ze Skanii znajdowane są znacznie dalej na wschodzie (np. Czubla, 
2001, 2006). Skały z Wysp Alandzkich swoją bardzo szeroką strefę rozrzutu (Korn, 1927) zawdzięczają zapewne licznemu występowaniu i łatwej identyfikacji w osadach plejstoceńskich. Pojawiły się też obserwacje, które skłaniają do rozszerzenia obszaru rozrzutu skał alandzkich aż po Wyspy Brytyjskie (Milthers, 1950; Ehlers, 1988).

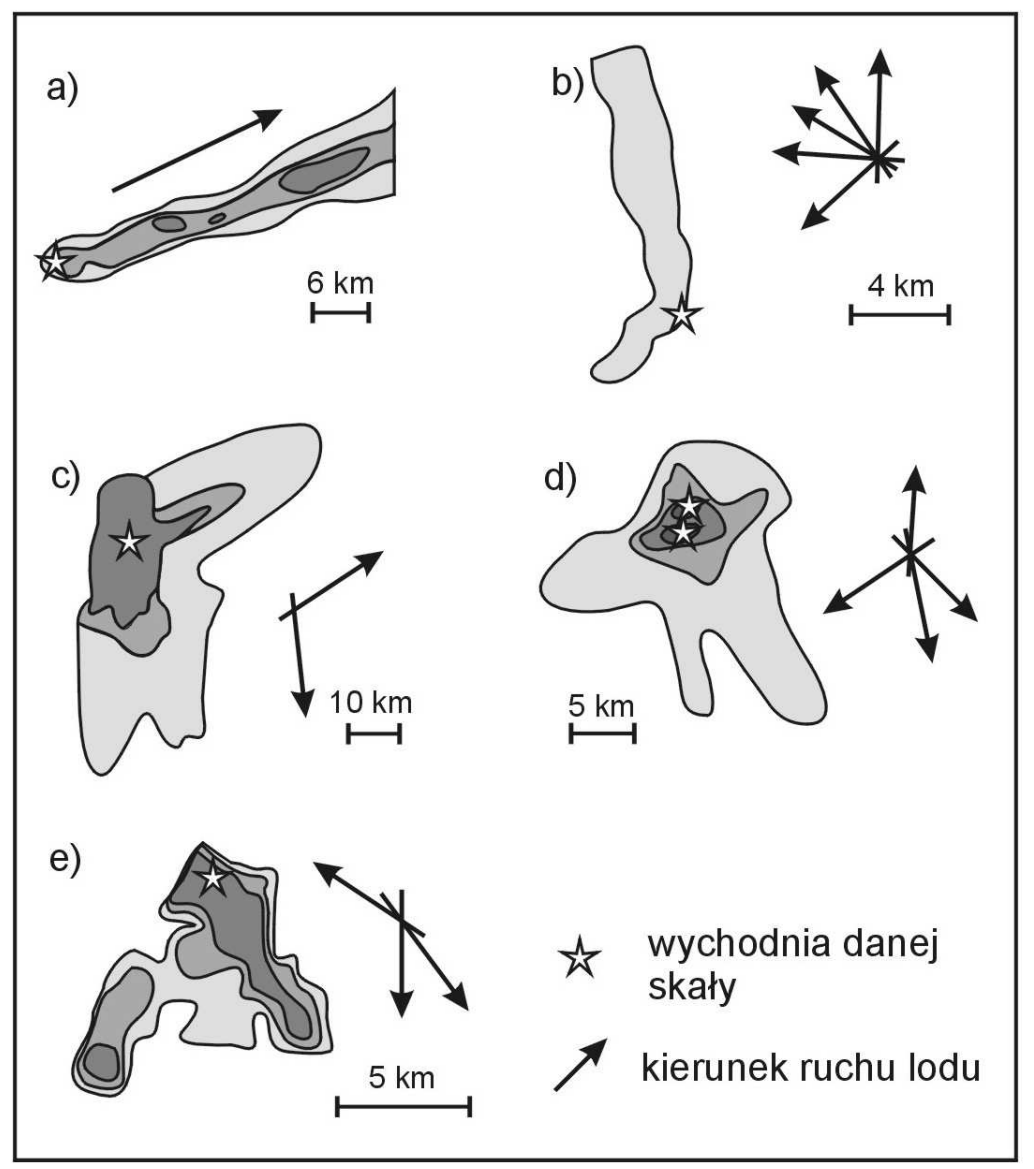

Rys. 11.1. Charakterystyczne typy stref rozrzutu eratyków w glinie wyróżniane w Kanadzie (według Trommelen i in., 2013, zmienione): a) wstęgowa strefa rozrzutu, Strange Lake, Labrador; za Batterson, 1989, b) nałożona (palimpsestowa) strefa rozrzutu, Contwoyto fan, Nunavut; za Stea i in., 2009,

c) nałożona (palimpsestowa) strefa rozrzutu, Gaspesie, Quebec, za Charbonneau i David, 1993,

d) amebowata strefa rozrzutu, Garden of Eden, Nova Scotia, za Turner i Stea, 1987, e) amebowata strefa rozrzutu, Beaver River till, Nova Scotia, za Stea i Finck, 2001

Figure 11.1. Examples of common dispersal patterns in till, from various detailed studies in Canada: a) ribbon dispersal, Strange Lake, Labrador; after Batterson, 1989, b) palimpsest dispersal, Contwoyto fan, Nunavut; after Stea et al., 2009, c) palimpsest dispersal, Gaspesie, Quebec, after Charbonneau \& David, 1993, d) amoeboid dispersal, Garden of Eden, Nova Scotia, after Turner \& Stea, 1987, e) amoeboid dispersal, Beaver River till, Nova Scotia, after Stea \& Finck, 2001; stars represent the bedrock source (according to Trommelen et al., 2013, modified) 
Większość wachlarzy rozrzutu rysowanych przez Korna (1927) i jego poprzedników obejmowała tylko zachodnią i środkową Europę. Równolegle prowadzono jednak badania i na wschodzie kontynentu (np. Czirvinskij, 1914 - fide Gudelis, 1971 - str. 16). W północno-wschodniej Europie lądolód rozprzestrzeniał się z dwóch lub trzech ośrodków, tj. Fennoskandii, Nowej Ziemi i Uralu. Zasięg ich oddziaływania można przeanalizować w oparciu o wachlarze rozrzutu eratyków (m.in. Yakovlev, 1939, 1953; Yakovleva, 1940, 1956, 1961, 1963, 1966; Andreicheva i Marchenko-Vagapova, 2007; Andreicheva, 2013). Wyróżnienie i analiza rozmieszczenia skał przewodnich, charakterystycznych dla poszczególnych lobów lądolodu fennoskandzkiego (białomorskiego, oneskiego, ładoskiego) pozwoliła ustalić strefy ich zasięgu (Yakovleva, 1956).

Zdaniem Gaigalasa (1971b) granice wachlarzy rozrzutu powinny być wyznaczane w oparciu o co najmniej 1\%-owy udział danego eratyka w całkowitej liczbie analizowanych głazów narzutowych. Autor nie precyzuje, czy chodzi o 1\% wśród wszystkich eratyków krystalicznych, czy tylko wśród zidentyfikowanych eratyków wskaźnikowych należących do trzech podstawowych kategorii (przewodnie główne, drugorzędne i towarzyszące). Raczej nie wydaje się prawdopodobne, żeby chodziło o wszystkie skały krystaliczne, ponieważ w takim przypadku metoda wykluczyłaby rysowanie wachlarzy rozrzutu dla większości skał przewodnich (tylko najpospolitsze miałyby szanse osiągnąć minimalny próg 1\%). Kolejnym krokiem miałoby być wyznaczenie stref maksymalnego rozprzestrzenienia dla poszczególnych eratyków wskaźnikowych, które pozwoliłyby określić drogę napływu mas lodowych (Gaigalas, op. cit.). W zbliżonym kierunku prowadziły analizy na terytorium Białorusi, gdzie w oparciu o m.in. strefy rozrzutu eratyków wydzielono 3 duże regiony litoglacjalne (w sumie 15 litoprowincji) i dla każdego z nich określono główne obszary alimentacyjne lądolodu (Astapova, 1993).

Interpretację strefy rozrzutu eratyków w obrazie trójwymiarowym oraz jej stosunku do obszaru źródłowego przedstawił DiLabio (1990). Z jego obserwacji wynika, że strefa ta wznosi się stopniowo w kierunku płynięcia lodowca pod kątem $1-3^{\circ}$. Do odmiennych wniosków prowadzą rozważania Rötlisbergera (1968), który sugeruje stopniowe dociskanie przemieszczającego się lodu do podłoża i koncentrację głazików w stopie lądolodu (por. rys. 8.1). Strefa rozrzutu powinna zatem przebiegać poziomo, a jeśli, np. na skutek deformacji wewnętrznych lodu, analizowane eratyki znalazły się w nieco wyższej strefie lądolodu, to przy udziale ablacji w stopie powinny stopniowo zbliżać się do podłoża, czyli strefa rozrzutu byłaby nachylona zgodnie z kierunkiem ruchu lodu. Przedstawiona różnica wynika zapewne z odmiennej oceny udziału ślizgu bazalnego i deformacji wewnętrznych w ruchu lodowca. Koncepcja DiLabio odnosi się raczej do ruchu odbywającego się głównie na drodze deformacji wewnętrznych i przy znikomym lub zerowym udziale ablacji w stopie.

Pojedyncza transgresja lądolodu powinna doprowadzić do promienistego rozprzestrzenienia się eratyków z centrum Fennoskandii ku jej obrzeżom - w sposób analogiczny do tworzenia się stref rozrzutu typu Dubawnt Lake (sensu Dyke i Morris, 1988). Nakładanie się na siebie stref występowania eratyków wywodzących się z różnych 
regionów Fennoskandii dowodzi jednak znacznej zmienności czasowej kierunków napływu lodu. Nic nie wskazuje na to, żeby to zróżnicowanie kierunków transgresji było wyrazem zmienności przebiegu strumieni lodowych. Zakładana przez większość autorów intensywna erozja w podłożu takiego strumienia (np. Sharp, 1988; Smith i in., 2007; Dyke, 2008) prowadziłaby raczej do stabilizacji raz zaistniałego układu (dzięki przeformowaniu rzeźby podłoża), aniżeli do jego zmian. W kolejnych zlodowaceniach rzeźba sprzyjałaby odtwarzaniu się poprzedniego układu strumieni lodowych, a to z kolei musiałoby doprowadzić do ukształtowania się w osadach glacjalnych bardzo wyraźnych stref rozrzutu eratyków typu Boothia oraz Dubawnt Lake, uznawanych za ważny wskaźnik charakteru ruchu lodu (Dyke i Morris, 1988). W rzeczywistości wachlarze rozrzutu eratyków wywodzących się z różnych regionów Fennoskandii w znacznym stopniu pokrywają się. Dystrybucja eratyków w osadach glacjalnych może być zatem traktowana jako wiarygodny argument przeciwko dłuższemu funkcjonowaniu strumieniowego modelu dynamiki lądolodu. Tak dużego przemieszania materiału skalnego pochodzącego z różnych regionów Fennoskandii nie da się w przekonywujący sposób wyjaśnić wyłącznie inkorporacją materiału przyniesionego przez starsze lądolody, bądź rozwleczonego uprzednio przez systemy rzeczne.

Najlepsze warunki do wyznaczania stref rozrzutu występują na obszarach, gdzie lądolód przemieszczał się po twardym podłożu. W Europie dotyczyło to przede wszystkim Fennoskandii i Wysp Brytyjskich. Analiza obszarów rozrzutu eratyków dalekiego transportu na Szetlandach i Orkadach dostarczyła danych, które wraz z innymi obserwacjami przyczyniły się do uściślenia stosunków przestrzennych pomiędzy brytyjską i fennoskandzką czaszą lodową (Bradwell i in., 2008). Interesujących wyników dostarczyły również badania stref rozproszenia eratyków w zasięgu irlandzkiej czaszy lodowej (Greenwood i Clark, 2009).

W obrębie wachlarza rozrzutu, wraz z odległością od wychodni, następuje rozpraszanie skał. Strefa rozproszenia może mieć bardzo zróżnicowany zasięg od mniejszego niż kilometr (Averill, 1990) do ponad tysiąca km (Clark, 1987; Prest i in., 2000). Stwierdzono również współwystępowanie w tej samej jednostce glin krótkich i długich szlaków rozrzutu (Finck i Stea, 1995). Skład gliny odzwierciedla stopień rozproszenia. Krótki transport skutkuje istnieniem związku pomiędzy składem gliny i rodzajem skał podłoża (por. Clark, 1987), co łatwo wykazać dla obszarów tarcz krystalicznych rys. 9.3. Dalej na południe, gdzie w podłożu dominują starsze osady glacjalne lub luźne osady preglacjalne, udowodnienie takiej zależności jest już znacznie trudniejsze.

Rozpraszanie materiału transportowanego w lodzie jest uwarunkowane szeregiem czynników, m.in. wielkością wychodni, rzeźbą podłoża, bazalną prędkością lodu, właściwościami fizycznymi inkorporowanych skał (np. odporność na abrazję, wielkość i kształt składników, porowatość etc.) - por. m.in. Holmes (1952), Gilberg (1965, 1967), Dreimanis i Vagners (1969), Haldorsen (1977), Boulton (1979), Clark (1987). Największą odpornością charakteryzują się skały krystaliczne, za nimi są piaskowce, skały węglanowe i łupki. Skały luźne w stanie zamarzniętym mają odporność zbliżoną do łupków, 
ale w literaturze przedmiotowej nie są prezentowane odpowiednie badania porównawcze. Oczywistym jest, że udział konkretnej skały w materiale morenowym jest zależny od powierzchni wychodni (por. np. Harrison, 1960; Peltoniemi, 1985). Wpływ rzeźby na transport i rozproszenie materiału transportowanego przez lodowce był szeroko analizowany (m.in. Holmes, 1952; Gilberg, 1965; Gross i Moran, 1971; Shilts, 1973, 1976; Haldorsen, 1977). W obszarach o zróżnicowanym ukształtowaniu powierzchni transport wzdłuż dolin odbywa się na znacznie większą odległość niż na wzniesieniach.

Ze względu na bardzo dużą odległość, jaka dzieli obszar alimentacji kolejnych lądolodów fennoskandzkich i strefę depozycji osadów glacjalnych w Polsce, analiza wachlarzy rozrzutu eratyków nie może dostarczyć precyzyjnych informacji na temat szlaków transportu w konkretnych zlodowaceniach. Transport odbywał się zapewne w kilku etapach i współczesne obszary występowania poszczególnych eratyków na Niżu Środkowoeuropejskim są wypadkową bliżej nieokreślonej liczby wcześniejszych epizodów transportu (por. Lüttig i Meyer, 2007). W konsekwencji obszar współczesnej Polski znalazł się w strefie rozrzutu skał z Dalarny, Smålandu, Upplandu, Wysp Alandzkich, Ångermanlandu, środkowego Bałtyku oraz częściowo Bornholmu, Skanii i południowo-zachodniej Finlandii. Przeprowadzone badania potwierdziły zatem opinię funkcjonującą już w literaturze przedmiotowej, np. Górska (2000; Górska-Zabielska, 2008), Czubla (2001, 2006), Gałązka (2004b). 


\section{WIETRZENIE GLIN LODOWCOWYCH I JEGO WPŁYW NA BADANIA ERATYKÓW}

Istotny wpływ na skład frakcji żwirowej i głazowej glin lodowcowych wywiera wietrzenie - zwłaszcza chemiczne. Nasilało się ono podczas interglacjałów i interstadiałów, ponieważ podwyższone temperatury sprzyjają większości procesów wietrzeniowych. Jednym ze skutków wietrzenia jest wzrost udziału frakcji ilastej uwarunkowany m.in. hydrolizą skaleni. W efekcie tego procesu kryształy minerałów krzemianowych (głównie wspomnianych skaleni) o bardzo zróżnicowanych rozmiarach przechodzą w agregat bardzo drobnych ziaren kaolinitu.W trakcie hydrolizy uwalniana jest również krzemionka.

Przypowierzchniowe warstwy osadów glacjalnych podlegają utlenianiu. Proces ten w glinach objawia się przede wszystkim zmianą zabarwienia osadu z szarego na brązowawy, czerwonawy lub żółtawy. Odmienna kolorystyka jest związana ze zmianą stopnia utlenienia żelaza z drugiego na trzeci. Związki żelaza na trzecim stopniu utleniania przyjmują najczęściej zabarwienia brązowe, rdzawe, czerwone i żółtawe. Zabarwienie glin bywa traktowane jako ważny wskaźnik stopnia zwietrzenia. Warstwy glin lub ich części zabarwione na kolory brązowawe, żółtawe i czerwonawe interpretowane są jako zwietrzałe, a szare jako niezwietrzałe (np. Hiscock i Tabatabai Najafi, 2011). Strefę wietrzenia glin Elsterianu we wschodniej Anglii wspomniani autorzy rozciągają do głębokości około $5 \mathrm{~m}$. Miąższość zwietrzałej serii osadów glacjalnych może być jednak zarówno znacznie większa, jak i dużo mniejsza od wskazanej wartości. Na dodatek w obrębie tej samej warstwy gliny, w zależności od warunków lokalnych (np. tekstura i struktura osadu, skład mineralny i chemiczny) mogą występować strefy o bardzo zróżnicowanym zasięgu pionowym procesów wietrzeniowych. Opieranie się na zabarwieniu gliny jako głównym wskaźniku stopnia zwietrzenia może być bardzo mylące. W przypadku niegrubych pokładów glin na obszarach trwale zawilgoconych może dojść do oglejenia (żelazo ulega wówczas redukcji) mocno zwietrzałej gliny, a to skutkuje możliwością błędnego potraktowania jej jako osadu niezwietrzałego.

Do przyspieszenia wietrzenia przyczynia się rozwój roślinności, uwalniającej do podłoża ditlenek węgla oraz kwasy organiczne. Obecność $\mathrm{CO}_{2}$ ułatwia rozpuszczanie węglanów. Woda zawierająca rozpuszczone związki wapnia infiltruje w głębsze warstwy podłoża, a następnie wytrąca je na większej głębokości w postaci konkrecji. Eksperymentalnie udowodniono, ze obecność jonów wodorowych przyspiesza hydrolizę minerałów krzemianowych (White i Blum, 1995).

W kontekście badań eratyków ważniejszy jest stan zaawansowania wietrzenia frakcji żwirowej w glinie lodowcowej, aniżeli gliny jako całości. W trakcie prowadzonych badań autor wielokrotnie zetknął się z sytuacją, kiedy w glinie, obok klastów bez istotnych oznak wietrzenia, występowały liczne głaziki (identyczne pod względem litologicznym, a nawet reprezentujące skały odporniejsze na wietrzenie) mocno zwietrzałe, a niekiedy 
nieomal rozpadające się przy wydobywaniu ze ściany. Wskazuje to na inkorporację przez lądolód zwietrzeliny preglacjalnej lub interglacjalnej już w Fennoskandii, bądź wchłonięcie zwietrzałych osadów pozostawionych przez starsze nasunięcia lodowca. Rozstrzygnięcie, z którym konkretnym przypadkiem mamy do czynienia nie jest możliwe bez precyzyjnych badań geochemicznych.

Spośród skał wykorzystywanych w badaniach litostratygraficznych osadów glacjalnych najbardziej podatne na wietrzenie są, obok niektórych typów lokalnych skał osadowych, skały węglanowe. Ogólnie przyjmuje się, że dolomity są odporniejsze aniżeli wapienie, ale często pojawiają się wątpliwości, czy zawsze jest to zgodne z rzeczywistością. Zdaje się na to wskazywać wyższa twardość (3,5-4 w skali Mohsa) minerału dolomitu - głównego składnika skały o tej samej nazwie, niż kalcytu (3 w skali Mohsa), będącego podstawowym składnikiem większości wapieni. Aragonit (rombowa odmiana polimorficzna $\mathrm{CaCO}_{3}$ ), mający twardość porównywalną z dolomitem, w paleozoicznych i mezozoicznych skałach węglanowych już nie występuje. Już dawno uległ rozpuszczeniu lub w efekcie rekrystalizacji przekształcił się w kalcyt. Łatwo zauważalna i powszechnie znana jest również wyższa odporność na działanie kwasów dolomitu aniżeli kalcytu i aragonitu - wykorzystywana do rozróżniania wspomnianych minerałów i zbudowanych z nich skał. Zróżnicowanie odporności na wietrzenie fizyczne potwierdzają badania modelowe. Kalcyt cechuje się mniejszą odpornością na mikrospękania uwarunkowane wahaniami temperatury (Siegesmund i in., 2000; Weiss i in., 2002). Badania przeprowadzono na próbkach marmurów kalcytowych i dolomitowych, co nie pozostaje bez znaczenia, bo w ten sposób udało się pozyskać materiał o bardzo podobnej budowie wewnętrznej. W trakcie podgrzewania lub chłodzenia w kalcycie wcześniej zaczynały tworzyć się mikrospękania (uwarunkowane naprężeniami generowanymi w efekcie rozszerzalności cieplnej blastów) aniżeli w dolomicie. Na dodatek te same zmiany termiczne (wahania temperatury) powodowały powstawanie spękań o większym zasięgu w marmurach kalcytowych niż w dolomitowych. Autorzy zauważają jednak, że zmienność propagacji mikrospękań w warunkach stresu termicznego jest większa dla jednego minerału, jeżeli występują w nim duże różnice teksturalne, aniżeli pomiędzy dwoma analizowanymi minerałami, jeżeli cechują się jednakową teksturą (Weiss i in., 2002). Powyższe badania wykazały wyższą odporność marmurów dolomitycznych na wietrzenie termiczne. Zróżnicowanie teksturalne wietrzejącej skały wpływa jednak znacząco na przewodnictwo cieplne i tym samym staje się ważniejszą (niż skład mineralny) zmienną, warunkującą odporność marmurów na wietrzenie fizyczne.

Podobnie zróżnicowane wyniki uzyskano w badaniach odporności kalcytu i dolomitu na rozpuszczanie. Zmierzona w warunkach laboratoryjnych, a więc $w$ temperaturze pokojowej, przy niskim pH i przy małym nasyceniu roztworu w odniesieniu do węglanów, rozpuszczalność dolomitów okazała się o kilka rzędów wielkości niższa od rozpuszczalności kalcytu (Chou i in., 1989; Morse i Arvidson, 2002). Najnowsze badania zweryfikowały nieco powyższe dane. $\mathrm{W}$ temperaturze $+20^{\circ} \mathrm{C}$ i przy $\mathrm{pH} 3,8$ rozpuszczalność kalcytu okazała się około 8 do 10 razy wyższa od rozpuszczalności dolomitu, a przy pH 5,5 różnica ta maleje do 2-2,2 razy (Franke, 2009). 
Obserwacje terenowe w wielu przypadkach zaprzeczają jednak twierdzeniu o wyższej odporności dolomitu na procesy wietrzeniowe. Na bałtyckim wybrzeżu Rosji i Litwy (od płw. Sambia aż po granicę z Łotwą) zaobserwowano w żwirach plażowych bardzo niski udział otoczaków dolomitowych (Jurgaitis, 1970), pomimo położenia obszaru badań w bliskim sąsiedztwie wychodni dolomitów. Wśród skał węglanowych na wapienie przypadało tam około 90\%, na dolomity zaś zaledwie 0,5 do 3\% przeanalizowanych ziaren. Badania prowadzono we frakcji 0,5-20 mm. Duże wahania zawartości dolomitów w glinach Dolnej Saksonii tłumaczone są wysoką podatnością tej skały na wietrzenie (Meyer i Lüttig, 2007). Podobnie w części prób przeanalizowanych przez autora wietrzenie szybciej wyeliminowało dolomity aniżeli wapienie. W glinach Polski Środkowej dolomity stanowiły średnio 13,09\% ogółu skał węglanowych, przy czym w glinach opisywanych wówczas jako odrzańskie wskaźnik ten wynosił 8,57\%, a w warciańskich 13,82\% (Czubla, 2001). W przeanalizowanych przez Meyera (1998) pryzmach kamieni polnych w okolicach Zawidowic na południe od Oleśnicy - mimo ewidentnie wschodniego pochodzenia udokumentowanego nie tylko skałami krystalicznymi, ale i licznymi paleozoicznymi wapieniami - w ogóle nie znaleziono dolomitów. To wskazuje na ich eliminację w procesach wietrzeniowych, którym nie uległy znacznie, na pozór, podatniejsze wapienie.

Jedną z przyczyn wspomnianej niezgodności obserwacji terenowych z analizami laboratoryjnymi mogą być różnice teksturalne wapieni i dolomitów. Większość skał węglanowych pochodzenia bałtycko-fennoskandzkiego nie podlegała procesom metamorficznym, lecz tylko dość intensywnej kompakcji i rekrystalizacji. W efekcie wapienie paleozoiczne mają teksturę zbitą, w której przestrzenie porowe dostrzegalne makroskopowo występują jedynie wyjątkowo. W przeciwieństwie do syngenetycznych zazwyczaj wapieni, dolomity są pochodzenia diagenetycznego lub epigenetycznego, co oznacza, że utworzyły się z pierwotnych wapieni w procesach metasomatycznych. Zastępowanie części jonów $\mathrm{Ca}^{2+}$ jonami $\mathrm{Mg}^{2+}$ w strukturze krystalicznej kalcytu, prowadzące do przekształcenia w dolomit, wiąże się z redukcją objętości o kilka do maksymalnie kilkunastu procent. W przypadku dolomitów diagenetycznych na ogół nie ma to znaczenia dla tekstury skały, ponieważ proces przekształcenia zachodzi w osadzie niezlityfikowanym. Dolomityzacja epigenetyczna przebiega w obrębie skały już zlityfikowanej. Front dolomityzacji bywa bardzo nieregularny, ponieważ proces ten postępuje strefowo, wykorzystując zróżnicowanie budowy wewnętrznej osadu, tj. porowatości, uziarnienia, warstwowania oraz składu mineralnego i innych cech. W związku z tym redukcja miąższości całej warstwy lub jej fragmentów jest już prawie niemożliwa. W efekcie, spadek objętości będący skutkiem dolomityzacji, objawia się porowatością skały pochodnej. Przestrzenie porowe w wielu przypadkach widoczne są nawet makroskopowo. Stanowią one drogę wnikania (migracji) roztworów wodnych w głąb skały, jak również strefę ułatwionej wymiany ciepła z otoczeniem. Przypuszczalnie to właśnie porowata tekstura dolomitów epigenetycznych jest przynajmniej częściowo odpowiedzialna za przyspieszone (w stosunku do wapieni) wietrzenie dolomitów w osadach plejstoceńskich Polski. 
Dodatkowych przesłanek pozwalających wyjaśnić nadreprezentację wapieni w stosunku do dolomitów w próbach pobranych z nadwietrzałych glin dostarczyły badania laboratoryjne. Stała równowagi z roztworem nasyconym dla dolomitu w temperaturze poniżej $25^{\circ} \mathrm{C}$ przewyższa analogiczną wartość wyznaczoną dla kalcytu, a to oznacza, że dolomit jest potencjalnie łatwiej rozpuszczalny niż kalcyt w obszarach o niskiej średniej temperaturze rocznej (Langmuir, 1997). W odniesieniu do polskich warunków w glebie i zwietrzelinie temperaturę rzędu $20-25^{\circ} \mathrm{C}$ (w której prowadzona jest większość eksperymentów laboratoryjnych) można zaobserwować jedynie w lecie i to tylko w najpłytszej warstwie. Głębiej temperatura jest znacznie niższa (w warstwie izotermicznej rzędu $6-7^{\circ} \mathrm{C}$ ), co sprzyja przyspieszonemu wietrzeniu analizowanego minerału. Tym bardziej trudno spodziewać się występowania wysokich temperatur, spowalniających rozpuszczanie dolomitu w stosunku do kalcytu, w strefie wietrzenia w plejstocenie. Badania geochemiczne wód glebowych w glebach rozwiniętych na osadach glacjalnych w Michigan potwierdziły pogląd, że w warunkach dość chłodnego klimatu dolomit może rozpuszczać się intensywniej niż kalcyt (Jin i in., 2008). Podobne wnioski wysnuto w oparciu o badania w dorzeczach Rzeki Św. Wawrzyńca i Dunaju (Szramek i in., 2007). Poza niską temperaturą pozytywny wpływ na wzrost rozpuszczalności dolomitów ma również stężenie $\mathrm{CO}_{2}$ w wodzie - zwłaszcza w sytuacji, kiedy te dwa czynniki się sumują (Busenberg i Plummer, 1982). Szybsze ługowanie dolomitu aniżeli węglanu wapnia z pokryw martwicowych wytworzonych w obrębie torfowiskowych kopuł źródliskowych stwierdzono też w Polsce - Wardzyń na południe od Łodzi (Ziułkiewicz i in., 2012). Znikomy udział dolomitów w próbach pobranych głównie w osadach fluwioglacjalnych Pojezierza Meklemburskiego (Górska-Zabielska, 2007b) stanowi zapewne efekt wyeliminowania większości ziaren tej skały przez wietrzenie.

W odniesieniu do przytoczonych obserwacji i badań bardzo trudno wyjaśnić odnotowany w centralnej części Pojezierza Mazurskiego podwyższony udział dolomitów i odpornych skał północnych w glinach spływowych w stosunku do ich zawartości w równowiekowych (?) glinach z wytopienia (Lisicki, 1998, 2003). Wspomniany autor zasugerował, że może to być cecha charakterystyczna dla tego obszaru Polski, ale nie wyjaśnił, co do tego doprowadziło, ani dlaczego podobne proporcje grup petrograficznych nie powtarzają się w innych regionach Polski (Lisicki, 2003). Analiza podatności skał na wietrzenie kazałaby raczej przypuszczać, że w osadach wzbogaconych w odporne skały krystaliczne zawartość dolomitów powinna ulec względnemu obniżeniu. Logicznym wyjaśnieniem może być założenie, że gliny spływowe ukształtowały się akurat $w$ tym regionie $z$ materiału morenowego dalekiego transportu o specyficznym składzie petrograficznym, podczas gdy gliny z wytopienia zawierają głównie materiał transportowany $w$ facji bazalnej lądolodu. Ten ostatni typ transportu wiąże się z wielokrotną redepozycją materiału, co mogło wpłynąć na zmniejszenie udziału bardziej podatnego składnika, jakim są dolomity. Dodatkową wskazówką mogłoby być określenie stosunków pomiędzy mniej i bardziej odpornymi na wietrzenie skałami krystalicznymi. W materiale redeponowanym udział skał mało odpornych powinien być wyraźnie obniżony w stosunku do „świeżych” osadów. Procedura badawcza przyjęta przez 
Lisickiego (op. cit.) nie pozwala jednak na wyróżnianie mniej lub bardziej odpornych na wietrzenie skał krystalicznych, a wręcz przeciwnie - każe je nawet ujmować razem z piaskowcami (Trembaczowski, 1961, 1967; Rzechowski, 1971; Kenig, 1998).

Większość minerałów skał magmowych i metamorficznych jest znacznie bardziej odporna na procesy wietrzeniowe aniżeli minerały węglanowe. Skalenie potasowe w temperaturze $+20^{\circ} \mathrm{C}$ i przy pH 5,5 mają rozpuszczalność prawie 300-krotnie, a plagioklazy około 240 razy mniejszą od kalcytu (Franke, 2009). Kwarc jest prawie nierozpuszczalny w wodzie. $W$ efekcie głaziki skał krystalicznych są mniej podatne na wtórną selekcję, prowadzącą do zmiany składu materiału morenowego. Ustalenie rankingu odporności najpospolitszych minerałów ma charakter wyłącznie orientacyjny, ponieważ wpływ na tempo wietrzenia ma bardzo wiele zmiennych, zależnych nie tylko od samego minerału i jego składu, ale i od wielu czynników zewnętrznych, które w różnym stopniu, a niekiedy i w odmiennym kierunku mogą wpływać na przemiany danego minerału. Zazwyczaj przyjmuje się, że bardzo mało odporne są krzemianowe minerały femiczne (w kolejności wzrastającej odporności: oliwiny - pirokseny - amfibole), nieco odporniejsze skalenie (jw.: plagioklazy wapniowe - plagioklazy sodowe - skalenie potasowe), następnie muskowit, wreszcie najodporniejszy pozostaje kwarc. Mimo że badania laboratoryjne wskazują na zbliżoną odporność skaleni potasowych i plagioklazów (Blum i Stillings, 1995), badania terenowe jednoznacznie wykazały, że plagioklazy wietrzeją znacznie szybciej niż skalenie potasowe (White i in., 2001). Studia eksperymentalne potwierdziły znane już od wielu lat obserwacje, że podatność na wietrzenie plagioklazów rośnie wraz z udziałem cząsteczki anortytowej (plagioklaz wapniowy) i z obniżającym się pH środowiska (Blum i Stillings, op. cit.).

Znacznie trudniejsze byłoby uszeregowanie typów skał według odporności na procesy wietrzeniowe. Zmienność składu mineralnego oraz budowy wewnętrznej wpływają na duże przedziały zróżnicowania odporności skał należących do tej samej grupy petrograficznej, np. granitoidów. Granitoidy bogate w biotyt i plagioklazy, jak np. niektóre skały z Upplandu dość łatwo ulegają rozpadowi ziarnistemu w efekcie selektywnego chemicznego wietrzenia kryształów biotytu. W zwietrzałych glinach tworzą często ziarniste skupienia kryształów kwarcu, częściowo zmienionych skaleni i związków żelaza, będących produktem rozkładu biotytu, które przy próbie wyodrębnienia z gliny zupełnie się rozsypują. Uboższe w biotyt granitoidy ze Smålandu w o wiele mniejszym stopniu podlegają przemianom $w$ wietrzejących osadach glacjalnych, dzięki czemu są znacznie tatwiejsze do zidentyfikowania od poprzednich.

Na ogół skały metamorficzne są bardziej podatne na wietrzenie niż skały magmowe. Wpływa na to powszechnie występująca tekstura kierunkowa, podkreślona często obecnością łyszczyków - zwłaszcza biotytu. Nie ulega wątpliwości, że skały bogate w biotyt, a do takich należy większość gnejsów, łatwiej ulegają wietrzeniu, aniżeli ich odpowiedniki uboższe $w$ ten minerał. Wynika to $z$ faktu, że biotyt jest jednym z najpodatniejszych na wietrzenie chemiczne pospolitych minerałów skałotwórczych skał magmowych kwaśnych i wielu skał metamorficznych. Skały bogate w biotyt, zwłaszcza gnejsy i łupki łyszczykowe, w intensywnie zwietrzałych glinach zachowują się w postaci 
skupień produktów wietrzenia i wyizolowanych odporniejszych minerałów, których nie da się już przyporządkować do konkretnego obszaru alimentacyjnego w Fennoskandii. Przy tak wysokim zaawansowaniu procesów wietrzeniowych skał magmowych i metamorficznych, w glinach na ogół nie ma już składników węglanowych, bądź pozostały tylko nieliczne klasty wapieni o mocno zwietrzałej, porowatej powierzchni, która w wielu przypadkach uniemożliwia jednoznaczną identyfikację konkretnego typu. Dolomitów w takich osadach zwykle zupełnie już nie ma. Badania porównawcze odporności na wietrzenie marmurów kalcytowych i granitów wykazały, że te ostatnie są od 7600 do 69 tysięcy razy (w zależności od rodzaju skaleni i zawartości biotytu) bardziej odporne na ten proces (Franke, 2009).

Podstawowe eratyki przewodnie należą do skał magmowych - w większości cechujących się wysoką odpornością na procesy wietrzeniowe. W związku z tym w trakcie wietrzenia osadów glacjalnych proporcje pomiędzy nimi zmieniają się w niewielkim stopniu. Problem może wystąpić w przypadku skał grubokrystalicznych, które są stosunkowo wrażliwe na duże wahania temperatury. Naprężenia, wynikające z anizotropii rozszerzalności cieplnej, generowane na styku sąsiednich kryształów, szybko prowadzą do rozpadu eratyka na pojedyncze kryształy, a to uniemożliwia jego identyfikację. Zagrożenie dla wiarygodności badań może również stanowić wietrzenie bogatych w biotyt granitoidów - m.in. pochodzących z Upplandu. W miarę wietrzenia zmieniają się proporcje pomiędzy stosunkowo odpornymi skałami plutonicznymi drobnokrystalicznymi i skrytokrystalicznymi wulkanitami, a znacznie łatwiej wietrzejącymi skałami grubokrystalicznymi. Konieczne jest zatem uwzględnianie stopnia zwietrzenia osadu, z którego została pobrana próba, w interpretacji wyników analizy eratyków. Odporność na wietrzenie wybranych krystalicznych eratyków przewodnich przeanalizował Dudziak (1985). Udało mu się wykazać, że skały alandzkie rozpadają się na drobne ostrokrawędziste odłamki, niekiedy możliwe do oznaczenia, a identyfikacja pyterlitów możliwa jest tylko w grubszych frakcjach. Bardziej odporne na wietrzenie są dalarneńskie porfiry, ale występują one głównie w stosunkowo drobnych frakcjach. Dudziak (1985) zaobserwował również, że szare granity (głównie z Upplandu) bardzo łatwo wietrzeją, podczas gdy ich czerwone odpowiedniki ze Smålandu znajdowane są często w postaci świeżych klastów. Obserwacje poczynione przez autora m.in. w Polsce Środkowej potwierdzają słuszność powyższych wniosków.

Skały metamorficzne, znacznie bardziej od magmowych podatne na procesy wietrzeniowe, bardzo rzadko wykorzystywane są w charakterze eratyków przewodnich. Tylko nieliczne spośród nich znajdowane były w badanych przez autora stanowiskach. Najczęściej występowały gnejsy bornholmskie oraz amfibolity z granatami. Powyższe gnejsy są stosunkowo ubogie w biotyt, co zmniejszało prawdopodobieństwo redukcji ich udziału w procesach postdepozycyjnych, amfibolity zaś mają ograniczone znaczenie przewodnie ze względu na występowanie w wielu stanowiskach porozrzucanych w różnych regionach Fennoskandii. Pozostałych skał metamorficznych uznawanych za przewodnie przez niektórych autorów (Hesemann, 1975; Smed, 1994, 2002; Zandstra, 1999) nie napotkano w przeanalizowanych stanowiskach. W związku z tym wpływ 
potencjalnej eliminacji niektórych skał metamorficznych przez wietrzenie na wyniki badań eratyków przewodnich jest bardzo ograniczony i może zostać pominięty. Istnieje natomiast duże niebezpieczeństwo, że wietrzenie może w znaczący sposób wpłynąć na proporcje pomiędzy poszczególnymi grupami skał, wyróżniane w uproszczonych badaniach petrograficznych drobnej frakcji żwirowej.

W największym stopniu wietrzenie wpływa na skład zespołów eratyków bogatych w skały osadowe. Dotyczy to zarówno słabo zdiagenezowanych skał lokalnych, jak i paleozoicznych wapieni i dolomitów. Ich udział szybko maleje wraz z postępem wietrzenia. Reguła ta nie obowiązuje w stosunku do piaskowców północnych. Większość z nich, w następstwie eliminacji skał bardziej podatnych, zwiększa swój względny udział $w$ analizowanych zespołach głazowych.

Zależność składu głazowego od stopnia zwietrzenia osadów opisywał już Hesemann (1933a). Dostrzegł on, że w osadach zwietrzałych udział niektórych typów skał jest wyraźnie wyższy, ale starannie unikał wyraźnego stwierdzenia, że skład głazowy zależy od skali zaawansowania procesów wietrzeniowych. Było to do przewidzenia, skoro większość jego badań bazowała na materiale zebranym z powierzchni terenu, a więc bez wątpienia zwietrzałym (m.in. 1930, 1931a, 1931b, 1933a, 1933b, 1935, 1937, 1938). W tej sytuacji wydaje się, że Hesemann szukał raczej uzasadnienia dla własnej metodyki, aniżeli dążył do jej rzetelnego zweryfikowania. Odmienne stanowisko reprezentował Woldstedt (1954), który słusznie uważał pobór eratyków z powierzchni terenu za wątpliwy metodycznie, ponieważ jego zdaniem tylko glina niezwietrzała zawiera pierwotny i niezmieniony zespół eratyków. W Polsce poglądy Woldstedta, w oparciu o badania przeprowadzone na przedpolu Karpat, poparł Dudziak (1985). Wpływem wietrzenia na skład osadów glacjalnych zajmowali się również m.in. Lamparski (1971), Schuddebeurs (1980) i Hall (1983).

Wietrzenie może w niektórych przypadkach przyczynić się do wzrostu udziału oznaczonych eratyków przewodnich wśród klastów pobranych z osadów glacjalnych. Dotyczy to np. badań Schuddebeursa (1980/1981, 1986) i Zandstry (1983). Należy jednak pamiętać, że osady glacjalne w Holandii są najczęściej odwapnione i silnie zwietrzałe. W konsekwencji doszło tam do eliminacji skał węglanowych oraz skał krystalicznych bogatych w biotyt, wśród których tylko bardzo nieliczne mają znaczenie przewodnie. W ten sposób dochodzi do wtórnego podwyższenia udziału oznaczalnych skał przewodnich - w skrajnym przypadku w Holandii aż do $28 \%$ (Schuddebeurs, 1986). Na badanym przez autora obszarze Polski wskaźnik ten wyniósł maksymalnie około 15,8\% (Tum k/tęczycy) i również dotyczył gliny zwietrzałej (Czubla i Forysiak 2013, 2014). 


\section{WYKORZYSTANIE ANALIZ ERATYKÓW W GEOLOGII ZŁOŻOWEJ}

Transport skał i zwietrzeliny przez lód i wody fluwioglacjalne dostarcza cennych danych, wykorzystywanych w geologii złożowej obszarów niedawno zlodowaconych. Wychodnia użytecznego surowca ma zazwyczaj niewielką powierzchnię i dopiero rozproszenie poszukiwanego surowca na większym obszarze sprzyja jego wykryciu. Lodowce i lądolody pobierają klasty z wychodni, transportują i następnie odkładają je wśród osadów glacjalnych w nowym miejscu. Obszar, na którym lód pozostawił rozrzucone ziarna danego minerału lub skały nosi nazwę strefy rozproszenia lub rozrzutu (dosłownie szlaki, łańcuchy rozrzutu - dispersal trains) (Shilts, 1982; Larson i Mooers, 2004; Tremblay i in., 2009). Samo stwierdzenie obecności pożądanego minerału w osadach glacjalnych nie kończy prac poszukiwawczych. Najczęściej jego koncentracja jest zbyt mała, by pozwolić na uzasadnioną ekonomicznie eksploatację. Znalezienie nawet śladowych ilości surowca mineralnego i powiązanie ich z informacjami o kierunku napływu lodu pozwalają jednak znacząco zawęzić obszar szczegółowych poszukiwań pierwotnego złoża, przykrytego najczęściej osadami plejstoceńskimi (np. Plouffe i in., 2011). Metoda poszukiwawcza wykorzystująca strefy (wachlarze) rozrzutu eratyków określana jest jako śledzenie wskaźników glacjalnych (glacial indicator tracing) (por. m.in. Saarnisto, 1990; Shilts, 1993; McClenaghan i in., 2000, 2001). Wachlarze rozrzutu (rozproszenia) rozpoczynają się na obszarze wychodni i są rozciągnięte zgodnie z kierunkiem transgresji lądolodu. W ich zasięgu koncentracja minerałów złożowych początkowo wzrasta jeszcze na obszarze wychodni, by za nią zacząć się obniżać (m.in. Shilts, 1976, 1993; DiLabio, 1981, 1990; Puranen, 1990; Larson i Mooers, 2004) - rys. 13.1.

W analizach wskaźników glacjalnych najbardziej użyteczne są eratyki o niewielkich rozmiarach, włącznie z frakcją aleurytową i pelitową, które interpretowane są metodami geochemicznymi. Duże głazy w osadach glacjalnych występują stosunkowo nielicznie i prawdopodobieństwo, że będą pochodzić akurat z obszaru złożowego jest znikome.

Poszukiwania złóż przykrytych osadami glacjalnymi oparte są głównie na eratykach krótkiego i bardzo krótkiego transportu, ponieważ wraz z odległością dochodzi do szybkiego spadku udziału ziaren pochodzących z konkretnego miejsca (Shilts, 1976; Eriksson, 1983). Już Sauramo (1924) stwierdził, że analiza stref rozrzutu pod kątem poszukiwania surowców ma sens tylko w odległości do $25 \mathrm{~km}$ od wychodni, dalej materiał jest już za bardzo rozproszony. W trakcie długiego transportu możliwe są wielokrotna redepozycja, zmiany kierunków ruchu i w efekcie daleko idące przemieszanie różnowiekowego, a więc przyniesionego z różnych kierunków, materiału morenowego. Dużą ostrożność w badaniach składu glin dla potrzeb złożowych zalecają Parent i in. (1996), którym udało się zidentyfikować strefy rozrzutu, będące efektem nakładania się 
różnych kierunków napływu lodu w kolejnych awansach (palimpsestowe szlaki rozrzutu) - por. rys. 11.1. Ich wątpliwości znalazły potwierdzenie w badaniach stref rozproszenia minerałów ziem rzadkich oraz uranu w regionie jeziora Snyder w Manitobie (Trommelen, 2011). Podjęcie badań w pobliżu znanej wcześniej wychodni, będącej źródłem wspomnianych minerałów, miało na celu weryfikację i uaktualnienie metod badań stref rozrzutu. Okazało się, że nakładają się tam na siebie co najmniej cztery fazy napływu lodu o zróżnicowanych kierunkach, które znajdują odzwierciedlenie w rozprzestrzenieniu minerałów złożowych.

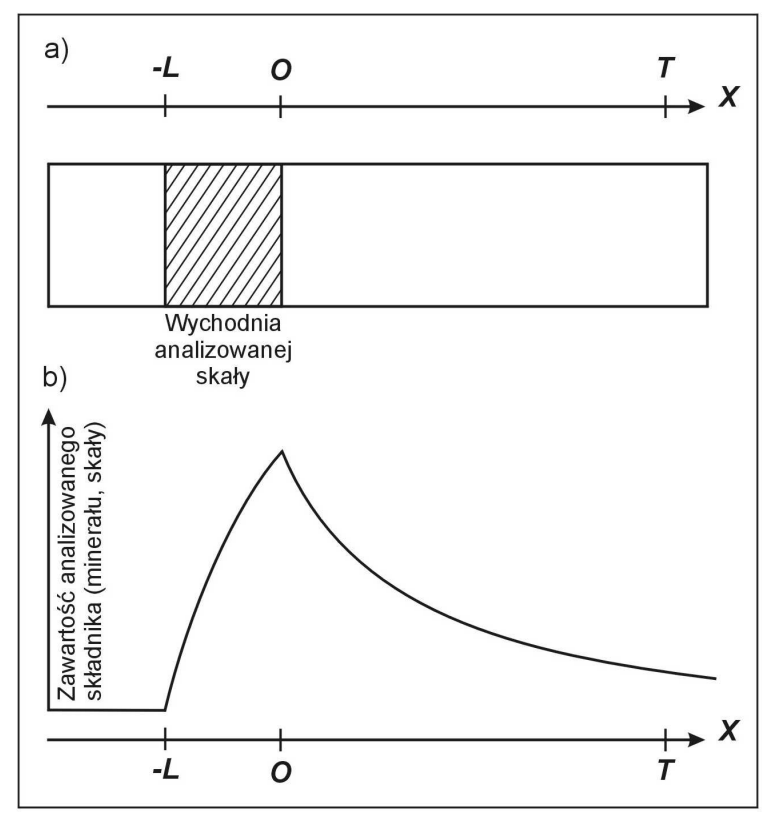

Rys. 13.1. Schematyczny model rozproszenia skały pobranej przez lód z podłoża; a) zakres modelu,

b) zawartość analizowanego składnika (minerału wskaźnikowego) w zależności od długości transportu:

$\mathrm{L}$ - maksymalna długość transportu ponad wychodnią, $\mathrm{O}$ - dystalna w stosunku do ruchu lodu granica wychodni w podłożu, T - długość transportu od dystalnej granicy wychodni (według Larson i Mooers, 2004)

Figure 13.1. Schematic of dispersal model; a) the model domain, b) the concentration of indicator material as a function of transport length; $T$ is any arbitrary transport length down-ice of the down-ice edge indicator source, $-L$ is the transport length to the up-ice edge of the indicator source $(0)$ corresponding to a flowline length of the indicator outcrop (L) (after Larson \& Mooers, 2004)

Gilberg $(1965,1967)$ opisuje strefę rozrzutu i długość transportu w lodzie, używając pojęcia dystansu połowicznego (half distance), oznaczającego odległość w kierunku zgodnym z ruchem lodu, na której zawartość analizowanego składnika spada o 50\% w stosunku do maksymalnej. Pod normalną czaszą lodową wartość ta spada szybko (wykładniczo) i zazwyczaj dystans połowiczny wynosi od kilkuset metrów do kilku kilometrów (Clark, 1987; Klassen, 2001). Strobel i Faure (1987) wyznaczyli połowiczny dystans na północy USA w przedziale od 2 do $16 \mathrm{~km}$ w zależności od właściwości 
mechanicznych klastów i podłoża. Zbliżone wartości w przedziale od 1 do $10 \mathrm{~km}$ podawane są również dla lądolodu fennoskandzkiego (Puranen, 1990). Skrajnie mały dystans połowiczny (3 do $5 \mathrm{~km}$ ) został wyznaczony dla wzgórz Vesthold we wschodniej Antarktyce (Gore i in., 2003). Strefy rozrzutu powstałe przy udziale strumieni lodowych cechują się dużo większym zasięgiem, a spadek udziału analizowanego składnika jest znacznie powolniejszy - liniowy (Dyke i Prest, 1987, Klassen, 2001; Dyke, 2008; Ross i in., 2009). Jednak nawet $w$ osadach potencjalnych strumieni lodowych strefa dystansu połowicznego dla skał (złóż) fennoskandzkich znajdowałaby się daleko na północy poza terytorium Polski.

Już bardzo dawno dostrzeżono, że analiza stref rozrzutu nie zawsze daje wynik zbieżny z pomiarami rys glacjalnych (Sauramo, 1924). Autor tłumaczy to wpływem rzeźby na lokalne kierunki ruchu lodu oraz zachowaniem się prawie wyłącznie rys ostatniej generacji. Zdecydowanie bardziej wiarygodna jest analiza dystrybucji eratyków pozwalająca określić generalny, a nie tylko lokalny kierunek ruchu lodu. Sauramo zwraca również uwagę na możliwość powstawania „wtórnych” wachlarzy rozrzutu, powstałych na skutek rozpadu większego bloku na małe fragmenty. Możliwe są też błędy spowodowane przenoszeniem eratyków przez dryfujące kry lodowe.

Niekiedy strefę rozrzutu można zidentyfikować gołym okiem na podstawie zabarwienia, jak np. wzbogacone w skały węglanowe strefy w glinach, rozciągające się na Wyspie Księcia Walii, Somerset i półwyspie Boothia (Dyke i Morris, 1988; Dyke i in., 1992) oraz na Wyspie Baffina (Tippett, 1985) w kanadyjskiej Arktyce. Identyfikacja stref rozproszenia jest stosunkowo łatwa w przypadku nietypowych dla danego obszaru skał, jak np. piaskowce, dolomity i niektóre typy diabazów w Finlandii. Bardzo pomocne wich wyznaczaniu mogą też być rysy glacjalne. Wyznaczanie strefy rozproszenia w oparciu o pojedynczy eratyk, nawet przy wykorzystaniu wspomnianych rys, jest bardzo ryzykowne, a najczęściej niemożliwe. Jako przykład posłużyć może eratyk pochodzący z żyły dolomitowej zawierającej domieszkę złota, znaleziony w Kemi (Finlandia). Rozbudził on nadzieję na znalezienie złoża złota, ale nie udało się powiązać go z żadnym konkretnym stanowiskiem i dlatego wyrażono przypuszczenie, że może to być głaz przywleczony przez preglacjalny czynnik transportowy, np. krę lodową na rzece Kemi lub morzu, kiedy obszar ten leżał znacznie niżej, niż obecnie (Sauramo, 1924).

Analizy eratyków w grubszych frakcjach mają zwykle charakter wstępny i pozwalają wyznaczyć ogólne zarysy strefy rozproszenia. Nawet jeżeli poszukiwany minerał lub skała są łatwo identyfikowalne makroskopowo, to dla potrzeb geologii złożowej i tak niezbędne jest przeprowadzenie analiz laboratoryjnych, w tym geochemicznych. Analizy geochemiczne glin należą do standardowych metod badawczych m.in. w Kanadzie i Finlandii (np. Klassen, 1999; McClenaghan i in., 2001; Vanhanen, 2001). W ten sposób wykryto anomalie zawartości $\mathrm{Cu}$, Te i innych metali w rejonie Säkkilä-Juuma (Pulkkinen, 1996) oraz Liikasenvaara (Vanhanen, 2001) w Finlandii. W bezpośrednim sąsiedztwie ultrazasadowej intruzji w Quebeku w Kanadzie ukształtowała się strefa rozproszenia wyraźnie wzbogacona w nikiel (Shilts, 1993). Analiza osadów glacjalnych pozwala wykryć właściwie każdy rodzaj surowca, który charakteryzuje się jakimś charakterystycz- 
nym zespołem mineralnym, np. wspomniane wyżej rudy Ni i Cu (Averill, 2009). Wykrycie na półwyspie Boothia w Kanadzie minerałów wskaźnikowych dla kimberlitów, m.in. ilmenitu, forsterytu, granatów, chromitu oraz drobnych ziaren złota rodzimego i nawiązanie do kierunków napływu lodu pozwoliło określić potencjalne obszary występowania złóż diamentów i złota (Tremblay i in., 2009).

W badaniach wskaźników glacjalnych za najbardziej wiarygodne uważane są próby pozyskane z glin glacjalnych (Klassen, 2001). Analizie poddaje się jednak także próby z osadów fluwioglacjalnych (Cummings i in., 2011). Porównanie możliwości transportu frakcji piaszczystej $\mathrm{i} z ̇$ wirowej $w$ lodzie oraz $w$ wodach in- lub subglacjalnych (Hellaakoski, 1931; Lee, 1965; Gillberg, 1968; Pertunnen, 1989; Bolduc, 1992 - fide Cummings i in., 2011; Levasseur i Prichonnet, 1995) pozwala wnioskować, że na ogół długość transportu jest zbliżona, chociaż strefa rozrzutu materiału jest w przypadku transportu fluwioglacjalnego przesunięta o kilka do maksymalnie $25 \mathrm{~km}$ zgodnie z kierunkiem ruchu lodu (Cummings $\mathrm{i}$ in., op. cit.). Zdaniem przywoływanych autorów, pierwotnym źródłem materiału w ozach jest zazwyczaj nie twarde podłoże, lecz glina (często starsza od deponowanej przez transgredujący lądolód), a strefa rozrzutu w osadach fluwioglacjalnych ma charakter wtórny. W związku z tym śledzenie wskaźników glacjalnych w ozach jest czynnością dwuetapową - najpierw należy prześledzić szlak ziaren w ozie, by dotrzeć do strefy rozrzutu $w$ glinie i dopiero na jej podstawie można dotrzeć do wychodni poszukiwanego minerału w podłożu (rys. 4.2).

Obszerny przegląd metodyczny analiz wskaźników glacjalnych wraz z licznymi przykładami zastosowań tej metody w Ameryce Północnej i Fennoskandii zawierają opracowania Kujansuu i Saarnisto (1990), McClenaghan i in. (2001). Nadal jednak precyzyjne wyjaśnienie procesów powstawania glin i tworzenia się stref rozproszenia minerałów w osadach glacjalnych pozostaje jednym z najważniejszych, nierozwiązanych problemów współczesnej stosowanej geologii glacjalnej (Cummings i in., 2011).

Pierwszy udokumentowany przypadek wykrycia bilansowego złoża w oparciu o kartowanie i analizę stref rozproszenia, z uwzględnieniem również kierunków rys glacjalnych, dotyczył rud miedzi w Outukumpu w Finlandii i miał miejsce w 1910 roku (Sauramo, 1924; Hucke, 1937). Od tego czasu metodyka została znacznie dopracowana, co pozwoliło na wykrycie wielu złóż, np. rud miedzi i żelaza w Finlandii (Sauramo, 1924), diamentonośnych kimberlitów w Kanadzie (Krajick, 2001; Kjarsgaard i Levinson, 2002) i dziś stanowi jedną z podstawowych metod badawczych geologii złożowej na obszarach niedawno zlodowaconych (Larson i Mooers, 2004). Dobre wyniki daje poszukiwanie tą metodą minerałów ziem rzadkich, zalegających pod przykryciem osadów czwartorzędowych (por. Jones, 1973; Shilts, 1982; DiLabio i Coker, 1989; Kujansuu i Saarnisto, 1990), diamentonośnych kimberlitów (Krajick, 2001; Kjarsgaard i Levinson, 2002; Tremblay i in., 2009), złota, rud uranu.

Budowa geologiczna Polski nie pozwala na racjonalne wykorzystanie analizy składu glin w celu poszukiwania złóż surowców mineralnych. Pierwsze nasunięcie lądolodu nastąpiło na obszar pokryty głównie słabo skonsolidowanymi lub luźnymi osadami 
kenozoicznymi, kolejne natomiast przemieszczały się najczęściej po niedawno odłożonych osadach interglacjalnych lub glacjalnych. Przeważającą część składników glin (zwłaszcza w grubszych frakcjach) stanowi materiał dalekiego transportu, w którym doszło już do olbrzymiego rozproszenia potencjalnych minerałów wskaźnikowych. Nawet gdyby udało się wyznaczyć dla nich strefę rozrzutu, to obszar źródłowy znalazłby się poza terytorium Polski. Teoretycznie istnieją możliwości zastosowania tej metody w tych częściach Polski, gdzie lądolód przekraczał wychodnie twardego podłoża, $\mathrm{np}$. w rejonie Gór Świętokrzyskich i na południe od nich, ale dotychczas nie udało się odnotować sukcesu w tej dziedzinie.

W przebadanych przez autora zespołach eratyków frakcji >20 mm znajdowane były nieliczne ślady mineralizacji, ale bardzo długi transport i występowanie w postaci pojedynczych klastów uniemożliwiają dowiązanie ich do potencjalnego złoża w Fennoskandii. Dodatkowym czynnikiem, który zmniejsza perspektywy zastosowania analiz wskaźników glacjalnych w badaniach materiału dalekiego transportu jest duża podatność większości minerałów rudnych na wietrzenie - zwłaszcza utlenianie. Znajdowane dość często w eratykach na terenie całej Polski kamienie półszlachetne - granaty, turmaliny, różne odmiany niskotemperaturowego kwarcu i chalcedonu, np. agaty stanowią jedynie ciekawostkę mineralogiczną i nie mają znaczenia złożowego. 


\section{ANALIZA STATYSTYCZNA SKŁADU PETROGRAFICZNEGO OSADÓW GLACJALNYCH}

Zweryfikowanie i właściwa ocena wyników badań analitycznych zespołów eratyków wymagała dodatkowo przeprowadzenia analizy statystycznej. Metody statystyczne w interpretacji wyników badań składu petrograficznego frakcji drobnożwirowej są już stosowane dość często (m.in. Anders i in., 1991; Zabielski, 2000; Gałązka, 2004b; Gałązka i Zabielski, 2004; Górska i Zabielski, 2006; Górska-Zabielska, 2008; Górska-Zabielska i Zabielski, 2011). Do wyjątków należą natomiast opracowania statystyczne frakcji >20 mm, wykraczające poza obliczenia teoretycznych ośrodków głazowych - na terenie Polski dotychczas przeprowadził je tylko Gałązka (2004b; Gałązka i Zabielski 2004). Na unikanie analiz statystycznych w badaniach eratyków przez większość europejskich badaczy, obok konieczności zgromadzenia odpowiednio licznej próby statystycznej, mogły wpłynąć wyniki prac prowadzonych w Ameryce Północnej, z których wynika, że na szlaku lądolodu już w odległości około $70 \mathrm{~km}$ od wychodni częstotliwość występowania danej skały z punktu widzenia analizy statystycznej wynosi praktycznie zero (względem sumarycznej ilości przeniesionego materiału), a pojedyncze znaleziska nie pozwalają na wiarygodną analizę ilościową (Shilts, 1976; Clark, 1987). Wśród skał przewodnich spotykanych w osadach glacjalnych Polski nie ma ani jednej, która pokonałaby pomiędzy wychodnią, a miejscem depozycji drogę krótszą niż 100 km. W przypadku Polski Środkowej dystans ten rośnie do co najmniej 400 km, co w świetle cytowanych prac zupełnie neguje sensowność dokonywania analizy statystycznej rozproszenia (udziału) konkretnych typów skał przewodnich w całkowitej masie materiału morenowego, ale jednak nie wyklucza innych rodzajów analizy statystycznej. W związku z powyższym autor podjął próbę statystycznego przetestowania wyników badań w przekonaniu, że przytoczone zarzuty nie są słuszne w odniesieniu do proporcji/udziału pojedynczych typów skał w poszczególnych zespołach eratyków, pobranych z osadów glacjalnych danego wieku. W tym celu wybrano metody statystyczne możliwie najbardziej skuteczne w badaniach przyrodniczych, a zwłaszcza geologicznych (por. m.in. Davis, 2002; Ross, 2009; McKillup i Darby Dyar, 2010; Walpole i in., 2012).

Opracowanie statystyczne składu petrograficznego osadów glacjalnych objęło w sumie 138 prób eratyków frakcji $>20 \mathrm{~mm}$ pobranych w 60 stanowiskach. Ze względu na występowanie zmienności przestrzennej w rozmieszczeniu różnych typów eratyków (patrz rozdz. 10 i 11), stanowiska pogrupowano zgodnie z ich położeniem geograficznym. W ten sposób możliwe było wyróżnienie kilku regionów testowych:

1. Dolny Śląsk,

2. Polska Wschodnia (Podlasie i Lubelszczyzna),

3. Polska Środkowa i wschodnia Wielkopolska,

4. Pomorze, Powiśle i Kujawy. 
W dwóch ostatnich regionach analizy statystyczne przeprowadzono dodatkowo niezależnie dla wschodniej Wielkopolski, Pomorza, Kujaw i Powiśla. Było to uzasadnione rozległością wyróżnianych regionów, a możliwe dzięki dużej liczbie przebadanych stanowisk. Gliny opróbowane w czwartym regionie reprezentują jednak głównie ostatnie zlodowacenie, a możliwości analizy petrograficznej starszych osadów glacjalnych były tam bardzo ograniczone ich głębokim na ogół zaleganiem. Dodatkowy problem stanowiła duża zmienność przestrzenna i czasowa dynamiki lądolodu na Pomorzu i Powiślu, przejawiająca się m.in. zróżnicowaniem składu zespołów eratyków w równowiekowych osadach glacjalnych nawet w stanowiskach położonych bardzo blisko siebie (por. m.in. Czubla i in., 2007a; Woźniak i in., 2008, 2009, 2011, 2012b, 2013a, 2013c; Woźniak i Czubla 2014a, 2014b, w druku). Najbardziej wartościowe były dane z Polski Środkowej i ze wschodniej Wielkopolski, gdzie opróbowano osady wszystkich zlodowaceń, jakie objęły ten obszar i przebadano największą liczbę zespołów eratyków.

Przeprowadzenie pełnej analizy statystycznej i interpretacji dla prób z Dolnego Śląska oraz z Polski Wschodniej było niemożliwe z uwagi na zbyt małą liczbę stanowisk. Pozyskane wyniki trudno uznać za reprezentatywne i mogą one zostać wykorzystane jedynie w charakterze materiału porównawczego. Mała liczba stanowisk nie stanowiła natomiast żadnej przeszkody dla podstawowych obliczeń statystycznych (współczynniki petrograficzne, teoretyczne ośrodki głazowe etc.), ponieważ są one wykonywane i tak dla każdej próbki niezależnie. Takie postępowanie nie jest sprzeczne z zasadami statystyki, ponieważ pojedyncza próba liczyła średnio aż 1080 klastów.

W analizach statystycznych uwzględniono wszystkie grupy i wskaźniki petrograficzne wymienione w tab. 4.3, a dodatkowo także wyróżnienia (petrograficzne grupy regionalne) stosowane przez Hesemanna (m.in. 1930, 1931) i Gałązkę (2004b) (tab. 14.1). Wszystkie powyższe dane (parametry) dla potrzeb statystycznych zostały zinterpretowane jako skorelowane w obrębie danej grupy zmienne losowe. Dane do obliczeń w obrębie poszczególnych regionów zostały pogrupowane zgodnie z przyjmowanym wiekiem osadów, z których pobierane były próbki.

W obrębie prób pochodzących z konkretnego regionu badawczego i powiązanych z tym samym nasunięciem lądolodu przeprowadzono podstawowe testy statystyczne. Wyznaczono wartości minimalne i maksymalne oraz obliczono średnie wartości analizowanych danych, odchylenia standardowe i błędy standardowe średniej. Takie postępowanie było najbardziej uzasadnione w odniesieniu do zespołów danych o rozkładzie zbliżonym do rozkładu normalnego. Niektóre parametry analizowanych próbek cechowały się jednak dużą zmiennością w obrębie grupy i sporadycznym pojawianiem się wartości znacznie odbiegających od pozostałych i od średniej. W związku z tym konieczne było zastosowanie również metod nieparametrycznych. Wyliczono w tym celu medianę i odchylenie medianowe oraz kwartyle (tab. 14.2 i 14.3).

Istnieją wątpliwości dotyczące traktowania cech petrograficznych osadów jako zmiennych o rozkładzie normalnym. Większość zmiennych w badaniach petrograficznych Górskiej-Zabielskiej odbiega znacząco od rozkładu normalnego, co skłoniło 
Tabela 14.1. Grupy regionalne eratyków wyróżniane przez Hesemanna i Gałązkę, uwzględnione w analizach statystycznych (zestawiono obszary pochodzenia, ale liczba typów eratyków wykorzystywanych przez cytowanych autorów była odmienna)

Table 14.1. Regional groups of indicator erratics distinguished by Hesemann and Gałązka, included in the statistical analysis (the source areas recognized by both authors cited are shown together, but the number of erratic types used by them was different)

\begin{tabular}{|c|c|}
\hline Regiony wg Hesemanna $(1930,1931)$ & $\begin{array}{c}\text { Regiony pochodzenia eratyków } \\
\text { wg Gałązki (2004b) }\end{array}$ \\
\hline \multirow{5}{*}{$\begin{array}{l}\text { I - Finlandia, Wyspy Alandzkie, N-Szwecja, } \\
\text { N-Bałtyk z Zatoką Botnicką (25 typów skał } \\
\text { przewodnich) }\end{array}$} & VI - Ăngermanland - 7 typów skał przewodnich \\
\hline & $\begin{array}{l}\text { VII - Środkowy Bałtyk - } 2 \text { typy skał (z I grupy } \\
\text { Hesemanna tylko czerwony porfir bałtycki) }\end{array}$ \\
\hline & $\begin{array}{l}\text { VIII - Wyspy Alandzkie i Zatoka Botnicka } \\
-12 \text { typów }\end{array}$ \\
\hline & IX - SW-Finlandia - 11 typów \\
\hline & $X$ - SE-Finlandia - 7 typów \\
\hline \multirow{3}{*}{$\begin{array}{l}\text { II - środkowa Szwecja i środkowy Bałtyk } \\
\text { (10 typów) }\end{array}$} & IV - Dalarna - 16 typów \\
\hline & V - Uppland - 10 typów \\
\hline & $\begin{array}{l}\text { VII - Środkowy Bałtyk - } 2 \text { typy skał (z II grupy } \\
\text { Hesemanna tylko brunatny porfir bałtycki) }\end{array}$ \\
\hline \multirow{3}{*}{ III - S- i W-Szwecja, S-Bałtyk i Bornholm (33 typy) } & I- Bornholm - 6 typów \\
\hline & II - Bohuslän - 3 typy \\
\hline & III - Småland - 23 typy \\
\hline IV - S-Norwegia, Kattegat (9 typów) & skały norweskie nie były uwzględnione w podziale \\
\hline
\end{tabular}

autorkę do stosowania słabszych testów, tj. testów nieparametrycznych, np. Manna-Whitneya (Górska i Zabielski, 2006; Górska-Zabielska, 2008; Górska-Zabielska i Zabielski, 2011). Odmienne stanowisko zajmuje Gałązka (2004b), który dowodzi, że cechy petrograficzne glin charakteryzują się rozkładem normalnym. W materiale przebadanym przez autora stwierdzono występowanie cech charakteryzujących się rozkładem normalnym w obrębie poszczególnych grup prób, ale zanotowano też obecność takich cech, dla których rozrzut wartości jest znacznie większy i mniej regularny (nie spełnia warunków rozkładu normalnego - test Gearyego, Geary, 1947; Walpole i in., 2012). Ta sama cecha petrograficzna w różnych zbiorach danych (różny wiek osadów lub region geograficzny) mogła spełniać warunki rozkładu normalnego lub nie. Dlatego w kolejnym etapie analiz dla potrzeb niniejszego opracowania zastosowano zarówno test istotności różnicy dwóch średnich (t-test) stosowany dla porównywania grup cechujących się rozkładem normalnym, jak również test nieparametryczny (U-test). Test istotności różnicy dwóch średnich pozwala określić różnicę pomiędzy dwoma zbiorami danych (w tym przypadku próby z osadów glacjalnych o odmiennym wieku), scharakteryzowanymi przez wartości średnie i odchylenia standardowe wyróżnionych cech petrograficznych. Na podstawie powyższych danych obliczono wartości parametru $t$ (według wzoru 2.48 - Davis, 2002 - str. 73), a następnie wyznaczono liczbę stopni swobody. 


\begin{tabular}{|c|c|c|c|c|c|c|c|c|c|c|c|c|c|c|c|}
\hline 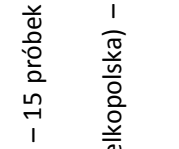 & 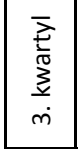 & $\sigma$ & $\begin{array}{l}0 \\
0 \\
0 \\
0 \\
0 \\
0\end{array}$ & $\begin{array}{l}\frac{1}{\hat{\alpha}} \\
\vdots \\
0 \\
0 \\
0\end{array}$ & 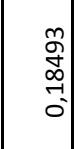 & 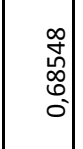 & $\begin{array}{l}\mathbf{1} \\
0 \\
6 \\
0 \\
0\end{array}$ & 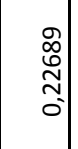 & 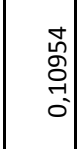 & $\begin{array}{l}0 \\
0 \\
0 \\
0 \\
0 \\
0 \\
0\end{array}$ & $\begin{array}{c}0 \\
0 \\
0 \\
0 \\
0 \\
0\end{array}$ & $\begin{array}{l}\overrightarrow{0} \\
\stackrel{0}{0} \\
0 \\
0 \\
0\end{array}$ & $\begin{array}{l}\text { 怘 } \\
\text { ñ. } \\
0 \\
0\end{array}$ & 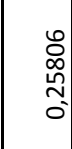 & 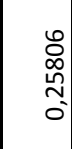 \\
\hline 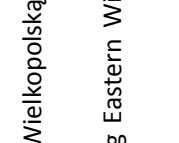 & $\begin{array}{l}\bar{\lambda} \\
\frac{\lambda}{\pi} \\
\frac{2}{2} \\
-i\end{array}$ & $\infty$ & $\begin{array}{l}0 \\
0 \\
0 \\
0 \\
0 \\
0\end{array}$ & $\begin{array}{l}\tilde{n} \\
\stackrel{n}{0} \\
0 \\
0\end{array}$ & $\begin{array}{l}\text { ñ } \\
0 \\
\llcorner \\
0 \\
0\end{array}$ & $\begin{array}{c}2 \\
0 \\
\infty \\
m \\
7 \\
0\end{array}$ & 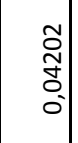 & $\begin{array}{l}\text { Na } \\
\text { นิ } \\
0 \\
0 \\
0\end{array}$ & \begin{tabular}{l}
0 \\
\multirow{5}{*}{} \\
$\tilde{m}$ \\
0 \\
0
\end{tabular} & 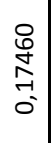 & 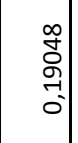 & 0 & 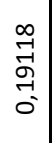 & 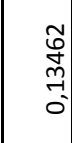 & 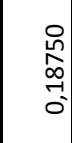 \\
\hline 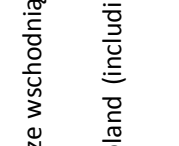 & 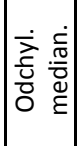 & 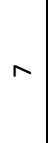 & 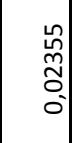 & 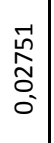 & \begin{tabular}{l} 
mे \\
0 \\
\hdashline \\
0 \\
0
\end{tabular} & 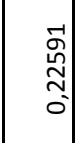 & 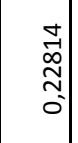 & $\begin{array}{l}\mathscr{D} \\
\widetilde{1} \\
0 \\
0 \\
0\end{array}$ & $\begin{array}{l}\tilde{0} \\
0 \\
\tilde{n} \\
0 \\
0 \\
0\end{array}$ & 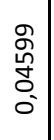 & \begin{tabular}{l}
\multirow{2}{N}{} \\
Иิ \\
0 \\
0
\end{tabular} & $\begin{array}{l}n \\
\tilde{n} \\
\tilde{n} \\
0 \\
0\end{array}$ & $\begin{array}{l}\stackrel{0}{1} \\
\infty \\
0 \\
0 \\
0\end{array}$ & 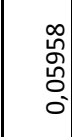 & 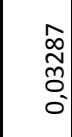 \\
\hline 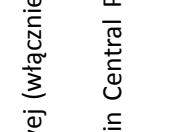 & $\frac{\dot{\vec{v}}}{\sum^{\frac{\pi}{2}}}$ & 0 & $\begin{array}{l}0 \\
0 \\
0 \\
h \\
0 \\
0\end{array}$ & $\begin{array}{l}\text { P } \\
0 \\
\text { 员 } \\
\text { م. }\end{array}$ & $\begin{array}{l}\infty \\
\overrightarrow{7} \\
\overrightarrow{-} \\
6 \\
0\end{array}$ & $\begin{array}{l}u \\
0 \\
0 \\
o \\
0 \\
0\end{array}$ & $\begin{array}{l}7 \\
\\
0 \\
0 \\
0\end{array}$ & 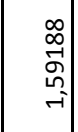 & 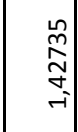 & 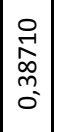 & 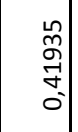 & 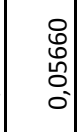 & $\begin{array}{c}\tilde{N} \\
\vdots \\
\infty \\
m \\
0 \\
0\end{array}$ & 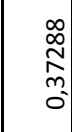 & 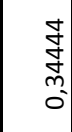 \\
\hline 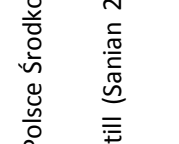 & $\stackrel{\leftrightarrows}{\Sigma}$ & n & 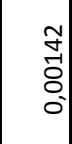 & $\begin{array}{l}\mathcal{N} \\
\mathcal{A} \\
8 \\
0 \\
0\end{array}$ & $\begin{array}{l}\text { 20 } \\
-1 \\
0 \\
0 \\
0\end{array}$ & 0 & 이 & $\begin{array}{l}m \\
m \\
-1 \\
0 \\
0\end{array}$ & 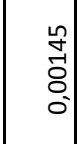 & $\mid \begin{array}{c}\infty \\
\tilde{n} \\
\\
\stackrel{-}{0} \\
0\end{array}$ & 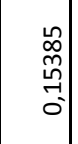 & 0 & $\begin{array}{l}\hat{1} \\
\mathscr{0} \\
0 \\
0 \\
0\end{array}$ & $\begin{array}{l}n \\
\hat{n} \\
0 \\
0 \\
0\end{array}$ & $\begin{array}{l}n \\
0 \\
- \\
7 \\
- \\
0\end{array}$ \\
\hline $\begin{array}{l}\frac{x}{0} \\
\frac{0}{a} \\
0 \\
0 \\
\frac{n}{n}\end{array}$ & 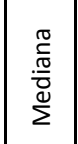 & $\sigma$ & 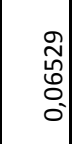 & $\begin{array}{l}\hat{\delta} \\
\stackrel{2}{0} \\
0 \\
0\end{array}$ & 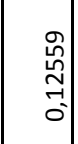 & 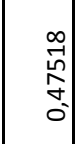 & 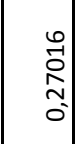 & 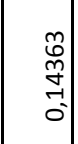 & 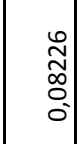 & 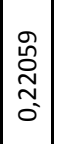 & 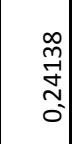 & $\begin{array}{l}\text { N్} \\
\infty \\
-1 \\
0 \\
0\end{array}$ & $\mid \begin{array}{c}0 \\
\tilde{n} \\
\stackrel{1}{-} \\
0 \\
0\end{array}$ & 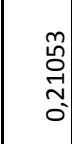 & 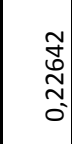 \\
\hline 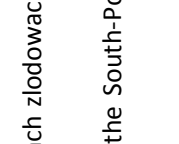 & 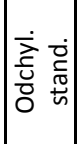 & $m$ & $\begin{array}{l}-\vec{n} \\
\stackrel{n}{m} \\
\stackrel{-1}{0}\end{array}$ & 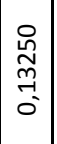 & 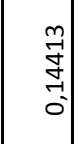 & 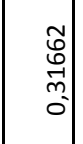 & $\begin{array}{l}\stackrel{p}{N} \\
\infty \\
\stackrel{2}{0} \\
0\end{array}$ & $\begin{array}{c}\tilde{N} \\
m \\
\infty \\
m \\
0 \\
0\end{array}$ & 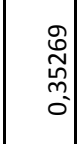 & $\mid \begin{array}{c}-1 \\
0 \\
0 \\
0 \\
0 \\
0\end{array}$ & $\begin{array}{l}5 \\
0 \\
0 \\
0 \\
0\end{array}$ & $\begin{array}{l}m \\
0 \\
0 \\
0 \\
0 \\
0\end{array}$ & 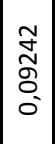 & \begin{tabular}{l}
\multirow{1}{\Lambda}{} \\
0 \\
0 \\
0
\end{tabular} & $\begin{array}{l}2 \\
0 \\
0 \\
0 \\
0 \\
0\end{array}$ \\
\hline 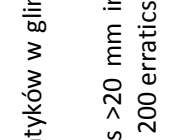 & 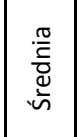 & $\sim$ & 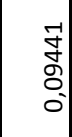 & $\begin{array}{l}0 \\
0 \\
0 \\
0 \\
0 \\
0\end{array}$ & $\begin{array}{l}0 \\
0 \\
0 \\
-1 \\
0 \\
0\end{array}$ & $\begin{array}{l}\hat{N} \\
9 \\
g \\
0 \\
0\end{array}$ & $\begin{array}{l}\text { Nิ } \\
\hat{n} \\
m \\
0 \\
0\end{array}$ & $\begin{array}{c}2 \\
0 \\
0 \\
\stackrel{0}{0} \\
0\end{array}$ & $\begin{array}{l}0 \\
0 \\
0 \\
0 \\
-1 \\
0\end{array}$ & 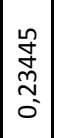 & 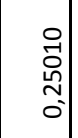 & 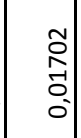 & 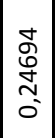 & 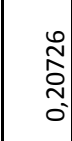 & 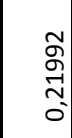 \\
\hline 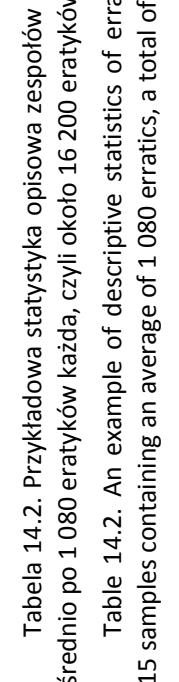 & 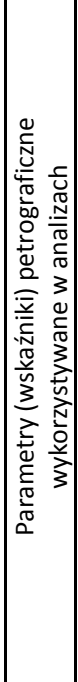 & $r$ & 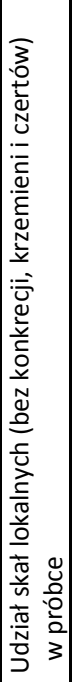 & 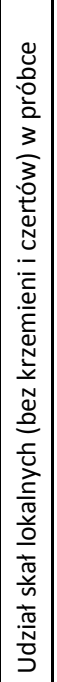 & 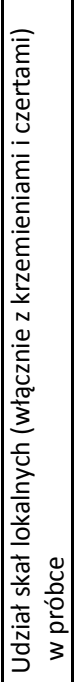 & 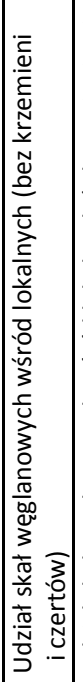 & 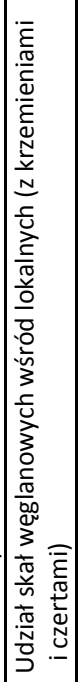 & 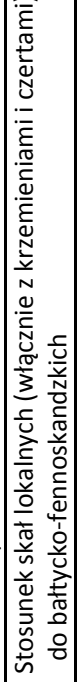 & 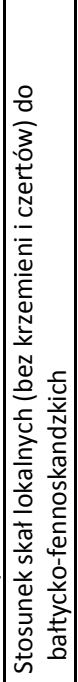 & 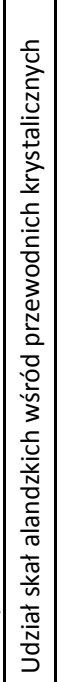 & 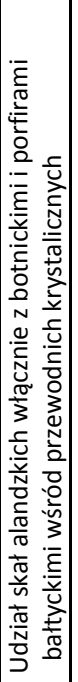 & 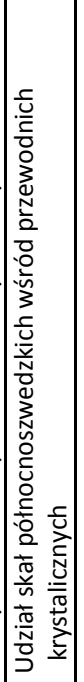 & 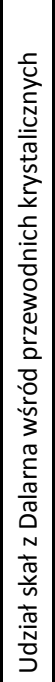 & 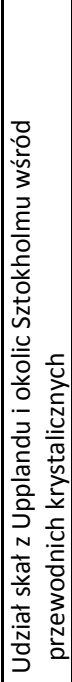 & 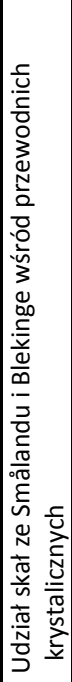 \\
\hline
\end{tabular}




\begin{tabular}{|c|c|c|c|c|c|c|c|c|c|c|c|c|c|c|c|c|c|c|}
\hline$\sigma$ & $\begin{array}{l}0 \\
0 \\
0 \\
0 \\
0 \\
0\end{array}$ & 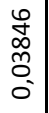 & $\begin{array}{l}0 \\
0 \\
\infty \\
\tilde{o} \\
0 \\
0 \\
0\end{array}$ & 0 & $\begin{array}{l}n \\
0 \\
0 \\
0 \\
0 \\
0\end{array}$ & $\begin{array}{l}\tilde{o}_{0} \\
\stackrel{0}{m} \\
m_{0}\end{array}$ & 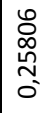 & $\begin{array}{l}\underset{0}{\tilde{N}} \\
\tilde{N} \\
0 \\
0\end{array}$ & $\left|\begin{array}{l}m \\
0 \\
0 \\
0 \\
0 \\
0\end{array}\right|$ & $\begin{array}{l}\tilde{D} \\
0 \\
0 \\
\tilde{O} \\
\tilde{o}\end{array}$ & $\begin{array}{l}0 \\
\hat{n} \\
\tilde{N} \\
0 \\
0\end{array}$ & 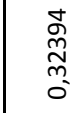 & $\begin{array}{l}\stackrel{n}{\mathbb{N}} \\
\hat{0} \\
\stackrel{0}{0} \\
0\end{array}$ & $\mid \begin{array}{c}0 \\
\stackrel{\hat{n}}{\sim} \\
\tilde{m} \\
\tilde{c}\end{array}$ & 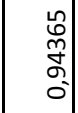 & 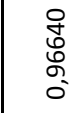 & $\begin{array}{l}\mathbb{N} \\
\hat{6} \\
\infty \\
0 \\
0 \\
0\end{array}$ & 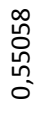 \\
\hline$\infty$ & 이 & 0 & 0 & 0 & 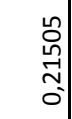 & \begin{tabular}{l}
$\overrightarrow{7}$ \\
$\infty$ \\
$\infty$ \\
$\rightarrow 1$ \\
\hdashline \\
0
\end{tabular} & 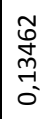 & 0 & 0 & 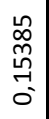 & $\begin{array}{l}\widehat{N} \\
\infty \\
0 \\
0 \\
0 \\
0\end{array}$ & 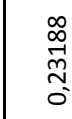 & $\begin{array}{l}q \\
\tilde{m} \\
\vec{y} \\
0 \\
0\end{array}$ & 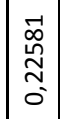 & $\begin{array}{l}0 \\
0 \\
-1 \\
0 \\
0 \\
0\end{array}$ & 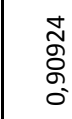 & 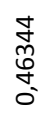 & $\begin{array}{l}\text { ○్ } \\
\text { o } \\
\text { ñ } \\
0\end{array}$ \\
\hline r & 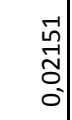 & 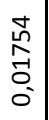 & $\begin{array}{l}\text { 苟 } \\
-1 \\
0 \\
0 \\
0\end{array}$ & 0 & 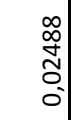 & $\begin{array}{l}\stackrel{0}{\hat{k}} \\
\infty \\
0 \\
0\end{array}$ & 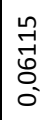 & 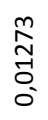 & $\left|\begin{array}{l}9 \\
0 \\
0 \\
0 \\
0 \\
0\end{array}\right|$ & $\begin{array}{l}\text { 号 } \\
\text { す } \\
0 \\
0\end{array}$ & $\begin{array}{l}n \\
\hat{6} \\
0 \\
0 \\
0 \\
0\end{array}$ & 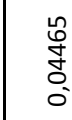 & \begin{tabular}{|l} 
के \\
Oे \\
पे \\
0 \\
0
\end{tabular} & $\mid \begin{array}{c}0 \\
\infty \\
\text { Ŷे } \\
0 \\
0 \\
0\end{array}$ & 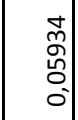 & $\begin{array}{l}\text { गे } \\
\tilde{m}^{2} \\
0 \\
0 \\
0\end{array}$ & $\begin{array}{l}-1 \\
0 \\
\tilde{n} \\
0 \\
0 \\
0\end{array}$ & $\begin{array}{l}8 \\
\stackrel{8}{1} \\
0 \\
0 \\
0\end{array}$ \\
\hline 6 & 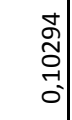 & $\begin{array}{l}\tau \\
\emptyset \\
f \\
0 \\
0\end{array}$ & $\begin{array}{l}\infty \\
\infty \\
0 \\
\vdots \\
0 \\
0 \\
0\end{array}$ & $\begin{array}{l}\tilde{N} \\
\sigma \\
0 \\
0 \\
0\end{array}$ & 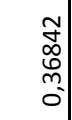 & $\begin{array}{l}\tilde{O} \\
\stackrel{0}{0} \\
\infty \\
0 \\
0\end{array}$ & 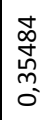 & $\begin{array}{l}0 \\
\text { นn } \\
น \\
0 \\
0 \\
0\end{array}$ & $\left|\begin{array}{l}\hat{\hat{0}} \\
0 \\
0 \\
0 \\
0\end{array}\right|$ & 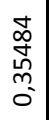 & $\begin{array}{l}\text { ర్ } \\
\text { ח. } \\
0 \\
0 \\
0\end{array}$ & 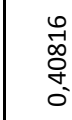 & 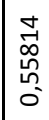 & 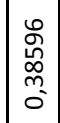 & 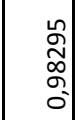 & 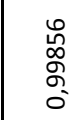 & $\begin{array}{c}\text { O } \\
\infty \\
\infty \\
\infty \\
\infty \\
0 \\
0\end{array}$ & $\begin{array}{l}\text { ని } \\
\infty \\
\omega_{0} \\
0 \\
0\end{array}$ \\
\hline เn & 0 & 0 & 0 & 0 & 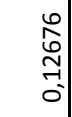 & $\begin{array}{l}\hat{\sigma} \\
\text { ğ } \\
0\end{array}$ & 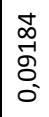 & 0 & 0 & $\begin{array}{c}\text { జ్ } \\
\stackrel{-}{-1} \\
\stackrel{-}{0} \\
0\end{array}$ & 0 & 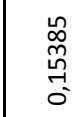 & $\begin{array}{l}m \\
\tilde{0} \\
-1 \\
m \\
0 \\
0\end{array}$ & $\mid \begin{array}{c}-1 \\
8 \\
0 \\
-1 \\
-1 \\
0\end{array}$ & $\begin{array}{c}\tilde{\infty} \\
心 \\
\infty \\
n \\
n \\
0\end{array}$ & $\begin{array}{l}\text { Oे } \\
\text { जे } \\
\dot{y} \\
0\end{array}$ & 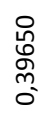 & 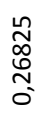 \\
\hline$\sigma$ & 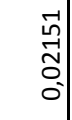 & 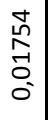 & $\begin{array}{l}\text { 苍 } \\
\stackrel{-1}{0} \\
0 \\
0\end{array}$ & 0 & 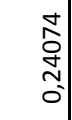 & $\begin{array}{l}\stackrel{0}{\pi} \\
\underset{\sim}{N} \\
\text { o }\end{array}$ & 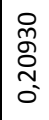 & $\begin{array}{l}\text { N } \\
\infty \\
\infty \\
0 \\
0 \\
0\end{array}$ & $\mid \begin{array}{l}\text { ㅇ } \\
0 \\
0 \\
0 \\
0 \\
0\end{array}$ & 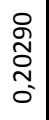 & $\begin{array}{l}\text { ঠo } \\
\hat{n} \\
0 \\
0 \\
0\end{array}$ & 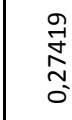 & 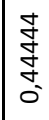 & 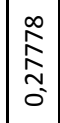 & 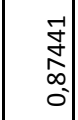 & 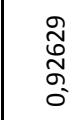 & 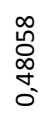 & 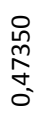 \\
\hline$m$ & 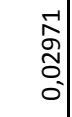 & 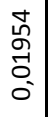 & 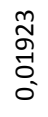 & 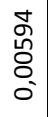 & $\begin{array}{l}0 \\
\circ \\
8 \\
0 \\
0\end{array}$ & $\begin{array}{l}\vec{m} \\
\text { ஜे } \\
\text { Oे } \\
0\end{array}$ & $\begin{array}{l}\text { O్ } \\
\tilde{N} \\
0 \\
0 \\
0\end{array}$ & $\begin{array}{l}0 \\
\infty \\
0 \\
0 \\
0 \\
0\end{array}$ & 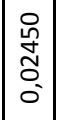 & $\begin{array}{l}m \\
0 \\
0 \\
0 \\
0 \\
0\end{array}$ & $\begin{array}{l}\text { Oूg } \\
\text { ป } \\
\text { o } \\
0\end{array}$ & 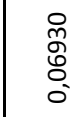 & \begin{tabular}{l}
$\tilde{N}$ \\
\multirow{-}{\hat{0}}{} \\
0 \\
0
\end{tabular} & 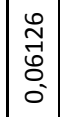 & $\begin{array}{c}\stackrel{m}{7} \\
\underset{J}{J} \\
\underset{0}{-}\end{array}$ & 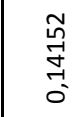 & 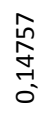 & 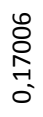 \\
\hline$N$ & 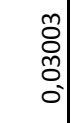 & \begin{tabular}{c}
\multirow{0}{0}{} \\
$\infty$ \\
0 \\
0 \\
0
\end{tabular} & $\begin{array}{l}0 \\
0 \\
0 \\
0 \\
0 \\
0 \\
0\end{array}$ & $\begin{array}{l}\text { ָ̃ } \\
\text { రิ } \\
0 \\
0\end{array}$ & 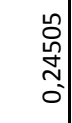 & 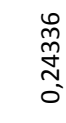 & 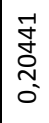 & $\begin{array}{l}m \\
0 \\
0 \\
0 \\
0 \\
0 \\
0\end{array}$ & $\left|\begin{array}{l}-1 \\
0 \\
0 \\
0 \\
0 \\
0\end{array}\right|$ & 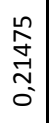 & $\begin{array}{l}\text { ô } \\
\text { ơt } \\
\text { o }\end{array}$ & 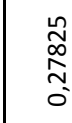 & 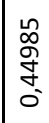 & $\mid \begin{array}{c}- \\
\\
\\
0 \\
0\end{array}$ & 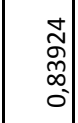 & $\begin{array}{l}\text { fे } \\
\text { مे } \\
0^{-} \\
0^{-}\end{array}$ & 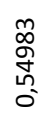 & 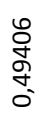 \\
\hline-1 & 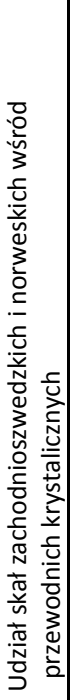 & 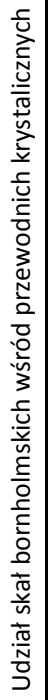 & 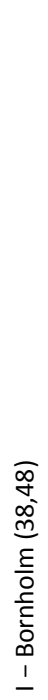 & 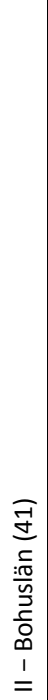 & 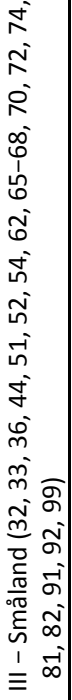 & 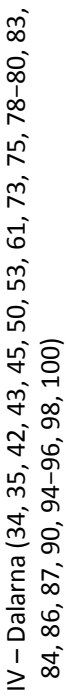 & 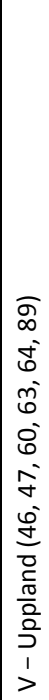 & 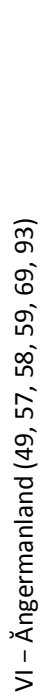 & 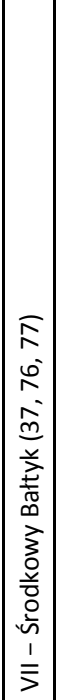 & 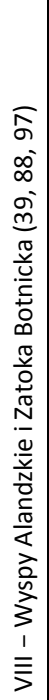 & 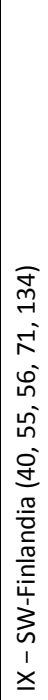 & 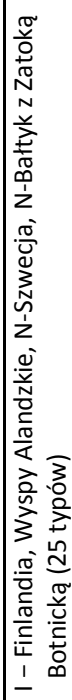 & 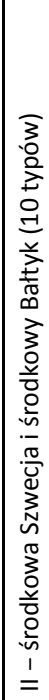 & 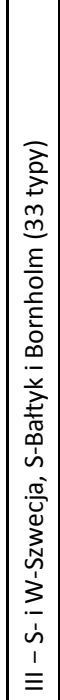 & 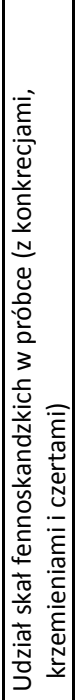 & 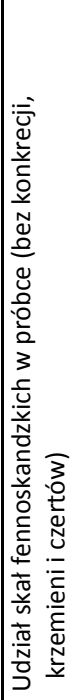 & 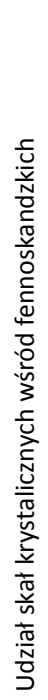 & 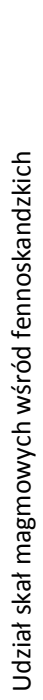 \\
\hline
\end{tabular}




\begin{tabular}{|c|c|c|c|c|c|c|c|c|c|c|c|c|c|c|c|c|c|c|}
\hline$\sigma$ & \begin{tabular}{l}
$\tilde{y}$ \\
\multirow{2}{0}{} \\
$\stackrel{n}{0}$ \\
0
\end{tabular} & $\begin{array}{l}\text { స్ } \\
\hat{\Lambda} \\
0 \\
0 \\
-\end{array}$ & $\mid \begin{array}{c}0 \\
f \\
0 \\
+ \\
-1 \\
0 \\
0\end{array}$ & $\begin{array}{l}\text { o } \\
\text { o } \\
0 \\
0 \\
0\end{array}$ & 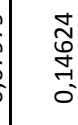 & 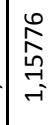 & 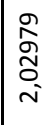 & $\begin{array}{l}\text { นn } \\
\text { H్ } \\
\text { - } \\
0 \\
0\end{array}$ & 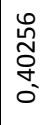 & $\begin{array}{l}\vec{b} \\
\overrightarrow{0} \\
0 \\
0 \\
0\end{array}$ & $\begin{array}{l}\hat{g} \\
\text { gे } \\
\stackrel{-}{0} \\
0\end{array}$ & 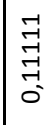 & 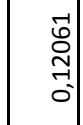 & 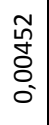 & 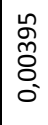 & 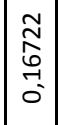 & $\begin{array}{c}\stackrel{\infty}{\stackrel{n}{n}} \\
\stackrel{n}{n} \\
0\end{array}$ & $\begin{array}{l}\stackrel{8}{0} \\
\stackrel{0}{0} \\
\stackrel{-}{0} \\
0\end{array}$ \\
\hline$\infty$ & $\begin{array}{l}\vec{\nabla} \\
\stackrel{1}{0} \\
\tilde{m} \\
0 \\
0\end{array}$ & $\begin{array}{l}0 \\
0 \\
0 \\
0 \\
0 \\
0\end{array}$ & 0 & $\begin{array}{l}\mathbb{Z} \\
\mathbb{Z} \\
0 \\
0\end{array}$ & $\begin{array}{l}\infty \\
0 \\
0 \\
-1 \\
-1\end{array}$ & 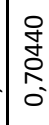 & $\begin{array}{l}\text { Oे } \\
\text { Oे } \\
\text { On } \\
\text { - }\end{array}$ & \begin{tabular}{|l}
0 \\
o \\
0 \\
0 \\
0 \\
0
\end{tabular} & 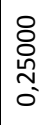 & \begin{tabular}{l}
$\infty$ \\
\multirow{2}{n}{} \\
0 \\
0 \\
0
\end{tabular} & $\begin{array}{l}\overrightarrow{9} \\
\stackrel{9}{0} \\
0 \\
0 \\
0\end{array}$ & $\begin{array}{l}\Omega \\
\hat{\imath} \\
\delta \\
0 \\
0\end{array}$ & $\begin{array}{l}\infty \\
0 \\
0 \\
0 \\
0 \\
0\end{array}$ & 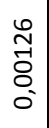 & $\begin{array}{l}\text { के } \\
\text { Oे } \\
\text { o }\end{array}$ & $\begin{array}{l}\widetilde{0} \\
\overrightarrow{0} \\
0 \\
0 \\
0 \\
0\end{array}$ & $\begin{array}{l}n \\
\stackrel{5}{n} \\
-1 \\
0 \\
0\end{array}$ & 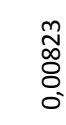 \\
\hline$\wedge$ & 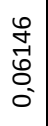 & $\begin{array}{l}0 \\
0 \\
0 \\
0 \\
0 \\
0 \\
0\end{array}$ & $\left|\begin{array}{l}-1 \\
0 \\
-1 \\
0 \\
0 \\
0\end{array}\right|$ & 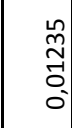 & \begin{tabular}{l}
$\stackrel{0}{0}$ \\
$m$ \\
\hdashline \\
0 \\
0
\end{tabular} & 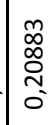 & 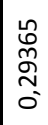 & 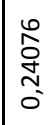 & \begin{tabular}{|l}
0 \\
$\stackrel{\infty}{+}$ \\
$\stackrel{1}{0}$ \\
0 \\
0 \\
0
\end{tabular} & 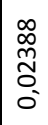 & $\begin{array}{l}\frac{\infty}{2} \\
m \\
0 \\
0 \\
0\end{array}$ & \begin{tabular}{|l}
$\infty$ \\
$\infty$ \\
\multirow{8}{*}{} \\
0 \\
0
\end{tabular} & 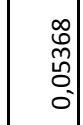 & $\begin{array}{l}0 \\
0 \\
0 \\
0 \\
0 \\
0\end{array}$ & $\begin{array}{l}\text { 昌 } \\
\text { 号 } \\
0\end{array}$ & $\mid \begin{array}{l}\hat{\infty} \\
o \\
o \\
0 \\
0\end{array}$ & 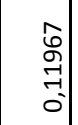 & $0^{\circ}$ \\
\hline 6 & $\begin{array}{l}\vec{m} \\
\stackrel{2}{0} \\
\infty \\
0 \\
0\end{array}$ & $\begin{array}{l}\infty \\
\stackrel{\infty}{0} \\
0 \\
0 \\
-1 \\
0\end{array}$ & $\left|\begin{array}{l}\infty \\
o \\
\vdots \\
-1 \\
- \\
0\end{array}\right|$ & $\begin{array}{l}\stackrel{m}{\infty} \\
\stackrel{m}{m} \\
\stackrel{-}{\sigma}\end{array}$ & $\begin{array}{l}\text { N } \\
\stackrel{\text { }}{\infty} \\
-1 \\
\stackrel{0}{0}\end{array}$ & 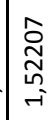 & 엇 & $\begin{array}{l}0 \\
0 \\
6 \\
7 \\
-1\end{array}$ & 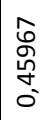 & \begin{tabular}{|l}
0 \\
0 \\
0 \\
0 \\
0 \\
0 \\
0
\end{tabular} & 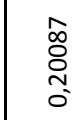 & 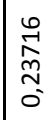 & 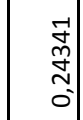 & 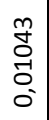 & 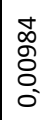 & 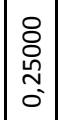 & $\begin{array}{c}\stackrel{-}{0} \\
\stackrel{n}{2} \\
m \\
0 \\
0\end{array}$ & $\begin{array}{l}0 \\
\text { N } \\
\text { o }\end{array}$ \\
\hline in & 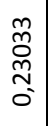 & $\begin{array}{l}0 \\
0 \\
m \\
0 \\
0 \\
0\end{array}$ & 0 & $\begin{array}{l}\text { Oे } \\
\text { ชิ } \\
0 \\
0\end{array}$ & $\begin{array}{l}8 \\
0 \\
0 \\
0 \\
0\end{array}$ & 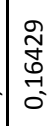 & 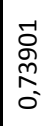 & $\begin{array}{l}\mathcal{Z} \\
\text { I } \\
0 \\
0 \\
0\end{array}$ & 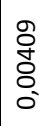 & 0 & 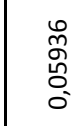 & 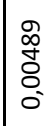 & 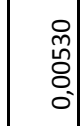 & 0 & 0 & 0 & 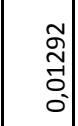 & $\begin{array}{l}\text { ஜ̊ } \\
\text { О' }\end{array}$ \\
\hline$\nabla$ & \begin{tabular}{l}
$\tilde{D}$ \\
$\sim$ \\
\multirow{J}{*}{} \\
0 \\
0
\end{tabular} & 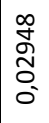 & $\left|\begin{array}{l}-1 \\
0 \\
-1 \\
0 \\
0\end{array}\right|$ & 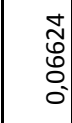 & $\begin{array}{l}\stackrel{0}{0} \\
\stackrel{9}{m} \\
\stackrel{-1}{0}\end{array}$ & $\begin{array}{l}\infty \\
0 \\
0 \\
\infty \\
0 \\
-i\end{array}$ & 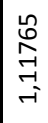 & $\begin{array}{l}\infty \\
0 \\
0 \\
0 \\
0 \\
0\end{array}$ & 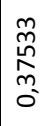 & $\begin{array}{l}\frac{1}{\hat{N}} \\
\hat{m} \\
0 \\
0\end{array}$ & 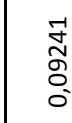 & $\begin{array}{l}0 \\
0 \\
2 \\
0 \\
0 \\
0\end{array}$ & $\begin{array}{l}0 \\
0 \\
0 \\
8 \\
0 \\
0\end{array}$ & 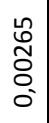 & $\begin{array}{l}0 \\
\tilde{N} \\
\delta \\
0 \\
0\end{array}$ & $\left|\begin{array}{l}\infty \\
0 \\
0 \\
0 \\
-1 \\
0 \\
0\end{array}\right|$ & $\begin{array}{l}\tilde{N} \\
\hat{m} \\
- \\
0\end{array}$ & $\begin{array}{l}\text { 今్ } \\
\text { ర్ } \\
0 \\
0\end{array}$ \\
\hline$m$ & $\begin{array}{c}0 \\
\stackrel{0}{2} \\
\rightarrow \\
0 \\
0\end{array}$ & 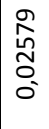 & $\left|\begin{array}{l} \pm \\
0 \\
0 \\
0 \\
0 \\
0 \\
0\end{array}\right|$ & $\begin{array}{l}m \\
0 \\
\vdots \\
0 \\
0 \\
0\end{array}$ & $\begin{array}{l}\stackrel{0}{0} \\
\tilde{ల} \\
0 \\
0 \\
0\end{array}$ & 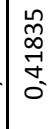 & 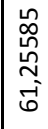 & 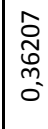 & 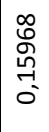 & 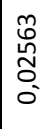 & $\begin{array}{l}\text { शे } \\
\hat{0} \\
0 \\
0\end{array}$ & $\begin{array}{l}n \\
\\
0 \\
\& \\
0 \\
0\end{array}$ & $\begin{array}{l}0 \\
0 \\
m \\
0 \\
0 \\
0\end{array}$ & 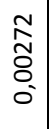 & 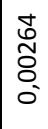 & $\begin{array}{l}\text { Oे } \\
\stackrel{+}{\hat{0}} \\
0 \\
0\end{array}$ & 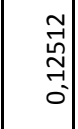 & 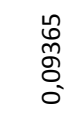 \\
\hline$\sim$ & 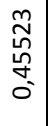 & $\begin{array}{l}\mathbf{D} \\
\infty \\
\infty \\
\infty \\
0 \\
0 \\
0\end{array}$ & 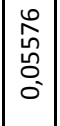 & $\begin{array}{l}0 \\
\stackrel{y}{0} \\
0 \\
0 \\
0\end{array}$ & 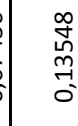 & $\begin{array}{l}\stackrel{+}{m} \\
\stackrel{\sim}{\sim} \\
\sigma \\
\sigma\end{array}$ & 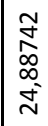 & 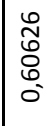 & 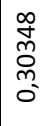 & 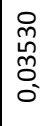 & $\begin{array}{l}\stackrel{8}{\circ} \\
\stackrel{0}{\circ} \\
-1 \\
0\end{array}$ & $\begin{array}{l}\infty \\
0 \\
0 \\
0 \\
0 \\
0\end{array}$ & $\begin{array}{l}n \\
\hat{N} \\
0 \\
0 \\
0\end{array}$ & $\begin{array}{l}\text { 芴 } \\
0 \\
0 \\
0\end{array}$ & 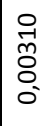 & 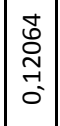 & $\begin{array}{l}0 \\
0 \\
0 \\
\stackrel{7}{0} \\
0\end{array}$ & $\begin{array}{l}\text { స్గ } \\
\infty \\
0 \\
0\end{array}$ \\
\hline-1 & 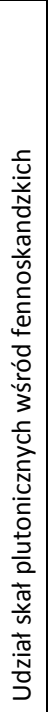 & 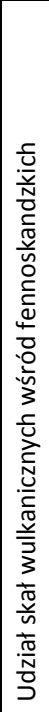 & 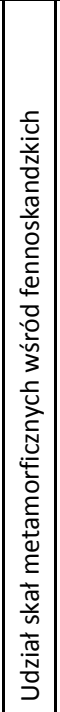 & 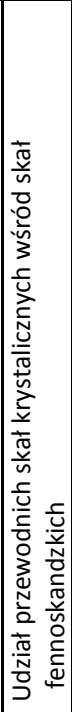 & 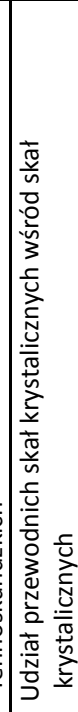 & $\mid \begin{array}{l}2 \\
0 \\
+ \\
0 \\
+ \\
+ \\
0 \\
0 \\
+ \\
0 \\
3 \\
11\end{array}$ & 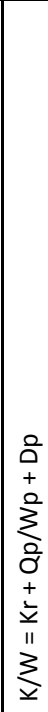 & $\begin{array}{l}8 \\
0 \\
+ \\
0 \\
0 \\
+ \\
+2\end{array}$ & 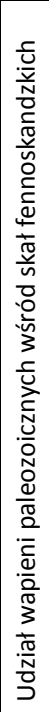 & 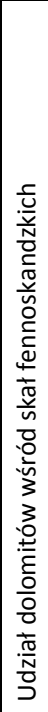 & 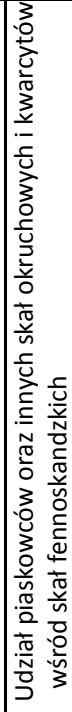 & 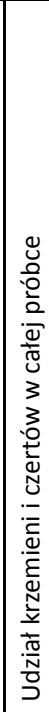 & 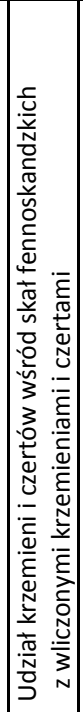 & 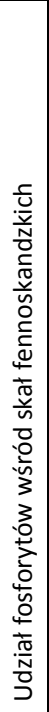 & 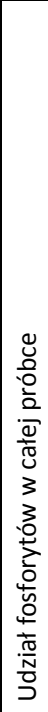 & 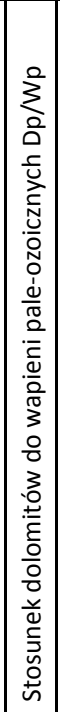 & 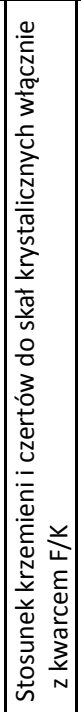 & 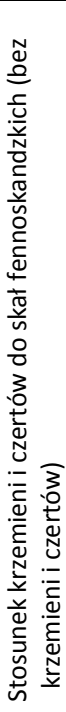 \\
\hline
\end{tabular}




\begin{tabular}{|c|c|c|c|c|c|c|c|c|c|c|c|c|c|c|}
\hline$\sigma$ & 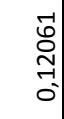 & $\begin{array}{l}\text { g } \\
\text { ర } \\
0 \\
0 \\
0\end{array}$ & $\begin{array}{l}\infty \\
\stackrel{\infty}{-} \\
\stackrel{-}{-} \\
\text { ஸे }\end{array}$ & 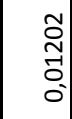 & $\begin{array}{l}\infty \\
\text { న్ } \\
\text { గ్ } \\
0 \\
0\end{array}$ & $\mid \begin{array}{c}\infty \\
-1 \\
0 \\
-1 \\
0 \\
0 \\
0\end{array}$ & 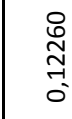 & 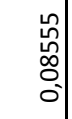 & $\begin{array}{l}0 \\
\text { 유. } \\
- \\
0 \\
0 \\
0\end{array}$ & 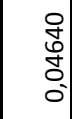 & 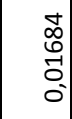 & $\begin{array}{l}n \\
0 \\
\varnothing \\
0 \\
-1 \\
0\end{array}$ & $\begin{array}{l}m \\
\infty \\
⿱ 亠 \\
0 \\
0 \\
0\end{array}$ & $\begin{array}{l}\stackrel{0}{\mathbb{N}} \\
\tilde{+} \\
\stackrel{-}{-} \\
0\end{array}$ \\
\hline$\infty$ & $\begin{array}{l}\infty \\
\infty \\
0 \\
0 \\
0\end{array}$ & $\begin{array}{l}-1 \\
\overline{\tilde{O}} \\
0 \\
0 \\
0\end{array}$ & 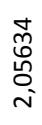 & 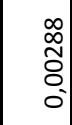 & \begin{tabular}{|l}
$d$ \\
0 \\
0 \\
0 \\
0 \\
0
\end{tabular} & $\begin{array}{l}m \\
2 \\
o \\
0 \\
0\end{array}$ & $\begin{array}{l}\hat{0} \\
0 \\
0 \\
0 \\
0\end{array}$ & $\begin{array}{l}-1 \\
0 \\
0 \\
0 \\
0 \\
0\end{array}$ & 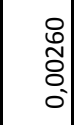 & \begin{tabular}{l}
$\infty$ \\
\multirow{0}{0}{} \\
-1 \\
0 \\
0
\end{tabular} & $\begin{array}{l}\text { مू } \\
\stackrel{2}{0} \\
0 \\
0\end{array}$ & $\begin{array}{l}0 \\
0 \\
0 \\
0 \\
0 \\
0\end{array}$ & $\begin{array}{l}0 \\
0 \\
m \\
m \\
0 \\
0 \\
0\end{array}$ & $\begin{array}{l}m \\
\stackrel{0}{h} \\
0 \\
0 \\
0\end{array}$ \\
\hline$n$ & $\begin{array}{l}\infty \\
0 \\
\tilde{N} \\
0 \\
0 \\
0\end{array}$ & $\begin{array}{l}\tilde{n} \\
\tilde{y} \\
\tilde{\Xi} \\
0 \\
0\end{array}$ & 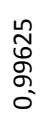 & 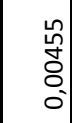 & $\begin{array}{l}\text { No } \\
\text { 令 } \\
0 \\
0\end{array}$ & $\left|\begin{array}{l}0 \\
0 \\
0 \\
0 \\
0 \\
0\end{array}\right|$ & 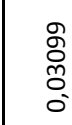 & $\begin{array}{l}m \\
\widetilde{m} \\
\tilde{n} \\
0 \\
0\end{array}$ & 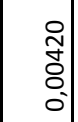 & $\begin{array}{l}0 \\
0 \\
0 \\
0 \\
0 \\
0\end{array}$ & $\begin{array}{l}2 \\
\hat{2} \\
0 \\
0 \\
0\end{array}$ & 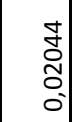 & $\begin{array}{l}\tilde{0} \\
0 \\
\tilde{n} \\
0 \\
0\end{array}$ & $\begin{array}{l}\infty \\
0 \\
0 \\
0 \\
0 \\
0 \\
0\end{array}$ \\
\hline 6 & 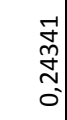 & $\begin{array}{l}\mathscr{\ell} \\
\varnothing \\
\swarrow \\
0 \\
0 \\
0\end{array}$ & 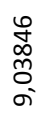 & 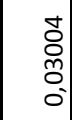 & $\begin{array}{l}\text { న్ } \\
\text { o } \\
0 \\
0 \\
0\end{array}$ & $\begin{array}{l}\tilde{n} \\
\tilde{n} \\
\\
0 \\
0 \\
0\end{array}$ & $\begin{array}{l}8 \\
8 \\
0 \\
0 \\
0\end{array}$ & 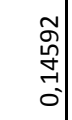 & 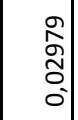 & 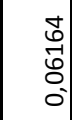 & $\begin{array}{l}\hat{9} \\
\tilde{y} \\
0 \\
0\end{array}$ & 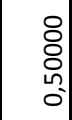 & \begin{tabular}{l}
$\infty$ \\
0 \\
\multirow{2}{+}{} \\
$\stackrel{-}{-}$ \\
0
\end{tabular} & 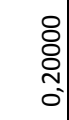 \\
\hline in & $\begin{array}{l}0 \\
\tilde{ల} \\
\stackrel{0}{0} \\
0 \\
0\end{array}$ & 0 & 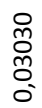 & 0 & 0 & 0 & 0 & 0 & 0 & 0 & 0 & 0 & 0 & 0 \\
\hline$\sigma$ & 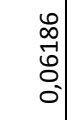 & 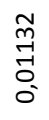 & $\begin{array}{l}\hat{0} \\
\stackrel{0}{0} \\
\stackrel{0}{*}\end{array}$ & $\begin{array}{l}n \\
\stackrel{y}{q} \\
0 \\
0 \\
0\end{array}$ & $\begin{array}{l}\stackrel{n}{\sim} \\
\stackrel{\sim}{\tilde{0}} \\
0 \\
0\end{array}$ & 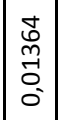 & 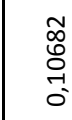 & 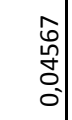 & 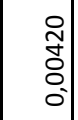 & $\begin{array}{l}m \\
2 \\
\vdots \\
0 \\
0\end{array}$ & 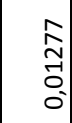 & $\begin{array}{l}\text { षे } \\
\$ \\
0 \\
0 \\
0\end{array}$ & $\begin{array}{l}0 \\
\text { ڤ్ } \\
\tilde{n} \\
0 \\
0\end{array}$ & 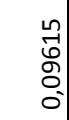 \\
\hline$m$ & 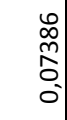 & 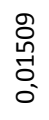 & $\begin{array}{l}\text { 유 } \\
\text { 守 } \\
\text { N }\end{array}$ & $\begin{array}{l}n \\
\tilde{0} \\
0 \\
0 \\
0 \\
0\end{array}$ & 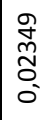 & $\begin{array}{l}0 \\
\stackrel{0}{m} \\
\dot{m} \\
0 \\
0\end{array}$ & 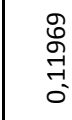 & $\begin{array}{l}-1 \\
-1 \\
0 \\
0 \\
0\end{array}$ & 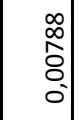 & $\begin{array}{l}\hat{0} \\
0 \\
0 \\
0 \\
0\end{array}$ & $\begin{array}{l}0 \\
\stackrel{\infty}{-} \\
-1 \\
0 \\
0 \\
0\end{array}$ & 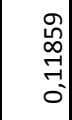 & $\begin{array}{l}\tilde{\approx} \\
\stackrel{0}{0} \\
0 \\
0\end{array}$ & $\begin{array}{l}-1 \\
\text { مू} \\
\text { ஸે } \\
0 \\
0\end{array}$ \\
\hline$\sim$ & $\begin{array}{l}n \\
\stackrel{n}{N} \\
0 \\
0\end{array}$ & $\begin{array}{l}8 \\
8 \\
0 \\
0 \\
0 \\
0\end{array}$ & 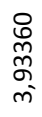 & $\begin{array}{l}\overrightarrow{1} \\
0 \\
0 \\
0 \\
0\end{array}$ & $\begin{array}{l}\hat{F} \\
\tilde{\tilde{n}} \\
0 \\
0\end{array}$ & 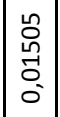 & 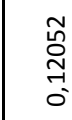 & 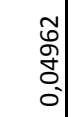 & $\begin{array}{l}\vec{n} \\
\hat{0} \\
8 \\
0\end{array}$ & $\begin{array}{l}\text { ñ. } \\
\text { ญิ } \\
\text { రิ } \\
0\end{array}$ & $\begin{array}{l}\stackrel{\infty}{m} \\
\stackrel{m}{=} \\
\stackrel{0}{0} \\
0\end{array}$ & 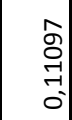 & 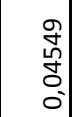 & $\begin{array}{l}\stackrel{0}{O} \\
\stackrel{0}{0} \\
\stackrel{-}{\circ}\end{array}$ \\
\hline-1 & 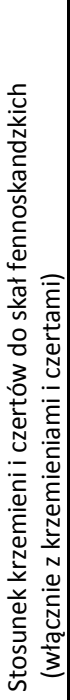 & 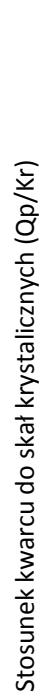 & 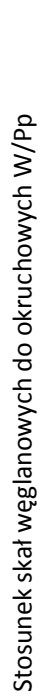 & 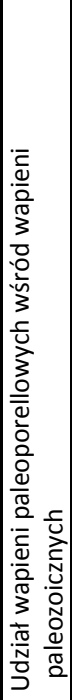 & 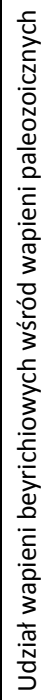 & 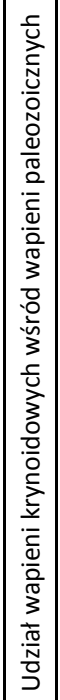 & 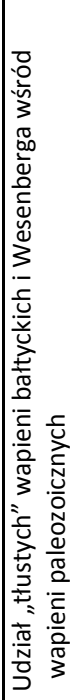 & 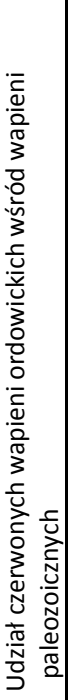 & 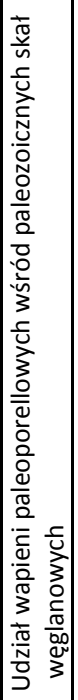 & 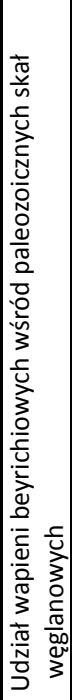 & 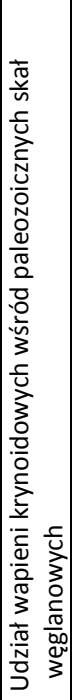 & 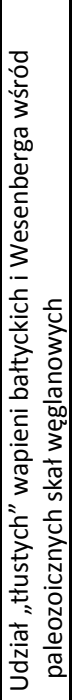 & 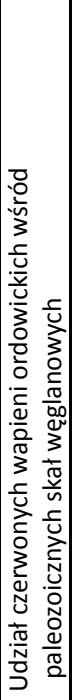 & 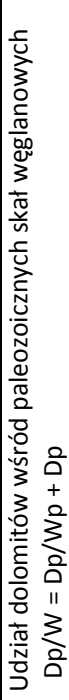 \\
\hline
\end{tabular}




\begin{tabular}{|c|c|c|c|c|c|c|c|c|c|c|c|c|c|c|c|}
\hline 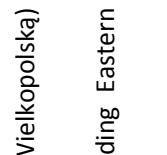 & 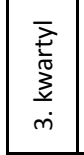 & $\sigma$ & $\begin{array}{l}8 \\
\stackrel{9}{1} \\
\hat{m} \\
0 \\
0\end{array}$ & 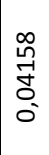 & 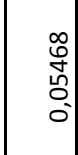 & 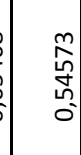 & $\begin{array}{l}m \\
0 \\
0 \\
m \\
0 \\
0\end{array}$ & $\begin{array}{l}\mathbf{0} \\
2 \\
\\
0 \\
0\end{array}$ & \begin{tabular}{l}
7 \\
\multirow{y}{y}{} \\
0 \\
0 \\
0
\end{tabular} & 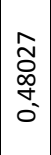 & 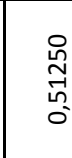 & $\begin{array}{l}\text { ? } \\
\text { ने } \\
0 \\
0\end{array}$ & 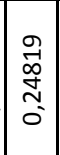 & 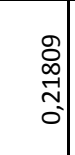 & \\
\hline $\begin{array}{l}\stackrel{U}{\subseteq} \\
\overline{0} \\
\frac{c}{0} \\
\frac{0}{0}\end{array}$ & $\begin{array}{l}\overline{\vec{V}} \\
\frac{0}{0} \\
\frac{2}{2} \\
-i\end{array}$ & $\infty$ & $\begin{array}{l}0 \\
0 \\
5 \\
0 \\
0 \\
0\end{array}$ & 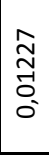 & \begin{tabular}{l}
0 \\
\multirow{1}{*}{} \\
$\vdots$ \\
0 \\
0
\end{tabular} & 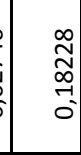 & $\begin{array}{l}\text { Na } \\
\text { ô } \\
\text { - } \\
0\end{array}$ & 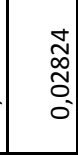 & 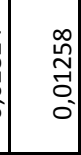 & $\mid \begin{array}{c}0 \\
0 \\
0 \\
\\
\vdots \\
0\end{array}$ & $\begin{array}{l}\text { oे } \\
\text { ठ̀ } \\
\text { n. } \\
0\end{array}$ & 0 & $\mid \begin{array}{c}1 \\
0 \\
0 \\
0 \\
-1 \\
0\end{array}$ & $\begin{array}{l}\text { शे } \\
0 \\
\text { - } \\
- \\
0\end{array}$ & \\
\hline 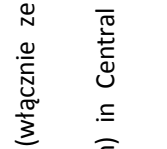 & 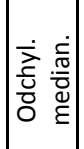 & $r$ & $\begin{array}{l}m \\
0 \\
m \\
0 \\
0 \\
0 \\
0\end{array}$ & 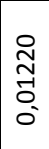 & 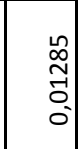 & 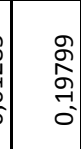 & 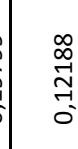 & 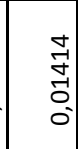 & 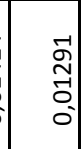 & \begin{tabular}{|l|}
$\infty$ \\
0 \\
0 \\
0 \\
0 \\
0 \\
0 \\
0
\end{tabular} & 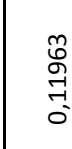 & 0 & $\mid \begin{array}{l}\infty \\
0 \\
0 \\
0 \\
0 \\
0\end{array}$ & 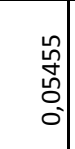 & \\
\hline 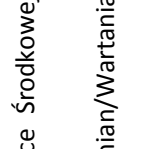 & $\frac{\dot{v}}{\sum}$ & 6 & $\begin{array}{l}\infty \\
\stackrel{0}{n} \\
\stackrel{m}{-} \\
0 \\
0\end{array}$ & $\begin{array}{l}\infty \\
\omega_{n}^{n} \\
-1 \\
-1 \\
0\end{array}$ & 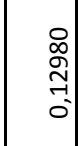 & 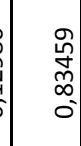 & $\begin{array}{l}0 \\
0 \\
0 \\
\tilde{\pi} \\
0 \\
0\end{array}$ & 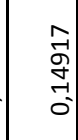 & 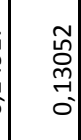 & $\mid \begin{array}{c}\hat{n} \\
\hat{n} \\
\hat{n} \\
0 \\
0\end{array}$ & 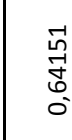 & $\begin{array}{l}5 \\
2 \\
\text { 2n } \\
0 \\
0\end{array}$ & 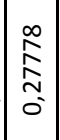 & 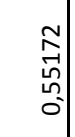 & \\
\hline $\begin{array}{l}\frac{0}{\overline{0}} \\
\text { 이 }\end{array}$ & $\stackrel{5}{\Sigma}$ & in & 0 & 0 & $\begin{array}{l}1 \\
\tilde{N} \\
0 \\
0 \\
0\end{array}$ & 0 & 0 & 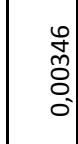 & 0 & $\begin{array}{l}- \\
- \\
- \\
- \\
- \\
0 \\
0\end{array}$ & $\begin{array}{l}\hat{\mathscr{0}} \\
\stackrel{0}{0} \\
-1 \\
0\end{array}$ & 0 & 0 & 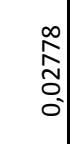 & ఫ্ \\
\hline$\varepsilon$ & 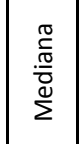 & $\theta$ & 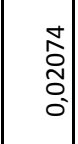 & 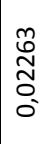 & \begin{tabular}{l}
$\mathcal{T}$ \\
\multirow{0}{*}{} \\
0 \\
0 \\
0
\end{tabular} & $\begin{array}{c}\hat{9} \\
0 \\
\text { o. } \\
0 \\
0\end{array}$ & 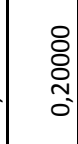 & 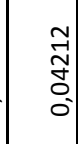 & $\begin{array}{c}0 \\
0 \\
\tilde{n} \\
0 \\
0 \\
0\end{array}$ & $\mid \begin{array}{c}0 \\
\hat{N} \\
\hat{n} \\
\tilde{n} \\
0\end{array}$ & $\begin{array}{l}\text { o } \\
\infty \\
\infty \\
m \\
0 \\
0\end{array}$ & 0 & 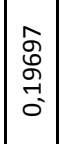 & $\begin{array}{l}m \\
0 \\
0 \\
0 \\
-1 \\
0 \\
0\end{array}$ & ה \\
\hline 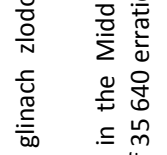 & 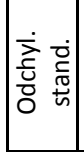 & $m$ & $\begin{array}{l}\hat{n} \\
\tilde{n} \\
0 \\
0 \\
0\end{array}$ & 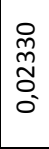 & $\begin{array}{c}0 \\
0 \\
\tilde{n} \\
0 \\
0 \\
0\end{array}$ & 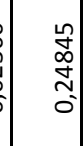 & 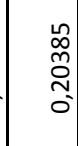 & $\begin{array}{l}0 \\
0 \\
0 \\
0 \\
0 \\
0\end{array}$ & $\begin{array}{l}0 \\
0 \\
0 \\
0 \\
0 \\
0\end{array}$ & $\mid \begin{array}{c}m \\
o \\
o \\
m \\
\tilde{c} \\
0\end{array}$ & $\begin{array}{l}\tilde{N} \\
\stackrel{n}{m} \\
\stackrel{-}{0}\end{array}$ & \begin{tabular}{l}
$m$ \\
\multicolumn{6}{|}{} \\
0 \\
0 \\
0
\end{tabular} & \begin{tabular}{l}
\multirow{2}{n}{} \\
$\mathscr{8}$ \\
0 \\
0
\end{tabular} & $\begin{array}{l}8 \\
\text { à } \\
\text { - } \\
0 \\
0\end{array}$ & 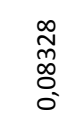 \\
\hline 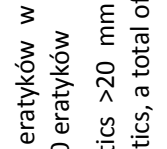 & 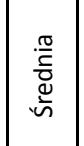 & $\sim$ & $\begin{array}{l}\hat{n} \\
\hat{n} \\
0 \\
0 \\
0\end{array}$ & 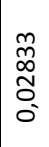 & $\begin{array}{l}\tilde{n} \\
\tilde{n} \\
\tilde{0} \\
0 \\
0\end{array}$ & $\begin{array}{l}\hat{\jmath} \\
0 \\
0 \\
0 \\
0 \\
0\end{array}$ & 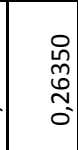 & $\begin{array}{l}0 \\
0 \\
0 \\
0 \\
0\end{array}$ & $\begin{array}{l}0 \\
0 \\
0 \\
0 \\
0 \\
0\end{array}$ & 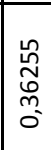 & $\begin{array}{l}\text { Oे } \\
\text { Oे } \\
\text { d } \\
\text { ó }\end{array}$ & $\begin{array}{l}8 \\
8 \\
0 \\
0 \\
0\end{array}$ & 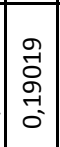 & 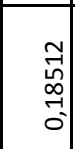 & $\begin{array}{l}\stackrel{m}{\rightarrow} \\
\overrightarrow{7} \\
0\end{array}$ \\
\hline 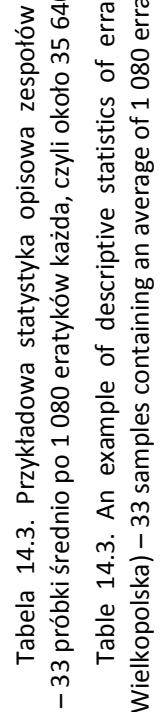 & 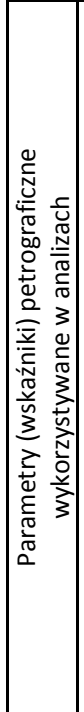 & $r$ & 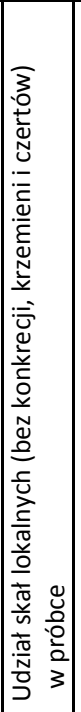 & 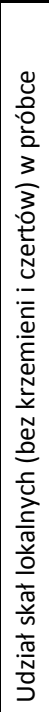 & 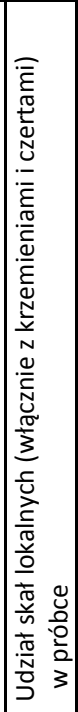 & 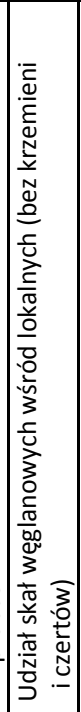 & 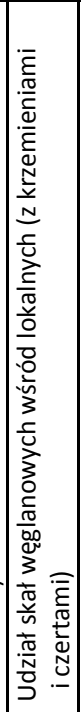 & 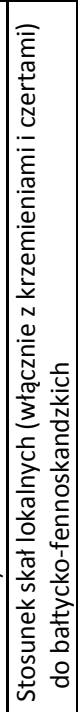 & 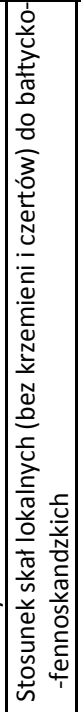 & 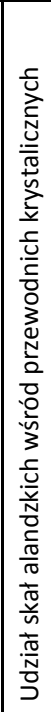 & 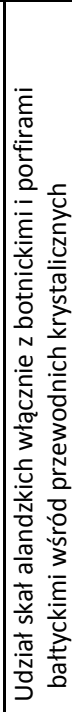 & 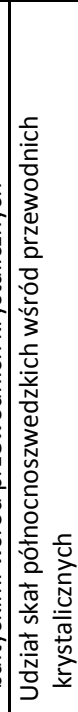 & 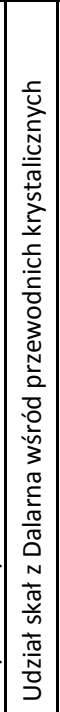 & 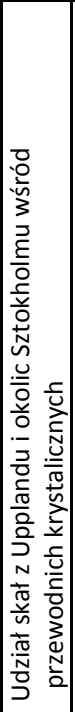 & 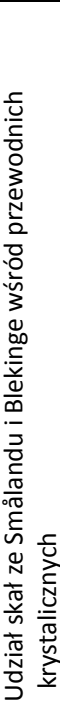 \\
\hline
\end{tabular}




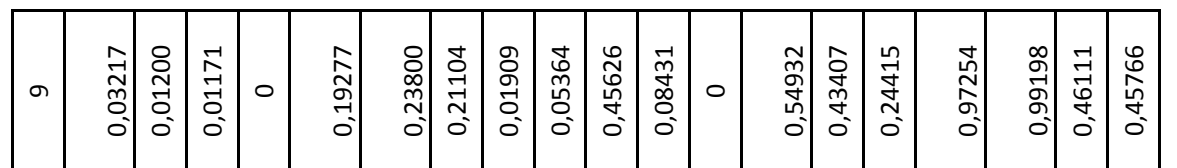

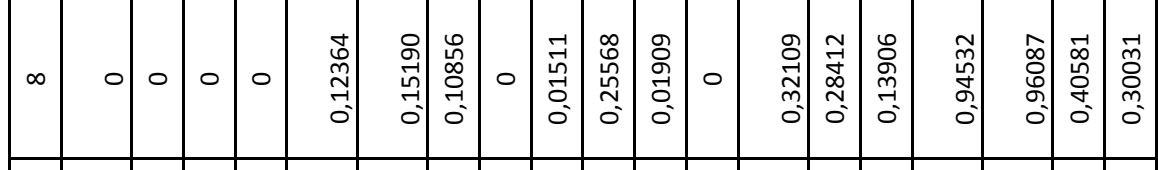

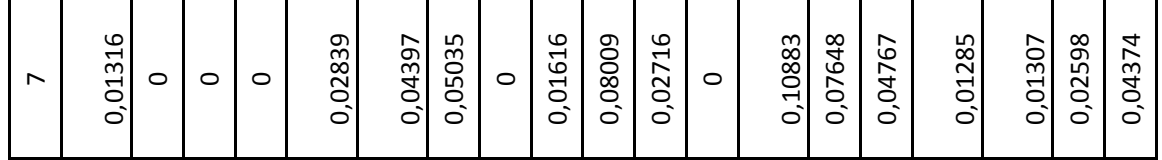

\begin{tabular}{|c|c|c|c|c|c|c|c|c|c|c|c|c|c|c|c|c|c|c|c|}
\hline 6 & $\begin{array}{l}\exists \\
\exists \\
\text { I } \\
\text { - }\end{array}$ & \begin{tabular}{l}
0 \\
\multirow{2}{n}{} \\
$\hat{0}$ \\
0 \\
0
\end{tabular} & $\begin{array}{l}n \\
0 \\
o \\
0 \\
0 \\
0\end{array}$ & 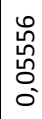 & $\begin{array}{l}\text { ठ } \\
\infty \\
+ \\
0\end{array}$ & 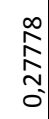 & 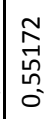 & 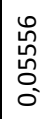 & 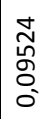 & $\begin{array}{l}\underset{N}{N} \\
\hat{\sim} \\
0 \\
0\end{array}$ & 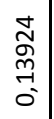 & $\begin{array}{l}\text { no } \\
\hat{0} \\
0 \\
0 \\
0 \\
0\end{array}$ & $\begin{array}{l}-1 \\
8 \\
0 \\
0 \\
0\end{array}$ & $\begin{array}{l}\mathscr{0} \\
\mathscr{0} \\
\infty \\
0 \\
0 \\
0\end{array}$ & 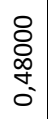 & 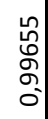 & -1 & 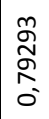 & 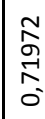 \\
\hline
\end{tabular}

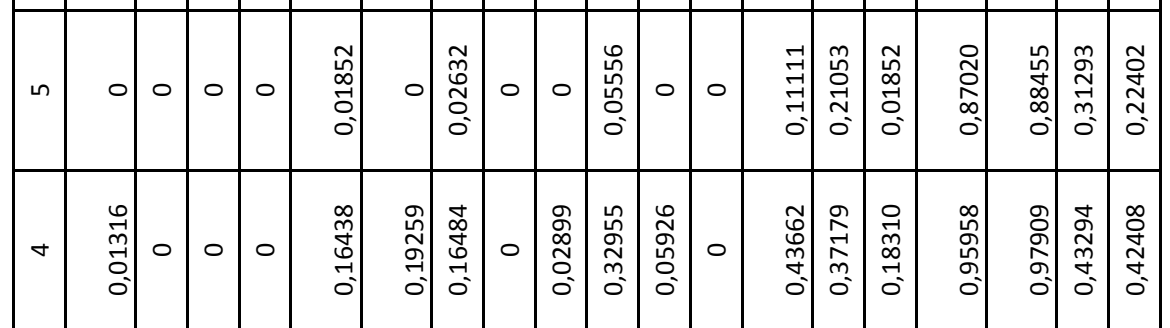

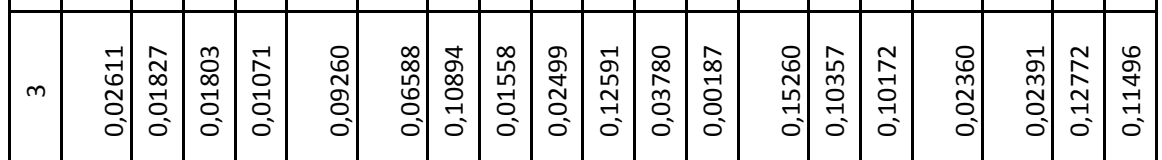

\begin{tabular}{|c|c|c|c|c|c|c|c|c|c|c|c|c|c|c|c|c|c|c|c|}
\hline$N$ & $\begin{array}{l}\hat{\text { Dे }} \\
\text { o } \\
0\end{array}$ & $\begin{array}{l}\infty \\
\stackrel{0}{ } \\
\delta \\
0 \\
0 \\
0\end{array}$ & $\begin{array}{l}\text { ปे } \\
\text { ठे } \\
\text { ठ }\end{array}$ & 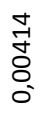 & 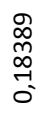 & 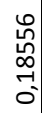 & 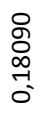 & $\begin{array}{l}1 \\
0 \\
0 \\
0 \\
0\end{array}$ & \begin{tabular}{l} 
No \\
\multirow{2}{*}{} \\
0 \\
0
\end{tabular} & $\begin{array}{c}m \\
\infty \\
m \\
m \\
\sigma^{\prime}\end{array}$ & $\begin{array}{l}\text { 苟 } \\
\text { 足 } \\
0\end{array}$ & $\begin{array}{l}\tilde{m} \\
\stackrel{0}{0} \\
\stackrel{0}{0} \\
0^{\prime}\end{array}$ & 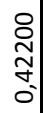 & 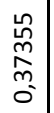 & 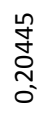 & $\begin{array}{l}\hat{\hat{o}} \\
\text { م⿱ } \\
0 \\
0\end{array}$ & $\begin{array}{l}\infty \\
o \\
o \\
o \\
o \\
0\end{array}$ & \begin{tabular}{l}
$\tilde{N}$ \\
$\stackrel{n}{f}$ \\
\multirow{0}{0}{}
\end{tabular} & \begin{tabular}{l}
-1 \\
\multicolumn{2}{|c}{} \\
0 \\
0 \\
0 \\
0
\end{tabular} \\
\hline
\end{tabular}

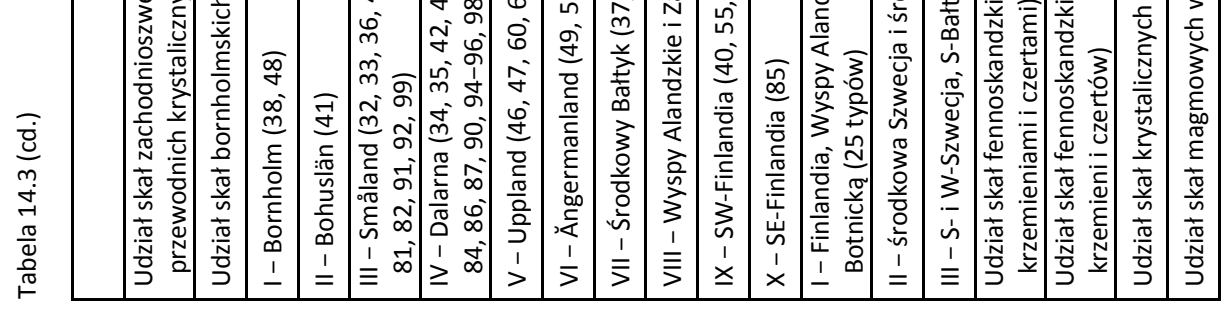




\begin{tabular}{|c|c|c|c|c|c|c|c|c|c|c|c|c|c|c|c|c|c|c|}
\hline$\sigma$ & $\begin{array}{l}\mathbb{N} \\
\vec{H} \\
\dot{J} \\
0\end{array}$ & $\begin{array}{l}m \\
0 \\
0 \\
0 \\
0 \\
0\end{array}$ & 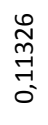 & $\begin{array}{l}\text { o } \\
\text { ô } \\
0 \\
0 \\
0\end{array}$ & 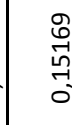 & - & $\begin{array}{l}\infty \\
\stackrel{\infty}{\sigma} \\
\stackrel{0}{0} \\
-i\end{array}$ & 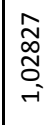 & 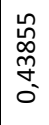 & $\begin{array}{l}\infty \\
\infty \\
0 \\
0 \\
0 \\
0 \\
0\end{array}$ & 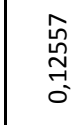 & 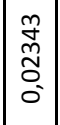 & 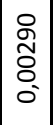 & 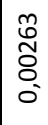 & 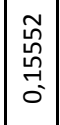 & 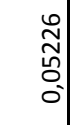 & 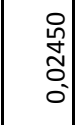 & 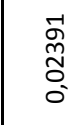 \\
\hline$\infty$ & 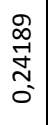 & $\begin{array}{l}-1 \\
0 \\
0 \\
0 \\
0 \\
0\end{array}$ & 0 & $\begin{array}{l}\tilde{N} \\
\text { ปn } \\
0 \\
0 \\
0\end{array}$ & $\begin{array}{l}\hat{\sigma} \\
\vec{b} \\
\overrightarrow{-} \\
0\end{array}$ & $\begin{array}{l}\text { ñ } \\
\text { o } \\
o \\
-1 \\
-1\end{array}$ & 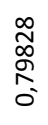 & $\begin{array}{l}\vec{N} \\
\stackrel{N}{N} \\
\stackrel{0}{0}\end{array}$ & $\begin{array}{l}\text { ô } \\
0 \\
\infty \\
m \\
0 \\
0\end{array}$ & 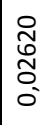 & $\begin{array}{l}\text { f } \\
\text { م⿱ } \\
0 \\
0^{\circ}\end{array}$ & $\left|\begin{array}{l}\infty \\
0 \\
0 \\
0 \\
0\end{array}\right|$ & $\mid \begin{array}{l}0 \\
\hat{0} \\
0 \\
0 \\
0\end{array}$ & 令 & 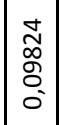 & $\begin{array}{l}\tilde{D} \\
0 \\
0 \\
0 \\
0 \\
0\end{array}$ & $\begin{array}{l}\hat{0} \\
0 \\
0 \\
0\end{array}$ & $\begin{array}{l}\text { مे } \\
\text { on } \\
0 \\
0\end{array}$ \\
\hline$\wedge$ & 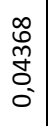 & $\mid \begin{array}{c}\infty \\
\stackrel{n}{0} \\
\hat{-} \\
0 \\
0\end{array}$ & $\begin{array}{l}\frac{1}{N} \\
\overrightarrow{8} \\
0 \\
0\end{array}$ & $\begin{array}{l}\text { ñ } \\
\text { o. } \\
0 \\
0\end{array}$ & $\begin{array}{l}\tilde{n} \\
0_{n}^{-1} \\
0 \\
0 \\
0\end{array}$ & 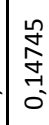 & $\begin{array}{l}0 \\
0 \\
0 \\
0 \\
0 \\
0\end{array}$ & 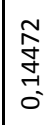 & 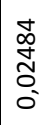 & \begin{tabular}{|l}
0 \\
0 \\
0 \\
-1 \\
0 \\
0 \\
0
\end{tabular} & $\begin{array}{l}\stackrel{\sim}{m} \\
\stackrel{\sim}{\Xi} \\
0 \\
0\end{array}$ & $\mid \begin{array}{l} \pm \\
0 \\
0 \\
0 \\
0 \\
0 \\
0\end{array}$ & 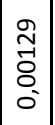 & 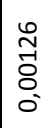 & $\mid \begin{array}{c}\mathcal{Z} \\
\text { 工్ } \\
0 \\
0 \\
0\end{array}$ & 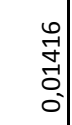 & $\begin{array}{l}0 \\
0 \\
0 \\
8 \\
0 \\
0\end{array}$ & $\begin{array}{l}8 \\
\stackrel{0}{0} \\
0\end{array}$ \\
\hline 6 & $\begin{array}{l}\infty \\
0 \\
\mathbb{N} \\
0 \\
0 \\
0 \\
0\end{array}$ & $\begin{array}{l}\text { o } \\
\stackrel{2}{ } \\
\text { જે } \\
0 \\
0\end{array}$ & 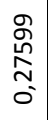 & 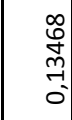 & $\begin{array}{l}\infty \\
\bigcap^{\circ} \\
\infty \\
-1 \\
0\end{array}$ & 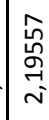 & $\underset{m}{m}-$ & 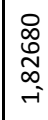 & $\begin{array}{l}\text { N } \\
\hat{N} \\
\hat{\Lambda} \\
0 \\
0\end{array}$ & $\begin{array}{l}9 \\
0 \\
6 \\
-1 \\
-1 \\
0\end{array}$ & $\begin{array}{l}\text { O) } \\
\underset{\sim}{N} \\
\text { o }\end{array}$ & $\left|\begin{array}{l}n \\
0 \\
0 \\
0 \\
0 \\
0 \\
0\end{array}\right|$ & $\mid \begin{array}{c}\hat{N} \\
\hat{n} \\
0 \\
0 \\
0\end{array}$ & 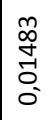 & 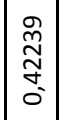 & $\begin{array}{l}\text { 员 } \\
\text { م⿱ } \\
0 \\
0 \\
0 \\
0\end{array}$ & $\begin{array}{l}\hat{\hat{n}} \\
\stackrel{2}{0} \\
0 \\
0\end{array}$ & $\begin{array}{l}\text { ô } \\
\text { Нี } \\
\text { م. } \\
0\end{array}$ \\
\hline in & $\begin{array}{c}\mathbb{1} \\
\infty \\
\infty \\
\rightarrow \\
0 \\
0\end{array}$ & 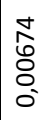 & 0 & 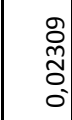 & $\begin{array}{l}0 \\
0 \\
\stackrel{2}{0} \\
0 \\
0 \\
0\end{array}$ & 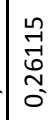 & 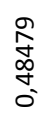 & 0 & 0 & 0 & $\begin{array}{l}\text { ปे } \\
\text { ఫे } \\
\text { o }\end{array}$ & 0 & 0 & 0 & 0 & 0 & 0 & 0 \\
\hline$\nabla$ & 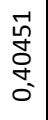 & 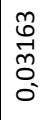 & \begin{tabular}{l}
\multirow{2}{*}{} \\
- \\
8 \\
0 \\
0
\end{tabular} & 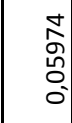 & $\begin{array}{l}\stackrel{\infty}{\sim} \\
\stackrel{\sim}{7} \\
0\end{array}$ & 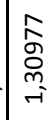 & 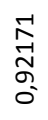 & $\begin{array}{l}\underset{\sim}{\sim} \\
\text { - } \\
\infty \\
0 \\
0\end{array}$ & $\begin{array}{l}0 \\
\text { o } \\
\text { ô } \\
\text { o. } \\
\text { - }\end{array}$ & 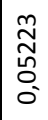 & 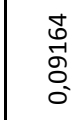 & 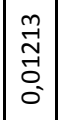 & 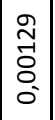 & 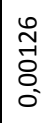 & $\mid \begin{array}{c}0 \\
-1 \\
m \\
n \\
-1 \\
0\end{array}$ & 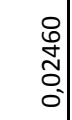 & 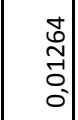 & 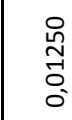 \\
\hline$m$ & 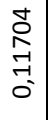 & 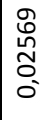 & $\begin{array}{l}\hat{n} \\
\hat{n} \\
0 \\
0 \\
0\end{array}$ & 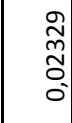 & $\begin{array}{l}\hat{0} \\
\stackrel{n}{n} \\
0 \\
0 \\
0\end{array}$ & 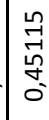 & $\begin{array}{l}\stackrel{n}{\stackrel{-}{I}} \\
\stackrel{\sim}{\sim}\end{array}$ & $\begin{array}{l}\text { J } \\
\text { مे } \\
\text { స̃ } \\
\text { o }\end{array}$ & 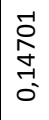 & $\begin{array}{l}n \\
0 \\
0 \\
\tilde{O} \\
0 \\
0\end{array}$ & $\begin{array}{l}\vec{g} \\
\text { O } \\
\text { O } \\
0\end{array}$ & 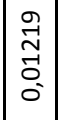 & $\begin{array}{c}\infty \\
\tilde{N} \\
o \\
0 \\
0\end{array}$ & $\begin{array}{l}m \\
\tilde{m} \\
\stackrel{0}{0} \\
0\end{array}$ & $\left|\begin{array}{l}0 \\
0 \\
0 \\
0 \\
0 \\
0\end{array}\right|$ & 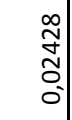 & 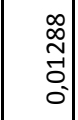 & 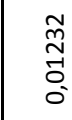 \\
\hline$\sim$ & 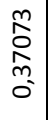 & 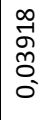 & $\begin{array}{l}\tilde{N} \\
\hat{\bigcap} \\
\varnothing \\
0 \\
0\end{array}$ & 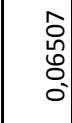 & $\begin{array}{l}\stackrel{N}{N} \\
\stackrel{n}{\oplus} \\
\stackrel{0}{0}\end{array}$ & 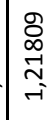 & 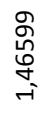 & $\begin{array}{l}\mathscr{0} \\
\mathscr{0} \\
0 \\
-1 \\
0 \\
0\end{array}$ & 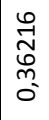 & $\begin{array}{l}\text { 웅 } \\
0 \\
0 \\
0 \\
0 \\
0\end{array}$ & $\begin{array}{l}\infty \\
\stackrel{1}{\infty} \\
\stackrel{0}{0} \\
\overbrace{}^{\prime}\end{array}$ & 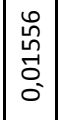 & 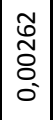 & 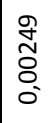 & $\left|\begin{array}{c}m \\
\tilde{N} \\
\tilde{n} \\
- \\
0 \\
0\end{array}\right|$ & $\begin{array}{l}\text { Dे } \\
m \\
\tilde{m} \\
0 \\
0 \\
0\end{array}$ & $\begin{array}{l}\text { ñ } \\
0 \\
0 \\
0 \\
0 \\
0\end{array}$ & $\begin{array}{l}\text { مू } \\
\text { م్ } \\
0 \\
0\end{array}$ \\
\hline- & 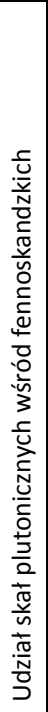 & 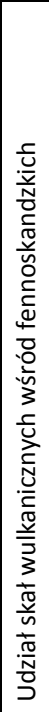 & 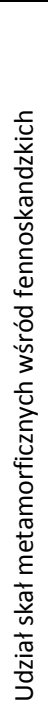 & 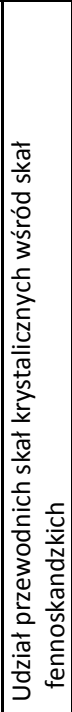 & 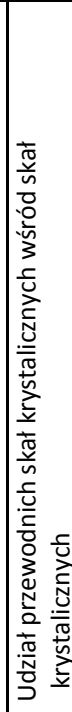 & 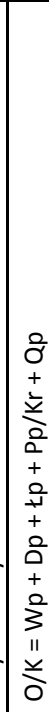 & 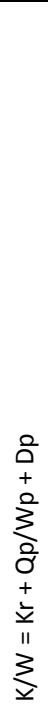 & 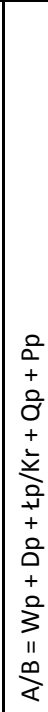 & 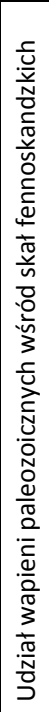 & 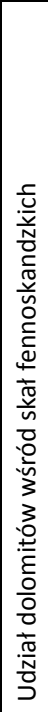 & 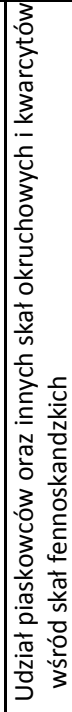 & 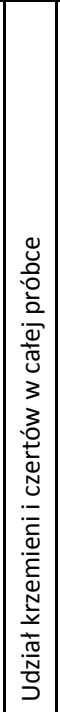 & 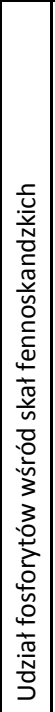 & 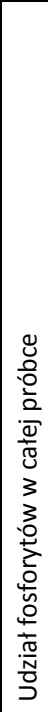 & 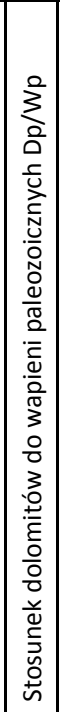 & 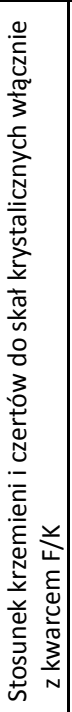 & 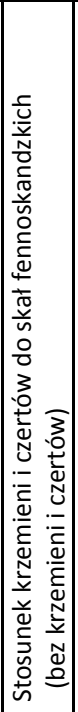 & 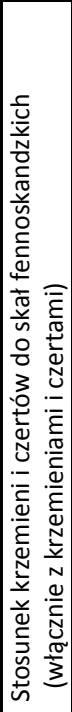 \\
\hline
\end{tabular}




\begin{tabular}{|c|c|c|c|c|c|c|c|c|c|c|c|c|c|}
\hline$\sigma$ & $\begin{array}{l}\stackrel{8}{2} \\
\stackrel{+}{-} \\
0 \\
0\end{array}$ & $\begin{array}{l}\stackrel{-1}{\hat{N}} \\
\stackrel{\infty}{N} \\
\stackrel{6}{ }\end{array}$ & 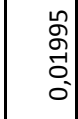 & $\begin{array}{l}\text { o } \\
8 \\
0 \\
0 \\
0\end{array}$ & $\begin{array}{l}\stackrel{0}{\Lambda} \\
\stackrel{n}{n} \\
0 \\
0 \\
0\end{array}$ & 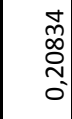 & 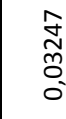 & $\begin{array}{l}0 \\
\infty \\
\stackrel{1}{1} \\
0 \\
0\end{array}$ & $\begin{array}{l}-1 \\
\text { ñ } \\
\tilde{0} \\
0 \\
0\end{array}$ & \begin{tabular}{l}
$\infty$ \\
\multirow{1}{n}{} \\
$\tilde{0}$ \\
0 \\
0
\end{tabular} & $\begin{array}{c}m \\
5 \\
\infty \\
-1 \\
0\end{array}$ & 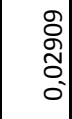 & 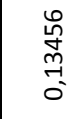 \\
\hline$\infty$ & 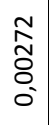 & $\begin{array}{l}\overrightarrow{-} \\
\stackrel{8}{9} \\
\dot{9}\end{array}$ & $\begin{array}{l}\infty \\
0 \\
0 \\
0 \\
0 \\
0\end{array}$ & $\mid \begin{array}{l}0 \\
0 \\
0 \\
0 \\
0 \\
0\end{array}$ & $\begin{array}{c}\tilde{O} \\
\stackrel{7}{-1} \\
0 \\
0\end{array}$ & $\begin{array}{l}\text { L్ } \\
0 \\
0 \\
0 \\
0\end{array}$ & $\begin{array}{l}\text { ñ } \\
\text { స్ } \\
0 \\
0 \\
0\end{array}$ & $\begin{array}{l}8 \\
0 \\
0 \\
0 \\
0\end{array}$ & \begin{tabular}{l} 
I \\
\multirow{G}{0}{} \\
0 \\
0
\end{tabular} & $\begin{array}{l}\text { ठ্ } \\
8 \\
0 \\
0\end{array}$ & 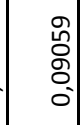 & $\begin{array}{l}0 \\
0 \\
0 \\
0 \\
0 \\
0\end{array}$ & $\begin{array}{l}\text { J } \\
\stackrel{0}{0} \\
0 \\
0\end{array}$ \\
\hline$r$ & $\begin{array}{l}0 \\
0 \\
\stackrel{0}{0} \\
0 \\
0\end{array}$ & $\begin{array}{l}\stackrel{\infty}{+} \\
\stackrel{\text { }}{N} \\
\stackrel{\text { ஸे }}{\sim}\end{array}$ & $\begin{array}{l}\hat{9} \\
\text { ఫे } \\
\text { ○े }\end{array}$ & $\begin{array}{l}\text { o } \\
\text { I } \\
-1 \\
0 \\
0 \\
0\end{array}$ & $\begin{array}{l}\infty \\
o \\
\stackrel{m}{0} \\
\stackrel{0}{0} \\
0\end{array}$ & 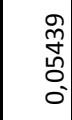 & $\begin{array}{l}\infty \\
\stackrel{0}{0} \\
0 \\
0\end{array}$ & $\begin{array}{l}m \\
0 \\
0 \\
0 \\
0 \\
0\end{array}$ & 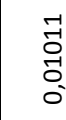 & $\begin{array}{l}\hat{\sigma} \\
G \\
\sigma \\
0 \\
0\end{array}$ & 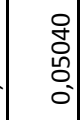 & $\begin{array}{l}\tilde{D} \\
\stackrel{n}{0} \\
0 \\
0\end{array}$ & 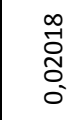 \\
\hline 6 & 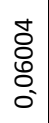 & 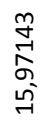 & 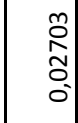 & $\mid \begin{array}{l}-\vec{n} \\
\tilde{\varrho} \\
0 \\
0\end{array}$ & 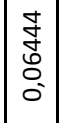 & $\begin{array}{c}\widehat{c} \\
0 \\
\infty \\
\sim \\
0 \\
0\end{array}$ & $\begin{array}{l}m \\
\stackrel{n}{-1} \\
\varnothing \\
0 \\
0\end{array}$ & \begin{tabular}{l}
0 \\
\multirow{2}{*}{} \\
0 \\
0 \\
0
\end{tabular} & 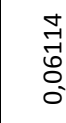 & $\begin{array}{l}8 \\
\text { 옹 } \\
\text { ஸे }\end{array}$ & $\begin{array}{c}\hat{\infty} \\
\stackrel{1}{N} \\
\stackrel{2}{N} \\
0\end{array}$ & $\begin{array}{l}\hat{y} \\
\hat{n} \\
0 \\
0\end{array}$ & 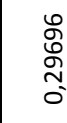 \\
\hline n & 0 & 0 & 0 & 0 & 0 & $\begin{array}{l}8 \\
0 \\
0 \\
\text { م⿱ } \\
0\end{array}$ & 0 & 0 & 0 & 0 & $\begin{array}{l}9 \\
n \\
n \\
0 \\
0 \\
0\end{array}$ & 0 & 0 \\
\hline$\nabla$ & $\begin{array}{l}\text { นn } \\
0 \\
0 \\
0 \\
0\end{array}$ & $\begin{array}{l}\text { ปั } \\
\text { ஸू } \\
\text { ஸ் } \\
\text { ஸ் }\end{array}$ & \begin{tabular}{l}
7 \\
\multirow{7}{n}{} \\
0 \\
0 \\
0
\end{tabular} & \begin{tabular}{l}
$m$ \\
\multirow{2}{\Delta}{} \\
$\delta$ \\
0 \\
0
\end{tabular} & 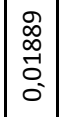 & \begin{tabular}{l}
$\mathscr{J}$ \\
\multirow{2}{*}{} \\
$\stackrel{5}{-}$ \\
0
\end{tabular} & 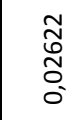 & 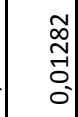 & 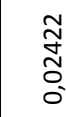 & 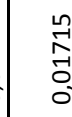 & 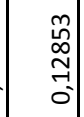 & 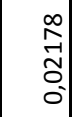 & 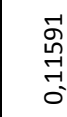 \\
\hline$m$ & \begin{tabular}{l}
\multirow{0}{0}{} \\
$m$ \\
$\stackrel{1}{0}$ \\
0
\end{tabular} & $\begin{array}{l}\infty \\
\infty \\
\infty \\
\infty \\
\stackrel{1}{1} \\
m\end{array}$ & $\begin{array}{l}8 \\
\circ \\
8 \\
0 \\
0\end{array}$ & $\begin{array}{l}n \\
\infty \\
n \\
0 \\
0 \\
0 \\
0\end{array}$ & 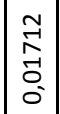 & $\begin{array}{l}\infty \\
\text { o } \\
\stackrel{0}{0} \\
0^{\circ}\end{array}$ & $\begin{array}{l}\text { Dे } \\
\text { I } \\
0 \\
0\end{array}$ & 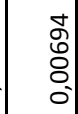 & \begin{tabular}{l} 
F \\
\multirow{J}{*}{} \\
$0_{0}^{\prime}$
\end{tabular} & $\begin{array}{l}\tilde{m} \\
\tilde{n} \\
\stackrel{0}{0} \\
0\end{array}$ & $\begin{array}{l}\infty \\
0 \\
0 \\
0 \\
0 \\
0\end{array}$ & $\begin{array}{l}0 \\
\infty \\
-1 \\
-1 \\
0 \\
0\end{array}$ & 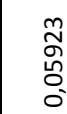 \\
\hline$\sim$ & 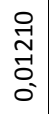 & $\begin{array}{l}\tilde{0} \\
0 \\
00 \\
0 \\
\text { in }\end{array}$ & 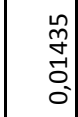 & $\begin{array}{l}n \\
\tilde{N} \\
\tilde{\Sigma} \\
0 \\
0\end{array}$ & 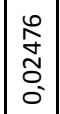 & $\begin{array}{l}\vec{m} \\
\widehat{్} \\
-1 \\
0\end{array}$ & 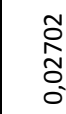 & 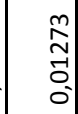 & 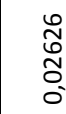 & $\begin{array}{l}\text { ñ } \\
\stackrel{\text { İ }}{0} \\
0 \\
0\end{array}$ & 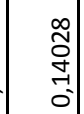 & 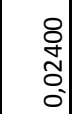 & 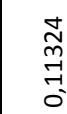 \\
\hline$\rightarrow$ & 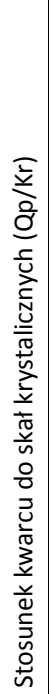 & 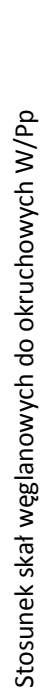 & 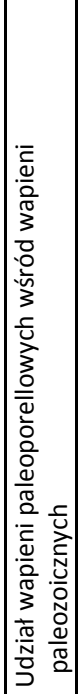 & 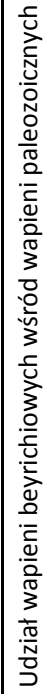 & 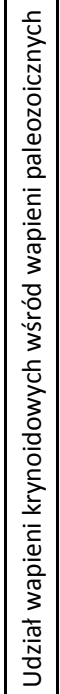 & 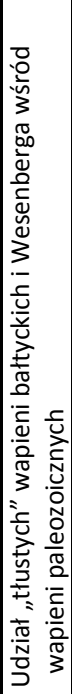 & 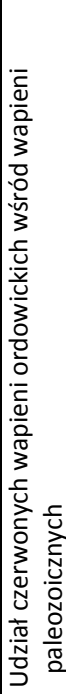 & 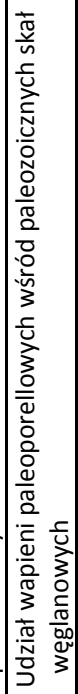 & 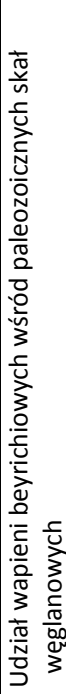 & 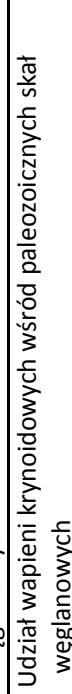 & 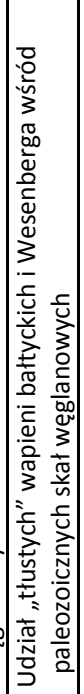 & 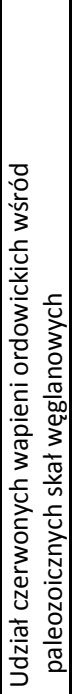 & 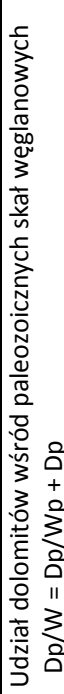 \\
\hline
\end{tabular}


Dzięki temu możliwe było wyliczenie prawdopodobieństwa zgodności/odrębności grup. Ze względu na poszukiwanie cech wskazujących na rozbieżność analizowanych grup przyjęto powszechnie akceptowany w naukach przyrodniczych poziom ufności $\alpha \leq 0,05$ (czyli oczekiwane prawdopodobieństwo odrębności miało wynosić co najmniej 95\%) i porównywano z nim wyliczone wartości prawdopodobieństwa testowego $(p)$. Im niższe było prawdopodobieństwo zgodności analizowanych grup dla danego parametru petrograficznego, tym lepiej nadawał się on do odróżniania różnowiekowych osadów glacjalnych. Następnie wykonano analizę statystyczną przy użyciu nieparametrycznego testu Manna-Whitneya (U-test). Może on być bardziej wiarygodny przy rozkładzie danych odbiegającym od rozkładu normalnego. Ocenę zgodności/odrębności poszczególnych cech petrograficznych dla prób z różnowiekowych osadów przeprowadzono poprzez porównanie parametru $U$ z wartościami krytycznymi podanymi przez Walpole'a i in. (2012). W przypadku, kiedy $U$ jest większe od krytycznej wartości, na danym poziomie ufności nie można stwierdzić rozbieżności grup danych. Oznacza to, że dla potwierdzenia rozbieżności danych wartość parametru $U$ musi być mniejsza, a co najwyżej równa, wartości krytycznej. U-test jest słabszy niż $t$-test, a ewentualna rozbieżność wyników może być związana z małą liczbą danych w jednej z porównywanych grup. Należy przy tym zaznaczyć, że przy rosnącej liczbie prób, nawet dla parametrów niespełniających warunków rozkładu normalnego, łączny rozkład danych zbliża się do krzywej Gaussa, tj. do rozkładu normalnego (centralne twierdzenie graniczne - Pólya, 1920). Oznacza to, że w przypadku odpowiednio licznych prób (zbiorów danych) testy parametryczne i nieparametryczne powinny dać bardzo porównywalne wyniki. Warto pamiętać, że w zwykłym teście statystycznym (t-test) wartości danych są istotne i uwzględnia się je w obliczeniach. W przypadku testu nieparametrycznego (U-test) wartości nie wpływają bezpośrednio na wynik, lecz podstawowe znaczenie ma ich miejsce w porządku rosnącym.

Dla kilku wybranych par parametrów petrograficznych przeprowadzono również test korelacji liniowej. Obliczono w tym celu współczynnik Pearsona ( $r x y)$. Jeżeli korelacja występuje, to oznacza, że stosunek analizowanych parametrów w obrębie grupy jest w przybliżeniu stały i może charakteryzować grupę. Weryfikowano hipotezę statystyczną braku korelacji. Założono, że podstawowym warunkiem granicznym odrzucenia tej hipotezy jest poziom istotności (prawdopodobieństwo braku korelacji) $\alpha \leq 5 \%$, ale weryfikowano również korelację przy poziomie istotności złagodzonym do $10 \%$ (5\%< $\alpha \leq 10 \%)$. Warto zwrócić uwagę na fakt, że w stosowanych w naukach przyrodniczych do oceny siły korelacji skalach Stanisza czy Guilforda, kryteria są o wiele łagodniejsze. W skali Stanisza korelację nikłą przyjmuje się dla 0,0 < |rxy $\mid \leq 0,1$ (Stanisz, 1998, 2007), a w skali Guillforda słaba zależność (współczynnik prawie nic nieznaczący) wyrażona jest wartościami 0,0 < |rxy $\mid \leq 0,2$ (Guilford, 1964, 1965).

Te same dane petrograficzne zostały również przeanalizowane pod względem istnienia korelacji liniowej przy pomocy nieparametrycznego współczynnika Spearmana. Uzyskana wartość była porównywana z wartością krytyczną w oparciu o dane Davisa 
(2002 - str. 613). Obydwa testy korelacji liniowej nie wniosły istotnych informacji do analizy składu petrograficznego glin w Polsce i ich wyniki nie zostały włączone do przedstawionych rozważań.

Podstawowym celem analizy statystycznej było wskazanie cech petrograficznych przydatnych do rozróżniania różnowiekowych osadów glacjalnych oraz określenie ich potencjalnej przydatności w skali ponadregionalnej. Cechy te były analizowane niezależnie dla zestawionych $\mathrm{w}$ różnowiekowe pary zbiorów prób osadów, np. dla Polski Środkowej (włącznie ze wschodnią Wielkopolską) przeanalizowano różnice składu petrograficznego w aż 10 parach: nida i san 2, nida i odra/krzna, nida i odra/warta, nida i wisła, san 2 i odra/krzna, san 2 i odra/warta, san 2 i wisła, odra/krzna i odra/warta, odra/krzna i wisła, odra/warta i wisła (+ niewliczane tutaj porównania ze składem żwirów), podczas gdy analogiczne badania na Pomorzu i Powiślu objęły już tylko 1 parę zbiorów prób, tj. odra/warta i wisła. Następnie sprawdzono, czy cechy różnicujące różnowiekowe osady glacjalne powtarzają się w różnych regionach badawczych, a zatem czy mają zasięg ponadregionalny.

\subsection{Polska Środkowa i wschodnia Wielkopolska}

Najlepszy poligon badawczy dla testów odrębności różnowiekowych osadów glacjalnych stanowiła Polska Środkowa (włącznie ze wschodnią Wielkopolską). Jednak nawet tutaj część nasunięć glacjalnych reprezentowana jest przez zbyt małą liczbę stanowisk, by można było przeprowadzić pełną analizę statystyczną. Najbardziej wiarygodne są wyniki badań porównawczych osadów pozostawionych przez lądolody san 2 i odra (włącznie ze stadiałem recesywnym warta), ponieważ bazują na największej liczbie stanowisk i prób - 15 z osadów sanu 2 i 33 z glin odry/warty (tab. 14.2 i 14.3). W powyższym przypadku przeprowadzony test dwu średnich (t-test) wykazał występowanie istotnego statystycznie zróżnicowania 22 cech petrograficznych spośród 63 poddanych procedurze, podczas gdy słabszy test nieparametryczny (U-test) wskazał aż 34 takie parametry petrograficzne (tab. 14.4). Na szczególną uwagę zasługuje udział skał ze Szwecji południowej (Småland, Blekinge) i środkowej (Dalarna) oraz z Wysp Alandzkich (rys. 14.1), liczone zarówno w autorski sposób, jak i wg podziałów regionalnych Hesemanna (1930) oraz Gałązki (2004b). Oznacza to, że zespoły eratyków z analizowanych osadów glacjalnych będą wyraźnie różnić się położeniem teoretycznych ośrodków głazowych, co zresztą potwierdziło się w przeprowadzonych badaniach (rys. 5.3). Cechą różnicującą te osady glacjalne jest również zawartość krzemieni oraz niektórych typów wapieni, tj. paleporellowych i krynoidowych. Roli wyróżnika nie może natomiast pełnić żaden współczynnik wykorzystujący zawartość dolomitów. Wynika to ze znacznej wrażliwości tego typu skały na wietrzenie (patrz rozdz. 12), a za tym idzie - duże zróżnicowanie zawartości tej skały w próbkach. Spośród współczynników wykorzystywanych w badaniach drobnej frakcji żwirowej jedynie O/K miał wartość jako cecha różnicująca omawiane gliny we frakcji > 20 mm, ale należy zachować ostrożność w przypadku jego interpretacji. 


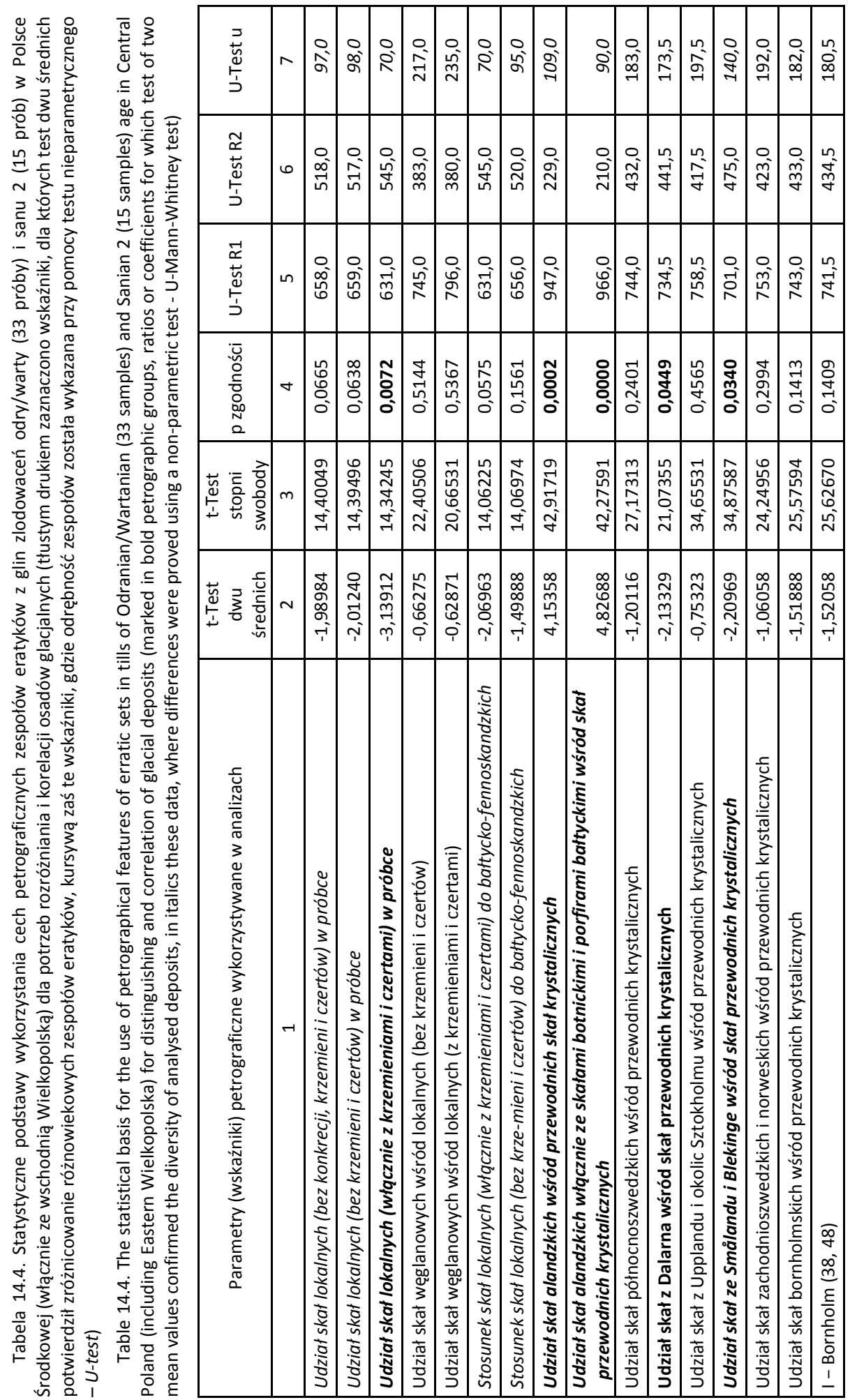




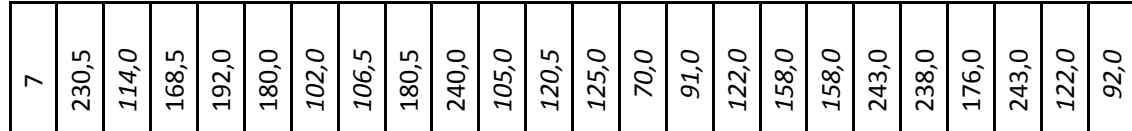

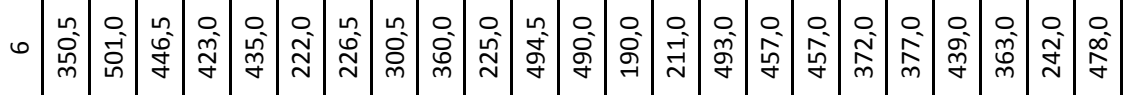

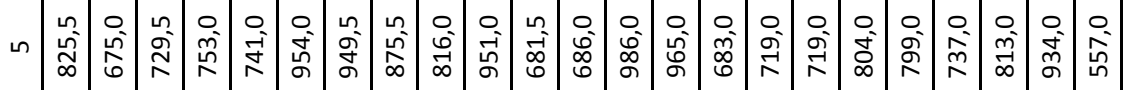

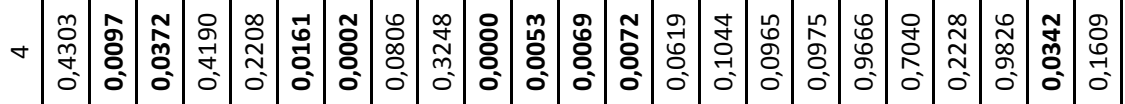

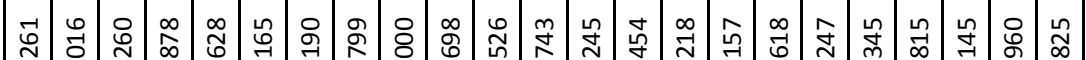

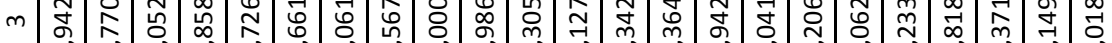

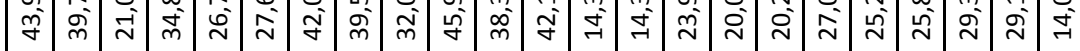

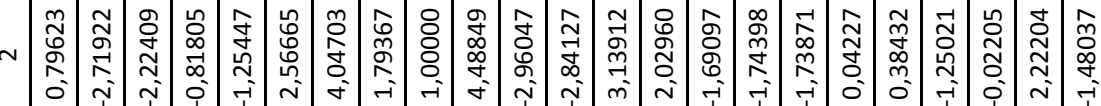

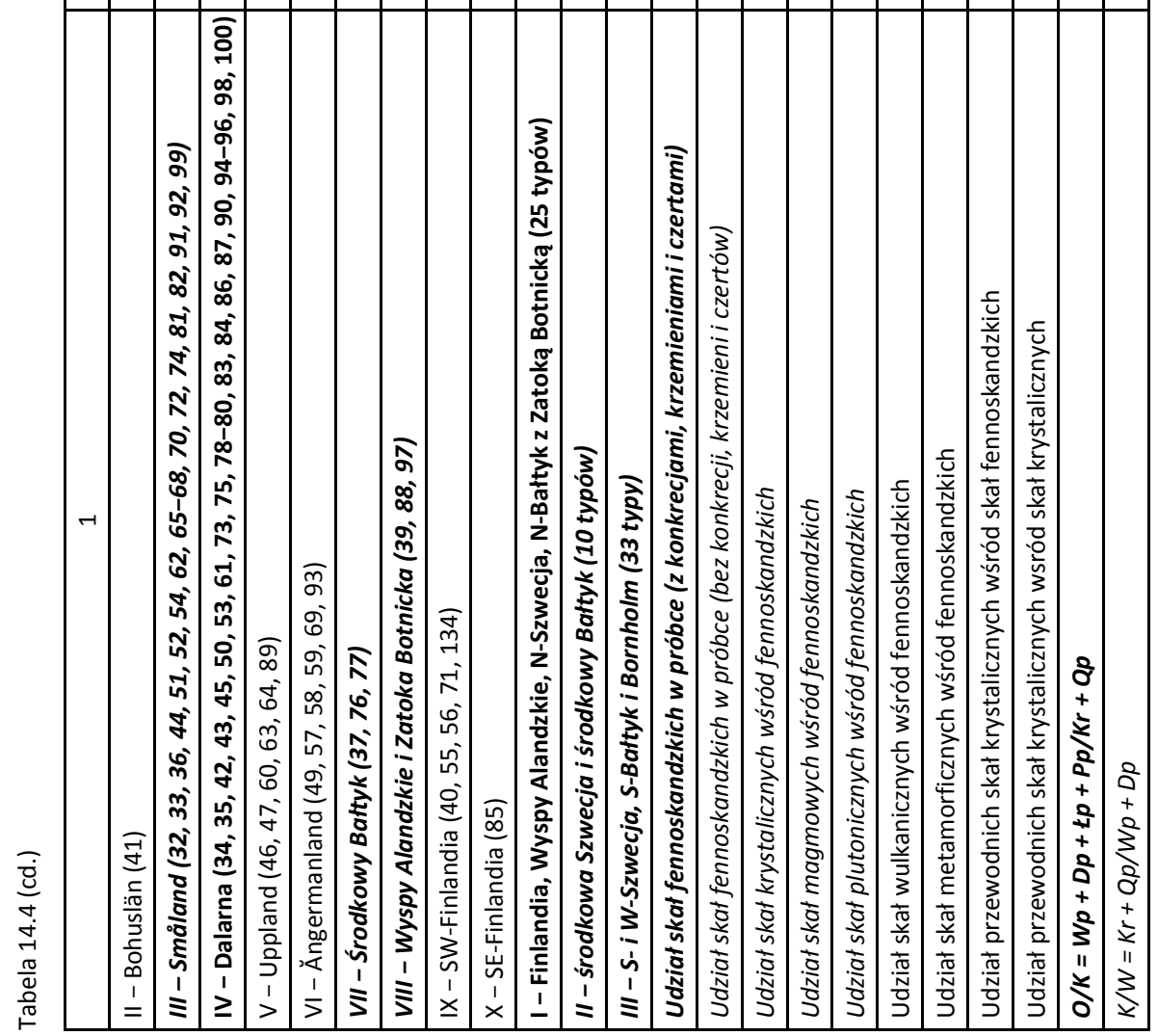




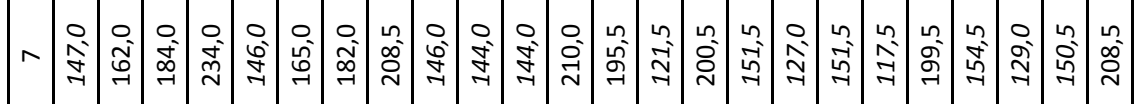

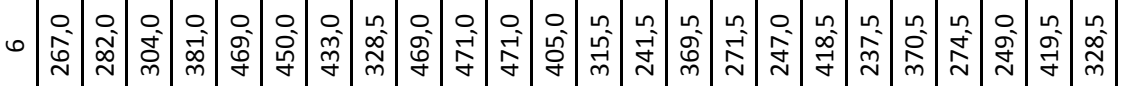

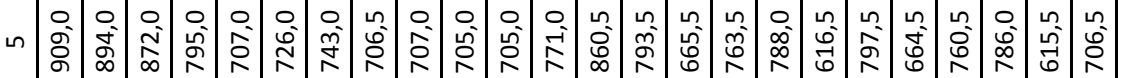

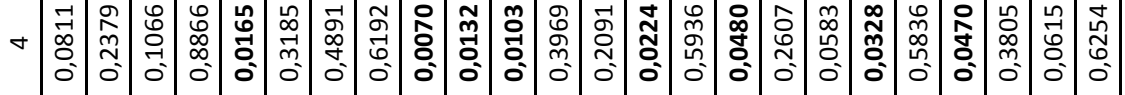

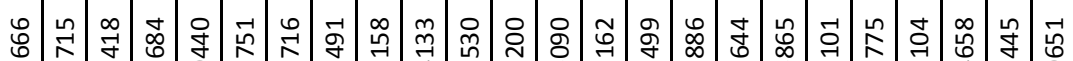

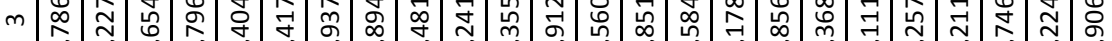

হి

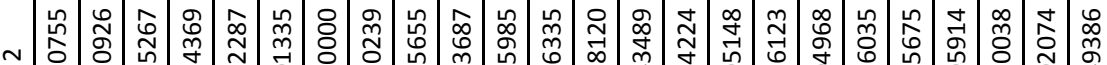

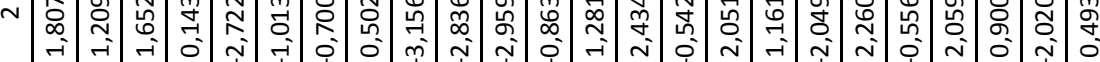

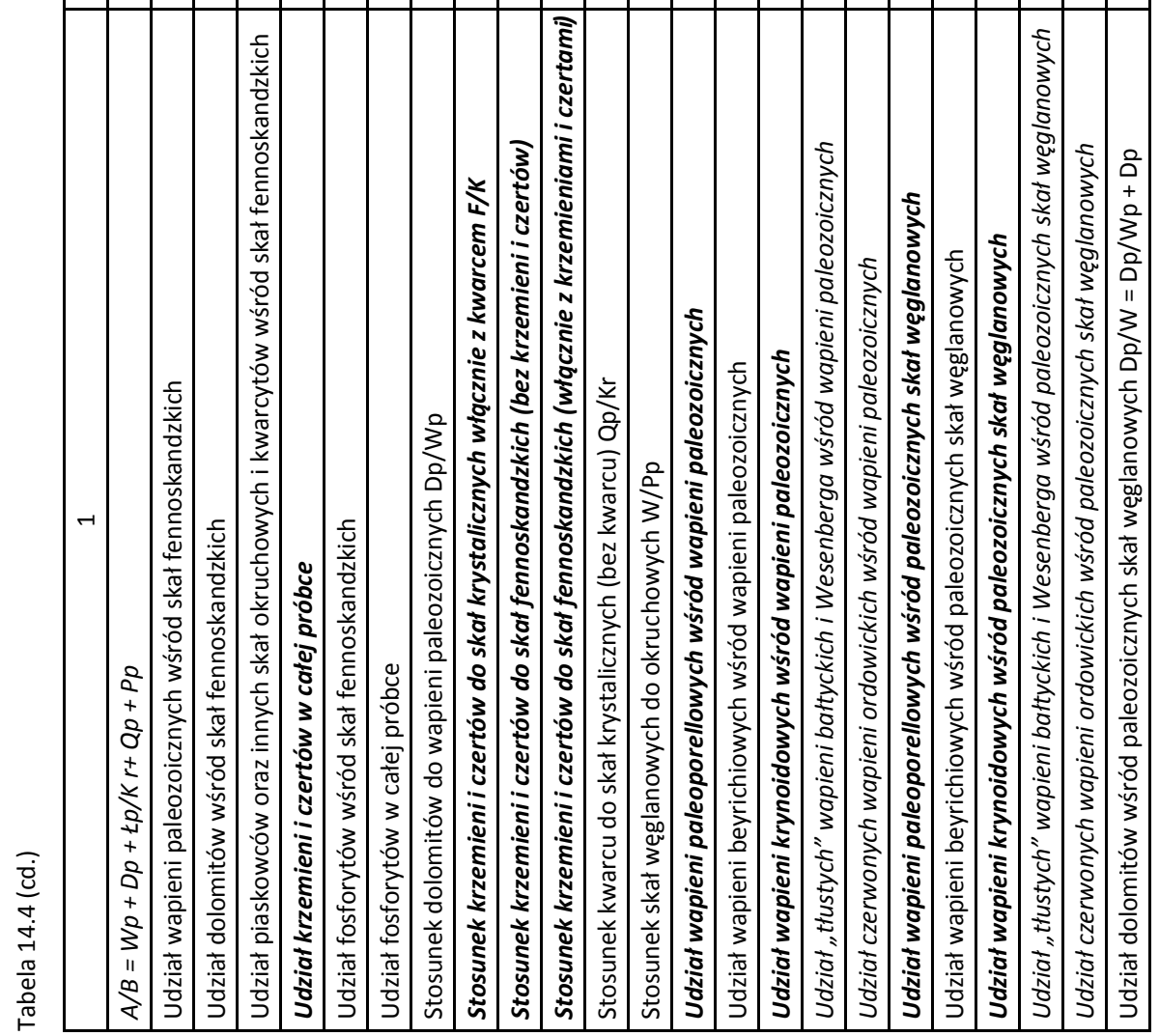


Analogiczna próba oceny zróżnicowania dwóch nasunięć glacjalnych kompleksu środkowopolskiego, tj. osadów krzny (2 próby) i odry/warty (33 próby) wykazała istnienie zróżnicowania aż 24 cech petrograficznych. Wśród nich znalazł się udział skał z północnej (Ångermanland) i zachodniej Szwecji (Bohuslän) oraz z Bornholmu, liczone w autorski sposób i według podziału regionalnego Gałązki (2004b). Podział Hesemanna (1930) jest już zbyt ogólnikowy i tej różnicy nie wychwycił. Cechą różnicującą te osady glacjalne jest również zawartość skał lokalnych oraz niektórych typów wapieni, tj. „tłustych" wschodniobałtyckich, Wesenberga, beyrichiowych i krynoidowych. W tym wypadku dobrym wyznacznikiem jest też zawartość dolomitów (rys. 14.2). Należy od razu zastrzec się, że współczynniki bazujące na skałach węglanowych są bardzo podatne na wpływ wietrzenia i mogą być stosowane wyłącznie w odniesieniu do niezwietrzałych osadów glacjalnych.
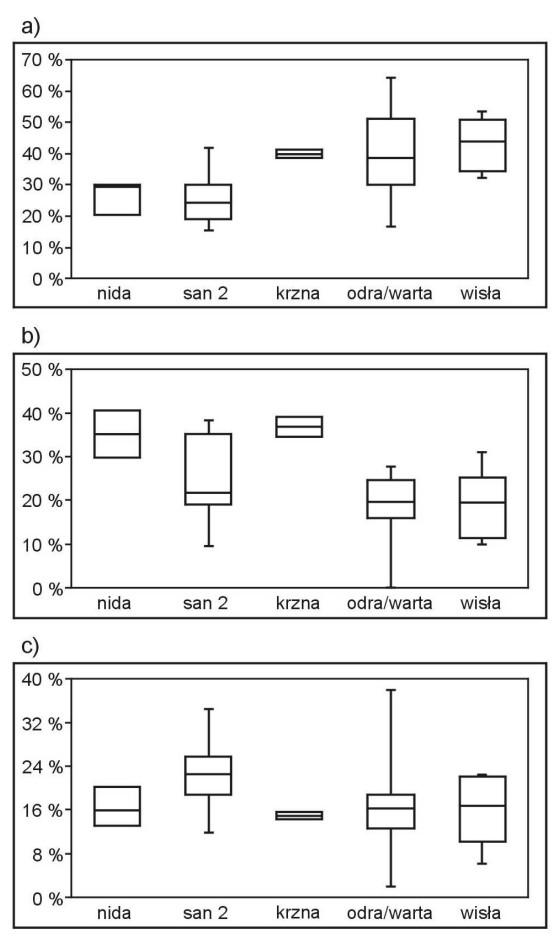

Powyższe wyniki mogą stanowić jedynie przyczynek do dalszych badań, ponieważ udało się pobrać zaledwie 2 odpowiednio liczne próby eratyków z osadów glacjalnych zlodowacenia krzny. Wykonywanie testu nieparametrycznego na takim zespole danych było zupełnie bezcelowe, a wynik testu dwu średnich ma charakter wyłącznie orientacyjny. Identyfikacja glin krzny i odróżnianie ich od osadów glacjalnych innego wieku w oparciu o cechy petrograficzne zespołów eratyków wymaga potwierdzenia dotychczasowych wstępnych wyników w kolejnych, dobrze udokumentowanych stratygraficznie stanowiskach, których brakuje i to nie tylko w Polsce Środkowej.

Zestawienie składu petrograficznego glin krzny (2 próby) i sanu 2 (15 prób) pozwoliło wskazać aż 29 różnicujących je wskaźników. Podstawową rolę odgrywa wśród nich udział skał z różnych regionów źródłowych w Fennoskandii - Wysp Alandzkich, Dalarny, południowej Szwecji, Bornholmu (rys. 14.1 i 14.3).

Rys. 14.1. Parametry statystyczne eratyków przewodnich w różnowiekowych osadach glacjalnych Polski Środkowej i wschodniej Wielkopolski: a) eratyki z Wysp Alandzkich i dna Zatoki Botnickiej, b) eratyki z Dalarny, c) eratyki ze Smålandu i Blekinge; na wykresach pudełkowych zaznaczono kolejno od dołu: minimum, 1. kwartyl, mediana, 3. kwartyl, maksimum

Figure 14.1. Statistical parameters of indicator erratics in glacial sediments of Central Poland and Eastern Wielkopolska: a) Åland and the Gulf of Bothnia rocks, b) Dalarna rocks, c) Småland and Blekinge rocks; in box-and-whisker plots are marked in a sequence from the bottom: minimum, $1^{\text {st }}$ quartile, median, $3^{\text {rd }}$ quartile, maximum 
Nieco mniejsze znaczenie mają proporcje pomiędzy skałami lokalnymi i fennoskandzkimi. W mniej zwietrzałych glinach korelację oraz rozróżnianie osadów sanu 2 i krzny mogą ułatwiać także dolomity oraz wapienie krynoidowe i beyrichiowe. Duża liczba odmiennych cech petrograficznych wskazuje na znaczną różnicę obszarów alimentacji lądolodów z późnego kompleksu południowopolskiego i wczesnego środkowopolskiego, co potwierdzają analizy teoretycznych ośrodków głazowych - rys. 5.3. Uzyskane wyniki należy jednak potraktować jedynie jako wstępną interpretację, ponieważ opierają się na niespełniającej kryteriów statystycznych liczbie prób z glin zlodowacenia krzny.
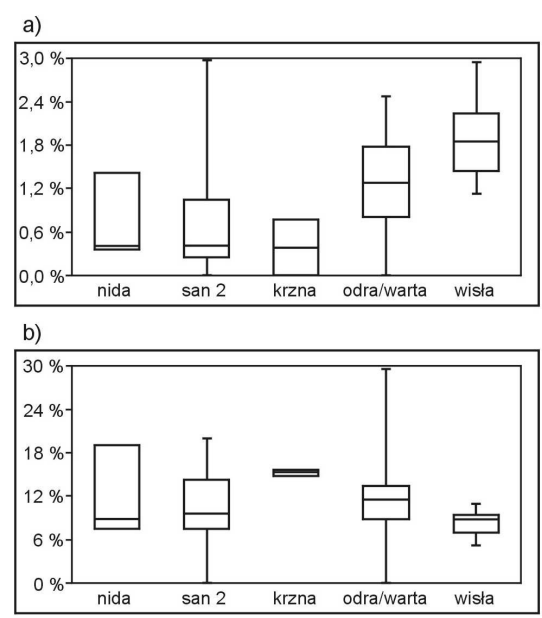

c)

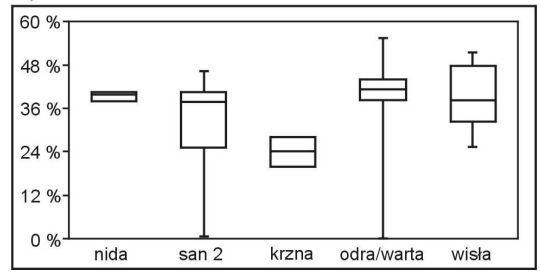

Porównanie zespołów eratyków przewodnich w glinach zlodowaceń nidy (3 próby) i odry/warty (33 próby) wykazało stosunkowo niewielkie zróżnicowanie petrograficzne. Zaledwie 10 cech petrograficznych wyraźnie wskazuje na odmienność petrograficzną analizowanych glin (t-test). Na dodatek część z tych cech może być ściśle powiązana ze stopniem zwietrzenia (np. udział różnych skał w grupie eratyków lokalnych, czy stosunek kwarcu do skał krystalicznych). W tej sytuacji za decydujące należy uznać zróżnicowanie udziału skał z Dalarny oraz z regionu Wysp Alandzkich w opisywanych osadach (rys. 14.3). Różnicującą rolę skał dalarneńskich i alandzkich potwierdził również test nieparametryczny (U-test), ale jego wartość przy trzech zaledwie próbach z glin nidziańskich jest bardzo ograniczona (rys. 14.1). Podstawowe grupy petrograficzne skał fennoskandzkich mają znaczenie drugorzędne.

Rys. 14.2. Parametry statystyczne eratyków pomocniczych w różnowiekowych osadach glacjalnych Polski Środkowej i wschodniej Wielkopolski: a) udział wapieni paleoporellowych w grupie paleozoicznych skał węglanowych, b) udział dolomitów w grupie paleozoicznych skał węglanowych, c) udział wapieni w grupie skał fennoskandzkich; na wykresach pudełkowych zaznaczono kolejno od dołu: minimum, 1. kwartyl, mediana, 3. kwartyl, maksimum

Figure 14.2. Statistical parameters of auxiliary erratics in glacial sediments of Central Poland and Eastern Wielkopolska: a) share of Paleoporella limestone among Paleozoic carbonate rocks, b) percentage of dolomites in the group of Paleozoic carbonate rocks, c) share of limestone among Balto-Fennoscandian erratics; in box-and-whisker plots are marked in a sequence from the bottom: minimum, $1^{\text {st }}$ quartile, median, $3^{\text {rd }}$ quartile, maximum 
Nawet w przypadku skał, których makroskopowe oznaczenie nie budzi większych wątpliwości, jak np. piaskowce, należy liczyć się z potencjalnym wpływem wietrzenia, które, eliminując skały węglanowe, względnie zwiększyło udział odporniejszych skał okruchowych.
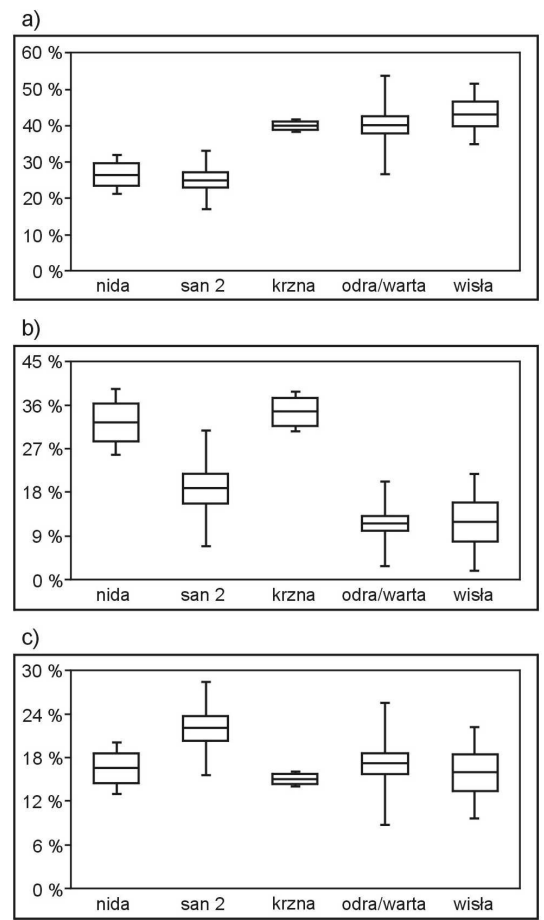

Warto zauważyć, że w analizowanym przypadku skały węglanowe nie mają żadnego znaczenia dla odróżniania i korelacji osadów glacjalnych. Przynajmniej częściowo może to być związane z dużym zróżnicowaniem stopnia zwietrzenia glin nidziańskich, a co za tym idzie, znacznym rozrzutem wartości charakteryzujących je wskaźników petrograficznych. Rozrzut wartości nie przeszkodził natomiast we wskazaniu czerwonych wapieni ordowickich jako cechy różnicującej osady glacjalne nidy i odry/warty $w$ teście nieparametrycznym. Niewielka liczba prób z glin nidziańskich skłania do traktowania powyższych cech odróżniających je od glin odry/warty z bardzo dużą dozą ostrożności. Bardziej pomocne i wiarygodne okazują się w tym przypadku teoretyczne ośrodki głazowe (rys. 5.3), które bazują na dużej liczbie typów skał, a nie na pojedynczych parametrach (patrz rozdz. 4 i 5 ).

Rys. 14.3. Parametry statystyczne eratyków przewodnich w różnowiekowych osadach glacjalnych Polski Środkowej i wschodniej Wielkopolski: a) eratyki z Wysp Alandzkich i dna Zatoki Botnickiej, b) eratyki z Dalarny, c) eratyki ze Smålandu i Blekinge; na wykresach pudełkowych zaznaczono kolejno od dołu: średnia - (minus) odchylenie standardowe, średnia - (minus) błąd standardowy średniej, średnia, średnia + błąd standardowy średniej, średnia + odchylenie standardowe

Figure 14.3. Statistical parameters of indicator erratics in glacial sediments of Central Poland and Eastern Wielkopolska: a) Åland and the Gulf of Bothnia rocks, b) Dalarna rocks, c) Småland and Blekinge rocks; in box-and-whisker plots are marked in a sequence from the bottom: mean - (minus) the standard deviation, mean - (minus) the standard error of the mean, mean, mean + standard error of the mean, mean + standard deviation

Jeszcze gorsze wyniki przyniosła analiza porównawcza glin odłożonych przez dwa lądolody kompleksu południowopolskiego, tj. nidy (3 próby) i sanu 2 (15 prób). Osady tego wieku są prawie pozbawione dobrych cech delimitacyjnych. Zgodnie z wynikami testu dwu wartości średnich zaledwie 4 cechy spośród przebadanych 63 mogą pełnić taką funkcję, ale przy bardzo małej liczbie prób z glin nidy pozostaje niewyjaśnione, czy nie jest to tylko efektem przypadku. Test nieparametryczny wykazał odmienność tylko jednej cechy petrograficznej. Jeżeli badania na bardziej reprezentatywnym zbiorze prób nidziańskich potwierdzą dotychczasowe rezultaty, to do rozróżniania tych glin może 
posłużyć głównie udział wapieni oraz skał okruchowych w grupie skał fennoskandzkich. Podrzędną rolę mogą odgrywać także fennoskandzkie skały metamorficzne, ale makroskopowe zaklasyfikowanie skał drobnoblastycznych i afanitowych może być subiektywne, co stawia ten wskaźnik pod dużym znakiem zapytania. Ponadto na wartości wskazanych w analizie parametrów duży wpływ mają zmiany wywołane wietrzeniem. Na obecnym etapie badań należy zatem przyjąć, że gliny nidy i sanu 2 w Polsce Środkowej na podstawie samych wskaźników petrograficznych (we frakcji $>20 \mathrm{~mm}$ ) są od siebie zupełnie nieodróżnialne. Podobnie, jak w poprzednim przypadku, rozstrzygnięcie może przynieść analiza teoretycznych ośrodków głazowych.

Możliwości rozróżniania osadów glacjalnych nidy i krzny przy pomocy wskaźników petrograficznych nie zostały dostatecznie rozpoznane ze względu na zbyt małą liczbę przeanalizowanych prób - odpowiednio 3 i 2 (efekt bardzo małej liczby odsłonięć dostępnych do badań). Cechami różnicującymi okazały się niemal wyłącznie współczynniki bazujące na zawartościach liczonych w różny sposób skał lokalnych. Tego typu wskaźniki są w olbrzymim stopniu zależne od budowy geologicznej podłoża oraz od skali zwietrzenia osadu, co bardzo obniża ich wiarygodność dla potrzeb korelacji osadów glacjalnych.

Osady zlodowacenia wisły sprawiają dość duże problemy przy próbach korelacji i odróżniania od osadów innego wieku w oparciu o cechy petrograficzne. Zawierają one najwięcej materiału redeponowanego, pozostawionego przez starsze nasunięcia i mają skład w pewnym stopniu „uśredniony”. Ponadto one same wyróżniają się dużym zróżnicowaniem składu zarówno w przestrzeni, jak i w czasie, czego dowiodły chociażby analizy glin z Pomorza i Powiśla (np. Woźniak i in., 2009, 2013a; Woźniak i Czubla 2014a, 2014b, w druku). W konsekwencji liczba cech petrograficznych odróżniających gliny odry/warty (33 próby) i wisły (6 prób) wynosi zaledwie 11 i przeważająca ich część odnosi się do udziału i wzajemnych proporcji skał lokalnych, które mogą podlegać dużym zmianom w zależności od podłoża, po którym transgredował lądolód. Pozostałe cechy różnicujące gliny zlodowaceń odry/warty i wisły związane są z udziałem eratyków przewodnich z dna Bałtyku oraz z wyjątkową na terenie Polski obecnością skał z zachodniej Szwecji. Pomocne w rozróżnianiu mogą też być dolomity (rys. 14.4). W tym przypadku wyniki testu nieparametrycznego niemal idealnie pokryły się z wynikami testu dwu wartości średnich (rys. 14.2).

Znacznie wyraźniej na obszarze Polski Środkowej zaznacza się różnica składu petrograficznego frakcji $>20 \mathrm{~mm}$ pomiędzy glinami zlodowaceń wisły (6 prób) i sanu 2 (15 prób). Ich rozróżnianie możliwe jest głównie w oparciu o zawartość skał alandzkich, północnoszwedzkich i w mniejszym stopniu bałtyckich. Wskazują na to zarówno autorskie regionalne grupy petrograficzne, jak również cztery regiony wyznaczane przez Gałązkę (2004b) i jeden z regionów Hesemanna (1930). W przypadku niezwietrzałych osadów glacjalnych dla potrzeb korelacyjnych i delimitacyjnych warto również przeanalizować udział wapieni paleoporellowych (rys. 14.4). Powyższe parametry pozwalają na stosunkowo pewne rozróżnienie analizowanych glin. Przedstawione wyniki testu dwu wartości średnich zostały potwierdzone także w teście nieparametrycznym, który wskazał niemal dokładnie te same cechy (9 spośród 11 ). 
Różnica pomiędzy osadami glacjalnymi wisły i krzny jest na obszarze Polski Środkowej stosunkowo słabo udokumentowana z uwagi na znikomą liczbę prób z glin krzny (tylko 2). Możliwe jest, co prawda, wyznaczenie aż 20 cech petrograficznych różnicujących te osady, ale ich wartość interpretacyjna jest bardzo mała. Pominąwszy dość zmienne przestrzennie skały lokalne i proporcje pomiędzy nimi, dość dużą rolę delimitacyjną odgrywają eratyki północnoszwedzkie i dalarneńskie. W przypadku niezwietrzałych skał przydatny może też być udział dolomitów, wapieni krynoidowych oraz beyrichiowych. Pomocniczą rolę mogą odgrywać kryteria oparte na proporcjach pomiędzy grupami petrograficznymi eratyków. Wśród tych ostatnich udział piaskowców wydaje się być najbardziej wiarygodny i odporny na ewentualne błędy przy makroskopowym oznaczaniu. Znaczne rozszerzenie liczby prób, które uwiarygodniłoby porównawcze analizy statystyczne, jest mało realne ze względu na brak odsłonięć i niemożność wykorzystania materiału wiertniczego.
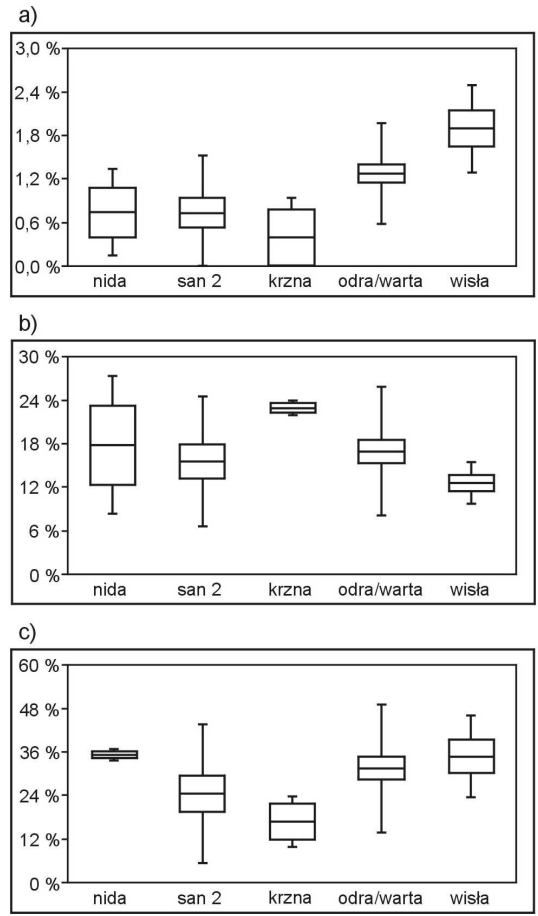

Powyższe zastrzeżenia odnoszą się również do prób rozróżniania glin zlodowaceń wisły i nidy w oparciu o dane petrograficzne. Mała liczba prób (tylko 3 z osadów nidy), niedostatek odsłonięć, pozwalających rozszerzyć zakres badań, kryteria delimitacyjne oparte na podstawowych grupach petrograficznych bardzo obniżają wiarygodność wyników. Spośród ośmiu parametrów petrograficznych wskazanych przez test dwu wartości średnich, pomocny może być co najwyżej udział eratyków alandzkich i dalarneńskich. Ich wzajemny stosunek jest jednak znacznie łatwiejszy do interpretacji w oparciu o teoretyczne ośrodki głazowe - wysoki udział skał z Dalarny przesuwa TCG na zachód, a skał alandzkich na wschód.

Rys. 14.4. Parametry statystyczne eratyków pomocniczych w różnowiekowych osadach glacjalnych Polski Środkowej i wschodniej Wielkopolski: a) udział wapieni paleoporellowych w grupie paleozoicznych skał węglanowych, b) udział dolomitów w grupie paleozoicznych skał węglanowych, c) udział wapieni w grupie skał fennoskandzkich; na wykresach pudełkowych zaznaczono kolejno od dołu: średnia - (minus) odchylenie standardowe, średnia - (minus) błąd standardowy średniej, średnia, średnia + błąd standardowy średniej, średnia + odchylenie standardowe

Figure 14.4. Statistical parameters of auxiliary erratics in glacial sediments of Central Poland and Eastern Wielkopolska: a) share of Paleoporella limestone among Paleozoic carbonate rocks, b) percentage of dolomites in the group of Paleozoic carbonate rocks, c) share of limestone among Balto-Fennoscandian erratics; in box-and-whisker plots are marked in a sequence from the bottom: mean - (minus) the standard deviation, mean - (minus) the standard error of the mean, mean, mean + standard error of the mean, 


\subsection{Kujawy}

Na Kujawach jedynie gliny zlodowaceń odry/warty i wisły dostępne były do badań petrograficznych frakcji $>20 \mathrm{~mm}$. Zbiory prób z osadów obydwu zlodowaceń były niemal równoliczne - 11 z glin wisły i 10 z odry/warty. Analiza statystyczna wykonana z użyciem $t$-testu i U-Testu (nieparametrycznego) dała identyczne wyniki, tj. wskazała 15 cech petrograficznych różnicujących opisywane osady glacjalne (tab. 14.5). Prawie połowa z nich odnosi się do udziału skał lokalnych lub stosunków pomiędzy różnymi ich typami. Mają one ograniczone znaczenie korelacyjne, ponieważ są bardzo wrażliwe na lokalne zróżnicowanie budowy geologicznej podłoża na drodze lądolodu. Znacznie istotniejsze są różnice w zawartości skał alandzkich, botnickich oraz południowoszwedzkich (Småland i Blekinge), wyrażone zarówno autorskimi parametrami, ale też grupami proponowanymi przez Gałązkę (2004b), a nawet bardzo ogólnymi grupami regionalnymi Hesemanna (1930).

\subsection{Pomorze i Powiśle}

Na Pomorzu i Dolnym Powiślu bardzo liczne są stanowiska z odsłaniającymi się na powierzchni osadami glacjalnymi zlodowacenia wisły (27 przebadanych), podczas gdy starsze gliny występują tylko w nielicznych odsłonięciach - klify i kopalnie (przebadano 6 prób z osadów odry/warty). Gliny różnych faz zlodowacenia wisły, a nawet gliny tej samej fazy, ale w różnych częściach Pomorza lub Powiśla, kształtowały się pod wpływem bardzo zmiennej czasowo i przestrzennie dynamiki lądolodu fennoskandzkiego. W konsekwencji już w samych osadach ostatniego zlodowacenia występuje duże i nie do końca jasne zróżnicowanie cech petrograficznych oraz zespołów eratyków przewodnich i pomocniczych (por. m.in. Czubla i in., 2007a; Woźniak i in., 2008, 2009, 2011, 2012b, 2013a, 2013c; Woźniak i Czubla, 2014a, 2014b, w druku). Efektem jest znikoma liczba cech różnicujących gliny wisły i odry/warty. Poza niezbyt wartościowymi pod względem interpretacyjnym proporcjami pomiędzy skałami lokalnymi i północnymi, poziom ufności 95\% (prawdopodobieństwo odrębności analizowanych grup) spełnia jedynie udział „tłustych” wapieni pelitowych oraz Wesenberga z północno-wschodniej części niecki Bałtyckiej. Niewiele więcej można wywnioskować z analizy teoretycznych ośrodków głazowych, a to skłania do poszukiwania innych niż petrograficzne metod korelacji i delimitacji glin wisły (w tym poszczególnych faz tego zlodowacenia) i odry/ warty na tym obszarze.

Stwierdzone na Pomorzu i Dolnym Powiślu zróżnicowanie składu osadów glacjalnych ostatniego zlodowacenia ma najczęściej charakter lokalny (patrz prace cytowane powyżej). Wydaje się, że dość szybko zanika ono przy przesuwaniu się na południe - na obszar Kujaw. Być może ujednolicenie cech petrograficznych glin wisły na Kujawach wpłynęło na uwypuklenie ich odmienności w stosunku do glin odry/warty. 


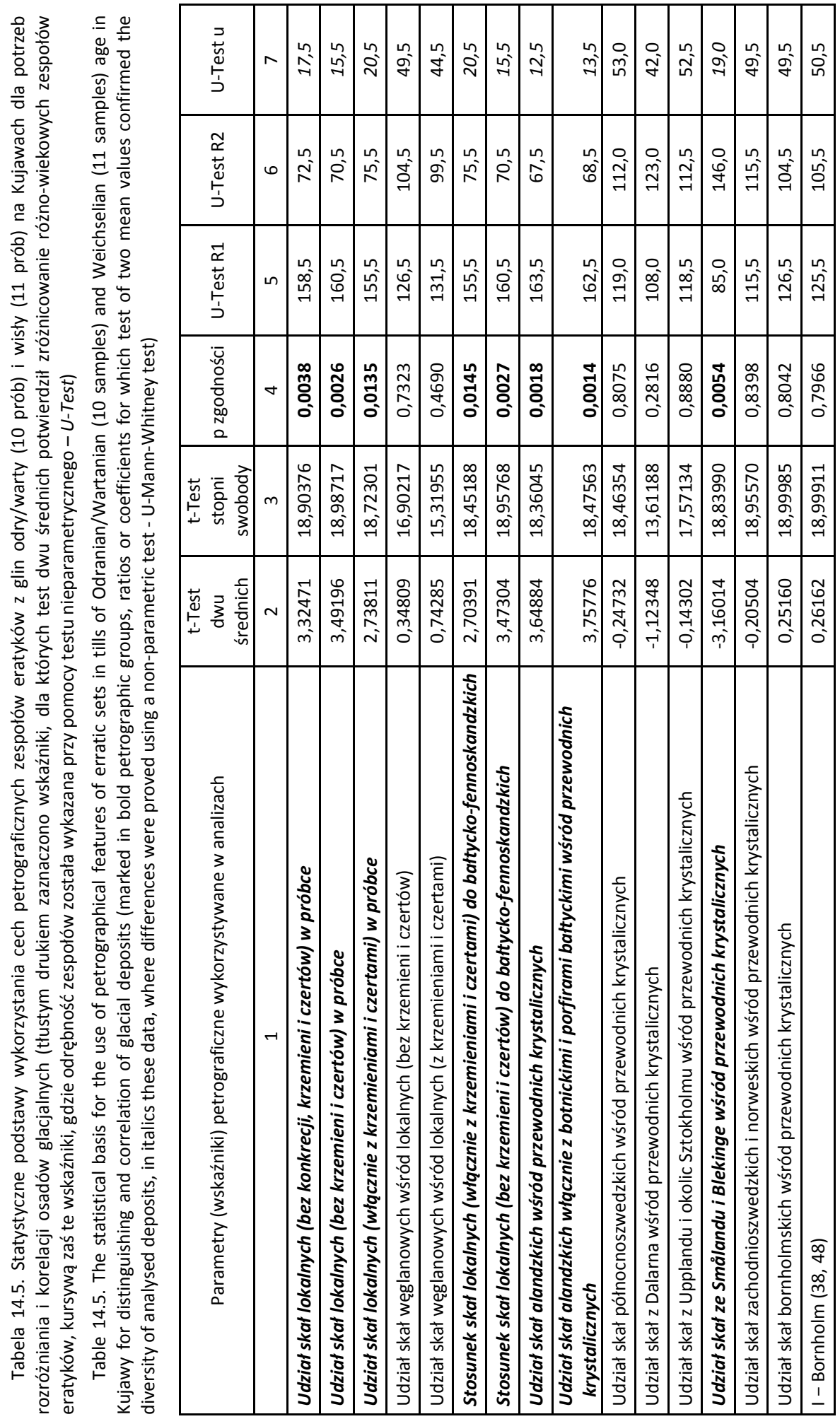




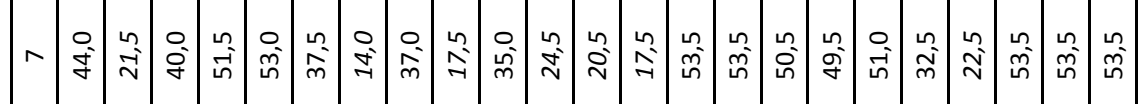

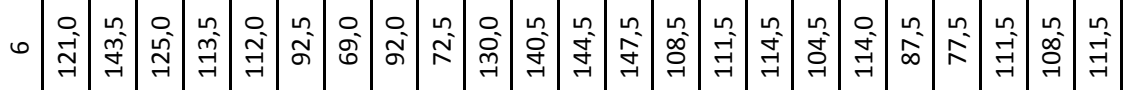

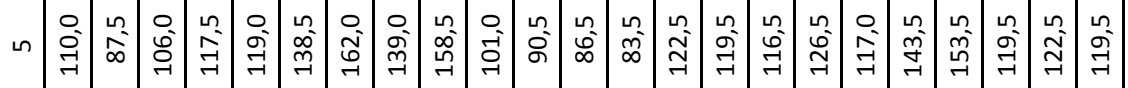

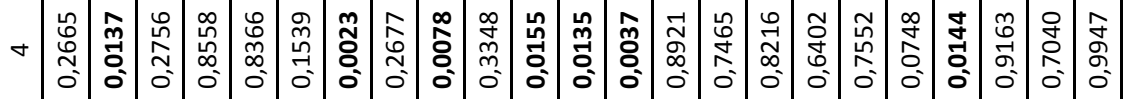

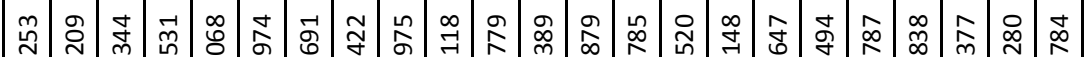

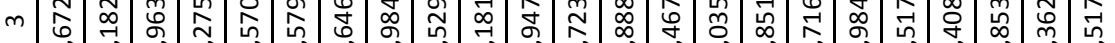

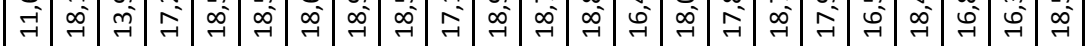

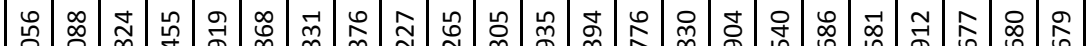

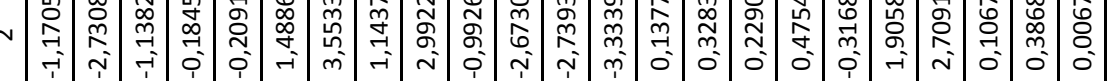

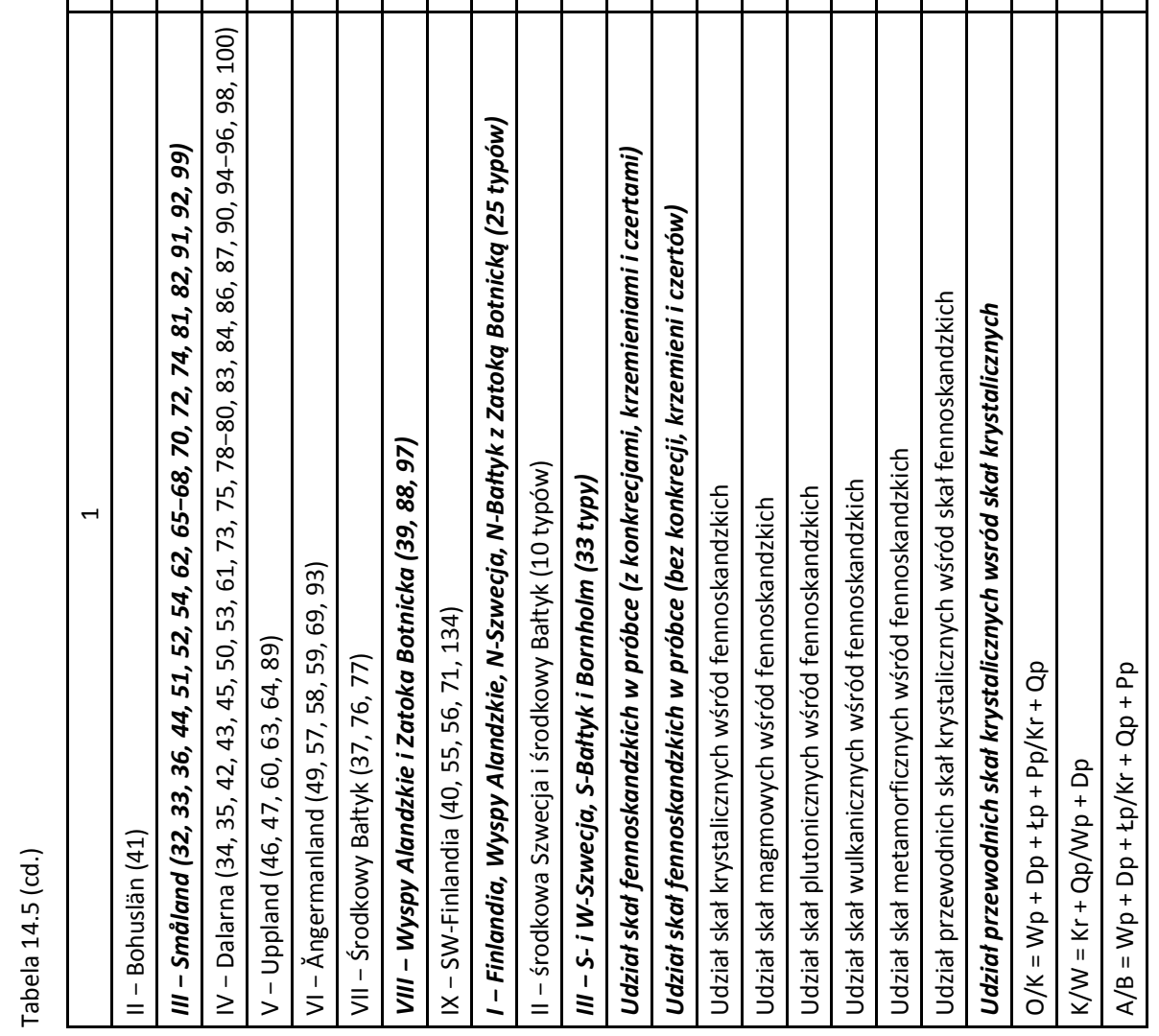




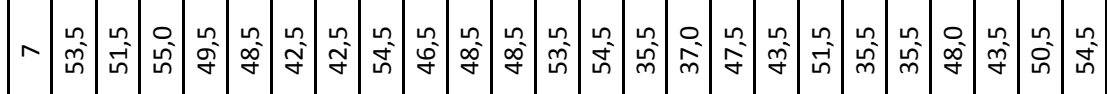

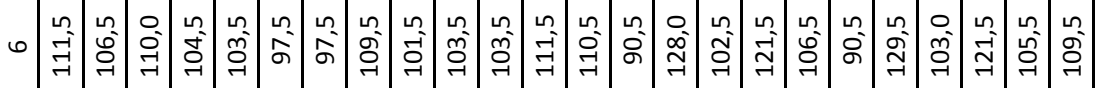

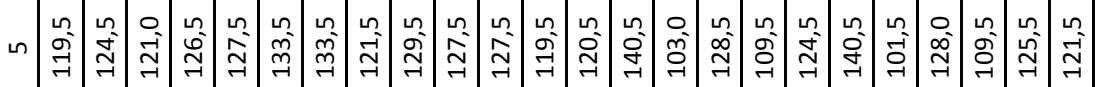

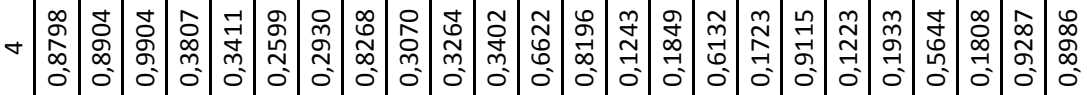

ऽิ

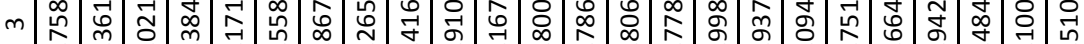

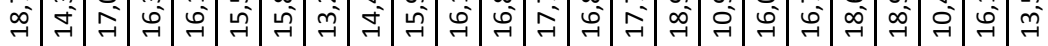

m

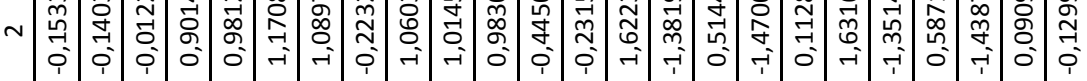

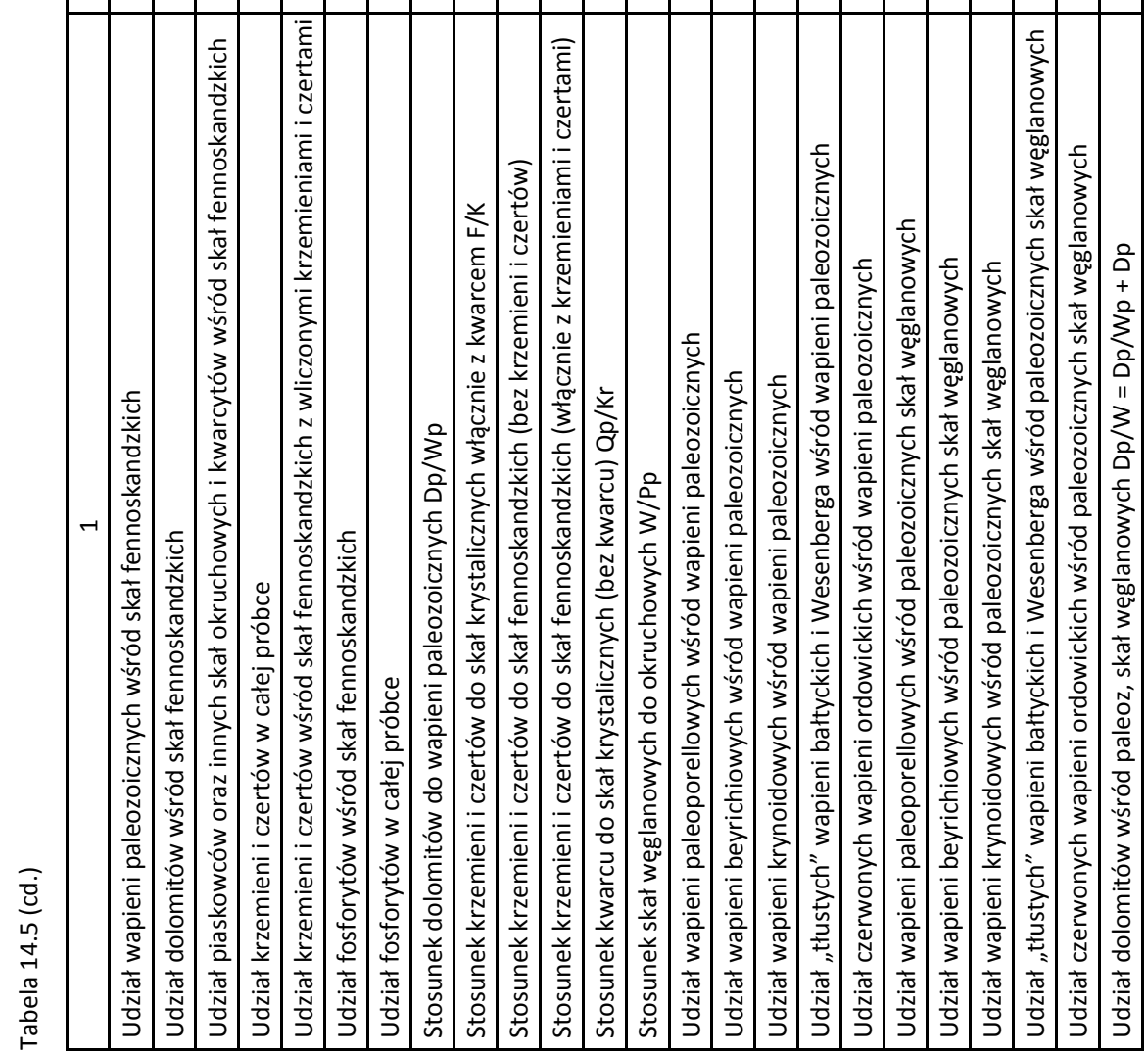




\subsection{Podlasie i Lubelszczyzna}

We wschodniej Polsce możliwe było tylko bardzo ogólne porównanie glin sanu 2 z osadami odry/warty. Z uwagi jednak na bardzo małą liczbę prób (odpowiednio 5 i 3) wiarygodna interpretacja statystyczna nie była możliwa, a otrzymane wyniki należy traktować wyłącznie jako wstępne. Zaznaczyć jednak warto, że t-test i U-Test dały w tym wypadku niemal identyczny rezultat. Różnica pomiędzy osadami glacjalnymi sanu 2 i odry/warty na Podlasiu i Lubelszczyźnie wyrażona jest stosunkowo słabo. Przejawia się ona przede wszystkim w udziale skał dalarneńskich oraz południowoszwedzkich (Småland i Blekinge) (rys. 14.5), zgodnie z wydzieleniami zaproponowanymi przez autora i grupami regionalnymi wyróżnianymi przez Gałązkę (2004b). Potwierdza to również rola III (szwedzkiej) grupy Hesemanna (1930). Sumaryczna analiza zespołów eratyków przewodnich, wyrażona lokalizacją teoretycznych ośrodków głazowych (rys. 5.4), potwierdza jednak te wstępne wyniki i wskazuje na wyraźną odmienność składu analizowanych glin.
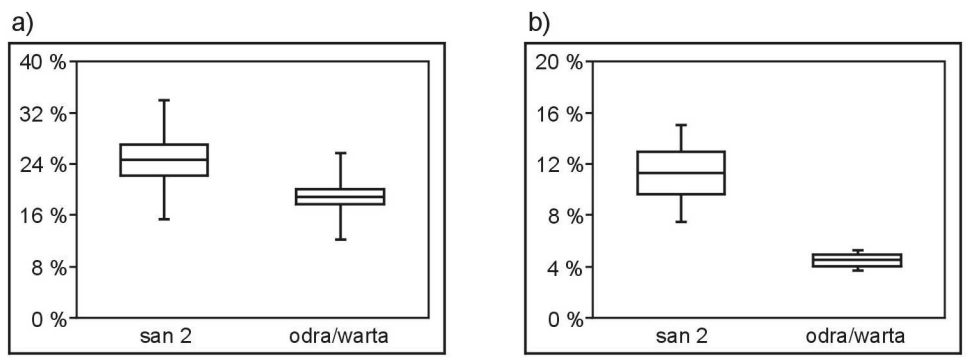

c)

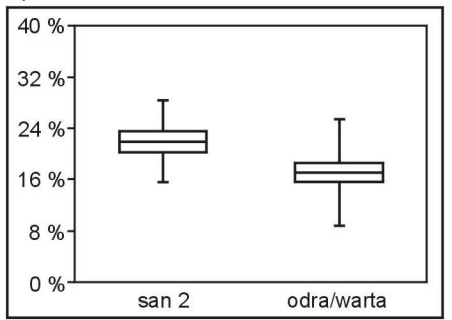

d)

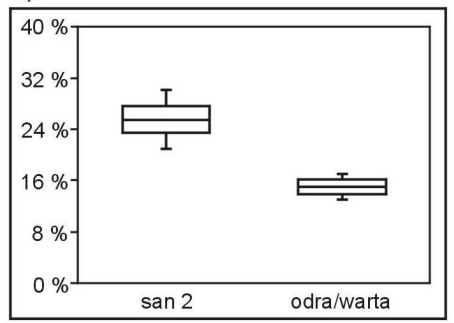

Rys. 14.5. Parametry statystyczne eratyków przewodnich w osadach glacjalnych: a) Polska Środkowa i wschodnia Wielkopolska - eratyki z Dalarny, b) Podlasie i Lubelszczyzna - eratyki z Dalarny,

c) Polska Środkowa i wschodnia Wielkopolska - eratyki ze Smålandu i Blekinge, d) Podlasie i Lubelszczyzna - eratyki ze Smålandu i Blekinge; na wykresach pudełkowych zaznaczono kolejno od dołu: średnia - (minus) odchylenie standardowe, średnia - (minus) błąd standardowy średniej, średnia, średnia + błąd standardowy średniej, średnia + odchylenie standardowe

Figure 14.5. Statistical parameters of indicator erratics in glacial sediments: a) Central Poland with Eastern Wielkopolska - Dalarna erratics, b) Eastern Poland - Dalarna erratics, c) Central Poland with Eastern Wielkopolska - Småland and Blekinge erratics, d) Eastern Poland - Småland and Blekinge erratics; in box-and-whisker plots are marked in a sequence from the bottom: mean - (minus) the standard deviation, mean

- (minus) the standard error of the mean, mean, mean + standard error of the mean, mean + standard deviation 
Zróżnicowanie petrograficzne pomiędzy osadami glacjalnymi sanu 2 i odry/warty wyraża się tymi samymi wskaźnikami (grupami regionalnymi eratyków) w Polsce Środkowej i Wschodniej. Różnica rangi (udziału) skał przewodnich z Dalarny oraz ze Smålandu i Blekinge w zespołach eratyków z opisywanych glin jest nawet wyraźniejsza na Podlasiu i Lubelszczyźnie (rys. 14.5). Nieparametryczna analiza statystyczna daje mniej czytelny obraz, ale potwierdza powyższy wniosek (rys. 14.6). Jest to jedyny zaobserwowany przypadek, w którym te same parametry petrograficzne mogą posłużyć do rozróżniania różnowiekowych osadów glacjalnych w stosunkowo odległych regionach (w linii prostej dzieli je ponad $200 \mathrm{~km}$ ).

a)

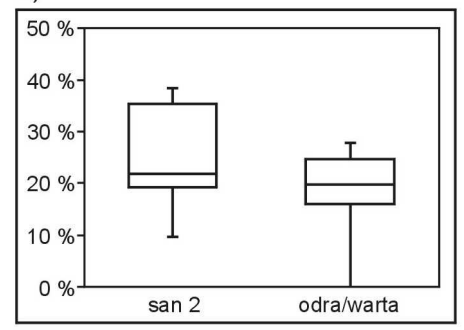

c)

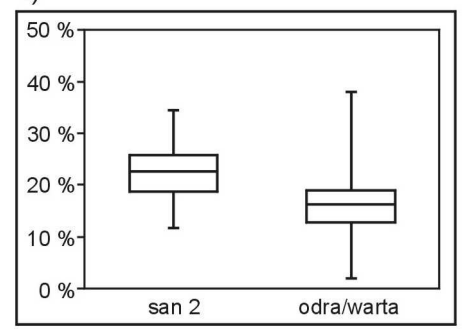

b)

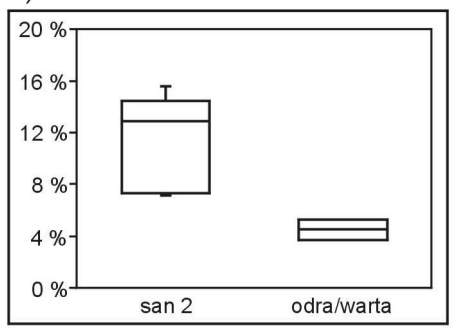

d)

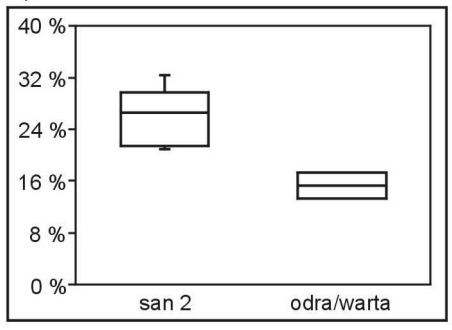

Rys. 14.6. Parametry statystyczne eratyków przewodnich w osadach glacjalnych: a) Polska Środkowa i wschodnia Wielkopolska - eratyki z Dalarny, b) Podlasie i Lubelszczyzna - eratyki z Dalarny,

c) Polska Środkowa i wschodnia Wielkopolska - eratyki ze Smålandu i Blekinge, d) Podlasie i Lubelszczyzna

- eratyki ze Smålandu i Blekinge; na wykresach pudełkowych zaznaczono kolejno od dołu: minimum, 1. kwartyl, mediana, 3. kwartyl, maksimum

Figure 14.6. Statistical parameters of indicator erratics in glacial sediments: a) Central Poland with Eastern Wielkopolska - Dalarna erratics, b) Eastern Poland - Dalarna erratics, c) Central Poland with Eastern Wielkopolska - Småland and Blekinge erratics, d) Eastern Poland - Småland and Blekinge erratics; in box-and-whisker plots are marked in a sequence from the bottom: minimum, $1^{\text {st }}$ quartile, median, $3^{\text {rd }}$ quartile, 


\section{PODSUMOWANIE WYNIKÓW}

\subsection{Metody badań eratyków w osadach glacjalnych}

Skały lokalne stanowią bardzo dobry wskaźnik lokalnych kierunków ruchu lądolodu (np. Woźniak i in. 2012a, 2012b, 2013a, 2013c, Woźniak i Czubla 2014a, 2014b) i potwierdzają wnioski wysnute $z$ analizy cech teksturalnych gliny oraz struktur sedymentacyjnych. Ze względu jednak na specyfikę budowy geologicznej Polski (bardzo mały udział skał zlityfikowanych w podłożu transgredującego lądolodu) tylko w nielicznych obszarach mogą one pełnić tę rolę. Na ogół lokalny transport w Polsce obejmuje drobnoziarniste, słabo zwięzłe lub niezlityfikowane skały preglacjalne oraz osady glacjalne i fluwioglacjalne złożone przez ten sam bądź poprzednie lądolody - zawierające eratyki nieodróżnialne od przywleczonych na teren Polski bezpośrednio z Fennoskandii (eratyków dalekiego transportu).

Osady glacjalne i fluwioglacjalne na obszarze Polski Środkowej cechują się odmiennym składem petrograficznym. Różnica przejawia się przede wszystkim znacznie większą inkorporacją materiału lokalnego (w tym pozostawionego przez starsze zlodowacenia) przez wody ablacyjne aniżeli przez sam lód. Do podobnych wniosków prowadzą obserwacje na Lubelszczyźnie, gdzie w osadach glacjalnych odsetek skał lokalnych (włącznie z krzemieniami) był znikomy, podczas gdy tamtejsze osady fluwioglacjalne charakteryzują się zdaniem R. Dobrowolskiego (2014 - inf. ustna) wysokim i bardzo zmiennym udziałem krzemieni, traktowanych jako skały lokalne. Lokalny charakter tamtejszych krzemieni potwierdza niemal zupełny ich brak w przebadanych osadach glacjalnych na Podlasiu, a zatem na potencjalnej drodze lodu na południe.

Bardzo wyraźnie zaznacza się również różnica składu zespołów eratyków w glinach bazalnych i w spływowych diamiktonach. Oznacza to, że tylko badania eratyków w glinach bazalnych mogą być wykorzystywane dla potrzeb korelacji stratygraficznej osadów glacjalnych.

Występowanie rozpoznawalnych eratyków wskaźnikowych w poszczególnych frakcjach jest nierównomierne. Skały grubokrystaliczne (np. granity Arnö, Revsund, wyborgit) są identyfikowalne tylko w postaci stosunkowo dużych eratyków - co najmniej 5-6 cm średnicy. Rozmiary wulkanitów są najczęściej ograniczone gęstością pierwotnego ciosu termicznego, a ponadto niektóre z nich są bardzo odporne na wietrzenie (czerwony porfir bałtycki, porfir Bredvad), co sprzyja ich identyfikacji także w drobniejszych frakcjach, nawet w mocno już zwietrzałych osadach glacjalnych. Wskazuje to na celowość objęcia badaniami możliwie dużego przedziału rozmiarów ziaren. 
Wielkość i sposób poboru próbki całkowicie wykluczają wykorzystanie w badaniach materiału z wierceń. W tym kontekście bardzo wątpliwe są wyniki Korna (1895) z Prus Wschodnich, gdzie rzekomo bardzo licznie występowały eratyki skał fińskich (Korn bazował na materiale pochodzącym właśnie z wierceń).

\subsection{Metodyka badań a korelacja i rozróżnianie różnowiekowych osadów glacjalnych}

Różnice pomiędzy zespołami eratyków pochodzącymi z różnowiekowych osadów glacjalnych najwyraźniej zaznaczają się w położeniu teoretycznych ośrodków głazowych. Skuteczne są przede wszystkim metody obliczeń wykorzystujące większość lub wszystkie typy krystalicznych skał przewodnich. Radykalna redukcja liczby typów skał przewodnich uwzględnianych w obliczeniach (podobnie jak włączenie skał pomocniczych) pociąga za sobą wzrost rozproszenia wyników i tym samym zmniejszenie ich wiarygodności.

Próby regionalnego i petrograficznego grupowania eratyków (skał przewodnich, pomocniczych i pozostałych), analizy ich udziału w różnowiekowych osadach glacjalnych oraz wyliczania różnych współczynników, mające służyć korelacji i rozróżnianiu różnowiekowych glin, dają znacznie gorsze i mniej czytelne rezultaty aniżeli analiza teoretycznych ośrodków głazowych.

Analiza teoretycznych ośrodków głazowych pozwala stosunkowo najłatwiej odróżnić osady glacjalne zlodowaceń sanu 2 i odry/warty i to na dużym obszarze, rozciągającym się od wschodniej Wielkopolski aż po Lubelszczyznę i Podlasie. W tym celu można wykorzystać testowe TCG-W1, obliczane w oparciu o zredukowaną liczbę eratyków przewodnich (skały alandzkie, botnickie, bałtyckie, dalarneńskie, smalandzkie i bornholmskie). Co prawda, dla Polski Środkowej wynik będzie trochę słabszy, aniżeli pozyskany z wykorzystaniem wszystkich skał przewodnich, ale ta uproszczona wersja obliczeń pozwoli zrezygnować z rozpoznawania części eratyków wskaźnikowych, mających niewielki wpływ na rezultat badań. Większa redukcja liczby eratyków wykorzystywanych do obliczania testowych TCG (TCG-W2 - TCG-W7) powoduje wzrost rozproszenia wyników. Częściowo może to wynikać z mniejszej w takich przypadkach całkowitej liczby eratyków w próbce i nieosiąganiem wówczas minimalnej liczby 50 głazików skał przewodnich.

Odróżnianie glin poszczególnych zlodowaceń kompleksu południowopolskiego przy użyciu teoretycznych ośrodków głazowych zostało potwierdzone na Dolnym śląsku i w Polsce Środkowej (najskuteczniejszy okazał się i w tym przypadku wskaźnik TCG-W1). Ze względu jednak na zbyt małą liczbę stanowisk z glinami tego wieku, wyniki należy potraktować jako wstępne i wymagające weryfikacji w kolejnych stanowiskach o jednoznacznie ustalonej pozycji stratygraficznej.

Obiecujące wydają się również wyniki analiz porównawczych osadów odłożonych przez lądolody kompleksu środkowopolskiego (MIS-8 i MIS-6). Zarówno w Polsce Środowej, jak i na Podlasiu osady starszego lądolodu (krzna?) są znacznie bogatsze w skały dalarneńskie, co przesuwa ich teoretyczne ośrodki głazowe na zachód w stosunku do 
TCG młodszego nasunięcia. Wiarygodne potwierdzenie powyższej obserwacji wymaga jednak znalezienia kolejnych stanowisk z glinami tego wieku dostępnymi do bezpośrednich badań.

Analiza teoretycznych ośrodków głazowych jest znacznie mniej skuteczna w przypadku rozróżniania osadów glacjalnych zlodowaceń odry/warty i wisły. Jedynie na Kujawach czytelne jest wyraźne wysunięcie TCG glin odry/warty na południowy zachód w stosunku do osadów ostatniego zlodowacenia. Różne metody obliczania teoretycznych ośrodków głazowych prowadzą do podobnych rezultatów i różnią się jedynie stopniem rozproszenia wyników - różnicę pomiędzy glinami tego wieku najłatwiej odczytać w oparciu o TCG-W8.

Korelacja i rozróżnianie osadów kolejnych nasunięć glacjalnych ostatniego zlodowacenia z zastosowaniem TCG okazały się dość wątpliwe. Gliny zlodowacenia wisły cechują się uśrednionym składem zespołów głazowych, co wynika zapewne ze znaczącego wpływu inkorporacji osadów złożonych we wcześniejszych awansach lądolodu. Analogiczny proces uśredniania osadów glacjalnych w rezultacie inkorporacji starszych osadów zaobserwowano w paleozoicznej formacji Dwyka w południowej Afryce, gdzie tylko dla najstarszego diamiktonu udało się ustalić kierunek transportu glacjalnego, młodsze zaś warstwy zawierały już przemieszany materiał, przyniesiony z różnych obszarów (Visser i in., 1986). Dodatkowy problem stanowi bardzo duże zróżnicowanie przestrzenne zespołów eratyków w glinach wisły, będące skutkiem lokalnej zmienności dynamiki lądolodu fennoskandzkiego i warunków termicznych w jego stopie. Oznacza to, że zespoły eratyków mogą w tym przypadku posłużyć głównie do interpretacji kierunków napływu mas lodowych i ich zmienności. Nieznaczne różnice pomiędzy różnowiekowymi glinami zlodowacenia wisły zaznaczają się nieco lepiej na Kujawach, ale i tu korelacja możliwa jest tylko w przypadku stanowisk położonych stosunkowo blisko siebie.

Analiza kartodiagramów (map kołowych) jest bardzo pomocna w określaniu warunków paleogeograficznych, w tym dróg napływu lodu na badany obszar. Korelacja osadów glacjalnych w oparciu o interpretację tych map jest jednak bardzo trudna i obarczona wadą subiektywizmu - brak matematycznego lub geometrycznego wskaźnika, charakteryzującego cały zespół eratyków i nadającego się do porównywania wielu prób.

\subsection{Rezultaty analizy statystycznej}

Nie ma uniwersalnych cech petrograficznych, które umożliwiałyby jednoznaczne identyfikowanie różnowiekowych osadów glacjalnych we wszystkich przeanalizowanych regionach Polski. Analizy eratyków we frakcji >20 mm (udział poszczególnych typów lub grup skał przewodnich i innych, grupy regionalne eratyków przewodnich, współczynniki petrograficzne obliczane dla wszystkich skał północnych) znajdują zastosowanie głównie w skali jednego niezbyt wielkiego regionu, ale na ogół nie sprawdzają się w odniesieniu do całego kraju. 
Jedyny zaobserwowany przypadek pełnej zbieżności analiz w skali ponadregionalnej dotyczył osadów kompleksu południowopolskiego i środkowopolskiego w Polsce Środkowej oraz na Podlasiu i Lubelszczyźnie. W obydwu wymienionych regionach gliny zlodowacenia san 2 są bardzo bogate w skały południowoszwedzkie, a stosunkowo ubogie w skały alandzkie i bałtyckie, co skutkuje również wysunięciem teoretycznych ośrodków głazowych na południowy zachód. Osady glacjalne odry/warty cechują się odwrotnymi stosunkami ilościowymi pomiędzy eratykami z wymienionych regionów Fennoskandii i dna Bałtyku, a to determinuje północno-wschodnią lokalizację TCG dla glin tego wieku. W omawianych regionach zauważalna jest również różnica pomiędzy różnowiekowymi glinami w obrębie kompleksu środkowopolskiego. Polega ona na znacznie większym udziale skał dalarneńskich w starszych glinach (krzna?) niż w glinach odry/warty.

Większość spośród cech petrograficznych wskazanych w analizie statystycznej jako różnicujące dwie różnowiekowe gliny nie ma znaczenia delimitacyjnego $\mathrm{w}$ odniesieniu do innych par porównywanych osadów glacjalnych.

Różnica pomiędzy osadami zlodowaceń odry/warty i wisły jest zmienna przestrzennie. Na Kujawach gliny środkowopolskie zawierają liczne eratyki południowoszwedzkie (ze Smålandu i Blekinge), a stosunkowo niewiele skał przewodnich pochodzących z regionu Wysp Alandzkich i Zatoki Botnickiej. W osadach glacjalnych zlodowacenia wisły proporcje zmieniają się na korzyść skał wywodzących się z północno-wschodniej części obszaru alimentacyjnego. Ta tendencja zanika jednak szybko wraz z przesuwaniem się na północ i na Pomorzu jest już zupełnie nieczytelna.

\subsection{Rozmieszczenie eratyków wskaźnikowych}

Wraz z przesuwaniem się na wschód zróżnicowanie eratyków przewodnich w osadach glacjalnych Polski maleje. Stopniowo zanikają eratyki norweskie i zachodnioszwedzkie (spotykane sporadycznie niemal wyłącznie w zachodniej części kraju), maleje udział skał południowoszwedzkich oraz bornholmskich, a dopiero poza wschodnią granicą Polski zastępują je eratyki fińskie i karelskie.

Bardzo nieliczne okazały się w Polsce skały fińskie (oprócz alandzkich). Typowe wyborgity zdarzają się wyjątkowo rzadko (nawet w Polsce Wschodniej) i to właściwie jedynie w postaci dużych głazów. W mniejszych klastach, pobieranych z osadów glacjalnych, nie udało się zidentyfikować ani jednego okazu tej skały, co przynajmniej po części wynika z grubokrystalicznej tekstury tych skał i ich podatności na rozpad podczas wietrzenia na pojedyncze kryształy (niemożliwe do przypisania do konkretnej skały pierwotnej). Znikomy udział skał fińskich w osadach glacjalnych Polski potwierdza oparte na analizie rys glacjalnych i innych wskaźnikach geomorfologicznych wnioski o ruchu mas lodowych przez południową Finlandię w kierunku równoleżnikowym na wschód i o odprowadzaniu skał fińskich daleko od polskiego terytorium.

Sporadyczną obecność skał zachodnioszwedzkich i norweskich w plejstoceńskich osadach Polski można wyjaśnić ich transportem w krach lodowych po powierzchni morza, które co najmniej od holsztynu rozwijało się w interglacjałach w południowej 
części niecki bałtyckiej. Wraz z innymi osadami ówczesnych mórz były one następnie inkorporowane przez transgredujący lądolód i transportowane na południe.

Przez wschodnią Polskę przebiega osiowa część strefy rozrzutu skał alandzkich, co podkreślone jest ich udziałem, sięgającym w niektórych stanowiskach nawet 50\% oznaczonych eratyków przewodnich.

Utożsamianie występowania brunatnych porfirów bałtyckich z zasięgiem zlodowaceń środkowopolskich (odra, warta) nie znajduje potwierdzenia w systematycznych badaniach litostratygraficznych. Sugerowany dawniej brak tej skały poza zasięgiem warty, a w środkowej Polsce odry (Radomki - Różycki, 1967) wynikał zapewne z bardzo małego jej udziału w osadach kompleksu południowopolskiego - 0,5\% i wyraźnego przyrostu znaczenia w osadach młodszych zlodowaceń - 1,2\% w kompleksie środkowopolskim i aż 3,3\% w północnopolskim. Przytoczony przyrost udziału mógł być spowodowany systematycznym odsłanianiem i powiększaniem przez erozję glacjalną wychodni tej skały, zlokalizowanej w niecce bałtyckiej na południe od Wysp Alandzkich.

Wykorzystywanie udziału dolomitów jako wskaźnika różnicującego poziomy morenowe jest nieuzasadnione, ponieważ ten typ skały, wbrew obiegowej opinii, bazującej na wyższej od kalcytu twardości, jest w warunkach naturalnych bardziej podatny na wietrzenie niż wapienie i szybciej ulega wyeliminowaniu z osadów.

W większości modeli lądolodu fennoskandzkiego Dalarna miała znajdować się w najbliższym sąsiedztwie linii podziału lodu. Zgodnie z przyjmowanymi obecnie założeniami i obserwacjami współczesnych lądolodów, tempo ruchu lodu było tam tak małe, że skały dalarneńskie powinny należeć do rzadkości w pobliżu strefy maksymalnego zasięgu zlodowaceń. Sprzeczna z powyższym założeniem liczna obecność skał dalarneńskich w różnowiekowych osadach glacjalnych Polski (włącznie z południową częścią kraju) skłania do poszukiwania odmiennego rozkładu prędkości lodu w lądolodzie fennoskandzkim, aniżeli postulowany przez Donnera (1989) lub stwierdzony w lądolodzie antarktycznym (np. Rignot i in., 2011).

Wysoka zawartość skał z Dalarny i występowanie skał z Ångermanlandu w osadach glacjalnych Polski dowodzą nieprawidłowości wszelkich modeli termodynamicznych lądolodu, zakładających trwałe utrzymywanie się w środkowej Szwecji zimnego reżimu termicznego stopy lądolodu. Ekstremalny przykład modelu sprzecznego z badaniami petrograficznymi stanowi koncepcja Forsströma i in. (2003). Zasięg obszaru o zimnym reżimie podłoża lądolodu fennoskandzkiego musiał być znacznie mniejszy, aniżeli estymowany w większości opracowanych dotychczas modeli termodynamicznych lądolodów.

Obecność w osadach glacjalnych Pomorza, Powiśla, Kujaw i Polski Środkowej skał ze Skanii i Bornholmu jest przesłanką świadczącą albo o istotnym udziale innych niż lód czynników transportu w dostarczaniu materiału skalnego na obszar Polski, albo o przynajmniej okresowym funkcjonowaniu nietypowego kierunku napływu lodu - odmiennego zarówno od modelu strumieniowego, jak i od starszego modelu opisującego promieniste rozpływanie się lodu z centrum Skandynawii. 
Łupki paleozoiczne pojawiają się tylko sporadycznie w przeanalizowanych przez autora osadach glacjalnych. Wynika to z ich podatności na wietrzenie, ale też z występowania głównie w drobniejszej niż badana frakcji (Schulz przypisywał im frakcję głównie 1-10 mm - 1996).

Większość eratyków w osadach glacjalnych jest stosunkowo mało zwietrzała, a jeżeli wietrzenie zaznacza się dość wyraźnie, to zazwyczaj na większości klastów, co wskazuje na raczej postdepozycyjny charakter tego procesu. W niektórych przypadkach dostrzeżono jednak bardzo duże różnice w stopniu zaawansowania procesów wietrzeniowych wśród eratyków identycznych pod względem litologicznym, a nawet natrafiono na klasty reprezentujące skały teoretycznie odporne na wietrzenie, a jednak bardziej zwietrzałe od niektórych klastów skał bardziej podatnych na procesy wietrzeniowe. Świadczy to o inkorporacji przez transgredujący lądolód zwietrzeliny preglacjalnej lub interglacjalnej już w Fennoskandii, bądź o wchłonięciu na drodze ku miejscu depozycji zwietrzałych osadów pozostawionych przez starsze nasunięcia lodowca. W większości przypadków te bardziej zwietrzałe ziarna uległy rozdrobnieniu podczas transportu glacjalnego i nie wpłynęły na skład frakcji $>20 \mathrm{~mm}$, będącej przedmiotem badań autora.

Większość eratyków frakcji >20 mm, występujących w osadach glacjalnych Polski, cechuje się dość wysokim stopniem obtoczenia, a to może świadczyć, że przynajmniej część swojej drogi musiały one pokonać transportowane w strefie bazalnej lądolodu. Pozostawanie w trakcji dennej musiało być krótkotrwałe - w przeciwnym wypadku głaziki uległyby dalszemu rozdrobnieniu. Na tym etapie została zapewne wyeliminowana z badanej frakcji większość skał bardziej podatnych na niszczenie, np. łupków paleozoicznych lub skał już wcześniej (przed pobraniem przez lód) zwietrzałych. Możliwe też, że część ziaren już w momencie pobierania przez lód cechowała się dobrym obtoczeniem, np. w efekcie wcześniejszego transportu w środowisku rzecznym lub dzięki obróbce w strefie brzegowej interglacjalnego morza.

\subsection{Eratyki a model strumieniowy lądolodu}

Dla potrzeb badań petrograficznych osadów glacjalnych konieczne jest odróżnianie strumieni lodowych (sensu Swithinbank, 1954) i prądów (potoków) lodowych, definiowanych jako indywidualne masy lodu, poruszające się w obrębie lądolodu z prędkością równą otoczeniu, a różniące się od niego co najwyżej składem materiału morenowego.

Nigdzie na terenie Polski nie udało się zidentyfikować typowej dla strumieniowego ruchu lodu strefy rozrzutu typu Boothia. Nie jest to zaskakujące ze względu na dużą odległość, jaka dzieli stanowiska badawcze od wychodni litego podłoża. Na szlaku hipotetycznych strumieni lodowych vistulianu podłoże zbudowane było z luźnych osadów starszych zlodowaceń, zawierających przemieszany materiał skalny z różnych obszarów Fennoskandii i dna Bałtyku. Jedynie w Polsce Zachodniej dystans ten był mniejszy, ale tam opisano strefy rozrzutu, które przypominają raczej typ Dubawnt. Oznacza to, że badania eratyków nie dostarczyły żadnych dowodów potwierdzających funkcjonowanie lądowych strumieni lodowych na obszarze naszego kraju. 
Intensywna erozja w podłożu strumieni lodowych prowadzi raczej do stabilizacji rozwiniętego już układu (dzięki przeformowaniu rzeźby podłoża), aniżeli do jego zmian. W kolejnych zlodowaceniach rzeźba sprzyja odtwarzaniu się poprzedniego układu strumieni lodowych, a to z kolei musiałoby doprowadzić do ukształtowania się w osadach glacjalnych bardzo wyraźnych stref rozrzutu eratyków typu Boothia oraz Dubawnt Lake (sensu Dyke i Morris, 1988). W rzeczywistości wachlarze rozrzutu eratyków wywodzących się z różnych regionów Fennoskandii w znacznym stopniu pokrywają się. Dystrybucja eratyków w osadach glacjalnych Polski może być zatem traktowana jako wiarygodny argument przeciwko dłuższemu funkcjonowaniu strumieniowego modelu dynamiki lądolodu. Liczne występowanie w osadach glacjalnych Polski eratyków pochodzących z południowej i środkowej Szwecji potwierdza tezę, że bałtycki strumień lodowy funkcjonował bardzo krótko i wykształcił się dopiero na etapie deglacjacji, kiedy jego potencjalna rola w depozycji osadów glacjalnych i kształtowaniu ich składu petrograficznego była bardzo ograniczona, a obszar Polski był już zapewne wolny od lodu. Gdyby bałtycki strumień lodowy był aktywny we wcześniejszym etapie rozwoju lądolodu fennoskandzkiego, to musiałby odizolować terytorium Polski od napływu skał ze Szwecji.

Model Punkariego $(1993,1997)$ jest bardzo trudny do pogodzenia z wynikami badań petrograficznych osadów glacjalnych na terenie Polski. Nawet jeśli główny strumień bałtycki i jego hipotetyczne „odgałęzienia” istniały, to asynchronicznie i niezależnie od siebie, gdyż położony w izostatycznym (głębszym niż współczesne) obniżeniu główny strumień musiałby raczej drenować swoje otoczenie niż je zasilać. Oznacza to, że indywidualne strumienie lodowe Wisły i Odry są starsze i niekoniecznie równowiekowe - być może powiązane ze schyłkowym etapem rozwoju lądolodu w fazie poznańskiej. Przyjęcie tego założenia wyjaśniałoby dalszy zasięg lądolodu w lobie płockim w fazie poznańskiej niż w leszczyńskiej. Główny bałtycki strumień lodowy rozwinął się zapewne już u schyłku fazy poznańskiej (wskazują na to badania w Danii - Kjær i in., 2003) lub jeszcze później (np. w fazie gardnieńskiej), kiedy żadne odgałęzienie nie mogło już skierować się daleko na południe i w konsekwencji nie miał on żadnego wpływu na skład osadów glacjalnych w Polsce. Mógł natomiast w znacznym stopniu wpływać na kształtowanie się składu petrograficznego glin w Danii czy w południowej Szwecji.

\subsection{Wybrane koncepcje glacjologiczne w świetle badań eratyków}

Przesunięcie ośrodka alimentacji lądolodu na wschód w trakcie rozwoju lądolodu (zgodnie z koncepcją Ehlersa - 1983; Ehlers i in., 1984) daje się zaobserwować w glinach kompleksu środkowopolskiego - pomiędzy krzną i odrą/wartą i to zarówno w Polsce Środkowej, jak i Wschodniej. Analogiczna migracja obszaru zasilania lądolodu w materiał skalny widoczna jest również w kompleksie południowopolskim na Dolnym Śląsku, gdzie teoretyczne ośrodki głazowe glin zlodowacenia san 2 zlokalizowane są na wschód od analogicznych wskaźników obliczonych dla glin sanu 1. W glinach kompleksu północnopolskiego sytuacja jest zdecydowanie bardziej skomplikowana z uwagi na potencjalny wpływ hipotetycznych paleostrumieni lodowych na kształtowanie się składu 
osadów glacjalnych. Większość analiz zespołów eratyków z glin tego wieku została przeprowadzona na obszarze Pomorza Gdańskiego i Dolnego Powiśla, gdzie zmienność czasowa i przestrzenna dynamiki lądolodu wisły jest bardzo duża.

Teoria momentalnego (spontanicznego) zlodowacenia - instantaneous glacierisation - jest sprzeczna z powszechnym występowaniem skał nordyckich na Niżu Środkowoeuropejskim. Przyjęcie tego mechanizmu dla lądolodu fennoskandzkiego musiałoby doprowadzić do dominacji moren lokalnych w Polsce i krajach ościennych.

Znacząca inkorporacja materiału skalnego z podłoża możliwa jest tylko w przypadku lądolodu przemieszczającego się w oparciu o ślizg denny oraz deformacje luźnego podłoża. Ślizg denny może przyjmować pulsacyjny charakter (ruch przywierająco-ślizgowy), związany z okresowym przywieraniem stopy lądolodu do podłoża i jej uwalnianiem się. Ten typ ruchu wydaje się sprzyjać pobieraniu skał z podłoża (lokalne przymarzanie i następnie odrywanie przez lód fragmentów skał podłoża). Deformacje luźnego podłoża umożliwiają wielokrotną depozycję i powtórną inkorporację osadów w stopie lądolodu. Transport materiału morenowego odbywa się w tym przypadku najczęściej na stosunkowo krótkim odcinku. Im większy byłby zatem udział tego mechanizmu w ruchu lądolodu, tym mniejsza byłaby możliwość transportu skał fennoskandzkich na teren Niżu Środkowoeuropejskiego. Doprowadziłoby to do wyraźnej dominacji skał lokalnych w osadach glacjalnych Polski, czego jednak nie zaobserwowano. Należy zatem przyjąć, że rola deformacji luźnego podłoża w ruchu lądolodu była stosunkowo mała. Wewnętrzny ruch lodu (płynięcie deformacyjne) nie ma wpływu na pobór materiału skalnego, ale może decydować o długości i prędkości transportu materiału skalnego.

Na większości obszaru Polski erozja glacjalna skał lokalnego podłoża jest zamaskowana inkorporacją głównie starszych osadów plejstoceńskich - w zasadzie nieodróżnialnych od materiału świeżo przyniesionego z Fennoskandii lub niecki bałtyckiej. Efekty erozji czytelne są tylko wtedy, jeśli na drodze lądolodu znalazły się zwięzłe skały preglacjalnego podłoża. 


\section{WNIOSKI}

Przeprowadzone badania umożliwiły realizację podstawowych celów, przedstawionych we wstępnej części opracowania. Udało się wyjaśnić szereg wątpliwości odnoszących się do metodyki badań, paleogeografii obszarów objętych zlodowaceniami plejstoceńskimi, sposobu rozwoju lądolodu i stratygrafii osadów glacjalnych. Pozwoliło to przedstawić poniższe (najważniejsze) wnioski:

1. Zróżnicowanie petrograficzne różnowiekowych osadów glacjalnych najwyraźniej zaznacza się w położeniu teoretycznych ośrodków głazowych (TCG), obliczonych w oparciu o wszystkie typy krystalicznych skał przewodnich. Inne wskaźniki nie mają równie uniwersalnego charakteru.

2. Uproszczenie procedury badawczej, polegające na uwzględnieniu tylko części eratyków przewodnich (testowe TCG), wpływa negatywnie na wiarygodność i porównywalność wyników.

3. Osady glacjalne i fluwioglacjalne na obszarze Polski cechują się odmiennym składem petrograficznym, co wyklucza wykorzystanie w korelacji osadów glacjalnych wyników badań przeprowadzonych w osadach o odmiennej genezie i litologii.

4. Nie ma uniwersalnych cech petrograficznych frakcji >20 mm (wskaźniki, udział różnych eratyków), które umożliwiałyby jednoznaczne identyfikowanie różnowiekowych osadów glacjalnych we wszystkich przeanalizowanych regionach Polski.

5. Zasięg ponadregionalny (od wschodniej Wielkopolski przez Polskę Środkową, aż po Lubelszczyznę i Podlasie) ma jedynie odmienność składu glin zlodowaceń san 2 i odra/warta (pierwsze są bogate w skały południowoszwedzkie, a ubogie w skały alandzkie i bałtyckie; drugie odwrotnie).

6. Utożsamianie występowania brunatnych porfirów bałtyckich z zasięgiem zlodowaceń środkowopolskich (odra, warta) nie znajduje potwierdzenia w systematycznych badaniach litostratygraficznych.

7. Wraz z przesuwaniem się na wschód na obszarze Polski maleje zróżnicowanie zespołów eratyków w osadach glacjalnych - głównie spada udział skał południowoszwedzkich i bornholmskich, a rośnie udział skał alandzkich.

8. Przez wschodnią Polskę przebiega osiowa część strefy (wachlarza) rozrzutu skał alandzkich.

9. Znikomy udział skał południowofińskich (z „kontynentalnej” części Finlandii) w osadach glacjalnych Polski świadczy o ich wynoszeniu przez lądolód poza terytorium naszego kraju - najprawdopodobniej w kierunku wschodnim. 
10. Dobra obróbka większości eratyków w glinach Polski wskazuje, że ich transport odbywał się głównie w strefie bazalnej lądolodu.

11. Liczne występowanie skał fennoskandzkich w osadach glacjalnych Polski przemawia przeciwko znaczącemu udziałowi deformacji luźnego podłoża w ruchu lądolodu.

12. Skład osadów glacjalnych w Polsce kształtował się pod wpływem radialnego rozpływania się lodu na zewnątrz czaszy lądolodu fennoskandzkiego; brak dowodów istotnego wpływu strumieni lodowych na zespoły eratyków w glinach Polski.

13. Modele lądolodu fennoskandzkiego, zakładające długotrwałe utrzymywanie się zimnego reżimu termicznego w środkowej Szwecji są nie do zaakceptowania w świetle powszechnego i licznego występowania skał z Dalarny oraz dość częstej obecności eratyków z Ångermanlandu w osadach glacjalnych Polski i krajów ościennych.

14. Rozkład prędkości lodu w lądolodzie fennoskandzkim musiał być inny niż we współczesnym lądolodzie antarktycznym (w centrum lądolodu znacznie szybszy od obecnie przyjmowanych kilku metrów na rok, co wykluczałoby daleki transport wywodzących się z tego obszaru skał).

15. Strumienie lodowe $\mathrm{w}$ lądolodzie fennoskandzkim rozwijały się tylko na etapie deglacjacji i asynchronicznie, co pozwoliło zachować ich ślady geomorfologiczne bez pozostawiania petrograficznych świadectw ruchu strumieniowego.

16. Dla potrzeb badań petrograficznych osadów glacjalnych konieczne jest odróżnianie strumieni lodowych i prądów (potoków) lodowych, definiowanych jako indywidualne masy lodu, poruszające się w obrębie lądolodu z prędkością nieodbiegającą znacząco od otoczenia. 


\section{LITERATURA}

Aarseth I., 1997, Western Norwegian fjord sediments: age, volume, stratigraphy, and role as temporary depository during glacial cycles, „Marine Geology”, 143, 39-53.

Aber J.S., 1985, The character of glaciotectonism, „Geologie en Mijnbouw”, 64, 389-395.

Aber J.S., Ber A., 2007, Glaciotectonism, Developments in Quaternary Science, $6^{\text {th }}$ Vol., Amsterdam, Elsevier, $246 \mathrm{~s}$.

Adam W.G., 2006, Moraine sediment characteristics as indicators of former basal ice layers, [w:] P.G. Knight (red.), Glacier science and environmental change, Blackwell, 439-441.

Adams J., Maslin M., Thomas E., 1999, Sudden climate transitions during the Quaternary, „Progress in Physical Geography", 23, 1-36.

Ahrens H., Lotsch D., Schwab G., 1982, Präglaziale tektonische Aktivierung im Nordteil der DDR, „Zeitschrift für geologische Wissenschaften", 10, 5, 671-678.

Aitken M.J., 1985, Thermoluminescence Dating, Academic Press, London, $359 \mathrm{~s}$.

Alexanderson H., Adrielsson L., Hjort C., Möller P., Antonov O., Eriksson S., Pavlov M., 2002, Depositional history of the North Taymyr ice-marginal zone, Siberia - a landsystem approach, „Journal of Quaternary Science", 17, 361-382.

Alley R.B., 1991, Deforming-bed origin for southern Laurentide Till Sheets?, „Journal of Glaciology”, 37 (125), 67-76.

Alley R.B., 1993, In search of ice-stream sticky spots, „Journal of Glaciology”, 39, 447-454.

Alley R.B., Anandakrishnan S., Dupont T.K., Parizek B.R., Pollard D., 2007, Effect of sedimentation on ice-sheet grounding-line stability, „Science”, 315, 1838-1841.

Alley R.B., Blankenship D.D., Bentley C.R., Rooney S.T., 1986, Deformation of till beneath Ice Stream B, West Antarctica, „Nature”, 322 (6074), 57-59.

Alley R.B., Blankenship D.D., Rooney S.T., Bentley C.R., 1987, Continuous till deformation beneath ice sheets, [w:] E.D. Waddington, J.S. Walder (red.), The physical basis of ice sheet modeling, Proceedings of the Vancouver Symposium, August 1987, IAHS Publication, 170, 81-91.

Alley R.B., Blankenship D.D., Rooney S.T., Bentley C.R., 1989, Sedimentation beneath ice shelves - the view from Ice Stream B, „Marine Geology”, 85, 101-120.

Alley R.B., Cuffey K.M., Evenson E.B., Strasser J.C., Lawson D.E., Larson G.J., 1997, How glaciers entrain and transport basal sediment: physical constrains, „Quaternary Science Reviews”, 16, 1017-1038.

Alley R.B., Lawson D.E., Evenson E.B., Larson G.J., 2003a, Sediment, glaciohydraulic supercooling, and fast glacier flow, „Annals of Glaciology”, 36, 135-141.

Alley R.B., Lawson D.E., Evenson E.B., Strasser J.C., Larson G.J., 1998, Glaciohydraulic supercooling: A freeze-on mechanism to create stratified, debris-rich basal ice: II. Theory, „Journal of Glaciology”, 44, 563-569.

Alley R.B., Lawson D.E., Larson G.J., Evenson E.B., Baker G.S., 2003b, Stabilizing feedbacks in glacier bed erosion, „Nature”, 424, 758-760.

Alley R.B., MacAyeal D.R., 1994, Ice-rafted debris associated with binge/purge oscillations of the Laurentide Ice Shee, „Paleoceanography”, 9, 4, 503-511. 
Alley R.B., Strasser J.C., Lawson D.E., Evenson E.B., Larson G.J., 1999, Glaciological and geological implications of basal ice accretion in overdeepenings, „Geological Society of America Special Papers”, 337, 1-9.

Amantov A., 1995, Plio-Pleistocene erosion of Fennoscandia and its implication for the Baltic Area, [w:] J.E. Mojski (red.), Proceedings of the 3rd Marine Geological Conference "The Baltic", "Prace Państwowego Instytutu Geologicznego", 149, 47-56.

Amantov A., 1996, Geological map of the Baltic Shield, map S-1 Southern Fennoscandia, Scale 1 : 3 million.

Amantov A., Hagenfeldt S., Söderberg P., 1995, The Mesoproterozoic to Lower Palaeozoic sedimentary bedrock sequence in the northern Baltic Proper, Aland Sea, Gulf of Finland and Lake Ladoga, [w:] J.E. Mojski (red.), Proceedings of the 3rd Marine Geological Conference "The Baltic”, „Prace Państwowego Instytutu Geologicznego", 149, 19-25.

Anandakrishnan S., Alley R.B., 1994, Ice Stream C, Antarctica, sticky spots detected by microearthquake monitoring, „Annals of Glaciology”, 20, 183-186.

Anandakrishnan S., Alley R.B., 1997, Stagnation of ice stream C, West Antarctica, by water piracy, "Geophysical Research Letters", 24, 265-268.

Anders T., Kratzert P., Kühl A., 1991, Statistische Analysenmethoden zur Beschreibung und Klassifizierung von Datenkollektiven, angewandt auf die Geschiebezählung, „Zeitschrift für angewandte Geologie”, 37, 2, 70-75.

André M.F., 2004, The geomorphic impact of glaciers as indicated by tors in North Sweden (Aurivaara $68^{\circ} \mathrm{N}$ ), "Geomorphology", 57, 403-421.

Andreicheva L.N., 1992, Osnovnyje moreny Evropejskogo Sieviero-Vostoka Rossiji i ich litostratigrafičeskoje značenije, Nauka, Sankt Petersburg, $124 \mathrm{~s}$.

Andreicheva L.N., 2012, Litologiya vierchnie-sriednieplejstocienovych tillov na krajniem sieviero-vostokie Evropejskoj Rossiji, „Litologiya i Poleznye Iskopaemye”, 47, 3, 285-297.

Andreicheva L.N., 2013, Stratigraphy, paleogeography and paleoclimates of the Pleistocene in the north of European Russia, „Geologija”, 55, 1, 8-22.

Andreicheva L.N., Marchenko-Vagapova T.I., 2007, The Neopleistocene of North European Russia: Stratigraphy, Paleogeography, and Paleoclimate, „Stratigraphy and Geological Correlation”, 15, 4, 421-436.

Andrews J.T., Mahaffy M.A.W., 1976, Growth rate of the Laurentide Ice Sheet and sea level lowering (with emphasis on the 115,000 BP sea level low), „Quaternary Research”, 6, 167-183.

Argow B.A., Hughes Z.J., FitzGerald D.M., 2011, Ice raft formation, sediment load, and theoretical potential for ice-rafted sediment influx on northern coastal wetlands, „Continental Shelf Research”, 31, 1294-1305.

Arnold N., Sharp M., 2002, Flow variability in the Scandinavian ice sheet: modelling the coupling between ice sheet flow and hydrology, "Quaternary Science Reviews”, 21, 485-502.

Astakhov V.I., Kaplyanskaya F.A., Tarnogradsky V.D., 1996, Pleistocene permafrost of West Siberia as a deformable glacier bed, „Permafrost and Periglacial Processes”, 7, 165-191.

Astapova S.D., 1983, Faktory opriedielajuščije vieščestviennyj sostav moren Biełarusi, „Dokłady AN Biełarusi”, $27,9,838-841$.

Astapova S.D., 1987, Rukovodiaščije vałuny krajevych lednikovych obrazovanij Biełorusskoj griady, „Dokłady AN Biełarusi", 31, 8, 747-750.

Astapova S.D., 1993, Litologo-paleogeografičeskoje rajonirovanije lednikovych otłożenij Biełarusi, „Dokłady AN Biełarusi", 37, 4, 105-108.

Atkins C.B., Barrett P.J., Hicock S.R., 2002, Cold glaciers do erode and deposit: evidence from Allan Hills, Antarctica, "Geology”, 30, 659-662.

Augustinus P., 1995, Glacial valley cross-profile development: the influence of in situ rock stress and rock mass strength, with examples from the Southern Alps, New Zealand, "Geomorphology”, 14, 87-97.

Averill S.A., 1990, Drilling and sample processing methods for deep till geochemistry surveys: making the right choices, [w:] S.A. Averill, A. Bolduc, W.B. Coker, N.W. Dilabio, M. Parent, J.E. Veillette (red.), Application 
de la géologie du Quaternaire à l'exploration minerale, Association professionelle des géologues et des geophysiciens du Quebec, 139-173.

Averill S.A., 2009, Useful Ni-Cu-PGE versus kimberlite indicator minerals in surficial sediments: similarities and differences (abstract), Manitoba Mining and Minerals Convention, Winnipeg, Manitoba. November 2009, $19-21$.

Bahr D.B., Rundle J.B., 1996, Stick-slip statistical mechanics at the bed of a glacier, "Geophysical Research Letters", 23, 2073-2076.

Balwierz Z., Goździk J., Marciniak B., 2006, Palinologiczne i diatomologiczne badania osadów interglacjału mazowieckiego z odsłonięcia w kopalni Bełchatów, „Przegląd Geologiczny”, 54, 1, 61-67.

Balwierz Z., Goździk J., Marciniak B., 2008, Geneza misy jeziornej i warunki środowiskowe akumulacji limniczno-bagiennej w interglacjale mazowieckim w rowie Kleszczowa (środkowa Polska), „Biuletyn Państwowego Instytutu Geologicznego", 428, 3-22.

Bamber J.L., Vaughan D.G., Joughin I., 2000, Widespread complex flow in the interior of the Antarctic Ice Sheet, „Science”, 287 (5456), 1248-1250.

Baraniecka M.D., 1980, Objaśnienia do Szczegółowej Mapy Geologicznej Polski 1 : 50 000. Arkusz Grójec (596), Państwowy Instytut Geologiczny, Warszawa, $116 \mathrm{~s}$.

Baraniecka M.D., Goździk J., Ziomek J., 1995, Lithologic, mineralogic and petrographic composition of tills from the vicinity of Bełchatów, „Acta Geographica Lodziensia”, 68, 29-46.

Barnes P.W., Kempema E.W., Reimnitz E., McCormick M., 1994, The influence of ice on southern Lake Michigan coastal erosion, „Journal of Great Lakes Research”, 20, 179-195.

Barry J., 1992, Aland islands erratics in Britain, „Humberside Geologist”, 10, 23-25.

Baturin G.N., Ilyin A.V., 2013, Comparative Geochemistry of Shell Phosphorites and Dictyonema Shales of the Baltic, "Geochemistry International”, 2013, 51, 1, 23-32.

Baudenbacher R., 1986, Zur Geschiebestand der Sammlung Gläsel im Naturwissenschaftlichen Museum Leipzig, „Altenburger naturwissenschaftliche Forschungen”, 3, 80-104.

Beeman M., Durham W.B., Kirby S.H., 1988, Friction of ice, „Journal of Geophysical Research", 93, 7625-7633.

Beget J.E., 1986, Modeling the influence of till rheology on the flow and profile of the Lake Michigan lobe, southern Laurentide ice sheet, USA, „Journal of Glaciology”, 32 (111), 235-241.

Bell M., Laine E., 1985, Erosion of the laurentide region of North America by glacial and glaciofluvial processes, "Quaternary Research”, 23, 154-174.

Bell R.E., Blankenship D.D., Finn C.A., Morse D.L., Scambos T.A., Brozena J.M., Hodge S.M., 1998, Influence of subglacial geology on the onset of a West Antarctic ice stream from aerogeophysical observations, „Nature", 394, 58-62.

Benn D.I., Evans D.J.A., 1997, Glaciers and Glaciation, Arnold, London, $734 \mathrm{~s}$.

Benn D.I., Evans D.J.A., 2010, Glaciers and Glaciation, Arnold, London, $816 \mathrm{s.}$

Bennett M.R., 2003, Ice streams as the arteries of an ice sheet: their mechanics, stability and significance, „Earth Science Reviews", 61, 309-339.

Bennett M.R., Glasser N.L., 2009, Glacial geology. Ice Sheets and Landforms, Wiley-Blackwell, 385 s.

Bennett M.R., Doyle P., Mather A.E., 1996, Dropstones: their origin and significance, „Palaeogeography, Palaeoclimatology, Palaeoecology", 121, 3, 331-339.

Bennhold W., 1928, Zur Verbreitung der aus dem südlichen Norwegen stammenden Geschiebe. Sammelbericht, „Zeitschrift für Geschiebeforschung”, 4, 153-156.

Bennhold W., 1931, Über den "Trebuser Sandstein” und seine Begleitgesteine, „Zeitschrift für Geschiebeforschung", 7, 4, 150-154.

Bennhold W., 1932, Konzentrische Entfärbungsringe (LIESEGANG'sche Ringe) auf rotem „Trebuser Sandstein”, „Zeitschrift für Geschiebeforschung", 8, 184-187.

Bentley C.R., 1987, Antarctic ice streams, a review, „Journal of Geophysical Research”, 92, 8843-8858. 
Ber A., 2000, Plejstocen Polski północno-wschodniej w nawiqzaniu do głębszego podłoża obszarów sqsiednich, „Prace Państwowego Instytutu Geologicznego", 170, 1-89.

Ber A., Janczyk-Kopikowa Z., Krzyszkowski D., 1998, A new interglacial stage in Poland (Augustovian) and the problem of the age of the oldest Pleistocene till, "Quaternary Science Reviews”, 17, 8, 761-773.

Ber A., Lindner L., Marks L., 2007, Propozycja podziału stratygraficznego czwartorzędu Polski, „Przegląd Geologiczny", 55, 2, 115-118.

Bijlsma S., 1981, Fluvial sedimentation from the Fennoscandian area into the North-West European Basin during the Late Cenozoic, [w:] A.J. van Loon (red.), Quaternary Geology: a farewell to A.J. Wiggers, „Geologie en Mijnbouw", 60, 337-345.

Bilz W., 1995, Geschiebefunde an der Abbruchkante der Eckernförder Bucht. Sedimentärgeschiebe des Präkambrium und Unterkambrium, „Der Geschiebesammler”, 28, 3, 109-128.

Bindschadler R., 1997, Actively surging West Antarctic ice streams and their response characteristics, „Annals of Glaciology", 24, 409-414.

Bindschadler R.A., King M.A., Alley R.B., Anandakrishnan S., Padman L., 2003, Tidally Controlled Stick-Slip Discharge of a West Antarctic Ice Stream, „Science”, 301, 1087-1089.

Bintanja R., van de Wal R.S.W., Oerlemans J., 2005, Modelled atmospheric temperatures and global sea levels over the past million years, "Nature”, 437, 125-128.

Błaszczyszyn A., Gudelis W., Litwin W., Swiridow N., Charin G., 1982, Budowa geologiczna dna Morza Bałtyckiego, [w:] W.K. Gudelis, J.M. Emelyanov (red.), Geologia Morza Bałtyckiego, Wydawnictwa Geologiczne, Warszawa, 36-94.

Blatter H., 1985, On the thermal regime of Arctic Glaciers, „Zürcher Geographische Schriften”, 22, 1-107.

Blatter H., 1990, Effect of climate on the cryosphere. Climatic conditions and the polythermal structure of Glacier, Federal Institute of Technology, Zürich, 190, $101 \mathrm{s.}$

Blatter H., Hutter K., 1991, Polythermal conditions in Arctic glaciers, „Journal of Glaciology”, 37, 261-269.

Blum A.E., Stillings L.L., 1995, Feldspar dissolution kinetics, [w:] A.F. White, S.L. Brantley (red.), Chemical Weathering Rates of Silicate Minerals, Reviews in mineralogy, 31, 291-351.

Bluszcz A., 2000, Datowanie luminescencyjne osadów czwartorzędowych - teoria, ograniczenia, problemy interpretacyjne, „Zeszyty Naukowe Politechniki Śląskiej, Matematyka - Fizyka”, 86, („Geochronometria”, 17), Gliwice, 1-104.

Bogucki A., Vołoszyn P., Gaigalas A., Melešyte M., Zaleski J., 1998, Glacigeniczny kompleks Polesia Wołyńskiego, stanowiska - Rostań i Kalinówka, [w:] IV Zjazd Geomorfologów Polskich, tom III Przewodnik wycieczek, 65-81.

Bolduc A.M., 1992, The formation of eskers based on their morphology, stratigraphy, and lithologic composition, Labrador, Canada, Niepublikowana praca doktorska, Lehigh University, $190 \mathrm{~s}$. - fide Cummings i in., 2011.

Böse M., 1979, Die geomorphologische Entwicklung im westlichen Berlin nach neueren stratigraphischen Untersuchungen, „Berliner Geographische Abhandlungen”, 28, 1-43.

Bouchard M.A., Salonen V.-P., 1990, Boulder transport in shield areas, [w:] R. Kujansuu, M. Saarnisto (red.), Glacial indicator tracing, Balkema, Rotterdam/Brookfield, 87-107.

Bougamont M., Christoffersen P., 2012, Hydrologic forcing of ice stream flow promotes rapid transport of sediment in basal ice, "Geology", 40, 8, 735-738.

Boulton G.S., 1970, On the origin and transport of englacial debris in Svalbard glaciers, „Journal of Glaciology", 9, 213-229.

Boulton G.S., 1974, Processes and patterns of subglacial erosion, [w:] D.R. Coates (red.), Glacial Geomorphology. Proceedings of the Fifth Annual Geomorphology Symposia, Binghamton, State University of New York, Allen i Unwin, London, 41-87.

Boulton G.S., 1975, Processes and patterns of subglacial sedimentation: A theoretical approach, [W:] A.E. Wright, F. Moseley (red.), Ice Ages: Ancient and modern, „Geological Journal”, Sp. Iss., 6, 7-42. 
Boulton G.S., 1978, Boulder shapes and grain-size distributions of debris as indicators of transport paths through a glacier and till genesis, "Sedimentology”, 25, 773-799.

Boulton G.S., 1979, Processes of glacier erosion on different substrates, „Journal of Glaciology”, 23, 15-38.

Boulton G.S., 1986, A paradigm shift in glaciology?, "Nature”, 322, 18.

Boulton G.S., 1987, Progress in glacial geology during the last fifty years, „Journal of Glaciology”, Sp. Ed., 25-32.

Boulton G.S., 1996, The origin of till sequences by subglacial sediment deformation beneath mid-latitude ice sheets, „Annals of Glaciology”, 22, 75-84.

Boulton G.S., 2006, Glaciers and their coupling with hydraulic and sedimentary processes, [w:] P.G. Knight (red.), Glacier Science and Environmental Change, Blackwell, Oxford, 3-22.

Boulton G.S., Dent D.L., Morris E.M., 1974, Subglacial shearing and crushing, and the role of water pressures in tills from south-east Iceland, "Geografiska Annaler", 56A, 134-145.

Boulton G.S., Dobbie K.E., Zatsepin S., 2001a, Sediment deformation beneath glaciers and its coupling to the subglacial hydraulic system, „Quaternary International”, 86, 3-28.

Boulton G.S., Dongelmans P., Punkari M., Broadgate M., 2001b, Palaeoglaciology of an ice sheet through a glacial cycle: the European ice sheet through the Weichselian, "Quaternary Science Reviews", 20, 591625.

Boulton G.S., Hagdorn M., 2006, Glaciology of the British Isles Ice Sheet during the last glacial cycle: form, flow, streams and lobes, "Quaternary Science Reviews”, 25, 3359-3390.

Boulton G.S., Hindmarsh R.C.A., 1987, Sediment deformation beneath glaciers: rheology and geological consequences, „Journal of Geophysical Research”, 92, B9, 9059-9082.

Boulton G.S., Jones A.S., 1979, Stability of temperate ice caps and ice sheets resting on beds of deformable sediment, „Journal of Glaciology”, 24, 29-43.

Boulton G.S., Payne A., 1994, Mid-latitude ice sheets through the last glacial cycle: glaciological and geological reconstructions, [w:] J.-C. Duplessy, M.-T. Spyridakis (red.), Long-term Climatic Variations, NATO ASI Series I, 22, 177-212.

Boyce J.I., Eyles N., 1991, Drumlins carved by deforming till streams below the Laurentide Ice Sheet, "Geology", 19, 787-790.

Bradwell T., Stoker M.S., Golledge N.R., Wilson C., Merrit J., Long D., Everest J.D., Hestvik O.B., Stevenson A., Hubbard A., Finlayson A., Mathers H., 2008, The northern sector of the Last British Ice Sheet: maximum extent and demise, „Earth Science Reviews”, 88, 3-4, 207-226.

Bradwell T., Stoker M.S., Larter R., 2007, Geomorphological signature and flow dynamics of The Minch palaeo-ice stream, NW Scotland, „Journal of Quaternary Science”, 22, 609-622.

Brasier M.D., 1980, The Lower Cambrian transgression and glauconite-phosphatic facies in western Europe, „Journal of the Geological Society", 137, 695-703.

Braun D.D., 1989, Glacial and periglacial erosion of the Appalachians, "Geomorphology”, 2, 233-256.

Briner J.P., Miller G.H., Davis P.T., Bierman P.R., Caffee M., 2003., Last Glacial Maximum ice sheet dynamics in Arctic Canada inferred from young erratics perched on ancient tors, "Quaternary Science Reviews", 22, 437-444.

Briner J.P., Swanson T.W., 1998, Using inherited cosmogenic ${ }^{36} \mathrm{Cl}$ to constrain glacial erosion rates of the Cordilleran ice sheet, „Geology”, 26, 3-6.

Brodzikowski K., 1987, Charakterystyka oraz interpretacja paleogeograficzna osadów formacji Chojny, [w:] M.D. Baraniecka, K. Brodzikowski, L. Kasza (red.), Czwartorzęd rejonu Bełchatowa, II Sympozjum, Komisja Badań Czwartorzędu PAN, Wydawnictwo Geologiczne, Wrocław-Warszawa, 47-62.

Bromwich D.H., Toracinta E.R., Want S.-H., 2002, Meteorological perspective on the initiation of the Laurentide Ice Sheet, "Quaternary International”, 95-96, 113-124.

Brown C.S., Hallet B., Booth D.B., 1987, Rapid soft bed sliding of the Puget glacial lobe, „Journal of Geophysical Research", 92, B9, 8985-8997. 
Budd W.F., Keage P.L., Blundy N.A., 1979, Empirical studies of ice sliding, „Journal of Glaciology”, 28 (89), 157-170.

Busenberg E., Plummer L.N., 1982, The kinetics of dissolution of dolomite in $\mathrm{CO}_{2}-\mathrm{H}_{2} \mathrm{O}$ systems at 1.5 to $65^{\circ} \mathrm{C}$ and 0 to $1 \mathrm{~atm} \mathrm{pCO}_{2}$, "American Journal of Science", 282, 45-78.

Calov R., 2006, Modelling of terrestrial ice sheets in palaeo-climate research, http://www. pik-potsdam. $\mathrm{de} / \mathrm{members} / \mathrm{calov} /$ publications-1/pre-prints/inland_ice.pdf (dostęp: 14.08.2012).

Cao T., Aki K., 1986, Seismicity simulation with a rate-and-state friction law, „Pure and Applied Geophysics”, 124, 3, 487-513.

Casper C., 1931, Ein Rhombenporphyrgeschiebe bei Thorn, „Zeitschrift für Geschiebeforschung”, 7, 93.

Catania G.A., Scambos T.A., Conway H., Raymond C.F., 2006, Sequential stagnation of Kamb Ice Stream, West Antarctica, "Geophysical Research Letters", 33, 14, L14502, doi:10.1029/2006GL026430, $4 \mathrm{~s}$.

Cepek A.G., 1969, Zur Bestimmung und stratigraphischen Bedeutung der Dolomitgeschiebe in der Grundmoränen im Nordteil der DDR, „Geologie”, 18, 6, 657-673.

Charbonneau R., David P.P., 1993, Glacial dispersal of rock debris in central Gaspesie, Quebec, Canada, "Canadian Journal of Earth Sciences", 30, 1697-1707.

Charbonneau R., David P.P., 1995, A shear-diffusion model of till genesis based on the dispersal pattern of indicator rocks in the Grand-Volume Till of central Gaspésie, Québec, Canada, „Boreas”, 24, 281-292.

Chou L., Garrels R.M., Wollast R., 1989, Comparative study of the kinetics and mechanisms of dissolution of carbonate minerals, "Chemical Geology”, 78, 269-282.

Christoffersen P., Tulaczyk S., 2003a, Response of subglacial sediment to basal freezeon: I. Theory and comparison to observations from beneath West Antarctic ice Sheet, „Journal of Geophysical Research”, 108, B4, 2222, doi:10.1029/2002JB001935, $16 \mathrm{~s}$.

Christoffersen P., Tulaczyk S., 2003b, Thermodynamics of basal freeze-on: predicting basal and subglacial signatures of stopped ice streams and interstream ridges, „Annals of Glaciology”, 36, 233-243.

Christoffersen P., Tulaczyk S., Carsey F.D., Behar A.E., 2006, A quantitative framework for interpretation of basal ice facies formed by ice accretion over subglacial sediment, „Journal of Geophysical Research”, 111, F1, F01017, doi:10. 1029/2005JF000363, $12 \mathrm{~s}$.

Clarhäll A., Jansson K.N., 2003, Time perspectives on glacial landscape formation-glacial flow chronology at Lac aux Goélands, northeastern Québec, Canada, „Journal of Quaternary Science”, 18, 5, 441-452.

Clarhäll A., Kleman J., 1999, Distribution and glaciological implications of relict surfaces on the Ultevis plateau, northwestern Sweden, „Annals of Glaciology”, 28, 202-208.

Clark C.D., Hughes A.L.C., Greenwood S.L., Jordan C., Sejrup H.P., 2012, Pattern and timing of retreat of the last British-Irish Ice Sheet, „Quaternary Science Reviews”, 44, 112-146.

Clark C.D., Knight J.K., Gray J.T., 2000, Geomorphological reconstruction of the Labrador sector of the Laurentide Ice Sheet, "Quaternary Science Reviews", 19, 1343-1366.

Clark C.D., Stokes C.R., 2001, Extent and basal characteristics of the M'Clintock Channel Ice Stream, „Quaternary International", 86, 81-101.

Clark C.D., Stokes C.R., 2003, The palaeo-ice stream landsystem, [w:] D.J.A. Evans (red.), Glacial Landsystems, Edward Arnold, London, 204-227.

Clark P.U., 1987, Subglacial sediments dispersal and till composition, „Journal of Geology”, 95, 527-541.

Clark P.U., 1994, Unstable behaviour of the Laurentide Ice Sheet over deforming sediment and its implications for climate change, "Quaternary Research", 41, 19-25.

Clark P.U., Alley R.B., Pollard D., 1999, Northern Hemisphere icesheet influences on global climate change, "Science", 286, 1104-1111.

Clark P.U., Lea P.D. (red.), 1992, The Last Interglacial-Glacial Transition in North America, "Geological Society of America Special Paper", 270, 1-317. 
Clarke G.K.C., 1987a, Fast glacier flow: Ice streams, surging, and tidewater glaciers, „Journal of Geophysical Research", 92, B9, 8835-8842.

Clarke G.K.C., 1987b, Subglacial till: a physical framework for its properties and processes, „Journal of Geophysical Research", 92, 9023-9036.

Clarke G.K.C., Collins S.G., Thompson D.E., 1984, Flow, thermal structure and subglacial condition of surge-type glacier, "Canadian Journal of Earth Science”, 21, 2, 232-240.

Cohen E., Deecke W., 1892, Über Geschiebe aus Neu-Vorpommern und Rügen, „Mitteilungen aus dem naturwissenschaftlichen Verein für Neuvorpommern Rügen", 23, 1-84.

Cohen E., Deecke W., 1896, Über Geschiebe aus Neu-Vorpommern und Rügen, „Mitteilungen aus dem naturwissenschaftlichen Verein für Neuvorpommern Rügen", 28, 1-95.

Cohen D., Hooyer T.S., Iverson N.R., Thomason J.F., Jackson M., 2006, Role of transient water pressure in quarrying: a subglacial experiment using acoustic emissions, „Journal of Geophysical Research", 111, F03006, doi:10.1029/2005JF000439, $13 \mathrm{~s}$.

Colgan P.M., 2009, Glacial erratic, [w:] V. Gornitz (red.), Encyclopedia of Paleoclimatology and Ancient Environments, Springer, 354-354.

Cook S.J., Robinson Z.P., Fairchild I.J., Knight P.G., Waller R.I., Boomer I., 2010, Role of glaciohydraulic supercooling in the formation of stratified facies basal ice: Svínafellsjökull and Skaftafellsjökull, southeast Iceland, „Boreas”, 39, 24-38.

Cook S.J., Swift D.A., Graham D.J., Midgley N.G., 2011, Origin and significance of 'dispersed facies' basal ice: Svínafellsjökull, Iceland, „Journal of Glaciology”, 57 (204), 710-720.

Cook S.J., Waller R.I., Knight P.G., 2006, Glaciohydraulic supercooling: the process and its significance, „Progress in Physical Geography", 30, 577-588.

Cornish R., 1983, Glacial erosion in an ice-divide zone, "Nature”, 301 (5899), 413-415.

Cuffey K.M., Conway H., Gades A.M., Hallet B., Raymond C.F., 1999, Interfacial water in polar glaciers and glacier sliding at $-17^{\circ} \mathrm{C}$, "Geophysical Research Letters”, 26, 751-754.

Cuffey K.M., Conway H., Gades A.M., Hallet B., Lorrain R., Severinghaus J.P., Steig E.J., Vaughn B., White J.W.C., 2000a, Entrainment at cold glacier beds, "Geology”, 28, 4, 351-354.

Cuffey K.M., Conway H., Gades A.M., Hallet B., Raymond C.F., Whitlow S., 2000b, Deformation properties of subfreezing glacier ice: role of crystal size, chemical impurities, and rock particles inferred from in situ measurements, „Journal of Geophysical Research”, 105, B12, 27895-27915.

Cummings D.I., Kjarsgaard B.A., Russel H.A.J., Sharpe D.R., 2011, Eskers as mineral exploration tools, „Earth Science Reviews", 109, 32-43.

Cutler P.M., MacAyeal D.R., Mickelson D.M., Parizek B.R., Colgan P.M., 2000, A numerical investigation of ice-lobe-permafrost interaction around the southern Laurentide Ice Sheet, „Journal of Glaciology", 46, 311325.

Czirvinskij W.N., 1914, Materiały k poznaniu chimičeskogo i petrografičeskogo sostava lednikovych otłożenij Jugo-Zapadnoj Rossii w swiazi z voprosom o dviżenii lednikovogo pokrova, „Zapiski Kijevskogo Obszczestva Estestvoispytatielej", 24, 2 i 3, 119 s.

Czubla P., 1998, Skały fennoskandzkie w utworach czwartorzędu KWB „Bełchatów” i ich znaczenie stratygraficzne, [w:] III Seminarium: Geneza, litologia i stratygrafia utworów czwartorzędowych, Instytut Badań Czwartorzędu UAM, Poznań, 35-36.

Czubla P., 1999a, Eratyki fennoskandzkie w utworach czwartorzędowych Polski Środkowej i ich znaczenie stratygraficzne, Praca doktorska, Archiwum Wydziału Nauk Geograficznych Uniwersytetu Łódzkiego, Łódź, $227 \mathrm{~s}$.

Czubla P., 1999b, Badania głazowe jako narzędzie stratygraficzne na przykładzie utworów morenowych wschodniej Wielkopolski. VI Konferencja stratygrafii plejstocenu Polski „Czwartorzęd wschodniej części Kotliny Sandomierskiej", Czudec 1999, 14-18. 
Czubla P., 2001, Eratyki fennoskandzkie w utworach czwartorzędowych Polski Środkowej i ich znaczenie stratygraficzne, „Acta Geographica Lodziensia”, 80, 1-174.

Czubla P., 2006, The stratigraphic significance of Indicator Erratics Counts from Glacial Deposits - An Example from Eastern Wielkopolska (Great Poland Lowland), „Archiv für Geschiebekunde”, 5, 1-5 [Festband Gerd Lüttig], 177-190.

Czubla P., 2011, Pozycja stratygraficzna gliny odsłoniętej na lewym brzegu doliny Wisły $w$ Wiqgu $w$ świetle analizy eratyków przewodnich, [w:] J. Kordowski, P. Lamparski, K. Pochocka-Szwarc (red.), XVIII Konferencja Naukowo-Szkoleniowa Stratygrafia Plejstocenu Polski „Rozwój i zanik lq̨dolodu fazy pomorskiej zlodowacenia Wisty na Pomorzu Wschodnim (Kociewie)", Stara Kiszewa 5-9 września 2011, PIG-PIB, Warszawa, 24-25.

Czubla P., 2013a, Analiza frakcji >20 mm w glinie ze żwirowni w Mokrzeszowie, [w:] XX Konferencja Stratygrafia Plejstocenu Polski „Plejstocen przedpola Sudetów Środkowych”, Lasocin 2-6 września 2013, PIGPIB, Warszawa, 171-174.

Czubla P., 2013b, Analiza frakcji >20 mm w glinie ze żwirowni Siedlakowice 2 w Zachowicach, [w:] XX Konferencja Stratygrafia Plejstocenu Polski „Plejstocen przedpola Sudetów Środkowych”, Lasocin 2-6 września 2013, PIG-PIB, Warszawa, 220-223.

Czubla P., Forysiak J., 2003, Pozycja stratygraficzna utworów morenowych w odkrywce Smulsko (KWB Adamów) w świetle analiz petrograficznych, [w:] K. Kenig (red.), Konferencja "Cechy litologiczne plejstoceńskich glin morenowych źródłem informacji stratygraficznych i paleogeograficznych", 21-22 listopada 2003, Streszczenia referatów i posterów, Warszawa, 12-13.

Czubla P., Forysiak J., 2004, Pozycja stratygraficzna glin morenowych w odkrywce "Smulsko” (KWB Adamów) w świetle analiz petrograficznych, „Przegląd Geologiczny”, 52, 7, 574-578.

Czubla P., Forysiak J., 2006, Pozycja stratygraficzna gliny w Besiekierzu koło Łodzi w świetle analiz petrograficznych, [w:] W. Morawski (red.), XIII Konferencja Stratygrafia Plejstocenu Polski „Plejstocen południowej Warmii i zachodnich Mazur na tle struktur podłoża", Maróz 4-8 września 2006, Materiały konferencyjne, 50-52.

Czubla P., Forysiak J., 2013, Na czym stoi grodzisko w Tumie koło Łęczycy? - rezultaty badań petrograficznych na tle stratygrafii regionu, [w:] XX Konferencja Stratygrafia Plejstocenu Polski „Plejstocen przedpola Sudetów Środkowych", Lasocin 2-6 września 2013, PIG-PIB, Warszawa, 41-45.

Czubla P., Forysiak J., 2014, Petrograficzno-litologiczna charakterystyka utworów gliniastych podłoża grodziska w Tumie, [w:] P. Kittel, K. Ludwisiak, J. Twardy, I. Nowak (red.), VIII Sympozjum Archeologii Środowiskowej tódź-Łęczyca, 22-25 września 2014 roku „Naturalne i archeologiczno-historyczne uwarunkowania osadnictwa średniowiecznego". Środowisko i Kultura tom 10 - VIII Sympozjum Archeologii Środowiskowej, 140-143.

Czubla P., Forysiak J., Petera-Zganiacz J., 2008, Strefa brzeżna zastoiska koźmińskiego w świetle badań litostratygraficznych (odkrywka Koźmin, Kotlina Kolska), [w:] W. Rączkowski, M. Derkacz, J. Przasnyska (red.), XV Konferencja Stratygrafia Plejstocenu Polski „Plejstocen Tatr i Podhala - zlodowacenia tatrzańskie”, Zakopane 1-5 września 2008, Materiały konferencyjne, Warszawa, 29-30.

Czubla P., Forysiak J., Petera-Zganiacz J., 2010a, Lithological and petrographic features of tills in the Koźmin region and their value for stratigraphical interpretation of glacial Lake Koźmin deposits, Central Poland, "Geologija", 52, 1/4, 1-8.

Czubla P., Forysiak J., Petera-Zganiacz J., Grajoszek M., Wiśniewska M., 2013a, Charakterystyka litologiczno-petrograficzna osadów czwartorzędowych w dolinie Warty (stanowisko Koźmin Północ), „Przegląd Geologiczny", 61, 2, 120-126.

Czubla P., Forysiak J., Twardy J., 2013b, Diamicton in Besiekierz (Central Poland) - how to avoid ministerpretation of superposition in Quaternary geology, "Geological Quarterly”, 57, 4, 629-636.

Czubla P., Gałązka D., Górska M., 2006, Eratyki przewodnie w glinach morenowych Polski, „Przegląd Geologiczny", 54, 4, 352-362.

Czubla P., Godlewska A., Terpiłowski S., Zieliński T., Zieliński P., Kusiak J., Pidek I.A., Małek M., 2013c, Glacial till petrography of the South Podlasie Lowland (E Poland) and stratigraphy of the Middle Pleistocene 
Complex (MIS 11-6), [w:] A. Damušytè, A. Grigienè (red.), Palaeolandscapes from Saalian to Weichselian, South Eastern Lithuania. Abstracts of International Field Symposium. June 25-30, 2013, Vilnius-Trakai, Lithuania, 27-29.

Czubla P., Krzyszkowski D., 2013, Charakterystyka petrograficzna glin z wybranych stanowisk Dolnego Ślqska, [w:] XX Konferencja Stratygrafia Plejstocenu Polski „Plejstocen przedpola Sudetów Środkowych”, Lasocin 2-6 września 2013, PIG-PIB Warszawa, 27-32.

Czubla P., Sokołowski R., 2014, Zróżnicowanie petrograficzne różnowiekowych glin morenowych w zachodniej części strumienia lodowego Wisty, [w:] K. Pochocka-Szwarc (red.), XXI Konferencja Stratygrafia Plejstocenu Polski „Dynamika lqqdolodów plejstoceńskich na obszarze Sokólszczyzny i Równiny Augustowskiej”, Augustów, 1-5.09.2014 r., PIG-PIB Warszawa, 58-59.

Czubla P., Terpiłowski S., Godlewska A., 2010b, Koncepcje maksymalnego zasięgu lobu Bugu laqdolodu zlodowacenia warty a skład eratyków przewodnich najmłodszych glin lodowcowych, [w:] L. Marks, K. Pochocka-Szwarc (red.), XVII Konferencja Stratygrafia Plejstocenu Polski „Dynamika zaniku lqdolodu podczas fazy pomorskiej w północno-wschodniej części Pojezierza Mazurskiego", Jeziorowskie 6-10 września 2010, Materiały konferencyjne, Warszawa, 56-57.

Czubla P., Wachecka-Kotkowska L., 2009, Pozycja stratygraficzna glin lodowcowych w Masłowicach (Wyżyna Przedborska) w świetle badań petrograficznych, [w:] M. Żarski, S. Lisicki (red.), XVI Konferencja Stratygrafia Plejstocenu Polski "Strefa marginalna ladolodu zlodowacenia warty i pojezierza plejstoceńskie na południowym Podlasiu", Zimna Woda k. Łukowa 31 sierpnia - 4 września 2009, Materiały konferencyjne, Warszawa, 56-57.

Czubla P., Woźniak P.P., Wysiecka G., 2007a, Zapis kierunków transportu glacjalnego w litologii glin morenowych na pograniczu Pobrzeży Gdańskiego i Koszalińskiego, [w:] E. Smolska, D. Giriat (red.), Rekonstrukcja dynamiki procesów geomorfologicznych - formy rzeźby i osady, Warszawa, 105-116.

Czubla P., Woźniak P.P., Wysiecka G., 2007b, Zróżnicowanie składu petrograficznego glin morenowych na pograniczu Pobrzeży Gdańskiego i Koszalińskiego, [w:] P. Molewski, W. Wysota, P. Weckwerth (red.), XIV Konferencja Stratygrafia Plejstocenu Polski „Plejstocen Kujaw i dynamika lobu Wisły w czasie ostatniego zlodowacenia", Ciechocinek 3-7 września 2007, Materiały konferencyjne, Warszawa, 55-56.

Daigneault R.-A., 1990, Résultats préliminaires sur les directions d'écoulement glaciaire dans la région de Salluit et des lacs Nuvilik, Nouveau-Québec, „Geological Survey of Canada Paper”, 90-1C, 25-29.

Darmody R.G., Seppälä M., Thorn C.E., Li Y.K., Campbell S.W., Harbor J., 2007, Age and weathering status of granite tors in arctic Finland, "Landform Analysis”, 5, 16-17.

Davies M.T., Atkins C.B., Van Der Meer J.J., Barrett P.J., Hicock S.R., 2009, Evidence for cold-based glacial activity in the Allan Hills, Antarctica, "Quaternary Science Reviews", 28, 3124-3137.

Davis J.C., 2002, Statistics and Data Analysis in Geology (3rd ed.), John Wiley and Sons, $638 \mathrm{~s}$.

Davis P.T., Briner J.P., Coulthard R.D., Finkel R.W., Miller G.H., 2006, Preservation of Arctic landscapes overridden by cold-based ice sheets, "Quaternary Research", 65, 156-163.

De Angelis H., Kleman J., 2007, Palaeo-ice streams in the Foxe/Baffin sector of the Laurentide Ice Sheet, "Quaternary Science Reviews", 26, 1313-1331.

Denton G.H., Hughes T.J., 1981, The Last Great Ice Sheets, Wiley, New York, $484 \mathrm{~s}$.

DiLabio R.N.W., 1981, Glacial dispersal of rocks and minerals at the south end of Lac Mistassini, Quebec, with special reference to the Icon dispersal train, "Geological Survey of Canada Bulletin”, 323, $46 \mathrm{~s}$.

DiLabio R.N.W., 1990, Glacial dispersal trains, [w:] R. Kujansuu, M. Saarnisto (red.), Glacial Indicator Tracing, A.A. Balkema, Rotterdam/Brookfield, 109-122.

DiLabio R.N.W., Coker W.B. (red.), 1989, Drift Prospecting, „Geological Survey of Canada Paper”, 89-20, 169 s.

Dionne J.C., 1972, Caractéristiques des blocks erratiques des rives de l'estuaire du Saint-Laurent, „Revue de Géographie de Montréal", 26, 2, 125-152.

Dionne J.C., 1989, An Estimate of Shore Ice Action in a Spartina Tidal Marsh, St Lawrence Estuary, Quebec, Canada, „Journal of Coastal Research”, 5, 281-293. 
Dionne J.C., 1993, Sediment load of shore ice and ice rafting potential, upper St. Lawrence Estuary, Quebec, Canada, „Journal of Coastal Research", 9, 628-646.

Dionne J.C., 2003, Observations géomorphologiques sur les méga-blocs du secteur sud-est de la batture argileuse de la baie à l'Orignal, au parc du Bic, dans le Bas-Saint-Laurent (Québec), „Géographie physique et Quaternaire", 57, 1, 95-101.

Dionne J.C., 2009, Aspects géomorphologiques de la batture à blocs entre Sainte-Luce-sur-Mer et Sainte-Flavie, côte sud de l'estuaire maritime du Saint-Laurent, „Bulletin de recherché”, 185, $47 \mathrm{~s}$.

Donner J., 1989, Transport distances of Finnish crystalline erratics during the Weichselian glaciations, [w:] M. Perttunen (red.), Transport of glacial drift in Finnland, "Geological Survey of Finland Special Paper”, 7, 7-13.

Dowdeswell J.A., 1986, The distribution and character of sediments in a tidewater glacier, southern Baffin Island, NWT, Canada, „Arctic and Alpine Research”, 18, 45-56.

Dowdeswell J.A., Evans J., Ó Cofaigh C., Andersen B.G., 2006, Morphology and sedimentary processes on the continental slope off Pine Island Bay, Amundsen Sea, West Antarctica, "Geological Society of America Bulletin", 118, 5-6, 606-619.

Drake L.D., 1972, Mechanisms of clast attrition in basal till, "Geological Society of America Bulletin", 83, 2159-2166.

Dreimanis A., 1976, Tills: their origin and properties, [w:] R. F. Legget (red.), Glacial Till, „The Royal Society of Canada Special Publication", 12, 11-49.

Dreimanis A., 1990, Formation, deposition and identification of subglacial and supraglacial till, [w:] R. Kujansuu, M. Saarnisto, (red.), Glacial Indicator Tracing, Rotterdam, Brookfield, Balkema, 35-59.

Dreimanis A., Vagners U.J., 1969, Lithologic relation of till to bedrock, [w:] H.E. Wright Jr. (red.), Quaternary geology and climate, "National Academy of Science Publication”, 1701, 93-98.

Dreimanis A., Vagners U.J., 1971, Bimodal distribution of rock and mineral fragments in basal tills, [w:] R.P. Goldthwait (red.), Till - a Symposium, Ohio St. Univ. Press, Columbus, 237-250.

Drewry D.J., 1986, Glacial Geologic Processes. Edward Arnold Publishers, London, 276 s.

Dudziak J., 1970, Studia nad kierunkami transgresji lqqdolodu plejstoceńskiego, „Prace Geologiczne Komitetu Nauk Geologicznych PAN w Krakowie", 66, 7-92.

Dudziak J., 1973, Badania składu głazowego moren zlodowacenia południowopolskiego, „Kwartalnik Geologiczny" 17, 4, 787-802.

Dudziak J., 1974, Zależność składu głazowego od frakcji w osadach glacjalnych zlodowacenia południowopolskiego, „Rocznik Polskiego Towarzystwa Geologicznego”, 44, 4, 577-591.

Dudziak J., 1978, Der Geschiebeinhalt von Glazialablagerungen im Vorland der Westkarpaten, „Zeitschrift für Geologische Wissenschaften", 6, 10, 1245-1250.

Dudziak J., 1980, Geschiebeführung der Elster-Vereisung mit verschiedenen Methoden geprüft, „Der Geschiebesammler", 13, 3/4, 139-145.

Dudziak J., 1985, Die Abhängigkeit der Geschiebeführung von der Korngrösse in den Glazialablagerungen im Vorland der Westkarpaten, „Der Geschiebesammler”, 19, 1, 31-36.

Dühnforth M., Anderson R.S., Ward D., Stock G., 2010, Bedrock fracture control of glacial erosion processes and rates, Geology, 38, 423-426.

Dyke A.S., 1993, Landscapes of cold-centered late Wisconsinan ice caps, Arctic Canada, „Progress in Physical Geography", 17, 223-247.

Dyke A.S., 2008, The Steensby Inlet Ice Stream in the context of the deglaciation of Northern Baffin Island, Eastern Arctic Canada, „Earth Surface Processes and Landforms”, 33, 4, 573-592.

Dyke A.S., Morris T.F., 1988, Drumlin fields, dispersal trains, and ice streams in Arctic Canada, "Canadian Geographer", 32, 86-90.

Dyke A.S., Morris T.F., Green D.E.C., England J.H., 1992, Quaternary geology of Prince of Wales Island, central Canadian Arctic, „Geological Survey of Canada, Memoir”, 433, 1-142. 
Dyke A.S., Prest V.K., 1987, Late Wisconsinan and Holocene history of the Laurentide Ice Sheet, "Geographie Physique et Quaternaire", 41, 237-263.

Echelmeyer K., Wang Z., 1987, Direct observation of basal sliding and deformation of basal drift at subfreezing temperatures, „Journal of Glaciology”, 33 (113), 83-98.

Echelmeyer K.A., Clarke T.S., Harrison W.D., 1991, Surficial glaciology of Jakobshavn Isbrae, West Greenland: part 1. Surface morphology, „Journal of Glaciology”, 37, 368-382.

Egholm D.L., Pedersen V.K., Knudsen M.F., Larsen N.K., 2012, Coupling the flow of ice, water, and sediment in a glacial landscape evolution model, "Geomorphology”, 141-142, 47-66.

Ehlers J., 1979, Fine gravel analysis after the Dutch method as tested out on Ristinge Klint, Denmark, „Bulletin of the Geological Society of Denmark", 27, 157-165.

Ehlers J., 1981, Problems of the Saalian Stratigraphy in the Hamburg area, „Mededelingen Rijsk Geologische Dienst", 34, 5, 26-29.

Ehlers J., 1983, Different till types in North Germany and their origin, [w:] E.B. Evenson, Ch. Schlüchter, J. Rabassa (red.), Tills and related deposits, A.A. Balkema, Rotterdam, 61-80.

Ehlers J., 1988, Skandinavische Geschiebe in Großbritannien, Der Geschiebesammler, 22, 2, 49-64.

Ehlers J., 1990a, Reconstructing the dynamics of the North-West European Pleistocene Ice-Sheet, "Quaternary Science Reviews", 9, 71-83.

Ehlers J., 1990b, Untersuchungen zur Morphodynamik der Vereisungen Norddeutschlands unter Berücksichtigung benachbarter Gebiete, „Bremer Beiträge zur Geographie und Raumplanung”, 19, 1-166.

Ehlers J., 1992, Origin and distribution of red tills in North Germany, „Sveriges geologiska Undersökning”, Ser. $\mathrm{Ca}, 81,97-105$.

Ehlers J., 2011, Das Eiszeitalter, Spektrum Akademischer Verlag (Springer), Heidelberg, $363 \mathrm{~s}$.

Ehlers J., Gibbard P.L., Hughes P.D. (red.), 2011, Quaternary Glaciations - Extent and Chronology. A Closer Look, Elsevier, Amsterdam, $1108 \mathrm{~s}$.

Ehlers J., Meyer K.-D., Stephan H.-J., 1984, The pre-Weichselian glaciations of North-West Europe, „Quaternary Science Reviews", 3, 1-40.

Ehlers J., Stephan H.J., 1983, Till fabric and ice movement, [w:] J. Ehlers (red.), Glacial deposits in North-West Europe, A.A. Balkema, Rotterdam, 267-274.

Elson J.A., 1989, Comment on glaciotectonite, deformation till, and comminution till, [w:] R.P. Goldthwait, C.L. Matsch (red.), Genetic Classification of Glacigenic Deposits, Balkema, Rotterdam, 85-88.

Elverhøi A., Hooke R., Le B., Solheim A., 1998, Late Cenozoic erosion and sediment yield from the Svalbard-Barents Sea region: implications for understanding erosion of glacierised basins, „Quaternary Science Reviews", 17, 209-241.

Embleton C., King C.A.M., 1975, Glacial geomorphology, Edward Arnold, London, $573 \mathrm{s.}$

Embleton C., Thornes J. (red.), 1985, Geomorfologia dynamiczna, PWN, Warszawa, $479 \mathrm{~s}$.

Emelyanov E.V., Kharin G.S., 1988, Geological map of eastern and southern Baltic Sea, [w:] B. Winterhalter (red.), The Baltic Sea, „Geological Survey of Finland Special Paper”, 6, 59-67.

Engelhardt H., Kamb B., 2013, Kamb Ice Stream flow history and surge potential, „Annals of Glaciology”, 54, 63, 287-298.

Eriksson K., 1983, Till investigations and mineral prospecting, [w:] J. Ehlers (red.), Glacial Deposits in North-West Europe, Rotterdam, Balkema, 107-113.

Eskola P., 1927, Petrographische Charakteristik der kristallinen Gesteine von Finnland, „Fortschritte der Mineralogie, Kristallographie und Petrographie", 11, 1, 57-112.

Eskola P., 1933, Tausend Geschiebe aus Lettland, „Annales Academiae Scientiarum Fennicae”, (A) 39, 5, 1-41.

Eskola P., 1934, Über die Bottenmeerporphyre, „Bulletin de la Commission Géologique de Finlande”, 104, 111-127. 
Evans D.J.A., Clark C.D., Rea B.R., 2008, Landform and sediment imprints of fast glacier flow in the southwest Laurentide Ice Sheet, „Journal of Quaternary Science”, 23, 249-272.

Evans D.J.A., Hiemstra J.F., Boston C.M., Leighton I., Ó Cofaigh C., Rea B.R., 2012, Till stratigraphy and sedimentology at the margins of terrestrially terminating ice streams: case study of the western Canadian prairies and high plains, „Quaternary Science Reviews”, 46, 80-125.

Evans D.J.A., Lemmen D.S., Rea B.R., 1999, Glacial landsystems of the southwest Laurentide Ice Sheet: modern Icelandic analogues, „Journal of Quaternary Science”, 14, 673-679.

Evans D.J.A., Rea B.R., 1999, Geomorphology and sedimentology of surging glaciers: a landsystems approach, „Annals of Glaciology", 28, 75-82.

Evans D.J.A., Rea B.R., 2003, Surging glacier landsystem, [w:] D.J.A. Evans (red.), Glacial Landsystems, Arnold, London, 259-288.

Evans D.J.A., Rea B.R., Hiemstra J.F., Ó Cofaigh C., 2006, A critical assessment of subglacial mega-floods: a case study of glacial sediments and landforms in south-central Alberta, Canada, „Quaternary Science Reviews", 25, 1638-1667.

Eyles N., 2006, The role of meltwater in glacial processes, „Sedimentary Geology”, 190, 257-268.

Fabel D., Fink D., Fredin O., Harbor J., Land M., Stroeven A.P., 2006, Exposure ages from relict lateral moraines overridden by the Fennoscandian ice sheet, "Quaternary Research", 65, 136-146.

Fabel D., Stroeven A.P., Harbor J., Kleman J., Elmore D., Fink D., 2002, Landscape preservation under Fennoscandian ice sheets determined from in situ produced ${ }^{10} \mathrm{Be}$ and ${ }^{26} \mathrm{Al}$, „Earth and Planetary Science Letters", 201, 397-406.

Fettes D., Desmons J. (red.), 2007, Metamorphic Rocks: A Classification and Glossary of Terms, Cambridge University Press, Cambridge, $256 \mathrm{~s}$.

Finck P.W., Stea R.R., 1995, The compositional development of tills overlying the South Mountain Batholith, Nova Scotia, Nova Scotia Department of Natural Resources, Mines and Energy Branches, Paper 95-1, 52s.

Fischer U.H., Clarke G.K.C., 1997, Stick-slip sliding behavior at the base of a glacier, „Annals of Glaciology”, 24, 390-396.

Fitzsimons S.J., 1990, Ice-marginal depositional processes in a polar maritime environment, Vestfold Hills, Antarctica, „Journal of Glaciology”, 36 (124), 279-286.

Flint R.F. 1971, Glacial and Quaternary geology, Wiley and Sons, New York, 892 s.

Flodén T., 1973, De jotniska sediment-bergarternas utbredning i Östersjön, Ymer Årsbock, 93, 47-58.

Flodén T., 1984, Der Strukturbau im Seegebiet von Schweden, „Zeitschrift für angewandte Geologie”, 30, 1, 2-16.

Förster L., 2006, Impaktgeschiebe aus Ostholstein, „Archiv für Geschiebekunde”, 5, 1-5, 109-112.

Forström P.-L., Sallasmaa O., Greve R., Zwinger T., 2003, Simulation of fast-flow features of the Fennoscandian ice sheet during the Last Glacial Maximum, „Annals of Glaciology”, 37, 383-389.

Franke W.A., 2009, The durability of rocks - developing a test of rock resistance to chemical weathering, „American Journal of Science”, 309, 711-730.

Fredén C. (red.), 1994, National Atlas of Sweden, Geology, Almqvist and Wiksell International, Stockholm, 208s.

Fredin 0., 2002, Glacial inception and Quaternary mountain glaciations in Fennoscandia, "Quaternary International", 95-96, 99-112.

Fredin O., Hättestrand C., 2002, Relict lateral moraines in northern Sweden - evidence for an early mountain centred ice sheet, "Sedimentary Geology”, 149, 145-156.

Fricker H.A., Scambos T., Bindschadler R., Padman L., 2007, An active subglacial water system in West Antarctica mapped from space, „Science”, 315, 1544-1548.

Fu P., Harbor J., 2011, Glacial erosion, [w:] V.P. Singh, P. Singh, U.K. Haritashya (red.), Encyclopedia of Snow, Ice and Glaciers, Springer, 332-341. 
Fuchs M., Owen L.A., 2008, Luminescence dating of glacial and associated sediments: review, recommendations and future directions, „Boreas”, 37, 636-659.

Gába Z., 1974a, Rhombenporphyr und Prickgranit als Geschiebe im Tschechoslowakischen Schlesien, „Der Geschiebesammler", 9, 1, 29-30.

Gába Z., 1974b, Rombový porfyr jako souvek z Žulové ve Slezsku, „Zprávy Vlastivedného ústavu Olomouci”, $167,5-9$.

Gába Z., 1977, Petrografie ledovcových souvku Jesenické oblasti ve Slezsku, „Práce Odboru Prírodních Ved Vlastivedného Ústavu v Olomouci", 30, $39 \mathrm{~s}$.

Gába Z., 2001, Głazy narzutowe rejonu Jesenika i Osoblahy (Republika Czeska), [w:] J. Badura, B. Przybylski (red.), VIII Konferencja Stratygrafia Plejstocenu Polski „Serie rzeczne i lodowcowe południowej Opolszczyzny", PIG Oddział Dolnośląski, Wrocław, 40-41.

Gába Z., 2006, Västervik-Quarzit als Geschiebe in der Tschechischen Republik, „Archiv für Geschiebekunde”, 5, 1-5 [Festschrift Gerd Lüttig], 113-118.

Gába Z., Matyásek J., 1997, Rhombenporphyr-Geschiebe in der Tschechischen Republik, „Geschiebekunde aktuell", 13, 4, 123-125.

Gagel C., Korn J., 1918, Der Geschiebeinhalt des wolhynischen Diluviums, „Zeitschrift der Deutschen Geologischen Gesellschaft", 70, 83-94.

Gaigalas A., 1971a, Alandskije ostrova, [w:] V. Gudelis (red.), Kristalličeskije rukovodiaščije vałuny Pribaltiki, Izd. Mintis, Vilnius, 41-43.

Gaigalas A., 1971b, Klassifikacija kristalličeskich rukovodiaščich vałunov i niekotoryje woprosy metodiki ich izučenija, [w:] V. Gudelis (red.), Kristalličeskije rukovodiaščije vałuny Pribaltiki, Izd. Mintis, Vilnius, 22-27.

Gaigalas A., Gudelis V., 1965, Erratičeskije vałuny stadialnych obrazovanij posledniego oledienienija jużnoj Pribaltiki i dinamika lednikovogo pokrova, „Baltica”, 2, 213-232.

Gałązka D., 2004a, Badania eratyków przewodnich z glin zwałowych w sq̨siedztwie strefy miedzylobowej, rejon Iławy (północna Polska), [w:] A. Ber, Z. Krysiak, S. Lisicki (red.), XI Konferencja Stratygrafia plejstocenu Polski „Zlodowacenia i interglacjały wschodniej Polski. Problemy plejstocenu Wysoczyzny Białostockiej", PIG, Warszawa, 37-39.

Gałązka D., 2004b, Zastosowanie makroskopowych badań eratyków do określenia stratygrafii glin lodowcowych środkowej i północnej Polski (maszynopis niepublikowanej rozprawy doktorskiej), Archiwum Wydziału Geologii Uniwersytetu Warszawskiego, $255 \mathrm{s.}$

Gałązka D., Małek M., Maleszyk M., 2009, Sytuacja geologiczna i pochodzenie łukowskich kier jurajskich, [w:] M. Żarski, S. Lisicki (red.), XVI Konferencja Stratygrafia plejstocenu Polski „Strefa marginalna lądolodu zlodowacenia warty i pojezierza plejstoceńskie na południowym Podlasiu", PIG-PIB, Warszawa, 60-63.

Gałązka D., Marks L., Morawski W., 2006, Maksymalny zasięg lqadolodu zlodowacenia wisły w południowo-zachodniej części Mazur, [w:] W. Morawski (red.), XIII Konferencja Stratygrafia plejstocenu Polski „Plejstocen południowej Warmii i zachodnich Mazur na tle struktur podłoża", PIG, Warszawa, 14-19.

Gałązka D., Zabielski R., 2004, Eksperymentalne wyniki badań petrograficznych w odkrywkach kopalni wegla brunatnego w rejonie Konina, [w:] A. Ber, Z. Krysiak, S. Lisicki (red.), XI Konferencja Stratygrafia plejstocenu Polski "Zlodowacenia i interglacjały wschodniej Polski. Problemy plejstocenu Wysoczyzny Białostockiej", PIG, Warszawa, 88-89.

Gauger W., 1980, Sedimentpetrographische Untersuchung (Kiesanalyse) flintartefakt-haltiger Schotter bei Lübbow (s. Lüchow) und ihre Einstufung in die Pleistozän Stratigraphie, „Der Geschiebesammler”, 13, 3/4, 115-138.

Gauger W., Meyer K.-D., 1970, Ostbaltische Geschiebe (Dolomite, Old Red-Sandsteine) im Gebiet zwischen Lüneburg und Uelzen, „Der Geschiebesammler”, 5, 1, 1-12.

Geary R.C., 1947, Testing for normality, „Biometrika”, 34, 3/4, 209-242.

Gehl O., 1965, Gesetzmäßigkeiten in der Verbreitung der Schollen im Jungpleistozänen Mecklenburgs, „Geologie", 14, 5-6, 663-676. 
Geisler T., 1996, Die permokarbonischen Dolerite in Schonen: petrographische und petrochemische Charakterisierung und ihre Bedeutung als Leitgeschiebe, „Archiv für Geschiebekunde”, 2, 2, 105-117.

Geisler T., 1999, A 32 bit Windows program for the analysis and presentation of indicator counts by the Circle Map Method, „Archiv für Geschiebekunde”, 2, 8, 597-600.

Gibbard P.L., 1988, The history of the great north-west European rivers during the past three million years, „Philosophical Transactions of the Royal Society of London”, B 318, 559-602.

Gibbard P.L., West R.G., Zagwijn W.H., Balson P.S., Burger A.W., Funnell B.M., Jeffrey D.H., de Jong J., van Kolfschoten T., Lister A.M., Meijer T., Norton P.E.P., Preece R.C., Rose J., Stuart A.J.,Whiteman C.A., Zalasiewicz J.A., 1991, Early and Early Middle Pleistocene correlations in the southern North Sea Basin, "Quaternary Science Reviews", 10, 23-52.

Gillberg G., 1965, Till distribution and ice movements on the northern slopes of the south Swedish highlands, "Geologiska Föreningens i Stockholm Förhandlingar", 86, 433-484.

Gillberg G., 1967, Further discussion of the lithological homogeneity of till, „Geologiska Föreningens i Stockholm Förhandlingar", 89, 22-49.

Gjessing J., 1965, On „plastic scouring” and „subglacial erosion”, „Norsk Geografisk Tidsskrift”, 20, 1-2, 1-37.

Glasser N.F., 1995, Modelling the effect of topography on ice sheet erosion, Scotland, „Geografiska Annaler”, 77A, 67-82.

Glasser N.F., Crawford K.R., Hambrey M.J., Bennett M.R., Huddart D., 1998, Lithological and structural controls on the surface wear characteristics of glaciated metamorphic bedrock surfaces: Ossian Sarsfjellet, Svalbard, „Journal of Geology”, 106, 319-330.

Glasser N.F., Ghiglione M.C., 2009, Structural, tectonic and glaciological controls on the evolution of fjord landscapes, "Geomorphology”, 105, 291-302.

Goldthwait R.P., 1951, Development of end moraines in east-central Baffin Island, „Journal of Geology", 59, 567-577.

Golledge N.R., Stoker M.S., 2006, A palaeo-ice stream of the British Ice Sheet in eastern Scotland, „Boreas”, $35,231-243$.

Goodman D.J., King G.C.P., Millar D.H.M., Robin G. de Q., 1979, Pressure-melting effects in basal ice of temperate glaciers: laboratory studies and field observations under Glacier d'Argentiére, „Journal of Glaciology", 23, 259-271.

Goodsell B., Hambrey M.J., Glasser N.F., 2002, Formation of band ogives and associated structures at Bas Glacier dArolla, Valais, Switzerland, „Journal of Glaciology”, 48 (161), 287-300.

Gore D.B., Snape I., Leishman M.R., 2003, Glacial sediment provenance, dispersal and deposition, Vestfold Hills, East Antarctica, „Antarctic Science”, 15, 2, 259-269.

Gottsche C., 1883, Die Sedimentaer-Geschiebe der Provinz Schleswig-Holstein, Yokohama, 66 s. (Reprint: „Der Geschiebesammler", 1, 1, 21-44, 1966; 1, 2, 25-44, 1966; 1, 3/4, 43-70, 1967; 2, 1, 35-41, 1967).

Gow A.J., Epstein S., Sheehy W., 1979, On the origin of stratified debris in ice cores from the bottom of the Antarctic ice sheet, „Journal of Glaciology”, 23, 185-192.

Goździk J., 1980, Zastosowanie morfoskopii i graniformametrii do badań osadów w kopalni węgla brunatnego "Betchatów”, „Studia Regionalne”, tódź, 4, 9, 101-114.

Goździk J., 1986, Czwartorzęd w rejonie kopalni węgla brunatnego „Bełchatów”, [w:] Przewodnik wycieczek II Zjazdu Geografów Polskich, 11-13 września 1986, Łódź, 109-114.

Górska M., 2000, Wybrane właściwości petrograficzne vistuliańskich moren dennych środkowej i zachodniej Wielkopolski oraz ich znaczenia dla oceny dynamiki ostatniego lqdolodu, „Prace Komisji Geograficzno-Geologicznej Poznańskiego Towarzystwa Przyjaciół Nauk", 26, 145 s.

Górska M., 2003a, Analiza petrograficzna narzutniaków skandynawskich, [w:] M. Harasimiuk, S. Trepiłowski (red.), Analizy sedymentologiczne osadów glacigenicznych, Wyd. UMCS, Lublin, 23-31.

Górska M., 2003b, Nowe znalezisko porfiru rombowego z Oslo na terenie północno-zachodniej Polski, „Przegląd Geologiczny", 51, 7, 580-585. 
Górska M., 2006, Fennoscandian erratics in glacial deposits of the Polish lowland - methodical aspects, „Studia Quaternaria", 23, 11-15.

Górska M., Zabielski R., 2006, Petrographic characteristic of fluvioglacial deposits of the Odra lobe, Poland: a statistical analysis, „Geological Quaterly”, 50, 2, 239-246.

Górska-Zabielska M., 2007a, Narzutniaki skandynawskie - metodyka i interpretacja, [w:] E. Mycielska-Dowgiałło, J. Rutkowski (red.), Badania cech teksturalnych osadów czwartorzędowych i wybrane metody oznaczania ich wieku, Wydawnictwo Szkoły Wyższej Przymierza Rodzin, Warszawa, 75-82.

Górska-Zabielska M., 2007b, Narzutniaki skandynawskie osadów lodowcowych Pojezierza Meklemburskiego, [w:] P. Molewski, W. Wysota, P. Weckwerth (red.), XIV Konferencja Stratygrafia Plejstocenu Polski „Plejstocen Kujaw i dynamika lobu Wisły w czasie ostatniego zlodowacenia", Ciechocinek 3-7 września 2007, Materiały konferencyjne, 57-59.

Górska-Zabielska M., 2008, Fennoskandzkie obszary alimentacyjne osadów akumulacji glacjalnej i glacjofluwialnej lobu Odry, Wydawnictwo Naukowe UAM, Poznań, Geografia, 78, 330 s.

Górska-Zabielska M., 2010, Analiza petrograficzna osadów glacjalnych - zarys problematyki, „Landform Analysis", 12, 49-70.

Górska-Zabielska M., Zabielski R., 2011, Kleinkieszählungen und Leitgeschiebe des Oderlobus, „Zeitschrift für Geomorphologie", 55, 4, 493-513.

Górska-Zabielska M., Wachecka-Kotkowska L., 2014, Petrographical analysis of Warthian fluvioglacial gravels as a tool to trace the source area - a case study from central Poland, "Geologos”, 20, 3, 183-199.

Graham A.G.C., Lonergan L., Stoker M.S., 2007, Evidence for Late Pleistocene ice stream activity in the Witch Ground Basin, central North Sea, from 3D seismic reflection data, „Quaternary Science Reviews”, 26, 627-643.

Gravenor C.P., 1975, Erosion by continental ice sheets, „American Journal of Science”, 275, 594-604.

Graversen O., 2004, Upper Triassic - Cretaceous stratigraphy and structural inversion offshore SW Bornholm, Tornquist Zone, Denmark, „Bulletin of the Geological Society of Denmark”, 51, 111-136.

Graversen O., 2009, Structural analysis of superposed fault systems of the Bornholm horst block, Tornquist Zone, Denmark, „Bulletin of the Geological Society of Denmark”, 57, 25-49.

Greenwood S.L., Clark C.D., 2009, Reconstructing the last Irish Ice Sheet 2: a geomorphologically-driven model of ice sheet growth, retreat and dynamics, "Quaternary Science Reviews”, 28, 3101-3123.

Groetzner J.-P., 1972, Geschiebeführung und Stratigraphie saaleeiszeitlicher Ablagerungen (Pleistozän) im Südwestteil des Uelzener Beckens (Nordost-Niedersachsen), „Mitteilungen aus dem Geologischen Institut der Technischen Universität Hannover", 11, 1-75.

Gross D.L., Moran S.R., 1971, Grain-size and mineralogical gradation within tills of the Allegheny Plateau, [w:] R.P. Goldthwait (red.), Till a Symposium, Ohio State Univ. Press, 251-274.

Grube F., 1979, Zur Morphogenese und Sedimentation im quartaren Vereisungsgebiet Norddeutschlands, „Verhandlungen des Naturwissenschaftlichen Vereins in Hamburg”, NF, 23, 69-80.

Gry H., 1932, Undersøgelser over Ledeblokke i Skaane , „Meddelelserfra Dansk GeologiskForening”, 8, 143-166. Gry H., 1974, Ledeblokkes Kornstørrelsesforhold og Transportmåde, „Dansk Geologisk Forening, Årsskrift” (for 1973), 140-151.

Gudelis V. (red.), 1971, Rukovodiašcije kristalliceskije vałuny Pribaltiki, Izd. Mintis, Vilnius, $132 \mathrm{s.}$

Gudmundsson G.H., 2007, Tides and the flow of Rutford Ice Stream. West Antarctica, „Journal of Geophysical Research", 112, F04007.

Guilford J.P., 1964, Podstawowe metody statystyczne w psychologii i pedagogice, PWN, Warszawa, 570 s.

Guilford J.P., 1965, Fundamental Statistics in Psychology and Education, McGraw-Hill, New York, 605 s.

Gurski B.M., Astapova S.D., Zuś M. J. (red.), 1993, Ledavikovyja vałuny Biełarusi, Navuka i Technika, Mińsk, $159 \mathrm{~s}$. 
Gustavson T.C., Boothroyd J.C., 1982, Subglacial fluvial erosion: a major source of stratified drift, Malaspina Glacier, Alaska, [w:] R. Davidson-Arnott, W. Nickling, B.D. Fahey (red.), Research in Glacial, Glacio-fluvial and Glaciolacustrine Systems, Geo Books, Norwich, 93-116.

Guyader J., 1977, Blocs erratiques dans le quaternaire de la baie de Seine, „Bulletin de la Société Géologique de Normandie et de Amis du Muséum du Havre - Trimestrielle", 64, 4, 35-37.

Haberlah D., Strong C., Pirrie D., Rollinson G.K., Gottlieb P., Botha P.PWSK, Butcher A.R., 2011, Automated petrography applications in quaternary science, "Quaternary Australasia", 28, 2, 3-12.

Hagen J.O., Wold B., Liestøl O., Østrem G., Sollid J.L., 1983, Subglacial processes at Bondhusbreen, Norway: Preliminary results, „Annals of Glaciology”, 4, 91-98.

Haldorsen S., 1977, The petrography of tills - a study from Ringsaker, south-eastern Norway, „Norges geologiske undersøkelse", 336, 1-36.

Haldorsen S., 1981, Grain-size distribution of subglacial till and its relation to glacial crushing and abrasion, „Boreas”, 10, 91-105.

Halicka A., 1986, Zarys petrografii moren Wileńszczyzny, „Prace Muzeum Ziemi”, 38, 13-45.

Hall A.M., Sugden D.E., 1987, Limited modification of mid-latitude landscapes by ice-sheets: the case of northeast Scotland, „Earth Surface Processes and Landforms", 12, 531-542.

Hall R.D., 1983, The influence of till petrology on wethering of moraines in southwestern Montana and northwestern Wyoming, [w:] E.B. Evenson, Ch. Schlüchter, J. Rabassa (red.), Tills and related deposits, A.A. Balkema, Rotterdam, 127-139.

Hallet B., 1975, Subglacial silica deposits, „Nature”, 254, 682-683.

Hallet B., 1979, A theoretical model of glacial abrasion, „Journal of Glaciology”, 23, 39-50.

Hallet B., 1981, Glacial abrasion and sliding: Their dependance on the debris concentration in basal ice, „Annals of Glaciology”, 2, 23-28.

Hallet B., 1996, Glacial quarrying: a simple theoretical model, „Annals of Glaciology”, 22, 1-8.

Hallet B., Hunter L., Bogen J., 1996, Rates of erosion and sediment yield by glaciers: a review of field data and their implications, "Global and Planetary Change", 12, 213-235.

Hambrey M.J., Glasser N.F., 2012, Discriminating glacier thermal and dynamic regimes in the sedimentary record, "Sedimentary Geology”, 251-252, 1-33.

Hanáček M., Nývlt D., 2009, Subglaciální štěrkovité tilly u Jindřichova na Osoblažsku, „Časopis Slezskégo musea v Opavě" (A), 58, 193-214.

Hänel R., Staroste E. (red.), 1988, Atlas of Geothermal Resources in the European Community, Austria and Switzerland, Publishing company Th. Schaefer, Hannover, Germany, $110 \mathrm{~s}$.

Harbor J., Warburton J., 1992, Glaciation and denudation rates, „Nature”, 356, 751.

Harff J., Björck S., Hoth P. (red.), 2011, The Baltic Sea Basin, Central and Eastern European Development Studies, Springer Verlag, Berlin, Heidelberg, $449 \mathrm{~s}$.

Harrison W., 1960, Original bedrock composition of Wisconsin till in central Indiana, „Journal of Sedimentary Petrology", 30, 3, 432-446.

Hart J.K., 1995, An investigation of the deforming layer/debris-rich basal ice continuum, illustrated from three Alaskan glaciers, „Journal of Glaciology”, 41 (139), 619-633.

Hart J.K., 1998, The deforming bed debris-rich basal ice continuum and its implications for the formation of glacial landforms (flutes) and sediments (melt-out till), "Quaternary Science Reviews", 17, 8, 737-754.

Hart J.K., Rose J. (red.), 2001, Glacier deforming-bed processes, „Quaternary International”, 86, 1-150.

Hättestrand C., Kleman J., 1999, Ribbed moraine formation, "Quaternary Science Reviews”, 18, 43-61.

Hättestrand C., Stroeven A.P., 2002, A relict landscape in the centre of Fennoscandian glaciation: geomorphological evidence of minimal Quaternary glacial erosion, "Geomorphology”, 44, 127-143. 
Hausen H., 1912, Studier öfver de sydfinska ledblockens spredning i Ryssland, jämte en öfversikt af is-recessionens förlopp i Ostbaltikum, Preliminärd meddelande, „Bulletin de la Commission géologique de Finlande”, 32, 1-32, (artykuł powtórzony w: „Fennia, Societas Geographica Fenniae”, 32, 3, 1-32).

Hausen H., 1913, Über die Entwicklung der Oberflächenformen in den russischen Ostseeländern und angrenzenden Gouvernements in der Quartärzeit, „Fennia, Societas Geographica Fenniae”, 34 (1913/14), 3, $1-142$.

Hausen H., 1921, Data amgående förekomsten av fennoskandiska ledblock i Osteuropas kvartära aflagringar, jämte några drag av Rysslands kvartära geomorfologi; reseberättelse, „Fennia, Societas Geographica Fenniae", 42, 8, 1-34.

Hawkes L., 1951, The Erratics of the English Chalk, „Proceedings of the Geologists' Association”, 62, 4,257-268.

Heine J.T., McTigue D.F., 1996, A case of cold-based continental ice sheets - a transient thermal model, „Journal of Glaciology”, 42, 37-42.

Hellaakoski A., 1931, On the transportation of materials in the esker of Laitila, „Fennia”, 52, 282-311.

Herman F., Beaud F., Champagnac J.D., Lemieux J.M., Sternai P., 2011, Glacial hydrology and erosion patterns: a mechanism for carving glacial valleys, „Earth and Planetary Science Letters”, 310, 498-508.

Herron S., Langway C.C.Jr., 1979, The debris-laden ice at the bottom of the Greenland ice sheet, „Journal of Glaciology", 23, 193-207.

Hesemann J., 1930, Wie sammelt und verwertet man kristalline Geschiebe?, „Sitzungsberichte des Geologischen Landesamt", Berlin, 188-196.

Hesemann J., 1931a, Das Glazialdiluvium Dänemarks, Hollands und Norddeutschlands vom geschiebekundlichen Standpunkt aus, "Geologische Rundschau”, 22, 145-155.

Hesemann J., 1931b, Quantitative Geschiebebestimmungen im norddeutschen Diluvium, „Jahrbuch der Preußischen Geologischen Landesanstalt", N. F., 51 (za 1930r.), 714-758.

Hesemann J., 1932, Die bisherigen Geschiebezählungen aus dem norddeutschen Diluvium im Diagramm, „Zeitschrift für Geschiebeforschung”, 8, 164-175.

Hesemann J., 1933a, Über die Bedeutung von Korngröße, Verwitterung und Art der Ablagerung für die Geschiebeführung, „Zeitschrift für Geschiebeforschung”, 9, 1-6.

Hesemann J., 1933b, Zur Geschiebeführung und Geologie des Odergletschers. 1. Äußere, Rosenthaler und Velgaster Randlage, „Jahrbuch der Preußischen Geologischen Landesanstalt”, N. F., 53, 70-84.

Hesemann J., 1934, Ergebnisse und Aussichten einiger Methoden zur Feststellung der Verteilung kristalliner Leitgeschiebe, „Jahrbuch der Preußischen Geologischen Landesanstalt”, N. F., 55, 1-27.

Hesemann J., 1935, Neue Ergebnisse der Geschiebeforschung im norddeutschen Diluvium (kristalline Geschiebe), ",Geologische Rundschau”, 26, 186-198.

Hesemann J., 1936, Zur Petrographie einiger nordischen kristallinen Leitgeschiebe, „Abhandlungen der Preußischen Geologischen Landesanstalt", 173, 5-168.

Hesemann J., 1937, Geschiebeuntersuchungen in Schleswig-Holstein, „Jahrbuch der Preußischen Geologischen Landesanstalt", N. F., 57, 418-434.

Hesemann J., 1938, Zur Geschiebeführung und Geologie des Odergletschers. 2. Der Züllichauer Bogen, "Jahrbuch der Preußischen Geologischen Landesanstalt", N. F., 58, 455-471.

Hesemann J., 1939, Zur Petrographie weiterer hauptsächlich ost-fennoskandischer Leitgeschiebe, „Zeitschrift für Geschiebeforschung", 15, 68-98.

Hesemann J., 1960, Geschiebeforschung im Rück- und Ausblick, „Berichte der Geologischen Gesellschaft in der DDR", 5, 191-205.

Hesemann J., 1975, Kristalline Geschiebe der nordischen Vereisungen, Geologisches Landesamt Nordrhein-Westfalen, Krefeld, $267 \mathrm{~s}$.

Hildes D., Clarke G., Flowers G., Marshall S., 2004, Subglacial erosion and englacial sediment transport modelled for North American ice sheets, „Quaternary Science Reviews”, 23, 409-430. 
Hindmarsh R.C.A., 1996, Sliding of till over bedrock: scratching, polishing, comminution and kinematic-wave theory, „Annals of Glaciology”, 22, 41-47.

Hiscock K.M., Tabatabai Najafi M., 2011, Aquitard characteristics of clay-rich till deposits in East Anglia, Eastern England, „Journal of Hydrology”, 405, 288-306.

Hoare P.G., 2012, Scandinavian indicators in East Anglia's „pre-glacial” succession, [w:] R.G. Dixon (red.), A Celebration of Suffolk Geology, GeoSuffolk $10^{\text {th }}$ Anniversary Volume, GeoSuffolk, Ipswich, 341-352.

Hodgson D.A., 1994, Episodic ice streams and ice shelves during retreat of the northwesternmost sector of the Late Wisconsinan Laurentide Ice Sheet over the central Canadian Arctic Archipelago, "Boreas”, 23, 1, 14-28.

Hoffmann K., Meyer K.-D., 1997, Leitgeschiebezählungen von elster- und saalezeitlichen Ablagerungen aus Sachsen, Sachsen-Anhalt und dem östlichen Niedersachsen, „Leipziger Geowissenschaften”, 5, 115-128.

Hoffmann K., Meyer K.-D., 1999, Indicator stone counts on Elsterian and Saalian sediments from eastern Germany, „Geological Quarterly”, 43, 2, 233-240.

Hoffmann K., Piotrowski J.A., 2001, Till mélange at Amsdorf, central Germany: sediment erosion, transport and deposition in a complex, soft-bedded subglacial system, "Sedimentary Geology”, 140, 215-234.

Högbom A.G., 1920, Geologisk beskrifning öfver Jemtlands län, „Sveriges Geologiska Undersökning C”, 140, 1-139.

Holmes C.D., 1952, Drift dispersion in West-Central New York, „Geological Society of America Bulletin”, 63, 10, 993-1010.

Holmes C.D., 1960, Evolution of till-stone shapes, central New York, "Geological Society of America Bulletin”, $71,1645-1660$.

Holmlund P., Fastook, J., 1993, Numerical modeling provides evidence of a Baltic ice stream during the younger dryas, „Boreas”, 22, 2, 77-86.

Hooke R.L., Elverhøi A., 1996, Sediment flux from a fjord during glacial periods, Isforden, Spitsbergen, „Global and Planetary Change", 12, 237-249.

Hooyer T.S., Cohen D., Iverson N.R., 2012, Control of glacial quarrying by bedrock joints, "Geomorphology”, 153-154, 91-101.

Houmark-Nielsen M., 1983, The compositional features of Danish glacial deposits, [w] J. Ehlers (red.), Glacial Deposits in Northwest Europe, A.A. Balkema, Rotterdam, 199-202.

Houmark-Nielsen M., 1987, Pleistocene stratigraphy and glacial history of the central part of Denmark, „Bulletin of the Geological Society of Denmark” 36, 1-189.

Houmark-Nielsen M., 1999, A lithostratigraphy of Weichselian glacial and interstadial deposits in Denmark, „Bulletin of the Geological Society of Denmark”, 46, 101-114.

Houmark-Nielsen M., 2004, The Pleistocene of Denmark: a review of stratigraphy and glaciation history, [w:] J. Ehlers, P.L. Gibbard (red.), Quaternary Glaciations - Extent and Chronology. Part I, Europe, Developments in Quaternary Science, Elsevier, Amsterdam, 2, 35-46.

Howat I.M., Box J.E., Ahn Y., Herrington A., McFadden E.M., 2010, Seasonal variability in the dynamics of marine-terminating outlet glaciers in Greenland, „Journal of Glaciology”, 56 (198), 601-613.

Howat I.M., Joughin I., Scambos T.A., 2007, Rapid changes in ice discharge from Greenland outlet glaciers, „Science", 315, 1559-1561.

http://wis.pol.lublin.pl/przegroda/index.php?show=spis_mat (dostęp: 12.07.2012).

Hubbard B., Cook S., Coulson H., 2009, Basal ice facies: a review and unifying approach, „Quaternary Science Reviews", 28, 1956-1969.

Hubbard B., Tison J.L., Janssens L., Spiro B., 2000, Ice-core evidence of the thickness and character of clear-facies basal ice: Glacier de Tsanfleuron, Switzerland, „Journal of Glaciology”, 46 (152), 140-150.

Hucke K., 1917, Die Sedimentärgeschiebe des norddeutschen Flachlandes, Quelle und Meyer, Leipzig, 202 s. 
Hucke K., 1926, Über horizontale und vertikale Geschiebeverbreitung, „Zeitschrift für Geschiebeforschung”, 2, $1,27-44$.

Hucke K., 1937, Geschiebeforschung und Aufsuchung nutzbarer Lagerstätten; ein Aufruf, „Zeitschrift für Geschiebeforschung und Flachlandsgeologie", 13, 2, 51-59.

Hughes T., 1992, Abrupt climatic change related to unstable ice-sheet dynamics: toward a new paradigm, „Palaeogeography, Palaeoclimatology, Palaeoecology”, 97, 203-234.

Humlum O., 1985, Changes in texture and fabric of particles in glacial traction with distance from source, Myrdalsjökull, Iceland, „Journal of Glaciology”, 31, 150-156.

Hutter K., 1982, Glacier flow, „American Scientist”, 70, 1, 26-34.

Hutter K., Blatter H., Funk M., 1988, A model computation of moisture content in polythrmal glaciers, „Journal of Geophysical Research", 93, 12205-12214.

Hutton J., 1795, Theory of the earth, with proofs and illustrations, 2 vols., Edinburgh/London, William Creech/Cadell and Davies (http://www. sacred-texts. com/earth/toe/index. htm).

Huybrechts P., T'siobbel S., 1995, Thermomechanical modelling of Northern Hemisphere ice sheets with a two-level mass-balance parameterization, „Annals of Glaciology”, 21, 111-6.

Imbrie J., Imbrie K.P., 1979, Ice Ages: Solving the Mystery, Cambridge, Harvard University Press, 224 s.

Iverson N.R., 1990, Laboratory simulations of glacial abrasion: Comparison with theory, „Journal of Glaciology", 36, 304-314.

Iverson N.R., 1991a, Morphology of glacial striae: Implications for abrasion of glacier beds and fault surfaces, „Geological Society of America Bulletin”, 103, 1308-1316.

Iverson N.R., 1991b, Potential effects of subglacial water-pressure fluctuations on quarrying, „Journal of Glaciology", 37, 27-36.

Iverson N.R., 1993, Regelation of ice through debris at glacier beds: implications for sediment transport, "Geology", 21, 559-562.

Iverson N.R., 2000, Sediment entrainment by a soft-bedded glacier: a model based on regelation into the bed, „Earth Surface Processes and Landforms”, 25, 881-893.

Iverson N.R., 2002, Processes of glacial erosion, [w:] J. Menzies, (red.), Modern and Past Glacial Environments, Butterworth-Heinemann, Oxford, 131-145.

Iverson N.R., Baker R.W., Hooke R., Le B., Hanson B., Jansson P., 1999, Coupling between a glacier and a soft bed: I. A relation between effective pressure and local shear stress determined from till elasticity, „Journal of Glaciology", 45, 31-40.

Ives J.D., 1962, Indications of recent extensive glacierization in north-central Baffin Island, N.W.T., Canada, „Journal of Glaciology”, 4, 197-206.

Ives J.D., 1978, The maximum extent of the Laurentide ice sheet along the east coast of North America during the last glaciation, „Arctic”, 31, 24-53.

Ives J.D., Andrews J.T., Barry R.G., 1975, Growth and Decay of the Laurentide Ice Sheet and Comparisons with Fenno-Scandinavia, "Naturwissenschaften”, 62, 118-125.

Jahn A., 1950, Nowe dane o położeniu kry jurajskiej w Łukowie, „Annales Societatis Geologorum Poloniae”, $19,372-385$.

James A.L., 2003, Glacial erosion and geomorphology in the northwest Sierra Nevada, CA, "Geomorphology", $55,283-303$.

Jamieson S.S.R., Sugden D.E., Hulton N.R.J., 2010, The evolution of the subglacial landscape of Antarctica, „Earth and Planetary Science Letters", 293, 1-27.

Jania J., 1988, Klasyfikacja i cechy morfometryczne lodowców otoczenia Hornsundu, Spitsbergen, [w:] Wyprawy polarne Uniwersytetu Ślqskiego, Katowice, 12-48.

Jania J., 1993, Glacjologia. Nauka o lodowcach, Wydawnictwo Naukowe PWN, Warszawa, 359 s. 
Jaroszewicz-Kłyszyńska A., 1938a, Kamienie narzutowe, ich znaczenie naukowe i historia badań, „Wiadomości Muzeum Ziemi", 4, 129-136.

Jaroszewicz-Kłyszyńska A., 1938b, O utworach morenowych Łysej Góry pod Wilnem, „Starunia”, 15, 1-46.

Jasiewicz J., 2001, Vistuliańskie gliny czerwone i ich znaczenie stratygraficzne dla wydzielenia fazy gardnieńskiej, [w:] K. Rotnicki (red.), Przemiany środowiska geograficznego nizin nadmorskich południowego Bałtyku w vistulianie i holocenie, Bogucki Wydawnictwo Naukowe, 53-56.

Jasiewicz J., 2006, Mechanizm kształtowania się składu petrograficznego glin morenowych ostatniego zlodowacenia na obszarze perybałtyckim - aktualne problemy interpretacyjne, „Badania Fizjograficzne nad Polską Zachodnią Seria A - Geografia Fizyczna", 57, 61-82.

Jasiewicz J., 2007, Weichselian red tills in the Gardno Phase End Moraine (Dębina Cliff) - criteria of distinction, origin and stratigraphic position, and implications for the origin and course of the Baltic Ice Stream, „Eiszeitalter und Gegenwart (Quaternary Science Journal)”, 56, 4, 295-310.

Jenkins A., Dutrieux P., Jacobs S.S., McPhail S.D., Perrett J.R., Webb A.T., White D., 2010, Observations beneath Pine Island Glacier in West Antarctica and implications for its retreat, "Nature Geoscience”, 3, 468-472.

Jennings C.E., 2006, Terrestrial ice streams - a view from the lobe, "Geomorphology", 75, 100-124.

Jenson J.W., Clark P.U., MacAyeal D.R., Ho C., Vela J.C., 1995, Numerical modelling of advective transport of saturated deforming sediment beneath the Lake Michigan Lobe, Laurentide Ice Sheet, "Geomorphology", 14, 157-166.

Jin L., Williams E.L., Szramek K.J., Walter L.M., Hamilton S.K., 2008, Silicate and carbonate mineral weathering in soil profiles developed on Pleistocene glacial drift (Michigan, USA): Mass balances based on soil water geochemistry, "Geochimica et Cosmochimica Acta”, 72, 4, 1027-1042.

Jiskoot H., Murray T., Boyle P., 2000, Controls on the distribution of surge-type glaciers in Svalbard, „Journal of Glaciology", 46 (154), 412-22.

Johansson M., Migoń P., Olvmo M., 2001a, Development of joint-controlled rock basins in Bohus granite, SW Sweden, "Geomorphology", 40, 145-161.

Johansson M., Olvmo M., Lidmar B.K., 2001b, Inherited landforms and glacial impact of different palaeosurfaces in southwest Sweden, „Geografiska Annaler”, 83A, 67-89.

Johnson C.B., 1975, Characteristics and mechanics of formation of glacial arcuate abrasion cracs [Ph.D. thesis], University Park, Pennsylvania, Pennsylvania State University, 264 s. (fide Iverson, 1991).

Jones M.J. (red.), 1973, Prospecting in Areas of Glaciated Terrain, Institution of Mining and Metallurgy, London.

Jonsson S., 1983, On the geomorphology and past glaciation of Storöya, Svalbard, "Geografiska Annaler", 65A, 1-17.

Jørgensen F., Piotrowski J.A., 2003, Signature of the Baltic Ice Stream on Funen Island, Denmark during the Weichselain glaciation, „Boreas”, 32, 242-255.

Joughin I., Abdalati W., Fahnestock M., 2004, Large fluctuations in speed on Greenland's Jakobshavn Isbrae glacier, "Nature”, 432 (7017), 608-610.

Joughin I., Bindschadler R.A., King M.A., Voigt D., Alley R.B., Anandakrishnan S., Horgan H., Peters L., Winberry P., Das S.B., Catania G., 2005, Continued deceleration of Whillans Ice Stream, West Antarctica, "Geophysical Research Letters", 32, 22, L22501.

Junge F.W., 1998, Die Bändertone Mitteldeutschlands und angrenzender Gebiete. Ein regionaler Beitrag zur quartären Stausee-Entwicklung im Randbereich des elsterglazialen skandinavischen Inlandeises, „Altenburger Naturwissenschaftliche Forschungen", 9, 1-210.

Jurgaitis A., 1970, O minerałogo-petrografičeskom sostavje płażevych gravijno-galječnych otłożenij Jugo-Vostočnogo pobjereżja Baltijskogo Morja, „Baltica”, 4, 249-257.

Kalm V., 2012, Ice-flow pattern and extent of the last Scandinavian Ice Sheet southeast of the Baltic Sea, "Quaternary Science Reviews", 44, 51-59. 
Kamb B., 1970, Sliding motion of glaciers: theory and observations, "Reviews of Geophysics and Space Physics", 8, 4, 673-728.

Kamb B., Raymond C.F., Harrison W.D., Engelhardt H.F., Echelmeyer K.A., Humphrey N.F., Brugman M.M., Pfeffer T., 1985, Glacier surge mechanism: 1982-1983 surge of Variegated Glacier, Alaska, "Science”, 227, 469-479.

Karabanov A.K., Matveyev A.V., Pavlovskaya I.E., 2004, The main glacial limits in Belarus, [w:] J. Ehlers, P.L. Gibbard (red.), Quaternary Glaciations - Extent and Chronology Part I: Europe, Developments in Quaternary Science 2, Amsterdam, Elsevier, 15-18.

Keilhack K., 1896, Erläuterungen zur geologischen Specialkarte von Preussen und den Thüringischen Staaten 1:25. 000, Blatt Klannin, Berlin, $33 \mathrm{~s}$.

Kenig K., 1998, Petrograficzne podstawy litostratygrafii glin morenowych Polski północno-wschodniej, „Biuletyn Państwowego Instytutu Geologicznego", 380, 1-99.

Kenig K., 2009, Litologia glin morenowych na Niżu Polskim - podstawowe metody badawcze, „Biuletyn Państwowego Instytutu Geologicznego", 437, 1-58.

Kharin G.S., 2009, Phosphorite Potential of Cretaceous and Paleogene Rocks in the Kaliningrad and Southeastern Baltic Regions, „Lithology and Mineral Resources”, 44, 4, 305-327.

Kharin G.S., Zagorodnykh V.A., 2011, Fosfority Kaliningradskoy Obłasti i Jugo-Vostočnoy Baltiki, „Gornyi Zhurnal", 2011, 10, 25-27.

Kirkbride M.P., 2002, Processes of glacial transportation, [w:] J. Menzies (red.), Modern and Past Glacial Environments, Butterworth-Heinemann, Oxford, 147-169.

Kjær K.H., Houmark-Nielsen M., Richardt N., 2003, Ice-flow patterns and dispersal of erratics at the southwestern margin of the last Scandinavian Ice Sheet: signature of palaeo-ice streams, "Boreas", 32, 130-148.

Kjaran S.P., Eliasson J., 1983, Geothermal Reservoir Engineering Lecture Notes, Report 1983-2, U.N. Univ. Geothermal Training, Iceland, $250 \mathrm{~s}$.

Kjarsgaard B.A., Levinson A.A., 2002, Diamonds in Canada, „Gems and Gemology”, 38, 208-238.

Klassen R.A., 1999, The application of glacial dispersal models to the interpretation of till geochemistry in Labrador, Canada, „Journal of Geochemical Exploration”, 67, 245-269.

Klassen R.A., 2001, A Quaternary geological perspective on geochemical exploration in glaciated terraine, [w:] M.B. McClenaghan, P.T., Bobrowsky, G.E.M. Hall, S.J. Cook (red.), Drift Exploration in Glaciated Terrain, The Geological Society, London, 1-17.

Kleman J., 1994, Preservation of landforms under ice sheets and ice caps, "Geomorphology", 9, 19-32.

Kleman J., Borgström I., Hättestrand C., 1994, Evidence for a relict glacial landscape in Quebec-Labrador, „Palaeogeography, Palaeoclimatology, Palaeoecology”, 111, 217-228.

Kleman J., Glasser N.F., 2007, The subglacial thermal organisation (STO) of ice sheets, "Quaternary Science Reviews", 26, 5-6, 585-597.

Kleman J., Hättestrand C., 1999, Frozen-bed Fennoscandian and Laurentide ice sheets during the Last Glacial Maximum, „Nature”, 402, 63-66.

Kleman J., Hättestrand C., Borgström I., Stroeven A., 1997, Fennoscandian paleoglaciology reconstructed using a glacial geological inversion model, „Journal of Glaciology”, 43, 283-299.

Kleman J., Hättestrand C., Clarhäll A., 1999, Zooming in on frozen-bed patches: scale dependent controls on Fennoscandian ice sheet basal thermal zonation, „Annals of Glaciology”, 28, 189-194.

Kleman J., Hättestrand C., Stroeven A., Jansson K.N., De Angelis H., Borgström I., 2006, Reconstruction of palaeo-ice sheets - inversion of their glacial geomorphological record, [w:] J. Knight (red.), Glacier Science and Environmental Change, Blackwell Publishing, Oxford, 192-198.

Kleman J., Jansson K., De Angelis H., Stroeven A.P., Hättestrand C., Alm G., Glasser N., 2010, North American Ice Sheet build-up during the last glacial cycle, 115-21 kyr, „Quaternary Science Reviews”, 29, 2036-2051. 
Kleman J., Stroeven A.P., Lundqvist J., 2008, Patterns of Quaternary ice sheet erosion and deposition in Fennoscandia and a theoretical framework for explanation, „Geomorphology”, 97, 1-2, 73-90.

Kleman J., Stroeven A.P., 1997, Preglacial surface remnants and Quaternary glacial regimes in northwestern Sweden, „Geomorphology”, 19, 35-54.

Knight P.G., 1987, Observations at the edge of the Greenland ice sheet: boundary condition implications for modelers, IAHS Publ. 170 (Symposium at Vancouver 1987 - The Physical Basis of Ice Sheet Modelling), 359-366.

Knight P.G., 1997, The basal ice layer of glaciers and ice sheets, „Quaternary Science Reviews”, 16, 975-993.

Knight P.G., 2002, Glacial sedimentary evidence supporting stick-slip basal ice flow, „Quaternary Science Reviews", 21, 975-983.

Knight P.G., Knight D.A., 1994, Correspondence. Glacier sliding, regelation water flow and development of basal ice, „Journal of Glaciology”, 40 (136), 600-601.

Knight P.G., Waller R.I., Patterson C.J., Jones A.P., Robinson Z.P., 2002, Discharge of debris from ice at the margin of the Greenland ice sheet, „Journal of Glaciology”, 48 (161), 192-198.

Kobojek E., 1997, Morfologia i budowa geologiczna środkowego odcinka doliny Rawki między Rawq Mazowieckq a Nowym dworem, „Acta Universitatis Lodziensis, Folia Geographica Physica”, 1, 187-195.

Kobojek E., 2000, Morfogeneza doliny Rawki, „Acta Geographica Lodziensia”, 77, 157 s.

Koerner R.M., 1989, Ice core evidence for extensive melting of the Greenland ice sheet during the last interglacial, „Science”, 244 (4907), 964-968.

Konieczny S., 1956, Z badań nad rozmieszczeniem eratyków krystalicznych zlodowacenia plejstoceńskiego w zachodniej Polsce, „Prace Komisji Geograficzno-Geologicznej Poznańskiego Towarzystwa Przyjaciół Nauk", 2, 1, 3-42.

Konieczny S., Wdowiak J., 1971, Głazy narzutowe w morenach zlodowacenia środkowopolskiego Kotliny Kłodzkiej, „Badania Fizjograficzne nad Polską Zachodnią”, 24 (Seria A Geogr. Fiz.), 67-75.

Königsson L.K., Svantesson S.I., 1975, The petrography of gravel deposits on the island of Gotland in the Baltic, "Geologiska Föreningens i Stockholm Förhandlingar", 97, 312-320.

Korn J., 1895, Ueber diluviale Geschiebe der Königsberger Tiefbohrungen, D. Sc. Diss. L. Schade, Berlin, 1-66.

Korn J., 1917, Untersuchungen in der Glaziallandschaft östlich vom Odergletscher, „Jahrbuch der Königlichen Preußischen Geologischen Landesanstalt", 38, 396-420.

Korn J., 1920, Die Ostgrenze der norwegischen Diluvialgeschiebe in Norddeutschland, „Jahrbuch der Königlichen Preußischen Geologischen Landesanstalt", 39, 25-31.

Korn J., 1927, Die wichtigsten Leitgeschiebe der nordischen kristallinen Gesteine im norddeutschen Flachlande; Ein Führer für den Sammler kristalliner Geschiebe, Preussische Geologische Landesanstalt, Berlin, $\mathrm{XX}+64 \mathrm{~s}$.

Kosar K., Ross M., Gosse J., 2011, Subglacial sediment-landsystems analysis of a corridor of streamlined ridges, Southampton Island, Nunavut: Implications for drift exploration, [w:] Geohydro 2011. Joint Meeting of the Canadian Quaternary Association and the Canadian Chapter of the International Association of Hydrogeologists, August 28-31, 2011, Quebec City, Quebec, 7 s. http://www. geohydro2011. ca/gh2011_ user/cle_usb/pdf/doc-2265. pdf.

Kosmowska-Ceranowicz B., 1989, Tajemnice bursztynu, Wyd. Sport i Turystyka, $231 \mathrm{~s}$.

Kosmowska-Ceranowicz B., 2002, Nagromadzenie bursztynu na Kurpiowszczyźnie, [w:] B. Kosmowska-Ceranowicz (red.), Znaleziska i dawne kopalnie bursztynu w Polsce. Od Bałtyku przez Kurpie do Karpat, Biblioteka Kurpiowska im. Stacha Konwy, 2, 8-12.

Kosmowska-Ceranowicz B., 2003, Quaternary Amber-bearing deposits on the Polish coast, "Zeischrift für Angewandte Geologie", Sonderheft 2, 73-84.

Kozarski S., Kasprzak L., 1992, Glacidynamometamorfoza osadów nieskonsolidowanych w makro- i mezoglacitektonitach Niziny Wielkopolskiej, „Przegląd Geograficzny”, 64, 1-2, 95-119. 
Krabbendam M., Glasser N.F., 2011, Glacial erosion and bedrock properties in NW Scotland: Abrasion and plucking, hardness and joint spacing, „Geomorphology”, 130, 374-383.

Krajick K., 2001, Barren Lands: An Epic Search for Diamonds in the North American Arctic, Freeman, W.H., $442 \mathrm{~s}$.

Kramarska R. (red.), 1999, Mapa geologiczna dna Bałtyku bez utworów czwartorzędowych, Państwowy Instytut Geologiczny, Gdańsk-Warszawa.

Kramarska R., 2000, Podłoże czwartorzędu na nowej mapie odkrytej południowego Bałtyku, „Przegląd Geologiczny", 48, 7, 567-570.

Kraus E., 1934, Über die Geschiebe in Lettland, „Zeitschrift für Geschiebeforschung”, 10, 2, 67-80.

Krause K., 1997, Durch Gletscher und Wasser verfrachtet: Bernstein - Transport und Transportwege, „Arbeitskreis Paläontologie Hannover”, 25, 166-174.

Krzemiński T., 1974, Geneza młodoplejstoceńskiej rzeźby glacjalnej w dorzeczu środkowej Warty, „Acta Geographica Lodziensia", 33, 1-171.

Krzemiński T., 1997, Cechy rozwoju i zaniku laqdolodu warciańskiego w środkowej Polsce, „Acta Universitatis Lodziensis, Folia Geographica Physica", 1, 47-65.

Krzemiński T., Świerczewska A., Uchman J., 1993, Udział skał lokalnych w utworach wodnolodowcowych środkowej Polski, „Acta Geographica Lodziensia”, 65, 185-206.

Krzyszkowski D., 1990, Chojny Formation in the Kleszczów Graben (Central Poland) - an Example of the Fluvial Activity during the Pilica Interstadial (Drenthe/Warthe Stage), „Bulletin of the Polish Academy of Science, Earth Sciences", 38, 77-99.

Krzyszkowski D., 1992, Czwartorzęd rowu Kleszczowa: litostratygrafia i tektonika. Zarys problematyki na podstawie obserwacji w odkrywce KWB „Bełchatów”, „Acta Universitatis Wratislaviensis”, 1252, „Studia Geograficzne", 54, $158 \mathrm{~s}$.

Krzyszkowski D., 1995, An outline of the Pleistocene stratigraphy of the Kleszczów Graben, Bełchatów outcrop, Central Poland, "Quaternary Science Reviews", 14, 61-83.

Kuhn B.F., 1787, Versuch einer Beschreibung des Grindelwaldthales, „Magazin für die Naturkunde Helvetiens”, Hrsg. v. A., 1787.

Kujansuu R., Saarnisto M. (red.), 1990, Glacial indicator tracing, Balkema, Rotterdam/Brookfield, $252 \mathrm{~s}$.

Kummerow E., 1927, Die Geschiebeforschung als Mittel zur Erforschung der Bewegungsrichtung des Inlandeises, „Centralblatt für Mineralogie, Geologie und Paläontologie (B), Geologie und Paläontologie”, 1927, 9, 366-374.

Kummerow E., 1930, Fortschritte der Geschiebeforschung. (Bewegungsrichtung des Inlandeises, Drift- und Schollentransport), „Centralblatt für Mineralogie Geologie und Paläontologie”, B, 4, 136-145.

Kummerow E., 1950, Fortschritte in der Diluvialgeologie (Drift- und Inlandeistheorie - Herkunft und Verbreitung der Geschiebe), „Die Erde Zeitschrift der Gesellschaft für Erdkunde zu Berlin”, 1950/51, 1, 16-24.

Kummerow E., 1954, Grundfragen der Geschiebeforschung (Heimat, Transport und Verteilung der Geschiebe), "Geologie", 3, 1, 42-54.

Kummerow E., 1956, Heimat, Transport und Verbreitung unserer nordischen Diluvialgeschiebe, „Forschungen und Fortschritte Nachrichtenblatt der Deutschen Wissenschaft und Technik", 30, 4, 97-103.

Laberg J.S., Andreassen K., Vorren T.O., 2012, The late Cenozoic erosion of the south-western Barents Sea shelf revisited, „Geological Society of America Bulletin”, 124, 1/2, 77-88.

Ladwig H., 1938, Geschiebezählungen als Forschungsmittel zur Diluvial-stratigraphie und Tektonik Ostpommerns, „Abhandlungen aus dem geologisch-paläeontologischen Institut Greifswald”, 19, 1-45.

Lagally M., 1932, Zur Thermodynamic der Gletscher, „Zeitschrift für Gletscherkunde”, 20, 199-214.

Lagerbäck R., 1988, Periglacial phenomena in the wooded areas of Northern Sweden - relicts from the Tarendd Interstadial, „Boreas”, 17, 487-499.

Laitakari I., 1989, How the glacial erratics were broken loose from the bedrock? [w:] M. Perttunen (red.), Transport of glacial drift in Finland, "Geological Survey of Finland, Special Paper”, 7, 15-18. 
Laitakari l., Aro K., 1985, The effect of jointing on glacial erosion of bedrock hills in southern Finland, „Fennia”, 163, 2, 369-371.

Lambeck K., Smither S., Johnston P., 1998, Sea-level change, glacial rebound and mantle viscosity for Northern Europe, "Geophysical Journal International”, 134, 102-144.

Lamparski Z., 1971, Egzaracja lodowcowa w marginalnej strefie zlodowacenia środkowopolskiego, „Biuletyn Geologiczny UW", 13, 5-74.

Lamparski Z., 1992, Metody litologiczne, [w:] L. Lindner (red.), Czwartorzęd. Osady, metody badań, stratygrafia, Wydawnictwo PAE, Warszawa, 276-293.

Langmuir D., 1997, Aqueous Environmental Geochemisty, Prentice Hall, Upper Saddle River, NY, $600 \mathrm{~s}$.

Larkin N.R., Lee J.R., Connell E.R., 2011, Possible ice-rafted erratics in late Early to early Middle Pleistocene shallow marine and coastal deposits in northeast Norfolk, UK, „Proceedings of the Geologists' Association", 122, 445-454.

Larson G.J., Lawson D.E., Evenson E.B., Alley R.B., Knudsen Ó., Lachniet M.S., Goetz S.L., 2006, Glaciohydraulic supercooling in former ice sheets?, "Geomorphology”, 75, 20-32.

Larson G.J., Lawson D.E., Evenson E.B., Knudsen Ó., Alley R.B., Phanikumar M.S., 2010, Origin of stratified basal ice in outlet glaciers of Vatnajökull and Öræfajökull, Iceland, „Boreas”, 39, 457-470.

Larson P.C., Mooers H.D., 2004, Glacial indicator dispersal processes: a conceptual model, „Boreas”, 33, 238249.

Lauri L.S., Nironen M., Rämö O.T., 2005, The Finnish Precambrian in a nutshell, [w:] O.T. Rämö, J. Halla, M. Nironen, L.S. Lauri, M.I. Kurhila, A. Käpyaho, P. Sorjonen-Ward, O. Äikäs, EUROGRANITES 2005-Proterozoic and Archean Granites and Related Rocks of the Finnish Precambrian, 14-17.

Lawson D.E., 1979, Sedimentological analysis of the western terminus region of the Matanuska Glacier, Alaska, CRREL Rep., 79, 9, $122 \mathrm{~s}$.

Lawson D.E., Strasser J.C., Evenson E.B., Alley R.B., Larson G.J., Arcone S.A., 1998, Glaciohydraulic supercooling: a freeze-on mechanism to create stratified, debris-rich basal ice. I. Field evidence, „Journal of Glaciology", 44, 547-561.

Laymon C.A., 1992, Glacial geology of western Hudson Strait, Canada, with reference to Laurentide Ice Sheet dynamics, „Geological Society of America Bulletin”, 104, 9, 1169-1177.

Le Maitre R.W. (red.), 2004, Igneous rocks: a classification and glossary of terms, Cambridge University Press, Cambridge, $236 \mathrm{~s}$.

Le Maitre R.W., Bateman T., Dudek A., Keller J., Lameyre Le Bas M.J., Sabine P.A., Schmid R., Sorensen H., Streckeisen A., Wooley A.R., Zanettin B., 1989, A classification of igneous rocks and glossary of terms, Blackwell, Oxford, $193 \mathrm{~s}$.

Lee H.A., 1965, Investigations of eskers for mineral exploration/buried valleys near Kirkland Lake, Ontario, "Geological Survey of Canada Paper", 65-14, $24 \mathrm{~s}$.

Lee J.R., Busschers F.S., Sejrup H.P., 2012, Pre-Weichselian Quaternary glaciations of the British Isles, The Netherlands, Norway and adjacent marine areas south of $68^{\circ} \mathrm{N}$ : implications for long-term ice sheet development in northern Europe, "Quaternary Science Reviews", 44, 213-228.

Lehtovaara J.J., 1982, Palaeozoic sedimentary rocks in Finland, „Annales Academiae Scientarum Fennicae”, A. III. $133,35 \mathrm{~s}$.

Levasseur D., Prichonnet G., 1995, La dispersion clastique des debris rocheux dans les esker et le till adjacent de la region de Chapais-Chibougamau (Quebec) au Wisconsinien superieur, "Géographie physique et Quaternaire", 32, 590-602.

Li Y.K., Harbor J., Stroeven A.P., Fabel D., Kleman J., Fink D., Caffee M., Elmore D., 2005, Ice sheet erosion patterns in valley systems in northern Sweden investigated using cosmogenic nuclides, "Earth Surface Processes and Landforms", 30, 1039-1049.

Lindén A., 1975, Till petrographic studies in an Archaean bedrock area in southern central Sweden, „Striae”, 1, $1-57$. 
Lindner L., 1970, Glacjalne terasy marginalne lq̨dolodu zlodowacenia środkowopolskiego na północno-zachodnim obrzeżeniu Gór Świętokrzyskich, „Acta Geologica Polonica”, 20, 3, 603-633.

Lindner L., 1988, Zarys stratygrafii plejstocenu rejonu Białej Podlaskiej wraz z próbq korelacji z przyległymi obszarami Zwiqzku Radzieckiego, „Przegląd Geologiczny”, 36, 11, 637-647.

Lindner L. (red.), 1992, Czwartorzęd. Osady, metody badań, stratygrafia, Wydawnictwo PAE, Warszawa, $683 \mathrm{~s}$.

Lindner L., 1996, Pomazowieckie osady lodowcowe $i$ wodnolodowcowe w rejonie Białej Podlaskiej $i$ ich wiek w świetle dyskusji nad problemem zlodowacenia warty w Polsce, „Biuletyn Państwowego Instytutu Geologicznego", 373, 87-96.

Lindner L., 2009, O trzech przyczynach przypowierzchniowego występowania osadów interglacjału mazowieckiego na południowym Podlasiu i Polesiu Lubelskim, [w:] M. Żarski, S. Lisicki (red.), XVI Konferencja Stratygrafia Plejstocenu Polski "Strefa marginalna ladolodu zlodowacenia warty i pojezierza plejstoceńskie na południowym Podlasiu", Zimna Woda k. Łukowa 31 sierpnia-4 września 2009, Materiały konferencyjne, 68-71.

Lindner L., Marks L., 2012, O podziale klimatostratygraficznym kompleksu środkowopolskiego w plejstocenie Polski, „Przegląd Geologiczny”, 60, 1, 36-45.

Lindner L., Marks L., Nita M., 2013, Climatostratigraphy of interglacials in Poland: Middle and Upper Pleistocene lower boundaries from a Polish perspective, "Quaternary International”, 292, 113-123.

Lindström, E., 1988, Are roches moutonnées mainly preglacial forms?, "Geografiska Annaler", 70A, 323-331.

Linnemann U., Romer R.L., Pin C., Aleksandrowski P., Buła Z., Geisler T., Kachlik V., Krzemińska E., Mazur S., Motuza G., Murphy J.B., Nance R.D., Pisarevsky S.A., Schulz B., Ulrich J., Wiszniewska J., Żaba J., Zeh A., 2008, Precambrian, [w:] T. McCann (red.), The Geology of Central Europe. Vol. 1: Precambrian and Palaeozoic, Geological Society, London, 21-101.

Lipka E., 2011, Zróżnicowanie cech petrograficznych osadów polodowcowych na Wysoczyźnie Lubuskiej, Manuskrypt pracy doktorskiej, Wydział Nauk Geologicznych i Geograficznych, Repozytorium UAM w Poznaniu, $108 \mathrm{~s}$.

Lisicki S., 1998, Interpretacja wyników analizy petrograficznej frakcji żwirowej glin zwałowych w nawiqzaniu do ich genezy, „Przegląd Geologiczny”, 46, 5, 410-416.

Lisicki S., 2003, Litotypy i litostratygrafia glin lodowcowych plejstocenu dorzecza Wisły, „Prace Państwowego Instytutu Geologicznego", 177, 1-105.

Liu G.N., Chen Y.X., Zhang Y., Fu H.R., 2009, Mineral deformation and subglacial processes on ice-bedrock interface of Hailuogou Glacier, "Chinese Science Bulletin”, 54, 18, 3318-3325.

Livingstone S.J., Ó Cofaigh C., Stokes C.R., Hillenbrand C.-D., Vieli A., Jamieson S.S.R., 2012, Antarctic paleo-ice streams, „Earth-Science Reviews", 111, 90-128.

Lliboutry L., 1968, General theory of subglacial cavitation and sliding of temperate glaciers, „Journal of Glaciology", 7, 21-58.

Lliboutry L., 1987, Realistic, yet simple bottom boundary conditions for glaciers and ice sheets, „Journal of Geophysical Research", 92, B9, 9101-9109.

Lliboutry L., 1994, Monolithologic erosion of hard beds by temperate glaciers, „Journal of Glaciology", 40 (136), 433-450.

Lloyd Davies M.T., Atkins C.B., van der Meer J.J.M., Barrett P.J., Hicock S.R., 2009, Evidence for cold-based glacial activity in the Allan Hills, Antarctica, "Quaternary Science Reviews”, 28, 3124-3137.

Ludwig A.O., 1967, Der präquartäre Untergrund der Ostsee. Teil I. Nordliche und Mittlere Ostsee, „Wissenschaftliche Zeitschrift der Universität Rostock", R. 16, 9/10, 1105-1136.

Lundqvist J., 2004, Glacial history of Sweden, [w:] J. Ehlers, P.L. Gibbard (red.), Quaternary Glaciations Extent and Chronology Part I: Europe, Developments in Quaternary Science 2, Amsterdam, Elsevier, 401412. 
Lüthgens C., Böse M., Krbetschek M., 2010, On the age of the young morainic morphology in the area ascribed to the maximum extent of the Weichselian glaciation in north-eastern Germany, "Quaternary International", 222, 72-79.

Lüttig G., 1954, Alt- und mittelpleistozäne Eisrandlagen zwischen Harz und Weser, Inaugural-Dissertation, Göttingen 1952, „Geologisches Jahrbuch”, 70, 43-125.

Lüttig G., 1958, Methodische Fragen der Geschiebeforschung, "Geologisches Jahrbuch", 75, 361-418.

Lüttig G., 1991, Erratic boulder statistics as a stratigraphic aid. Examples from Schleswig-Holstein, „Newsletters on Stratigraphy", 25, 2, 61-74.

Lüttig G., 1995, Geschiebezählungen - eine terminologische Richtigstellung, „Geschiebekunde aktuell”, 11, 4, 109-112.

Lüttig G., 1997, Das geröllanalytisch-morphometrische Psammit-Psephit-Diagramm, „Leipziger Geowissenschaften", 5, 9-23.

Lüttig G., 1999, Geschiebestatistische Anmerkungen zur Quartärstratigraphie des nordischen Vereisungsgebietes, „Eiszeitalter und Gegenwart”, 49, 144-163.

Lüttig G., 2005, Geschiebezählungen im westlichen Mecklenburg, „Archiv für Geschiebekunde”, 4, 9, 569-608.

Lüttig G., 2007, Crescit - tabescit: glacies. Glaziologisch-wissenschaftsphilosophische Betrachtungen, „Archiv für Geschiebekunde", 4, 10, 609-642.

Lüttig G., Maarleveld G.C., 1961, Nordische Geschiebe in Ablagerungen Prä-Holstein in den Niederlanden (Komplex von Hattem), „Geologie en Mijnbouw”, 40, 4 (N.S. 23), 163-174.

Lüttig G., Maarleveld G.C., 1962, Über altpleistozäne Kiese in der Veluwe, „Eiszeitalter und Gegenwart”, 13, 231-237.

Manikowska B., 1966, Gleby młodszego plejstocenu w okolicach Łodzi, „Acta Geographica Lodziensia”, 22, 166s.

Männil R.M., 1988, Entwicklungsgeschichte des baltischen Becken im Ordovizium, „Der Geschiebesammler”, 22, 2, 65-84.

Marcinkowski B., Mycielska-Dowgiałło E., 2013, Heavy-mineral analysis in Polish investigations of Quaternary deposits: a review, „Geologos”, 19, 1-2, 5-23.

Marcussen I., 1978, Über die Verwendbarkeit von Geschieben in Grundmoränen als Hilfsmittel der Stratigraphie, „Der Geschiebesammler”, 12, 2/3, 13-20.

Marczinski R., 1968a, Zur Geschiebekunde und Stratigraphie des Saaleglazials im nördlichen Niedersachsen zwischen Unterweser und Unterelbe, „Rotenburger Schrifte”, Sonderheft 11, $132 \mathrm{~s}$.

Marczinski R., 1968b, Zur Häufigkeit und Verteilung von Geschieben in verschiedenen Korngroßen-Bereichen Saaleglazialer Ablagerungen Norddeutschlands, „Mitteilungen aus dem Geologischen Institut der Technischen Universität Hannover", 8, 74-86.

Marks L., 1998, Rola egzaracji w kształtowaniu rzeźby północnej Polski, [w:] A. Kostrzewski (red.), Rzeźba i osady czwartorzędowe obszarów współczesnego i plejstoceńskiego zlodowacenia półkuli północnej, „Zeszyty Naukowe UAM”, Seria Geografia, 58, 143-151.

Marks L., 2002, Last Glacial Maximum in Poland, „Quaternary Science Reviews”, 21, 103-110.

Marks L., 2004, Quaternary research in Poland: selected achievements and prospects, „Przegląd Geologiczny”, $52,8 / 2,800-805$.

Marks L., 2005, Pleistocene glacial limits in the territory of Poland, „Przegląd Geologiczny”, 53, 988-993.

Marks L., 2011, Quaternary Glaciations in Poland, [w:] J. Ehlers, P.L. Gibbard, P.D. Hughes (red.), Quaternary Glaciations - Extent and Chronology. A Closer Look, Elsevier, Amsterdam, 299-303.

Marks L., Pavlovskaya I., 2003, The Holsteinian Interglacial river network of mid-eastern Poland and western Belarus, „Boreas”, 32, 2, 337-346.

Martinsson A., 1965, Aspects of a Middle Cambrian thanatotope on Öland, „Geologiska Föreningens i Stockholm Förhandlingar", 87, 219-221. 
Matoshko A.V., 2011, Limits of the Pleistocene Glaciations in the Ukraine: A Closer Look, [w:] J. Ehlers, P.L. Gibbard, P.D. Hughes (red.), Quaternary Glaciations - Extent and Chronology. A Closer Look, Elsevier, Amsterdam, 405-418.

McClenaghan M.B., Bobrowsky P.T., Hall G.E.M., Cook S.J. (red.), 2001, Drift Exploration in Glaciated Terrain, The Geological Society, London, $350 \mathrm{~s}$.

McClenaghan M.B., Thorleifson L.H., DiLabio R.N.W., 2000, Till geochemical and indicator mineral methods in mineral exploration, „Ore Geology Reviews”, 16, 145-166.

McKillup S., Darby Dyar M., 2010, Geostatistics Explained. An Introductory Guide for Earth Scientists, Cambridge University Press, $396 \mathrm{~s}$.

Meier M.F., Post A., 1969, What are glacier surges?, „Canadian Journal of Earth Sciences”, 6, 807-817.

Mende F., 1926, Typengesteine kristalliner Diluvialgeschiebe aus Südfinnland und Åland - II. Teil: Außerhalb der Rapakiwi- und Uralitporphyritgebiete anstehende Typengesteine, „Zeitschriftfür Geschiebeforschung”, 2, 1, 1-22.

Menzies J., 1990, Brecciated diamictons from Mohawk Bay, S. Ontario, Canada , ,Sedimentology”, 37, 481-493.

Menzies J., 2002, Ice flow and hydrology, [w:] J. Menzies (red.), Modern and Past Glacial Environments, Butterworth-Heinemann, Oxford, 79-130.

Menzies J., Shilts W.W., 2002, Subglacial environments, [w:] J. Menzies (red.), Modern and Past Glacial Environments, Butterworth-Heinemann, Oxford, 183-278.

Meyer K.-D., 1970, Zur Geschiebe-Führung des Ostfriesisch-Oldenburgischen Geestrückens, „Abhandlungen der naturwissenschaftlichen Verein Bremen", 37, 3/2, 227-246.

Meyer K.-D., 1983, Indicator pebbles and stone count methods, [w:] J. Ehlers (red.), Glacial Deposits in North-West Europe, Rotterdam, Balkema, 275-287.

Meyer K.-D., 1985, Zur Methodik und über den Wert von Geschiebezählungen, „Der Geschiebesammler”, 19, $2 / 3,75-83$.

Meyer K.-D., 1987, Über seltene „jungvulkanische“ Geschiebe aus dem nördlichen Niedersachsen und ihre möglichen Beziehungen zu skandinavischen Meteoritenkratern, „Der Geschiebesammler”, 20, 4, 125-145.

Meyer K.-D., 1991, Zur Entstehung der westlichen Ostsee, „Geologisches Jahrbuch”, A, 127, 429-446.

Meyer K.-D., 1998, Zur Geschiebegemeinschaft des Sadewitzer Kalkes, „,Der Geschiebesammler”, 31, 4, 167-175.

Meyer K.-D., 2000, Geschiebekundlich-stratigraphische Untersuchungen im Hannoverschen Wendland (Niedersachsen), „Brandenburgische Geowissenschaftliche Beiträge”, 7, 115-125.

Meyer K.-D., Lüttig G., 2007, Was verstehen wir unter einem „Leitgeschiebe”?, „Geschiebekunde aktuell”, 23, 4, 106-121.

Meyer M.C., Austin P., Tropper P., 2013, Quantitative evaluation of mineral grains using automated SEM-EDS analysis and its application potential in optically stimulated luminescence dating, „Radiation Measurements", 58, 1-11.

Milthers K., 1942, Ledeblokke og Landskabsformer i Danmark, „Danmarks Geologiske Unders øgelse”, II række, 69, 1-137.

Milthers V., 1909, Scandinavian indicator-boulders in the Quaternary deposits. Extension and distribution, „Danmarks Geologiske Undersøgelse”, (2. Række), 23, 1-153.

Milthers V., 1933, Leitgeschiebe auf Gotland und Gotska Sandön sowie die Heimat der Ostseeporphyre, „Geologiska Föreningens i Stockholm Förhandlingar”, 55, 1, 19-28.

Milthers V., 1934, Die Verteilung skandinavischer Leitgeschiebe im Quartär von Westdeutschland, „Abhandlungen der preußischen geologischen Landesanstalt", N.F., 156, 74 s.

Milthers V., 1936, Eine Geschiebegrenze in Ostdeutschland und Polen und ihre Beziehungen zu den Vereisungen, „Jahrbuch der preußischen geologischen Landesanstalt”, 56, 248-263.

Milthers V., 1939, Beiträge skandinavischer Leitgeschiebe für die Bestimmung der Vereisungsgrenzen, „Zeitschrift der deutschen geologischen Gesellschaft”, 91, 261-272. 
Milthers V., 1950, Die Gliederung und Verbreitung der skandinavischen Vereisungen in Nordwesteuropa, "Geologiska Föreningens i Stockholm Förhandlingar", 72, 3, 257-268.

Milthers V., Milthers K., 1938, Die Verteilung einiger wichtiger skandinavischer Leitgeschiebe in einem Teile Polens, „Biuletyn Państwowego Instytutu Geologicznego”, 5, 1-26.

Mizerski W., 1980, Jurajskie kry lodowcowe w okolicach Łukowa, „Prace Mazowieckiego Ośrodka Badań Naukowych", 51, 397, 412.

Mizerski W., 2009, Stanowisko Łapiguz. Jurajskie kry lodowcowe w okolicach Łukowa, [w:] M. Żarski, S. Lisicki (red.), XVI Konferencja Stratygrafia Plejstocenu Polski „Strefa marginalna lqdolodu zlodowacenia warty i pojezierza plejstoceńskie na południowym Podlasiu", Zimna Woda k. Łukowa 31 sierpnia-4 września 2009, Materiały konferencyjne, 150-151.

Mojski J.E. (red.), 1995, Atlas Geologiczny Południowego Bałtyku 1:500 000, Państwowy Instytut Geologiczny, Sopot-Warszawa.

Mojski J.E., 2005, Ziemie polskie w czwartorzędzie: Zarys morfogenezy, Państwowy Instytut Geologiczny, Warszawa, $404 \mathrm{~s}$.

Molewski P., 1999, Rynna Gopła - problem jej genezy i roli w odpływie wód roztopowych podczas zlodowacenia vistuliańskiego, „Studia Societatis Scientiarum Torunensis”, C 10, 6, $172 \mathrm{~s}$.

Molewski P., 2007, Neotektoniczne i glacjodynamiczne uwarunkowania wykształcenia plejstocenu Wysoczyzny Kujawskiej, Wyd. UMK, Toruń, 140 s.

Moon T., Joughin I., Smith B., Howat I., 2012, 21 $1^{\text {st }}$-Century Evolution of Greenland Outlet Glacier Velocities, "Science”, 336, 576-578.

Morland L.W., Boulton G.S., 1975, Stress in an elastic hump: the effects of glacier flow over elastic bedrock, „Proceedings of the Royal Society London”, A, 344, 157-173.

Morse J.W., Arvidson R.S., 2002, The dissolution kinetics of major sedimentary carbonate minerals, „Earth-Science Reviews", 58, 51-84.

Münnich G., 1936, Quantitative Geschiebeprofile aus Dänemark und Nordostdeutschland mit besonderer Berücksichtigung Vorpommerns, „Abhandlungen aus dem geologisch-paläontologischen Institut Universität Greifswald", 15, 1-52.

Munyikwa T., 2014, Luminescence Chronology, [w:] N.-A. Morner (red.), Geochronology: Methods and Case Studies, 31-71.

Murray T., 1997, Assessing the paradigm shift: deformable glacier beds, "Quaternary Science Reviews", 16, 995-1016.

Murton J.B., French H.M., 1994, Cryostructures in permafrost, Tuktoyaktuk Coastlands, Western Arctic Cana$d a$, , Canadian Journal of Earth Sciences”, 31, 737-747.

Murton J.B., Whiteman C.A., Waller R.I., Pollard W.H., Clark I.D., Dallimore S.R., 2005, Basal ice facies and supraglacial melt-out till of the Laurentide Ice Sheet, Tuktoyaktuk Coastlands, western Arctic Canada, "Quaternary Science Reviews", 24, 681-708.

Narloch W., Piotrowski J.A., Wysota W., Larsen N.K., Menzies J., 2012, The signature of strain magnitude in tills associated with the Vistula Ice Stream of the Scandinavian Ice Sheet, central Poland, "Quaternary Science Reviews", 57, 105-120.

Narloch W., Wysota W., Piotrowski J.A., 2013, Sedimentological record of subglacial conditions and ice sheet dynamics of the Vistula Ice Stream (north-central Poland) during the Last Glaciation, "Sedimentary Geology", 293, 30-44.

Nechay W., 1927a, O prq̨dach w lq̨dolodzie, II Zjazd Słowiańskich Geografów i Etnografów w Polsce, Sekcja II Geomorfologja i Geologja, Warszawa-Kraków, 3 strony nienumerowane.

Nechay W., 1927b, Utwory lodowcowe Ziemi Dobrzyńskiej, „Sprawozdania Państwowego Instytutu Geologicznego", 4, 1-2, 61-144.

Nenonen K., 1995, Pleistocene stratigraphy of Southern Finland, [w:] J. Ehlers, S. Kozarski, P. Gibbard (red.), Glacial deposits of North-East Europe, A.A. Balkema, Rotterdam-Brookfield, 11-28. 
Nesje A., Dahl S.O., Valen V., Øvstedal J., 1992, Quaternary erosion in the Sognefjord drainage basin, western Norway, "Geomorphology”, 5, 511-520.

Nielsen A.T., Schovsbo N.H., 2007, Cambrian to basal Ordovician lithostratigraphy in southern Scandinavia, „Bulletin of the Geological Society of Denmark”, 53, 47-92.

Niewiarowski W., 1995, Diagnostic features of subglacial channel of glacial and glaciofluvial origin exampled by channels of the Chetmno-Dobrzyń and the eastern Gniezno Lakelands, "Quaestiones Geographicae", Sp. Iss., 4, 225-231.

Nobles L.H., Weertman J., 1971, Influence of irregularities of the bed of an ice-sheet on deposition rate of till, [w:] R.P. Goldthwait (red.), Till a Symposium, Ohio State University Press, 117-126.

Noe-Nygaard A., 1975, Erratics of the Danish Maastrichtian and Danian marine limestones, „Bulletin of the Geological Society of Denmark", 24, 75-81.

Noormets R., Flodén T., 2002, Glacial deposits and ice-sheet dynamics in the north-central Baltic Sea during the last deglaciation, „Boreas”, 31, 362-377.

Nunberg J., 1971, Próba zastosowania metod statystycznych do badań zespołu głazów fennoskandyjskich występujqcych w utworach glacjalnych północno-wschodniej Polski, „Studia Geologica Polonica”, 37, $1-103$.

Nunberg J., 1979, Erratics selection index as a value determining the origin of marginal forms and glacial sediments, "Quaternary Studies in Poland", 1, 65-69.

Nygård A., Sejrup H.P., Haflidason H., Lekens W.A.H., Clark C.D., Bigg G.R., 2007, Extreme sediment and ice discharge from marine-based ice streams: new evidence from the North Sea, "Geology", 35, 395-398.

Ó Cofaigh C., Dowdeswell J.A., Evans J., Larter R.D., 2008, Geological constraints on Antarctic palaeo-ice stream retreat, „Earth Surface Processes and Landforms", 33, 513-525.

Ó Cofaigh C., Evans D.J.A., Smith I.R., 2010, Large-scale reorganization and sedimentation of terrestrial ice streams during late Wisconsinan Laurentide Ice Sheet deglaciation, „Geological Society of America Bulletin", 122, 743-756.

Ó Cofaigh C., Taylor J., Dowdeswell J.A., Pudsey C.J., 2003, Palaeo-ice streams, trough-mouth fans and high latitude continental slope sedimentation, „Boreas”, 32, 37-55.

Obst K., 2001, Kullaite und ihre Bedeutung als Leitgeschiebe, „Geschiebekunde aktuell”, 17, 2/3 [Festschrift 65 Jahre Deutsches Archiv für Geschiebeforschung], 75-84.

Oftedahl C., 1981, Norges geologi, Tapir, Trondheim, $169 \mathrm{~s}$.

Olszewski A., 1974, Jednostki litofacjalne glin subglacjalnych nad dolnq Wisła w świetle analizy ich makrotekstur i makrostruktur, „Studia Societatis Scientiarum Torunensis”, sec. C, 8, 2, 1-145.

Olvmo M., Johansson M., 2002, The significance of rock structure, lithology and pre-glacial deep weathering for the shape of intermediate-scale glacial erosional landforms, „Earth Surface Processes and Landforms", $27,251-268$.

Olvmo M., Lidmar-Bergström K., Lindberg G., 1999, The glacial impact on an exhumed sub-Mesozoic etch surface in southwestern Sweden, „Annals of Glaciology”, 28, 153-160.

Orłowski A., 2008, Poligenetyczne obniżenia podczwartorzędowe i porwaki w osadach plejstoceńskich między Wieprzq a Łupawq, „Landform Analysis", 7, 119-129.

Ostaficzuk S., 2001, Podziemne magazynowanie energii cieplnej, Technika Poszukiwań Geologicznych, „Geosynoptyka i Geotermia", 40, 5, 89-94.

Ottesen D., Rise L., Knies J., Olsen L., Henriksen S., 2005, The Vestfjorden-Trænadjupet palaeo-ice stream drainage system, mid-Norwegian continental shelf, "Marine Geology", 218, 175-189.

Ottesen D., Stokes C.R., Rise L., Olsen L., 2008, Ice-sheet dynamics and ice streaming along the coastal parts of northern Norway, "Quaternary Science Reviews", 27, 922-940.

Overeem I., Bishop C., Weltje G.J., Kroonenberg S.B., 2001, The Late Cenozoic Eridanos delta system in the southern North Sea basin Basin: a climate signal in sediment supply?, „,Basin Research”, 13, 293-312. 
Overweel C.J., 1977, Distribution and transport of Fennoscandinavian indicators, „Scripta Geologica”, 43, 1-117.

Parent M., Paradis S.J., Boisvert W., 1995, Ice-flow patterns and glacial transport in the eastern Hudson Bay region: implications for the Late Quaternary dynamics of the Laurentide Ice Sheet, "Canadian Journal of Earth Sciences", 32, 12, 2057-2070.

Parent M., Paradis S.J., Doiron A., 1996, Palimpsest glacial dispersal trains and their significance for drift prospecting, „Journal of Geochemical Exploration”, 56, 123-140.

Paterson W.S.B., 1981, The physics of glaciers, Pergamon Press, Oxford, $380 \mathrm{~s}$.

Paterson W.S.B., 1994, The Physics of Glaciers, $3^{\text {rd }}$ Edition, Pergamon Press, Oxford, 480 s.

Patterson C.J., 1997, Southern Laurentide ice lobes were created by ice streams: Des Moines Lobe in Minnesota, USA, „Sedimentary Geology”, 111, 249-261.

Patterson C.J., 1998, Laurentide glacial landscapes: the role of ice streams, „Geology”, 26, 643-646.

Pattyn F., 2003, A new three-dimensional higher-order thermomechanical ice sheet model: basic sensitivity, ice stream development, and ice flow across subglacial lakes, "Journal of Geophysical Research-Solid Earth", 108, 2382-2396.

Pattyn F., 2010, Antarctic subglacial conditions inferred from a hybrid ice sheet/ice stream model, „Earth and Planetary Science Letters", 295, 451-461.

Pawlak W. (red.), 1997, Atlas Ślqqska Dolnego i Opolskiego, Uniwersytet Wrocławski, Polska Akademia Nauk Oddział we Wrocławiu, Wrocław, $8+\mathrm{XII}+117 \mathrm{~s}$.

Pawłowska K., Greenfield H., Czubla P., 2014, 'Steppe' mammoth (Mammuthus trogontherii) remains in their geological and cultural context from Betchatów (Poland): A consideration of human exploitation in the Middle Pleistocene, "Quaternary International”, 326-327, 448-468.

Payne A.J., 1995, Limit cycles in the basal thermal regime of ice sheets, „Journal of Geophysical Research”, 100, B3, 4249-4263.

Payne A.J., Baldwin D.J., 1999, Thermomechanical modeling of the Scandinavian ice sheet: implications for ice-stream formation, „Annals of Glaciology”, 28, 83-89.

Payne A.J., Vieli A., Shepherd A.P., Wingham D.J., Rignot E., 2004, Recent dramatic thinning of largest West-Antarctic ice stream triggered by oceans, "Geophysical Research Letters", 31, L23401.

Peltoniemi H., 1985, Till lithology and glacial transport in Kuhmo, eastern Finland, „Boreas”, 14, 67-74.

Pertunnen M., 1977, The lithologic relation between till and bedrock in the region of Hämeenlinna, southern Finland, "Geological Survey of Finland Bulletin”, 291, $68 \mathrm{~s}$.

Pertunnen M., 1989, Transportation of garnets in glaciofluvial deposits in southeastern Finland, [w:] R.N.W. DiLabio, W.B. Coker (red.), Drift Prospecting, "Geological Survey of Canada Paper”, 89-20, 13-20.

Petersen G., 1924, Die Schollen der norddeutschen Moränen in ihrer Bedeutung für die diluvialen Krustenbewegungen, „Fortschritte der Geologie und Palaeontologie”, 9, 179-274.

Petersen H.I., Nielsen L.H., Bidstrup T., Thomsen E., 2003, Burial depth and post-Early Cretaceous uplift of Lower-Middle Jurassic strata in the Fennoscandian Border Zone based on organic maturity, [W:] J.R. Ineson, F. Surlyk (red.), The Jurassic of Denmark and Greenland, "Geological Survey of Denmark and Greenland Bulletin", 1, 611-630.

Phemister J., 1926, The distribution of Scandinavian Boulders in Britain, „The Geological Magazine”, 63, 10, 433-454.

Pidek I.A., Zieliński T., Terpiłowski S., Czubla P., Hrynowiecka A., Kusiak J., Godlewska A., Zieliński P., Małek M., 2013, Unique features of interglacial deposits (MIS 11, E-Poland); comparison of palaeobotanical and geological data, [w:] R. Rocha, J. Pais, J.C. Kullberg, L. Castro, P. Caetano, P. Legoinha (red.), STRATI 2013 $1^{\text {st }}$ International Congress on Stratigraphy "On the cutting edge of stratigraphy", Lisboa 1-7 July 2013 (abstracts of the Congress held in Portugal), "Ciências da Terra", Vol. Esp. VII, 93-93.

Pidek I.A., Zielinski T., Terpilowski S., Czubla P., Hrynowiecka A., Kusiak J., Godlewska A., Zielinski P., Małek M., 2014, Unique Features of Interglacial Deposits (MIS 11, E Poland): Comparison of Palaeobotanical and 
Geological Data, [w:] R. Rocha, J. Pais, J.C. Kullberg, S. Finney (red.), STRATI 2013 First International Congress on Stratigraphy. At the cutting edge of Stratigraphy, Springer, 569-572.

Piotrowski J.A., Mickelson D.M., Tulaczyk S., Krzyszkowski D., Junge F.W., 2001, Were deforming subglacial beds beneath past ice sheets really widespread?, „Quaternary International”, 86, 139-150.

Piotrowski J.A., Mickelson D.M., Tulaczyk S., Krzyszkowski D., Junge F.W., 2002, Reply to the comments by G.S. Boulton, K.E. Dobbie, S. Zatsepin on: Deforming soft beds under ice sheets: how extensive were they?, „Quaternary International”, 97-98, 173-177.

Piotrowski J.A., Larsen N.K., Junge F.W., 2004, Reflections on soft subglacial beds as a mosaic of deforming and stable spots, „Quaternary Science Reviews”, 23, 993-1000.

Plouffe A., Anderson R.G., Gruenwald W.,Davis W.J., Bednarski J.M., Paulen R.C., Fisher T. 2011, Integrating ice-flow history, geochronology, geology, and geophysics to trace mineralized glacial erratics to their bedrock source: An example from south-central British Columbia, "Canadian Journal of Earth Sciences”, 48, 6, 1113-1129.

Pollard D., DeConto R.M., Nyblade A.A., 2005, Sensitivity of Cenozoic Antarctic ice sheet variations to geothermal heat flux, „Global and Planetary Change”, 49, 63-74.

Pólya G., 1920, Über den zentralen Grenzwertsatz der Wahrscheinlichkeitsrechnung und das Momentenproblem, „Mathematische Zeitschrift”, 8, 171-181.

Postelmann A., 1936, Der „Hindenburgstein” für das Reichsehrenmal in Tannenberg, „Zeitschrift für Geschiebeforschung und Flachlandsgeologie", 12, 1, 1-32.

Prest V.K., Donaldson J.A., Mooers H.D., 2000, The omar story: the role of omars in assessing glacial history of west-central North America, "Géographie physique et Quaternaire”, 54, 3, 257-270.

Prest V.K., Nielsen E., 1985, The Laurentine ice sheet and long-distance transport, [w:] R. Kujansuu, M. Saarnisto (red.), INQUA Till Symposium, „Geological Survey of Finland Special Paper”, 3, 91-101.

Pulkkinen E., 1996, Sallan kartta-alueen kallioperä (in Finnish), summary: Results of the regional geochemical survey of till in the Salla area, eastern Finnish Lapland, Geological Survey of Finland, Explanary notes to geochemical maps, Sheet 46, $43 \mathrm{~s}$.

Punkari M., 1984, The relations between glacial dynamics and tills in the eastern part of the Baltic Shield, „Striae”, 20, 49-54.

Punkari M., 1993, Modelling of the dynamics of the Scandinavian ice sheet using remote sensing and GIS methods, [w:] J.S. Aber (red.), Glaciotectonics and Mapping Glacial Deposits, Proceedings of the INQUA Commission on Formation and Properties of Glacial Deposits, Regina, Canadian Plains Research Center, 232-250.

Punkari M., 1997, Glacial and glaciofluvial deposits in the interlobate areas of the Scandinavian ice sheet, „Quaternary Science Reviews”, 16, 7, 741-753.

Puranen R., 1990, Modelling of glacial transport of tills, [w:] R. Kujansuu, M. Saarnisto (red.), Glacial Indicator Tracing, Rotterdam, A.A. Balkema, 15-34.

Racinowski R., 2010, Główne przezroczyste minerały ciężkie w osadach czwartorzędowych Polski, „Biuletyn Państwowego Instytutu Geologicznego", 438, 99-105.

Racinowski R., Rzechowski J., 1969, Minerały ciężkie w glinach zwałowych Polski środkowej, „Kwartalnik Geologiczny", 13, 479-490.

Rappol M., 1987, Saalian till in The Netherlands: A review, [w:] J.J.M. van der Meer (red.), Tills and Glaciotectonics, A.A. Balkema, Rottedam, 3-21.

Rasmussen E.S., Heilmann-Clausen C., Waagstein R., Eidvin T., 2008, The Tertiary of Norden, „Episodes”, 31, 1, 66-72.

Rastas J., Seppälä M., 1981, Rock jointing and abrasion forms on roches moutonnées, SW Finland, „Annals of Glaciology", 2, 159-163.

Ratajczak M., 2007, Geologia i geneza piasków, żwirów i glin lodowcowych - fizyczne warunki sedymentacji w rzekach lodowcowych, w spływach mas oraz pod lodem lodowcowym (stanowisko Dębówko Nowe), 
[w:] L. Kasprzak (red.), Strefy glacimarginalnej Wielkopolski - zapis sedymentacyjny i ekspresja morfologiczna, Stowarzyszenie Geomorfologów Polskich, 113-118.

Rauhaniemi T., Huhta P., Salonen V.-P., 1999, Map of glacial flow indicators in Finland, „Geological Survey of Finland Special Paper", 27, 55-59.

Raukas A., 1971, Dno vostočnoj časti Finskogo zaliva i ostrov Suursaari (Gogland), [w:] V. Gudelis (red.), Kristalličeskije rukovodiaščije vałuny Pribaltiki, Izd. Mintis, Vilnius, 35-37.

Raukas A., 1995, Estonia - a land of big boulders and rafts, „Quaestiones Geographicae”, SI 4, 247-253.

Raukas A., Teedumäe A. (red.), 1997, Geology and Mineral Resources of Estonia, Estonian Academy Publishers, Tallinn, $436 \mathrm{~s}$.

Rdzany Z., 1997, Kształtowanie rzeźby terenu między górnq Rawkq a Pilicq w czasie zaniku lqqdolodu warciańskiego, „Acta Geographica Lodziensia”, 73, 1-146.

Rdzany Z., 2004, Formy marginalne lobu Rawki miedzy Inowłodzem a Nowym Miastem nad Pilica na tle poglądów na zasięg lqqdolodu zlodowacenia warty, [w:] M. Harasimiuk, S. Terpiłowski (red.), Zlodowacenie warty w Polsce, UMCS, Lublin, 87-102.

Rdzany Z., 2009, Rekonstrukcja przebiegu zlodowacenia warty w regionie łódzkim, Wydawnictwo Uniwersytetu Łódzkiego, Łódź, $310 \mathrm{~s}$.

Rea B.R., 1994, Joint control in the formation of rock steps in the subglacial environment, [w:] D.A. Robinson, R.B.G. Williams (red.), Rock Weathering and Landform Evolution, John Wiley, London, 473-486.

Reading H.G., 1996, Sedimentary Environments: Processes, Facies and Stratigraphy, Blackwell Science, Oxford, $688 \mathrm{~s}$.

Reinardy B.T.I., Larter R.D., Hillenbrand C.-D., Murray T., Hiemstra J.F., Booth A.D., 2011, Streaming flow of an Antarctic Peninsula palaeo-ice stream, both by basal sliding and deformation of substrate, „Journal of Glaciology", 57 (204), 596-608.

Reinhard H., 1967, Geschiebeverfrachtung durch Eisschollen, „Wissenschaftliche Zeitschrift der Ernst-Moritz-Arnt-Universität Greifswald”, Math. Naturw. R., 16, 209-220.

Retzlaff R., Bentley C.R., 1993, Timing of stagnation of Ice Stream C, West Antarctica, from short pulse radar studies of buried surface crevasses, „Journal of Glaciology”, 39 (133), 553-561.

Richter K., 1933, Gefüge und Zusammensetzung des Norddeutschen Jungmoränengebietes, „Abhandlungen aus dem geologisch-palaeontologischen Institut Greifswald", 11, 1-63.

Richter K., 1937, Die Eiszeit in Norddeutschland, Gebrüder Borntraeger, Berlin, $179 \mathrm{s.}$

Richter K., 1958, Geschiebegrenzen und Eisrandlagen in Niedersachsen, „Geologisches Jahrbuch”, 76, 223-234.

Rignot E., 2008, Changes in West Antarctic ice stream dynamics observed with ALOS PALSAR data, "Geophysical Research Letters", 35, L12505.

Rignot E., Kanagaratnam P., 2006, Changes in the Velocity Structure of the Greenland Ice Sheet, "Science”, 311, 986-990.

Rignot E., Mouginot J., Scheuchl B., 2011, Ice Flow of the Antarctic Ice Sheet, „Science”, 333, 1427-1430.

Ringberg B., Holland B., Miller U., 1984, Till stratigraphy and provenance of the glacial chalk rafts at Kvarnby and Ängdala, southern Sweden, „Striae”, 20, 79-90.

Roberts D.H., Dackombe R.V., Thomas G.S.P., 2007, Palaeo-ice streaming in the central sector of the British Irish Ice Sheet during the Last Glacial Maximum: evidence from the northern Irish Sea Basin, „Boreas”, 36, 115-129.

Roberts M.J., Tweed F.S., Russell A.J., Knudsen Ó., Lawson D.E., Larson G.J., Evenson E.B., Björnsson H., 2002, Glaciohydraulic supercooling in Iceland, "Geology”, 30, 439-442.

Robin G. de Q., 1976, Is the basal ice of a temperate glacier at the pressure melting point?, „Journal of Glaciology", 16 (74), 183-196.

Rohde A., 2007, Fossilien sammeln an der Ostseeküste; Trilobiten, Seeigel, Donnerkeile und Co. Fossilführende Gesteine des südwestlichen Ostseeraumes, Wachholz Verlag, Neumünster, $224 \mathrm{~s}$. 
Rohde A., 2008, Auf Fossiliensuche an der Ostsee; Gesteine - Fossilien - Fundmöglichkeiten, Wachholtz Verlag, Neumünster, $272 \mathrm{~s}$.

Ronnert L., Mickelson D.M., 1992, High porosity of basal till at Burroughs glacier, southeastern Alaska, „Geology”, 20, 849-852.

Ross M., Campbell J.E., Parent M., Adams R.S., 2009, Palaeo-ice streams and the subglacial landscape mosaic of the North American mid-continental prairies, „Boreas”, 38, 421-439.

Ross S.M., 2009, Introduction to Probability and Statistics for Engineers and Scientists (4 ${ }^{\text {th }}$ ed.), Elsevier Academic Press, $664 \mathrm{~s}$.

Rötlisberger H., 1968, Erosive processes which are likely to accentuate or reduce the bottom relief at valley glaciers, IASH Pub., 79 (General Assembly of Bern 1967 - Snow and Ice), 87-97.

Rötlisberger H., Iken A., 1981, Plucking as an effect of water-pressure variations at the glacier bed, „Annals of Glaciology", 2, 56-62.

Różycki S.Z., 1965, Die stratigraphische Stellung des Warthe-Stadiums in Polen, „Eiszeitalter und Gegenwart”, 16, 189-201.

Różycki S.Z., 1967, Plejstocen Polski Środkowej, PWN, Warszawa, 251 s.

Różycki S.Z., 1972, Plejstocen Polski środkowej na tle przeszłości w górnym trzeciorzędzie, PWN, Warszawa, $316 \mathrm{~s}$.

Rudberg S., 1973, Glacial erosion forms of medium size - a discussion based on four Swedish case studies, „Zeitschrift für Geomorphologie”, Suppl. Bd., 17, 33-48.

Rudberg S., 1978, Der Einfluss der Vereisungen auf die Gestaltung des heutigen Reliefs von Skandinavien, „Schriftenreihe geologische Wissenschaften”, 9, 257-289.

Rudnicka J., 1969, Statisticzeskij metod issledovanija sostava i rasprostranienija fiennokandinavskich eraticzeskich vałunov w lednikovych otłożenijach, „Zeszyty Naukowe UAM”, Seria Geografia, 8, 177-185.

Rudolph F., 2008a, Strandsteine; Sammeln und Bestimmen von Steinen an der Ostseeküste (8. Wyd.), Wachholz Verlag, Neumünster, $160 \mathrm{~s}$.

Rudolph F., 2008b, Noch mehr Strandsteine; Sammeln und Bestimmen von Steinen an der Nord- und Ostseeküste und im Binnenland, Wachholz Verlag, Neumünster, $224 \mathrm{~s}$.

Rundle J.B., Jackson D.D., 1977, Numerical simulation of earthquake sequences, „Bulletin of the Seismological Society of America", 67, 5, 1363-1377.

Ruszczyńska-Szenajch H., 1976, Glacitektoniczne depresje i kry lodowcowe na tle budowy geologicznej SW-Mazowsza i S-Podlasia, „Studia Geologica Polonica”, 50, 7-92.

Ruszczyńska-Szenajch H., 1987, The origin of glacial rafts: detachment, transport, deposition, „Boreas”, 16, 101-112.

Rutkowski J., 2007, Petrografia żwirów - możliwości badawcze i podstawy interpretacji wyników, [w:] E. Mycielska-Dowgiałło, J. Rutkowski (red.), Badania cech tekstualnych osadów czwartorzędowych $i$ wybrane metody oznaczania ich wieku, Wyd. Szkoły Wyższej Przymierza Rodzin, Warszawa, 45-74.

Ryka W., Maliszewska A., 1991, Słownik petrograficzny, Wydawnictwa Geologiczne, Warszawa, $416 \mathrm{~s}$.

Rzechowski J., 1971, Granulometryczno-petrograficzne właściwości glin zwałowych w dorzeczu środkowej Widawki, „Biuletyn Instytutu Geologicznego”, 254 (Z badań czwartorzędu w Polsce, 13), 111-156.

Saarnisto M., 1990, An outline of glacial indicator tracing, [w:] R. Kujansuu, M. Saarnisto (red.), Glacial Indicator Tracing, A.A. Balkema, Rotterdam/Brookfield, 1-13.

Saarnisto M., Salonen V.-P., 1995, Glacial history of Finland, [w:] J. Ehlers, S. Kozarski, P. Gibbard (red.), Glacial deposits of North-East Europe, A.A. Balkema, Rotterdam/Brookfield, 3-10.

Salonen V.-P., 1986, Glacial transport distance distributions of surface boulders in Finland, „Geological Survey of Finland Bulletin", 338, 1-57.

Salonen V.-P., 1987, Observations on boulders transport in Finland, „Geological Survey of Finland Special Paper", 3, 103-110. 
Salonen V.-P., 1991, Glacial dispersal of Jotnian sandstone fragments in southwestern Finland, "Geological Survey of Finland Special Paper", 12, 127-130.

Saltzman B., 2002, Dynamical Paleoclimatology: Generalized Theory of Global Climate Change, Academic Press, $354 \mathrm{~s}$.

Samyn D., Svensson A., Fitzsimons S.J., Lorrain R.D., 2005, Ice crystal properties of amber ice and strain enhancement at the base of cold Antarctic glaciers, „Annals of Glaciology”, 40, 185-190.

Sauer E.K., 1978, The engineering significance of glacier ice-thrusting, "Canadian Geotechnical Journal”, 15, 457-472.

Sauramo M., 1924, Tracing of Glacial Boulders and its Application in Prospecting, „Bulletin de la Commission géologique de Finlande", 67, 1-37.

Saussure H.-B. de, 1779-1796, Voyages dans les Alpes (in 4 Vol.), Neuchâtel/Genève (Fauche-Borel).

Saussure H.-B. de, 1786, Voyages dans les Alpes précédés d'un essai sur l'histoire naturelle des environs de Genève, Tome second, 641s., Neuchâtel (Fauche-Borel).

Sawicki L. (red.), 1995, Mapa geologiczna regionu dolnoślqskiego z przyległymi obszarami Czech i Niemiec (bez utworów czwartorzędowych) 1 : 100 000, Państwowy Instytut Geologiczny, Warszawa.

Sawicki L. (red.), 1997a, Mapa geologiczna regionu dolnoślqaskiego z przyległymi obszarami Czech i Niemiec 1:100 000; Podstawy litostratygraficzne i kodyfikacja wydzieleń, Państwowy Instytut Geologiczny, Warszawa, $181 \mathrm{s.}$

Sawicki L., 1997b, Utwory starsze od czwartorzędu, [w:] W. Pawlak (red.), Atlas Ślq̨ska Dolnego i Opolskiego, Uniwersytet Wrocławski, Polska Akademia Nauk - Oddział we Wrocławiu, Wrocław, 13-14.

Schallreuter R., 1997, Sedimentärgeschiebe als Leitgeschiebe, „Archiv für Geschiebekunde”, 2, 3, 146.

Schallreuter R., 1998, Klastenforschung unter besonderer Berücksichtigung der Geschiebeforschung, „Archiv für Geschiebekunde", 2, 5, 265-322.

Schuddebeurs A.P., 1958, Erosie en transport van gesteenten door gletschers en landijs, „Grondboor en Hamer", 4, 6/7, 129-142.

Schuddebeurs A.P., 1980/1981, Die Geschiebe im Pleistozän der Niederlande, „Der Geschiebesammler”, 13, 163-178; 14, 33-40, 91-118, 147-198; 15, 73-90, 137-157, 181-187.

Schuddebeurs A.P., 1980, Over enkele Noord-Nederlandse zwerfsteen-gezelschappen, „Grondboor en Hamer”, 2, 51-64.

Schuddebeurs A.P., 1981, Results of counts of Fennoscandinavian erratics in The Netherlands, „Mededelingen Rijks Geologische Dienst", 34-3, 10-14.

Schuddebeurs A.P., 1986, Einige Bemerkungen zu K.D. Meyers: "Zur Methodik und über den Wert von Geschiebezählungen”, „Der Geschiebesammler”, 19, 4, 151-156.

Schuddebeurs A.P., Zandstra J.G., 1983, Indicator pebble counts in The Netherlands, [w:] J. Ehlers (red.), Glacial deposits in North-West Europe, Balkema, Rotterdam, 357-360.

Schuddebeurs A.P., Zwenger W.H., 1992, Trebuser zandsteen, "Grondboor en Hamer", 4/5/6, 106-118.

Schulz W., 1973, Rhombenporphyr-Geschiebe und deren östliche Verbreitungsgrenze im nordeuropäischen Vereisungsgebiet, „Zeitschrift für Geologische Wissenschaften”, 9, 1, 1141-1154.

Schulz W., 1996, Zur Bedeutung der Korngröße bei Geschiebezählungen, „Der Geschiebesammler” 29, 3, 91102.

Schulz W., 1999, Der baltische Bernstein in quartären Sedimenten, eine Übersicht über die Vorkommen, die größten Funde und die Bernstein-Museen, „Archiv für Geschiebekunde”, 2, 7, 459-478.

Schulz W., 2003, Geologischer Führer für den norddeutschen Geschiebesammler, cw Verlagsgruppe, Schwerin, $508 \mathrm{~s}$.

Sederholm J.J., 1911, Sur la géologie quaternaire et la géomorphologie de la Fennoscandia, „Bulletin de la Commission Géologique de Finlande”, 30, 66 s. (to samo powtórzone w: „Fennia, Societas Geographica Fenniae", 30, 5, 66 s.). 
Sharp M., 1988, Surging glaciers: geomorphic effects, „Progress Physical Geography”, 12, 4, 533-559.

Sharp M., Jouzel J., Hubbard B., Lawson W., 1994, The character, structure and origin of the basal ice layer af a surge-type glacier, „Journal of Glaciology”, 40 (135), 327-340.

Sharpe D.R., 1988, Late glacial landforms of Wollaston Peninsula, Victoria Island, Northwest Territories: Product of ice-marginal retreat, surge, and mass stagnation, "Canadian Journal of Earth Sciences", 25, 2, 262-279.

Sharpe D.R., Shaw J., 1989, Erosion of bedrock by subglacial meltwater, Cantley, Quebec, "Geological Society of America Bulletin", 101, 1011-1020.

Shaw J., Piper D.J. W., Fader G.B.J., King E.L., Todd B.J., Bell T., Batterson M.J., Liverman D.G.E., 2006, A conceptual model of the deglaciation of Atlantic Canada, "Quaternary Science Reviews", 25, 20592081.

Shilts W.W., 1973, Glacial dispersal of rocks, minerals and trace elements in Wisconsinan till, southeastern Quebec, Canada, [w:] R.F. Black, R.P. Goldwaith, H.B. Wilmann (red.), The Wisconsinan Stage, "Geological Society of America, Memoir", 136, 189-219.

Shilts W.W., 1976, Glacial till and mineral exploration, [w:] R.F. Leggett (red.), Glacial till, „Royal Society of Canada Special Publication", 12, 205-224.

Shilts W.W., 1980, Flow patterns in the central North American ice sheet, „Nature”, 286, 213-218.

Shilts W.W., 1982, Glacial dispersal; principles and practical applications, "Geoscience Canada", 9, 42-47.

Shilts W.W., 1993, Geological Survey of Canada's contribution to understanding the composition of glacial sediments, "Canadian Journal of Earth Sciences", 30, 333-353.

Shoemaker E.M., 1988, On the formulation of basal debris drag for the case of sparse debris, „Journal of Glaciology", 34 (118), 259-264.

Shreve R.L., 1984, Glacier sliding at subfreezing temperatures, „Journal of Glaciology”, 30 (106), 341-347.

Shuster D.L., Cuffey K.M., Sanders J.W., Balco G., 2011, Thermochronometry Reveals Headward Propagation of Erosion in an Alpine Landscape, "Science”, 332, 84-88.

Shuster D.L., Ehlers T.A., Rusmore M.E., Farley K.A., 2005, Rapid Glacial Erosion at 1.8 Ma Revealed by ${ }^{4} \mathrm{He}$ 队 He Thermochronometry, „Science”, 310, 1668-1670.

Siegert M.J., Dowdeswell J.A., 2004, Numerical reconstructions of the Eurasian Ice Sheet and climate during the Late Weichselian, „Quaternary Science Reviews”, 23, 11-13, 1273-1283.

Siegert M.J., Welch B., Morse D., Vieli A., Blankenship D.D., Joughin I., King E.C., Leysinger Vieli G.J.-M.C., Payne A.J., Jacobel R., 2004, Ice Flow Direction Change in Interior West Antarctica, „Science”, 305, 19481951.

Siegesmund S., Ullemeyer K., Weiss T., Tschegg E., 2000, Physical weathering of marbles caused by thermal anisotropic expansion, „International Journal of Earth Science”, 89, 170-182.

Simonen A., 1960, Pre-Quaternary rocks in Finland, „Bulletin de la Commission Géologique de Finlande”, 191, 1-49, Helsinki.

Šliaupa S., Hoth P., 2011, Geological Evolution and Resources of the Baltic Sea Area from the Precambrian to the Quaternary, [w:] J. Harff, S. Björck, P. Hoth (red.), The Baltic Sea Basin, Central and Eastern European Development Studies, Springer Verlag, Berlin, Heidelberg, 13-51.

Smed P., 1993, Indicator studies: a critical review and a new data-presentation method, „Bulletin of the Geological Society of Denmark", 40, 3-4, 332-344.

Smed P., 1994, 2002 (2. wyd.), Steine aus dem Norden: Geschiebe als Zeugen der Eiszeit in Norddeutschland, (tłumaczył z duńskiego i opracował J. Ehlers), Gebrüder Borntraeger, Berlin-Stuttgart, $194 \mathrm{~s}$.

Smed P., 1997, Kommentare zu Leitgeschiebezählmethoden, „Archiv für Geschiebekunde”, 2, 3, 141-145.

Smed P., 2000, Über den Hesemann-Milthers-Streit und die von Hesemann verwendete Abbildungsmethode für Geschiebezählungen. Ein Kommentar zu Gerhard Schönes Artikel in Geschiebekunde aktuell 16 (2), "Geschiebekunde aktuell", 16, 4, 127-131. 
Smed P., 2010, Indicator count methods tested out on Møn, Denmark, „Quaternary Science Journal” (Eiszeitalter und Gegenwart), 59, 1-2, 76-87.

Smith A.M., Murray T., 2009, Bedform topography and basal conditions beneath a fast-flowing West Antarctic ice stream, "Quaternary Science Reviews", 28, 584-596.

Smith A.M., Murray T.M., Nicholls K.W., Makinson K., Adalgeirsdóttir G., Behar A.E., Vaughan D.G., 2007, Rapid erosion, drumlin formation, and changing hydrology beneath an Antarctic ice stream, "Geology", 35, 127-130.

Spedding N., Evans D.J.A., 2002, Sediments and landforms at Kviárjökull, south-east Iceland: a reappraisal of the glaciated valley landsystem, "Sedimentary Geology”, 149, 1-3, 21-42.

Staiger J.K.W., Gosse J.C., Johnson J.V., Fastook J., Gray J.T., Stockli D.F., Stockli L., Finkel R., 2005, Quaternary relief generation by polythermal glacier ice, „Earth Surface Processes and Landforms”, 30, 1145-1159.

Stalker A., Mac S., 1976, Megablocks, or the enormous erratics of the Albertan Prairies, "Geological Survey of Canada Paper", 76-1C, 185-188.

Stankowska A., 1979, Stratygraficzne i regionalne zróżnicowanie glin morenowych na terenie Polski w świetle badań minerałów ilastych, UAM Geografia, 17, $225 \mathrm{~s}$.

Stankowski W., 1983, Selected aspects of the dynamics of an ice sheet as exemplified by the Vistulian glaciations (a discussion), "Quaestiones Geographicae”, 9, 137-144.

Stanley S.M., 2002, Historia Ziemi, Wydawnictwo Naukowe PWN, Warszawa, 705 s.

Stanisz A., 1998, Przystępny kurs statystyki w oparciu o program STATISTICA na przykładach z medycyny, tom 1, StatSoft Polska, Kraków, $362 \mathrm{~s}$.

Stanisz A., 2007, Przystępny kurs statystyki z zastosowaniem STATISTICA PL na przykładach z medycyny. Tom 2. Modele liniowe i nieliniowe, StatSoft, Kraków, $868 \mathrm{~s}$.

Stea R.R., Finck P.W., 2001, An evolutionary model of glacial dispersal and till genesis in Maritime Canada, [w:] M.B. McClenaghan, P.T. Bobrowsky, G.E.M. Hall, S.J. Cook (red.), Drift Exploration in Glaciated Terrain, The Geological Society of London, London, 237-265.

Stearns L.A., Smith B.E., Hamilton G.S., 2008, Increased flow speed of a large East Antarctic outlet glacier caused by subglacial floods, „Nature Geoscience”, 1, 827-831.

Stephan H.J., 1987, Moraine stratigraphy in Schleswig-Holstein and adjacent areas, [w:] J.J.M. van der Meer (red.), Tills and Glaciotectonics, A.A. Balkema, Rottedam, 23-30.

Stephan H.J., Ehlers J., 1983, North German till types, [w:] J. Ehlers (red.), Glacial Deposits in North-West Europe, Rotterdam, Balkema, 239-247.

Stephani E., Fortier D., Shur Y., 2010, Applications of cryofacies approach to frozen ground engineering - Case study of a road test site along the Alaska Highway (Beaver Creek, Yukon, Canada), [w:] Join $63^{\text {rd }}$ Canadian Geotechnical Conference and $6^{\text {th }}$ Canadian Permafrost Conference, September 12-16, 2010, Calgary, Canada, 476-483.

Stephenson S.N., Bindschadler R.A., 1988, Observed velocity fluctuations on a major Antarctic ice stream, „Nature", 334, 695-697.

Stoker M.S., Bradwell T., 2005, The Minch palaeo-ice stream, NW sector of the British-Irish Ice Sheet, „Journal of the Geological Society London", 162, 425-428.

Stokes C.R., 2011, Paleo-ice stream, [w:] V.P. Singh, P. Singh, U.K. Haritashya (red.), Encyclopedia of Snow, Ice and Glaciers, Springer, 803-808.

Stokes C.R., Clark C.D., 1999, Geomorphological criteria for identifying Pleistocene ice streams, „Annals of Glaciology", 28, 67-74.

Stokes C.R., Clark C.D., 2001, Palaeo-ice streams, „Quaternary Science Reviews”, 20, 1437-1457.

Stokes C.R., Clark C.D., 2002, Are long subglacial bedforms indicative of fast ice flow?, „Boreas”, 31, 239-249.

Stokes C.R., Clark C.D., 2003a, The Dubawnt Lake palaeo-ice stream: evidence for dynamic ice sheet behaviour on the Canadian Shield and insights regarding the controls on ice-stream location and vigour, "Boreas", $32,263-279$. 
Stokes C.R., Clark C.D., 2003b, Laurentide ice streaming on the Canadian Shield: a conflict with the soft-bedded ice stream paradigm?, "Geology”, 31, 347-350.

Stokes C.R., Clark C.D., 2004, Evolution of late glacial ice-marginal lakes on the northwestern Canadian Shield and their influence on the location of the Dubawnt Lake palaeo-ice stream, "Palaeogeography, Palaeoclimatology, Palaeoecology", 215, 155-171.

Stokes C.R., Clark C.D., Darby D.A., Hodgson D.A., 2005, Late Pleistocene ice export events into the Arctic Ocean from the M'Clure Strait Ice Stream, Canadian Arctic Archipelago, „Global and Planetary Change”, 49, 3-4, 139-162.

Stokes C.R., Clark C.D., Lian O.B., Tulaczyk S., 2007, Ice stream sticky spots: A review of their identification and influence beneath contemporary and palaeo-ice streams, „Earth-Science Reviews”, 81, 217-249.

Stokes C.R., Clark C.D., Storrar R., 2009, Major changes in ice stream dynamics during deglaciation of the north-western margin of the Laurentide Ice Sheet, „Quaternary Science Reviews”, 28, 7-8, 721-738.

Stokes C.R., Tarasov L., Dyke A.S., 2012, Dynamics of the North American Ice Sheet Complex during its inception and build-up to the Last Glacial Maximum, „Quaternary Science Reviews”, 50, 86-104.

Strasser J.C., Lawson D.E., Larson G.J., Evenson E.B., 1996, Preliminary results of tritium analyses in basal ice, Matanuska Glacier, Alaska, USA: evidence for subglacial ice accretion, „Annals of Glaciology”, 22, 126133.

Strobel M., Faure G., 1987, Transport of indicator clasts by ice sheets and the transport half-distance: a contribution to prospecting for ore deposits, „Journal of Geology”, 95, 687-697.

Stroeven A.P., Fabel D., Hättestrand C., Harbor J., 2002a, A relict landscape in the centre of Fennoscandian glaciation: cosmogenic radionuclide evidence of tors preserved through multiple glacial cycles, "Geomorphology", 44, 145-154.

Stroeven A.P., Fabel D., Harbor J., Hättestrand C., Kleman J., 2002b, Quantifying the erosional impact of the Fennoscandian ice sheet in the Torneträsk-Narvik corridor, northern Sweden, based on cosmogenic radionuclide data, „Geografiska Annaler”, 84A, 275-287.

Stupnicka E., 2007, Geologia regionalna Polski, Wydawnictwo Uniwersytetu Warszawskiego, Warszawa, 346 s.

Sugden D.E., 1976, A case against deep erosion of shields by ice sheets, "Geology”, 4, 580-582.

Sugden D.E., 1977, Reconstruction of the morphology, dynamics, and thermal characteristics of the Laurentide ice sheet at its maximum, „Arctic and Alpine Research", 9, 1, 21-47.

Sugden D.E., 1978, Glacial erosion by the Laurentide ice sheet, „Journal of Glaciology”, 20, 367-391.

Sugden D.E., 1989, Modification of old land surfaces by ice sheets, „Zeitschrift für Geomorphologie”, Supplementband 72, 163-172.

Sugden D.E., John B.S., 1976, Glaciers and Landscape - A Geomorphological Approach, Edward Arnold, London, $376 \mathrm{~s}$.

Sugden D.E., Knight P.G., Livesey N., Souchez R., Lorrain R., Tison J.-L., Jouzel J., 1987, Evidence for two zones of debris entrainment beneath the Greenland ice sheet, "Nature”, 328, 6127, 238-241.

Swift D.A., Evans D.J.A., Fallick A.E., 2006, Transverse englacial debris-rich ice bands at Kviáriökull, southeast Iceland, "Quaternary Science Reviews”, 25, 13-14, 1708-1718.

Swithinbank C.W.M., 1954, Ice streams, „Polar Record”, 7, 48, 185-186.

Szabo J.P., Govett G.J.S., Latjai E.Z., 1975, Dispersion trends of elements and indicator pebbles in glacial till around Mt. Pleasant, New Brunswick, Canada, "Canadian Journal of Earth Science”, 12, 1534-1556.

Szewczyk J., Nawrocki J., 2011, Deep-seated relict permafrost in northeastern Poland, „Boreas”, 40, 385-388.

Szramek K., McIntosh J.C., Williams E.L., Kanduc T., Ogrinc N., Walter L.M., 2007, Relative weathering intensities of calcite vs. dolomite in carbonate-bearing temperate zone watersheds: carbonate geochemistry and fluxes from catchments within the St. Lawrence and Danube River Basin, "Geochemistry, Geophysics, Geosystems", 8, Q04002, doi:10.1029/2006GC001337.

Takeda A., Cox S., Payne A.J., 2002, Parallel numerical modelling of the Antarctic Ice Sheet, „Computers and Geosciences", 28, 723-734. 
Tarvydas R., 1957, Niekotoryje predvaritelnyje dannyje izučenija kristalličeskich vałunov na territorii Litwy, „Moskliniai Pranešimai, Geologija ir Geografija”, 4, 297-310.

Tarvydas R., 1960, Crystalline boulders of the last and penultimate glaciations in Lithuania, Collectanea Act. Geol. Lithuanica, Coll. Pap. 21. Sess. Intern. Geol. Cong., 215-220.

Tarvydas R., 1971a, Dno Botničeskogo zaliva, [w:] V. Gudelis (red.), Kristalličeskije rukovodiaščije vałuny Pribaltiki, Izd. Mintis, Vilnius, 43-45.

Tarvydas R., 1971b, Jużnaja Švecija, [w:] V. Gudelis (red.), Kristalličeskije rukovodiaščije vałuny Pribaltiki, Izd. Mintis, Vilnius, 62-64.

Tarvydas R., 1971c, Sieviernaja Šwecija, [w:] V. Gudelis (red.), Kristalličeskije rukovodiaščije vałuny Pribaltiki, Izd. Mintis, Vilnius, 48-54.

Tarvydas R., 1971d, Srednaja Švecija, [w:] V. Gudelis (red.), Kristalličeskije rukovodiaščije vałuny Pribaltiki, Izd. Mintis, Vilnius, 55-62.

Tarvydas R., Gudelis V., 1958, Paskutiniojo ir priešpaskutiniojo apledéjimu kristaliniu vedamuju rieduliu pasiskirstymo désningumo Lietuvos TSR teritorijoje klausimu, „Moskliniai Pranešimai, Geologija ir Geografija", 6, 55-75.

Tavast E., Raukas A., 1982, Relief koriennykh porod Estonii, Valgus, Tallinn, $192 \mathrm{s.}$

Terpiłowski S., Dobrowolski R., 2004, Rola morfologii dolinnej w rozwoju moren akumulacyjnych lobu Bugu zlodowacenia warty w rejonie Mielnika (Wysoczyzna Drohicka), [w:] M. Harasimiuk S. Terpiłowski (red.), Zlodowacenie warty w Polsce, UMCS, Lublin, 153-161.

Terpiłowski S., Zieliński T., Czubla P., Pidek I.A., Godlewska A., Kusiak J., Małek M., Zieliński P., Hrynowiecka A., 2012, Pozycja stratygraficzna „ciepłej” serii fluwialnej w dolinie rzeki Samicy (rejon Łukowa, wschodnia Polska), [w:] XIX Konferencja Stratygrafia Plejstocenu Polski „Korelacja osadów plejstocenu na pograniczu polsko-niemieckim w Dolinie Dolnej Odry", Cedynia 3-7 września 2012, PIG-PIB Warszawa, 101-102.

Terpiłowski S., Zieliński T., Czubla P., Pidek I.A., Kusiak J., Godlewska A., Zieliński P., Małek M., Mroczek P., Hrynowiecka A., 2013, Klimatyczne cykle kompleksu środkowopolskiego w zapisie sukcesji osadowej w rejonie Łukowa (wschodnia Polska), [w:] XX Konferencja Stratygrafia Plejstocenu Polski „Plejstocen przedpola Sudetów Środkowych", Lasocin 2-6 września 2013, PIG-PIB, Warszawa, 85-85.

Terpiłowski S., Zieliński T., Kusiak J., Pidek I.A., Czubla P., Hrynowiecka A., Godlewska A., Zieliński P., Małek M., 2014, How to resolve Pleistocene stratigraphic problems by different methods? A case study from eastern Poland, „Geological Quarterly”, 58, 2, 235-250.

Thorarinsson S., 1969, Glacier surges in Iceland, with special reference to the surges of Brúarjökull, „Canadian Journal of Earth Sciences", 6, 875-882.

Tippett C.R., 1985, Glacial dispersal train of Paleozoic erratics, central Baffin Island, N.W.T., Canada, „Canadian Journal of Earth Sciences", 22, 1818-1826.

Tokarski J., 1932, Neue mikroskopisch-chemische Analysen der Phosphorite aus der Umgebung von Grodno (Polen), „Bulletin de la Académie Polonaise des Sciences”, Cl. Math-nat.”, Ser. A, 300-317.

Toucanne S., Zaragosi S., Bourillet J.-F., Marieu V., Cremer M., Kageyama M., Van Vliet-Lanoë B., Eynaud F., Turon J.-L., Gibbard P.L., 2010, The first estimation of Fleuve Manche palaeoriver discharge during the last deglaciation: Evidence for Fennoscandian ice sheet meltwater flow in the English Channel ca 20-18 ka ago, „Earth and Planetary Science Letters”, 290, 459-473.

Toucanne S., Zaragosi S., Bourillet J.F., Gibbard P.L., Eynaud F., Giraudeau J., Turon J.L., Cremer M., Cortijo E., Martinez P., Rossignol L., 2009, A 1.2 My record of glaciation and fluvial discharges from the West European Atlantic margin, „Quaternary Science Reviews”, 28, 2974-2981.

Trembaczowski J., 1961, Przyczynki do metodyki badań granulometryczno-petrograficznych utworów morenowych, „Annales UMC-S”, sect. B, 16, 3, 63-94.

Trembaczowski J., 1967, Granulometryczno-petrograficzna charakterystyka glin zwałowych Wysoczyzny Północnokonińskiej, „Prace Instytutu Geologicznego”, 48, 147-162. 
Tremblay T., James D.J., Ryan J.J., Kjarsgaard I.M., 2009, Kimberlite indicator mineral survey and ice flow studies in Boothia mainland (NTS 57A, 57B, 57C and 57D), Kitikmeot region, Nunavut, „Geological Survey of Canada", Open File 6040, 31 s., http://geogratis. gc. ca/api/en/nrcan-rncan/ess-sst/bfebb17c-e0dd56af-9076-470f813f3c44. html (dostęp: 04.07.2012).

Trommelen M.S., 2011, Far North Geomapping Initiative: Quaternary geology of the Snyder-Grevstad lakes area, far northwestern Manitoba (parts of NTS 64N5), Report of Activities 2011, Manitoba Innovation, Energy and Mines, Manitoba Geological Survey, 18-28.

Trommelen M.S., Ross M., Campbell J.E., 2013, Inherited clast dispersal patterns: Implications for palaeoglaciology of the SE Keewatin Sector of the Laurentide Ice Sheet, „Boreas”, 42, 693-713.

Truffer M., Fahnestock M., 2007, Rethinking ice-sheet timescales, „Science”, 315, 1508-1510.

Truffer M., Harrison W.D., Echelmeyer K.A., 2000, Glacier motion dominated by processes deep in underlying till, „Journal of Glaciology”, 46, 153, 213-221.

Turkowska K., 2006, Geomorfologia regionu łódzkiego, Wyd. UŁ, Łódź, 238 s.

Turner R.G., Stea R.R., 1987, The Garden of Eden dispersal train, Nova Scotia Department of Mines and Energy, Mines and Minerals Branch, Report of Activities 1986, 165-169.

Tuuling I., Flodén T., 2001, The structure and the relief of the bedrock sequence in the Gotland-Hiiumaa area, northern Baltic Sea, „GFF”, 123, 1, 35-49.

Tuuling I., Bauert H., Willman S., Budd G.E., 2011, The Baltic Sea-geology and geotourism highlights, NGO GEOGuide Baltoscandia, Tallin, $84 \mathrm{~s}$.

Ūsaitytè D., 2000, The geology of the southeastern Baltic Sea: a review, „Earth-Science Reviews”, 50, 137-225.

Utescher T., Mosbrugger V., Ashraf A.R., 2000, Terrestrial climate evolution in Northwest Germany over the last 25 million years, „Palaios”, 15, 430-449.

Van der Meer J.J.M., Menzies J., Rose J., 2003, Subglacial till: the deforming glacier bed, „Quaternary Science Reviews", 22, 1659-1685.

Van der Veen C.J., 1999, Fundamentals of glacier dynamics, A.A. Balkema, Rotterdam, $462 \mathrm{~s}$.

Van der Wateren F.M., 2005, Ice-marginal Terrestrial Landsystems: Southern Scandinavian Ice Sheet Margin, [w:] D.J.A. Evans (red.), Glacial Landsystems, Hodder Arnold, 166-203.

Vanhanen E., 2001, Geology, mineralogy and geochemistry of the Fe-Co-Au-(U) deposits in the Paleoproterozoic Kuusamo Schist Belt, northeastern Finland, „Geological Survey of Finland Bulletin”, 399, 1-229.

Veenstra H.J., 1963, Microscopis studies of boulder clay, manuskrypt dysertacji, Groningen, $211 \mathrm{~s}$.

Veltheim V., 1962, On the pre-Quaternary geology of the bottom of the Bothnian Sea, „Bulletin de la Commission Géologique de Finlande", 200, 1-166.

Verhaard A.G.J., 2005, Mieniet als zwerfsteen bij Markelo; Het ontstaan en voorkomen van mienitgesteente, "Grondboor and Hamer", 59, 5/6, 109-114.

Vieli A., Jania J., Blatter H., Funk M., 2004, Short-term velocity variations on Hansbreen, a tidewater glacier in Spitsbergen, „Journal of Glaciology”, 50, 389-398.

Viiding H., 1957, Rasprostranienije i petrografija erratičeskich vałunov Estonskoj SSR, „Moskliniai Pranešimai, Geologija ir Geografija", 4, 285-295.

Viiding H., 1971a, Jugo-vostočnaja Finlandia i sieviero-zapadnyje rajony SSSR, [w:] V. Gudelis (red.), Kristalličeskije rukovodiaščije vałuny Pribaltiki, Izd. Mintis, Vilnius, 28-32.

Viiding H., 1971b, Jugo-Zapadnaja Finlandia, [w:] V. Gudelis (red.), Kristalličeskije rukovodiaščije vałuny Pribaltiki, Izd. Mintis, Vilnius, 37-41.

Viiding H., 1971c, Sriednaja čast’ Jużnoj Finlandii, [w:] V. Gudelis (red.), Kristalličeskije rukovodiaščije vałuny Pribaltiki, Izd. Mintis, Vilnius, 32-35.

Vinx R., 1996, Granatcoronit (mafischer Granulit): ein neues Leitgeschiebe SW-schwedischer Herkunft, „Archiv für Geschiebekunde", 2, 1, 3-20. 
Vinx R., 1998, Neue kristalline SW-schwedische Leitgeschiebe: Granoblastischer mafischer Granulit, HallandRetro-Eklogit und deformierter, bunter Pegmatit, „Archiv für Geschiebekunde”, 2, 6, 363-377.

Vinx R., 1999, Der Järeda-Granit als Leitgeschiebe: Ein roter Småland-Granit mit spezifischen Merkmalen, „Archiv für Geschiebekunde”, 2, 9, 687-696.

Vinx R., 2015 (4. wyd.; poprzednie w 2005, 2008 i 2011), Gesteinsbestimmung im Gelände, Springer Spektrum, Berlin, Heidelberg, $480 \mathrm{~s}$.

Vinx R., Grube A., Grube F., 1997, Vergleichende Lithologie, Geschiebeführung und Geochemie eines Prä-Elster-I-Tills von Lieth bei Elmshorn, „Leipziger Geowissenschaften”, 5, 83-103.

Virkkala K., 1971, On the lithology and provenance of the till of a gabbro area in Finland, VIII International Congress INQUA, Paris 1969, „Etudes sur le Quaternaire dans le Monde”, 711-714.

Virkkala K., 1974, On the Würmian till deposits in Finland, „Zeszyty Naukowe UAM, Geografia”, 10, 59-80.

Víšek J., Nývlt D., 2006, Leitgeschiebestatistische Untersuchungen im Kontinentalvereisungsgebiet Nordböhmens, „Archiv für Geschiebekunde”, 5, 1-5 [Festband Gerd Lüttig], 229-236.

Visser J.N.J., Hall K.J., Loock J.C., 1986, The application of stone counts in the glacigene Permo-Carboniferous Dwyka Formation, South Africa, "Sedimentary Geology", 46, 3-4, 197-212.

Vivian R., 1975, Les glaciers des Alpes Occidentales, Imprimerie Allier, Grenoble, $513 \mathrm{s.}$

Vorren T.O., 1977, Weichselian ice movement in South Norway and adjacent areas, „Boreas”, 6, 247-257.

Vorren T.O., Laberg J.S., 1997, Trough mouth fans - palaeoclimate and ice-sheet monitors, „Quaternary Science Reviews", 16, 865-881.

Waard D. de, 1949, Glacigeen Pleistoceen. Een geologisch detailonderzoek In Urkerland (N.O.-polder), „Verhandelingen van het Koninklijk Nederlands Geologisch Mijnbouwkundig Genootschap", 15, 70-246.

Wachecka-Kotkowska L., Czubla P., Górska-Zabielska M., 2012a, Petrografia osadów kompleksu środkowopolskiego w okolicach Piotrkowa Trybunalskiego, [w:] XIX Konferencja Stratygrafia Plejstocenu Polski "Korelacja osadów plejstocenu na pograniczu polsko-niemieckim w Dolinie Dolnej Odry", Cedynia 3-7 września 2012, PIG-PIB, Warszawa, 110-113.

Wachecka-Kotkowska L., Czubla P., Górska-Zabielska M., Król E., 2012b, Poligeneza pagóra w okolicach Mqkolic na wododziale Wisły i Odry na Wysoczyźnie Bełchatowskiej, region łódzki, „Acta Geographica Lodziensia", 100, 161-178.

Wachecka-Kotkowska L., Czubla P., Górska-Zabielska M., Król E., 2012c, Stanowisko 5. Mq̨kolice. Pagór na wododziale Wisły i Odry jako przykład formy poligenicznej, [w:] D. Dzieduszyńska, M. Roman (red.), Czynniki różnicowania rzeźby Niżu Polskiego, Uniejów, 13-15.06.2012, 131-139.

Wachecka-Kotkowska L., Czubla P., Górska-Zabielska M., Król E., Barczuk A., 2013a, Saalian palaeogeography of Central Poland - Mq̨kolice case, [w:] A. Damušytė, A. Grigienè (red.), Palaeolandscapes from Saalian to Weichselian, South Eastern Lithuania, Abstracts of International Field Symposium, June 25-30, 2013, Vilnius-Trakai, Lithuania, 101-102.

Wachecka-Kotkowska L., Czubla P., Górska-Zabielska M., Król E., Barczuk A., 2013b, Transgresja lqqdolodu warciańskiego w południowo-wschodniej części regionu łódzkiego, [w:] XX Konferencja Stratygrafia Plejstocenu Polski „Plejstocen przedpola Sudetów Środkowych”, Lasocin 2-6 września 2013, PIG-PIB, Warszawa, 89-91.

Wachecka-Kotkowska L., Czubla P., Górska-Zabielska M., Król E., Barczuk A., 2013c, Wiek stref glacimarginalnych SE części regionu łódzkiego, [w:] A. Kostrzewski, G. Rachlewicz, M. Woszczyk (red.), VI Seminarium "Geneza, litologia i stratygrafia utworów czwartorzędowych", Poznań 14-15 listopada 2013, 163-167.

Wagenbreth O., 1978, Die Feuersteinlinie in der DDR, ihre Geschichte und Popularisierung, „Schriftenreihe für Geologische Wissenschaften", 9, 339-368.

Waller R.I., Hart J.K., Knight P.G., 2000, The influence of tectonic deformation on facies variability in stratified debris-rich basal ice, "Quaternary Science Reviews”, 19, 8, 775-786.

Waller R.I., Murton J.B., Kristensen L., 2012, Glacier-permafrost interactions: Processes, products and glaciological implications, „,Sedimentary Geology”, 255-256, 1-28. 
Walpole R.E., Myers R.H., Myers S.L., Ye K., 2012, Probability and Statistics for Engineers and Scientists ( $9^{\text {th }}$ ed.), Prentice Hall, $791 \mathrm{~s}$.

Wawryk W., 1961, Fosforyty oligoceńskie kry glacjalnej z Krzywania (pow. Słupsk), „Rocznik Polskiego Towarzystwa Geologicznego", 31, 1, 119-127.

Weertman J., 1957, On the sliding of glaciers, „Journal of Glaciology”, 3 (21), 33-38.

Weertman J., 1964, The theory of glacier sliding, „Journal of Glaciology”, 5, 287-303.

Weertman J., 1979, The unsolved general glacier sliding problem, „Journal of Glaciology”, 23 (89), 97-115.

Weiss T., Siegesmund S., Fuller E.R., 2002, Thermal stresses and microcracking in calcite and dolomite marbles via finite element modeling, [w:] S. Siegesmund, T. Weiss, A. Vollbrecht (red.), Natural Stone, Weathering Phenomena, Conservation Strategies and Case Studies, Geol. Soc. London, Sp. Publ., 205, 89-102.

Wentworth C.K., 1922, A scale of grade and class terms for clastic sediments, „Journal of Geology”, 30, 377392.

Westaway R., Bridgland D.R., 2010, Causes, consequences and chronology of large-magnitude palaeoflows in Middle and Late Pleistocene river systems of northwest Europe, "Earth Surface Processes and Landforms", 35, 1071-1094.

White W.A., 1972, Deep erosion by continental ice sheets, "Geological Survey of Finland Bulletin", 83, 10371056.

White W.A., 1988, More on deep glacial erosion by continental ice sheets and their tongues of distributary ice, "Quaternary Research", 30, 137-150.

White A.F., Blum A.E., 1995, Effects of climate on chemical weathering rates in watersheds, "Geochimica et Cosmochimica Acta", 59, 1729-1747.

White A.F., Bullen T.D., Schulz M.S., Blum A.E., Huntington T.G., Peters N.E., 2001, Differential rates of feldspar weathering in granitic regoliths, "Geochimica et Cosmochimica Acta”, 65, 847-869.

Williams L.D., 1978, Ice-sheet initiation and climatic influences of expanded snow cover in Arctic Canada, "Quaternary Research", 10, 141-149.

Winsborrow M.C.M., Andreassen K., Corner G.D., Laberg J.S., 2010a, Deglaciation of a marine-based ice sheet: Late Weichselian palaeo-ice dynamics and retreat in the southern Barents Sea reconstructed from onshore and offshore glacial geomorphology, "Quaternary Science Reviews", 29, 3-4, 424-442.

Winsborrow M.C.M., Clark C.D., Stokes C.R., 2004, Ice streams of the Laurentide Ice Sheet, "Géographie physique et Quaternaire", 58, 269-280.

Winsborrow M.C.M., Clark C.D., Stokes C.R., 2010b, What controls the location of ice streams?, „Earth-Science Reviews", 103 1-2, 45-59.

Winterhalter B., Flodén T., Ignatius H., Axberg S., Niemistö L., 1981, Geology of the Baltic sea, [w:] A. Voipio (red.), The Baltic Sea, Elsevier Oceanography Series, 30, Elsevier, Amsterdam, 1-122.

Woldstedt P., 1935, Über stratigraphischen Wert von Geschiebeuntersuchungen in Norddeutschland, „Zeitschrift der Deutschen Geologischen Gesellschaft", 87, 6, 360-369.

Woldstedt P., 1954, Das Eiszeitalter. Grundlinien einer Geologie des Quartärs, Ferdinand Enke Verlag Stuttgart, $374 \mathrm{~s}$.

Woźniak P.P., Czubla P., 2011, Geological processes record in the vertical and horizontal changeability of the Weichselian tills profiles in northern Poland - a concept of the research project and preliminary results, [w:] P. Johansson, J.-P. Lunkka, P. Sarala (red.), Late Pleistocene glacigenic deposits from the central part of the Scandinavian Ice Sheet to Younger Dryas End Moraine Zone. Excursion guide and abstracts of the INQUA Peribaltic Working Group Meeting and Excursion in Finland, 12-17 June 2011, "Geological Survey of Finland", Rovaniemi, 137-138.

Woźniak P.P., Czubla P., 2014a, Nowe spojrzenie na gliny lodowcowe w Gdyni Orłowie, [w:] R. Sokołowski (red.), Ewolucja środowisk sedymentacyjnych regionu Pobrzeża Kaszubskiego, Wydział Oceanografii i Geografii Uniwersytetu Gdańskiego, Gdańsk, 115-122. 
Woźniak P.P., Czubla P., 2014b, Złożona sekwencja glacjalna osadów górnego vistulianu w stanowisku Gdynia Babie Doły, [w:] R. Sokołowski (red.), Ewolucja środowisk sedymentacyjnych regionu Pobrzeża Kaszubskiego, Wydział Oceanografii i Geografii Uniwersytetu Gdańskiego, Gdańsk, 93-102.

Woźniak P.P., Czubla P., (w druku), The Late Weichselian glacial record in northern Poland - towards a wider perspective: a new look at debris transport routes by the FIS, "Quaternary International” (15 stron); http://dx.doi.org/10.1016/j.quaint.2015.01.014.

Woźniak P.P., Czubla P., Fedorowicz S, 2012a, Interpretacja pionowego zróżnicowania litologicznego glin morenowych (późny vistulian, północna Polska), [w:] XIX Konferencja Stratygrafia Plejstocenu Polski „Korelacja osadów plejstocenu na pograniczu polsko-niemieckim w Dolinie Dolnej Odry", Cedynia 3-7 września 2012, PIGPIB, Warszawa, 114-116.

Woźniak P.P., Czubla P., Fedorowicz S., 2012b, The changeability of the Late Weichselian tills petrographic composition, Northern Poland, [w:] A. Zhirov, V. Kuznetsov, D. Subetto, J. Thiede (red.), Proceedings of the Joint International Conference "Geomorphology and palaeogeography of polar regions", Leopoldina Symposium and INQUA Peribaltic Working Group Workshop, Saint-Petersburg, SPbSU, 9-17 September 2012, Saint-Petersburg State University, Saint-Petersburg, 472-473.

Woźniak P.P., Czubla P., Fedorowicz S., 2013a, The Weichselian glacial record in Northern Poland - towards a wider perspective, [w:] A. Damušytė, A. Grigienè (red.), Palaeolandscapes from Saalian to Weichselian, South Eastern Lithuania. Abstracts of International Field Symposium, June 25-30, 2013, Vilnius-Trakai, Lithuania, 107-108.

Woźniak P.P., Czubla P., Wysiecka G., 2008, Petrographic Composition and Directional Properties of Tills in the Puck Region, [w:] S. Lisicki (red.), Quaternary of the Gulf of Gdańsk and Lower Vistula Regions in Northern Poland: Sedimentary Environments, Stratigraphy and Palaeogeography, Warszawa, 97-102.

Woźniak P.P., Czubla P., Wysiecka G., Drapella M., 2009, Petrographic composition and directional properties of tills on the NW surroundings of the Gdańsk Bay, Northern Poland, "Geologija”, 51, 3/4, 59-67.

Woźniak P.P., Fedorowicz S., Czubla P., 2013b, Formation time-frames of the Late Weichselian tills in Northern Poland, [w:] N. Piotrowska (red.), $11^{\text {th }}$ International Conference "Methods of absolute chronology", Abstracts and Programme, 15-18 ${ }^{\text {th }}$ May 2013, Podlesice, Poland, 40-40.

Woźniak P.P., Matla M., Czubla P., Fedorowicz S., 2013c, Zapis kierunków paleotransportu w rzeźbie i osadach na Garbie Tczewskim, [w:] XX Konferencja Stratygrafia Plejstocenu Polski „Plejstocen przedpola Sudetów Środkowych", Lasocin 2-6 września 2013, PIG-PIB, Warszawa, 95-95.

Wysota W., 2002, Stratygrafia i środowiska sedymentacji zlodowacenia wisły w południowej części dolnego Powiśla, Wyd. UMK, Toruń, $144 \mathrm{~s}$.

Wysota W., Molewski P., 2007, Ostatni lqqdolód skandynawski w lobie Wisły-kontrowersje i nowe spojrzenie, [w:] P. Molewski, W. Wysota, P. Weckwerth (red.), Plejstocen Kujaw i dynamika lobu Wisły w czasie ostatniego zlodowacenia. XIV Konferencja - Stratygrafia Plejstocenu Polski, Wyd. PIG, Warszawa, 13-21.

Wysota W., Molewski P., 2011, Chronologia i zasięgi nasunięć lądolodu na obszarze lobu Wisły podczas stadiału głównego ostatniego zlodowacenia, „Przegląd Geologiczny”, 59, 3, 214-225.

Wysota W., Molewski P., Sokołowski R., 2009, Record of the Vistula ice lobe advances in the Late Weichselian glacial sequence in north-central Poland, "Quaternary International”, 207, 26-41.

Yakovlev S.A., 1939, Rukovodjaščije vałuny, moreny i granicy rasprostranienija novoziemielskogo oledienija na Russkoj Ravninie, „Bulleten Komissii po Izucheniyu Chetvertichnogo perioda Akademii Nauk SSSR”, 5, 1-120.

Yakovlev S.A., 1953, O sootnoszenijach lednikovych pokrovov četviertičnogo perioda ischodivšich iz skandinavskogo, novoziemielskogo i uralskogo centrov oledienija, „Bulleten Komissii po Izucheniyu Chetvertichnogo perioda Akademii NaukSSSR", 18, 1-292.

Yakovleva S.V., 1940, Issledovanije lednikovych vałunov. Kratkaja instrukcja po geologičeskoj sjemkie četviertičnych otłożenij, Gosgeolizdat, Moskwa, $127 \mathrm{~s}$.

Yakovleva S.V., 1956, K izučeniju lednikovych vałunov na Russkoj ravninie, Materiały po Četviertičnoj Geologii Geomorfologii SSSR, Gosgeoltechizdat, Moskwa, 18-43. 
Yakovleva S.V., 1961, Uspiechi w obłasti četviertičnoj geologii dostignutyje s pomoščiju izučenija lednikovych vałunov w SSSR, [w:] Materijały po genezisu i litologii četvertičnych otłożenij, Izd. AN BSSR, Minsk, 52-114.

Yakovleva S.V., 1963, Niekotoryje rezultaty izučenija lednikovych vałunov na jugozapadnom pobierieżje Ładożskogo Oziera, „Trudy VSEGEI”, novaja seria, 90, 1-107.

Yakovleva S.V., 1966, Gławniejšije puti rasprostranienija mołodych oledienij na sieviero-zapadie Russkoj ravniny po dannym litologičeskogo izučenija moren, [w:] Sovriemiennyj i četviertičnyj kontinentalnyj litogenez, Iz-vo Nauka, Moskwa, 147-161.

Zabielski R., 2000, Charakterystyka petrograficzna glin lodowcowych rejonu Konina w świetle analizy statystycznej, „Przegląd Geologiczny”, 48, 4, 345-350.

Zachos J., Pagani M., Sloan L., Thomas E., Billups K., 2001, Trends, Rhytms, and Aberrations in Global Climate 65 Ma to Present, „Science”, 292, 686-693.

Zandstra J.G., 1971, Geologisch onderzoek in de stuwwal van de oostelijke Veluwe bij Hattem en Wapenveld, „Mededelingen Rijks Geologische Dienst", NS, 22, 215-259.

Zandstra J.G., 1974, Over de uitkomsten van nieuwe zwerfsteentellingen en een keileemtypenindeling in $\mathrm{Ne}$ derland, "Grondboor en Hamer", 5, 95-108.

Zandstra J.G., 1976, Sedimentpetrographische Untersuchungen des Geschiebelehms von Emmerschans (Drenthe, Niederlande) mit Bemerkungen über eine Typeneinteilung der Saale-Grundmoräne, „Eiszeitalter und Gegenwart", 27, 30-52.

Zandstra J.G., 1983a, A new subdivision of crystalline Fennoscandian erratic pebble assemblages (Saalian) in the central Netherlands, "Geologie en Mijnbouw”, 62, 3, 455-469.

Zandstra J.G., 1983b, Fine gravel, heavy mineral and grain-size analyses of Pleistocene, mainly glacigenic deposits in the Netherlands, [w:] J. Ehlers (red.), Glacial deposits in North-West Europe, Balkema, Rotterdam, 361-377.

Zandstra J.G., 1986, Tellingen van noordelijke kristallijne gidsgesteenten in de Achterhoek en Zuidelijk Overijssel en opmerkingen over de depositiegebieden van het landijs tijdens het saalien in Nederland, "Grondboor en Hamer", 40, 3/4, 76-96.

Zandstra J.G., 1988, Noordelijke Kristallijne Gidsgesteenten, E.J. Brill, Leiden, 469 s.

Zandstra J.G., 1999, Platenatlas van noordelijke kristallijne gidsgesteenten, Foto's in kleur met toelichting van gesteentetypen van Fennoscandinavië, Backhuys, Leiden, XII + $412 \mathrm{~s}$.

Zandstra J.G., 2002, Schisteuze granaatamfiboliet en andere metamorfieten uit Zuidwest-Zweden: gidsgesteenten?, "Grondboor en Hamer", 6, 145-150.

Zelčs V., Markots A., 2004, Deglaciation history of Latvia, [w:] J. Ehlers, P.L. Gibbard (red.), Quaternary Glaciations - Extent and Chronology. Part l: Europe, Elsevier, 225-243.

Zieliński T., Goździk J., 2001, Palaeoenvironmental interpretation of a Pleistocene alluvial succession in central Poland: sedimentary facies analysis as a tool for palaeoclimatic inferences, „Boreas”, 30, 240-253.

Ziułkiewicz M., Okupny D., Forysiak J., Fortuniak A., 2012, Warunki funkcjonowania kopuł źródliskowych w południowej części Wzniesień tódzkich, "Czasopismo Geograficzne”, 83, 3, 175-196.

Zotikov I.A., 1982, Tiepłofizika lednikovych pokrovov, Gidrometeoizdat, Leningrad, $287 \mathrm{~s}$.

Zwally H.J., Abdalati W., Herring T., Larson K., Saba J., Steffen K., 2002, Surface melt-induced acceleration of Greenland Ice-Sheet flow, „Science”, 297, 218-222.

Zwenger W., 2010, Der Trebuser Sandstein - ein Massenvorkommen jotnischer Sandsteingeschiebe, „Brandenburgische Geowissenschaftliche Beiträge", 17, 77-90. 


\section{SPIS RYSUNKÓW, FOTOGRAFII I TABEL}

\section{Rysunki}

Rys. 4.1. Rozmieszczenie stanowisk badawczych na tle zasięgów zlodowaceń.

Rys. 4.2. Strefy rozproszenia skały z litego podłoża w osadach glacjalnych, fluwioglacjalnych i fluwialnych.

Rys. 5.1. Graficzny obraz zmodyfikowanych formuł Hesemanna.

Rys. 5.2. Eratyki przewodnie w glinach Dolnego Śląska.

Rys. 5.3. Teoretyczne ośrodki głazowe w Polsce Środkowej.

Rys. 5.4. Położenie testowych teoretycznych ośrodków głazowych wyznaczonych dla osadów ze stanowisk w Polsce Wschodniej.

Rys. 5.5. Położenie testowych teoretycznych ośrodków głazowych wyznaczonych dla osadów glacjalnych sanu 1 i sanu 2 na Dolnym Śląsku.

Rys. 5.6. Położenie teoretycznych ośrodków głazowych wyznaczonych dla osadów glacjalnych zlodowaceń odra/warta i wisła.

Rys. 5.7. Eratyki wskaźnikowe (przewodnie i pomocnicze) w osadach glacjalnych odkrywki Koźmin Północ.

Rys. 5.8. Eratyki wskaźnikowe (przewodnie i pomocnicze) w osadach glacjalnych odkrywki Wapienno na Kujawach.

Rys. 6.1. Rozkład prędkości i mechanizmy ruchu lodu w lodowcu w zależności od reżimu termicznego oraz rodzaju podłoża.

Rys. 6.2. Rozmieszczenie skał budujących powierzchnię Ziemi na półkuli północnej.

Rys. 6.3. Rozkład prędkości lodu (efekt modelowania matematycznego) w lądolodzie na wschodzie Antarktydy.

Rys. 6.4. Zmiany prędkości ruchu lodu wraz z oddalaniem się od lododziału (linii podziału lodu).

Rys. 7.1. Typy strumieni lodowych kończących się w morzu.

Rys. 7.2. Typy strumieni lodowych kończących się na lądzie.

Rys. 7.3. Szlaki rozrzutu eratyków.

Rys. 7.4. Strumieniowy model lądolodu fennoskandzkiego w vistulianie.

Rys. 7.5. Układ strumieni lodowych w Saalianie i Weichselianie na Niżu Środkowoeuropejskim.

Rys. 8.1. Dociskanie fragmentów skalnych do podłoża w wyniku płynięcia deformacyjnego lodu oraz topnienia lodu.

Rys. 8.2. Schemat bałtyckiego systemu rzecznego (Eridanos).

Rys. 8.3. Model warunków termodynamicznych w podłożu lądolodu fennoskandzkiego.

Rys. 8.4. Rezultaty symulacji temperatury podłoża lądolodu fennoskandzkiego.

Rys. 8.5. Lodowiec politermalny.

Rys. 8.6. Reżim termiczny podłoża lądolodu fennoskandzkiego w LGM i okresie bezpośrednio poprzedzającym lub następującym.

Rys. 9.1. Schematyczny profil lodowca Matanuska.

Rys. 9.2. Rozkład uziarnienia w facjach lodu bazalnego. 
Rys. 9.3. Zależność składu zespołu eratyków frakcji 20-60 mm w glinie od rodzaju podłoża.

Rys. 10.1. Obszary macierzyste bałtycko-fennoskandzkich skał wskaźnikowych.

Rys. 10.2. Rozmieszczenie obszarów źródłowych eratyków przewodnich i wybranych eratyków pomocniczych.

Rys. 10.3. Rozmieszczenie skał alandzkich w przebadanych osadach glacjalnych kompleksu południowopolskiego i północnopolskiego.

Rys. 10.4. Rozmieszczenie skał alandzkich $w$ przebadanych osadach glacjalnych kompleksu środkowopolskiego.

Rys. 10.5. Występowanie piaskowców jotnickich w Fennoskandii.

Rys. 10.6. Rozmieszczenie skał z Dalarny i Värmlandu w przebadanych osadach glacjalnych kompleksu południowopolskiego i północnopolskiego.

Rys. 10.7. Rozmieszczenie skał z Dalarny i Värmlandu w przebadanych osadach glacjalnych kompleksu środkowopolskiego.

Rys. 10.8. Rozmieszczenie porfirów Bredvad w przebadanych osadach glacjalnych kompleksu południowopolskiego i północnopolskiego.

Rys. 10.9. Rozmieszczenie skał wulkanicznych z Dalarny i Värmlandu w przebadanych osadach glacjalnych kompleksu południowopolskiego i północnopolskiego.

Rys. 10.10. Rozmieszczenie skał plutonicznych z Dalarny i Värmlandu w przebadanych osadach glacjalnych kompleksu południowopolskiego i północnopolskiego.

Rys. 10.11. Rozmieszczenie skał z Upplandu i okolic Sztokholmu w przebadanych osadach glacjalnych kompleksu południowopolskiego i północnopolskiego.

Rys. 10.12. Rozmieszczenie granitów sztokholmskich w przebadanych osadach glacjalnych kompleksu południowopolskiego i północnopolskiego.

Rys. 10.13. Rozmieszczenie brunatnych porfirów bałtyckich w osadach kompleksu południowopolskiego i północnopolskiego.

Rys. 10.14. Rozmieszczenie brunatnych porfirów bałtyckich w osadach kompleksu środkowopolskiego.

Rys. 10.15. Rozmieszczenie czerwonych porfirów bałtyckich w osadach kompleksu południowopolskiego i północnopolskiego.

Rys. 10.16. Rozmieszczenie czerwonych porfirów bałtyckich w osadach kompleksu środkowopolskiego.

Rys. 10.17. Udział dolomitów w grupie skał fennoskandzkich w osadach kompleksu południowopolskiego i północnopolskiego.

Rys. 10.18. Udział dolomitów w grupie skał fennoskandzkich w osadach kompleksu środkowopolskiego.

Rys. 10.19. Udział dolomitów w grupie skał węglanowych w osadach kompleksu południowopolskiego i północnopolskiego.

Rys. 10.20. Rozmieszczenie eratyków ze Smålandu, Skanii i Blekinge w osadach kompleksu południowopolskiego i północnopolskiego.

Rys. 10.21. Rozmieszczenie eratyków ze Smålandu, Skanii i Blekinge w osadach kompleksu środkowopolskiego.

Rys. 10.22. Rozmieszczenie eratyków granitu Vånevik w osadach kompleksu południowopolskiego i północnopolskiego.

Rys. 10.23. Rozmieszczenie eratyków granitu Vånevik w osadach kompleksu środkowopolskiego.

Rys. 10.24. Rozmieszczenie eratyków bazaltu ze Skanii w osadach glacjalnych Polski.

Rys. 10.25. Rozmieszczenie eratyków piaskowca Hardeberga w osadach glacjalnych kompleksu południowopolskiego i północnopolskiego.

Rys. 10.26. Rozmieszczenie eratyków piaskowca Hardeberga w osadach glacjalnych kompleksu środkowopolskiego. 
Rys. 10.27. Rozmieszczenie eratyków skał z Bornholmu w osadach kompleksu południowopolskiego i północnopolskiego.

Rys. 10.28. Rozmieszczenie konkrecji fosforytowych w osadach glacjalnych Polski.

Rys. 11.1. Charakterystyczne typy stref rozrzutu eratyków w glinie wyróżniane w Kanadzie.

Rys. 13.1. Schematyczny model rozproszenia skały pobranej przez lód z podłoża.

Rys. 14.1. Parametry statystyczne eratyków przewodnich w różnowiekowych osadach glacjalnych Polski Środkowej i wschodniej Wielkopolski.

Rys. 14.2. Parametry statystyczne eratyków pomocniczych w różnowiekowych osadach glacjalnych Polski Środkowej i wschodniej Wielkopolski.

Rys. 14.3. Parametry statystyczne eratyków przewodnich w różnowiekowych osadach glacjalnych Polski Środkowej i wschodniej Wielkopolski.

Rys. 14.4. Parametry statystyczne eratyków pomocniczych w różnowiekowych osadach glacjalnych Polski Środkowej i wschodniej Wielkopolski.

Rys. 14.5. Parametry statystyczne eratyków przewodnich w osadach glacjalnych.

Rys. 14.6. Parametry statystyczne eratyków przewodnich w osadach glacjalnych.

\section{Fotografie}

Fot. 3.1. Głazy narzutowe na wybrzeżu Estonii; fot. P. Czubla 2012.

Fot. 3.2. Głaz narzutowy Trollastenen, znany też jako Maglestenen koło Bäckashog w Skanii; fot. P. Czubla 2003.

Fot. 8.1. Rysy lodowcowe na proksymalnym stoku mutona na wybrzeżu Bałtyku koło Saltvik na Wyspach Alandzkich; fot. P. Czubla 2002.

Fot. 8.2. Ukształtowany przez abrazję wygład glacjalny z rysami w Järrestad koło Simrishamn w Szwecji; fot. P. Czubla 2003.

Fot. 8.3. Stopnie utworzone przez detrakcję na dystalnym stoku mutona na wybrzeżu Bałtyku koło Saltvik na Wyspach Alandzkich; fot. P. Czubla 2002.

Fot. 10.1. Granit Revsund, Valla - Ragunda, środkowa Szwecja; fot. P. Czubla 2015.

Fot. 10.2. Granit Ragunda, Ragunda, środkowa Szwecja; fot. P. Czubla 2015.

Fot. 10.3. Alnöit, Näset, środkowa Szwecja; fot. P. Czubla 2015.

Fot. 10.4. Alandzki granit rapakiwi, eratyk - odkrywka KWB Bełchatów; fot. P. Czubla i Z. Machnicki 1999.

Fot. 10.5. Granit Haga, eratyk - odkrywka KWB Bełchatów; fot. P. Czubla 2015.

Fot. 10.6. Granitoporfir alandzki, eratyk - odkrywka KWB Bełchatów; fot. P. Czubla i Z. Machnicki 1999.

Fot. 10.7. Granit Ytö, Ytö k/Laitilla, zachodnia Finlandia; fot. P. Czubla 2015.

Fot. 10.8. Kamieniołom granitów w Ytö, Katinhäntä (na zachód od Laitila); fot. P. Czubla 2003.

Fot. 10.9. Granit Prick, eratyk - odkrywka KWB Bełchatów; fot. P. Czubla 2015.

Fot. 10.10. Fiński pyterlit, eratyk - Smulsko; fot. P. Czubla 2015.

Fot. 10.11. Wyborgit (granit rapakiwi), Ylämaa, wschodnia Finlandia; fot. P. Czubla 2015.

Fot. 10.12. Wyborgit (fiński granit rapakiwi), eratyk - odkrywka KWB Bełchatów; fot. P. Czubla 2015.

Fot. 10.13. Granit Garberg, eratyk - Moszczenica k/Piotrkowa Trybunalskiego; fot. P. Czubla 2015.

Fot. 10.14. Porfir Bredvad, okolice zapory Trängslet, Dalarna, środkowa Szwecja; fot. P. Czubla 2015.

Fot. 10.15. Porfir Tandsjöborg, Tandsjöborg, Dalarna, środkowa Szwecja; fot. P. Czubla 2015.

Fot. 10.16. Ignimbryt Särna (fioletowy), Särna, środkowa Szwecja; fot. P. Czubla 2015.

Fot. 10.17. Tinguait (särnait), Siksjöberget k/Bergswallen, środkowa Szwecja; fot. P. Czubla 2015. 
Fot. 10.18. Kamieniołom piaskowców jotnickich, Mångsbodarna, Dalarna, środkowa Szwecja; fot. P. Czubla 2003.

Fot. 10.19. Odlewy szczelin z wysychania w piaskowcu jotnickim, Mångsbodarna, Dalarna, środkowa Szwecja; fot. P. Czubla 2003.

Fot. 10.20. Zlepieniec Digeberga, Höghed, Dalarna, środkowa Szwecja; fot. P. Czubla 2015.

Fot. 10.21. Granit sztokholmski, Sånga na N od Stenhamra, środkowa Szwecja; fot. P. Czubla 2015.

Fot. 10.22. Granit Sala, Heby, środkowa Szwecja; fot. P. Czubla 2015.

Fot. 10.23. Granit Uppsala, Berga, środkowa Szwecja; fot. P. Czubla 2015.

Fot. 10.24. Granit Vänge, Kristineberg k/Laby, środkowa Szwecja; fot. P. Czubla 2015.

Fot. 10.25. Brunatny porfir bałtycki, eratyk - Moszczenica; fot. P. Czubla i Z. Machnicki 1999.

Fot. 10.26. Czerwony porfir bałtycki, eratyk - Siedlątków nad Wartą; fot. P. Czubla 2015.

Fot. 10.27. Piaskowiec tessini, Äleklinta, Olandia; fot. P. Czubla 2010.

Fot. 10.28. Piaskowiec Kalmarsund, Värsnäs k/Kalmaru, południowa Szwecja; fot. P. Czubla 2015.

Fot. 10.29. Wapień paleoporellowy, eratyk - Smulsko; fot. P. Czubla i Z. Machnicki 1999.

Fot. 10.30. Wapień krynoidowy, klif Hoburgen, Gotlandia; fot. P. Czubla 2003.

Fot. 10.31. Granit Vånevik, Vånevik, Småland, południowa Szwecja; fot. P. Czubla 2015.

Fot. 10.32. Granit Uthammar, Uthammar, Småland, południowa Szwecja; fot. P. Czubla 2015.

Fot. 10.33. Granit Karlshamn, Hällaryd, Blekinge, południowa Szwecja; fot. P. Czubla 2015.

Fot. 10.34. Bazalt, Vägashed, Skania, południowa Szwecja; fot. P. Czubla 2015.

Fot. 10.35. Diabaz Kinne, Kinnekule, zachodnia Szwecja; fot. P. Czubla 2015.

Fot. 10.36. Granit Hammer, Moaselökken na półwyspie Hammeren, Bornholm; fot. P. Czubla 2015.

Fot. 10.37. Granit Alminding, kamieniołom w Bjergbakke, Almindingen, Bornholm; fot. P. Czubla 2015.

Fot. 10.38. Piaskowiec Nexö, Nexö, Bornholm, fot. P. Czubla 2015.

Fot. 10.39. Kreda pisząca z warstwą krzemieni, Stevns Klint, Dania; fot. O. Czubla 2009.

\section{Tabele}

Tab. 4.1. Stanowiska badawcze.

Tab. 4.2. Grupy petrograficzne wyróżniane w trakcie analizy prób.

Tab. 4.3. Wybrane wskaźniki i współczynniki przeanalizowanych zespołów eratyków poddane analizie statystycznej.

Tab. 4.4. Współrzędne geograficzne centralnych punktów wychodni eratyków wskaźnikowych - przewodnich i pomocniczych.

Tab. 5.1. Główne skały przewodnie wykorzystywane przez Milthersa pogrupowane regionalnie oraz współczynnik s/ $\varnothing$ dla stanowisk z Polski Wschodniej.

Tab. 5.2. Udział regionów wyróżnianych przez Hesemanna oraz formuły Hesemanna obliczone dla prób ze stanowisk wschodniej Polski.

Tab. 5.3. Wartości formuł Hesemanna wyliczone dla osadów glacjalnych Polski Wschodniej i Polski Środkowej.

Tab. 5.4. Rodzaje skał przewodnich wykorzystane do obliczeń testowych teoretycznych ośrodków głazowych.

Tab. 8.1. Przewodność cieplna właściwa skał $\lambda$.

Tab. 10.1. Udział wybranych typów wapieni fennoskandzkich w całkowitej liczbie eratyków fennoskandzkich skał węglanowych.

Tab. 14.1. Grupy regionalne eratyków wyróżniane przez Hesemanna i Gałązkę, uwzględnione w analizach statystycznych. 
Tab. 14.2. Przykładowa statystyka opisowa zespołów eratyków w glinach zlodowacenia sanu 2 w Polsce Środkowej (włącznie ze wschodnią Wielkopolską).

Tab. 14.3. Przykładowa statystyka opisowa zespołów eratyków w glinach zlodowacenia odry/warty w Polsce Środkowej (włącznie ze wschodnią Wielkopolską).

Tab. 14.4. Statystyczne podstawy wykorzystania cech petrograficznych zespołów eratyków z glin zlodowaceń odry/warty i sanu 2 w Polsce Środkowej (włącznie ze wschodnią Wielkopolską) dla potrzeb rozróżniania i korelacji osadów glacjalnych.

Tab. 14.5. Statystyczne podstawy wykorzystania cech petrograficznych zespołów eratyków z glin odry/warty i wisły na Kujawach dla potrzeb rozróżniania i korelacji osadów glacjalnych. 


\title{
19. FENNOSCANDIAN ERRATICS IN GLACIAL SEDIMENTS OF POLAND AND THEIR RESEARCH SIGNIFICANCE
}

\section{SUMMARY}

\begin{abstract}
This study presents the results of the research of erratic assemblages of the fraction $>20 \mathrm{~mm}$, collected from the glacial deposits in Poland. A total of 138 samples were analysed from 60 sites located along the latitudinal transect from Lower Silesia, Central Poland to the Podlasie Region, and along the meridional transect from Gdańsk Pomerania to Kuyavia and Central Poland. The results were compared with those of other authors, which allowed a detailed analysis of the distribution of indicator and auxiliary erratics, not only in Poland, but also in the area of the neighbouring countries.
\end{abstract}

The current erratics research methods and presentation of the results developed in Germany, Denmark, the Netherlands and Poland were verified, and the new methods were proposed and tested. The collected petrographic data were subjected to statistical analysis, which helped identify the most differentiating features of the variously aged glacial sediments.

The possibilities of the correlation of glacial deposits based on assemblages of indicator erratics in local and regional scale were defined. The petrographic features of tills representing all three glacial complexes in different regions of Poland were compared. The study confirmed the possibility of using petrographic features for distinguishing between the Sanian and the Odranian/Wartanian glacial tills in the area stretching from the eastern Wielkopolska to the Poland's borders in the east. The research also verified the older analysis of sediments from Central Poland ( 40 samples), including the reinterpretation of the stratigraphy of sediments filling the Kleszczów Graben as well as proposal of the new Pleistocene stratigraphy of Poland.

The qualitative analysis of pre-glacial and other processes influencing the petrographic composition of glacial deposits was conducted. The author analysed mechanisms of inclusion of the bedrock fragments into the ice, as well as glacial erosion, transport and possible processing of the moraine material in the ice sheet. A minor role of the subglacial bed deformation in the ice sheet transgression on the territory of Poland has been shown. The petrographic results were confronted with the thermodynamic models of the Fennoscandian ice sheet, which allowed disproving the models involving a large extent of the cold thermal regime of the ice sheet sole.

Based on the petrographic studies, the importance of the Baltic ice stream in the formation of sediments of the Weichselian Glaciation in Poland was questioned. The author was unable to identify the spreading zones of the Boothia erratics, which is indicative of the stream ice sheet 
motion. Widespread presence of rocks from the southern and central Sweden in glacial sediments of the Weichselian in Poland precludes the long-term separation of the rock source areas in Scandinavia and deposition areas on the Polish territory by the postulated ice stream.

\section{Introduction and problems}

One of the key issues in the Quaternary geology is to determine the stratigraphic position of the glacial deposits and their correlation. The solution to this problem may be the petrographic analyses of the gravel and pebble fraction in tills, especially as an effective method of dating glacial deposits has not been developed.

The analyses of the fine-gavel fraction (up to $10 \mathrm{~mm}$ in the particle diameter) are commonly carried out. Much less often coarse-gravel and pebble fractions examinations are performed, mainly due to the enormous effort in the form of both field and laboratory work. However, such studies provide more detailed information. Apart from glacial deposits correlation, erratics can be used to determine the conditions and length of debris transport in the ice and reconstruction of the paleogeographical conditions during the formation, advance and disintegration of the ice sheet. Based on the proportions of the different types of erratics, it is possible to locate the rock source area and determine the probable route of individual ice masses to the deposition area. Petrographic data allow looking critically at the idealised thermodynamic models of the ice sheet and referring them to the actual conditions prevailing during the Pleistocene in Europe.

The above assumptions helped to define the basic objectives of this research, which include:

1. Analysing of the spread of the selected types of indicator erratics in the glacial sediments of Poland,

2. Tracing variation of the erratic assemblages in horizontal transects (latitudinal and meridional) in Poland,

3. Determining the impact of pre-glacial processes on the formation of erratic assemblages,

4. Reviewing the data relating to the importance of the erosion type and ice movement mechanism for the delivery of the Fennoscandian rock material to the Central European Lowlands,

5. Analysing the composition of the erratic assemblages in the glacial sediments in relation to the modern thermodynamic ice sheet models,

6. Assessing conformity of the erratic analyses results with the selected glaciological concepts, including the ice stream model of the Fennoscandian ice sheet dynamics,

7. Verifying and simplifying the methodology used in the studies of erratics to promote the dissemination of this type of analyses as well as increase the reliability of the results,

8. Reviewing and updating the results of the erratics research carried out in Central Poland in the light of the new data on the stratigraphy of the sediments in the lignite open cast mine "Bełchatów" and changes in the Pleistocene stratigraphy of Poland,

9. Controlling suitability of the erratics analyses for stratigraphic correlation on a regional and not just local scale, 
10. Analysing suitability of erratics in the studies of the Pleistocene stratigraphy of the selected regions of Poland (distinguishing variously aged glacial deposits and their correlation).

Thus formulated scientific objectives required research in the sites along the latitudinal axis extending from the valley of the Bóbr in the west to the Bug river valley to the east. The variation of erratic assemblages was also analysed in the belt stretching from the Baltic coast in the north to the Przedbórz Upland in the south (Fig. 4.1). The research methodology ruled out the use of the material from the drilling and led to the selection of mainly large outcrops, where it was possible to collect proper size samples from the glacial deposits (at least a thousand clasts of the fraction $>20 \mathrm{~mm}$ ). With this selection of the research sites, the study examines the surface prevalence of all three glacial complexes (sensu Ber et al., 2007) distinguished in the Pleistocene of Poland. In total the research was performed at 60 sites in which 138 samples were collected (Tab. 4.1).

\section{Methods}

The research was carried out almost exclusively in glacial sediments (125 samples). For comparative purposes, however, in a few sites fluvioglacial gravels (11 samples) as well as flow diamictons (2 samples) were sampled, but the results of their studies were not included in the statistical analyses. Different composition of fluvioglacial deposits (resulting from at least two-stage transport, which is evidenced by, among others, a clear increase in the share of rocks of the local provenance) undermines their credibility as a parameter of sediments correlation (Fig. 4.2). In total, about 150,000 erratics were identified, almost exclusively of the northern origin. Only in Lower Silesia and the Lower Vistula Region in some sites high proportions of local rocks were recorded.

The study included all boulders (pebbles) greater than $20 \mathrm{~mm}$. Besides indicator erratics, about 40 petrographic groups were distinguished in the samples (Tab. 4.2), which can be used to search for features differentiating the variously aged deposits and to compare them with the research results of other authors. Based on this data, a number of petrographic indicators were calculated (Tab. 4.3), later on subjected to statistical analysis.

The primary objective of the statistical analysis was to identify the petrographic features useful to distinguish between variously aged glacial deposits and to determine their potential usefulness in the regional and supra-regional scales. The statistical study referred to four regions: 1. Lower Silesia, 2. East Poland, 3. Central Poland and Eastern Wielkopolska, 4. Pomerania, Lower Vistula Region and Kuyavia. The two latter regions were further sub-divided into five sub-regions. In the individual regions and sub-regions the compatibility/separation tests were carried out on characteristics of sample sets from the variously aged glacial deposits at a given confidence level $\alpha \leq 0.05$ (i.e. the expected probability of separation of the variously aged assemblages was to be at least $95 \%)$.

The study tested the methods suggested by different authors and assessed their usefulness for the correlation and the delimitation of variously aged glacial deposits of Poland. The concepts of Milthers $(1909,1936)$ and Hesemann $(1930,1931)$ proved rather unsuccessful (Tabs. 5.1-5.3). The improvement of the results was reported, except for one of the generalisations made by 
Hesemann, when the vague formulas were replaced by the precision ternary plots (Fig. 5.1). Moreover, regional groups proposed by Gałązka (2004b) proved to be useful but the presentation of the results in the form of linear graphs hinders correlation of a larger number of samples (Fig. 5.2).

Based on the types and number of indicator erratic (Tab.4.4) identified in each sample, theoretical boulders centres (TBC) were calculated. The traditional method of Lüttig (1958), as well as its subsequent modifications (e.g. Groetzner, 1972; Czubla, 2001), were tested. Additionally, for the correlation needs it was attempted to use an index based solely on crystalline rocks, expecting that it will allow for the correlation of variously weathered sediments. In search of a simpler test method than the current one, the author analysed the additional eight test sets of indicator rocks of only the selected types of erratics, i.e. almost exclusively crystalline ones (Tab. 5.4). Including the aforementioned "traditional" methods, the calculation of the TBC was conducted in 16 variants. The radical reduction of the number of the indicator rock types used to calculate the TBC simplified the test procedure itself, but unfortunately impaired the reliability of the results and thus their use for correlation. The best results were presented by the test analysis TBC-W1 and TBC-W8, calculated on the basis of the relatively numerous types of indicator rocks.

The analysis of circle maps (Figs. 5.7 and 5.8) is very helpful in determining the paleogeographical conditions, including the directions of the ice sheet advance to the test area. However, the correlation of glacial deposits based on the interpretation of these maps is very difficult and fraught with subjectivity - there is no mathematical or geometrical ratio, characterising the whole erratic assemblage in a clear and simple way and suitable for comparing numerous samples.

\section{Correlating and distinguishing variously aged glacial deposits}

Differences between the erratic assemblages coming from variously aged glacial deposits are best indicated by the theoretical boulder centres (TBC). The attempts of regional and petrographic grouping of erratics (indicator rocks, auxiliary rocks and others), the analysis of their participation in the variously aged sediments, and the calculation of various factors which are to serve correlating and distinguishing variously aged tills, give poorer and less clear results.

Most distinguishable difference is recorded between the glacial deposits of the Sanian 2 and Odranian/Wartanian, observable in a large area stretching from the eastern Wielkopolska to the Lublin and Podlasie Regions (Figs. 5.3 and 5.4). This is the only case of the cross-regional reach of the petrographic feature allowing distinguishing variously aged tills. To do so one can either use the TBC-W1, calculated on the basis of the reduced number of indicator erratics (Åland, Bothnia, Baltic, Dalarna, Småland and Bornholm rocks), or a similar index based on the full set of indicator crystalline rocks. Significant reduction in the number of erratics used to calculate the tested TBC (TBC-W2 - TBC-W7) causes increased dispersion of the results (Fig. 5.4). In such cases, this may partly be due to a smaller total number of erratics in the sample, not reaching the minimum of 50 boulders. 
Distinguishing between tills of the various glaciations of the South-Polish Complex based on the theoretical boulder centres was initially confirmed in Lower Silesia and Central Poland, but requires verification in a larger number of sites (Figs. 5.3 and 5.5).

What also appears to be promising are the results of the comparative analyses of the sediments deposited by the ice sheets of the Middle-Polish Complex (MIS-8 and MIS-6). Both in Central Poland and the Podlasie Region the deposits of the older ice sheet (Krznanian?) are much richer in the Dalarna rocks; this moves their theoretical boulders centers to the west in relation to the TBC of the younger glacier. Also in this case, it is necessary to find new sites with older glacial tills.

The analysis of the theoretical boulder centres is much less effective in distin-guishing between the glacial deposits of the Odranian/Wartanian and the Weichselian. Only in Kuyavia in the Odranian/Wartanian till a clear shift of the TBC to the SW is visible in relation to the sediments of the last glaciation - the difference is easiest to read based on the TBC-W8 (Fig. 5.6).

The use of the dolomite participation as an indicator differentiating moraine levels (Figs. 10.17-10.19, 14.2 and 14.4) is not justified, because it depends on the degree of the sediment weathering. In the natural conditions dolomites may be subject to weathering even faster than limestone, which leads to their elimination from the sediments.

\section{Results of the statistical analysis}

The author failed to find universal petrographic features that would enable unambiguous identification of variously aged glacial deposits in all the analysed regions of Poland. The analyses of erratics of the fraction $>20 \mathrm{~mm}$ (shares of individual types or groups of rocks, regional groups of indicator erratics, petrographic indicators calculated for all the northern rocks) are mainly useful in the scale of one relatively small region (Figs. 14.1-14.4), but generally do not work with respect to the entire country.

The only case of the complete convergence of the analyses observed at the supraregional scale referred to the sediments of the South-Polish and Middle-Polish Complexes in Central Poland as well as in the regions of Podlasie and Lublin (also confirmed by the TBC studies). In both these regions the Sanian 2 deposits are very rich in the South Sweden rocks, and relatively poor in the Åland and Baltic rocks. The deposits of the Odranian/Wartanian show reverse quantitative relations between the erratics from these regions of Fennoscandia and the Baltic Sea bottom (Figs. 14.5 and 14.6). What is also promising, are the results of the comparative statistical analysis of the tills of the Middle-Polish Complex (Figs. 14.1b and 14.3b).

The difference between the sediments of the Odranian/Wartanian and the Weich-selian is spatially variable. In Kuyavia the tills of Middle-Polish Complex contain numerous South Sweden erratics (from Småland and Blekinge), and relatively few indicator rocks from the region the Åland Islands and the Gulf of Bothnia. In the sediments of the Weichselian glaciation these proportions change in favour of the rocks coming from the north-eastern part of the source area. This trend, however, quickly disappears as you move north and is completely unreadable in Pomerania. 


\section{Indicator erratics in Poland}

When moving to the east, the differentiation of indicator erratics in glacial sediments in Poland decreases. The erratics from Norway and West Sweden gradually disappear (occasionally found almost exclusively in the western part of the country), the share of the rocks from South Sweden (Figs. 10.21, 10.22 and 10.26) and Bornholm (Fig. 10.27) decreases, beyond the eastern border of Poland replaced by the Finnish and Karelian erratics.

Finnish rocks proved to be very rare in Poland (except Åland rocks). Typical vyborgites are extremely rare (even in Eastern Poland), and if so only in the form of large boulders. This confirms the conclusions referring to the ice masses moving through southern Finland in the latitudinal direction to the east and delivering the Finnish rocks far from the Polish territory. Across eastern Poland, though, runs the axial part of the zone of the Åland rocks distribution, visible in their participation, which in certain sites reaches up to $50 \%$ of the recognised indicator erratics (Figs. 10.3 and 10.4).

Correlating the presence of brown Baltic porphyry with the extent of the Middle-Polish glaciations is not confirmed by systematic lithostratigraphic studies. Previously suggested lack of this rocks (erratics) beyond the extent of the Wartanian, and in central Poland beyond the Odranian (Radomka - Różycki, 1967) probably resulted from its very low participation in the sediments of the South-Polish Complex $-0.5 \%$, and a clear increase in its importance in the younger glacial sediments $-1.2 \%$ in the Middle-Polish Complex and as much as $3.3 \%$ in the North-Polish Complex (Figs. 10.13 and 10.14).

Most erratics of the fraction $>20 \mathrm{~mm}$, occurring in glacial sediments of Poland, show a fairly high degree of roundness. This may indicate that at least part of their route must have been covered transported in the basal zone of the ice sheet (Fig. 8.1). However, remaining in the bottom traction must have been short - otherwise boulders would have undergone further comminution. At this stage most of the rocks which were more susceptible to weathering were probably eliminated from the studied fraction. For instance, this refers to Paleozoic slate or the rocks weathered before they were incorporated in the ice. It is also possible that some of the boulders showed good roundness at the time of their incorporation by the ice, e.g. as a result of earlier fluvial transport or due to the rounding in the coastal zone of the interglacial sea.

\section{Erratics versus Fennoscandian ice sheet models}

In most models of the Fennoscandian ice sheet the Dalarna province was near the ice-divide line of the ice sheet. According to the currently adopted assumptions and observations of the modern ice sheets, ice movement rate there was so small (Figs. 6.3, 6.4, 8.3 and 10.2), that the Dalarna rocks should be rare in the zone of the maximum extent of glaciations. Contrary to the above assumption, the presence of numerous Dalarna erratics in variously aged glacial sediments of Poland (Figs. 10.6-10.10) proves the need to look for a different velocity distribution of ice in the Fennoscandian ice sheet than that postulated by Donner (1989) or recorded in the Antarctic ice sheet (e.g. Rignot et al., 2011). 
Moreover, the high content of the Dalarna rocks and the presence of the rocks from Ångermanland in the glacial sediments of Poland disprove the models assuming a lasting persistence of the cold thermal regime of the ice sheet sole in Central Sweden. An extreme example of the model contrary to the petrographic studies was presented by Forsström et al. (2003) - Fig. 8.4. The actual extent of the area of a cold regime of the Fennoscandian ice sheet sole must have been much smaller (Figs. 8.6 and 10.2) than that estimated in the thermodynamic models of ice sheets developed up to date.

Significant incorporation of the rock material from the substrate is only possible if the ice sheet moves in the form of the basal sliding and deformation of the soft glacial bed (Fig. 6.1). The basal sliding can take the pulse character (coupling-sliding motion), associated with the periodic coupling of the ice sheet sole to the ground, and followed by decoupling (sticky-spot mechanism). This type of motion appears to promote the incorporation of the rocks from the substrate (local coupling and then decoupling of the ice from the substrate). Deformations of the soft substrate (Fig. 6.1C) allow repeated deposition and re-incorporation of the sediments in the ice sheet sole. In this case, the debris transport most often takes place at a relatively short distance. Therefore, the larger participation of this mechanism in moving the ice sheet, the lower the ability to transport the Fennoscandian rocks into the Central European Lowlands. This would lead to a clear dominance of rocks of local provenance in the glacial sediments of Poland, which, however, was not observed. It must therefore be assumed that the role of soft sediment deformation in the ice sheet movements was relatively small. Internal movement of ice (deformation flow) does not affect the incorporation of rock, but it can decide on the length and speed of the rock material transport.

The theory of instantaneous (spontaneous) glacierisation is contrary to the common occurrence of Nordic rocks in the Central European Lowlands. Such a development of the Fennoscandian ice sheet would lead to the domination of the local moraines in Poland.

Moving the rock source centre to the east during the development of the ice sheet (in accordance with the concept of Ehlers - 1983; Ehlers et al., 1984) can be observed in the tills of the Middle-Polish Complex, between the Krznanian and Odranian/Wartanian, both in Central and Eastern Poland. A similar migration in the rock source area is also visible in the South-Polish Complex in Lower Silesia, where the theoretical boulder centres of the Sanian 2 tills are located east of the corresponding indicators calculated for the Sanian 1 tills (Fig. 5.5).

For the purpose of petrographic studies of the glacial deposits, it is necessary to distinguish between ice streams (sensu Swithinbank, 1954) and ice currents, defined as individual ice masses, moving within the ice sheet at a speed equal to the surrounding but diverse - at the most - in terms of the composition of the glacial material.

The presence of the Skåne and Bornholm rocks in the glacial sediments of Pomerania, the Vistula Region, Kuyavia and Central Poland (Figs. 10.24-10.27) proves either a significant participation of non-ice transport factors in the supply of rocks into the area of Poland or at least periodic abnormal functioning of the direction of the ice advance, different from both the ice stream model, as well as the older model describing the radial spreading of the ice from the centre of Scandinavia. 
Nowhere in the Poland's territory was it possible to identify the Boothia erratic dispersal trains, typical for the ice streams (Fig. 7.3). Therefore, the petrographic evidence of the functioning of terrestrial ice streams (Fig. 7.2) in our country is missing.

Intense erosion at the ice streams sole leads to the stabilisation of the already developed system (thanks to the transformation of the topography of the substrate), rather than to its changes. In the following glaciations the topography favours the reconstruction of the previous ice stream layout, which in turn would lead to the formation of very clear zones of spreading of the erratics of the Boothia and Dubawnt Lake type in the glacial sediment (sensu Dyke and Morris, 1988). In fact, the erratics dispersal fans from different regions of Fennoscandia largely overlap. Distribution of erratics in the glacial sediments of Poland can be thus treated as a credible argument against the longer functioning of the stream model of the ice sheet dynamics. Numerous erratics from South and Central Sweden in glacial sediments of Poland (Figs. 10.6-10.12 and 10.20-10.26) confirm that the Baltic ice stream functioned very briefly, and formed only at the deglaciation stage, when its potential role in the deposition of glacial sediments and shaping their petrographic composition was very limited, and the area of Poland was already probably ice-free. If the Baltic ice stream was active at an earlier stage of the development of the Fennoscandian ice sheet, it would have to isolate the Polish territory from the inflow of rocks from Sweden.

In the case of the Punkari model $(1993,1997)$, it is very difficult to correlate it with the results of the petrographic research of the glacial deposits of Poland. Even if the main Baltic stream and its hypothetical "branches" existed (Figs. 7.4 and 7.5), they were asynchronous and independent of each other, as the main stream located in the isostatic depression (deeper than today) would drain its surroundings rather than feed it. This means that the individual ice streams of the Vistula and Odra are older and not necessarily of the same age - perhaps related to the end-stage of the development of the ice sheet in the Poznan (Frankfurt) Phase. The adoption of this assumption would explain the further extent of the ice sheet in the Płock lobe during the Poznan (Frankfurt) Phase than during the Leszno (Brandenburg) Phase. The main Baltic ice stream probably developed already in the late stage of the Poznan Phase (indicated by the studies in Denmark - Kjær et al., 2003) or even later (e.g. in the Gardno Phase), when no "branch" could advance to the far south and, consequently, there was no effect on the composition of the glacial deposits in Poland. 


\section{LIST OF FIGURES, PHOTOS AND TABLES}

\section{Figures}

Figure 4.1. Location of the research sites against the glacial limits.

Figure 4.2. Dispersal trains of the bedrock fragments in glacial, glaciofluvial (esker) and fluvial deposits.

Figure 5.1. Graphic presentation of modified Hesemann's formulas.

Figure 5.2. Indicator erratics in the glacial deposits of Lower Silesia.

Figure 5.3. Theoretical boulder centers (TBC) calculated for glacial tills of central Poland.

Figure 5.4. Experimental theoretical boulder centers calculated for glacial deposits in Eastern Poland.

Figure 5.5. Experimental theoretical boulder centers calculated for glacial deposits of the South-Polish Complex (Sanian 1 and Sanian 2) in Lower Silesia.

Figure 5.6. Theoretical boulder centers calculated for glacial deposits of Odranian/Wartanian and Weichselian Glaciations.

Figure 5.7. Indicator erratics (including auxiliary rocks) in glacial deposits of the Koźmin North outcrop.

Figure 5.8. Indicator erratics (including auxiliary rocks) in glacial deposits of the Wapienno open-cast mine in Kujawy (western part of the outcrop).

Figure 6.1. The velocity distribution within three glaciers of different basal thermal regimes resting on different substrate.

Figure 6.2. Types of bedrock on the Northern Hemisphere.

Figure 6.3. The velocity distribution (result of mathematical modeling) within the eastern part of Antarctic Ice-Sheet.

Figure 6.4. The flow rates in the Fennoscandian Ice Sheet.

Figure 7.1. Marine-based ice streams.

Figure 7.2. Terrestrial ice streams.

Figure 7.3. Erratics dispersal trains.

Figure 7.4. Ice streams model of the Scandinavian and Novaya Zemlya Ice Sheets during Weichselian.

Figure 7.5. Location of major ice streams in Central Europe during the Saalian and Weichselian glaciations.

Figure 8.1. Pressing the clasts to the ground due to deformation flow of ice and due to melting of ice on contact with the bedrock.

Figure 8.2. A schematic sketch of the Baltic river system (Eridanos fluvio-deltaic system).

Figure 8.3. Modeled thermodynamic evolution of the European ice sheet through the last glacial cycle along the transect from Lillehammer in Norway to LGM line in Middle Poland.

Figure 8.4. Simulation results of the basal temperature (in ${ }^{\circ} \mathrm{C}$ ) for the Fennoscandian Ice Sheet.

Figure 8.5. The first-order organization of erosion and deposition zones under a steady-state polythermal mid-latitude ice sheet.

Figure 8.6. First-order Fennoscandian subglacial thermal organization at the LGM or near-LGM stages. 
Figure 9.1. Schematic vertical section through Matanuska Glacier, Alaska, showing the distribution of ice facies.

Figure 9.2. Relative proportions of different particle sizes in the stratified, debris band and dispersed basal ice facies.

Figure 9.3. The relationship of the erratic boulders (fraction 20-60 mm) in glacial tills to the geology of bedrock.

Figure 10.1. Source areas of Baltic-Fennoscandian indicator rocks (auxiliary rocks including).

Figure 10.2. Location of geographical centers of the source areas of indicator erratics (selected types of auxiliary erratics including).

Figure 10.3. The distribution of Åland rocks in glacial deposits of the South-Polish Complex and of the North-Polish Complex.

Figure 10.4. The distribution of Åland rocks in glacial deposits of the Middle-Polish Complex.

Figure 10.5. The occurrence of Jotnian sandstones in Balto-Fennoscandia.

Figure 10.6. The distribution of Dalarna and Värmland rocks in glacial deposits of the South-Polish Complex and of the North-Polish Complex.

Figure 10.7. The distribution of Dalarna and Värmland rocks in glacial deposits of the Middle-Polish Complex.

Figure 10.8. The distribution of Bredvad porphyry in glacial deposits of the South-Polish Complex and of the North-Polish Complex.

Figure 10.9. The distribution of Dalarna and Värmland volcanic rocks in glacial deposits of the South-Polish Complex and of the North-Polish Complex.

Figure 10.10. The distribution of Dalarna and Värmland plutonic rocks in glacial deposits of the South-Polish Complex and of the North-Polish Complex.

Figure 10.11. The distribution of Uppland and Stockholm rocks in glacial deposits of the South-Polish Complex and of the North-Polish Complex.

Figure 10.12. The distribution of Stockholm granite in glacial deposits of the South-Polish Complex and of the North-Polish Complex.

Figure 10.13. The distribution of brown Baltic porphyry in glacial deposits of the South-Polish Complex and of the North-Polish Complex.

Figure 10.14. The distribution of brown Baltic porphyry in glacial deposits of the Middle-Polish Complex.

Figure 10.15. The distribution of red Baltic porphyry in glacial deposits of the South-Polish Complex and of the North-Polish Complex.

Figure 10.16. The distribution of red Baltic porphyry in glacial deposits of the Middle-Polish Complex.

Figure 10.17. The percentage of dolomites among Fennoscandian rocks in the tills of the South-Polish Complex and of the North-Polish Complex.

Figure 10.18. The percentage of dolomites among Fennoscandian rocks in the tills of the Middle-Polish Complex.

Figure 10.19. The percentage of dolomites among Nordic carbonate rocks in the tills of the South-Polish Complex and of the North-Polish Complex.

Figure 10.20. The distribution of Småland, Skåne and Blekinge erratics in glacial deposits of the South-Polish Complex and of the North-Polish Complex.

Figure 10.21. The distribution of Småland, Skåne and Blekinge erratics in glacial deposits of the Middle-Polish Complex.

Figure 10.22. The distribution of Vånevik granite in glacial deposits of the South-Polish Complex and of the North-Polish Complex.

Figure 10.23. The distribution of Vånevik granite in glacial deposits of the Middle-Polish Complex.

Figure 10.24. The distribution of Skåne basalts in glacial deposits of Poland. 
Figure 10.25. The distribution of Hardeberga sandstone in glacial deposits of the South-Polish Complex and of the North-Polish Complex.

Figure 10.26. The distribution of Hardeberga sandstone in glacial deposits of the Middle-Polish Complex.

Figure 10.27. The distribution of Bornholm erratics in glacial deposits of the South-Polish Complex and of the North-Polish Complex.

Figure 10.28. The distribution of phosphorite nodules in glacial deposits of Poland.

Figure 11.1. Examples of common dispersal patterns in till, from various detailed studies in Canada.

Figure 13.1. Schematic of dispersal model.

Figure 14.1. Statistical parameters of indicator erratics in glacial sediments of Central Poland and Eastern Wielkopolska.

Figure 14.2. Statistical parameters of auxiliary erratics in glacial sediments of Central Poland and Eastern Wielkopolska.

Figure 14.3. Statistical parameters of indicator erratics in glacial sediments of Central Poland and Eastern Wielkopolska.

Figure 14.4. Statistical parameters of auxiliary erratics in glacial sediments of Central Poland and Eastern Wielkopolska.

Figure 14.5. Statistical parameters of indicator erratics in glacial sediments.

Figure 14.6. Statistical parameters of indicator erratics in glacial sediments.

\section{Photos}

Photo 3.1. Erratic boulders on the coast of Estonia. Photo P. Czubla 2012.

Photo 3.2. Trollastenen erratic boulder, also known as Maglestenen near Bäckashog in Skåne; Photo $P$. Czubla 2003.

Photo 8.1. Glacial striations on the proximal slope of roche moutonnée - Baltic Sea coast near Saltvik (Åland Islands). Photo P. Czubla 2002.

Photo 8.2. Shaped by glacial abrasion (polished and striated) surface of bedrock in Järrestad near Simrishamn in Sweden. Photo P. Czubla 2003.

Photo 8.3. Structures formed by detraction on the distal slope of roche moutonnée - Baltic Sea coast near Saltvik (Åland Islands). Photo P. Czubla 2002.

Photo 10.1. Revsund granite, Valla - Ragunda, Central Sweden. Photo P. Czubla 2015.

Photo 10.2. Ragunda granite, Ragunda, Central Sweden. Photo P. Czubla 2015.

Photo 10.3. Alnöite, Näset, Central Sweden. Photo P. Czubla 2015.

Photo 10.4. Åland rapakivi granite, erratic - Bełchatów outcrop. Photo P. Czubla \& Z. Machnicki 1999.

Photo 10.5. Haga granite, erratic - Bełchatów outcrop. Photo P. Czubla 2015.

Photo 10.6. Åland granite porphyry, erratic - Bełchatów outcrop. Photo P. Czubla \& Z. Machnicki 1999.

Photo 10.7. Ytö granite, Ytö near Laitilla, western Finland. Photo P. Czubla 2015.

Photo 10.8. Granite quarry in Ytö, Katinhäntä (west of Laitila). Photo P. Czubla 2003.

Photo 10.9. Pyterlite from Finland, erratic - Smulsko outcrop. Photo P. Czubla 2015.

Photo 10.10. Prick granite, erratic - Bełchatów outcrop. Photo P. Czubla 2015.

Photo 10.11. Vyborgite (rapakivi granite), Ylämaa, eastern Finland. Photo P. Czubla 2015.

Photo 10.12. Vyborgite (rapakivi granite), erratic - Bełchatów outcrop. Photo P. Czubla 2015.

Photo 10.13. Garberg granite, erratic - Moszczenica near Piotrków Trybunalski. Photo P. Czubla 2015.

Photo 10.14. Bredvad porphyry, near the Trängslet dam, Dalarna, Central Sweden. Photo P. Czubla 2015.

Photo 10.15. Tandsjöborg porphyry, Tandsjöborg, Dalarna, Central Sweden. Photo P. Czubla 2015. 
Photo 10.16. Särna ignimbrite (violet), Särna, Central Sweden. Photo P. Czubla 2015.

Photo 10.17. Särna tinguaite (särnaite), Siksjöberget near Bergswallen, Central Sweden. Photo P. Czubla 2015.

Photo 10.18. Jotnian sandstone quarry, Mångsbodarna, Dalarna, Central Sweden. Photo P. Czubla 2003.

Photo 10.19. Castings of drying cracks in Jotnian sandstone, Mångsbodarna, Dalarna, Central Sweden. Photo P. Czubla 2003.

Photo 10.20. Digeberga conglomerate, Höghed, Dalarna, Central Sweden. Photo P. Czubla 2015.

Photo 10.21. Stockholm granite, Sånga, North of Stenhamra, Central Sweden. Photo P. Czubla 2015.

Photo 10.22. Sala granite, Heby, Central Sweden. Photo P. Czubla 2015.

Photo 10.23. Uppsala granite, Berga, Central Sweden. Photo P. Czubla 2015.

Photo 10.24. Vänge granite, Kristineberg near Laby, Central Sweden. Photo P. Czubla 2015.

Photo 10.25. Brown Baltic quartz porphyry, erratic - Moszczenica. Photo P. Czubla \& Z. Machnicki 1999.

Photo 10.26. Red Baltic quartz porphyry, erratic - Siedlątków on the Warta river. Photo P. Czubla 2015.

Photo 10.27. Tessini sandstone, Äleklinta, Öland Island. Photo P. Czubla 2010.

Photo 10.28. Kalmarsund sandstone, Värsnäs near Kalmar, Southern Sweden. Photo P. Czubla 2015.

Photo 10.29. Paleoporella limestone, erratic - Smulsko outcrop. Photo P. Czubla \& Z. Machnicki 1999.

Photo 10.30. Crinoidea limestone, Hoburgen Cliff, Gotland Island. Photo P. Czubla 2003.

Photo 10.31. Vånevik granite, Vånevik, Småland, Southern Sweden. Photo P. Czubla 2015.

Photo 10.32. Uthammar granite, Uthammar, Småland, Southern Sweden. Photo P. Czubla 2015.

Photo 10.33. Karlshamn granite, Hällaryd, Blekinge, Southern Sweden. Photo P. Czubla 2015.

Photo 10.34. Skåne basalt, Vägashed, Skåne, Southern Sweden. Photo P. Czubla 2015.

Photo 10.35. Kinne diabase, Kinnekule, western Sweden. Photo P. Czubla 2015.

Photo 10.36. Hammer granite, Moaselökken on the Hammeren Peninsula, Bornholm. Photo P. Czubla 2015.

Photo 10.37. Alminding granite, Bjergbakke quarry, Almindingen, Bornholm. Photo P. Czubla 2015.

Photo 10.38. Nexö sandstone, Nexö, Bornholm. Photo P. Czubla 2015.

Photo 10.39. Cretaceous chalk with a layer of flints, Stevns Klint, Denmark. Photo O. Czubla 2009.

\section{Tables}

Table 4.1. Research sites.

Table 4.2. Groups of rocks separated in petrographical analysis.

Table 4.3. Selected petrographical coefficients and ratios in analyzed erratics samples used in statistical analysis.

Table 4.4. Geographical coordinates of midpoints of indicator erratics (selected auxiliary ones including) source areas.

Table 5.1. Main indicator erratics used by Milthers grouped regionally and $s / \varnothing$ coefficient for the research sites in Eastern Poland.

Table 5.2. Shares of regions distinguished by Hesemann and values of Hesemann formula calculated for glacial deposits in Eastern Poland.

Table 5.3. The values of Hesemann formula calculated for glacial deposits in Eastern and Central Poland.

Table 5.4. Indicator rocks types used to calculate experimental theoretical boulder centers (TBC).

Table 8.1. The specific thermal conductivity of rocks $\lambda$.

Table 10.1. Shares of selected types of Fennoscandian limestone erratics in the total number of Nordic carbonate rocks. 
Table 14.1. Regional groups of indicator erratics distinguished by Hesemann and Gałązka, included in the statistical analysis.

Table 14.2. An example of descriptive statistics of erratics $>20 \mathrm{~mm}$ in the South-Polish Complex till (Sanian 2) in Central Poland (including Eastern Wielkopolska).

Table 14.3. An example of descriptive statistics of erratics $>20 \mathrm{~mm}$ in the Middle-Polish Complex till (Odranian/Wartanian) in Central Poland (including Eastern Wielkopolska).

Table 14.4. The statistical basis for the use of petrographical features of erratic sets in tills of Odranian/Wartanian and Sanian 2 age in Central Poland (including Eastern Wielkopolska) for distinguishing and correlation of glacial deposits.

Table 14.5. The statistical basis for the use of petrographical features of erratic sets in tills of Odranian/Wartanian and Weichselian age in Kujawy for distinguishing and correlation of glacial deposits. 